\title{
MILITARY AVIATION IN IRELAND
}

1921- 1945

By

\section{MICHAEL O'MALLEY}

\section{THESIS FOR THE DEGREE OF PHD \\ DEPARTMENT OF HISTORY \\ NATIONAL UNIVERSITY OF IRELAND MAYNOOTH}

Supervisor of Research: Dr. Ian Speller 


\section{IRISH MILITARY AVIATION 1921 - 1945}

This thesis initially sets out to examine the context of the purchase of two aircraft, on the authority of Michael Collins and funded by the second Dail, during the Treaty negotiations of 1921 . The subsequent development of civil aviation policy including the regulation of civil aviation, the management of a civil aerodrome and the possible start of a state sponsored civil air service to Britain or elsewhere is also explained.

Michael Collins' leading role in the establishment of a small Military Air Service in 1922 and the role of that service in the early weeks of the Civil War are examined in detail. The modest expansion in the resources and role of the Air Service following Collins' death is examined in the context of antipathy toward the ex-RAF pilots and the general indifference of the new Army leadership to military aviation.

The survival of military aviation - the Army Air Corps - will be examined in the context of the parsimony of Finance, and the administrative traumas of demobilisation, the Army mutiny and reorganisation processes of 1923/24.

The manner in which the Army leadership exercised command over, and directed aviation policy and professional standards affecting career pilots is examined in the contexts of the contrasting preparations for war of the Army and the Government.

The Air Corps' active roles during the Emergency are assessed against the background of inadequate preparation, insufficient and inappropriate aircraft and improbable tasking by GHQ. Secondary roles in support of the RAF war effort are also elucidated.

The Army's investigation, into the inadequacies of the Air Corps, is examined against the background of the command exercised by an inexpert and disciplinarian officer. The investigation itself is assessed in order to highlight any the bias or prejudice that may have pertained. 


\section{TABLE OF CONTENTS}

Acknowledgements

$\begin{array}{ll}\text { Abbreviations and acronyms } & \text { iv }\end{array}$

List of figures vii

List of tables viii

Location map - Civil War ix

Location map - Emergency $\quad x$

CHAPTER 1 Introduction page 1

CHAPTER 2 Civil aviation - developments in Saorstát Éreann 16

CHAPTER 3 Michael Collins, the Military Air Service and the Civil War 50

CHAPTER 4 From Civil War to Army mutiny 82

CHAPTER 5 Policy, organisation and command, 1924-1936 116

CHAPTER 6 Pupil pilot intake, 1922-1945 153

CHAPTER 7 Aviation policy and planning, 1935-1940 191

$\begin{array}{ll}\text { CHAPTER } 8 & \text { Government defence strategy and Anglo - } \\ & \text { Irish cooperation }\end{array}$

$\begin{array}{llr}\text { CHAPTER } 9 & 259\end{array}$

CHAPTER $10 \quad$ The Air Corps' Emergency 305

CHAPTER 11 The 1941 Air Corps investigation of 1941 and the 1943 reorganisation 354

$\begin{array}{lll}\text { CHAPTER } 12 & 399\end{array}$

$\begin{array}{ll}\text { BIBLIOGRAPHY } & 412\end{array}$

$\begin{array}{ll}\text { APPENDIXES } & 422\end{array}$ 


\section{ACKNOWLEDGEMENTS}

While I have been actively engaged in the research peculiar to this work only over the past four and a half years I must acknowledge relevant assistance received over a much longer period. My introduction to military archives was in the Red House in the early 1980s when the late Peter Young showed me the growing amount of material that would later become Military Archive. Though Peter and I were separated by corps loyalties he assisted me greatly in my early efforts to research military aviation in Ireland. In particular he introduced me to some of the most historically valuable documents relating to the history of the Air Corps and helped me acquire a small number of original copies. I am particularly grateful for the access he granted me to the personal files of a number of the early officers. It is only now that I realise the importance of the minutiae of the careers of individual officers in the context of documenting the history of the early years. Such unique access to personal files has, of course, long since ceased.

My thanks go to the late Madeline O'Rourke and to her husband Colm. Their interest in, and willingness to collect, research and share the history of the Air Corps was unique. I appreciate also the personal comments of the late Agnes Russell, in June 2004, regarding her late father Col. Charlie Russell. Regrettably she had to tell me that her father's private papers had been lost in a domestic fire many years previously. Similarly I owe a debt of gratitude to Ms Aine Broy for an understanding of aspects of the brief Air Service career of Col. Ned Broy. Thanksto the kindness of Capt. Eoin Hassett I had extended access to the small but very important collection of private papers of his late father, Lt. Col. P. J. (Laddie) Hassett who served in the Air Corps from 1926 to 1935.

I wish to express my sincere gratitude to Dr. Ian Speller of the Department of History, N.U.I. Maynooth, for his expert guidance, criticism, direction and advice over the past four years. I also acknowledge the foundation in history provided by the various academics at Maynooth, particularly Professor R. V. Comerford, during my diploma, degree and doctorate courses. 
My grateful thanks go to Dr. Sean Swords, formerly of the Air Support Company, Signal Corps at Baldonnell and of Trinity College, for his assistance and guidance in the matter of aeronautical communications.

Finally I must give credit where credit is due. I refer to the part my wife Barbara has played in my historical researches and study. It was, after all, her idea that I take up history as a substitute for squash. I never quite understood the analogy but I greatly appreciate her endless patience and understanding and her support of my mild obsession. 


\section{ABBREVIATIONS AND ACRONYMS}

$\begin{array}{ll}\text { A } & \text { Acting } \\ \text { AA } & \text { Anti-aircraft artillery } \\ \text { AAC } & \text { Army Air Corps } \\ \text { AAS } & \text { Army Air Service } \\ \text { AC } & \text { Air Corps } \\ \text { ACC } & \text { Airport construction committee } \\ \text { ACF/ } & \text { Air Corps flying (file) } \\ \text { AC HQ } & \text { Air Corps Headquarters } \\ \text { ACS } & \text { Assistant Chief of Staff } \\ \text { ADC } & \text { Aircraft Disposal Company } \\ \text { Adjt } & \text { Adjutant } \\ \text { AFO } & \text { Army finance officer } \\ \text { AG } & \text { Adjutant General } \\ \text { AM } & \text { Air Ministry } \\ \text { Arty } & \text { Artillery } \\ \text { AS } & \text { Air Service } \\ \text { AVRO } & \text { A. V. Roe \& Co. Ltd. } \\ \text { BTNI } & \text { British Troops Northern Ireland } \\ \text { Capt. } & \text { Captain } \\ \text { Cav } & \text { Cavalry } \\ \text { CFI } & \text { Chief flying instructor } \\ \text { CID } & \text { Committee of Imperial Defence (UK) } \\ \text { COD } & \text { Council of Defence } \\ \text { COE } & \text { Corps of Engineers. } \\ \text { COGS } & \text { Chief of General Staff } \\ \text { COI } & \text { Court of inquiry } \\ \text { Col. } & \text { Colonel } \\ \text { Comdt. } & \text { Commandant } \\ \text { Chief of Staff }\end{array}$




\begin{tabular}{|c|c|}
\hline Coy & Company \\
\hline CP Sqn. & Coastal Patrol Squadron \\
\hline $\mathrm{CSO}$ & Chief Staff Office \\
\hline DCA & Director of Civil Aviation \\
\hline DEA & Department of External Affairs \\
\hline DF & Department of Finance* \\
\hline DF & Defence Forces* \\
\hline $\mathrm{DF}, \mathrm{D} / \mathrm{F}$ & Direction Finding* \\
\hline DF HQ & Defence Forces Headquarters \\
\hline DFR & Defence Force Regulation \\
\hline DMA & Director of Military Aviation \\
\hline DO & Dominions Office \\
\hline DOD & Department of Defence (Departmental Secretariat and General Staff) \\
\hline DS & Director of Signals \\
\hline DT & Department of An Taoiseach (Prime Minister) \\
\hline $\mathrm{EC}$ & Executive Council \\
\hline E. Comd. & Eastern Command \\
\hline FS & Fighter Squadron \\
\hline GHQ & General Headquarters \\
\hline GOC & General Officer Commanding \\
\hline GOCF & General Officer Commanding the Forces \\
\hline $\mathrm{HC}$ & High commissioner \\
\hline HQ & Headquarters \\
\hline $\mathrm{I} \& \mathrm{C}$ & Department of Industry and Commerce \\
\hline IFS & Irish Free State \\
\hline IRA & Irish Republican Army \\
\hline Lt., Lieut. & Lieutenant \\
\hline MA & Military Archives \\
\hline Maj. & Major \\
\hline Maj. Gen. & Major General. \\
\hline MAS & Military Air Service \\
\hline
\end{tabular}


MFD Minister for Defence

MFF Minister for Finance

MP Mulcahy Papers

MS Military secretary

OC Officer commanding

OPW Office of Public Works

NA The National Archives, Kew.

NAI National Archives of Ireland

NI Northern Ireland

NLI National Library of Ireland

RAF Royal Air Force

R \& MB Sqn. Reconnaissance and Medium Bomber Squadron

RFC Royal Flying Corps

R/T Radio telephony

SC School commandant

SC Signal Corps

S. Comd. Southern Command

$\mathrm{Sec} \quad$ Secretary

SIS Special Intelligence Service (UK)

Sigs Signal Corps

Sqn Squadron

QM Quartermaster

QMG Quartermaster General

UCDA University College Dublin Archives

W. Comd. Western Command.

W/T Wireless telegraphy

* The sense should be clear from the context. 


\section{LIST OF FIGURES}

Location map - Civil War

Location map - Emergency

$\mathrm{X}$ 


\section{LIST OF TABLES}

Table 10.1 Establishment and strength - R \& MB Squadron detachment, Rineanna.

Table 10.2 Establishment and strength - No. 1 Fighter Squadron, Baldonnell. 


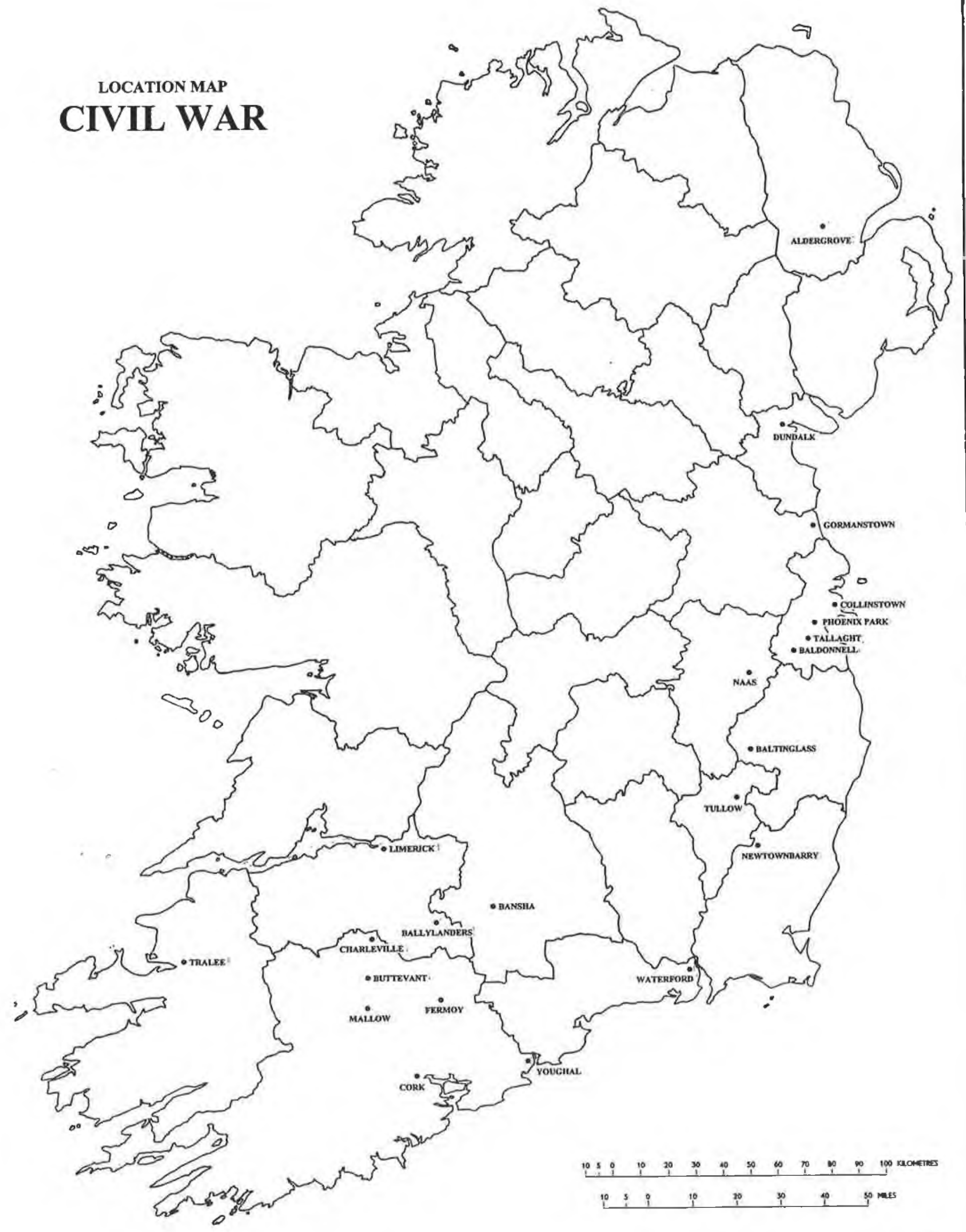




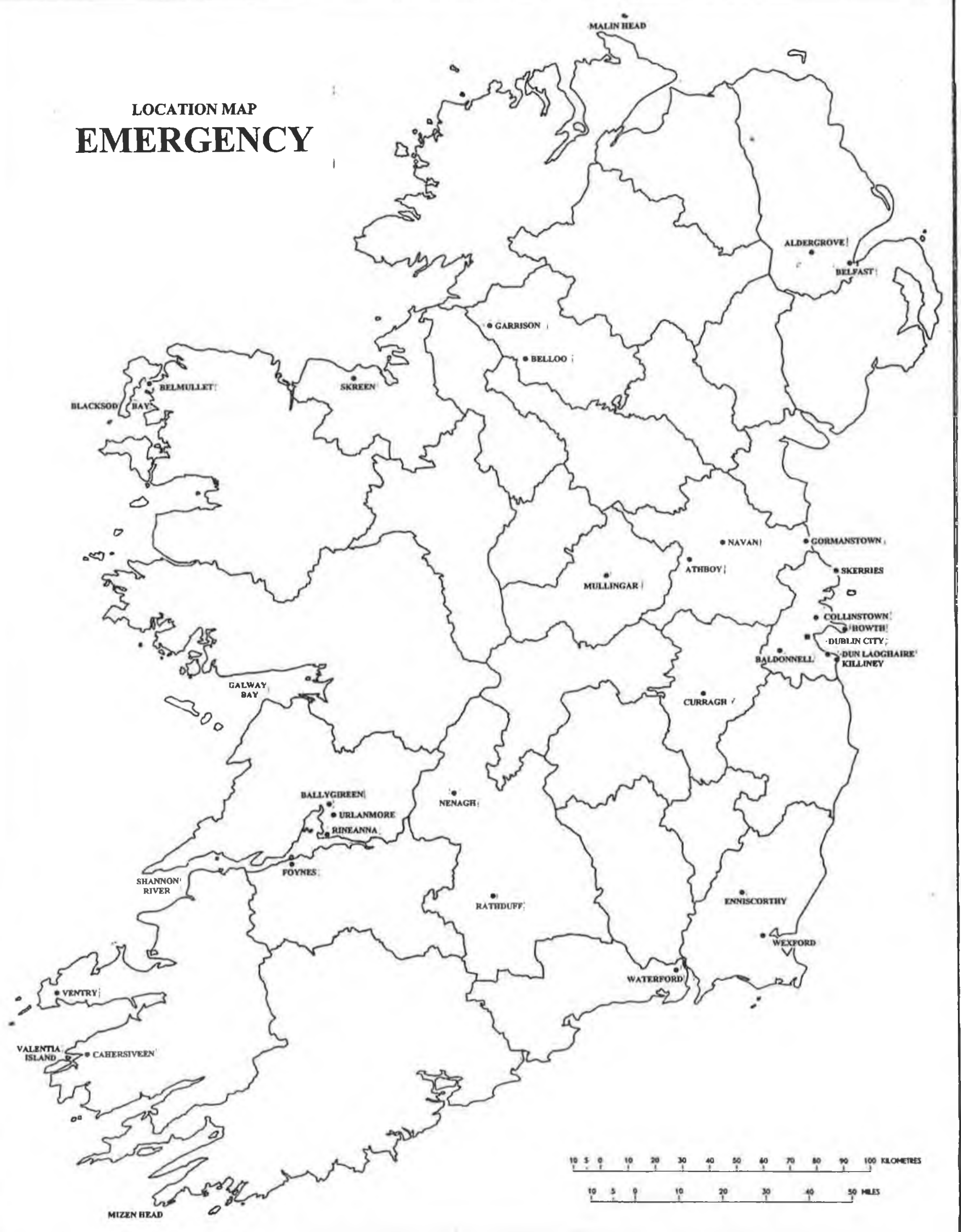




\section{CHAPTER 1}

\section{INTRODUCTION}

Until relatively recent times the study of the military and defence matters of the state has been very much a minority interest. With the establishment of Military Archives in 1986, and the release of increasing amounts of the more sensitive UK material, the years from 1990 have seen a significant upsurge in interest in the history of the early decades of the state. Inevitably greatest concentration has been on the period covering the War of Independence, the Civil War and the army mutiny, that is, 1919 to 1924 - in addition to the Emergency (1939 to 1945). Those major and minor works that do deal with aspects of military history very much concentrate on those aspects of the Defence Forces and defence policy that reflect the dominant army ideology and the precedence of the infantry ethos. In an infantry dominated Defence Forces the air element has traditionally constituted a very minor proportion of the personnel - about $10 \%$ at the maximum that pertained during the Emergency. Being perceived, in the two dimensional thinking of the Department of Defence and Defence Forces Headquarters, as being of much lesser military importance neither the state's air nor naval forces are represented by appropriately qualified staffs at DOD or the DFHQ. To a certain extent, reflecting this cultural imbalance, the main historical works of recent times have largely ignored air aspects of defence policy and practice.

To a major degree this imbalance in military historiography is a reflection of the cultural imbalance evident in successive Defence Forces handbooks and the manner in which the Air Corps has been presented. Produced and edited by a succession of Army officers these handbooks have generally presented a brief and somewhat simplistic and inaccurate picture of the history and heritage of military aviation. The most recent handbook (1988), in the course of a feature on the training schools of the Defence Forces, makes no reference to the Flying Training School that has been in existence at Baldonnell since 1922. Similarly no reference was made to the Air Corps Apprentice School that was set up in 1936, the fore-runner, by twenty years, of the Army Apprentice School. It is, however, considered that successive generations of Air Corps flying officers have been 
somewhat remiss in failing to foster a better historical awareness. Traditionally, flying officers, while progressive and up-to-date in professional and technical matters, have not been aware of or shown any great interest in their aeronautical past and roots. While it might be expected that a certain modicum of officers would have given a lead in the matter of the history and heritage of the corps, this has not been the case. With only a single exception to date the leadership of the corps have, in terms of historiography as in terms of projecting a unique military culture and ethos, remained meekly subservient to the dominant infantry culture of the forces. The resultant subjugation of the history of military aviation requires to be reversed by way of a comprehensive and objective study.

The first published general history of the Irish Army was just that - a history of the Army - as distinct from being a history of the complete Defence Forces. ${ }^{1}$ While Duggan's history purports to be inclusive of the Air Corps and Naval Service the occasional references to selected aspects of the two minor services only serve to illustrate the traditional irrelevance of air and naval matters in the overall scheme of things. It could be argued that this particular history attempted too much in a single volume and, as such, not only does it not do justice to air and naval matters, it does the Army no great service either. In paying lip service to the Air Corps Duggan reveals nothing new with the occasional interjection of a few well known facts. His opening remark, to the effect that 'the Air Corps sprung up spontaneously in 1922', sets the tone for a less than complete assessment of the military aviation of an infantry Army. ${ }^{2}$ He fails to identify the establishment of the Military Air Service on the authority of Michael Collins or the full extent and proper nature of its operational role during the Civil War. Similarly the activities of the Air Corps during the Emergency, particularly the roles of the operational squadrons are overlooked.

While O'Halpin's Defending Ireland is the most authoritative work on the subject of defence policy during the first eighty years of the State, it demonstrates some of the inadequacies that permeate both the major and minor literature insofar as it relates to military aviation. ${ }^{3}$ While one would recognize that aviation did not have a major role in the overall scheme of things in the National Anny of the Civil War period, this work does

\footnotetext{
'John P. Duggan, A history of the Irish Army (Dublin, 1991).

2 Ibid, p.108.

${ }^{3}$ Eunan O'Halpin, Defending Ireland: the Irish state and its enemies since 1922 (Oxford, 1999).
} 
not acknowledge the existence of military aviation in the form of the hastily and informally established Military Air Service (July 1922 to October 1924) or of the more legally based Army Air Corps, prior to 1932. O'Halpin, in the context of the ceremonial connected with the Eucharistic Congress of that year, makes inaccurate reference to 'a miscellany of Air Corps aircraft' that 'flew over Dublin in cruciform formation' as part of the Army's ceremonial function in connection with the Eucharistic Congress in June 1932. ${ }^{4}$ As appropriate to a small formation the six aircraft were all of the same type - the then recently-acquired Avro 631 Cadet training aircraft.

O'Halpin's treatment of the Air Corps and its functions in the benign Irish neutrality of the Emergency period is less than comprehensive. He confuses the 1939 peace establishment (April 1939) with the war establishment of May 1940 and gives no assessment of the personnel resources or their training. ${ }^{5}$ O'Halpin apparently overlooks the fact that the Corps' traditional role of army cooperation had been abandoned in favour of general reconnaissance, coastal patrol and fighter roles - all roles commensurate with a properly organised and equipped air force and, as was to be proved, quite outside the scope of the state's army aviation during the emergency. Similarly he did not mention that an Air Corps detachment had been sent to Rineanna, prior to the outbreak of war, for the purpose of maritime reconnaissance. ${ }^{6}$ While he recognised the lack of pre-war planning and the inadequacies of the various aircraft and their support, O'Halpin does not discuss the aviation ramifications of the air defence orders of the General Staff. And, while recognising that a 'woefully ill-equipped' Air Corps was of 'almost no operational use' during the Emergency he offers no explanation for the improbable air defence role assigned to No. 1 Fighter Squadron in $1940 .^{7}$

O'Halpin does note the aircraft recovery operation carried out by Air Corps for the benefit of the Allies. ${ }^{8}$ There was also the question of the refuelling and release of force-landed Allied aircraft and the military value thus provided to the UK and US. While mindful of the intelligence activities of the British air attaché he may not have

\footnotetext{
${ }^{4}$ Ibid, p.133.

¿ Ibid, p.154.

${ }^{6}$ W.J. Keane to OC S. Comd., 12 Apr. 1940, Appendix No. XXII, Report and findings of the committee, 10 Jan. 1942 (MA, ACS 22/23)

${ }^{7}$ Eunan O'Halpin, Defending Ireland: the Irish state and its enemies since 1922 (Oxford, 1999), p.154.

${ }^{8}$ Ibid, p. 155, citing Aiden Quigley 'Air aspects of the Emergency' in Irish Sword, xix, nos. 75 \& 76 (1993-4), p.89.
} 
appreciated the significant level of cooperation between the RAF and the Air Corps generated by the relationship between the attaché, Wing Commander Lywood, and Col. P.A. Mulcahy in 1940/42.

O'Halpin is very general in his observations on the proceedings, finding and recommendations of a very extensive and comprehensive report. ${ }^{9}$ While he rightly identifies unrest amongst Air Corps officers as a main reason for the inquiry of 1941 he does not discuss the fundamental reasons behind the unrest. O'Halpin's suggestion that 'the wartime experience of the Air Corps raised more questions than it answered about the practical value of the defence forces having an air arm at all' serves to illustrate a slightly incomplete understanding of the fact that the Air Corps had, in effect been placed on active service during the Emergency and given air missions for which it was neither prepared nor equipped. ${ }^{10}$ One must however recognize that O'Halpin, more than any other military historian, has achieved much in unravelling the rather elusive subject of defence policy. This subject had remained under-studied, and therefore undefined, up to the end of the twentieth century. In the context of a state with little or no concept of national defence, let alone air defence, his failure to identify an air policy can be understood. Similarly his relative lack of insight in to Air Corps wartime activities can be understood when one considers the extent to which Military Archives protects the material that it considers to be too sensitive for today's historians and students alike.

In a manner very similar to O'Halpin's, the major detailed study of the Civil War by Michael Hopkinson fails to reflect any aspect of the state's early military aviation and its role in the hostilities of the period June 1922 to May $1923 .{ }^{11}$ It may be that the author was aware of the purchase and the operation of aircraft for intelligence purposes, but considered their contribution to be irrelevant. However it might also be considered that the very deliberate action of Collins, in initiating a relatively small military air arm to conduct intelligence gathering activities, escaped the scrutiny of another historian of note. In his failure to perceive the first-hand involvement of Michael Collins in the state's first military aviation endeavours Hopkinson is not alone. He joins, or is joined by, many

\footnotetext{
${ }^{9}$ Proceedings of committee of investigation into the effectiveness, organisation, equipment, training and administration of the Air Corps, 10 Jan. 1942 (MA, ACS 22/23).

${ }^{10}$ Eunan O'Halpin, Defending Ireland, p.155.

"Michael Hopkinson, Green against green; the Irish Civil War (Dublin 1989).
} 
historians including Margery Forester, Tim Pat Coogan, Joseph Lee, Eoin Neeson, and more recently Peter Hart, who have studied Michael Collins and his times without detecting his considerable involvement with the early months of the country's civil and military aviation. It is of note that only one author dealing with the period, Meda Ryan, connects Collins and military aviation. In her case such matters were quite peripheral to her main thesis. ${ }^{12}$

The broad military and defensive ramifications of neutrality and of the interaction between British and Irish administrations during the Emergency period are elucidated in considerable and accurate detail by Robert Fisk. ${ }^{13}$ This seminal work on the political, diplomatic and military aspects of the Emergency cannot be faulted in the manner in which the author demonstrates how Eire survived the travails of the Emergency at a considerable cost to its political, military and diplomatic reputations. It must be appreciated that this work was researched and written before some of more sensitive material relating to Anglo-Irish relations, during the period 1938-1945 period, was made available at The National Archives, Kew. It was also prior to the National Archives Act, 1986 that established (Irish) Military Archives on a regulatory basis. At Military Archives Fisk only got access to carefully selected material which he cites as confidential Dublin sources. Access to the more sensitive material, still selectively retained from public scrutiny, would have allowed Fisk to better document the considerable cooperation between the military forces, north and south. While his understanding of the overall military situation in Eire was comprehensive, his comments on Air Corps matters were less incisive. In common with others he noted the wide range of inadequate aircraft and the general powerlessness of the air arm. He also comments on the aircraft recovery operation and the value to the Allies represented by the early repatriation of aircrew. However, also in common with others, and not unconnected with poor access to military records, both the unplanned and ill-prepared tasking of the Rineanna detachment and Fighter Squadron's ill-advised role in the defence of Dublin, escape his attention.

While his work reflects the fullest possible research of the material then available Fisk suggests that the public records that survive for the Emergency represent only a

\footnotetext{
12 Meda Ryan, The day Michael Collins was shot (Swords, 1994), pp 24-55.

${ }^{13}$ Robert Fisk, In time of war; Ireland, Ulster and the price of neutrality 1939-45 (London, 1983).
} 
fraction of that which should pack the shelves of the archives in Ireland. The statement that 'in 1945, the Irish authorities shredded about seventy tons of documents which were considered too sensitive for the scrutiny of historians' suggests that the full truth of the 1939 to 1945 period will probably never be known. One wonders was Fisk being too generous to the memories of de Valera and Aiken when he credits the 'authorities' with this apparently premeditated destruction. ${ }^{14}$

While not strictly a work of historical record one must comment on Donal MacCarron's book on Irish military aviation, Wings over Ireland, principally because it is the only substantial one that purports to tell the story of the Air Corps (for the period 1921 to 1996). ${ }^{15}$ While MacCarron tells the story of Irish military aviation it appears not to be based on broad research of the primary material. It is not comprehensive enough in its scope and is lacking in critical analysis. It is understood that much of the text covering the early years derives from informal interviews with some of the principals conducted in the latter years of their lives. As a result the story for the period of my interest, 1921 to 1945, is largely apocryphal and anecdotal and, being based on fading memories and inadequate research, somewhat imprecise. This book over-concentrates on accidents, mishaps and other incidents, and technical minutiae much loved by aircraft enthusiasts and not appreciated by the serious academic. While much more extensive and detailed in its coverage of the story of military aviation than any other, it is nonetheless lacking as a secondary source due to the absence of notated research of primary sources and adequate identification and acknowledgement of the secondary works reflected in the text.

Possibly the only article published in an academic journal and totally concerned with an aspects of the history of the State's military aviation is Aidan Quigley's in the Irish Sword of 1993-94. ${ }^{16}$ While this work does highlight and detail some of the personnel, training and equipment difficulties of the Emergency Air Corps, it does not identify the reasons for the lamentable lack of policy and preparation. Neither does the author identify the cultural chasm between the Army and the Air Corps that should have been obvious at the time. He did not detect the relationship that developed between his artillery corps commanding officer and the British air attache and the resultant close

\footnotetext{
${ }^{14} \mathrm{Ibid}, \mathrm{ix}$. This is the only substantial statement of fact the source of which is not cited by Fisk.

${ }^{15}$ Donal MacCarron, Wings over Ireland; the story of the Irish Air Corps (Leicester, 1996).

${ }^{16}$ Aidan Quigley, 'Air aspects of the Emergency' in Irish Sword xix, nos. 75 \& 76 (1993-94), pp 86-90.
} 
cooperation with the RAF. As the author was a very young Air Corps flying officer at the time his paper is somewhat influenced by a junior officer's perception of the rights and wrongs of the time and as such lacks a certain balance.

A significant difficulty arises in considering the much-admired Encyclopaedia of Ireland (2003), as a reference work, in the context of its coverage of military aviation. In common with the Land Commission, possibly the most important institution in the context of the agricultural economy and the modern social history of the Irish state, the Air Corps has been omitted from this work that purports to represent a comprehensive over-view of Irish development since earliest times. Against this background one wonders what inference to take from the exclusion, or indeed inclusion, of a particular subject, institution or individual. On the one hand the Royal Flying Corps / Royal Air Force, in Ireland for much of the time between September 1913 and the end of 1922, warrant an appropriate entry. So also do a select few 'Irish aviators' who served with the RFC / RAF in the two world wars. However the Air Corps is not listed in the subject index under either 'aviation' or 'military' and is only mentioned in passing in other aviation related entries. Baldonnell, the state's civil airport from 1919 to 1940, the Air Corps main base since May 1922 and the aerodrome with the longest record for continuous aviation activity on the island, is similarly ignored. Baldonnell is also omitted from a political map of Ireland that places a civil airport in the North Slobs of county Wexford. ${ }^{17}$

In Irish military historiography there are very few works that examine, in a critical yet balanced manner, aspects of the ideological approach of the Army leadership to the country's defence. Theo Farrell's paper properly questions the military thinking of the 1930 s that put a premium on the necessity to form a massive conventional defence force for the protection of the country against possible British invasion. ${ }^{18}$ While the work does not relate specifically to preparations for air defence, it goes a long way to explaining the rationale behind Col. M.J. Costello's grand plan (March 1938) for an air force of ten operational squadrons that, one presumes, was to be the air element of such a defence.

\footnotetext{
${ }^{17}$ Brian Lalor (Ed.), The enlyclopaedia of Ireland (Dublin, 2003), xxxiv.

${ }^{18}$ Theo Farrell, 'Professionalization and suicidal defence planning by the Irish Army, 1921-1941' in Journal of strategic studies 21 , no.3 (September 1998), pp 67-85.
} 
Bearing in mind the paucity of work on the state's military aviation, tremendous scope exists for the examination and elucidation of a subject virtually unknown to researchers and academics. The early section will aim to explain, for the first time, the genesis of the state's aim to establish a civil air service as early as 1922. Similarly the purchase of aircraft, on Michael Collins' authority during the treaty negotiations, will be examined in the context of civil and military aviation contingencies anticipated by Collins and his air advisor, C.F. Russell, a former RAF pilot officer. The formulation of a civil air policy, by Russell but with Collins' authority and backing, in the first half of 1922 was to lead to the establishment of a small civil aviation department in the Army. This department, however, was to give way to military aviation after the outbreak of hostilities. Also for the first time the purchase and operation of military aircraft, for intelligence purposes, will be assessed in the context of Collins' need for information on the disposition and activities of the Irregulars during the first months of the Civil War. By virtue of his actions Collins, in effect, established the Military Air Service that was to become the Air Corps in October 1924. The decisions and events of the period from July 1921 to August 1922, relating to civil and military aviation, casts light on an aspect of Collins' leadership and foresight that has escaped the attention of the country's historians heretofore. Similarly the use of aircraft, for intelligence purposes during the Civil War, adds a dimension to that campaign that has not previously been considered.

The threat to the future of the Air Service immediately after the Civil War and the efforts made to discharge its ex-RAF pilots will be assessed in the context of demobilisation, the reorganisation of the Army in 1923/24 and the trauma of the army mutiny of 1924. It will be seen that army aviation survived this period despite the ambivalence of the minister, Richard Mulcahy and of the antipathy of an anti-British clique of army officers. These aspects of the formative years of the Defence Forces have not previously been identified or studied. The survival of army aviation in the period coming up to the Emergency will be examined in the absence of defence policy and in the context of the government's continuing preference for civil aviation demonstrated by the establishment of Aer Lingus and of the meteorological, air traffic control and aeronautical communications services in 1936. 
My study of the contacts, between Irish civil service and military, and their UK counterparts, will demonstrate a considerable degree of cooperation between the two administrations in the matter of preparation for war. It will be suggested that this cooperation started at about the time of the return of the Treaty ports and continued, particularly at a military level, throughout the Emergency. There is new evidence that, as part of this cooperation, de Valera's administration was guided by the UK in preparing for the outbreak of hostilities by being supplied with several key war planning documents. The role that this cooperation and guidance played is illustrated by the nature of the passive defence strategy, developed by de Valera's government, but apparently based on British advice on censorship, petrol rationing, intelligence and other preparatory actions commensurate with such a passive defence strategy. This concept, that the British had a greater influence over Irish defence strategy than had the Irish military, has not previously been postulated. In the matter of pre-war military cooperation the role of Col. Liam Archer, acting under de Valera's specific, but unknown, instructions is identified. Several hitherto unknown meeting between Archer and UK officials or military officers suggest de Valera's personal oversight of both pre-war and wartime military cooperation with Britain.

The government's defensive strategy for the Emergency, based almost exclusively on passive defence measures, has not previously been identified in the surviving records. At the same time the Army will be seen to have adopted a contradictory position based on a major conventional force consisting of a much enlarged army and a significantly expanded air force. In the absence of aviation historiography the extent of the Army's ambitious plans for military aviation have not previously been recognised and studied. It will be argued that a grossly ineffective Air Corps resulted from the inability of the higher authorities - government and Department of Defence, to coordinate defensive plans and make the necessary preparation. It will also be suggested that aerodrome support services to military aviation such as meteorology, air traffic control and communications developed in a haphazard fashion that contributed to the ineffectiveness demonstrated during the Emergency. 
This work relies almost exclusively on primary sources, the vast majority of which appear not to have previously been visited by historians of any ilk - aviation, military, social or political. Accessing these sources has not represented any major initiative on my part. As I have observed in the past it was merely a matter of searching the appropriate major archives and being rewarded with a considerable quantity of material of the highest quality. One can only wonder why more of the sources are not already reflected in secondary works.

When Richard Mulcahy (1886 - 1971) left the positions of minister for Defence and commander-in-chief in April 1924 he had the good sense to take with him all the material relating to the early military affairs of the State. Whether this action was to safeguard this historic material or the reputations of himself and his pro-Treaty comradesin-arms is immaterial. While he may possibly have carried out some tidying up subsequently, this material eventually became available for research purposes having been deposited in the UCD Archives in 1972. This microfilmed material, the Mulcahy Papers, is possibly the single most important source for the history of the early Defence Forces. It is also essential to an understanding of the events and influences that brought about the Military Air Service in 1922. While much of the aviation material is concentrated on a single microfilm a trawl of the entire collection was required due to inadequate collating and cataloguing. The essentially air material includes much correspondence between the Air Service and Michael Collins in July and August 1922. Also included is material concerning aircraft purchase, the hiring of pilots and the organisation of reconnaissance operations during the Civil War. Some later material, mainly on administrative and supply matters, relate to the period from September 1922 to April 1924 when Mulcahy was in charge.

The MacEntee Papers, also in University College Dublin Archives, relate to prewar Army, including aviation, planning and include material that helps to explain the contradiction between what Theo Farrell termed the suicidal planning of the Irish army in the lead up to the Emergency and the passive defence strategy actually adopted by the government. 
The files of National Archives of Ireland, particularly the early Department of Finance files, those of the Taoiseach's office and Finance's supply files (DF S) provide some details of policy and financial decisions having relevance in the area of the state's military aviation. While a complete picture of policy and financing does not emerge some select subjects are illuminated. A relatively small number of the Department of An Taoiseach (DT S.) files relate to matters concerned with civil aviation policy. A single file, relating to the purchase of the state's first two aircraft in 1921 and to proposals for the development of civil aviation between 1921 and 1932, provides a detailed exposition of the emphasis of Michael Collins, and the first administration, on the concept of establishing a civil air service to the United Kingdom or to Europe in 1922. The file demonstrates that, while a civil aviation department had been set up by April 1922 the worsening military situation caused such matters to be put on the long finger The later material, from 1924 to 1932 , explains the continuing desire of the early administrations to foster civil aviation - something that had not transpired before the 1932 change of administration. A continuous thread was the perception of the Air Service / Air Corps, not as an instrument of defence policy, but rather as the nucleus of a civil air service. Mainly it was seen as the source of technical and professional personnel and support that would be the foundation on which a civil air service might be established.

A small number of early Finance files reflect some of the business transacted with the Aircraft Disposal Company in 1922/23 and facilitates an assessment of costs associated with early aircraft purchases. The Department of Finance supply files, because they generally deal with new or unexpected, as distinct from the annual recurring, expenditure are far from comprehensive in their scope. However these files, provide an overview of decisions of greater and lesser importance that demonstrate the total control exercised by Finance over defence policy on the basis of generally miserly amounts of money. Individual files deal with expenditure varying from the complete defence estimates for a given year (one to two million pounds) to authority for minor unexpected expenditure as small as ten shilling. A 1924 file affords a considerable insight into the start of the cadet scheme for Air Corps pilot officer recruitment and training. In particular the suspicious attitude to the infantry, towards potential pilots from outside the Army's realm of influence, is revealed. A similar file, covering the establishment of the short 
service pilot scheme in 1939 indicates that this scheme was basically established for the benefit of Aer Lingus and civil aviation after the Emergency rather than immediate pilot requirements. A 1939 file, dealing with the construction of an aircraft hangar at Rineanna (Shannon), helps to underline the precedence of expenditure on civil aviation over that of military aviation and the total lack of preparation for even a modest expansion of military air facilities in the run-up to the Emergency.

Military Archives holds the greatest bulk of material relating to military aviation (and to early civil aviation) considerations. The early Department of Defence series of files includes a small number dealing with the early months of the Air Service and in particular cover the purchase and delivery of Bristol Fighter aircraft in July and August 1922. With most of the other aircraft purchases of 1922 and 1923 also detailed these files provide a detailed insight into the start of the early air operations. While the collection of Air Corps files is far from complete some insight is provided into aircraft purchases, pilot recruitment and training, and organisation and establishment. Being mainly administrative in nature these files hold little relating to the policy and practice in military aviation. The DOD 2 Bar files, mainly supporting plans and proposals for which financial sanction would be required from the Department of Finance, represent DOD decisions on such matters as aircraft purchase and the recruitment and training of pilot officers.

The Emergency Plans Division material, representing the documentation produced by GHQ plans and operations staff during the Emergency, casts some light on the role of Fighter Squadron in 1940-41. In general the material is confusing due to inadequate collation and dating that precludes an adequate assessment of the chronology and development of the plans.

The single most important source in Military Archives is the proceedings and report of the investigation held in 1941. On completion on 10 January 1942 it appears to have been strictly limited to circulation within GHQ. There is no indication that the Air Corps received a copy. A 1942 memorandum by Major W.P. Delamere suggests that, at or about the time he was appointed officer commanding Air Corps, he was allowed examine the report. However he was only given sufficient time to read the findings and 
recommendations of the committee before making his observations. ${ }^{19}$ While the report and its findings have been commented upon very briefly by both Aidan Quigley and Eunan O'Halpin, no one heretofore appears to have studied it in depth and made an assessment of the conduct of the investigation and of the report and findings of the committee and its recommendations.

As befits such a voluminous report I intend to provide the first complete and objective appraisal of the report and the manner in which it was conducted in order to assess any bias or prejudice that may have existed. The report and proceedings consists of one report volume with annexes, three volumes of witness evidence and a further volume of appendixes. The investigation was, in effect, into the demoralised state of the Air Corps following the collapse of its operational capacity due to inappropriate and illequipped aircraft and inadequate supplies of spares in the early Emergency. The evidence given, supported by appendixes representing many policy-related documents not available elsewhere, gives considerable insight into the effectiveness, equipment, training, and general management of the Air Corps from 1935 and earlier. As a source that could support several doctorates it would be difficult to overestimate its importance in terms of discerning the exact circumstances that contributed to the mismanagement of the country's small air arm at a crucial time.

Arising out of my service in the Air Corps and a twenty-year interest in its history I have a personal collection of a small amount of material that aids my understanding of some of the main themes that I cover. Of particular relevance are files on meteorology, since 1924 and Air Traffic Control since 1935. I have been fortunate to acquire original copies of the early General Routine Orders (1922/23) and Staff Duty Memos (1923/24) that are essential to detailing the hiring and firing of officers in 1922 to 1924 . Original copies of the Air Corps establishment tables issued in 1924, 1931/32, 1934, 1937, 1939, 1940, 1943 and 1946 are essential to an understanding of the ever-changing organisation and structure of a very small corps. Complementing the establishment tables, I have acquired many nominal rolls showing the appointments of individual officers at various junctures. While some are undated cross-reference with the known dates of changes in establishments, and other events helps to establish the relevant dates reasonably

19 'Memorandum of discussion with the COS', 30 Dec.1942 (MA, EDP/24/2/1). 
accurately. The original organisation charts and nominal rolls of the Air Corps' flying units, apparently produced by the squadron commanders for the start of the investigation in January 1941, capture the exact disposition of personnel and aircraft at a critical juncture in the history of the Air Corps.

I was also fortunate to acquire, from Lt. Col. Jim Teague on his retirement in 1981, his private material relating to aircraft accidents from 1923 to 1978. The information, displayed only in tabular and graph form, demonstrates the correlation between aircraft flying hours and flying accidents. In particular it emphasises the inordinate incidence of flying accidents in the years 1936 to 1942 and the total number of aircraft written off during that period.

The National Archives at Kew hold a significant number of files dealing with military aviation matters in Ireland. The earlier material, the Air files covering aspects of the supply of the first Bristol Fighters in 1922, correspondence relating to the RAF withdrawal from Ireland and reports on aspects of the Air Service then being formed, all complement very well the Mulcahy Papers (UCDA), the early DOD files in Military Archives and the National Archives file on the development of civil aviation. The combination of the material from UCDA, National Archives, Military Archives and The National Archives greatly elucidates early developments in both civil and military aviation.

A small number of Air files give a flavour of the intelligence activities of the British air attaché in Eire in 1940/42 and of the exchange of assistance between the Air Corps and the RAF - particularly from 1940 to 1943. Less relevant, in the Air Corps context, are the many Air, Dominions Office and Cabinet files that detail the considerable level of staff planning and preparation carried out by the RAF in anticipation of being called upon to counter a German invasion of Ireland. Dominions Office and Cabinet files help to illustrate the nature of cooperation established between the two countries in preparation for the Emergency. In this respect they complement similar material in Military Archives. These files also support the contention that Col. Liam Archer was a frequent visitor to the UK prior to September 1939 and had a key role in the military cooperation between the two countries before and during the Emergency. 
I do not consider that there is any unusual aspect to the manner in which this subject has been researched or presented. Having served in the Air Corps from February 1961 to August 1999 I have had the distinct advantage of being trained in, and absorbing, the aviation culture and of meeting and serving with a few of those officers mentioned. I am however aware that familiarity with the people, the subject and the folklore could effect objectivity and have thus tried to strike a balance in the way that I perceive the decisions, actions and events of the first twenty-five years of the state's military aviation. 


\section{CHAPTER 2}

\section{'CIVIL AVIATION - DEVELOPMENTS IN SAORSTÁT ÉIREANN' 1}

The Defence Forces of today, consisting of army, air and naval elements, are officially designated as Oglaigh na hÉireann which traces its lineage and name back to the formation of the Irish Volunteers (Oglaigh na hËireann) at a meeting held in the mansion house on 25 November $1913 .^{2}$ Only partially quoting, but not citing, the aims of the Irish Volunteers, John P. Duggan describes this first Irish army as a 'volunteer force, a people's army formed to secure and maintain the rights and liberties common to all the people of Ireland without distinction of creed, class or politics'. ${ }^{3}$ However the Irish Republican Army that fought a guerrilla campaign in 1919-21 with the aim of ending British occupation and rule did not greatly reflect such lofty ideals. The Anglo-Irish War was 'characterised by guerrilla warfare, ambushes, raids on police barracks, and planned assassinations' on the part of the IRA and 'reprisals, the shooting-up and burning-up of town, executions and terrorising' on the part of the British forces. ${ }^{4}$ With the Anglo-Irish truce of July 1921 and the Treaty of December 1921 political differences caused divided loyalties that were to culminate in civil war by June of 1922 . The anti-treaty element of the IRA was to be termed the 'Irregulars' by the pro-treaty element which itself evolved to become the National or Free State Army backing the provisional government.

While the there was a significant RAF presence in Ireland during this IRA campaign, armed military aircraft were not to play a significant role. Royal Flying Corps aircraft had originally been deployed in Ireland as early as August / September 1913 when a detachment of five aircraft of No. 2 Squadron, with the requisite ground support personnel and equipment, was dispatched to Rathbane in Limerick to support the British

\footnotetext{
${ }^{1}$ Title of file (NAI, DT, S.4002).

${ }^{2}$ Defence Act 1954; Irish Defence Forces handboor(1968), p.1.

${ }^{3}$ Irish Defence Forces handbook (1968), p.1; John P. Duggan, A history of the Irish Army (Dublin, 1991), p. 1.

“Donal McCartney, 'From Parnell to Pearse (1891-1921)' in T.W. Moody, F.X. Martin (eds), The course of Irish history (Cork, 1984), p. 311.
} 
military manoeuvres in Munster. ${ }^{5}$ From May 1917 a major expansion in the number of squadrons, training new pilots to support the RFC aspect of the British war effort, brought about the selection of numerous aerodrome sites in Britain and Ireland. Sites for four substantial aerodromes were found in the general vicinity of Dublin. Starting about November 1917 training depot stations were built at Baldonnell, Cookstown or Tallaght, Collinstown (county Dublin) and Gormanston on the coast of county Meath. However with the armistice of November 1918 the nascent training regime was wound down, before it had gotten fully established and organised, and most personnel had been demobilised by February $1919 .{ }^{6}$

At various junctures during the Anglo-Irish war seven flights from 2 Squadron and 100 Squadron RAF occupied the major aerodrome at Baldonnell, the airfields at Fermoy, Castlebar and Oranmore as well as landing grounds at Athlone and Birr though an RAF presence was not continuous at all locations. As early as 1919 in the context of exercising military control in Ireland the viceroy had recommended to Lloyd George that aircraft should be deployed to strongly defended aerodromes so that patrolling by aircraft armed with bombs and machine guns would counteract the military activities of Sinn Fein. Seven flights of No. 2 and No. 100 Squadrons, RAF, mainly equipped with Bristol Fighters, were dispersed throughout the country during the 1919 to 1921 period. However, the government initially did not permit the aircraft to use bombs or machine guns mainly because of the difficulty of identifying, from the air, civilian-clad irregular soldiers operating amongst the general population. The greatest opposition to the use of armed aircraft came from Major General Sir Hugh Trenchard who opposed their use unless a state of war had been declared. ${ }^{7}$ Even though permission was granted in March 1921 to arm the aircraft caution dictated that 'the only real use which the Army found for the RAF was in transporting senior officers and in running an air mail service once the roads and ordinary mails had become dangerous'. ${ }^{8}$ Townshend asserts that the utility of RAF aircraft was limited due to the lack of communications with base or ground forces.

\footnotetext{
${ }^{5}$ Karl E. Hayes, A history of the Royal Air Force and the United States Naval Air Senvice in Ireland 1913 1923 (Irish Air Letter, 1988), pp 3-5.

${ }^{6}$ Ibid, pp 7-17.

${ }^{7}$ Patrick J. McCarthy, 'The R.A.F. and Ireland 1920-1922' in Irish Sivord xvii, no. 68 (1989), pp 174-88, passim.

${ }^{8}$ Charles Townshend, The British campaign in Ireland 1919-1921(Oxford, 1973), p. 171.
} 
He also suggested that the fact that "nothing was done to create air camps or increase the number of landing grounds' had contributed to a lack of effectiveness. ${ }^{9}$ However the listing of the many RAF facilities available would suggest that aerodrome infrastructure was not wanting. In addition to the four training depot stations there were four other class 'A' aerodromes - Fermoy (Cork), Omagh (Tyrone) Oranmore (Galway) and Aldergrove (Antrim). They also had forty-three class ' $B$ ' and ' $C$ ' airfields. In addition they had the use of over sixty sites, many on the landed estates of the Anglo-Irish gentry, generally located near a military or Royal Irish Constabulary barracks. These were marked with a large cross and were designated and listed as landing grounds. ${ }^{10}$ Townshend, citing the future Field Marshall Montgomery (Brigade Major, $17^{\text {th }}$ Brigade, Cork) as saying that the RAF aircrews knew nothing about the war, suggests that 'a more imaginative approach by the Army might have yielded different results'." Notwithstanding the caution exercised in the operation of military aircraft, the RAF lost a small number to IRA fire. Most of the losses resulted from opportunist attacks on individual aircraft involved in the delivery of military mails in the south western counties. ${ }^{12}$ With the signing of the Treaty in London on 6 December 1921 and its subsequent ratification by the Dail (Irish parliament) in January 1922 the two squadrons of RAF began withdrawing from Ireland. While 100 Squadron was withdrawn from Baldonnell in early February 1922 an 'Irish Flight' of four Bristol Fighters was formed there in April 1922 and operated in support of British army units withdrawing from Ireland. The Irish Flight operated from Collinstown from early May 1922 before moving to Aldergrove in Northern Ireland on 29 October 1922 and being disbanded from 1 November 1922. ${ }^{13}$ The Irish Flight had vacated Baldonnell on 3 May 1922 at the request of the Provisional Government who wanted to have it run as a civil airport. ${ }^{14}$

In terms of civil aviation Ireland was somewhat of an aeronautical backwater. The country had no aircraft manufacturing capacity other than the very limited efforts of

\footnotetext{
${ }^{9}$ Ibid, pp 170-71.

${ }^{10}$ [RAF, List of aerodromes], SO Book 122; Capt. C.H. Pixton, 'Complete List of Landing Grounds Ireland', Army Book 129 (in my possession). The contents of these undated reference books suggest that the period from late 1917 to late 1922 is covered.

11 Townshend, British campaign, p. 171.

12 Hayes, RAF and USNAS in Ireland, pp 50-57.

${ }^{13}$ Ibid, pp 60-65.

14،Minutes of Civil Aviation Department' meeting, 23 Mar. 1922 (NAI, DT, S.4002).
} 
enthusiastic amateurs while a significant sports aviation event had taken place on Leopardstown Racecourse as early as August 1910. ${ }^{15}$ The fact that the U.K. Civil Aviation Act, 1918 did not apply to Ireland reflected the paucity of aviation activity on the whole island of Ireland at this juncture. It was to be 1936, coinciding with the beginning of a state sponsored air service by the newly formed Aer Lingus, before primary legislation was passed by the Dail to provide for the regulation of civil aviation. 16 From 1919 Baldonnell Aerodrome functioned as Dublin's civil airport for the occasional aircraft that crossed the Irish Sea - a function that would continue under the new administration from May 1922 to January $1940 .{ }^{17}$

Against this background the Anglo-Irish Treaty of 1921, in addition to providing for Britain retention of the naval ports at Cobh, Castletownbere and Lough Swilly, provided for the installation of military aviation facilities in their vicinity if so required by British coastal or maritime defence considerations. The treaty also provided that 'a convention shall be made between the same governments for the regulation of civil communication by air'. ${ }^{18}$ The various accounts of the early days of Irish aviation cite the purchase of a passenger aircraft during the treaty negotiations in London as the first event in the history of the state's military aviation. These accounts also suggest that the aircraft was specifically purchased in order to facilitate an expeditious departure for Michael Collins and the other plenipotentiaries should the treaty negotiations fail. ${ }^{19}$ While this version of events is accepted in the mythology of Irish aviation and, though it is based on a personal recollection of an officer on the fringes of the treaty negotiations, it will be seen that the myth falls well short of the complete story.

The main aim of this opening chapter is to identify and examine the aviation connotations, military or civil, of the peace and treaty negotiations, as well as the personal position of Collins in such matters. These aspects are important in the context of identifying indicators of a future aviation policy. Key considerations will be establishing the motives behind the decision to purchase not one, but two aircraft, during the treaty

\footnotetext{
${ }^{15}$ Madeleine O'Rourke, Air spectaculars; air displays in Ireland (Dublin 1989), p.17.

${ }^{16}$ Air Navigation Act, 1936.

${ }^{17}$ Baldonnel; Dublin's civil airport 1919 to 1939 (Irish Air Letter, 1989), passim.

${ }_{18}$ Annex to 'Articles of agreement for a treaty between Great Britain and Ireland', 6 December 1921.

${ }^{19}$ Liam Byrne, History of aviation in Jreland (Dublin, 1980), p. 52; Donal McCarron, Wings over Ireland; the story of the Irish Air Corps (Leicester, 1996), p. 11.
} 
negotiations and to establish the full circumstances of same. Detailing the specific roles of Michael Collins and Charles F. Russell in the formulation of the state's first aviation policy and the precise intent of that policy in relation to establishing a civil air service is one of the main objectives of this chapter.

\section{Peace negotiations}

Following the truce of 9 July 1921, that marked the cessation of hostilities between the IRA and the British forces in Ireland, the latter half of that year was dominated firstly by peace negotiations carried out at arms length and, later in the year, by the bi-lateral negotiations carried out in London that lead to the Treaty of 6 December 1921. It was during these two negotiating phases that the initial concepts of Irish defence and aviation began to be formulated. An early British paper put considerable emphasis on the strategic position of Ireland.

The position of Ireland is also of great importance for the air services, both military and civil. The Royal Air Force will need facilities for all purposes that it serves; and Ireland will form an essential link in the development of air routes between the British Isles and the North American continent. It is therefore stipulated that Great Britain shall have all necessary facilities for the development of defence and of communication by Air. ${ }^{20}$

This and similar conditions, including a requirement that the new state contribute financially to the army, naval and air defence of Great Britain prefaced a negotiation process that, in terms of defence, greatly emphasised Britain's strategic requirements. At this early stage the Irish, particularly Erskine Childers still held out hopes of creating 'a gradually expanding, as finance allowed, modest naval force purely for coastal defence and reconnaissance' being able to slowly develop a small naval capability. Eventually recognition of the precedence of Britain's strategic needs combined with the financial

\footnotetext{
${ }^{20}$ Enclosure, 'Proposals of the British Government for an Irish settlement', David Lloyd George to Eamon De Valera, 20 July 1921, in Ronan Fanning (ed.) Documents on Irish foreign policy, i, 1921-1922 (Dublin, 1999), p. 237.
} 
impracticality of the proposition put the matter of an Irish naval force on the long finger. In regard to 'army and air' Childers suggested:

It is no doubt agreed that we should maintain an army with a small standing force highly disciplined and well-equipped, and a wider reserve; with a strategic organisation based on the idea of rapid concentration for coastal defence. A small air establishment disposed on the same principle, specialising in coast reconnaissance and perhaps in anti-submarine and commerce protection work. ${ }^{21}$

This modest proposal was quoted in the context of a British statement laying down a condition that Ireland contribute militarily and financially to the common defence requirements of Britain and Ireland. In consideration of aviation matters initial British concerns were totally selfish. They claimed that Ireland's geographic position was of great importance in the context of British 'military and civil air services' and 'that Ireland will form an essential link in the development of air routes between the British Isles and the North American Continent'. ${ }^{22}$ Childers proposed that the condition 'that Great Britain shall have all necessary facilities [in Ireland] for the development of defence and communications by air' be opposed on the basis 'that Atlantic reconnaissance and antisubmarine work can be done by her by other means'. The proposal to continue to have Royal Air Force stations in Ireland was rejected on the basis that their only possible use would be against Ireland. ${ }^{23}$ The provision of facilities for British civil and military aviation in Ireland did not feature in the Treaty eventually agreed and signed. However the initial civil aviation considerations, particularly that regarding future transatlantic air travel, is of interest in the context of the later development, by the Irish Government, of the flying boat base at Foynes and the nearby land aircraft base at Shannon. Foynes and Shannon would be developed prior to and during the Second World War - many years

\footnotetext{
21 'Memorandum by Erskine Childers on Irish defence as affected by British proposals of 20 July 1921', July 1921, Fanning (ed.), Documents on Irish foreign policy, i, 192 -1922, p. 239.

?2 Enclosure, 'Proposals of the British government for an Irish settlement', 20 July 1921, David Lloyd George to Eamon de Valera (London), in Ronan Fanning (ed.), Documents on Irish foreign policy, i, 19211922, p. 242.

${ }^{23}$ Memorandum by Erskine Childers, July 1921, Ronan Fanning, Documents on Irish foreign policy, i, 1921-1922, p. 239.
} 
before Irish commercial aviation had any use for facilities that would be of considerable benefit to the Allies during the 'Emergency'.

While the Irish peace negotiators in July 1921 were anxious to minimise, if not eliminate entirely, all aspects of the British military presence in Ireland and to negate the perception of any Irish obligation to contribute to Britain's military defence, it is doubtful if they had any defined concept of airspace or air defence. The preference in the peace negotiations, expressed as an overall defence policy was to stand alone 'with complete independent control of our own territory, waters and forces' suggests that military aviation was not identified as a separate consideration in the defence of the country. However the statement that 'we must be clear as to what our naval and military policy would be' could be interpreted as including aviation - on the basis that the term 'military' would include army and air in the early years of military aviation. ${ }^{24}$ The Irish policy position conceded that while naval defence was the essence of a country's defence, it would take some time to build up even a minimal capability. In the absence of air and naval defence the Irish policy position could be construed to suggest that greater defence was afforded by the absence of British forces. It was in effect an early admission that the new state would not be able to defend itself in naval and air terms and that in time of threat the erstwhile enemy would become an ally and defender.

\section{Treaty negotiations}

The first indication of an ideological environment conducive to the development of civil and military aviation in the new state came about during the Treaty negotiations in London in the autumn of 1921. The matter of military aviation in particular was approached by the British side in a manner similar to the policy adopted in regard to the retention of the ports and certain naval facilities, though examination of the accounts of the informal meeting of the defence groupings suggests that the British did not approach the discussions on aviation with a well thought out and unified position. The RAF was not represented at the initial meeting of the sub-group dealing with defence matters which was called to discuss the naval and air aspects of concern to both sides. However the

\footnotetext{
24 Ibid.
} 
opening British position was that Ireland would not be permitted either naval or air forces and that both functions would remain British responsibilities with Britain's defence requirements as the priority. ${ }^{25}$

At a later meeting Marshal of the Royal Air Force Lord Trenchard stated that "we want bases for our aeroplanes such as would be required for the defence of Britain'. He suggested that an attack on Britain, from the continent, might be made by 'aircraft routing around by the west of Ireland' and we 'want to be in a position to put a squadron in Ireland to deal with any attack by air'. He contended that an air attack that might come through Ireland constituted a particular threat to Britain. In their consideration of such matters the Irish delegation was fortunate to have as their secretary, though strictly speaking not a delegate, Robert Erskine Childers. Childers' experience as a naval officer, Royal Naval Air Service / Royal Air Force observer (navigator) and his knowledge of military and naval science placed him in an excellent position to counter any extreme position adopted by the British. ${ }^{26}$ Childers reminded Britain's main air delegate (his former superior), that Ireland did not play an important part, from an air point of view, in the war with Germany. He also pointed out that aircraft with sufficient range for such an attack had still not been developed. Trenchard agreed that aircraft with ranges of the order of 500 to 600 miles were then only available but that there was also the matter of carrier borne attack. ${ }^{27}$ It is possible that Trenchard had his own agenda to ensure the retention of a more substantial RAF. The RAF, as the third and very junior service of the British forces, was fighting for survival in the face of Army and Navy prejudice. ${ }^{28}$ It had been decimated after the Great $\mathrm{War}^{29}$ and a possible withdrawal from Ireland would lead to two more squadrons being disbanded, further undermining the cultural argument for the retention of an independent air force and parity with the Royal Navy and the British Army.

The matter was resolved by Winston Churchill who brought a degree of logic to the discussion by stating that any developments in air power that might be made by her

\footnotetext{
${ }^{25}$ Conference on Ireland, Committee of defence, 17 Oct. 1921 (UCDA, MP, P7/A/73/32.)

${ }^{26}$ Jim Ring, Erskine Childers (London, 1996), passim.

${ }_{27}$ Conference on Ireland, Committee of defence, 17 Oct. 1921 (UCDA, MP, P7/A/53).

${ }^{28}$ Sir Phillip Joubert de la Ferte, The third service; the story behind the Royal Air Force (London, 1955), pp 72-3.

${ }^{29}$ Michael Armitage, The Royal Air Force; an illustrated history (London, 1993), Appendixes 1, 2 and 3.
} 
enemies would be matched by similar technical advances by Britain and that it was therefore immaterial whether RAF aircraft were based in Britain or Ireland. He indicated that, in contrast to the case for naval bases and for possible naval airbases nearby, it would not be necessary for Britain to retain any RAF bases in the new Irish state. On the matter of civil aviation, while both Churchill and Trenchard emphasised that the British future requirement for 'stopping places for cross-Atlantic travel' the question remained unresolved - possibly because this was still a somewhat remote concept. Collins, showing no great concern about military aviation, asked if Britain 'would give us landing places in England [for a civil air service]', was apparently pleased to be reassured by Churchill that 'there would be perfect reciprocity' and that the State's future participation in civil aviation in particular would, by international convention, be on the same basis as any independent country. ${ }^{30}$ Some alarm was later caused in the Irish camp when the British indicated a new condition that Ireland would not be allowed develop an 'air force'. When queried on the matter the British quickly clarified that this only related to a prohibition on Irish naval aviation. ${ }^{31}$ While most discussion on Irish defence and air matters was confined to sub-committee level the most definitive statement on defence policy was to be made in the context of final stages of the main negotiations. A significant amendment to Article 7 of the draft agreement, attributed by Frank Pakenham to the 'republican wing' of the negotiating team, indicated a much more positive and strident policy position on defence than had been discussed internally or previously articulated in negotiations.

As an associated State Ireland recognises the obligation of providing for her own defence by sea, land, and air, and of repelling by force any attempt to violate the integrity of her shores and territorial waters. ${ }^{32}$

While this amendment, with most of the others proposed by the Irish negotiators on 4 December 1921, were turned down out of hand by the British and of course not reflected

\footnotetext{
${ }^{30}$ Minutes of committee of defence, 17 Oct. 1921, (UCDA, MP, P7/A/73/53).

${ }^{31}$ Minutes of conversation, Tom Jones / Erskine Childers, 28 October 1921, Ronan Fanning, Documents on Irish foreign policy, i, 1921-1922, p. 296.

32 'Amendments by the Irish representatives to the proposed articles of agreement', 4 Dec. 1921 (NAI, DE 2/304/1).
} 
in the signed Treaty, it is not clear to what extent it represented the actual defence ideology or doctrine that would guide the new Free State. In the context of the negotiations it did not meet with Collins' approval. ${ }^{33}$ It could be argued that the state's 'defence by sea, land and air', as undertaken in the 1920s and subsequent decades, fell well short of such aspirations. The tenth amendment proposed on 4 December 1921, to the effect that 'a convention shall be made between the British and Irish Governments for the regulation of civil communications by air' was ultimately included as paragraph three of the annex to 'The articles of agreement for a treaty between Great Britain and Ireland, December 6, 1921'.34 While it is not clear at whose insistence such a provision was made it would seem very likely that, in view of his previous concerns regarding possible future air services, it would have met with Collins' full approval.

\section{The purchase of aircraft}

In the mythology of Irish aviation it is accepted that, while the Treaty negotiations were still in progress, a civil passenger aircraft, a Martinsyde Type A, Mk. II, was bought in England in late October 1921 on the authority of Michael Collins. Based mainly on Emmet Dalton's recollections of 1951, the mythology also suggests that the machine was purchased solely to act as a ready means of escape to Ireland, for Collins and a small number of the his fellow negotiators, in the event of the Treaty negotiations breaking down. In 1951 Dalton responded to a query from Lt. Col. W.J Keane:

At this time I was chief liaison officer and also director of training for the army. I had discussions with Michael Collins, and together we put before the General Staff the idea formulated by me that we should purchase an air-plane in London and have it standing by in readiness to fly Collins ... back to Dublin in the event that the negotiations broke down. ${ }^{35}$

\footnotetext{
${ }^{33}$ Frank Pakenham, Peace by ordeal (London, 1962), p. 265.

${ }^{34}$ Ibid, p. 372.

${ }^{35}$ Emmet Dalton to Lt. Col. W.J. Keane, 23 Oct. 1951 (MA, PC 137).
} 
While Collins' safe passage home would have had a considerable degree of priority it is not easy to accept that Collins, and the second Dail, could justify the expenditure of $£ 2,600$, and more, solely on a get-away aircraft. ${ }^{36}$ Examination of Dalton's account of the events of October 1921, presumably reflecting original documents apparently still in his possession in 1951, together with the comments of Sean Dowling, one of his contemporaries, suggest that Dalton's account may not be fully accurate or indeed that he may not have been privy to the complete plan regarding the purchase of aircraft and that his part in the events may not have been as important as he suggested. The identities of the principals involved in the decision to purchase aircraft are not in doubt though the particular roles played by Collins, Russell, Dalton and McSweeney require clarification.

According to Dalton he was authorised by Collins to put into effect his plan to purchase an aircraft for the purpose outlined. He had known Jack McSweeney, more formally known as William J. McSweeney, a former RAF pilot officer who was a Dublin IRA Volunteer, from their involvement in a previous IRA operation and now sought his assistance in this aviation matter. Dalton was introduced to another ex-RAF pilot named Charles F. Russell, a member of the $4^{\text {th }}$ Dublin Battalion IRA, by Commandant Sean Dowling. Dalton was very matter-of -fact in his account of the start of a very important mission.

I called these two young men together, had a long conversation with them, became convinced of their loyalty, and sent them to England to examine the possibility of purchasing a suitable aircraft. Russell, who had spent some time in Canada, was to act as if he were making the purchase for a Canadian forestry department. ${ }^{37}$

Commandant Sean D. Dowling, formerly of $4^{\text {th }}$ Battalion, Dublin Brigade, had a somewhat different version of the thinking behind the proposal to purchase aircraft. He later recalled the first meeting of C.F. Russell and Emmet Dalton;

\footnotetext{
${ }^{36 .}$ Summary of expenses in connection with the purchase, maintenance and equipment of two acroplanes', C.F. Russell to M.Collins, 27 Feb. 1922 (NAI, DT, S.4002).

${ }^{37}$ Emmet Dalton to Lt. Col. W.J. Keane, 23 Oct. 1951 (MA, PC143).
} 
When I introduced Russell to Dalton they began to discuss how his special experience as a pilot could be helpful to the I.R.A. Russell said that, for instance, if the negotiations for a treaty broke off and fighting began again, he could go to England and seize a plane, fly it over here and bomb enemy positions. ${ }^{38}$

While this proposal did not relate to that of acquiring a passenger aircraft for a hasty retreat the idea of purchasing such an aircraft may have been the product of the discussions between Russell and Dalton, and possibly others, rather than the singular idea of any one person. Subsequent action, the purchase of a military training aircraft, would suggest that Russell's idea of bombing British forces became one of the main contingency plans adopted by Collins. Russell apparently accompanied Dalton to London at the time of the treaty negotiations, though his function there was solely in relation to the purchase of aircraft and the making of arrangements for a possible flight to Dublin. There is no contemporary record of McSweeney having been in London at this time though the payment by Russell of $£ 25$ 'to Lt. McSweeney, I.R.A.' for 'expenses before the purchase of the machine' strongly suggests that he had been in London for the aircraft evaluation phase but had returned to Dublin after a machine has been decided upon, to organise the personnel, equipment and arrangements for the possible arrival there of the aircraft carrying Collins. ${ }^{39}$ That McSweeney had performed 'GHQ staff duty in London during [the] treaty negotiation' in the autumn of 1921 is confirmed by his officer's history sheet compiled in early $1924 .^{40}$

In any event Russell, apparently accompanied by McSweeney, began a survey of aircraft manufacturing companies and an evaluation of the various aircraft they had to offer. He was seeking aircraft to fulfil three particular roles. Firstly he wanted a 'machine capable of direct flight [to Ireland] (a) for passengers, (b) freight'. Secondly he sought a 'machine suitable for military undertakings i.e. bombing in Ireland' and thirdly a 'machine sea-plane [sic] suitable for transporting freight from ship in home waters to [a] base in Ireland'. He 'interviewed' representatives of five aircraft manufacturing companies; Avro \& Co.; Martinsyde \& Co.; Short Bros.; Vickers Ltd. and De Haviland \&

\footnotetext{
${ }^{38}$ Sean Dowling to W.J. Keane, 12 May 1965 (MA. PC143).

${ }^{39}$ Enclosure (2), 21 Oct. 1921, Emmet Dalton to Lt. Col. W.J. Keane, 23 Oct. 1951 (MA, PC143).

${ }^{40}$ Officer's history sheet, 16 Feb.1924 (MA, SDR 3718).
} 
Co. and received quotations in respect of a variety of aircraft. The Vickers Viking and the Martinsyde Type A, Mk. II were the machines considered for the primary role of transporting passengers or freight. The Vickers Viking, which was an amphibious aircraft with a useful load of $1250 \mathrm{lbs}$ and a range of 400 miles, was rejected out of hand even though it was considered suitable for all three tasks. The aircraft 'is, we consider, out of the question at the price quoted $-£ 4,675^{\prime}$. The delivery period of three months after the placing of an order, and the aircraft's handling when landing on grass, were also deemed to be unacceptable. Its greater stability on water in bad weather conditions was cited as an advantage over the Martinsyde aircraft. However, apparently mainly on the basis of price, the Viking was eliminated.

The machine to our mind which is suitable for purpose (1) is the 'Martinsyde' Type A, Mk. II, 4 seater biplane. This machine is fitted with a Rolls Royce engine, and is complete with floats or land undercarriage, and is quoted to us at a price of $£ 2,600$. It has a range of 550 miles at [a] crusing [sic] speed of 100 miles per hour. Delivery could be made within twenty-eight days. (Photographs of this machine are enclosed) 41

Russell deemed that the Martinsyde would also be suitable for the ship to shore freight role. At first glance it is not obvious why Russell should have considered the Avro 504K in the context of bombing in Ireland. As noted by Russell in his evaluation this particular type, with its $110 \mathrm{HP}$ Le Rhone engine was 'the English Army standard training machine' and at 288 pounds, had a load carrying capacity that would normally be considered too low for bombing purposes. While a gunnery trainer version of the Avro $504 \mathrm{~K}$, with a $130 \mathrm{hp}$ engine, had been developed by way of modifications incorporated in the basic machine there is no record of a version fitted out for conventional bombing. ${ }^{42}$ Such a standard training aircraft could only be used for bombing by the rather crude practice of having the second crew member drop bombs over the side of the rear cockpit manually - an accepted practice in earlier times. However the major advantage of the

\footnotetext{
${ }^{41}$ 'Investigation into aircraft available in England for purposes which are as hereunder', Enclosure (1) Emmet Dalton to W.J. Keane, 23 Oct. 1951 (MA, PC 143).

42 A.J. Jackson, Avro aircraft since 1908 (London, 1990), p. 68.
} 
Avro 504K would be in the fact that, if questions were asked by the U.K. authorities, it could correctly be described as a training machine. Against the 504K Russell considered the de Haviland DH 9 which he stated 'was used during the European War as a long [range] bombing machine and was found very suitable as such'. The DH 9 was considered by Russell to be suitable for the proposed bombing role but he eliminated it on the basis of cost. He stated that 'the price however, being $£ 1000$ is exorbitant except for permanent use'. This latter comment suggests a short term bombing role for whatever aircraft was to be purchased and limitations as to the monies available.

The Martinsyde Type A Mk. II and the Avro 504K therefore comprised Russell's eventual choice of aircraft types. In effect he selected two aircraft to carry out four distinct roles. While the choice of the Avro 504K training aircraft in a bombing role must have been a considerable compromise caused by a lack of sufficient funds, the more intriguing aspect is why Collins felt he required an aerial bombing capability at that particular juncture. A likely explanation is that Collins, with the technical and professional assistance of Russell, was hedging his bets while awaiting the outcome of the treaty negotiations. On the one hand he was preparing for a peaceful outcome to the negotiations by purchasing an aircraft capable of several commercial roles. On the other hand he was preparing for the possible failure of negotiations and resumption of hostilities by having the same aircraft available to get back to Ireland in a hurry while also purchasing a training aircraft that might be used for bombing purposes should hostilities be rejoined. In the event of a successful outcome to the treaty negotiations the Avro $504 \mathrm{~K}$ would make a very satisfactory training aircraft for either the civil or the military aviation organisation, if and when developed in the new state.

The aircraft having been selected, Russell's next task was to affect the actual purchases. The financing of the aircraft purchases was, in itself, an interesting arrangement though the exact mechanics are not totally clear. While it is known that the Dail Defence Department channelled $£ 3050$ through the Irish Self-Determination League of Great Britain it is not clear exactly when the monies were paid to the League. The context suggested by the Dail accounts for 1 July to 31 December 1921 and Russell's account forwarded to Collins in late February 1922 indicate that $£ 3050$ was forwarded to the League on the basis of an estimate, by Russell, of what monies would be required to 
effect the purchase of aircraft. ${ }^{43}$ This mechanism appears to have been used to obviate the necessity for Russell to pay for goods and services by means of cheques drawn on a Dublin bank in order to hide the financial transaction from the British authorities in Dublin Castle. Dublin Castle not only monitored the Dail's Dublin bank accounts but had been engaged in 'pinching Michael Collins' "war chest" from the Munster and Leinster Bank' in October 1920 - apparently on dubious authority. ${ }^{44}$

On 19 October 1921, Russell received a cheque for £1,500 from Art O’Brien of the League. ${ }^{45}$ About two days later Dalton and Russell reported to the Chief of staff in Dublin:

We have succeeded in purchasing a Martynside [sic] Aeroplane which can carry ten passengers or 16,000 pounds weight of munitions. We intend that this shall serve several purposes - it can be used, if necessary, in a break of the present negotiations. I have the pilot over here and the machine will be ready for flight within two weeks. ${ }^{46}$

The content and styles of this progress report appear to indicate that the first two paragraphs, including the above extract, were written or dictated by a non-expert, such as Dalton, who appears to have greatly exaggerated the passenger and weight carrying capacities of the aircraft. With a full fuel load, a useful load of 600 pounds and two passengers, or a maximum of about 800 pounds, would have been more correct. While the transportation of five passengers would have necessitated a reduction in the fuel load Dublin would still have been well within range. ${ }^{47}$ The latter paragraphs, giving exact and coherent instructions covering all aspects of the arrangements to be put into effect by McSweeney in Dublin, were most likely dictated by Russell. Russell suggested that 'it would be necessary to have six men on the approved landing ground i.e. a flat part of the race course' at Leopardstown. Equipment and materials required included two motor

\footnotetext{
43 'Department of Defence special expenditure', 1July 1921 to 31 Dec. 1921 (NAI, DE 3/4/10); Irish Selfdetermination League, London office accounts, 1 Oct. 1921 to 31 Dec. 1921 (NLI, Art O'Brien papers, Mss 8431-2); C.F. Russell to M. Collins, 27 Feb. 1922 (NAI, DT, S. 4002).

${ }^{44}$ Michael Hopkinson (ed.), The last days of Dublin Castle; the Mark Sturgis diaries (Dublin, 1999), p.60.

${ }^{45}$ C.F. Russell to M. Collins, 27 Feb. 1922 (NAI, DT, S. 4002).

${ }^{46}$ Enclosure (2), Emmet Dalton to Lt. Col. W.J. Keane, 23 Oct. 1951 (MA, PC 143).

${ }^{47}$ Ibid; Ray Sanger, The Martinsyde file (Tunbridge, 1999), p. 181.
} 
cars, 'sixty gallons of $1^{\text {st }}$ grade Aero Petrol (this can be purchased from Lemass of [the] "L.S.E" Motor Company), 2 ft. square of chamois cloth, five gallons of water.' The instructions went on to detail all arrangements required including those peculiar to a possible night landing. ${ }^{48}$

Russell appears to have made a down-payment on the aircraft on or about 20 October 1921. In the case of the Martinsyde the basic price was $£ 2,300$ with a further $£ 300$ for floats. An additional $£ 100$ was paid to have the aircraft modified in order to increase the passenger seating capacity from four to five. In the case of the Avro 504K training aircraft, originally quoted at a price of $£ 175$, a down payment of $£ 130$ was made while the eventual cost was $£ 260$ though no reason for the increase is given. On 12 December 1921 Russell drew down a second payment, this time of $£ 1,200$, and a final amount of $£ 250$ on 30 December. All payments were apparently made 'on the instructions of the M.O.F.' (Minister of Finance - Collins). ${ }^{49}$ The measured manner in which Russell received the monies suggests that it was paid as required to meet his purchasing obligations and to a preset limit of $£ 3050$.

The total amount spent on the purchase of the two aircraft and the associated expenses was $£ 3,767.10$ s or almost $40 \%$ of the purchases made by the director of purchases of the Dail Eireann Department of Defence. ${ }^{50}$ In the context of the limited financial resources of the first and second Dails and of the then current ministerial salary of about $£ 300$ per annum, the expenditure of such a sum in aircraft, for whatever purpose they were intended, represented a very substantial, though risky, investment. ${ }^{51}$ It is not obvious to what extent the surreptitious circumstances surrounding the purchases contributed to the overall cost of the operation of buying two aircraft. However it is noted that while the two aircraft cost a total of $£ 2,960$ the associated costs increased this figure by some $24 \%$. The Martinsyde, after modification, was test flown at Brooklands on 24

\footnotetext{
${ }^{48}$ Enclosure (2), E. Dalton to W.J. Keane, 23 Oct. 1951 (MA, PC 143). Leopardstown was not an aerodrome. Ireland's first air display had been held there in August 1910.

${ }^{49}$ Irish Self-determination League, London office accounts, 1 Oct. 1921 to 31 Dec. 1921 (NLI, Art O'Brien papers, Mss 8431-2). These manuscripts comprise two boxes of miscellaneous unsorted material relating to the League and other Sinn Fein organisations in Britain.

${ }^{50}$ Russell to Collins, 27 Feb. 1922; 'Civil Aviation', 7 Apr. 1922 (NAI, DT, S. 4002); 'Quartermaster general's account', 1 Jan. 1922 to 1 Oct. 1923 (NAI, DE 3/4/7).

"Ronan Fanning, The Irish Department of Finance, 1922-58 (Dublin, 1978), pp 13-23,
} 
November 1921 by a Capt. Clarke who was paid $£ 25$ by Russell, apparently to ensure that the aircraft was ready to fly at short notice. (Appendix 1)

With the successful signing of the Treaty on 6 December 1921 and with no immediate necessity to use either aircraft both were put into storage and were eventually delivered to Baldonnell, as freight, in June $1922 .{ }^{52}$ One of the more interesting items of expenditure was one of $£ 25$ apparently incurred by Russell in late 1921. The payment was made to the director of the Handley-Page London / Paris air service for a report on the costs and 'the commercial possibilities of an air service between Cove [sic] and London'. ${ }^{53}$ The acquisition of such a report in early 1922 in conjunction with the roles specified for the Martinsyde aircraft, strongly suggest that the administration, with Collins and Russell as the prime movers, were seriously contemplating the early establishment of a civil air service.

In due course the expenditure of the monies, that had been authorised by Collins and expended by Russell, was accepted by the provisional government as a legitimate expense of the Free State. On 27 February 1922 Collins wrote 'asking for [a] statement of expenses incurred' by Russell. Replying the same day from the Aviation Department of GHQ, Beggars Bush barracks Russell acknowledged the receipt of $£ 3,110$ (the additional $£ 60$ was from 'other sources'), and accounted for the expenditure of $£ 3,247$. 10s., indicating that he was due to be repaid $£ 137$. 10s. (Appendix No.1) ${ }^{54}$ Subsequently Richard Mulcahy, in his capacity as Minister for Defence, wrote to the Minister for Finance:

I desire to make application for the sum of $£ 520$, being [the] immediate financial requirements for the civil aviation Dept. An outline of the expenditure to be covered, is attached. The cash is required urgently, please. ${ }^{55}$

The expenditure mentioned was the Civil Aviation Department's estimate of the expenses that were expected to arise from the storage in Britain, and the delivery to Ireland, of the

\footnotetext{
52 Aircraft log book, Avro No. 1; Log book Martinsyde Type A, Mk. II, Air Corps Museum.

53 'Irish air force... what is required', Aviation Department memo, 2/3 Mar. 1922 (MA, PC143).

${ }^{54}$ C. F. Russell to Michael Collins, 27 February 1922 (NAI, DT, S.4002).

${ }^{55}$ MFD to MFF, 7 Apr. 1922 (NAI, DT, S.4002).
} 
two aircraft purchased in October 1921. The note was initialled by 'MO'C' with the instruction that 'this application is in order, please pay'. ${ }^{56}$ Above the signature ' $\mathrm{M}$. O'Coileain', five days later, Collins wrote to Defence in regard to transactions by Russell in October 1921:

The total amount was $£ 3050$. It was decided at a provisional government meeting that we should accept liability for that sum. It is now a matter of putting the matter formally in order, so that we can get it repaid to the Dail. Will you please endorse this and send it forward to Mr. Duggan for his endorsement, in accordance with [the] recommendation regarding Defence accounts. ${ }^{57}$

As the above authorisation only related to the $£ 3050$ Russell had received from the SelfDetermination League, cabinet approval for the additional $£ 520$ was recorded on 18 April $1922 .^{58}$ It is not clear when the outstanding balance of the monies spent by Russell was endorsed by the Department of Defence and paid by the Department of Finance but it was probably with little delay. While civil aviation was to recede into the background after the start of hostilities on 28 June it appears to have been financed for some time thereafter. On some date between 1 November 1922 and 15 August 1923 the army finance officer, Thomas O'Gorman received some £1,364 from the Civil Aviation Account and refunded it to Dail Eireann. It must be presumed that Russell had been repaid the money due to him prior to 1 November $1922 .{ }^{59}$

\section{The Civil Air Service}

In early 1922, while the Provisional Government was beginning to take responsibility for the administration of the new Free State and the army was taking over a large number of military installations from the departing British Army and Royal Air Force, Russell and McSweeney were informally appointed to positions in the General Headquarters of

\footnotetext{
56 Ibid.

57 'Air Services', M. O Coileain to MFD, 12 Apr. 1922 (NAI. DT, S.4002).

58 'Extract from Cabinet minutes, 18 Apr. 1922' NAI, DT, S.4002).

${ }^{39}$ Refund to 'Minister for Defence account', 1 Nov. 1922 to 15 Aug. 1923' (NAI, DE 3/43A).
} 
Oglaigh na hEireann in Beggar's Bush Barracks under Emmet Dalton. Dalton explained to W.J. Keane:

Plans and suggestions were drawn up by McSweeney and Russell in what was known as the Aviation Department ..... This aviation dept. came into being as a subsidiary Department to my branch training' [sic]. ${ }^{60}$

In the initial weeks of 1922 the two officers worked in the Aviation Department where no apparent distinction was made between military and civil matters, though a conscious decision was made to the effect that 'the [civil] aviation service be worked as a military department'. ${ }^{61}$ However, it is apparent from the major surviving source on the subject, (DT file S.4002), that Russell was concentrating on policy matters relating to civil aviation while McSweeney was addressing the subject of military aviation. Their appointments received the formal approval of the Air Council meeting of 23 March 1922. The minutes record that 'Mr. W.J. McSweeney was appointed director of military aviation with the rank and allowance of a commandant general' and that 'Mr. Chas F. Russell was appointed director of civil aviation and secretary to the Air Council. It was decided that he should have an allowance equal to that of the military director' ${ }^{62}$ There are a number of indications that this division of responsibility was a considered decision on the part of the provisional government, indicating that Russell was the superior manager and staff officer and that the development of civil aviation, rather than military, was the new state's priority. Charles F. Russell had been selected by Dalton and apparently confirmed by Collins, ahead of McSweeney who, having joined the IRA earlier was notionally senior to Russell and who might have expected to take charge of the air operation. It seems that the superior ability of Russell was evident from an early stage. The decision to have Russell take charge of the operation to purchase aircraft and of the contingency plans associated with a hasty retreat from London must have been endorsed by Collins. Russell had apparently accomplished this task to the satisfaction of Dalton and, more importantly, to the satisfaction of Collins. Finally it would appear that

${ }^{60}$ E. Dalton to W.J. Keane, 23 Oct. 195 I(MA, PC I43).

${ }^{61}$ Extract from cabinet minutes, 27 Feb. 1922 (NAI, DT, DT, S.4002).

62 'Civil Aviation Dept. - minutes', 23 Mar. 1922 (NAI, DT, S.4002). 
Russell had been appointed, in an informal manner, to the new and more important, position of director of civil aviation by Collins himself on Saturday 18 February 1922, when, initially, the title of superintendent of civil aviation' was used. On that occasion Collins apparently asked Russell for a paper exploring the manner in which commercial civil aviation might be initiated in Ireland. Russell rsponed within days:

With reference to our conversation on Saturday [18 February 1922] I am sending you herewith [a] scheme for handling aeronautical affairs in Ireland, which however I have only had time to outline roughly. During the preparation of this report I have had before me reports on the management of aeronautical affairs in practically every country in the world, and while it is not an exact duplication of any one country's methods, it is more or less [on] the lines of the New Zealand government [policy]. ${ }^{63}$

The submission by Russell of a five page paper on civil and military aviation, based on material already in his possession, and in such a brief time, strongly suggests that he was, on his own initiative or on some understanding with Collins, well advanced in his study of military and civil aviation matters. Collins, having indicated his preference for civil aviation and for air communications with other countries during the Treaty negotiations, apparently required Russell's professional background and communications skills to further, in particular, the state's civil aviation aspirations. In the 'preliminary remarks' of his paper on a 'scheme for handling Irish aeronautical affairs - military and civil' Russell may have been simplistic when he stated that aviation could be divided into two branches - civil and military. However he was not only informing Michael Collins and his department but also educating ministers and officials of other departments as well as the General Staff, many, if not all, of whom would have little appreciation of air matters. He defined civil aviation as comprising 'aircraft construction' and 'civil air transportation which together aim at the acceleration of inter-communication and the expansion of trade by means of air transport'. He considered the ultimate objective of military aviation to be

\footnotetext{
${ }^{63}$ C. F. Russell to M. Collins, with enclosure, 20 Feb. 1922 (NAI, DT, S.4002). Russell apparently typed all his own papers.
} 
'direct defence'. He considered that 'the duties of Air forces once war is joined' would be to 'manoeuvre to attack enemy air, land and sea forces and territory, and to defend home territory from the air' and enable 'arterial air routes to continue to operate by protecting them from hostile air attack'. He highlighted the similarities of, and the differences between, civil and military aviation but emphasised the fact that they were closely allied 'because in future the actual cadres which compose [sic] the country's service air forces in peace, can only be augmented in war by a reserve of men (who might well be placed on a volunteer basis) by material and experience in construction and design afforded by Commercial aviation'. ${ }^{64} \mathrm{He}$ warned 'that commercial aviation cannot be fostered merely as a reserve for the country's military air forces' and that 'its test must be that of a commercial success'. He foresaw the main potential for the development of civil aviation 'for the time being' in the carrying of mails. Other roles included 'the high speed carriage of' 'small and valuable goods, passengers, and for sundry purposes such as mapping and survey work'. To support his claim for the transportation of mails he cited large savings made in the U.S. by a commercial air mail Service operating between large cities. However he did not suggest how such a service might fare in Ireland or between Ireland and Great Britain. ${ }^{65}$

In summarising 'Ireland's position' he stated that 'one may safely say that [as a nation] we know practically nothing about aviation either military or civil'. He stated that 'we have in Ireland about fifty ex. English army flying officers, 8 of whom served with the I.R.A' and that only one or two of whom had flown 'since the close of the European War' while suggesting that 'as far as can be ascertained we have only one' (unnamed) 'commercial aviator in Ireland at the moment'. He suggested that 'as a result of conditions in Ireland we have not yet had the necessity for a department to handle and foster commercial aviation'. Noting that the Civil Aviation Act, 1918 did not apply to Ireland Russell listed the various regulatory duties and functions, provided for in that Act, that would be required to be performed by a government 'aviation department'. These would include the testing and licensing of both pilots and aircraft and the issuing of appropriate certificates, airworthiness of aircraft; physical standards for air pilots, the

\footnotetext{
${ }^{64}$ Ibid.

${ }^{65}$ Ibid.
} 
collection of meteorological information, wireless communication with aircraft and much more. To carry out such an extensive range of duties Russell considered that a regulating aviation department required 'an aerodrome suitable from a commercial and military point of view', 'several aeroplanes for testing purposes' and 'suitable wireless equipment for communication within a radius of 500 miles'. In proposing that, in affect, an 'aviation department' would function as a regulatory body and as an aerodrome operator Russell was combining two functions that might later be considered incompatible. However, but in the context of a country with practically no aviation activity it probably made sense at the time. This dichotomy did not arise as the approaching civil war was to stymie early plans for the regulation of civil aviation and plans for state-sponsored commercial air operations. As a result the early administrations only slowly and reluctantly undertook their obligations under international conventions.

Russell's recommendations, of February 1922, for the development of civil or commercial aviation included aspects that he considered would dovetail with the military requirements of the new state;

Having in mind our present aeronautical condition, our army aerial requirements in the near future, together with the necessity for government assistance to commercial aviation - I hasten to suggest Government action on the lines mentioned hereunder.

"A" The creation of an aviation department under the Minister for Defencewhose duties shall be detailed elsewhere.

" $B$ " The creation of a school of aeronautics and flying at the government commercial aerodrome.

"C" The adoption of this school of flying and aeronautics by the military authorities.

"D" The appointment of a commercial air council - The following to be included on the Council:-

President, Minister for Defence.

Postmaster General. 
Representatives from Land[s] \& [Ordnance] Survey.

O/C Military Air Service.

Representatives of aviation companies in Ireland.

(Superintendent of Aviation Dept. to be secretary to Council) ${ }^{66}$

Russell detailed the duties of the Air Council in terms of exploring commercial air possibilities, considering a scheme for a mail and passenger service from Cobh to London or between other points, and of considering the possibilities of locating herring shoals from the air. He also foresaw that the 'comparative smallness' of the 'Military Air Service' should preclude it being 'saddled with the expense of a School of Aeronautics' and, as a result, would become the best customer of the 'civil aviation Dep[artmen]t of aeronautics and flying' and that the military and civil organisations would have a certain level of inter-dependence.

Russell proposed the appointment of a 'superintendent of commercial aviation' who would be responsible for the many regulatory duties provided for by the Civil Aviation Act, 1918. These included the registration, licensing and airworthiness of aircraft and for the licensing and fitness of pilots. Such an officer would also be responsible for the running of the aerodrome and schools of aeronautics and flying as well as advising the government on all aeronautical matters. The estimated annual cost of the office of the superintendent was put at $£ 12,000$, while the annual cost of the schools of aeronautics and flying was put at $£ 13,820$. He suggested that the position of superintendent of commercial aviation be announced sooner rather than later and advocated the taking over of Baldonnell which would be divided between 'the commercial people' and the military. ${ }^{67}$ While Russell displayed considerable confidence in the future of Irish aviation, the absence of legislation, regulation and the rudiments of commercial aviation activity - all fundamental aspects identified by him- were major obstacles to success on any level. Given these stark facts and the worsening political situation it would have been difficult for the provisional government to have great faith in the possible success, at that time, of the proposals as initially drawn up.

\footnotetext{
${ }^{66}$ Ibid

67 Ibid.
} 
On Thursday 23 March 1922, having apparently been postponed from both the 14 and 15 March, a 'meeting of members of the Government, members of the General Staff, and officers from the Military Aviation Department' was held at Beggars Bush Barracks to consider an agenda based on the various proposals contained in Russell's 'Scheme for handling Irish aeronautical affairs'.

The following were present at the meeting;-

Mr. R. Mulcahy, T.D., Minister for Defence - chairman.

Mr. M. Collins, T.D. Minister for Finance.

General O'Duffy, T.D. Chief of the General Staff.

Lieut. General J. O’Connell, Assistant Chief of staff.

Major General J.E. Dalton, director of training.

Commdt. General W. J. McSweeney, director of military aviation.

Mr. C.F. Russell, director of civil aviation and secretary to the Air Council. ${ }^{68}$

The numbers and elevated status of those attending the first meeting of the Air Council bears witness to the government's interest, at least at this juncture, in supporting both civil and military civil aviation. It is also probable that Collin's sponsorship of the concept of aviation in general had a positive influence on the level of attendance. Many decisions, mainly of an organisational or administrative nature, were recorded. It was decided 'that aviation be divided into two sections, namely military and civil'. McSweeney and Russell were confirmed in their respective appointments while the Air Council was confirmed as comprising; 'Minister for Defence; Minister for Finance; Minister for Trade; Chief of the General Staff; Director of Military Aviation; Director of Civil Aviation; and Representatives from Land \& Survey.' The meeting adopted a recommendation that the proposed school of aeronautics be directed by the proposed Civil Aviation Department and that fuller information be sought on a scheme proposed by Dublin Corporation that would provide such a school within the existing technical school system. The meeting also adopted the recommendation 'that a school of flying be started under the direction of the Civil Aviation Department' and that that school 'be

${ }^{68 .}$ Civil Aviation Department, minutes', 23 Mar. 1922 (NAI, DT, S.4002). 
adopted by the military aviation authorities for the training of their pilots.' It was decided that Baldonnel Aerodrome would be the most suitable for all purposes'. General Dalton, in his capacity as chief liaison officer, 'was directed to make the necessary arrangements for the taking over of this aerodrome at an early stage'. In the matter of military aviation 'it was decided that the military air authorities should aim at the organisation of one air squadron for the present'. The detailed consideration of 'air estimates' was postponed pro tem while 'both departments were asked for their immediate financial requirements'. 69

While aviation matters appear to have been of significant interest to Collins in particular, and to the administration in general, it is to be noted that no aviation proposal having significant financial implications was adopted at this stage of the planning process. There was evidence, in the first minutes, of a certain air of caution that was to become more pronounced in the coming weeks. While no reference is made to the deteriorating political situation heading towards civil war it was, no doubt, a major disincentive to any significant investment in personnel, aircraft, equipment or general facilities or even a regulatory body. In this regard the attendance at the next Air Council meeting was telling. The meeting held on 6 April 1922 was attended only by the Minister for Defence and the two directors. The minutes of the meeting reflect a significant slowing down of the initial impetus generated for Collins by Russell. Russell's Civil Aviation Department proposal for a school of aeronautics at Baldonnell was put on hold while a similar scheme proposed by the Dublin Corporation technical committee was referred to the engineers of both bodies so that a joint report could be prepared for consideration by the Air Council. In the meantime the estimates for the schools of aeronautics and flying were being withheld. It was also decided that Russell would produce a memorandum on the methods and conditions to apply to entry into the schools and on a possible scholarship scheme to ensure adequate numbers of students. In his paper he was also to address the matter of entry to a military air service by means of graduation through the schools. Russell indicated that the school of flying was the only aspect of civil aviation on which it was intended to incur expenditure for the time being and that all purchases of equipment would be brought up for the Air Council's sanction before it was purchased. The meeting decided to forward a statement of the Civil

${ }^{69}$ Ibid. 
Aviation Department's immediate financial requirements, no details of which were recorded in the minutes, to the Government.

The director of civil aviation 'enquired whether his department or the military department would be responsible' for the 'taking-over of Baldonnel Aerodrome.' The meeting decided 'that the military authorities should take over the aerodrome and arrange with the Civil Department to let them have the required number of sheds. ${ }^{70}$ This particular decision was ambiguous in that all aviation came under military control and the 'military authorities' was not defined. In the event the complete installation was eventually taken over by the Army on 3 May 1922 apparently as just another military barracks. $^{71}$ Subsequently responsibility for the aerodrome and the civil aviation functions were taken over by Russell in his capacity as director of civil aviation at some date between 3 and 12 May $1922 .^{72}$ The composition of the small staff of the civil aviation department that moved into Baldonnell in May 1922 confirms that it was initially administered as a civil rather than as military aerodrome. ${ }^{73}$ No discussion took place on the subject of the 'purchase of machines for the school of flying', or on 'the appointment of a consulting engineer', and was postponed to the next meeting. The matter of 'foreign quotations for aeroplanes' was discussed briefly and also deferred for consideration at the next meeting. ${ }^{74}$

On 25 April 1922 Russell had reported that he was in receipt of queries from two British based air service companies who had expressed an interest in running air services between Dublin and such cities as Manchester and London. One company was preparing to commence operations between London and Dublin via Manchester on 1 June 1922. The second company wanted to operate between London and Dublin and were requesting support from the Irish government in the form of a subsidy. These overtures brought into focus a number of problems that the government had not even begun to address. Firstly Baldonnell, then still occupied by the RAF, was not designated as an aerodrome for civil aircraft entering the state nor was it designated a customs aerodrome as required by the Convention for the regulation of aerial navigation. There were five other important areas,

\footnotetext{
${ }^{70}$ Minutes of Air Council meeting, 6 Apr. 1922 (NAI, DT, S.4002).

${ }^{71}$ Freeman's Journal, 4 May 1922.

72 E. Dalton to C.F. Russell, 12 May 1922 (MA, Liaison office file).

73 'Department of Civil Aviation, Baldonnell', 20 July 1922 (UCDA, MP, P7/49/38)

${ }^{74}$ Minutes of Air Council meeting, 6 April 1922 (NAI, DT, S.4002).
} 
including the formulation of local flying regulations at Baldonnell, where the absence of legislation and regulation was hindering the opening up of the country to civil aviation. The situation in respect of commercial activity was similarly difficult in that the government had not adopted a policy in respect of subsidies, if any, to be offered to companies interested in serving Baldonnell or elsewhere. ${ }^{75}$

Russell attempted to convene a meeting of the Air Council for the 5 May 1922 and distributed an agenda of seven items that included two important matters postponed from the poorly attended meeting on 6 April, as well as the matters of the air service proposals made by the two British companies. However there is no record of minutes of the 5 May 1922 meeting. A further meeting of the Air Council was requested by Russell for 15 May 1922, with an agenda of sixteen items agenda that included those carried over from the two previous agendas. The new items for discussion included a small number concerning the infrastructure and services at the recently taken over aerodrome at Baldonnell and some items relating to the schools of flying and aeronautics. Once more the absence of minutes suggests that this meeting did not take place. To overcome the absence of legislation and regulation an undated 'notice of motion by Mr. C.F. Russell' proposed that selected articles of the International Air Navigation Act, 1919 be adopted 'to form as a temporary measure, an arrangement whereby foreign aircraft can immediately undertake commercial air services to and from Ireland'. He also proposed the adoption of the appropriate articles of the same act 'to form as a temporary measure an arrangement whereby the necessary control over foreign aircraft arriving in Ireland, may be obtained' and included appropriate draft regulations. As with much of the previous correspondence on this file the absence of comment or annotation suggests the attention of the president of the Executive Council was elsewhere.

In the meanwhile Russell had prepared an exhaustive study of the policy and practice internationally in the matter of 'subsidies for civil aviation'. In an eleven page memorandum, dated 2 May 1922, he examined the direct and indirect assistance provided to air service companies by the governments of some eleven countries, mostly European but including the United States. He defined indirect assistance as the provision of 'aerodromes and ground mechanics, light houses, pilot training schools, meteorological

\footnotetext{
75، Foreign Air Services', C.F. Russell to M.Collins, 25 April 1922 (NAI, DT, S.4002).
} 
information, and technical and medical testing of pilots'. Direct assistance was supplied 'by means of subsidies generally based on the number of flights' 'or of passengers or so much per pound of freight'. The study was intended as an aid to Collins and the administration to formulate a policy on subsidies that might be used to help to foster commercial aviation. The material, indicating the definition of subsidies and exploring current international practice, should have left the Government in no doubt as to the range of options they might consider. ${ }^{76}$

Russell elicited no response to any of his correspondence after 6 April 1922 and apparently did not succeed in assembling the Air Council. With the inexorable approach of hostilities the government apparently had no time to consider aviation matters in general and civil or commercial aviation in particular. In effect the civil aviation file in the office of the President of the Executive Council, and most likely similar files in other departments, was to remain closed until January 1924.

\section{Pilot medical standards}

As early as 20 February 1922, in keeping with the emphasis on preparing for civil aviation, Russell had identified 'the maintenance of a physical standard for Air Pilots' as one of the more important duties of an aviation department. In preparation for the time when it would be necessary to have civilian pilots medically examined on a periodic basis Dr. E.A.K. Mills was instructed to visit 'London to enquire into the medical tests and qualifications for air pilots' and subsequently reported.

I visited the Air Ministry, Kingsway, W.C., where I interviewed Colonel Heald, who explained and demonstrated the medical tests. I also saw a pilot under examination. He facilitated me in every way and answered my queries to my entire satisfaction, and has given me complete insight to the various tests and scientific instruments necessary for the working of this department. ${ }^{77}$

\footnotetext{
76 'Subsidies for civil aviation', C.F. Russell to M. Collins, 2 May 1922 (NAI, DT, S.4002).

${ }^{77}$ Unsigned typed copy report, Ernest Mills, 6 May 1922 (MA, Liaison office general file)
} 
Mills was supplied with a complete list of the instruments and equipment required for the medical examination of pilots. He was brought to Oxford University and met specialists who were developing more searching medical tests for pilots. They advised him further on the general subject and offered assistance if required in the future. Mills also acquired a full bibliography of the English, American, French and Italian major works and articles relating to aviation medicine and got advanced notice of material about to be published. ${ }^{78}$ Though medical examination was originally intended specifically for civilian pilots the Army Medical Corps would first use the expertise for the benefit of military aviation which started in July $1922 .{ }^{79}$ Capt. E. A. K. Mills was to be discharged with effect from 27 June 1924, some weeks after the 'army mutiny' of that year. ${ }^{80}$

\section{Contrary opinion}

To what extent Michael Collins and his fellow ministers on the Air Council accepted Russell's staff papers, minutes of meetings and financial projections relating to the new State's aviation policy and plans for the development of commercial aviation is not absolutely clear. The main source for the period, the file 'Civil aviation - developments in Saorstat Eireann' (DT, S.4002) covering the period 1922 to 1932 comprises documents apparently forwarded to the president of the Executive Council for information only, and reflect no action or interest on his part. Without the benefit of the handwritten notes, queries and comments to be found on working documents it is not easy to judge how the matters may have been viewed by GHQ, by the minister for Trade and his department or indeed by Michael Collins himself in his capacity as Minister for Finance. At one level it can be observed that Russell's various papers appear to have received very little scrutiny or detailed investigation as to the merits of his general theories on aviation or the practicality of the proposed schemes. It is not unreasonable to suggest that if Russell's work had come in for adverse comment some such comments would be recorded on the file viewed. It is considered that while Russell's standing as an aviation specialist resulted from his considerable expertise in such matters, the unrecorded mandate received from

\footnotetext{
${ }^{78}$ Ibid.

${ }^{79}$ General Routine Order No. 9, 20 Dec. 1922.

${ }^{80}$ Staff Duties - Appointments and Discharges Memo No. 15, 31 Dec. 1924.
} 
Collins may also have protected him from possible detractors. While the Air Council, on Russell's recommendations made various recommendations for the expenditure of substantial sums the provisional government, through the early department of Finance, approved no significant capital investment. Nor did they sanction any significant recurring expenditure. The expense incurred involved no more than relatively nominal figures on, for example, the taking-over of Baldonnell as a civil aerodrome and the putting in place of a small civilian air staff. Civil aviation staff had been recruited as early as April 1922 and, notwithstanding waning interest caused by the worsening political and military situation, a total of sixteen personnel, including Russell, were eventually on the Army payroll on 20 July $1922 .{ }^{81}$ (Appendix 4)

The above is not to state that there was no dissenting voice to the various aviation proposals but this came from a member of the military staff of GHQ a Captain Dunphy. In April 1922 a brief report was made on 'the financial estimates presented by the aerial directors showing the initial outlay and general expenditure for one year' as presented to the GHQ. Severe criticism of Russell and McSweeney and of their plans for the expenditure of $£ 47,550$ on civil aviation and $£ 137,846$ on military aviation was detailed.

I understand that the expenditure of this amount will be for all practical purposes in the hands of the aerial directors. The directors did not furnish me with proofs of their competency to act as expert purchasers of machines and stocks [sic] or of their experience in selecting men for what may be regarded as lucrative appointments. The production of an air pilot's certificates would scarcely be regarded by the average businessman or government as sufficient to justify a claim to the establishment of an air force involving an initial outlay of $£ 180,000$. In my opinion, which has been stated by me to the directors, a simile between their claim and that of an engine driver to organise and establish a railway company is not incorrect .... The Great War has thrown upon the scrap heap many hundreds of competent airmen who are presently out of employment. The loosing off of a further supply

\footnotetext{
81 'Department of Civil Aviation', C.F. Russell to W.J. McSweeney, 20 July 1922, (UCDA, MP, $\mathrm{P} 7 / \mathrm{B} / 49 / 38)$
} 
of civil air pilots will not of itself bring the [Air] Council any nearer to accomplishing the object in view. ${ }^{82}$

Captain Dunphy was similarly critical of the estimated costs of raising a military squadron and warned that a squadron costing $£ 350,000$ annually in Britain could not be raised in Ireland for a sum between $£ 95,000$ and $£ 115,000$. He was also critical of the fact that the aviation proposals had not 'been discussed with the trading community, or chambers of commerce' He recommended that a 'scientific organiser competent to advise the Air Council on all matters relating to military and civil aviation be secured on loan from a foreign government' and that, taking into consideration the amount to be expended, the approximate cost of $£ 2,000$ for the services of a consultant expert for one year would be money well spent. ${ }^{83}$

While one could not question the advisability of having the civil and military aviation proposals critically examined from a financial point of view an impartial observer might consider that there was more to Capt. Dunphy's assessment of the aviation plans and estimates and to his implied personal criticism of the individuals responsible for formulating them. Given the personal relationship between Collins and Russell and McSweeney and the confidence the latter pair obviously enjoyed, Dunphy may have been unwise in his comments. It is possible that he may have perceived the two young directors in their former guise as enemies of the IRA and possibly owing too much allegiance to their former service - the RAF. It is a recognised fact that certain factions of the Army could not countenance the concept of ex-British personnel, particularly those without pre-truce service, serving in the emerging Free State National Army. ${ }^{84}$ In the context of the odium applying to ex-British personnel two very young officers, having the rank or status of commandant general and enjoying considerable influence at the highest level of government, were bound to become the objects of prejudice and professional jealousy. In any event it is unlikely that Russell and McSweeney appreciated the analogy between their profession as pilots and that of an engine driver. No doubt it would not be the last time that such sentiments would be expressed though possibly not recorded.

\footnotetext{
82، Aviation - Military and Civil', Captain M. Dunphy to COS, 8 April 1922 (NAI, DT, S. 4002).

${ }^{83}$ Ibid.

${ }^{84}$ Maryann Gialanella Valiulis, Almost a rebellion; the Irish army mutiny of 1924 (Cork, 1988), p. 24.
} 
It is noted that the aviation plans of early April 1922 were still underdeveloped and had not been subjected to the scrutiny of the Department of Finance. At the same time little expenditure had been sanctioned while the personnel of the civil department were on the Army payroll. Also it was most likely that other concerns were distracting the various ministers and their departments from making an adequate appraisal of all aspects of the aviation proposals. Russell himself had recommended 'the appointment of a consulting engineer' who would no doubt have evaluated the proposals before they were forwarded to the department of Finance. ${ }^{85}$ Capt. Dunphy's report made no allowance for the immature nature of the plans and in this regard his criticism may have been premature. In the circumstances it is unlikely that anti-British sentiment alone had any influence on the eclipsing of the civil and military aviation proposals. With the start of the Civil War civil aviation was to be subsumed into the military and in the absence of any formal sanction for the initiation of military aviation a rudimentary force was to evolve and be financed from existing army resources.

\section{Conclusion}

The peace and treaty negotiations of the latter part of 1921, apart from confirming that the new state could raise an army that included an aviation element, did not identify such aviation or other aspects of air defence as a national priority. However it is clear, from his relatively brief contribution to the discussions on civil aviation, that Michael Collins was very anxious to have civil air transportation services established between Ireland and the U.K and possibly to the continent. It is probable that it was at Collins' instigation that provision was made, as an annex to the Treaty articles of agreement, for an Anglo-Irish convention on civil aviation. While the Martinsyde aircraft was purchased in October 1921 with two contingencies in mind on balance it was an indicator of Collins' confidence in the outcome of the negotiations and of his intention to facilitate the commencement of commercial aviation at an early date. It does not seem at all reasonable that such an aircraft would be purchased solely as a means of escape from Britain. Bearing in mind the open circumstances of his presence at the negotiations and his

85 'Civil aviation department-minutes, 6 April 1922: Air Council agenda, 15 May 1922 (NAI, DT, S.4002). 
residing at Cadogan Gardens the concept of a dramatic escape by aeroplane would not appear to have been very practical. The attention, by Russell, to the specification of the machine and to the three distinct commercial roles that it could fulfil, very strongly suggest that the aircraft's commercial potential was paramount and that the escape function was a secondary consideration. In the case of the Avro 504K it seems probable that the balance between a possible bombing role and a future training role would have been even.

In the context of the efforts made, in the first half of 1922, to develop plans for the development of civil aviation in general and the establishing of a civil air service in particular, the working relationship between Michael Collins and C. F. Russell appears an intriguing one. It is almost universally agreed that that Collins was modern and progressive and had an uncanny knack of choosing the right individuals to whom he might delegate. As early as the Treaty negotiation Collins had shown a particular interest in civil air services and appropriate air access to Britain. The purchase of the Martinsyde demonstrated his intent to initiate such a service should the circumstances permit. In Russell Collins found an equally enthusiastic individual who had the professional expertise and the broad vision that allowed him identify and articulate the state's obligations in civil aviation regulation and its options in terms of developing and subsidising a civil air service to demonstrate a certain independence of Britain in such matters. It is not easy to identify which of the two was making the running. On balance it was possibly an equal partnership with Collins having the broader aim regarding air communications and being in a position to endorse and authorise those ideas projected by Russell which be considered best suited his purpose.

The diminishing interest shown by the lack of attendance at Air Council meetings very much indicated the extent to which the approaching civil war was impinging on ministers' thinking and on plans for aviation. It seems very possible, had the Civil War not intervened, that plans for a subsidised air service would have come to fruition sooner rather than later. As it was Russell had managed to progress matters to a position where a small Civil Aviation Department had been formed and was in possession of a viable civil aerodrome. In more favourable circumstances, with a five-seat passenger aircraft and the necessary financial sanction an air service could have undertaken with the minimum of 
difficulty. In the meanwhile, with enthusiasm for civil aviation having waned, there was no significant shift towards the development of military aviation. As a result, plans for establishing a military squadron were to remain very tentative until the actual outbreak of hostilities. 


\section{CHAPTER 3}

\section{MICHAEL COLLINS, THE MILITARY AIR SERVICE AND THE CIVIL WAR}

In the first six months after the Truce the peace negotiators showed no great urgency to develop a concept of national defence, and much less, air defence. Subsequently the provisional government, mainly influenced by Michael Collins who in turn was advised by C. F. Russell, displayed a distinct and pragmatic preference for the development of civil commercial aviation rather than adding an air element to an evolving regular army. Even as civil war loomed the new administration had requested that the RAF, then policing the British military withdrawal from Ireland, should vacate Baldonnell Aerodrome so that the new Civil Aviation Department could take it over as a civil airport. The Civil Department, under Charles F. Russell, took over Baldonnell in May 1922 while the concept of a military squadron, of token strength and an undefined role, received the administration's vague support and little or no financial backing. The evolving political and military circumstances of the spring and early summer of 1922, that would result in civil war from the end of June, dictated that civil aviation aspirations be abandoned and that the very modest levels of military and civil aviation resources then in place be amalgamated under military command so that a very basic level of air power be raised to enjoin the Civil War.

This section of the study examines the new state's reluctant change of emphasis from civil to military aviation and the role of Michael Collins in sanctioning the acquisition of aircraft and the commencement of military air reconnaissance operations. It will look at the functioning of an air element that was hastily assembled with the immediate task of gathering intelligence on the activities of the Irregulars in a situation where military wireless communications had not been developed to replace telephone communications that were being destroyed by the anti-Treaty forces. A central aspect of this particular study will be to assess the evolution of an air reconnaissance capability, its effectiveness or otherwise, in the first weeks of Civil War as well as the general state of military aviation at the time of Collins' death. 


\section{The start of military aviation}

With matters relating to both military and civil aviation being administered under the aegis of the nascent Army and while Russell was exhorting support for various aspects of civil aviation, W.J. McSweeney was carrying out a similar, if less thorough and expert, exercise in support of military aviation. An early proposal, for an 'air service department separate and distinct from any other department', included recommendations concerning the status and functions of the 'chief executive officer of the [Military] Air Service'. While they were not expressed in Russell's articulate manner the recommendations were to the effect that the officer commanding Air Services should be a member of the General Staff and have equal rank with the heads of other headquarters departments and army corps. This was proposed by McSweeney on the basis that the General Staff would have the benefit of professional expertise on air matters, to ensure that the Air Service would have the appropriate status and so that the officer commanding the Air Service would be au fait with the overall military operational situation and make decisions accordingly.' The record does not reflect how this particular matter was received by the army leadership.

The first policy document proposed by McSweeney that is known to have been forwarded to the Air Council for consideration was presented to the Chief of Staff on 4 March 1922. Entitled the 'Irish Air Force - the present position and what is required', the submission made an opening, inaccurate correct, statement to the effect that the aviation department, under the director of training, had 'one 5 seater aeroplane purchased at a cost of $£ 2,600$ and one dual control Avro machine purchased at a cost of $£ 130$ '. It stated, also inaccurately, that the 'total expenditure to date was $£ 3000$ ' though it did not account for the suggested balance of $£ 270$. The paper went on to detail three military options, all involving the disposal of the Martinsyde passenger aircraft (a very new and as yet unused civil machine), and the purchase of various numbers of single seat Martinsyde F.4 (Buzzard) scout or reconnaissance type aircraft, and of the two seat version, the Martinsyde F.4A. A detailed and priced proposal for the suggested constitution of a military air service again included provision for the officer commanding

\footnotetext{
I' 'What is required', unsigned memo dated 13 February 1922 (MA, Liaison office file). The document appears to be a re-typed copy.
} 
to be represented at General Staff level. The overall plan for personnel and for the purchase of aircraft and other equipment had, as its immediate objective, the establishing of a school of flying. This school, which would cost $£ 23,595$ to set up and run for six months, would train the personnel for a squadron of sixteen aircraft in six months. However an Air Squadron, consisting of only eight officers and forty other ranks, would cost four times as much to set up and run for six months. The 'grand summary air estimate' of $£ 150,026$, providing for an air squadron - $£ 95,346$; school of aeronautics $£ 8,583$; school of flying - $£ 23,597$ and air reserve - $£ 22,000$, was put to the Air Council meeting of 23 March 1922. The schools of flying and aeronautics were considered to be part of the civil department while the air reserve idea was lost. In the context of the time such possible expenditure appears to have received little consideration. The only aspect of the military air service proposal approved was the general concept of an air squadron. As mentioned previously 'it was decided that the military air authorities should aim at the organisation of one air squadron for the present'. ${ }^{2}$ As with the proposals in respect of civil aviation, no financial sanction for the proposed air squadron was sought, or provided. As a result the establishing of such a squadron remained in limbo pending a significant change in the military situation. It was of no help to McSweeney that the government, even as civil war was threatened, tended to encourage civil aviation almost to the exclusion of military. On the outbreak of civil war, therefore, a somewhat notional Military Air Service consisted of no more than eight personnel including 'Miss M. Kiernan, typist'. ${ }^{3}$ While the headquarters had remained at Beggar's Bush Barracks after the take-over of Baldonnell on 3 May 1922 the first non-commissioned personnel of the Air Service initially reported to Captain W. Stapleton of the garrison. ${ }^{4}$

The general circumstances surrounding the lead up to civil war are possibly best summarised in the words of the acknowledged authority on the subject and period:

It took six highly confused and tense six months for the divisions over the AngloIrish Treaty to result in civil war. During that period sundry attempts to settle the political and military divisions, or at least to postpone them, failed. On all sides,

2 'Civil Aviation Department' Air Council minutes', 23 Mar. 1922 (NAI, DT, S.4002).

3 'Military Aviation - personnel', 20 July 1922 (UCDA, MP, P7/B/49/37).

${ }^{4}$ Sgt. J. Curran, statement to W.J. Keane, June 1944 (MA, PC 143). 
however, there was a reluctance, right up to the Four Courts attack, to concede that war was inevitable. The Treaty left many issues open to debate and interpretation; such ambiguity made it less likely that divisions would quickly come to a final test. $^{5}$

Such was the pace of the evacuation by the British Army that military installations were taken over by the local IRA with the provisional government powerless to prevent antiTreaty forces occupying many such barracks, posts and airfields. In terms of territory the anti-Treaty forces occupied about two thirds of the country. ${ }^{6}$ In Dublin many elements of the No. 1 brigade had adopted an anti-Treaty stance though all barracks in the city remained under the control of the pro-Treaty IRA. ${ }^{7}$ The military take-over of the Four Courts by anti-Treaty forces of the Dublin No. 1 Brigade on 13 April 1922 was a symbolic act that illustrated how tenuous was the authority of the provisional government. The failure to prevent it and the delay in ending that occupation was to emphasise the Provisional Government's military weakness and to try the patience of the British Government as they awaited decisive action. ${ }^{8}$ While Free State forces, using artillery pieces borrowed from the British, had commenced the shelling of the Four Courts on 28 June 1922 initial efforts had not succeeded in dislodging the rebels. The following day Winston Churchill in his capacity as chairman of the CID sub-committee on Ireland, indicated that he was particularly anxious that adequate supplies of artillery ammunition should be available to the British forces not yet withdrawn from Ireland should the provisional government relent on its opposition to British military assistance and agree to the offer of heavy artillery to end the occupation of the courts building. Similarly Churchill proposed that the RAF should lend aircraft, painted in Free State colours, and pilots, to the Free State forces. While the chief of the air staff, on the grounds of the possible adverse effect on the morale of aircrew, was opposed to painting RAF aircraft in Free State colours but would do so if ordered by higher authority. He suggested that the RAF could bomb the Four Courts with 112-lb bombs with delayed

\footnotetext{
${ }^{5}$ Michael Hopkinson, Green against green: the Irish civil war (Dublin, 1986), p.52.

${ }^{6}$ Ibid, xix

${ }^{7}$ Ibid, pp $58-72$.

${ }^{8}$ Ibid, pp 72-3.
} 
action fuses that would burst inside the buildings. ${ }^{9}$ To prepare for such an eventuality the Royal Air Force prepared for dispatch to Dublin, or actually sent, a considerable array of aircraft and munitions:

The following is the position at 12 noon to-day $\left(30^{\text {th }}\right) \ldots 3$ DH 9A [aircraft] with 3 $112 \mathrm{lb}$ bombs each are at Shotwick awaiting .... good weather. .... 1 Vickers Vimy with $2550 \mathrm{lb}$ bombs is ready at Spittlegate... a lorry with $6250 \mathrm{lb}$ bombs had an accident by Spittlegate ... 6 sets of bomb racks crossed by mail steamer last night.... 50 112lb bombs with instantaneous and delay action fuses are due Kingstown to-night......there are $20020 \mathrm{lb}$ bombs at Collinstown and 500 at Aldergrove. Arrangements .... to send $12250 \mathrm{lb}$ bombs to Collinstown. ${ }^{10}$

Notwithstanding the Irish caveat regarding British military assistance, the Irish Flight, RAF had prepared for the possibility that it would be ordered to bomb the Four Courts. On the evening of 29 June, even as provisional government forces were bombarding the Irregulars, RAF crews were practicing their bombing techniques. Between 18.30 hours and 20.15 hours that evening at least four R.A.F. crews carried out bombing practices on their aerodrome at Collinstown using Bristol Fighter H.1485 (and possibly others). This particular aircraft was to be handed over to the National Army within the week. ${ }^{11}$ While stories, to the effect that British aircraft did in fact bomb the Four Courts, are told no evidence has yet been found to support the contention that the RAF carried out any bombing on behalf of the provisional government.

\section{Buying the first military aircraft}

In the meanwhile IRA Headquarters at Beggar's Bush Barracks had taken some steps to initiate the purchase of at least one military aircraft. On 20 June 1922 the Chief of Staff, General Eoin O'Duffy, received a receipt from William J. McSweeney recording that the latter had 'received from Chief of Staff the sum of one thousand three hundred pounds

\footnotetext{
${ }^{9}$ Ibid, p. 121.

${ }^{10}$ Air Ministry minute sheet, A.V.M., D.T.O. to CAS, 30 June 1922 (NA, Air 8/49).

"Aircraft log book, H.1585, 29 June 1922 (AC Museum).
} 
[for the] purchase of [an] aeroplane'. ${ }^{12}$ Before the end of the month O'Duffy apparently issued another cheque, this time for $£ 2,500$, bringing the total for which McSweeney would subsequently account to $£ 3,800 .^{13}$ It is unlikely that O'Duffy had any role in the matter other than that of supplying the funds and later a letter authorising the purchase. As Collins did not assume the functions of commander-in-chief until 12 July 1922 McSweeney's actions had to be authorised by his military superiors. The subsequent involvement of Collins in military aviation matters would strongly indicate that the initial decision to purchase a reconnaissance aircraft was his - probably advised by Russell and under pressure from the British to do something about the occupation of the Four Courts. ${ }^{14}$ McSweeney purchased a return ticket and travelled to London by boat and train on 21 June 1922, apparently with verbal orders to purchase a military aircraft. On 24 June he visited the Aircraft Disposal Company, the firm charged with the disposal of British war surplus aircraft. He handed over a cheque for $£ 400$, drawn on one of two accounts he held in Dublin, presumably as a deposit on a Bristol Fighter F2B. However, apparently not having written authorisation, he was not allowed take delivery of the machine. On 26 June he paid 'C. Baker' three pounds seven shilling and 'Gamages' two pounds two shillings for goods or services that are not identified. For reasons that are not obvious he stayed in London a further three days, arriving back in Dublin on the morning of the 30 June. $^{15}$ He apparently proceeded direct to GHQ and collected a letter of authorisation signed by the chief of staff. This was addressed, incorrectly, to "Martinsyde \& Co., Woking'.

The bearer, Commandant General McSweeney, has authority to purchase one two seater reconnaissance machine which he will fly back to Ireland. The account will be settled on being furnished to me. ${ }^{16}$

As O'Duffy had already given McSweeney thirteen hundred pounds it is not clear why he should wish to settle the subsequent account and, in the event, did not. Accompanied by

\footnotetext{
12 Receipt dated 20 June 1922 (MA, AC/2/2/1).

13 Army finance officer to W.J. McSweeney, 12 July 1923 (MA, AC/2/2/1).

${ }^{14}$ Hopkinson, Green against green, pp 72-3

15 'Statement of expenditure', Comdt. Gen. McSweeney, 28 July 1923 (MA, AC/2/2/1).

${ }^{16}$ COS to Martinsyde, 30 June 1922 (NA, Air 8/49).
} 
Volunteer Thomas Nolan, who was to act as observer or navigator for the delivery flight of the aircraft, McSweeney returned to Britain on the evening mail boat of 30 June 1922. On arriving at the Croydon offices of the Aircraft Disposal Company on 1 July McSweeney signed an undertaking, presumably dictated by him but typed on ADC notepaper, confirming the purchase of a Bristol Fighter aircraft:

At the direction of the chief of staff, General O'Duffy, I hereby place with you a firm order for one new Bristol Fighter fitted with [a] new 300 H.P. Hispano Suiza engine, at a price of $£ 875$ delivered to me in flying condition at your Croydon works. The machine to be fitted with one Vickers gun and one Lewis gun, at an additional price of $£ 225 \ldots$. The above price to include one dual instruction flight and one solo flight on your stock machine. ${ }^{17}$

The provision in the contract that McSweeney would undergo one instructional flight and one solo flight, on the company's stock aircraft, was apparently to refresh McSweeney's flying skills in view of the fact that he had probably not flown any aircraft since being discharged from the RAF almost exactly three years previously, on 4 July $1919 .{ }^{18}$ On the same day he paid a further $£ 400$ to the ADC. A further payment of $£ 1,100$, made on 15 July, brought the total paid to the ADC to $£ 1,900$ while the contract price for the Bristol Fighter was only $£ 1,100$ - compared with an original new price in the region of $£ 2561 .^{19}$ It is not clear why McSweeney paid $£ 800$ over and above the agreed price for the single aircraft particularly as there is no evidence of spares being purchased in addition. It is possible that this represented down payments on two additional aircraft, but there is no evidence of authority for such an action.

Despite the fact that McSweeney had informally ordered the aircraft a week earlier and confirmed it in writing on the 1 July the aircraft, 'Machine No. H.1251', was not ready to be test flown until 3 July. This was probably most likely due to the removal of the $200 \mathrm{hp}$ Arab E.3534 engine and its replacement with the $300 \mathrm{hp} \mathrm{Hispano-Suiza}$

\footnotetext{
17 'Certified true copy', 21 June 1954, Comdt. Gen. McSweeney to ADC, 1 July 1922 (MA, PC 143).

${ }^{18}$ Aircrew service record, W.J. McSweeney (NA, Air 76/329).

19 'Expenses of Major General McSweeney during [the] year 1922-1923'; 'Statement of Expenditure', 28 July 1923 (MA, AC/2/2/1); Chaz Bowyer, Bristol Fighter F2B; king of (wo-seaters (Shepperton, 1985), p.124.
} 
engine, the most powerful of no less than eleven engine options available for the Bristol Fighter. ${ }^{20}$ The machine was test flown by a Captain Stocken for fifteen minutes starting at 17.12 hours the same day. Even then the delivery flight could not commence as McSweeney had not had his familiarisation flights. These apparently occurred on 4 July. On that day McSweeney signed an undertaking or indemnity agreeing 'to exonerate unconditionally The Aircraft Disposal Company, Limited, from any responsibility whatever for any accident that may occur to me while flying machines the property of the said company'. He also agreed to pay for any damage done to Avro 504K D.9358. ${ }^{21}$ At this point the key records relating to the events of 3/4/5 July 1922 give rise to certain ambiguities. The signing of the undertaking and the completion of two familiarisation flights on 4 July suggest that the aircraft could not have left Croydon until the early afternoon of that day. In the meantime the aircraft log book records that the 'machine B.F.2B [H.] 1251 arrived at Baldonnel [on] 4/7/22. Time in air three hours', without citing any particulars of the crew, the route taken or the dates and times of individual legs of the journey - a timetable that is possible. ${ }^{22}$ However McSweeney's expense account, not tendered until August 1923, indicates that he and Nolan had departed Croydon on the 3 July, landed at Shotwich, presumably late that evening, and spent that night, and a second one, at a hotel in Chester and therefore could not have arrived at Baldonnell until 5 July 1922 at the earliest. This chronology does not allow for the familiarisation flights on 4 July and therefore may well indicate a slight error in McSweeney's expense account. The expense account entry that reads 'flew to Shotwick - arrived 3/7/22, Hotel Chester 34-5/7/22' might more correctly relate to a departure on 4 July followed by two overnights (4/5 July and 5/6 July) in Chester and a departure to, and arrival at, Baldonnell on 6 July 1922. This latter scenario is also suggested by a brief telephone message, recorded at GHQ on 7 July, stating that 'Comdt. General McSweeney rings from Baldonnel to say he has arrived with plane and awaits instructions'. This message suggests that McSweeney may have arrived at Baldonnell late on 6 July but did not inform GHQ until the following morning. ${ }^{2.3}$ In the circumstances, while it cannot be stated categorically on what date

\footnotetext{
${ }^{20}$ Log book, BF II (AC Museum); Bowyer, Bristol Fighter, p. 124.

21 W.J. McSweeney to ADC, 4 July 1922, 'certified true copy' by W.J. Keane, 21 June 1954 (MA, PC143).

22 Aircraft log book, BF II, p.5 (AC Museum).

${ }_{23}$ Phone message A/179, 7 July 1922 (UCDA, MP, P7/B/106/266).
} 
Bristol Fighter F2B 'BF II' was delivered, it is strongly suggested that it was not on 4 July 1922 and that, on balance, it is most likely that the aircraft arrived in Baldonnell on 6 July 1922. The log book entry indicating 4 July 1922 possibly relates to the departure from Croydon rather than the arrival at Baldonnell.

\section{Two RAF aircraft acquired}

In the meantime, in Dublin and surrounding counties, with the retaking of the Four Courts by provisional government forces, the Civil War was under way. At an early stage, in view of the destruction of telephone lines, Michael Collins had identified an urgent requirement for reconnaissance aircraft and took decisive action. On the morning of the 4 July Collins made representations to Dublin Castle as a result of which Alfred W. Cope, under-secretary at Dublin Castle, sent an urgent, yet long and detailed, telegram addressed to Lionel Curtis in the Irish Office at the Colonial Office, London, for the attention of Winston Churchill.

Collins wants two aeroplanes one with undercarriage for bombing and one without. Reasons for request are McSweeney has not brought over his plane yet due to inclement weather. Telegraph and telephone communication is interrupted and particulars of the surrounding country are not available. Reports come in of concentrations of irregulars in Dublin county and neighbouring counties. Troops and transport are sent out on these reports and search country for hours for these concentrations but fail to find them and men and time are wasted. Collins is satisfied he could clean up the country districts if he could get early information of concentrations and keep up communications. As an example of (2) above there were reports yesterday that irregulars were doing well in Drogheda. At P.G.'s request I got through to Gormanstown by wireless for information but wires were down between Gormanstown and Drogheda and no information could be obtained. It would be most undesirable for P.G. to use our pilots owing to the dead set which is being made by republicans on P.G. receiving assistance from us. Each issue of the Republic of Ireland mentions either Mr. Churchill, General Macready or myself 
as giving assistance in the fight and the mainspring of the republican propaganda is that British forces are prompting and assisting in the killing of Irishmen. I suggest one aeroplane being handed over at once. Can this be done please. The handing over should be at Baldonnell. The P.G. have one or two efficient airmen - of this I am certain. ${ }^{24}$

The citing of inclement weather as delaying the delivery of the aircraft from London does not appear valid. The reason quoted more likely represents the urgency and frustration of Collins who was awaiting the delivery of an aircraft the purchase of which he had, in all probability, authorised some two weeks previously. The appeal from Collins, which was received in the Colonial Office at 11.39 am the same day, in addition to constituting an urgent request for reconnaissance aircraft, explains much about the military situation as it was developing in the aftermath of the re-taking of the Four Courts. Collins recognised immediately that the absence of adequate communications rendered it very difficult, if not impossible, to counter the activities of the Irregulars who were, of course, responsible for the destruction. Even in the areas close to the city provisional government forces were apparently operating at a considerable disadvantage, a situation that required the type of intelligence that aircraft operating from Baldonnell could provide. With Churchill and the Colonial Office well disposed to Collins and the provisional government, the British government, in keeping with the policy of affording whatever military help might be requested, gave a swift and positive response. At 14.20 hours on 4 July 1922 the War Office sent a secret dispatch to the British GHQ in Dublin to the effect that 'two Bristol aeroplanes from [the Irish Flight at] Collinstown will be handed over at once to provisional government' and that the aircraft 'should be equipped as provisional government may desire'. ${ }^{25}$ Later that day the head of the RAF in Ireland, Group Captain Bonham-Carter received a secret dispatch by telegram:

Orders have been issued through War Office to supply provisional government with two service aeroplanes. You will hand over two serviceable Bristol Fighters armed

\footnotetext{
${ }^{24}$ Telegram, 'Cope to Curtis for Mr. Churchill', 4 July 192, (NA, Air 8/49). The word 'undercarriage' should, more correctly, read 'bomb racks'.

${ }^{25}$ Cipher M.O. 3, War Office to McCready, 4 July 1922 (NA, Air 8/49).
} 
and equipped as they may require. Machines will be replaced as soon as weather permits. Offer any technical advice and ensure that machines are efficient in every way. British marking [are] to be removed. ${ }^{26}$

With McSweeney still away taking delivery of the first aircraft C.F. Russell, the director of a Civil Aviation Department that was, in effect, under military command, was the only pilot available to take delivery of aircraft. It was to be early the following afternoon before C.F. Russell could proceed to Collinstown. There he took possession of one of the only three serviceable Bristol Fighters of the Irish Flight, RAF. Taking off at 15.00 hours and, allegedly wearing a bowler hat, he flew Bristol Fighter E.2411 the ten mile journey to Baldonnel in fifteen minutes. That this aircraft actually arrived at Baldonnel before the one flown from London by McSweeney is inferred by the fact that it was given the Air Service serial number 'BF I' though this cannot be taken as being conclusive. However, as argued above it is unlikely that McSweeney's aircraft arrived at Baldonnell before 6 July - and therefore was given the number 'BF II'. While log book entries should be the most reliable historical record manifest inconsistency in the keeping of log books, by an inexperienced and as yet poorly organised ground staff, was to make it difficult to detail the chronology of aircraft flights, to identify individual missions and assess the overall operational use of aircraft throughout the Civil War period.

\section{Air operations}

As the instigator of efforts to establish military aviation Michael Collins controlled and directed the operational use of aircraft during the months of July and August 1922. Telephone messages and other correspondence in the Mulcahy Papers indicate that the designation of particular missions was done by Collins in consultation with Russell or McSweeney or both, mainly by telephone but sometimes in person with the flying officers. There is no evidence that the staff of GHQ had any active role in the matter though, being in receipt of reconnaissance reports received by telephone or in writing or both, they would have been well aware that an air operation was in hand. At eight of ten

\footnotetext{
${ }^{26}$ AM to Bonham-Carter, 4 July 1922 (NA, Air 8/49).
} 
meeting of the general staff or War Council held in July and August, the subject of 'air' or 'aviation' featured on the agendas. However the relevant minutes reflect no discussion of the subject. This probably reflected a policy, dictated by Collins, which restricted the air intelligence to those who needed to know. While it is also possible that GHQ staff had very little interest in the activities of two ex-RAF pilot officers and had little faith in the use of aircraft for intelligence purposes it seems likely that Collins' reports to the War Council on aviation matters went unrecorded on his instructions. ${ }^{27}$

While there was no apparent policy or overall plan for air reconnaissance the air operation fell in to three fairly distinct phases - the month of July in the Leinster area, the month of August mainly in the Munster area and, from October 1922, in the Munster area with missions carried out from bases in Fermoy and Tralee. During the month of July about twelve reconnaissance missions were flown in the Dublin area and the south Leinster counties of Wicklow, Wexford, Carlow and Kilkenny against Irregulars who were being driven south by Provisional Government troops. C. F. Russell, now secondin-command to McSweeney, flew the majority of the reconnaissance patrols during July and August 1922. Given the standard of $\log$ book keeping and the paucity of reconnaissance reports it is not possible to be definitive about the extent of the air operation, either in July or later. The aircraft log books, in many cases, do not identify the mission area while flights are not recorded in chronological order. Some entries appear to have been written up days in arrears without regard for accuracy in the matter of dates. It appears that an unknown, though probably small number of entries, was omitted entirely. ${ }^{28}$ Reconnaissance reports appear not to have been made prior to 16 July, while only three are available for that month.

It should be appreciated that in early July 1922 the Military Air Service had only two pilots and two observers, and, with the delivery of the second RAF Bristol Fighter from Collinstown on 10 July, a total of three aircraft. ${ }^{29}$ W.J. McSweeney, who had been on the Army payroll since April 1922 had, as his observer or navigator, Lieut. Tom Nolan who was still of volunteer rank when hurriedly pressed into service on 30 June for the delivery flight of BF II. Lieut. Nolan is recorded as being appointed to a 'commission as

\footnotetext{
${ }^{27}$ Microfilm P7/B/47 (UCDA, MP).

${ }^{28} \mathrm{Ibid}$; Aircraft log books, BF I, BF II and BF III (AC Museum).

${ }^{29}$ Log book, BF III (AC Museum).
} 
$2^{\text {nd }}$ Lieutenant in the Aviation Section I.R.A.' by McSweeney on 7 July 1922 'subject to ratification by the chief of staff'. ${ }^{30}$ C.F. Russell, the only other pilot, had as his observer Staff Captain W. Stapleton who first flew on 10 July $1922 .^{31}$ Stapleton, who had been a member of the garrison at Baldonnell and who had 'put in a temporary transfer to aviation as an observer' is later recorded as actually joining the Air Service on 11 July. ${ }^{32}$ Like Nolan, Stapleton appears not to have had any aviation training or qualifications of any kind before commencing flying with the Air Service.

The first reconnaissance mission, for which a report survives, took place on Sunday 16 July 1922. That afternoon McSweeney and Nolan left Baldonnell at about 15.00 hours in Bristol Fighter 'BF III' to carry out reconnaissance in the Tullow and Baltinglas areas, apparently in preparation for an attack by government troops on Irregulars that was planned for the following morning. They observed nothing unusual at Baltinglass and observed at Tullow that 'the town was full of men' but that 'they were only standing around and there appeared to be no activity of a military nature' They also reported that the roads into the town were partially blocked but that there were no sentries at these barriers. On route to Newtownbarry (Bunclody, Co. Wexford) the engine of McSweeney's aircraft began to cut out forcing him to turn for home and to use the handpump to maintain fuel pressure. Eventually the engine failed from fuel starvation resulting in a forced landing in a field at Ballycane, Naas, Co. Kildare. Nolan was injured during the landing as the aircraft was badly damaged when it hit an open ditch. The aircraft was to remain out of service until February $1923 .{ }^{33}$ A number of significant factors may have contributed to this first accident for the Military Air Service. Firstly there was the matter of McSweeney's relative inexperience and lack of recent flying practice. Secondly his lack of familiarity with the operation of the systems of the particular aircraft type, a type he had not flown during his service with the RAF, put him a severe disadvantage. It appears unlikely that he had had sufficient time to receive technical instruction on such matters from the ADC at Croydon earlier that month. Even

\footnotetext{
${ }^{30}$ W.J. McSweeney to Vol. T. Nolan, 7 July 1922 (MA, PC143).

${ }^{31}$ Aircraft Log Book, BF 1 (AC Museum); 'Military Aviation - Personnel', 22 July 1922 (UCDA, MP, P7/B/49/37).

32 McSweeney to COGS, 24 July 1922 (MA, A/06886).

${ }^{33}$ McSweeney to AG, 17 July 1922 (UCDA, MP, P7/B49/41); Log book BF III (AC Museum).
} 
if he had his lack of experience with the fuel system would have told. ${ }^{34}$ This unfamiliarity most likely caused McSweeney to mismanage the somewhat complex fuel system of the Bristol Fighter and probably resulted in the fuel starvation that eventually caused the accident. $^{35}$

Subsequent events suggest that air reconnaissance missions, and the intelligence they afforded, were already an important aspect of the fight against the irregulars after just only one week of such operations. With the reconnaissance mission of 16 July to the Wicklow / Carlow / Wexford area not completed C.F. Russell and his observer, Capt. W. Stapleton were detailed, probably on a direct order from Collins, to undertake the same mission early the following morning. In very poor weather conditions Russell and Stapleton took off from Baldonnell at 07.00 hours in an unidentified Bristol Fighter, probably BF I. They carried out reconnaissance of the towns of Tullow and Baltinglass in particular. On their return to Baldonnell at 08.45 hours Russell reported the presence of barricades on the roads to the north and south of Tullow at about 07.40 hours though he 'found the town asleep' saw neither Irregulars nor state troops. When he arrived over Baltinglass he found 'a good number of people about the streets' and all roads and bridges intact. He reported that his aircraft had been hit by one of a total of eight shots, fired from three separate locations in Baltinglass, but that he was unable to return fire because of the poor visibility and mist at 200 feet. Russell's report was relayed by phone to Army Headquarters where it was recorded as being received at 09.15 hours. ${ }^{36}$ What effect this mission, and the information it provided, had on the ground operation against the Irregulars of the area is a matter of conjecture but by 22.40 hours that night GHQ had issued a press statement to the effect that at 14.00 hours troops had captured Baltinglass and that troops now occupy Baltinglass [and] Newtownbarry. Twenty-five men and a significant amount of arms and ammunition had also been seized. ${ }^{37}$

\footnotetext{
${ }^{34}$ Aircrew service record, W.J. McSweeney (NA, Air 76/329).

${ }^{35}$ Royal Air Force Training, Part 1, Flying Instruction (Air Ministry, 1923), pp 158-163.

${ }^{36}$ Reconnaissance report, 17 July 1922 (UCDA, MP, P7/B/107/69).

${ }^{37}$ Freeman's Journal, 18 July 1922.
} 


\section{Organisation and personnel}

By the outbreak of the Civil War on 28 June 1922 there were, in effect, three separate organisations, paid off the Army payroll, based at Baldonnell. The aerodrome at Baldonnell was actually under the military control of a garrison which had moved in after the aerodrome had been taken over by Capt. O'Grady from the departing Irish Flight of the RAF at midday on 3 May 1922. The newspaper reports of the matter suggest that the initial garrison consisted of troops from Clonskeagh Castle. However the same report records, incorrectly, that Baldonnell had been the demobilisation base for the RIC. (The major RIC demobilisation process took place at Gormanston, County Meath) On 28 June 1922 the garrison numbered about ninety all ranks and its main function and preoccupation was the security of the Camp. ${ }^{38}$

The Civil Air Service, that had been given Government approval to assume the functions of the civil aerodrome authority at Baldonnell, had seven staff members in April 1922, including Russell. In addition to its intended task relating to management and running of the civil aerodrome Russell's department was notionally preparing to facilitate commercial aviation if and when such activity received government sanction. By 20 July the Civil Aviation Department had a total of sixteen personnel, fourteen civilians, including 'Chas. F. Russell, the director of civil aviation and secretary to the Air Council' and two army volunteers. Five of the sixteen had been recruited after the commencement of the Civil War. Two engineers were included. Charles J. O'Toole had been employed as an aero ground engineer since 14 June 1922 and William J. Guilfoyle, a maintenance engineer had been on loan from Irish Lights since 30 April 1922 on the understanding that he would be reinstated to his previous position should his services not be permanently required by the civil department or service. ${ }^{39}$ The most recent member of staff, E. Broy, accountant and clerk, had been employed with effect from 19 July at a salary of $£ 5$ per week while A.J. Russell, brother of C.F. Russell, was being paid one pound ten shillings per week as a junior clerk. ${ }^{40}$ Broy's employment in the civil

\footnotetext{
${ }^{38}$ Report to staff meeting, 28 July 1922 (UCDA, MP, P7/B/10/40).

${ }^{39}$ 'Department of Civil Aviation', 20 July 1922 (UCDA, MP, P7/B/49/38).

40 Ibid.
} 
department was apparently as a result of representation he had made to Collins who in turn had arranged employment with the new air service. ${ }^{41}$

By way of contrast, the Military Air Service, which aspired to be equipped and function as the effective military air element of the Army, consisted of only five personnel, including 'Commandant General' W.J. McSweeney at the end of April and had only risen to a total of eight by 28 June. The Civil War was to bring about significant though contrasting changes in fortune to the two aviation departments though the function of GHQ in these developments would be reactive than rather than proactive. By 22 July 1922 the strength of the personnel in military aviation had increased by twentynine to a total of thirty six and included eight civilians. ${ }^{42}$ Much of this increase can be put down to the immediate effect of the general recruitment call of the minister for Defence in early July. In the case of Baldonnell the vast bulk of the new volunteers went to the Air Service. With continuing recruitment 100 officers and men had joined the Air Service by mid-November 1922 by which time the garrison unit, now known as the 'Air Service Infantry' had reached a similar figure. ${ }^{43}$

However, on or about 22 July 1922, the civil department ceased to exist for all practical purposes. This decision coincided with a review of organisation and personnel requested by the minister. On 17 July Richard Mulcahy had written to the Air Service, and sent a reminder four days later, requesting a statement of the number of men employed in that department plus a diagram indicating the organisation. 'Will you also let me know their ranks, duties, date from which they have been employed and their pay' and 'let me have the same particulars regarding the men employed in Civil Aviation under Russell'. ${ }^{44}$ McSweeney had Russell supply the required details of the sixteen personnel of his department and subsequently forwarded nominal rolls of the two air elements indicating, in the cases of almost all, the effective date, type of employment and weekly rates of pay. (Appendix 4) The nominal roll of McSweeney's thirty-five subordinates in the military department included five officers, twenty-two NCOs and Men as well as eight civilians. The names of five volunteers, posted to the unit on the 22

\footnotetext{
${ }^{41}$ Officer's personal file (MA, SDR 169).

42 'Military Aviation - personnel', 22 July 1922 (UCDA, MP, P7/B49/38).

${ }^{43}$ Baldonnell return, 12/13 Nov. 1922 (MA, Army census)

44 'Aviation', MFD to Comdt. General McSweeney, 17 July; 21 July 1922 (UCDA, MP, P7/B49/43-44).
} 
July, had been appended in manuscript. McSweeney also forwarded a covering letter that confirmed the amalgamation of the civil and military aviation resources at Baldonnell:

During the present hostilities, Civil and Military Aviation have been combined and the various Civil and Military Departments are working together as one unit, all under military control with the Director [of Civil Aviation] as $2^{\text {nd }}$ in command. The duties are divided into 7 details;

Discipline.

Aeroplane repair and maintenance.

Electric power and water supply and sewage.

Buildings, repairs and technical stores.

Aerodrome labourers (carpenters, labourers etc.)

Quartermaster Stores. ${ }^{45}$

McSweeney explained that while 'each department was under a responsible man' the organisation was 'only at an embryonic stage of development'. He stated that the attaining of maximum efficiency depended on the sanction for increased pay for qualified mechanics, the supply of more aeroplanes and new transport, all of which he had previously requested. While the Military Air Service had no transport of its own its transport depot was maintaining the transport on charge to the garrison. ${ }^{46} \mathrm{He}$ also forwarded a copy of a newly drafted 'Standing Orders' that detailed the daily routine to be observed by all military personnel, as well as standard practices and safety precautions to be observed by military and civilian alike, in the hangars and workshops.

While the bulk of the civil department employees merely transferred to the military payroll as civilians a small number, including C.F. Russell and his brother Arthur, joined the Military Air Service. ${ }^{47}$ On 19 July, McSweeney had already requested the chief of staff to 'please sanction' the appointment of 'Capt. C.F. Russell, director of civil aviation' to 'the rank of commandant'. ${ }^{48}$ Eamonn Broy also made the transfer from

\footnotetext{
${ }^{45}$ DMA to MFD, 22 July 1922 (UCDA, MP, P7/B/49/36).

${ }^{46}$ Ibid.

${ }^{47}$ Baldonnel return, 12/13 Nov.1922 (MA, Army census).

${ }^{48}$ W.J. McSweeney to COS, 19 July 1922 (UCDA, MP, P7/B/49/34).
} 
civilian to military. In light of his DMP background and his distinguished record in republican intelligence during the War of Independence his employment, initially in civil aviation, and later in military, might appear unusual. However he appears to have had a certain interest in aviation from at least October 1921 when he was in London with Collins and had been on the periphery of events associated with the purchase of aircraft at that time. It may well have been Broy who typed the Dalton / Russell report of 21 October 1921 informing GHQ about the purchase of aircraft. As a result of research carried out by the late Colonel Billy Keane in the 1950s we know that Broy, on 28 October 1921, had purchased a book entitled The German Air Force in the Great War and, much later, a German Air Force Handbook for the year $1936{ }^{49}$ While Eamonn Broy's level of interest in, and knowledge of, aviation, may be a matter of conjecture it appears that his drift towards civil aviation, in the first instance, and later into military aviation, may more correctly have been a drift away from intelligence work. A compelling reason for Broy's change of career is recorded on his military personal file in Military Archives:

Broy was in Oriel House up to some time in April 1922, when he left as a result of a disagreement with Tobin, who was at that time in charge of Oriel House. He later joined the Army, sometime in July or August 1922 I believe. ${ }^{50}$

While Broy had been employed in the Civil Air Service from 19 July 1922 ten days later he was given the commissioned rank of commandant and appointed adjutant, Air Service by order of Michael Collins and subsequently functioned as second-in-command to the director of military aviation until May 1923, apparently with considerable dedication to the Air Service and loyalty to General McSweeney. ${ }^{51}$ The suggestion, by Padraic O'Farrell, that Eamonn Broy adopted an anti-Treaty stance during the Civil War is quite erroneous. $^{52}$

\footnotetext{
49 These books were presented by Broy to the Officers' Mess, Baldonnell in the early 1950s. The flyleaf of the earlier book was annotated 'E. O'Broite, 15 Cadogan Gdns., Sloan Sqr. 28/X/1921'.

${ }^{50}$ Unsigned file memo, 13 Nov. 1925 (MA, SDR 169).

${ }^{51}$ Officer's history sheet (MA, SDR 169).

52 Padraic O'Farrell, Who's who in the Irish war of independence and civil war 1916-1923 (Dublin, 1997), p. 145.
} 
Two days after announcing the amalgamation of the civil and military aviation resources at Baldonnell McSweeney made a submission to the Chief of General Staff in terms that suggest that he considered that he had command of all army elements at Baldonnell, including the garrison, with himself holding the appointments of both DMA and station commander. His submission in relation to the garrison was imprecise but suggested the unit's strength to be in the region of 100 all ranks including five officers and sixteen NCOs but that the personnel were liable to be posted elsewhere, for civil war action, without being replaced. Indicating that a barrack staff of thirty men, a daily guard of twenty one men and a weekly emergency guard of twenty-one men could not be maintained from existing resources, he recommended that the garrison be increased to 250 men, or 2 companies and a barrack staff of 50 . He considered that 'the ratification of the following appointments will effect a considerable improvement in organisation. He recommended 'S/Capt. Conry to be permanent camp O.C.' and ' $2 /$ Lt. Wilson to be permanent camp adjutant with the rank of captain'. He also made recommendations for the posting of officers to various appointments including his own as station commander, apparently in addition to director of military aviation. ${ }^{53}$ The inference in McSweeney's submission regarding the command of the various elements at Baldonnell did not escape the notice of chief of general staff, Richard Mulcahy, though his instructions to Emmet Dalton, now GOC $1^{\text {st }}$. Eastern District, were brief and somewhat ambiguous. Mulcahy directed Dalton to make arrangements, sooner rather than later, 'to bring the Garrison at Baldonnell up to the numbers necessary to carry out garrison duties.' In a manuscript postscript to the note he indicated that 'the division of authority and responsibility between McSweeney and OC Garrison require clear definition and understanding, ${ }^{54}$ The inference in this direction is that Mulcahy considered the Air Service and the garrison to be of equal status under officers of similar standing. Dalton confirmed that he would increase the numbers in the garrison up to 100 (plus 50 of a barrack staff) and that he was 'also arranging the division of responsibility. ${ }^{55}$ However there is no evidence, then or subsequently, that Dalton issued any directive clarifying the matter of command.

\footnotetext{
${ }^{53}$ W.J. McSweeney to COGS, 24 July 1922 (MA, A/06886).

${ }^{54}$ COS to General Dalton, 24 July 1922 (UCDA, MP, P7/B/49/25).

${ }^{55}$ J.E. Dalton to COS, 26 July 1922 (UCDA, MP, P7/B/49/24).
} 
At this early juncture in the formation of the Air Service it appears that the infantry and air personnel had already divided along cultural lines undermining whatever authority McSweeney may have considered he had over the garrison on the basis of his rank. When an unknown GHQ officer visited the aerodrome on 30 July 1922 he recorded that he had met Commandant Russell and 'visited both camps, lower camp and upper camp generally speaking careless, number of men at present much too small for effective care and control'. While he observed that 'it is proposed to put the entire air establishment under army control' - something that had in fact been done a week earlier - he made no reference to the command status of the various formations at Baldonnell. ${ }^{56}$ A further indication of the apparent divide was the existence, in August 1922, of two guard rooms as well as separate sleeping quarters and officers' messes for infantry and air personnel. $^{57}$ That Dalton failed to act on the matter of the division of authority and responsibility can be inferred from a later communication that listed the various aspects of command and control which, at that late stage, still remained to be clarified. ${ }^{58}$ The failure of GHQ to approve a formal establishment and to clarify the command status of the Air Service was to leave McSweeney in a nebulous position, in effect, up to his eventual dismissal in March 1924. It is also noted that Dalton also failed to increase garrison numbers before he was transferred south to Cork in early August. By the time of the Army census in November 1922 the total of the combined garrison and barrack staff was still only about 100 .

\section{Reconnaissance missions in Munster}

Before the end of July the general line of contact between the Army and the Irregulars had cleared south Leinster as the latter group retreated southwards and westwards with the hostilities becoming somewhat concentrated in Munster. ${ }^{59}$ The radius of action of a Bristol Fighter operating from Baldonnell, as the RAF had found previously, extended

\footnotetext{
${ }^{36}$ Unsigned report, 'Visit to Baldonnell', 30 July 1922 (UCDA, MP, P7/B/10/28).

${ }^{57}$ Unsigned, undated memo, 'Telephones at Baldonnell', circa August, 1922 (UCDA, MP, P7/B/10/7).

${ }^{58}$ Unsigned, undated memo, 'Status of Air Service', with covering letter COGS to C-in-C, 24 Jan. 1923 (MA, A/08075).

${ }^{59}$ Duggan, Irish army, pp 89-91.
} 
only as far as Fermoy. ${ }^{60}$ As a result acrial patrols became less practical and productive due to the constraints of aircraft range and endurance. The report by Russell and Stapleton on their 'reconnaissance and propaganda-dropping flight' of 22 July illustrated the difficulty. Having been directed to drop newspapers in addition to carrying out reconnaissance Russell reported successfully distributing ' 600 copies of the Weekly Freeman's Journal (War Edition) and 9,000 copies of An tOglach (War Special)' among the main towns of the county of Kilkenny. However, having insufficient endurance over the operational area to pursue the required reconnaissance objectives he had to curtail the flight though he did report that one of the bridges in Clonmel had been blown up. ${ }^{61}$ While, according to a garbled report recorded in GHQ, a propaganda-dropping mission was flown into County Tipperary on the 2 August 1922 the military situation on the ground would require that aircraft be operated from airfields further south and eventually be based closer to the ground action. On 4 August Michael Collins recorded a brief note in relation to the 'Air Services':

Interviewed Commandant Russell, $4^{\text {th }}$ August, 11 am, arranged that as soon as practicable reconnaissance will be made of Youghal and Cork. This will be carried out probably from Waterford. The Waterford station is in the process of being fixed. ${ }^{62}$

This requirement was apparently already known to McSweeney who had gone down to Kilkenny by road on 29 July and, with Comdt. General Prout, had picked out two landing grounds. He considered that one of the grounds, which had been used by the British during the War of Independence, was only safe for landing 'in the directions NW \& SE'. He picked a second field six hundred yards away 'for landing in the directions NE \& SW'. The location of this former RAF ground was not specified but was most likely one of only three British landing grounds in county Kilkenny designated for use during the earlier hostilities. He also visited Waterford and inspected and approved a landing ground

\footnotetext{
${ }^{60}$ Undated map, 'RAF in Ireland' (NA, Air 8/49).

${ }^{61}$ 'Report of reconnaissance and propaganda-dropping flight', Capt. C.F. Russell to GHQ, 22 July 1922 (UCDA, MP, P7/B/107/138).

${ }^{62}$ M. Collins file memo, 4 Aug. 1922 (UCDA, MP, P7/B/10/29).
} 
at an unspecified race course - presumably that at Tramore, about seven miles south of the city. ${ }^{63}$ McSweeney prepared detailed instructions for the use of the forward 'aero bases' for the guidance of the troops that would have to support Air Service use of the selected fields. His instructions included provision for security, marking the landing grounds and the cutting of meadow grass to allow aircraft to operate. In particular he detailed the arrangements for the availability of fuel and oil that the Air Service would supply and forward to Kilkenny military barracks in advance of any mission involving either of the Kilkenny landing grounds. ${ }^{64}$

As McSweeney had departed for London on 30 July to purchase more aircraft it fell to Russell and Stapleton to carry out the reconnaissance mission to the Cork and Youghal area, though, for reasons that are not clear this did not get under way until 7 August. On 6 August the Air Service confirmed to Collins that 'arrangements have been made for the establishment of operational bases at Kilkenny and Waterford' confirming that base kits of petrol and oil supplies had been dispatched and had been received at both locations. ${ }^{65}$ The $\log$ book for BF I indicates that Russell and Stapleton left Baldonnell at 11.35 hours on 7 August 1922 to commence the mission to Cork with had four specific objectives. The main task was to meet the Cork commander and inform him that various requisites were being dispatched from Dublin. Russell was also to carry out reconnaissance of the whole area, give armed support to ground troops where required and distribute copies of a special air edition of An tOglach. ${ }^{66}$

With McSweeney and Russell away from base Commandant Eamonn Broy was in charge at Baldonnell and was keeping GHQ informed as to the positions, as he knew them, with regard to the Cork mission and McSweeney's trip to London. On 9 August Broy reported to GHQ that he had been unable to communicate with Kilkenny or Waterford by telephone or by wireless since the aircraft had left. 'I therefore had a private motor car commandeered yesterday and sent Lt. Nolan and a man in mufti to get through to Kilkenny and Waterford'. Having left Baldonnell at 20.45 hours on 8 August Lt. Nolan made contact with Russell in Waterford at 05.45 hours on the 9 August. Russell reported

\footnotetext{
${ }^{63}$ W.J. MaSweeney to GHQ, 30 July 1922 (UCDA, MP, P7/10/33).

${ }^{64 ،}$ 'Aero Bases', W.J. McSweeney to C-in-C, 30 July 1922 (UCDA, MP, P7/B/10/34).

${ }_{65}$ AS to M. Collins, 6 Aug. 1922 (UCDA, MP, P7/B/10/26).

66 'A erial reconnaissance report', C. F. Russell to GHQ, 10 Aug. 1922 (UCDA, MP, P7/B10/13-14).
} 
that 'they had made a successful landing at Kilkenny and Waterford' on the 7 August. Russell later reported to Broy that he had tried to send a message to Collins to the effect that he had not been able to fly on the 8 August due to the fact that it had been raining all day. ${ }^{67}$ The actual reconnaissance of Youghal and Cork apparently took place on 9 August though neither the aircraft log book nor Russell's report of the 10 August 1922 make this adequately clear. The reconnaissance mission coincided with the ship-borne attack by Government troops on Cork and environs. ${ }^{68}$ It was a relatively short mission, leaving Waterford at 16.10 hours returning by 18.10 hours. Russell subsequently reported that 'the message was delivered to the C.O. at his H.Q., Rochestown'. He also stated that Thomastown was very quiet while Youghal was similar with Free State troops moving freely about the town. He observed that two ships were tied up at Passage West and, while a few troops were about, there was no fighting and that civilians were moving freely through the streets. His report on Cork suggests that he had arrived over the city at or close to the termination of the military operation that had cleared the irregulars from the area.

One would imagine to see Cork city from the air that the whole town was enveloped in flames. Closer examination revealed the fact that all barracks, police and military, were on fire. Also what appeared to be a private house, half a mile north of Victoria Barracks. Victoria Barracks was, in spite of smoke and flame, a scene of great activity. Large numbers of men were moving about in a very excited manner. ${ }^{69}$

Russell reported that a total of 4,000 copies of An tOglach had been dropped over Youghal and Cork City and that while no opportunity had presented itself to use machine gun fire in cooperation with friendly troops he had returned fire after coming under attack at Midleton on the return journey to Waterford. ${ }^{70}$

\footnotetext{
67' Aerial action at Waterford', E. Broy to M. Collins, 9 Aug. 1922 (UCDA, MP, P7/B/10/21)

${ }^{68}$ Hopkinson, Green against green, pp 162-64.

69 'Aerial reconnaissance report', C. F. Russell to GHQ, 10 Aug. 1922 (UCDA, MP, P7/B/10/13).

${ }^{70}$ Ibid.
} 
After the taking of Cork Collins concentrated aerial reconnaissance on the general area of the counties of Limerick, Tipperary and Cork with some missions coinciding with his own visit to the area. Russell and Stapleton had been due to go to the Limerick area on 12 August but were again delayed by bad weather. ${ }^{71}$ At noon the following day Russell received a cipher message from Collin indicating that he should report to Limerick Junction at any time after eleven' and that all arrangements, including a car, were in place. ${ }^{72}$ After some difficulty with damaged telephone lines Broy replied, at 14.50 hours, to the effect that the aircraft had left at 13.00 hours for Limerick Junction. ${ }^{73}$ It is not at all clear whether Russell landed at Limerick Junction or not. However it appears that he did land at the Fair Green in Limerick on 13 August in BF 1 and operated from there on 13 and 14 August. Later on the first afternoon Russell carried out a patrol of a large part of north Cork. He subsequently reported that the railway bridges at Mallow and near Buttevant had been observed to have been blown up while the latter was still burning fiercely. He also reported that three small road bridges near Buttevant had been destroyed and that his aircraft had come under heavy fire from a machine gur post a half mile north of Mallow. ${ }^{74}$ On the morning of 14 August Russell patrolled the areas of Bansha, Ballylanders and Kilfinnane in Tipperary and reported little of interest other than being shot at from Ballylanders. ${ }^{75}$ In the afternoon he patrolled Charleville, Buttevant and Liscarroll in the county of Cork, subsequently reporting having observed only Free State troops in Charleville and having twenty shots fired at the aircraft in Buttevant. ${ }^{76}$

Some technical aspects relating to the operation from Limerick give rise to a degree of ambiguity. In preparation for the Limerick operations the Air Service had to have fuel and oil dispatched to Limerick, but still having no indigenous road transport, apparently arranged for the convoy bringing Collins southwards to convey the necessary supplies. For Collins' journey it had been suggested that 'only the best cars' were required. ${ }^{77}$ For reasons associated with the transport arranged for Collins' journey of 12

\footnotetext{
${ }_{72}^{71}$ Copy cipher message, 12 Aug. 1922 (Broy private papers, in possession of Ms. Aine Broy)

72 Ibid, 13 Aug. 1922.

73 Ibid, 13 Aug. 1922.

74 'A erial reconnaissance report', 13 Aug. 1922 (UCDA, MP, P7/B/39/21).

75 'Aerjal reconnaissance report', 14 Aug. 1922 (UCDA, MP, P7/B/39/17).

76 'Aerial reconnaissance report', 14 Aug. 1922 (UCDA, MP, P7/B/39/16).

${ }^{77}$ Unsigned, undated memo re 'Transport detail' (UCDA, MP, P7/B/3/73).
} 
August the aviation fuel supplies did not reach their destination. The matter is explained by a letter of complaint from Collins and directed at the QMG:

I have to report to you that on Saturday morning, $12^{\text {th }}$ Inst., there paraded as follows; one touring car, one Crossley tender, one Lancia car. The Lancia went at fire at Naas, was restarted, had difficulty getting to Roscrea. Near Roscrea the Crossley ran out of petrol - no spare petrol in any of the cars - and both the tender and Lancia would, therefore, have been left on the road were it not for a supply of aviation spirit which was being taken, at the request of the Air Service, to Limerick. $^{78}$

Aviation folklore suggests that, as a result of not having aviation fuel at Limerick, Russell's aircraft was supplied with motor petrol and that engine failure, a forced landing and damage to the undercarriage ensued. Indeed Collins' own diary and other records of the time suggest that the aircraft sustained a certain level of damage, most likely on Sunday 13 August. At 10.43 hours on 14 August Comdt. Broy received a wireless message, via ' $\mathrm{O} / \mathrm{C}$ Troops Limerick' and Portobello Barracks, requesting the dispatch of ' 10 hrs.[worth of] petrol and oil immediately, also spare wheel and two mechanics for duty here: send direct to Limerick City'. ${ }^{79}$ Within the hour Broy had confirmed that Russell's requirements had been dispatched at 11.30 hours. ${ }^{80}$ While it is not clear how and where Broy acquired the necessary transport at such short notice it is probable that he negotiated the use of a vehicle on charge to the Baldonnell garrison. On the following day Collins made a cryptic note in his diary confirming that the 'aeroplane wheel and strut smashed. Mechanics arrived for repairing on Monday $14^{\text {th }}$, at about midnight and that he had visited the Fair Green at 11.30 hours on Tuesday to find that the work had not started. $^{81}$

While all the indications are to the effect that Russell's aircraft had sustained, at some time on Sunday 13 August 1922 or early on the Monday morning, a level of

\footnotetext{
78 'Transport', M. Collins to QMG, 17 Aug. 1922 (UCDA, MP, P7/B/3/40).

${ }^{79}$ Wireless message, Russell to Broy, 14 Aug. 1922, Broy private paper (in possession of Ms Aine Broy).

${ }^{80} \mathrm{Copy}$ wireless message, Broy to O/C Troops, 14 Aug. 1922, Broy private papers (in possession of Ms. Aine Broy.

${ }^{81}$ Collins diary, 15 Aug. 1922 (UCDA, MP, Pa/62.)
} 
damage that might have precluded it being flown the reconnaissance reports indicate that one mission had been flow on Sunday afternoon and a further two on Monday 14 August. While the circumstances appear contradictory it must be assumed that the damage, while requiring a replacement wheel, was not sufficient to render the aircraft totally unserviceable. The fact that the repair work had not been initiated on the Monday afternoon and completed by Tuesday morning would tend to confirm this supposition. A more complete understanding of the matter is hindered by the fact that the aircraft log book (BF I) not only fails to record the reconnaissance flights of the 13 and 14 August but also contains no reference to repairs to the undercarriage of the aircraft about that time. However the completion of other repairs, carried out during August / September 1922, appear to be recorded twice. ${ }^{82}$

\section{Modest expansion and support services}

At the general staff meeting of Friday 28 July 1922 Michael Collins reported on the 'position with regard to the air force' based on a meeting he had with McSweeney and Russell earlier that day. He announced his decision to approve the purchase of two SE $5 \mathrm{~A}$ aircraft which he noted had a range of 200 miles and were fitted with two Vickers and one Lewis guns each as well as bomb racks. He indicated that 'these will be wired for this evening and one way or another will be across [here] on Monday evenings'. ${ }^{83}$ While Collins gave no rationale for the decision to purchase aircraft it was probably due to the poor serviceability of the existing machines and to the fact that two new pilots, Lieutenants F.S. Crossley and T.J. Maloney, had recently been appointed. ${ }^{84}$ Despite the tone of his briefing to the General Staff, that indicated a considerable degree of urgency, the objective of having two new aircraft delivered by the following Monday evening was to prove very optimistic.

McSweeney and Russell had apparently used their meeting with Collins to bring up matters of concern on which they hoped he could be of assistance. While Collins subsequently took up in writing several aspects of the support services required by

\footnotetext{
${ }^{82}$ Log book, BF I, pp 11- 12 (AC Museum).

83 'Position with regard to the air force', Collins to General Staff, 28 July 1922 (UCDA, MP, P7/B/10/33).

${ }^{84}$ Baldonnell return, 12/13 Nov. 1922, (MA, Army census).
} 
military aviation he noted in particular two subjects for mention at the general staff meeting. He informed the meeting, for the particular attention of the QMG, that the Air Service required 20,000 rounds of selected aerial ammunition and 2,000 rounds of tracer rounds as well as a Crossley tender and a three ton lorry. On the matter of special aerial ammunition for the Air Services Collins subsequently wrote to the QMG reminding him that he (the QMG) on 28 July had taken 'certain notes for the above, namely 20,000 rounds of selected aerial ammunition' and 2,000 tracer bullets in addition' and inquired as to whether he had received delivery yet. Collins emphasised that he was informed by Russell that aircraft guns were jamming after only five, ten or fifteen rounds while using ammunition intended for infantry weapons. ${ }^{85}$

In the first two weeks of August, while Russell and Stapleton were carrying out such reconnaissance flights as the weather would allow McSweeney was in London acquiring the aircraft recently approved by Collins. He left for London on 30 July, remained there for eight days that included certain delays, and completed the purchase of a Martinsyde F.4 ( Scout / Buzzard) and a S.E. 5A - not two S.E. 5A aircraft as indicated by Collins. Due to the urgency indicated by Collins McSweeney endeavoured to keep him informed at every stage. On Wednesday 2 August, writing from the Imperial Hotel, Russell Square, he informed Collins that he intended inspecting the aircraft on the following day with a view to carrying out test flights on the Friday and leaving for home the same day. ${ }^{86}$ However on Monday 7 August McSweeney again reported to Collins indicating that, while the aircraft were to have been ready for delivery on Friday 4 August one had a leaking radiator and that he had found the guns to be out of order on the other. As a result the aircraft were not ready until 17.00 hours on Saturday. The departure was further delayed by bad weather and the Bank Holiday. ${ }^{87}$

Eventually the two aircraft, the S.E.5A being flown by McSweeney, and the Martinsyde F. 4 by a Mr. Perry, left Waddon on Tuesday, 8 August routing to Shotwick in Chester. On route the aircraft ran into a thunderstorm - the same or similar weather to that being experience by Russell on his mission to Cork about the same time. Writing from the Lamb Hotel, Nantwich on the following day McSweeney reported that 'the rain

\footnotetext{
${ }^{85} \mathrm{C}$-in-C to QMG, 10 Aug. 1922 (UCDA, MP, P7/B/3/73).

${ }^{86}$ McSweeney to Collins, 2 Aug. 1922 (UCDA, MP, P7/10/27).

${ }^{87}$ McSweeney to Collins, 7 Aug. 1922 (UCDA, MP, P7/B/10/23).
} 
tore the fabric off one blade of my propeller and owing to the vibration and running out of petrol I had to make a forced landing in the nearest field' near Nantwich, Cheshire. The context suggests that it is more likely that the damage was caused by hailstones rather than by rain. The second aircraft, in a similar condition, had landed four miles away. He indicated that he had made arrangements to have new propellers fitted, hopefully by 10 August, with the intention of reaching Baldonnell the same day. ${ }^{88}$ Having first engaged the services of six men to picket and cover the two aircraft McSweeney verbally contracted the services of L.B. Fitch and an assistant to effect the replacement of the propellers. These two men stayed with the aircraft, day and night and completed the repairs on 10 August after which the two machines were flown to Shotwick. There the S.E. 5A was found to be unserviceable and, after a further delay of five days that is not explained, the Martinsyde was flown to Baldonnell by Perry on 15 August while McSweeney had returned by the mail boat on 14 August. ${ }^{89}$ The SE 5A was eventually delivered in early September. ${ }^{90}$ In effect the urgently required delivery of two aircraft had, due to technical and weather difficulties, taken about five weeks. The technical difficulties did not end there. Within days the SE 5A was lost. On 8 September 1922 the machine was being flown to Limerick by Lieut. F.S. Crosseley when he got lost in low cloud in north east Cork. He reported that the engine lost oil pressure due to the failure of the big end bearing and that he had made a forced landing in the vicinity of Macroom. The aircraft was subsequently burned by Irregulars. ${ }^{91}$

The next, and final, consultation with McSweeney and Russell was to result in Collins making policy decisions regarding aircraft, personnel and operations support services required by military aviation. These decisions and actions were to have major ramifications for the future of the air operation and, eventually, for the survival of the nascent air organisation itself. With Collins and Russell returning from the Munster area and McSweeney back from London a meeting was arranged for Baldonnell at 22.30

\footnotetext{
${ }^{88}$ W.J. McSweeney to Collins, 9 Aug. 1922 (UCDA, MP, P7/B/10/18).

89 'Expenses of Major General McSweeney during year 1922-1923', circa 1 Nov. 1923, (MA, AC/2/2/1); Aircraft log book, Martinsyde Scout MS I, Air Corps Museum.

${ }^{90}$ Anthony P. Kearns, 'The Irish Air Corps; a history' in Scale aircrafi modelling, Vol. 3, No. 10 (July 1981), p. 449.

"Wireless message; Crossley to McSweeney, 8 Sept. 1922; Russell to McSweeney, 11 Sept. 1922 (UCDA, MP, P7/B/48/134;/119)
} 
hours on 15 August 1922. ${ }^{92}$ Earlier that day McSweeney had carried out a reconnaissance mission in the Dundalk area. This apparently was the only such mission north of Dublin and apparently the first by McSweeney since his accident on 16 July. ${ }^{93}$

Collins, in summarising the major decisions taken at the meeting recorded that 'we discussed the question of air services generally and came to the conclusion that it essential that we order a flight of, say S.E. fives [sic], also two Avro [504k]s and a spare engine for an Avro [504K]' - for which McSweeney was to submit an estimate of costs. He also approved the decision that 'up to six pilots are to be taken on immediately' stating that 'these will be admitted on approval and if not satisfactory will be dispensed with at once'. The third major decision authorised the occupation of an air base in Munster. Arrangements were made for Russell to fly to Limerick and on to Fermoy to report on the condition of the ex-RAF aerodrome there. If Fermoy was found to be satisfactory Collins wanted McSweeney to fly down a second aircraft while "if the condition [was] not satisfactory the Board of Works would be requested to provide some temporary covering'. The ultimate intention was to conduct air operations from a base such as Fermoy as the ground war was well outside the range of aircraft operating from Baldonnell. A lesser concern to Collins 'was in regard to the fact that a previous decision, to have pilots paid two and a half times the rate of pay appropriate to 'ordinary volunteers', had not been acted upon. ${ }^{94}$

McSweeney and Russell apparently used the occasion to renew their representations regarding such matters as communications, ordnance, transport and meteorology though actions already initiated by Collins, mainly referring such matters to GHQ staff, would suggest that they were pushing an open door. On 17 August 1922 he wrote to the QMG on the matter of a 'car for Baldonnel aerodrome' pointing out that the 'old ford' was not reliable enough to bring reconnaissance reports in to GHQ after flights and requested that arrangements be made to 'exchange it for some really reliable serviceable car'. ${ }^{95}$ In the absence of a wireless, and satisfactory road transport, the telephone was the only means of communication available to the Air Service. While

\footnotetext{
92 Personal notes, M. Collins, 16 Aug. 1922 (UCDA, MP, P7a/62).

${ }^{93}$ Phone message, McSweeney to GHQ, 15 Aug. 1922; Undated pilot reports (UCDA, MP, P7/B/107/314; /331).

94 'Memo of interview', M. Collins, 16 Aug. 1922 (UCDA, MP, P7/10/11).

${ }^{95}$ Collins to QMG, 17 Aug. 1922 (UCDA, MP, P7/B/3/42).
} 
Collins noted the matter of 'aerodrome - air communications' it is not known if he made any firm direction on the matter of a wireless for Baldonnel. ${ }^{96} \mathrm{He}$ had earlier contacted the postmaster general with regard to the 'telephones at Baldonnel Aerodrome' claiming that it was difficult to be heard on a defective system which he described as being extremely unsatisfactory. ${ }^{97}$ The system was reported to be under repair on or about 21 August and was expected to be restored to service before the end of the month. ${ }^{98}$

Indicating the continuing urgency of the matter of aviation ammunition Collins sent the QMG a second reminder, eight days after the previous, asking curtly 'I should like to know if anything has yet been done about the matter' ${ }^{99}$ The QMG eventually replied on 22 August 1922 and begged to inform Collins that he had 'succeeded in procuring 4,800 rounds of special ammunition' which he understood was all that was available at the time. The response was too late to receive the Collins' attention and the related subject of the supply of bombs would later be taken up by McSweeney with Richard Mulcahy who replaced Collins as commander-in-chief.

While Collins' involvement in the matter is not totally clear, problems relating to meteorology were the subject of notes between GHQ, the Air Service and the Department of Agriculture. The basic problem probably related to the absence of meteorological forecasts for aviation purposes. In the context of Air Ministry's continued responsibility for the management of the country's meteorological stations, any short-term solution would do little to improve the situation. On 10 August the Department of Agriculture, replying to Collins' minute of the previous day, reported to him that it had arranged for the 'Meteorological Office of the Ordnance Office' to supply observations of 'barometer, rain, sunshine, approximate wind speed and direction, humidity, atmospheric temperature and fog' at 10.00 hours each morning. The Air Service at Baldonnell did not take observations and, even if it did, it had no expertise to generate forecasts. In the circumstances, the availability of the observations recorded in the Phoenix Park would have been of little benefit.

\footnotetext{
${ }^{96}$ Collins notes, 17 Aug. 1922 (UCDA, MP, P7a/62).

${ }^{97} \mathrm{C}$-in-C to Postmaster General, 10 Aug. 1922 (UCDA, MP, P7/B/10/6).

${ }^{98}$ E. Broy to Postmaster General, 21 Aug. 1922 (UCDA, MP, P7/B/10/5).

${ }^{99}$ Collins to QMG, 18 Aug. 1922 (UCDA, MP, P7/B/3/34).
} 


\section{Conclusions}

While recruitment for Russell's Civil Air Service continued after the start of hostilities the onset of war eventually caused the administration, through the foresight and initiative of Collins, to concern itself more with military aviation. While the initial authorisation to purchase aircraft indicated air reconnaissance as the preferred role Collins did not rule out bombing and other armed roles and actively supported the Air Service in procuring ammunition. By any objective yardstick the output for the period 6 July to 22 August 1922, in terms of the number missions flown, was very modest, amounting to about one mission every other day. The question arises as to how timely and valuable the air intelligence became in the overall context of the Civil War. In the absence of evidence that such evaluation was conducted at the time inferences must be drawn from the manner in which Collins used aircraft and endeavoured to extend their use. Many factors conspired to frustrate Collins' intent. Not least of these was what must have been seen as inordinate delay in actually procuring aircraft. Equally it could be said that he might have bought more aircraft earlier and, also earlier, hired more ex-RAF pilots. An underlying prejudice, amongst Collins' army subordinates, towards Ex British servicemen was probably a major factor.

Given the limitations in aircraft and pilot numbers and the effect of adverse weather, the intelligence gathered, while it might have been timely in individual instances, may not have indicated Irregular activity over a sufficiently large area. Due to the localised nature of the ground operations and centralised manner in which air patrols had to be directed and reported it is generally impossible to associate particular air patrols with specific military actions. Notwithstanding it is considered that very early in the reconnaissance regime the value of air patrols was realised. This is mainly demonstrated by the fact that the aborted patrol to the Wicklow / Wexford area on 16 July 1922 had to be completed early the following morning in preparation for an operation by Free State troops planned for that day. Similarly Collins saw the necessity for an extended patrol into Waterford and Cork in early August 1922. This air patrol was given four specific tasks that demonstrated the flexibility of such patrols though in this particular instance circumstances appear to have delayed the mounting of the operation until the Free State 
action in Cork was well under way while meteorological conditions affected its conduct and reduced its effectiveness.

Despite the relatively low level of air patrolling and an apparently modest return it is considered that Collins saw the potential of an expanded Air Service to contribute to the support of the army in its pursuit of the Irregulars as they undertook guerrilla style operations in the wider Munster area. The value Collins put an air reconnaissance can be gauged from the level of his support for better support services such as meteorology, communications, ordnance and transport and his eventual approval for a significant increase in both pilot and aircraft numbers. The increase in pilot numbers along with a substantial investment in aircraft and the associated move to a forward base such as Fermoy would represent a considerable increase in the air capability. However the change in leadership after Collins' death was to negate much of this potential due to the length of time taken to recruit pilots, to purchase additional aircraft and to effect the move to Fermoy.

While Michael Collins was the superior authority in such matters as personnel and aircraft purchase and also directed the conduct of aerial reconnaissance, the air effort during July and August was conducted by a veritable triumvirate - Collins, McSweeney and Russell. Under Collins' overall direction McSweeney was very much occupied with administrative and organisational matters and the purchase of the required aircraft while Russell did the bulk of the flying and possibly interfaced with Collins to a greater extent than McSweeney. Notwithstanding McSweeney's relative inexperience, and his nebulous position in the Army command structure, air reconnaissance assumed an important but limited role during July and August 1922 due no doubt to Collins' direction and sponsorship. With Collins' untimely demise and despite increased numbers of aircraft and pilots the positions and roles of Russell and Mc Sweeney in the overall scheme of things were to alter significantly. 


\section{CHAPTER 4}

\section{FROM CIVIL WAR TO ARMY MUTINY}

In the nine week period between the decision, on 20 June, to purchase the first reconnaissance aircraft, and the death of the Michael Collins on 22 August 1922, a very informal Military Air Service had been formed under the overall aegis of the regular National Army that was still evolving from its guerrilla roots. The Air Service of 22 August 1922 had a total of nine officers but only four (ex-RAF) pilots, two of whom had not yet seen operational service. The technical staff consisted of thirty-one NCOs and men of uncertain technical experience and expertise. The service had been so organised as to support the operation of aircraft in an armed reconnaissance role in support of ground troops against the anti-treaty Irregulars. While under the military command of W. J. McSweeney the air element had been subject to the close supervision and operational control of Michael Collins and reported to him. Based on his decisions the as yet poorly equipped and ill-prepared Military Air Service had greater potential for air operations than proven capacity at the time of Collins' death on 22 August 1922. The future of the service was uncertain in the hands of a new commander-in-chief and army hierarchy that had previously shown little enthusiasm for military aviation. To a great extent the policy decisions, to expand pilot and aircraft numbers and to extend the air operation into the south-west, were to direct the new leadership in the direction chosen by Collins whether they were convinced or not as to the potential of air power in a civil war situation. .

The following section aims to examine the implementation of Collins' expansion plans and the conduct of air support in the south-west during the guerrilla phase of the Civil War. It is intended to assess the role or roles undertaken and, if possible, the effectiveness of the use of aircraft by the local commanders and the extent to which the Army leadership at GHQ backed the development of the support services that the state's early military aviation required. The reasons for, and the results of the pilot recruitment and training programme initiated in late 1922, will be assessed in the context of the generally antagonistic attitude to former British service personnel. The start of the 
demobilisation and reorganisation processes, insofar as they affected the Air Service, will be examined against the backdrop of the disharmony of the 'army mutiny' of 1924.

\section{The implementation of expansion plans}

On the day Collins was killed it was reported that while the irregulars were being driven from their bases they were still not at all vulnerable in Cork and Kerry and that, while the Free State army was capturing towns, they were not capturing Irregulars or their weapons, in significant numbers. In effect the guerrilla phase of the war had commenced and, initially at least, government troops were not getting the upper hand. It was also suggested, in the Irish Times of 15 August 1922 that, if the pro-Treaty forces had moved quickly enough, the war could have been over in three weeks. ${ }^{1}$ Apparently it was for this phase of the war that Collins had authorised the expansion of the Air Service with the intention of occupying airfields in the south west. It had been Collins' obvious intention to have action taken on aircraft purchase and the recruitment of pilots and the move to Fermoy or elsewhere in Munster, sooner rather than later. However the taking on of additional pilots was the only matter that started with little delay but even that process proved tediously slow. A full month was to pass before McSweeney set off for London to buy more aircraft - the last of which would not be delivered until 22 November - four full months after Collins' death. Despite the urgency indicated by Collins, Fermoy would not be occupied by an air detachment until 1 October 1922 - a delay of almost six weeks.

The initial recruitment of additional pilots had started about 11 July with the signing of Lieut. J McCormac, who, for reasons that are not stated, was dismissed the

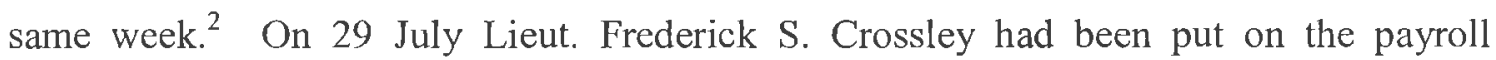
followed, on 19 August, by Lieut. Thomas J. Maloney. ${ }^{3}$ Like McSweeney and Russell the new pilots had previously served with the RAF - Crossley with No. 41 Squadron initially and later with 1 Squadron in France where he was wounded on 6 July 1918. Maloney had served with 57 Squadron. ${ }^{4}$ Unlike the two senior pilots the new pair had no

\footnotetext{
'Hopkinson, Green against green, p. 172.

$?$ 'Military Aviation - personnel', 22 July 1922 (UCDA, MP, P7/49/37).

${ }^{3}$ Officers' history sheets (MA, SDR 550; SDR 1767).

${ }^{4}$ Aircrew service records (NA, Air 76/115; Air 76/33).
} 
IRA service - pre-truce or post-truce. Probably greatly influenced by his own embarrassing experience when returning to flying after a three-year break, McSweeney sent Crossley and Maloney to the Aircraft Disposal Company in Croydon in early September 1922, to avail of instructional and solo flying by way of re-introduction to flying duties and as preparation for active service. While the number of hours flown by each is not known, it is probable that they only received a small amount of dual instruction Avro 504K and solo flying on Bristol Fighter. ${ }^{5}$

In September four more pilots, including William P. Delamere, were taken on. Delamere's later account of the early days of the Air Service, that reflects the adverse effect of the passage of fifty years on the memory, nonetheless gives an insight into the circumstances that surrounded the recruitment of the individual pilots. In his own case he recalled that while at home in Dublin, on holiday from his engineering employment in England, he was approached by an individual with connections to W.T. Cosgrave, president of the Executive Council. He was asked if he would like to fly again and, having answered in the affirmative was subsequently called for an interview by General McSweeney. Following the interview he "was accepted for an appointment as a pilot in the new Army Air Service'. He suggests that the manner in which other pilots were recruited was most likely similar. ${ }^{6}$ It is strongly suggested that the fact that the subject of the recruitment of ex-British service personnel, particularly those without pre-truce experience in Oglaigh na hEireann, was such a sensitive matter that the Army resorted to word-of-mouth rather than advertising the fact that positions for pilots existed - hence the somewhat surreptitious method of recruitment described by Delamere. It was to be early December 1922 before the last of the six pilots, as authorised by Collins in August, was taken on. With the departure of C.F. Russell to the Railway Maintenance and Protection Corps about the middle of September, the dismissal of Capt. John Arnott in mid-December and the recruitment of an additional two pilots in early December the total number in service at the end of 1922 would still only be ten. ${ }^{7}$ With few operational missions, that can be identified from log books or elsewhere, being flown after 16 August

\footnotetext{
5 ADC to W. J. McSweeney, circa 1 Sept. 1922 (in possession of A.P. Kearns).

${ }^{6}$ W.P. Delamere, 'Early days in the Army Air Service' in An Cosantoir xxxii (Sept. 1972), p. 168.

7 Appendix 4, Michael O'Malley, 'The military air service 1922-24' (BA thesis, July 2002, NUI

Maynooth).
} 
the latter part of August and much of September 1922 appears to have been taken up with the conduct of a series of instructional and re-familiarisation flights for newly recruited pilots. ${ }^{8}$

The correspondence of early September, between the new commander-in-chief and the Air Service and relating to military aviation matters, suggests a period of adjustment and review on the part of General Richard Mulcahy. It also possibly explains the delay in ordering and taking delivery of aircraft. An undated file memo, of circa 5 September, suggests an appraisal of the aviation resources required in the context of air operations in the west and south west. However the matters enumerated were couched in terms that suggest that they were items for an agenda rather than decisions taken. While the considerations listed were very similar to those matters on which Collins had made decisions on 16 August the fact that such decisions had already been made was not acknowledged. Mulcahy appears to have generally endorsed, Collins' decisions though in some respects the new proposals went further than Collins had. In relation to aircraft, where Collins had decided to acquire a flight (of unspecified number), Mulcahy proposed to discuss at a General Staff meeting general aviation arrangements and authorise, if necessary, the purchase of two more Bristol Fighters at a cost of $£ 1,160$ each - apparently in addition to the flight authorised by Collins on 16 August. Mulcahy proposed that Fermoy would be the main airfield for the whole south-west and that Russell would take charge of the area. He intended to attach four machines to Fermoy and two to Limerick. He further proposed to have enquires made by General Sean McEoin, GOC Western Command, with a view to finding the best location for basing two aircraft in the Clare area. $^{9}$

At about the same time Mulcahy, in responding to an aircraft purchase estimate submitted by McSweeney, presumably that originally requested by Collins on 16 August, indicated that he was unable to lay his hands on the estimate at that time but gave formal authority to proceed with the purchases as agreed in their recent conversations, that is instructional machines, three Bristol Fighters and three Martinsyde Scouts. ${ }^{10}$ Six days later Mulcahy wrote to the Air Service indicating that, in view of the loss of the SE 5A a

\footnotetext{
${ }^{8}$ Bristol Fighter; Martinsyde F. 4, log books (AC Museum).

9 'For aviation file', C-in-C undated memo, circa 5 Sept. 1922 (UCDA, MP, P7/B/49/15).

10 'Aviation', C-in- C to Comdt. General McSweeney, 5 Sept. 1922 (UCDA, MP, P7/B/49/16).
} 
few days previously, McSweeney should make arrangements to order two additional machines for the Western Area. ${ }^{11}$ The authorisations of 5 and 11 September translated into an order for two Avro 504K 'instructional machines', a total of five Bristol F2b Fighters and three single-seater Martinsyde F.4 scout aircraft - a total of ten aircraft.

As he later recorded McSweeney commenced his 'journey to London for [the] purchase of 5 Bristol Fighters, 3 Martynside [sic] F. 4's \& 2 Avros' on 22 September 1922 and stayed there for five days. While in London he apparently confirmed an order for five Bristol Fighters and two Avro 504K aircraft from the ADC at Croydon. He also travelled out to Woking in Surrey and there confirmed an order for three Martinsyde F.4 machines though the ADC acted as agents in this case. ${ }^{12}$ While he had authority to purchase ten aircraft in actual fact eleven machines, the additional one being a third Avro $504 \mathrm{~K}$, were delivered between 16 September and 22 November 1922 . It is noted that the first aircraft of this order, BF IV, was taken on charge at Baldonnell on 16 September, a week prior to McSweeney's latest trip to London. ${ }^{13}$ It appears that the ADC accepted a telephone, or more likely, a telegraph order from McSweeney on or about 14 September, fitted a 300hp Hispano Suiza engine to Bristol Fighter E.1958 (BF IV) on 15 September and, flown by a company pilot, had it delivered to Baldonnell the following day. This aircraft, which was delivered with Lewis and Vickers guns, and bomb racks for twenty pound bombs, was damaged on landing at Baldonnel on its delivery flight and did not enter service in Air Service colours. ${ }^{14}$ It appears that the additional Avro 504K, unlike the Bristol Fighter, a training aircraft, was an eleventh aircraft and was delivered by the ADC by way of compensation for failing to deliver a serviceable machine on 16 September. Unlike the circumstances when he had purchased the Bristol Fighter in July McSweeney was not in a position to settle by personal cheque. The account, for a total of $£ 15,000$, was forwarded for payment to the AFO via the QMG. ${ }^{15}$

\footnotetext{
"C-in-C to Comdt. General Sweeney (sic), 11 Sept. 1922 (UCDA, MP, P7/B/49/12).

12، McSweeney expenses', 1 Nov. 1923 (MA, AC/2/2/1); Ray Sanger, The Martinsyde file, p.246.

${ }^{13}$ Kearns, 'Irish Air Corps', p. 449.

14 ADC to Comdt. General McSweeney, 16 Sept. 1922 (MA, A/06959); Log book, BF IV (AC Museum); Delivery note, ADC to McSweeney, 15 Sept. 1922, in my possession. A.P. Kearns records this aircraft as E.1959 though the delivery note indicates E.1958.

${ }^{15}$ DMA to QMG, 17 Sept. 1922 (MA, A/06959).
} 


\section{Detachments to Fermoy and Tralee}

While Collins had appeared very anxious to have aircraft based at Fermoy before the end of August the first aircraft did not arrive there until 1 October $1922 .{ }^{16}$ It is not at all clear why this should have been so. While the number of pilots, at four, was very low a single aircraft and crew could have been posted before the end of August had the new c-in-c and general staff wished to put into immediate effect the decisions made by Collins. With the military activity largely concentrated in the Munster area, and Russell having operated in that area from a temporary base in Limerick there was no reason why a single aircraft and crew could not have been sent to the south west. Similarly the availability of aircraft appears not to have been a consideration as the service machines ordered on 14 September only began to enter service from 13 October, well after the eventual occupation of the aerodrome.

While the army leadership may initially have been waiting for the delivery of new aircraft before occupying Fermoy, it is possible that their hands may have been forced by circumstances in Baldonnell. It is suggested that Lieut. J.C. Fitzmaurice and Lieut. T.J Maloney were sent to Fermoy at short notice after a disagreement with General McSweeney. The point at issue was apparently the promotion to the rank of captain of John Arnott. Arnott had joined the Air Service (on 15 September) after both Maloney and Fitzmaurice and, in theory, would have been junior to both. Not only was he promoted to captain but he was also designated as 'acting $2^{\text {nd }}$ in command of flying'. The general tone of Fitzmaurice's unpublished memoir suggests that he had no doubts about his own worth as an officer and pilot and it would have been out of character for him not to have objected to such action. It is suggested that the Maloney and Fitzmaurice were contemplating resigning over this matter when they were detailed, at short notice, to fly to Fermoy. Three pilots are reported to have flown to Fermoy on 1 October 1922. In addition to Fitzmaurice in MS I, Lieut. Maloney and Lieut. F.S. Crossley are reported as travelling in a formation of three unspecified aircraft. ${ }^{17}$ The assertion that the three available service aircraft in the Air Service had moved to Fermoy on 1 October 1922

\footnotetext{
${ }^{16}$ Aircraft log book, MS I, AC Museum.

${ }^{17}$ Teddy Fennelly, Fitz and the famous flight (Portlaoise, 1997), p. 99; 'Names of staff employed in the Aviation Dept.', AG to C-in-C, 18 Oct. 1922 (MA, A/07279).
} 
cannot be confirmed from the aircraft log books. The log book for Martinsyde Scout (MS I) confirms that Fitzmaurice flew to Fermoy on 1 October 1922. However the log book for BF II records that Lieut. F.S. Crossley and 'A/M Spittel' arrived there on the following day. The log book for BF I records no flying, or servicing, between 24 September and 10 November 1922 and only indicates that the aircraft had been flown from Baldonnell to Fermoy on 13 November 1922 by Lieut. W.P. Delamere. The Army census records that Fitzmaurice, Crossley and Maloney were at Fermoy Aerodrome on the night of $12 / 13$ November 1922. Eventually four aircraft and crews were posted to Fermoy and a single machine, with air and ground crew was based at Tralee. ${ }^{18}$ As the senior officer Lieut. F.S. Crossely was the first commanding officer at Fermoy. However it appears that Fitzmaurice and Maloney were not satisfied with him as CO. With Maloney's connivance Fitzmaurice apparently brow-beat Crossley into vacating the position and Maloney was appointed to the post. Subsequently, after Maloney had been transferred back to Baldonnell, Fitzmaurice took over. ${ }^{19}$

Notwithstanding Collins' suggestion that the Board of Works should make good any damage to the aerodrome in preparation for aircraft the sight that greeted the Air Service was less than wholesome. The departing Irregulars had apparently left the aerodrome buildings in a ruinous state. Fitzmaurice subsequently provided a colourful description:

The aerodrome presented the appearance of having suffered an attack by a flock of locusts possessing a voracious appetite for galvanised iron sheets, wood, glass and everything that went to make up the aerodrome buildings. It had been completely stripped. The stripping had not been done in any amateurish fashion. The work had obviously been executed by skilled craftsmen and [the material] was intended for erection elsewhere. We discovered that the various buildings and station equipment had been dismantled and sold by auction and the materials scattered about in the numerous farmsteads for miles around. ${ }^{20}$

\footnotetext{
18 'Army Air Service', strength return, 21 Aug. 1923 (NAI, Fin 1/2875).

${ }^{19}$ Statement, J.C. Fitzmaurice to W.J. Keane, 7 Dec. 1950 (MA, PC143).

${ }^{20}$ J.C. Fitzmaurice, unpublished memoir, p. 128 (Estate of P. Selwyn -Jones).
} 
Fitzmaurice opined that the material had been sold at action and that the proceeds had gone to 'Mr. de Valera's war coffers'. However he claimed that all the material could be traced through the auctioneer's books. ${ }^{21}$ In the context of the aerodrome's immediate use it was of particular note that the steel-framed Robin type hangars built by the British had been stripped of the galvanised sheeting leaving a bare metal frame. The repair of this damage led to industrial unrest and to a question in the Dail. On 18 October the Voice of Labour was reported as carrying an article suggesting that soldiers were acting as scabs in the matter of the rebuilding of Fermoy aerodrome. ${ }^{22}$ On 25 October 1922 McSweeney replied to a query from the COS partially based on information he had received by wireless from the officer in charge of the detached flight at Fermoy. He confirmed that the corrugated sheeting of the hangars had been removed but that it was essential that aircraft to be covered against the elements. McSweeney reported that he had initially gone to Fermoy and had bought and supplied a number of tarpaulins to provide temporary cover for aircraft. The quartermaster had been instructed to engage the services of a local contractor to affect more permanent repairs but it was alleged that the contractor's labourers would not work due to high winds. Due to the urgency of the situation the Air Service engaged the services of unemployed locals at soldiers' rates of pay $-\mathfrak{k 1}$. $4 \mathrm{~s} 6 \mathrm{~d}$. per week, plus overtime, until the job of covering one shed had been was completed. ${ }^{23}$ In reply to the Dail question of Tomas de Nolga, Eamonn Duggan, on behalf of the Minister for Defence, put a slightly different slant on the matter:

The aerodrome at Fermoy is not being rebuilt. It was decided to cover one shed with corrugated iron sheets, and the work entailing the employment of 15 or 20 men at most was given to Mr. Mahoney. His men gave trouble by refusing to hold down the sheets on the shed in a gale, and soldiers had to be put on the job in order to get it done. Except in this case soldiers were not employed on the same work as civilians. ${ }^{24}$

\footnotetext{
21 Ibid.

22 File memo, 18 Oct. 1922 (MA, A/07472).

${ }^{23}$ DMA to COS, 25 Oct. 1922 (MA, A/07435).

${ }^{24}$ Dail Eireann, Parliamentary debates, vol. 1, 1922, 1962-63.
} 
To say that Fermoy was not being rebuilt would be a moot point. Considering Fitzmaurice's description of the skeletal nature of the various buildings rebuilding would be the appropriate term. In the circumstances of the time, with a civil war to be fought, the get-the-job-done attitude of Fitzmaurice seems to have been appropriate. However the condition of Fermoy aerodrome on 1 October 1922 was apparently much as it had been when abandoned by the Irregulars by the middle of August. Despite the fact that Collins had, back in August, identified the aerodrome as an important facility in the developing military scenario, and that it might require repairs, nothing had been done in the meanwhile to provide the basic facilities required for aircraft.

\section{Fermoy operations}

While the precise role of the Air Service detachment in Fermoy appears not to have been documented, the air support role differed somewhat from that the armed reconnaissance role carried out under the direction of Collins.

Our duties consisted of providing air escorts to military convoys moving through difficult mountain countryside. These convoys were engaged in cleaning up operations which called for the establishment of a garrison in every town and village. They were subject to ambush only in difficult country where the terrain was suitable to the irregulars, that is to say, stretches of country allowing them a safe commanding fire position from which a river or deep, wide rivulet prevented pursuit by the ambushed party. Trees were felled across the roads to contain the convoys during the period of these ambushes. Our arrival over such scenes brought an abrupt end to these capers. ${ }^{25}$

This general description suggests a change, from the armed reconnaissance approach of July and August to the armed escort role that would be practiced over the autumn and winter of 1922-23. However the first missions flown by Fitzmaurice, and many others

\footnotetext{
25 J.C. Fitzmaurice, unpublished memoir, p. 128 (Estate of P. Selwyn-Jones).
} 
carried out over the winter and spring of 1922-23, were general reconnaissance patrols initially to west Cork on 9 October and to east Cork on 10 October 1922. Other missions involved the dropping of propaganda material in territory held by Irregulars. Despite the fact that the Fermoy detachment consisted of four aircraft and four crews little is known of the day-to-day operation. This is mainly due to the fact that the central control of the Collins era was dispensed with and, with the Air Service detachment under the direct command of Maj. Gen. Emmet Dalton, GOC Cork Command, the recording of reconnaissance reports was apparently abandoned. Generally, in the absence of standing orders and patrol reports of any kind, it must be presumed that both types of mission were flown as directed by the local commander on a day to day basis. ${ }^{26}$

\section{The operations of the Tralee detachment.}

Lieutenant William P. Delamere, who reported to Baldonnell on 21 September 1922 and was posted to Fermoy on 13 October, subsequently operated out of Tralee from 1 December 1922 to 12 October 1923 - initially under General W.R.E. Murphy, GOC Kerry Command and, from January 1923, under Major General Paddy O'Daly. ${ }^{27}$ The Tralee detachment consisted of Delamere, who, along with his observer Lieut. Charles 'Tiny' Flanagan flew the single Bristol Fighter, and two unnamed technicians. The Tralee landing ground consisted of what appears to have been a marginally suitable field of about twenty two acres that adjoined the Militia Barracks in the townland of Cloon More in the south eastern part of Tralee town. It had a small hangar associated with it. This was located in an adjacent field, in Cloon Beg, and had been part of the original RAF Class B aerodrome of the 1919-1921 period. ${ }^{28}$ Unlike the practice at Fermoy most, if not all, of Delamere's operational flights appear to have been reconnaissance patrols (as distinct from escorts) over the 'very wild country' of the mountains of Kerry. Between the 4 and 21 December 1922 Delamere and Flanagan flew nine flights, mainly reconnaissance

\footnotetext{
${ }^{26}$ Log book, MS 1 (AC Museum); Fitzmaurice unpublished memoir, p.129 (Estate of P. Selwyn-Jones). Fitzmaurice's account of his civil war flying details a small number of missions but his recall is so colourful and idiosyncratic as to render such accounts unrepresentative. He fails to recall any mission flown by other pilots.

${ }^{27}$ Flying log book, W.P. Delamere (in possession of Peter Delamere); Duggan, Irish army, p. 85;

Hopkinson, Green against green, p. 205.

28 Drawing, 'Tralee landing ground'; RAF aerodrome book (in my possession).
} 
patrols that were somewhat curtailed by the mountainous terrain and the adverse winter weather. On 14 December he reported being fired on at Ballyheige while patrolling in the Listowel / Ballybunion area. He dropped propaganda pamphlets in the Ballyheige area on 19 December and in the Farranfore area two days later. Of a total of just six patrols carried out by Delamere and Flanagan in January only one was of note. On the afternoon of 16 January 1923 Delamere reported being fired on by Irregulars while patrolling in the Brennan's Glen area. He dropped two bombs and 'held the Pajoes in houses until dark troops approaching and attacked the Pajoes', killing one and wounding two. ${ }^{29}$ The Kerry Command's report of the event read slightly differently:

Army aeroplane flying over Brennan's Glen fired on by party of 30 Irregulars. One bomb dropped and machine gun fire opened from aeroplane. Simultaneously, Dublin Guards from Killarney arrived on scene and attempted encircling movement. Irregulars retreated and in running fight Irregulars suffered six casualties. $^{30}$

From an operational point of view February 1923 was even quieter. Though ten flights were flown, to Fermoy and Baldonnell, all were apparently for technical or administrative purposes. On 10 February Delamere and Flanagan flew to Baldonnell in Bristol Fighter BF I and, due to technical difficulties with the replacement aircraft, BF VIII, did not get back to Tralee until 9 March 1923. The rest of March was similar to the previous month, with only three flights out of thirteen being of an operational nature. A further three flights, all reconnaissance patrols, were carried out during April 1923.

In May 1923 Delamere carried out nine operational flights. The first of these he recorded as the first day of a big round-up operation in the Kenmare area. From an air reconnaissance point of view he recorded that there was little to report. Operating under a new operations order, they patrolled the areas of Killarney, Caragh Lake and Castleisland on the 8, 17 and 18 May respectively but recorded that 'nothing of

\footnotetext{
${ }^{29}$ W.P. Delamere log book (in possession of Peter Delamere).

${ }^{30}$ Kerry command operations report, 16 Jan. 1923 (MA, CW/OPS/12/B).
} 
importance was observed'. With the Irregular leadership declaring a ceasefire on 24 May 1923 Delamere was to fly his last operational mission on 20 June when he observed the 'railway troops [being] withdrawn from the lines' in the Killarney area. On 28 June 1923 he flew back to Fermoy and, on the following day commenced two weeks leave. ${ }^{31}$ In the absence of an explicit air operations policy at GHQ or Command level, and of patrol reports, it is not at all easy to assess the effectiveness or otherwise of the Tralee Detachment. However, even allowing for the difficult terrain and adverse weather, the completion of only thirty-one operational missions in seven months of civil war operations appears to represent a modest return while the military intelligence value must remain a matter of conjecture.

On 16 July 1923 Delamere and Flanagan, still flying BF VIII, returned to Tralee and flew on the occasion of the parade and march-past for President Cosgrave's visit to Ballymullen barracks on 12 July. After the Civil War, between July and October 1923, the detachment completed only nine flights, mainly between the bases of Tralee, Fermoy and Baldonnell. Tralee closed on 12 October 1923 and the small detachment moved back to Fermoy. Similarly aimless flying continued at Fermoy until it too as eventually closed on 14 April $1924 .{ }^{32}$ It is not clear why Tralee was kept open until October 1923 and Fermoy until April 1924. While it is possible that GHQ wanted to have aircraft in the south west in case of any minor hostilities it is possible that the detachments may simply have been forgotten - only coming to the attention of GHQ again in the context of the administration of the demobilisation and the reorganisation processes of 1923/24. There can have been little operational necessity for either detachment remaining in place after May 1923.

\section{Personnel and support services}

While Collins, in August 1922, had apparently been convinced of the necessity to provide standard support services to military aviation, such as transport, communications, ordnance and meteorology and had initiated appropriate action, these matters were not to

\footnotetext{
${ }^{31}$ W.P. Delamere, pilot's log book (in possession of Peter Delamere).

${ }^{32}$ Ibid.
} 
receive similar priority from the new leadership. The matter of communications, probably the most fundamental and essential support service, was a case in point. With no sign of a wireless station being established at Baldonnell by 26 September 1922 McSweeney made representations to Mulcahy:

In view of the establishment of an aero base at Fermoy two wireless sets are extremely urgently needed, one at Fermoy and one at Baldonnel to communicate with each other. It would be very economical if we could arrange the handing over of eight aeroplane wireless sets by the British Government for reconnaissance work .....worth $£ 40$ each... ${ }^{33}$

This was not an unreasonable request given that aircraft wireless telegraphy sets had been standard equipment on operational aircraft since the Great War and accordingly training in wireless telegraphy was a fundamental aspect of pilot training. In like manner communication between Fermoy and Baldonnell, using sets of appropriate frequency and power, would be considered essential to the management and operation of air resources. To date, as was demonstrated during Russell's mission to Waterford and Cork in early August, aircraft had no wireless communications with Baldonnell or elsewhere while all longer range communication with Baldonnell had to be relayed, via GHQ, by means of the local, short range, security net. Having been requested by Mulcahy to address McSweeney's request for ground stations and aircraft wireless sets Liam Archer, OC Communications Department, quoting from a report on the distribution of 30 watt wireless sets, indicated that one would be installed at Fermoy Aerodrome, apparently for communication with GHQ, but that no set was available for Baldonnell. ${ }^{34}$ In response Mulcahy asked for clarification on the matter of aircraft wireless sets, which Archer had apparently ignored. Archer's response was short and to the point and indicated that his report of ' 29 September had covered all queries raised by the memo of the director of aviation' ${ }^{35}$ Mulcahy did not pursue this line in the matter of aircraft radios further.

\footnotetext{
${ }^{33}$ DMA to C-in-C, 26 Sept. 1922 (A/07041, MA).

${ }^{34}$ Archer to C-in-C, 29 Sept. 1922 (MA, A/07041).

${ }^{35}$ C-in-c to Archer, 29 Sept. 1922; Archer to C-in-C, 3 Oct.1922 (MA, A/07041).
} 
Subsequently, and rather meekly, he approached the question of installing a wireless set at Baldonnell' from a different direction. The principal function of such a radio would be to receive meteorological reports. 'I would like to know if the 30 watt receiver will do their work effectively and whether there is a set to spare.' Archer replied succinctly that 'no 30 watt set was available for Baldonnell'. ${ }^{36}$ In effect Archer was bluntly ignoring the request of his commander-in-chief. It can only be implied that the position adopted by Archer, and apparently not subsequently challenged by Mulcahy, was that he (Archer), as director of communications, would decide what communications equipment, ground and air, was appropriate to military aviation. Mulcahy's failure to resolve this matter in effect confirmed that the air communications requirements of the Air Service was an independent signals function to be exercised without reference to the commanding officer of the State's military aviation. Unresolved difficulties in respect of the authority over aviation communications policy was to have a major influence on the relationship between the Signal Corps and the Air Corps in later years and, in particular, was to adversely affect the standard of the air-to-ground and ground-to-air air communications during the Emergency.

The position in relation to ordnance was not unlike that pertaining to communications, though in this case Mulcahy himself was to be responsible for the prevarication. The QMG had reported to the Mulcahy that he had succeeded in acquiring 4,800 rounds of aerial ammunition, probably from the departing RAF, in response to Collins' requests on the matter during the early weeks of August. There was also an uncertain level of interest in having the Air Service develop a capacity to drop bombs and, paradoxically, standard hand grenades from aircraft on patrol duties. ${ }^{37}$ While it is not clear what armament was being carried on operational aircraft most if not all were apparently capable of returning fire, with Vickers and or Lewis machine guns, if fired upon. In September 1922 McSweeney had a limited stock of 9 pound bombs that had possibly been acquired from the departing RAF and which he used to test for their effectiveness against Irregulars. He reported that he had used two aircraft on Sunday 24 September to test the new $9 \mathrm{lb}$. bombs. Stating that four bombs had been dropped from

\footnotetext{
${ }^{36} \mathrm{C}$-in-C to Archer, 10 Oct. 1922; Archer to C-in-C, 12 Oct. 1922 (MA, A/07041).

${ }^{37}$ QMG to C-in-C, 22 Aug. 1922; COS to DMA, 3 Sept. 1922 (UCDA, MP, P7/B/3/11; P7/B/49/17).
} 
500 feet and that holes, two feet wide and one foot deep, had been made in the selected grass area while pieces of shrapnel had been scattered twenty feet around. He suggested that such bombs should be very effective when used on roads. The $9 \mathrm{lb}$ bombs were apparently not compatible with the bomb racks (suitable for $20 \mathrm{lb}$ bombs) purchased with many aircraft thus making it necessary to manufacture launching tubes to be used by the observer in two-seat aircraft. He suggested that single seat aircraft, such as the Martinsyde F.4, required a compatible bomb and bomb rack combination that could be operated by cable. He also reported sending a Cooper type bomb, which he had ordered to be stripped, to the director of munitions in the hope that similar bombs could be manufactured locally. ${ }^{38}$ Having received no response to his report on the testing of $9 \mathrm{lb}$. bombs McSweeney reminded Mulcahy that he had attempted to order over 300 bombs and 105,000 rounds of assorted aerial ammunition, when he was last in London. The War and Colonial Offices required Mulcahy's authorisation before supplying the items. Mulcahy replied, stating that he was not taking any steps with regard such munitions until a conference with representatives of the British War Office due to be held in January 1923. By February 1923 Mulcahy had not met officials of the War Office and apparently did not perceive a genuine demand for such armament. He recorded a file memo to the effect that the bombs were not required at once and that the question of obtaining them need not be considered until Army representatives visited the War Office and continued to prevaricate on the matter. ${ }^{39}$

\section{Pilot training.}

By the end of 1922 a total of seventeen aircraft had been acquired by the Air Service though at least two of these had been written off as a result of accidents. At the same time ten pilots, of the thirteen recruited in 1922, remained in the service. C. F. Russell's last recorded flight during the Civil War had taken place on 6 September. He was transferred from the Air Service about that time and put in charge of the new Railway Maintenance and Protection Corps, a corps made necessary by the wanton destruction of the railway

\footnotetext{
${ }^{38}$ DMA to COS, 26 Sept. 1922 (MA, A/07189).

${ }^{39}$ DMA to COS, 4 Dec. 1922; COS to DMA, 5 Dec. 1922: C-in-c file memo 6 Feb. 1923 (MA, A/07189)..
} 
infrastructure perpetrated by the Irregulars. ${ }^{40}$ Donal MacCarron's account of the early years reflect the popular belief that Capt. John Arnott, the seventh ex-RAF pilot, who had been taken on 15 September 1922, was lucky to escape with his life when 'dismissed' about 21 December the same year. He had allegedly been identified as a former Auxiliary and invited at gunpoint to take the mail boat to Britain -- and did so!

With five aircraft and pilots stationed in the south west the remaining resources at Baldonnell were apparently directed to undertake pilot training. While the commencement of pilot training was not formally announced by GHQ until 20 December 1922, aircraft log books suggest that training had commenced, on a totally ad hoc basis, as early as the latter part of October 1922. About that time a number of officers, including Lieut. Arthur J. Russell, Lieut. Tom Nolan and Lieut. Ned Fogarty had commenced flying training on Avro 504K. ${ }^{41}$ On 20 December 1922 the Adjutant General advertised a limited number of vacancies for pupils in the 'aviation department of the Army'. Officers, between the ages of eighteen and twenty-three, wishing to transfer to the 'department of aviation' were invited to apply through their Command HQ. After interview successful applicants were to be attached to the 'Flying Corps' for an unspecified time and if found satisfactory as pilots would be transferred on a permanent basis. ${ }^{42}$ In the context of the involvement of a rudimentary Military Air Service in the Civil War, its ill-defined functions and poorly organised nature, the training of new pilots drawn from the officer body of a largely irregular army made little sense at the particular time. Its only logic was in the perception of an army leadership that apparently considered it necessary to replace Ex-RAF pilots with officers of an acceptable nationalist background as quickly as possible. (See Chapter 6)

\section{Demobilisation}

As soon as the Civil War had come to an end in May 1923 it was inevitable that action had to be initiated to effect reductions in Army strength and to reorganise for roles and

\footnotetext{
${ }^{40}$ General Routine Order No. 16, 24 Jan. 1923. The effective date of Russell's new appointment is not recorded in the GRO or on his Officer's history sheet on his personal file in MA.

${ }^{41}$ Log books, Avro 504K I, II, III and IV (AC Museum).

42 GRO No. 9, 20 Dec. 1922.
} 
functions more compatible with the new peace situation and the impecunious state of the country's finances. ${ }^{43}$ The initial demobilization proposed was a reduction, in total Army numbers, from the May 1923 figure of 55,000 to 31,300 by January $1924 .{ }^{44}$ Even before demobilisation had taken place the secretary of the Department of Finance, Joseph Brennan, questioned the necessity for the Air Service in terms that put its survival in severe doubt.

As the Minister of Defence is aware the position of the public finances is such as to render it imperative that drastic economies be affected in all services which are not immediately essential in the public interest. In this connection the Minister of Finance would be glad to learn whether the Minister of Defence sees any urgent reason for the maintenance at the present time of an air branch in the Army. The Minister of Finance finds it difficult to believe that the upkeep of an Air Service in this country at the present time can be justified by any arguments which are not much outweighed by counter-arguments based on the grave injury being done to the economic interests of the country by the present high level of taxation and of government expenditure.

The minister would also be glad to be supplied with details showing the strength, distribution and equipment of the Air Service at the present time.

Pending the further consideration of this matter the proposals put forward on $31^{\text {st }}$ ultimo by the army finance officer for the grant of additional and extra pay to Air Service personnel in certain cases are being held over. ${ }^{45}$

Nothing on the Department of Finance file indicates on what criterion they based their rather blunt opinion. It is generally acknowledged that military expenditure soared out of control during and immediately after the Civil War. ${ }^{46}$ However, it is not generally appreciated that the actual expenditure on the Army vote for the Civil War period was of

\footnotetext{
${ }^{43}$ Ronan Fanning, The Irish Department of Finance 1922-58 (Dublin, 1976), pp 114-6.

${ }^{44}$ J.P. Duggan, A history of the Irish Army (Dublin 1991), p. 130.

${ }^{45}$ Aireacht Airgid to Sec Ministry of Defence, 20 August 1923 (MA, A/09971).

${ }^{46}$ Peter Young, 'Defence and the new Irish state, 1919-39' in Irish Sword xix (1993-4), p. 10.
} 
the order of $£ 7,459,104$ for $1922 / 23$ and $£ 10,461,401$ for $1923 / 24 .^{47}$ On a purely financial basis it was clear that an army of over 55,000 simply could not be supported on a permanent basis. However when one considers the total numbers in uniform during the war and the rather minute size of the air component the cost of the aviation element may not have been disproportionate. The Military Air Service, including the infantry troops known as the Air Service Infantry and the garrison element at Baldonnell, had peaked at a total of 540 all ranks, 298 infantry and 242 aviation, in June $1923 .{ }^{48}$ The entire Air Service represented less than one percent of the whole Army at its maximum strength while the specific aviation element amounted to only .44\%. The cost of $.44 \%$ of the army for the two years works out at about $£ 79,000$. To this must be added the cost of purchasing and operating aircraft that would have been over and above the cost of infantry soldiers. The total cost of buying twenty-two aircraft, plus the operating cost of spare parts, fuel and oil during the Civil War was put at $£ 29,000$ by McSweeney and apparently was not contested by Defence or Finance. ${ }^{49}$ With no additional aircraft being purchased in 1923/24 a notional $£ 500$ would probably cover any additional costs to the end of the financial year 1923/24 - a total of $£ 29,500$. In effect the Air Service had cost the state less than $£ 110,000$ out of the total of $£ 17.91 \mathrm{~m}$ expended on the Army in the two year period. It is possible that Finance, based on the fact that sums of up to $£ 1,200$ had been spent on individual aircraft, had a perception that the Air Service could not be justified on a financial basis.

Despite several reminders and requests from Finance, the Defence files do not indicate that the minister had considered making a case for a future military air service or that he had referred the matter for the consideration of GHQ and the Air Service. The minister was further reminded that approval of a flying pay regime, decided by the Army Pay Commission in May 1923, and proposed for some Air Service personnel, was being withheld pending his reply to the original query. ${ }^{\text {so }}$ In November he did forward the statistical return requested in mid-August. As McSweeney had provided the required

\footnotetext{
${ }^{47}$ Undated memorandum, 'Expenditure from the Army vote in the Civil War period', circa 1939 (NAI, DT, S.11,101).

${ }_{48}$ Air Service strength return, June 1923 (MA, A/09971).

${ }^{49}$ Unsigned memorandum, 15 June 1923 (MA, A/09971).

${ }^{50}$ Minutes of $23^{\text {rd }}$ Session, Army Pay Commission, 3 May 1923 (NAI, DF, S.004/0248/24); File memo, 30 Oct. 1923 (MA, A/09971).
} 
information, on the numbers and distribution of personnel and details of the aircraft on charge, within two days there is no obvious reason for GHQ's delay in forwarding the same to Finance. ${ }^{51}$ As late as 24 December 1923 the Department of Finance was still endeavouring to elicit from the minister or from his department, the case required to justify the retention of the Air Service. ${ }^{52}$ Not only did Mulcahy fail to supply the required case but apparently failed to even acknowledge that such a case was required. In the absence of such a case it is not known what Mulcahy's policy on aviation may have been or why he was apparently so ambivalent or indecisive about the military aviation for which he was ultimately responsible. Based on the indifference to military aviation he displayed during the Civil War it might be considered that Mulcahy was reluctant to support either the continuation or demise of the Air Service and, in effect, seemed content to leave the judgement and decision to others.

In the meanwhile Major General W.J. McSweeney, GOC Air Service had submitted to GHQ a proposal, for an Air Service consisting of a headquarters and two squadrons, to be included in a reorganised Army. He cited the necessity to have sufficient, but undefined striking power, available to counter potential enemies. He also indicated the necessity to be able to patrol fishing grounds to identify, and presumably monitor foreign trawlers. While McSweeney considered two squadrons to be the minimum size of aviation unit that would be effective and viable the reasons he cited by way of justification may have been seen as far from compelling by a General Headquarters staff that had previously displayed little appreciation of air power and the operational application of aircraft. ${ }^{53}$ It was at times such as these that the absence of Russell's superior ability as an aviation staff officer was sorely missed. McSweeney was informed that an establishment for two squadrons were being recommended but that financial considerations might not permit. Within days it was also stated that in all probability it may be decided by the Executive Council to abolish the air force [sic] entirely'. ${ }^{54}$ In the event the officer establishment, eventually published in February 1924 and intended for activation in the following April, provided for a headquarters and two

\footnotetext{
${ }^{51}$ GOC AAS to CSO GHQ, 23 Aug. 1923 (MA, A/09971).

52 Sec DF to AFO, 24 Dec. 1923 (NAI, FIN I/2975).

${ }^{53}$ GOC, AAS, to COGS, 24 Oct. 1923 (MA, A/09971).

${ }^{54}$ COGS to GOC, AAS, 26 Oct.1923 (MA, A/09971).
} 
squadrons with a total of forty-three officers. With the addition of an appropriate establishment of NCOs and men this establishment, had it been proceeded with, might have been expected to bring total Air Service numbers to about 500 all ranks. In the new army McSweeney was to have been reduced to the rank of colonel. ${ }^{55}$ However the scheme proposed for the Air Service in February only provided for a total of 287 all ranks -43 officers, sixty NCOs and 184 privates. $^{56}$

As was the case throughout the Army, the reorganisation and demobilisation process in the Air Service was further interrupted and complicated by the Army 'mutiny' of March 1924. In personnel documentation the term 'crisis' was the more frequently euphemism denote the unpleasantness or internal strife that accompanied the reorganisation plans that were being attempted in 1923 and early 1924. The difficulty arose due to the manner of the demobilisation process aimed at reducing officer numbers from 3,300 to 1,800 and from the manner in which officers of War of Independence repute were allegedly being targeted for discharge. Three categories of officers were identified as being liable to dismissal: unsuitable officers, post-truce officers who had no special qualifications and pre-truce officers who were surplus to requirements. On 7 March 1924 some 900 officers were demobilised. ${ }^{57}$ In Baldonnell some eight officers fell into these categories. On 7 March 1924 four officers of the 'Air Service Infantry' and four of the 'Air Service' were demobilised. ${ }^{58}$ The latter group included Lieut. William McCullagh who had been injured in a flying accident on 25 June 1923 and was classified as 'long term sick'. He was apparently dismissed on medical grounds rather than coming under the demobilisation criteria proper. Also demobilised was 2/Lieut. John Vincent Norton, one of the trainee pilots taken on in $1922 / 23 .^{59}$

Brigadier General Liam Tobin and Colonel C.F. Dalton had assumed the leadership of the pre-Ttruce officer group who took exception to freedom fighters being discarded while ex-British officers and soldiers were retained. In fact only 157 technical officers, that would have included eleven former RAF pilots in the Air Service, were so

\footnotetext{
${ }^{5 j}$ Staff duty memo No. 12, 29 Feb. 1924.

56 'Notes on Army Estimates, 1924/25, June 1924 (NAI, DF, S.004/0005/27).

${ }^{57}$ Duggan, Irish Army, p. 131.

58 'Discharges', Staff Duty Memo No. 13,6 Mar'. 1924

${ }^{59}$ Officer's personal file, (MA, SDR 1182); Record of pilot intake to Air Corps (AC Museum).
} 
retained. ${ }^{60}$ After written and verbal confrontation with the government the 'mutiny' was contained and turned into what might nowadays be termed a redundancy scheme.

Thirteen Air Service officers who had been nominated for appointments in the reorganised Army, including McSweeney, are recorded as having 'resigned due to the crisis'. ${ }^{61}$ While in general the particular circumstances surrounding the mutiny and the discharge or demobilisation of individual officers are not detailed in the surviving records circumstances applying to some of the flying officers in Baldonnell can be elucidated. This is mainly due to access gained some years ago, to the Military Archives files on a very small number of pilot officers. Maj. Gen. W.J. McSweeney was one of the most senior officers to be listed as a mutineer and the only officer, other than Liam Tobin and C. F. Dalton who were actually named, who can be identified from the Dail debate of March 1924. It is considered pertinent that Colonel C.F. Dalton, one of the founder members of the Irish Republican Army Organisation in January 1923 and later one of the two officers who challenged the government on 6 March 1924, was adjutant at Baldonnell from 30 June 1923 to 29 March $1924 .^{62}$

While there is no evidence to confirm any ulterior motive in the matter some might consider it extremely odd that a disaffected officer like Dalton would be appointed adjutant to any military formation. His co-conspirator, Major General Liam Tobin had been appointed aide-de-camp to the governor general. The thinking behind the latter decision was possibly that, in such an appointment Tobin might not be in a position to spread the rot of dissent throughout the army barrel. However the appointment of Dalton could be interpreted as having malevolent intent. When C.F. Dalton was appointed adjutant, Army Air Service in July 1923 he succeeded Col. Ned Broy who had retired in June 1923 after less than a year in army uniform. ${ }^{63}$ It is not recorded why Broy retired but his marriage in July 1923 may have been an influence. ${ }^{64}$ Similarly it is possible that Broy, who was not a pilot and who was eleven years older than his immediate superior, General McSweeney, did not see a future for himself in military aviation thus precipitating a move back to his earlier calling as a policeman. Broy had originally been

\footnotetext{
${ }^{60}$ Duggan, Irish Army, pp. 130-137. See also O'Halpin, Defending Ireland, pp 45-52.

61 'List of officers who resigned owing to crisis', circa March 1924 (MA, A/11657).

${ }^{62}$ Valiulis, Almost a rebellion, p. 32; Officer's history sheet (MA, SDR 601).

${ }^{63}$ Officer's history sheet, (MA, SDR 601).

${ }^{64}$ Personal comment, Ms Aine Broy, 6 Feb. 2002.
} 
specifically appointed to his position in the Air Service by Michael Collins having immediately previously been briefly on the staff of the Civil Aviation Department. ${ }^{65}$ In September 1922 the Adjutant General reported that Broy 'had brought the standard of discipline to a very high pitch and that he is a person well suited to accept the responsibility of carrying on in the absence of the director [of military aviation] ${ }^{66}$ In May 1923 GHQ eventually got around to formally endorsing those temporary commissions and appointments of Air Service officers originally authorised by McSweeney and, in Broy's case, by Michael Collins. When this was done, by means of publication in General Routine Orders, Eamon Broy was the first Air Service officer so endorsed. On 4 May 1923 the former 'Lieut. Comdt.' E. Broy was confirmed in the rank of Colonel in the appointment of 'adjutant, Air Service, and $\mathrm{O} / \mathrm{C}$ ground organisation' in the chief of staff's department. Over three weeks later, on 28 May 1923 'Major General John [sic] McSweeney' was confirmed as 'officer commanding, Air Service', also in the chief of staff's department. Without a definition of the term 'ground organisation' it is unclear what Broy's responsibilities precisely were. In publishing Broy's appointment before that of McSweeney and in making Broy 'O/C ground organisation' GHQ may have been trying to make a clear distinction between the Air Service per se, that would be under McSweeney, and the Air Service Infantry and the garrison troops under Broy. It could be inferred that McSweeney's command only extended to Air Service personnel and that Broy was in command of ground troops at Baldonnell. This distinction was not made clear in May 1923 and was to be made no clearer in March 1924 when McSweeney and others were being dismissed as alleged parties to the mutiny.

Notwithstanding confirmation, on 4 May 1923, of his original appointment of 29 July 1922 Eamonn Broy resigned with effect from 22 June $1923 .{ }^{67}$ While his retirement may have been influenced by his forthcoming marriage, or his age, it is also possible that his resignation was related to the appointment of C.F. Dalton. There is at least one indication that Broy may have left Baldonnell abruptly. Shortly after the mutiny Commandant Mason, who was taking over the duties of camp commandant, found two trunks the property of Eamonn Broy in a room most recently vacated by McSweeney.

\footnotetext{
${ }^{65}$ W.J. McSweeney to AG, 18 Sept. 1922 (MA, A/06942).

${ }^{66}$ AG to C-in-C, 19 Sept. 1922, Officer's personal file (MA, SDR 169.

${ }^{67}$ Certificate of military service, 29 Sept. 1926 (MA, SDR 169).
} 
Apart from personal items one trunk contained some 896 rounds of .303 service ammunition. ${ }^{68}$ It would not normally be in the character of Eamonn Broy to abandon service ammunition in the manner suggested. Similarly there is no evidence of him falling out with McSweeney. It is possible that Broy had resigned and that while leaving Baldonnell in somewhat of a huff neglected to tidy up his affairs. A possible reason for an apparently rushed departure is that it may have been intimated to Broy that he accept a change of appointment to make way for Dalton and that he chose to resign rather than move elsewhere.

The appointment of C.F. Dalton as adjutant of the Air Service could be viewed in the context of the prejudice of the old IRA against ex-British officers holding commissioned rank in the National Army of 1923/24:

The old IRA men in the army generally objected to the presence of those who had never participated in the national movement, and particularly to those who were regarded as enemies prior to the Truce with England. ${ }^{69}$

As the Air Service had a significant concentration of such personnel it might be considered that it made little sense to appoint a disaffected officer such as Dalton to the position of adjutant. Considering the disciplinary aspects of the attendant duties the appointment of C.F. Dalton as successor to Broy could be viewed, at best, as careless and at worst, as being deliberately seditious. It cannot be ruled out that Dalton had been moved to Baldonnell, not to negate his potentially malevolent influence in the Army generally, but rather to foment dissent among a corps of ex-RAF officers, a group with which it would have been known he could not identify.

While the effect of Dalton's influence in Baldonnell cannot be judged validly it is significant that twelve infantry and air officers of an IRA background are recorded as having been dismissed as a result of the army crisis of 1924. Only one ex-RAF officer, McSweeney, is similarly listed though eventually two more would be dismissed. As pilot officers at Baldonnell were not in any of the three categories of officers originally

\footnotetext{
${ }^{68}$ Comdt. T. Mason to COGS, 14 Apr.1924 (MA, A/06942).

67. 'Report to Army enquiry', Col. M.J. Costello, 22 April 1924 (MA, PC586).
} 
designated for demobilisation the discharge of three pilots requires explanation. In particular McSweeney's retirement should not go without comment.

On an undated list of 'resignations, dismissals and absenters' McSweeney was recorded, along with C.F. Dalton as a deserter. ${ }^{70}$ On a list dated 19 March and apparently later than the first, McSweeney and Dalton are recorded under the heading 'Additional resignations due to crisis'. ${ }^{71}$ While his adjutant, Col. Dalton, was one of the ringleaders there is no direct evidence that McSweeney took an active part in the mutiny. In fact they were unlikely bedfellows - if bedfellows they were. McSweeney was one of the 157 exBritish officers whose proposed retention in the Army so antagonised Dalton and others. The circumstances surrounding McSweeney's dismissal are not clear and, in some respects, appear contradictory. J.C. Fitzmaurice, in his unpublished memoir, states that McSweeney, on some unspecified date about the time of the mutiny (February / March 1924), had travelled down to Fermoy in his own car allegedly in possession of a significant quantity of misappropriated arms. Fitzmaurice states that he was amazed to find that McSweeney had taken the side of the mutineers. Fitzmaurice, in stating that he was questioned as to his attitude and that of his officers in the matter, implies that the reason for the visit was to persuade Air Service officers to join the mutiny. Fitzmaurice, who had no time for McSweeney, confirmed his allegiance to the state and managed to persuade MsSweeney to leave Fermoy. ${ }^{72}$ In the absence of any other account it is not possible to confirm or deny the veracity of this serious allegation. The alleged incident does not sit well with other aspects of the mutiny period insofar as McSweeney was concerned. Had this incident happened it probably would not have gone unreported. Similarly an assertion by Comdt. J.J. Flynn is difficult to understand. In the course of contesting his own dismissal Flynn states that he found that his GOC was absent from Baldonnell on Monday 10 March 1924. The circumstances of McSweeney's resignation would appear to contradict this opinion.

In view of the unproven allegations against him it is fortunate that the circumstances of McSweeney's resignation or discharge can be detailed to a greater extent than most. On Saturday 8 March 1924, two days after the ultimatum to the

\footnotetext{
${ }^{70}$ Undated list, 'Resignations, dismissals and absenters' (NAI, DT, S.3720).

${ }^{71}$ List of Additional resignations due to crisis, 19 March 1924 (NAI, DT, S.3720).

${ }^{72}$ Fitzmaurice unpublished memoir, pp 140-1 (Estate of the late Patricia Selwyn-Jones).
} 
Government that had initiated the crisis, three line officers of the Air Service had absconded from Baldonnell with three Lewis guns and a Crossley tender. On Monday 10 March 1924 McSweeney made a phone call to General Mulcahy, commander-in-chief and Minister for Defence. While we do not know the initial reason, or all the matters discussed, we do know that they discussed the matter of McSweeney's resignation. The phone call was mentioned on 11 March when the matter of the mutiny, including the taking of arms from Baldonnell and elsewhere, was being reported to the Dail.

In connection with the Baldonnell incident the $\mathrm{OC}$ of the aerodrome yesterday tendered his resignation on the 'phone. He was told his resignation would not be accepted in that way, and he said that if that was so he would have to be regarded as a deserter. ${ }^{73}$

The clear inference in the Minister's statement is that McSweeny's resignation was directly related to the taking of weapons by absconding officers. It might be inferred that the minister had demanded the GOC's resignation holding him responsible for the actions of his subordinates. In the heat of the moment McSweeney appears to have tendered his resignation verbally, maybe indicating that he was unlikely to put it in writing. In the event McSweeney submitted not one but two letters of resignation. Immediately after the telephone call to the minister he wrote.

Baldonnell

$10 / 3 / 24$

Minister for Defence

Sir,

I have the honour to tender my resignation from the Army. I rang you up on the 'phone this evening and you accused me of breaking my word of honour. I assert now that I kept my word to the letter, also my Oath.

\section{W. J. McSweeney}

${ }^{73}$ Dail Eireann, parliamentary debates, Vol. 6, (1924), 1944. 
Following the telephone conversation a GHQ officer was sent out to Baldonnell. It is possible that he had instructions to request McSweeney's written resignation. The visit caused McSweeney to write again - this time, without due deference, to the chief of staff.

Baldonnell

$10 / 3 / 24$

\section{Lt. General Sean McMahon}

Parkgate

I desire to tender, from today, my resignation from the Army, and in doing so I wish to state that I faithfully kept my word I gave to you \& the M.D. last night. Judging from Col. O'Connor's arrival in Baldonnel, and the document he carried, you do not appreciate the word of honour of an officer.

\section{W. J. McSweeney \\ Major General \\ G.O.C. Air Service. ${ }^{75}$}

The arrival of an officer from GHQ, possibly with a prepared letter of resignation, and the writing of a second letter of resignation adds little to our understanding of the reason or reasons for the initial telephone call and ultimately for the resignation at the particular juncture. While McSweeney may have rung the minister on his own initiative it is more likely that he was responding to a query from the Minister, about the misappropriation of arms, in the context of an inevitable Dail debate. The tone of the letters of resignation suggests a difference of opinion on an important matter though it is not obvious what matter of honour was in question. As McSweeney was one of a number of the ex-British

\footnotetext{
${ }^{74}$ W.J. McSweeney to MFD,10 Mar. 1924, Officer's personal file (MA, SDR 3718).

${ }^{75}$ W.J. McSweeney to COS, 10 Mar. 1924, Officer's personal file (MA, SDR 3718).
} 
officers whose appointment and proposed retention was cited as a factor in the mutiny it probably suited Mulcahy to be able to hold him responsible for the mutinous actions of three line officers of the air station. In the context of the mutiny it may have suited the minister to be able to force the resignation of a major general who had no pre-Truce service but had previous service in the RAF. The misappropriation of arms by his subordinates was probably more than adequate reason for requiring McSweeney's resignation.

In spite of McSweeney's early resignation and the fact that the Army Enquiry Committee avoided giving reasons for individual 'resignations' the enquiry found that 'Major General William J. McSweeney' 'had absented himself in such a manner as to show wilful defiance of authority'. ${ }^{76}$ That he was absent is not supported by the fact that he telephoned the minister on the 10 March, was available to receive an emissary from the chief of staff and had resigned with immediate effect. Perhaps McSweeeny was deemed to be absent because he departed before his resignation had been accepted. Unfortunately the records fail to reflect the precise circumstances of officers who were deemed to have absconded or absent. Nor is there evidence to corroborate Fitzmaurice's assertion implying McSweeney's active, even armed, support for the mutiny.

The question still arises as to the exact nature of McSweeney's position vis-à-vis the mutiny. While he might not have seen eye to eye with C.F. Dalton for obvious reasons, as an officer who owed his rank and career to Michael Collins and who was due to be reduced to the rank of colonel in the proposed reorganisation, McSweeney might have held a grudge against the current leadership. Some evidence to support this is provided by Capt. Patrick (Joe) Mulloy, a former IRA officer and more recently of the Air Service Infantry, who was an Air Service observer by the time of the mutiny. In a pamphlet published some fifty years after the events he observed on the ease with which the infantry at Baldonnell might have contributed to a general coup d'etat initiated by Tobin and Dalton:

In Baldonnell the headquarters of the newly formed Air Corps [sic] the G.O.C., General McSweeney: the adjutant Colonel Dalton, one of the signatories on the

\footnotetext{
${ }^{76}$ Undated 'List A', Summary of officers (MA, A/1 1657).
} 
ultimatum presented to the government, and the bulk of the officers of the garrison were involved [in the mutiny], and it would be a comparatively simple matter for the G.O.C. to issue instructions that orders from him only were valid. The flying personnel were not involved as they were largely ex-R.A.F. and would take their orders from the G.O.C. Thus the whole camp, with the Air Corps [sic], could be taken overnight, without a shot being fired. ${ }^{77}$

These first-hand observations by Pat Mulloy seem to suggest that while McSweeney was in sympathy with the mutiny his position was a personal one and that he did not attempt to influence the rest of the ex - RAF group of officers. Similarly it can be argued that those infantry officers at Baldonnell, and the line and air officers of the Air Service, who supported the 'mutiny' and who would have had good republican records, were more likely to have been rallied to the cause by Dalton rather than by McSweeney. Fitzmaurice intimates that McSweeney did not enjoy the confidence of the ex-RAF pilot group though we only have his apparently jaundiced views on this matter. He described McSweeney as a 'youth who bore the exalted rank of major general' and who was 'an ex-cadet of the Royal Air Force whose flying experience was practically nil' ${ }^{78}$ On the basis of his background and military culture McSweeney would have been held in similar odium by the former IRA officers of the garrison. It is of note that McSweeney, who appears to have had little if any involvement in the mutiny, resigned on 10 March 1924 while C.F. Dalton did not resign until 25 March. $^{79}$ Their respective personal files in Military Archives indicate that W.J. McSweeney was paid off with $£ 100$ while C.F. Dalton was paid $£ 225$ for 'excellent service prior to the Truce'. 80 There is major irony in the fact that one of the main functions performed by Dalton during the demobilisation and reorganisation process was to bear witness to, and certify, the satisfactory nature of the service of the individual ex-RAF pilot officers. ${ }^{81}$

\footnotetext{
${ }^{77}$ Patrick Mulioy, Mutiny without malice (Thomond Publishing Company, London, 1974), p. 5. The earliest use of the name 'Army Air Corps' occurs in a draft establishment dated 2 May 1924 on DT file $\mathrm{S} .3442 \mathrm{~B}$ in NAI.

${ }^{78}$ J.C. Fitzmaurice, unpublished memoir, p. 121 (Estate of the late P. Selwyn-Jones).

${ }^{79}$ Letter of resignation, 25 March 1924 (MA, SDR 601).

${ }^{80}$ Officers' history sheets (MA, SDR 601; SDR 3718.

${ }^{81}$ Officer s' history sheet (MA, SDR 1333; SDR 1187; SDR 975).
} 
By definition Air Service pilots should have been excluded from the demobilisation process. Nevertheless a total of four ex- RAF pilots were discharged as a result of the intertwined reorganisation, mutiny and demobilisation processes. In addition to McSweeney only J.J. Flynn is recorded as having resigned due to the crisis. Commandant Flynn, who had been in charge of pilot training, was found to have absented himself in the same manner as McSweeney though again the precise circumstances are not explained. ${ }^{82}$ It is not impossible that a factor contributing to the dismissal of Comdt. J.J. Flynn, chief flying instructor, was the abject failure of the illadvised pilot training scheme that had been advertised directed by GHQ in December 1922. ${ }^{83}$ However the main reason cited is the fact that he was declared to be have been absent on or about 10 March 1924. The full circumstances, based on Flynn's account recorded some six weeks later, are as follows.

At the time of the army mutiny Commandant J.J. Flynn was second in command to McSweeney. It appears that he had received, on 9 March 1924, McSweeney's verbal permission to be absent from Baldonnell for twenty-four hours so that he could attend to private business in Sligo. On his return he found Baldonnell had been taken over by troops from the Dublin command and that McSweeney had absconded. He was arrested and spent ten days in Arbour Hill Detention Barracks. On 21 March 1924 he was released having given his 'parole to come up for trial when duly summoned'. ${ }^{84}$ About four weeks after his release he wrote to the Minister for Home Affairs, Kevin O'Higgins, giving an understandably biased account of his travails over the previous five or six weeks and seeking redress that he could not get elsewhere. He explained that he had been on leave and how he had been arrested on his return and spent ten days in Arbour Hill. He indicated that he had made his loyalty to the State known to the Chief of Staff. While he was considered to have been absent without leave he was not tried on any charge. While in Arbour Hill he had been referred to as a mutineer though not allowed to associate with that group of officers. On his release he was initially not allowed back into Baldonnell but was summoned there on 5 April and had an interview with the Chief of Staff to whom he explained his situation. As a result he was allowed back into Baldonnell but, while

\footnotetext{
${ }^{82}$ Undated 'List A', 'Summary of Officers' (MA, A/11657)

${ }^{83}$ General O'Duffy's Scheme, Explanatory Notes, p. 37 (NAI, DT, S.3442B).

${ }^{84}$ Declaration signed J.J. Flynn, 21 Mar. 1924 (MA, MS 388).
} 
retaining his rank, was removed from his position as squadron commander and made subordinate to Capt. T.J. Maloney (the new commanding officer). Dissatisfied with the situation he felt compelled to tender his resignation and did so on 10 April 1924. On 13 April he was informed by Capt. T.J. Maloney, apparently incorrectly, that his resignation had been accepted by the Chief of Staff. He was directed to report to the Staff Duties office in GHQ and was informed that he should proceed on leave while awaiting the decision of the Army Council as to whether his resignation would be accepted or not. Citing the fact that those at the top of the Air Service were being given greater recognition for their service with foreign armies than he was receiving as an old IRA man Flynn pleaded that, as the only remaining flying officer at Baldonnell with an IRA record and continued to support the Treaty. He requested Kevin O'Higgins to have the whole matter investigated and that he should be allowed withdraw his resignation. ${ }^{85}$

The case was referred by Kevin O'Higgins' office, to the office of the President of the Executive Council. The President referred the matter to General O'Duffy, GOC Forces, for his opinion. It was suggested that there might have been a mistake and that the treatment of Flynn might have been harsh. ${ }^{86}$ O'Duffy recommended that Flynn not be allowed withdraw his resignation. He did soon many grounds. Not least of these was that Flynn could not prove that he was not absent on 10 March 1924. O'Duffy's put great emphasis on the fact that Flynn had been 'absence from his post at the time practically the entire staff absconded from Baldonnel' stating that that it was more than a coincidence. The most damning comment was that which cited Flynn's letter of resignation in which he had expressed opinions that echoed those of Tobin and Dalton the chief mutineers. Citing also Flynn's 'mutinous and indisciplined [sic] remarks', and his intemperate language in his letter of resignation and his intemperate behaviour when dealing with the Chief of Staff, O'Duffy suggested that he 'could not reaccept him in the army in any capacity' and recommended accordingly. ${ }^{87}$

The tone and inference in O'Duffy's assessment of ex-Commandant J.J. Flynn is possibly more telling than the content as it emphasises the summary manner in which officers were found to have absconded, and subsequently discharged, without due

\footnotetext{
${ }^{85}$ J.J. Flynn to Kevin O'Higgins, 20 Apr. 1924, officer's personal file (MA, SDR 975).

${ }^{86}$ Undated Executive Council note, officer,s personal file (MA, SDR 975).

${ }^{87}$ GOCF to President, 7 May 1924, Officer's personal file (MA, SDR 975).
} 
process. Flynn had the misfortune to be absent from Baldonnell about the time that three officers had absconded with armament and a vehicle and so certain suspicions were attached to him at GHQ. Having been arrested and lodged in Arbour Hill he was put in the same category as those officers who had been arrested at a meeting of mutineers held in Delvin's hotel on 18 March $1924{ }^{88}$ Thereafter his own intemperate behaviour gave the GOCF and the COS sufficient cause to confirm his discharge. ${ }^{89}$ It appears that neither GHQ nor GOCF had any solid evidence against Flynn and though he had been arrested, and subsequently released, with a view to being charged he was never formally tried. While it might be considered that Flynn's greatest crime was to speak ill of his superiors the records suggest that he was discharged, without due process, on the suspicion of being absent for twenty-four hours. It is probable that many others were summarily dismissed in a similar manner as no formal charges were ever brought against alleged mutineers - not even Tobin and Dalton, the ringleaders.

The last of the four ex-RAF pilots to be let go was Wilfred D. Hardy who was discharged on 27 June 1924 though, as an officer with special qualifications he might have been retained. ${ }^{90}$ His commanding officer, Major T.J. Maloney, argued strongly in favour of his retention and protested 'at the proposed demobilisation of a good officer who was in line to be appointed flight commander' and suggested that Hardy had been selected for discharge on the basis that he was non-Catholic. ${ }^{91}$ Maloney had apparently not been told that Eoin O'Duffy, in his capacity as General Officer Commanding the Forces, had indicated to the Executive Council on 29 May 1924 that Hardy had two brothers in the Six Counties Special Constabulary and was being dismissed on those grounds. ${ }^{92}$

As the ex-RAF pilot group at Baldonnell were notionally exempt from demobilisation it could be concluded that GHQ made maximum use of the confused circumstances surrounding the mutiny to dismiss as many of that group as possible. In doing so they were, in effect, pandering to the prejudices of those, both serving and demobilised, whose main objection was to the proposed retention of ex-British officers

\footnotetext{
${ }^{88}$ See O'Halpin, Defending Ireland, pp 45-52.

${ }^{89}$ GOCF to president EC, 7 May 1924, Officer's personal file (MA, SDR 975).

${ }^{90}$ Officer's personal File (MA, SDR 1187).

91 OC Air Service to COS, 20 June 1924, Officer's personal file (MA, SDR 1187).

92 Gen. E. O’Duffy to President, EC, 29 May 1924 (NAI, DT S.3720).
} 
who had no pre-truce service. The pilot group, even though all were of Irish birth or origin, represented a considerable concentration of such officers and were an easy target for demobilisation. In effect no distinction was made between the RAF who left Ireland in 1922 and a small number of ex-RAF Irishmen who served the state well during the Civil War. One of the ex-RAF pilots, J.C. Fitzmaurice, writing some years later described, in very strong terms, the position in which that group had found themselves in 1924:

Unfortunately the stinking evils of patronage, nepotism and corruption, now rife in my native country and slowly bringing it to ruin, commenced raising their ugly heads about this [time] and we Irishmen who had held His Majesty's commissions were treated with grave distrust by the politicians and the majority of the Old I.R.A. officers who always referred to us as the 'Exers' - delightful term! ${ }^{93}$

A similar, though less trenchant opinion was expressed by another officer:

I am, of course, well aware of the prejudice against British officers which is openly exhibited by some officers of the National Army and under the circumstances that prejudice is inevitable, but I make no apology for the part I played in the Great War. $^{94}$

On the other hand Col. C.F. Russell, when asked by the mutiny inquiry committee if he had experienced hostility or jealousy on the grounds of being a former British officer, indicated that he had not experienced such treatment from either colleagues or from higher authority. ${ }^{95}$

\footnotetext{
${ }^{93}$ J.C. Fitzmaurice, unpublished memoir, p.143 (Estate of the late P. Selwyn-Jones).

9.4 'Statement of Lt. Col. Thomas Ryan', 12 Apr. 1924 (UCDA, MP, P7/C/8).

${ }^{95}$ C.F. Russell to Army committee of inquiry, 9 May 1924 (UCDA, MP, P7/C/28).
} 


\section{Conclusion}

After the death of Michael Collins it took a considerable length of time to implement his decisions regarding the extension of air operations in Cork and Kerry. This delay was symptomatic of the general failure to execute a rapid push into the south west that might have foreshortened the war. It took an inordinate length of time, three months, to recruit six additional pilots. This was most likely due to the informal manner in which the application and selection system appears to have operated.

Collin's decision to purchase additional aircraft had to be reviewed by his successor resulting in a delay of about three weeks before the order was placed and a further five weeks before the order was filled. In the meanwhile there was a delay of six week before the decision to occupy Fermoy was implemented. There was no apparent reason for this delay as it transpired that the move south was not dependent on obtaining all the additional pilots or the additional aircraft.

At Tralee, with the aircraft under local control there was a modest return in terms of operational missions flown. The intelligence value was probably similarly modest. With the air operation out of Fermoy under the command of General Dalton and with control exercised at local level it is probable that the overall return, in terms of the missions flown by four aircraft and crews, was equally modest. In the absence of contemporary records, such as reconnaissance reports, the effectiveness or otherwise of these escorts and patrols carried out cannot be gauged. After the Civil War it is doubtful if there was a good military reason for maintaining the Fermoy and Tralee detachments in place until well into 1924.

While the demobilisation mutiny processes had a significant affect on the Air Service considerably many more line officers than ex-British resigned or were discharged. In the absence of evidence to the contrary the posting of C.F. Dalton appears to have had little affect on the loyalty of Air Service officers. If he influenced anyone it appears more likely that it was line officers with pre-Truce service. While theoretically Air Service pilots were in a special category that was not subject to demobilisation the authorities appear to have taken advantage of the confused circumstances of the mutiny to discharge a significant proportion, four out of eleven, of the remaining ex-RAF pilots. 
Though McSweeney may have felt aggrieved at the prospect of being reduced in rank there is scant evidence of him having absconding - at least not until he had tendered two letters of resignation. In all probability, as had been implied by Mulcahy in the Dail, he was held responsible for the loss of arms that occurred at Baldonnell.

On the basis of the known details in his particular case Comdt. J.J. Flynn appears to have had good reason to feel aggrieved with the way he was treated. The records suggest that he had the misfortune to be missing from Baldonnell at a critical juncture. It also suggests that proof of his absence would not have passed the test for being beyond all reasonable doubt. The discharge of many officers as a result of the mutiny appears to have been based on perception rather than hard evidence and due process. Lieut. Hardy's only sin was to have two brothers in the Norther Irelans's Special Constabulary while it is not possible to assess the rights or wrongs of Lieut. W. A. McCullagh's demobilisation on medical grounds.

While it was inevitable that military expenditure would be reviewed and subsequently severely curtailed in the wake of the Civil War it is not at all clear on what precise financial basis the Department of Finance proposed to abolish the Air Service. It is obvious that the department was appalled by the cost of the war and most likely perceived aviation as being hugely expensive though it apparently cost less than a half of one percent of total Army expenditure for the period in question. Between May 1923 and March 1924 the Air Service appeared to survive more by accident than design. It was to take General O'Duffy's scheme of reorganisation to put it on a slightly firmer footing. 


\section{CHAPTER 5}

\section{POLICY, ORGANISATION AND COMMAND, 1924 - 1936}

In the early months of 1924 the implementation of the Army demobilisation and reorganisation processes was proceeding with difficulty against the background of unrest leading to mutiny. The Department of Finance, on the basis of excessive cost, had expressed itself to be very sceptical about the necessity for any aviation element in a reorganised and reduced Army. In the meanwhile General Richard Mulcahy, as Minister for Defence and commander-in-chief of the forces, was loath to express an opinion on the retention of the Air Service even though he was in overall charge of the reorganisation process. Under the reorganised establishment proposed in February 1924, and subsequently abandoned, the Air Service was to have consisted of a headquarters and two squadrons with appointments for a total of forty-three officers. This suggested the possible establishment of an air service totalling about 500 all ranks. Arising out of the Army mutiny (or crisis) of March 1924 some thirteen of the thirty officers nominated to fill vacancies under a new establishment are recorded as having resigned. As this number included the GOC, adjutant, quartermaster and chief technical officer of the Air Service, a camp commandant, backed up by troops from the Dublin Command was appointed to administer the aerodrome. Given the ambivalence of the post-Collins Army leadership where a military aviation unit dominated by ex-RAF pilots was concerned and the parsimonious attitude of the Department of Finance the future of the Air Service was not assured.

The following section of this study will examine the reorganisation process that resulted in the Air Service being reduced to a somewhat nominal Army Air Corps of 151 all ranks. The viability of the flying organisation of the October 1924 establishment will be assessed in the context of a predominantly infantry army. It is also intended to identify and examine the Army's air policy as reflected in day-to-day decisions on aircraft purchases and organisation in the period 1924 to about 1936. The ill-defined concept of the command of military aviation will be examined against the background of 
frequent and short-term changes of commanding officer. The reasons for the successive appointments of two inexpert (in an aviation context) army officers, Major J.J. Liston and Major P.A. Mulcahy, to the command of the Air Corps in the 1930s require examination as does the concept of the position of director of military aviation.

\section{The 1924 reorganisation}

In March 1924, as a consequence of the mutiny, General Eoin O'Duffy had been appointed Inspector General and General Officer Commanding Forces (GOCF). His main function was to oversee the completion of the demobilisation and reorganisation processes that had eluded General Mulcahy. O'Duffy's reorganisation proposal provided for an Army Air Corps of 155 all ranks as the air element of an Army of 18,966 all ranks.' It is necessary to examine the rationale behind O'Duffy's scheme of reorganisation to understand the position of the aviation element in the context of an infantry army. As the scheme was basically one for the reorganisation of the Army in the absence of a government or a ministerial statement on defence policy O'Duffy had to make assumptions in terms of what threat was to be guarded against. He decided to couch his proposals not in terms of national defence against external aggression but rather in terms of the threat to national security still posed by the IRA:

The question to be now considered is whether the Saorstat has greater reason to be apprehensive of an attack by forces from outside the state or an attack by Forces within its boundaries. The experience of the past two years combined with present day knowledge would go to show that internal disorder is more imminent and more to be apprehensive of. We must next decide as to the most effective arm of the service to cope with internal disorder. Again our experience has shown that the highly trained and mobile Infantry man was the most effective weapon used against the Irregulars while the practical utility of the Air Service was not considerable.

\footnotetext{
'General O'Duffys scheme, 'Army organisation', pp 28-9, GOCF to Executive Council, 2 May 1924 (NAI, DT, S.3442B).
} 
While the above statement might be considered more appropriate to a preamble outlining defence philosophy it was not cited in order to elucidate military doctrine but rather to minimise the value and potential of army aviation in the an internal security context of the state's defence requirements and to justify the establishment of what was to be a token Air Corps. O'Duffy's scheme of reorganisation was very heavily weighted towards 'the highly trained and mobile infantry man' and in effect established the precedence of an 'infantry arm' that was to dominate the military doctrine of the Defence Forces. ${ }^{2}$ This precedence was reflected in the essentially infantry nature of the establishment of GHQ and its three military departments (Chief of Staff, Adjutant General and Quartermaster General), the three territorial Commands and the Curragh Training Camp; nine brigades and twenty-seven infantry battalions. The 'infantry arm', in effect, comprised upwards of $75 \%$ of the reorganised Army.

While the case stated for the leadership structures, that demonstrated the precedence of the infantry ethos, were detailed and cohesive some of the cases made in support of the inclusion of individual corps and services were general and vague and demonstrated a lack of understanding of the individual nuances of standard military corps roles and functions. In particular the cases stated for such corps as the Artillery, Armoured Car, Air and Cavalry suggest that those drafting them lacked conviction as to the military value of, and necessity for, some of the more technical elements of a modern army.

The cases stated for the Army Transport Corps made a recommendation for no less than 407 all ranks and 282 horses for the Horse Transport division, in a Corps of 1142 all ranks, without suggesting how such equine resources would function in an internal security army. The composition of the Army Corps of Engineers case indicated a more professional approach and probably reflects the superior staff work of its first director, Col. C. F. Russell, who had initially impressed as director of civil aviation and second-in-command of the Military Air Service, and more recently as OC Railway Maintenance and Protection Corps. In general terms the explanatory notes portrayed the infantry arm as being indispensable and the other corps and services as optional extras, reflecting the belief that only the infantry soldier was capable of affecting a defence

\footnotetext{
2 Ibid; John P. Duggan, A history of the Irish Army (Dublin, 1991), passim.
} 
against an internal threat. It is known that, while the reorganisation scheme bore Eoin O'Duffy's signature when submitted to the Executive Council, the document had in fact been drafted by Col. Dan Hogan who later became Army Chief of Staff. ${ }^{3}$

The case made for an Army Air Corps in the new organisation was unstructured and vague and largely aspirational in tone. It clearly indicated that any aviation element established would, at best, have but a very minor and peripheral function in the overall scheme of defence. In the context of an army structured for internal security and dispersed around the country largely in the manner of the garrison units of the previous regime no operational function was envisaged for military aviation. The main arguments for the inclusion of an 'Army Air Corps' could be seen to be somewhat contradictory:

The question as to whether our financial resources would permit making the Army more complete and efficient by means of an adequate air service was to certain extent answered by the actual existence of such a unit containing personnel, plant and machinery and machines..... The necessity for the inclusion of an Air Service in the organisation of a modern Army is scarcely necessary to demonstrate Having regard to our limited finances it is not possible to build up an air force of adequate strength to afford protection against external aggression. ${ }^{4}$

While it was indicated that it was not necessary to state an ideological case for an air element in a modern army, it is obvious from the context that the main argument in favour of including an air element in the new establishment was that such an organisation already existed. While the case suggests that the inclusion of an air element in predominantly infantry army would make it more complete and efficient it was also contended that the effectiveness of military aviation in an internal security situation was not significant. In effect the case stated for an Army Air Corps was so lacking in conviction that it provided scope for higher authority to include or exclude such an element.

\footnotetext{
${ }^{3}$ General E. O'Duffy, letter re Col. Dan Hogan, 7 May 1930 (NLI, O’Duffy Papers, Box 5, Folder 40). I am indebted to Dr. Fearghal McGarry for this information and reference.

${ }^{4}$ General O'Duffy's scheme, Explanatory notes, 1 July 1924, pp 36-7 (NAI, DT, S.3442B).
} 
It is also obvious from the context that no review had taken place to establish the effectiveness, or otherwise, of the Air Service during the Civil War. It can be argued that such a review could not have taken place. There are various indications that Gen. O'Duffy and Col. Hogan did not have available any record of the operational use of aircraft for the period July 1922 to May 1923 on which to make such a judgement. The principal repository of material relating to armed aerial reconnaissance patrols and missions during the Civil War, the files of the commanders-in-chief (Collins and Mulcahy) which now constitute the Mulcahy Papers in UCDA, had been commandeered and retained by Mulcahy when he resigned in March 1924. In addition no record appears to have survived of the details of the air patrol and escort missions carried out by the Fermoy and Tralee air detachments in the period from October 1922 to May 1923. A particular instance is indicative of the GHQ's poor appreciation, and inadequate record, of military aviation activity in the early years. In early 1925, GHQ, while still trying to decide McSweeney's severance pay, found it necessary to write to the retired General Mulcahy to inquire about the former officer's service as GOC Air Corps in 1922. Mulcahy's succinct reply suggests that he had little appreciation of McSweeney's involvement in military aviation during the Civil War despite the fact that he, Mulcahy, had the records of the period in his possession. ${ }^{5}$

In such circumstances it is not easy to understand how O'Duffy and Hogan, neither of whom were on the staff of GHQ for the full duration of the Civil War or had expertise in air matters, could have made a valid appraisal of the effectiveness or otherwise of military aviation. Appropriate reflection might have indicated to them that Collins had demonstrated considerable faith in the intelligence value of military aviation in an internal security situation. The appraisal of the effectiveness of military aviation, apparently drafted by Hogan and endorsed by O'Duffy, was most probably based on inadequately informed perception.

The submission on the proposed Army Air Corps was not without progressive elements. It recognised that the scheme for pilot recruitment and training instigated in late 1922 had been singularly unsuccessful and therefore outlined a scheme for the

\footnotetext{
${ }^{5}$ Department of General Staff to Risteard O'Maolchatha, 24 Jan. 1925; Reply dated 25 Jan. 1925, Officer's personal file (MA, SDR 3718).
} 
recruitment of civilians that would become the cadet intake system, firstly for the Air Corps and eventually for the Army generally. The case for the future 'Army Air Corps' was summarised in simple terms:

There is therefore, no alternative but to decide what is the smallest aerial unit which would be sufficient to keep progressive thought stimulated........to give our troops a knowledge of the value of aerial co-operation, to train a small number of Infantry as Pilots, and for the purposes of research and watching the progress of other countries. After due consideration it was decided that one squadron consisting of 155 all ranks would meet these requirements. An annual purchase of one or two aeroplanes of the latest design would keep the unit conversant with modern developments.........6

However, in the context of Army structures, and of command and control, the Army Air Corps was put in a uniquely disadvantageous position. The explanatory notes on the reorganisation scheme as drafted extolled the merits of having the various corps disciplines represented in the GHQ staffs and of having corps staffs in the three Command Headquarters (Eastern, Southern and Western Commands) and the Curragh Training Camp and similarly having corps units in the brigades in each command. ${ }^{7}$ In sharp contrast the Air Corps, while designated as an army corps for the purposes of the 1923 Defence Act, was outside the GHQ / command / brigade chain of command. There were to be no air staff officers in GHQ or at the territorial command level. Similarly the minimalist organisation proposed could not be dispersed throughout the commands or brigades in the manner of other service corps units. At the same time neither did it have the status as an independent service. The Corps' only tenuous connection to the Army chain of command was that it was to be subject to the inspection of the 'first assistant chief staff officer of the Chief of Staff's department' - a mainly administrative functionary apparently not requiring aviation expertise. ${ }^{8}$ In effect, in terms of strength,

\footnotetext{
${ }^{6}$ General O'Duffy's scheme, 'Explanatory notes to Executive Council', 1 July 1924, p.36 (NAI, DT S.3442B)

${ }^{7}$ Ibid, p.23.

${ }^{8}$ Ibid, p.2,
} 
organisation and structure the proposed 'Army Air Corps' was to be a corps in name only. Similarly, in future years, the Air Corps was never to be dispersed, either in squadron or flight strength, throughout the country in support of commands or brigades in the manner of the units of other combatant corps. For some years after the implementation of the establishment under Orders No. 3, which came into effect on 1 October 1924, the Air Corps was, in effect, a tenant on an inadequately staffed aerodrome in a military camp garrisoned by various detachments of the $7^{\text {th }}$ Brigade in the territorial command of GOC, Eastern Command. ${ }^{9}$ As late as 1928 'B' Company $7^{\text {th }}$ Battalion, $7^{\text {th }}$ Brigade is cited as being 'attached to Baldonnnell for garrison duties'. ${ }^{10}$

While it had been proposed that a single squadron of 155 all ranks, acquiring one or two new aircraft a year to keep up to date technically, would fulfil the aviation requirements of the Army there is good reason to believe that the authors of the scheme did not believe this themselves. In 1925, while making a case for substantial improvements to the October 1924 establishment, Major T.J. Maloney, the senior air officer to survive the mutiny and demobilisation processes and now OC Air Corps, recalled how he had originally been directed, in April 1924, to draw up a scheme of reorganisation based on one squadron:

I received specific instructions that the new organisation of the Corps was to consist merely of a maintenance party sufficient to keep aircraft and equipment in a serviceable condition while the existence and the future of the Corps were being considered. $^{11}$

At the time Maloney, apparently reluctantly, recommended an organisation comprising about thirty-three officers, fifty-eight NCOs and 141 privates, a total of 232 all ranks and remarkably close to the maximum number (242) for the Air Service as recorded in June 1923 when total Army numbers were over 50,000. In General O'Duffy's reorganisation scheme Maloney's proposal was reduced to about two thirds of the strength required for a

${ }^{9}$ Orders No. 3, Defence Forces (Organisation) Order, 1 Oct. 1924, pp 34 - 5; Strength returns 1924 to 1927 (MA, LS8 \& LS9).

${ }^{10}$ Sgt. Billy Norton, 'Unit history $7^{\text {th }}$ Infantry Battalion $1923 / 59^{\prime}$ in An Cosantoir, xliv, no. 8 (Sept. 1983), pp 279-85.

11 'Army Air Corps establishment', OC AAC to CSO GHQ, 17 Apr. 1925 (MA, DOD RM 11). 
squadron. Maloney considered that the establishment numbers eventually decided upon were totally inadequate to maintain the aircraft and equipment to a standard commensurate with military efficiency. ${ }^{12}$ While O'Duffy had purported to establish a viable air unit Maloney apparently understood that the final size and shape of the Air Corps had yet to be decided and that the proposal for an establishment of 155 personnel was, in effect, little better than a care and maintenance organisation.

Not surprisingly there were many organisational and structural inadequacies in the proposed Army Air Corps. The most glaring of these was the fact that it had no provision for communications personnel - no signals officer, wireless operators or a switchboard operator for the telephone exchange in Baldonnell. In the explanatory notes the matters of communications and meteorological facilities services at Baldonnell were referred to obliquely and then only in the context of international obligations in respect of civil aircraft operations. ${ }^{13}$ Elsewhere in O'Duffy scheme it was recognised that a signal or communications facility was most essential to the Army Air Corps and suggested the matter of the provision of appropriate wireless equipment, was being carefully considered. $^{14}$ Similarly no separate provision was made for such aerodrome staff as would be standard on military aerodromes elsewhere - stores, messes, canteen, security and administration, not to mention transport and meteorology. While such functions may notionally have been included in the 155 all ranks the said establishment would have been totally inadequate for a corps headquarters, a flying unit and the aerodrome, garrison and support services of a military aerodrome.

Notwithstanding the contradictory aspects of the case stated by O'Duffy his Army Air Corps proposal was sufficiently coherent to ensure the retention of military aviation albeit in a rather tenuous condition and in token numbers. After being approved by the Executive Council, and before it was put into effect on 1 October 1924, the Army Air Corps establishment had, by some unseen sleight-of-hand, been amended down to 151 all- ranks. ${ }^{15}$ It may be no coincidence that this figure matched the actual strength return

\footnotetext{
12 Ibid.

${ }^{13}$ General O'Duffy's Scheme, Explanatory notes to Executive Council, 1 July 1924, pp 36-7 (NAI, DT S.3442B).

${ }^{14}$ Ibid, p.38.

${ }^{15}$ Orders No. 3, Defence Forces (Organisation) Order, 1 Oct.1924.
} 
for August 1924. Between June 1923 and August 1924 Air Service numbers had been reduced, from 242 to 151 , by demobilisation, the mutiny and natural wastage. ${ }^{16}$

At this juncture the newly designated Army Air Corps, with a token establishment and some twenty-two mainly obsolete aircraft had, at best, aspirations to perform viable aviation functions. During the rest of the 1920s the small air unit was, as Air Corps folklore would suggest, little better than a publicly funded aero club. The totally informal manner in which flying was initiated each morning and, in particular, Senator Oliver St. John Gogarty's easy access to military aircraft in 1925/27 period would support this notion. $^{17}$

The perilous position regarding the future of the Air Service as pertained in $1923 / 24$ is further illustrated by the proceedings of an 'army finance meeting', held on 5 June 1924, and relating to the 'purchase of spares \&c., for the air force [sic] at Baldonnel':

The army finance officer referred to the fact that authority had been obtained in the last financial year for a sum of $£ 3000$ to be expended on these spares, but owing to the circumstances at Baldonnel at the time at which the authority was secured action could not be taken towards the purchase in the last financial year. ${ }^{18}$

The meeting was informed that Commandant Maloney, who had recently taken charge of the Air Service, had requested that authority be granted for the spending, of the $£ 3,000$ withheld the previous financial year, in $1924 / 25 .^{19}$ In effect it had originally been considered by higher authority that unspecified circumstances pertaining during the period 1 April 1923 to 31 March 1924 had rendered it wise to withhold monies previously authorised for the purchase of spares. The adverse circumstances probably included the uncertainty of Army mutiny and possibly included the considerable reservations of Finance regarding the necessity for the retention of military aviation in a reorganised and much reduced army.

\footnotetext{
${ }^{16}$ Local Strength Returns, 29 Aug. 1924 (MA, LS9).

17 'No. 1 Squadron, Army Air Service, Duty of duty officer', Sept. 1924 (MA, MS 658); Ulick O'Connor, Oliver St. John Gogarty; a poet and his times (London, 1981), pp 227-35.

${ }^{18}$ Minutes, Army finance meeting, 5 June 1924 (MA, A/06959).

${ }^{19}$ Ibid
} 
With adequate signs that the retention of military aviation was not a priority with Finance and that GHQ was ambivalent on the matter, the withholding of authorised public funding may have been informally arranged between the two departments while awaiting the outcome of demobilisation and reorganisation. It is possible that purchase action was deliberately delayed until close to the end of the financial year 1923/24 in the belief that there was not sufficient time to spend the allotted monies while appearing to be supportive of the Air Service. With tentative arrangements made for the purchase and delivery of spares the AFO sought sanction from Finance.

For some time the Army Air Service has suffered neglect as regards the maintenance of the necessary air craft and at a recent meeting of the Council of Defence it was decided that efforts should be made to render this branch more efficient. $^{20}$

Stating that the COS considered that it would not be practicable to obtain delivery of more than half of a consignment costing almost $£ 6,000$ before the end of the financial year sanction was sought for 'Air craft spares and fittings up to a sum of $£ 3000$ out of the monies provided for the current year'. ${ }^{21}$ On 10 March 1924, the day McSweeney had resigned, Finance replied stating that 'the Minister for Finance has no objections to spending $£ 3000$ out of existing Army funds'. ${ }^{22}$ Apparently due to the mutiny Defence did not proceed and did not pursue the matter again until late May 1924. The army finance officer then explained that when the time came to inform the Air Service that that sanction had been granted for the purchase of spares authorise it was found that General McSweeney had left the service as a result of the recent Army mutiny and that no Air Service officer had been appointed to replace him. Stating that the air force was then in the charge of a responsible officer, the AFO requested that Commandant Maloney be given the necessary authority. ${ }^{23}$

\footnotetext{
${ }^{20}$ AFO to DF, 1 Mar. 1924 (MA, AC/2/2/2).

${ }_{21}$ Ibid.

$22 \mathrm{Sec}$ DF to AFO, 10 Mar. 1924 (MA, AC/2/2/2).

${ }^{23} \mathrm{AFO}$ to Sec DF, 24 May 1924 (MA, AC/2/2/2).
} 
The sanction for the spending of the $£ 3000$ in the 1924/25 financial year was renewed. ${ }^{24}$ Subsequent to negotiations with the Aircraft Disposal Company T.J. Maloney ordered $£ 1931$ worth of aircraft and engine spares. On the direction of Finance J.F Crowley and Partners, Consulting Engineers, 16 Victoria St., London, acted as some form of purchasing agents with Maloney 'being associated' 'as technical advisor with knowledge of what actually was required'. Given that the firm apparently had no aviation expertise it is not clear what its exact function was. A cynical observer might understand that some form of agency commission was being paid by Defence, without good cause, to consultants who were not expert in the field. ${ }^{25}$ While $£ 1,000$ was paid to the suppliers in advance to ensure delivery before the August week-end the full consignment was not completed until December $1924 .{ }^{26}$ Before the end of the financial year Finance sanctioned the expenditure of a further $£ 1,118$ on airframe and engine spares. Goods to the value of $£ 1,283$ were ordered from various companies and eventually delivered and paid for. ${ }^{27}$

It is not at all clear what combination of circumstances contributed to the failure to expend the authorised monies in 1923/24. In the normal course of events the first commandment in relation to defence purchases directed that purchase action would be initiated early in the financial year to ensure that the materiel was acquired and paid for in the financial year. If conditions prior to March 1924 had not been conducive to expenditure on aviation spares it is not understood how the purchases could have been contemplated when the alleged mutinous activity was at its worst. Even had the circumstances been right it is probable that the goods could not have been delivered and paid for within the financial year. The delay prior to March 1924 appears to have been deliberate and to have been based on general antipathy to the survival of the Air Service in the reorganisation processes. After 10 March 1924 the pretext cited was that there was no responsible air officer available to command the Air Service. Having initiated the purchase action at the last available moment it is possible that it suited the Department of Defence that McSweeney had resigned when he did. Thereafter Defence appears to have

\footnotetext{
${ }^{24} \mathrm{DF}$ to $\mathrm{AFO}, 13$ June 1924 (MA, AC2/2/2).

${ }^{25}$ Minutes of army finance meeting, 17 July 1924; T.J. Maloney to ADC, 23 July 1924 (MA, AC/2/2/2).

26 J.F. Crowley to AFO, 30 July 1924; OC AC to AFO, 27 Sept. 1924; OC AC to AFO, 19 Dec. 1924 (MA, $\mathrm{AC} / 2 / 2 / 2$ ).

${ }^{27}$ OC AC to COS, 31 Dec. 1924; QMG to AFO 5 Aug. 1925 (MA, AC/2/2/2).
} 
awaited the fruits of O'Duffy's deliberations, with the distinct possibility that no air element would be proposed, before deciding to proceed. A token Air Corps having been included in the proposed reorganisation Defence apparently no longer had difficulty in arranging sanction and the purchase of over $£ 3,000$ worth of spares in 1924/25.

\section{The Army's Air Corps policy 1924 to 1935}

In 1925, having been requested by GHQ to do so, and on the basis that his previous proposals had been reduced by one third, Major T. J. Maloney supplied a proposal for a new organisation and establishment. He proposed increases in personnel, from 151 to 223 all ranks, to provide for a self contained fighting unit capable of cooperating with the other special services and for infantry co-operation. He also recommended that provision be made for the training of ten cadets as pilots, and for observers and technicians as well as provision for unspecified civil aviation requirements. In numerical terms the main increase requested was in the 'total squadron establishment', from the existing sixty-eight all ranks, to a new figure of 139 for three flights of eight aircraft each. Despite being instructed to make such a submission Maloney's proposal appears to have disappeared without trace. In the context of the retrenchment in Army numbers being imposed by Finance it is not surprising that an increase of one third in Air Corps numbers was unlikely to be approved at that time.

Notwithstanding the rejection of Maloney's April 1925 proposal moves were apparently being made to improve organisational and policy matters. The context stated by the General Staff, however, does not quite ring true:

During the period under review [1923 to 1927] all endeavours were directed towards perfecting the organisation of the corps and train suitable personnel to fill vacancies in future military and civilian developments. The army crisis of 1924 gave a very serious setback to the development of the [Air] Corps. In addition, the organisation allowed in Orders No. 3 was found to be absolutely inadequate. Very little progress was made until $1926 .^{28}$

\footnotetext{
${ }^{28}$ Undated 'Memorandum on the development of the forces $1923-27$ ' (MA, MM/1, A/0876).
} 
The above only serves to disguise the antipathy of the Army and DOD to the future of military aviation and the fact that little positive was been achieved in the period. Maloney would have said that the 1924 Establishment was designed to provide little more than care and maintenance. The mention of progress in 1926 is most likely an oblique reference to the fact that in April 1926 sixteen officers were attracted to the corps for a course of flying instruction. In the context of the review it was suggested that a new organisation 'which had been passed by the organisation board' would 'allow of the efficient organisation of the corps'. The Army's main aims for the Air Corps were as follows:

To train a sufficient number of flying officers and mechanics to man the proposed peace-time coast defence and army co-operation units.

To create a reserve of flying officers and mechanics capable of filling appointments in future civil aviation concerns. ${ }^{29}$

On achieving the above it was proposed to develop other aviation aspects for the benefit of the country. These briefly were the setting up a meteorological service at Baldonnell, the conduct of aerial photography for survey and archaeological purposes and cooperation with the Ministry of Fisheries. The carrying of American mails from Cobh to England and the continent, and the setting up of a passenger service between Dublin and London - in effect the civil policy supported by Collins in 1921/22 - were also foreseen. ${ }^{30}$ The few instances of interaction with the Army in the 1920 s were in the context of exercises in September 1925 in the Curragh area and in September 1926 in connection with the manoeuvres involving the Eastern and Curragh Commands. In the latter exercise a flight of three aircraft from No. 1 Squadron operated from the Phoenix Park in support of the red army while a second flight supported the blue army of the Curragh. The main functions of the pilots and observers were to provide aerial observation of the opposing

\footnotetext{
29 Ibid.

${ }^{30}$ Ibid.
} 
armies, to take oblique photographs of their dispositions as observed and to keep a complete record of all messages and reconnaissance activities. ${ }^{31}$

However, while the General Staff appeared to be proposing the nucleus of an Air Corps primarily capable of coastal defence and army cooperation roles the reality was somewhat different. Early in 1926 the COS reminded C.F. Russell that the Minister had adopted a three year expansion programme for military aviation. This was to consist mainly of 'the completion of one complete fighter squadron by the year 1928/29'. ${ }^{32}$ In fact six new Bristol F2b Fighters had already been purchased (at a cost of over $£ 15,366$ ), and had been delivered in October and November $1925 .{ }^{33}$ It is not clear how the two, apparently separate and differing plans, were to be reconciled by GHQ. In the event no dichotomy arose as neither plan was pursued to completion. The fighter squadron did not materialise and the new aircraft, the primary role of which, in RAF service, was army cooperation, were initially used as the advanced training aircraft for the 1926/28 'wings' course and, much latter, in army cooperation training while coastal defence and army cooperation were apparently abandoned - at least for the time being. ${ }^{34}$

The consideration of more substantive roles for the Air Corps by the General Staff, and the later dispatch of pilots on courses with the RAF possibly stems from General Hugo McNeill's appreciation of the increasing importance of military aviation in defence. During the military mission to the US in 1926/27 McNeill had informal discussions, on air matters, with US Army Air Corps officers. He was particularly interested in the range of courses that might be availed of by Irish Air Corps officers. On his return he made observations on the benefits of the courses available in the Tactical Flying School. In particular he considered that courses dealing with observation, attack, pursuit and bombardment' and with cooperation with ground forces and independent air missions would be of particular value to Irish Air Corps officers' ${ }^{35}$ However no courses were availed of subsequently. It is possible the as a result of these discussions McNeill may have initiated the adoption of an army cooperation philosophy and have influenced

\footnotetext{
"Obituary, 'Commandant Maloney', in An t-Oglach, 3 October 1925; 'Operations Order No. 5', Col. C.F. Russell, 16 Sept. 1926, P.J. Hassett papers (in possession of Capt. Eoin Hassett).

3? Council of Defence minutes, 3 Feb. 1926; COS to OC AC, 3 Feb. 1926 (MA, MS 708).

${ }^{33}$ Anthony P. Kearns, 'The Irish Air Corps; a history' in Scale aircraft modelling, 3, no. 10 (July 1981), p. 448.

${ }^{34}$ Aircraft log books BF 17 - BF 22 (AC Museum).

${ }^{35}$ Undated 'Report of military mission to USA, 1926-7', pp 136-7 (MA, MM/3).
} 
the abandonment of the Minister's three-year fighter squadron programme. The abandonment of the fighter squadron option and the informal establishment of an army co-operation squadron, in 1930, would support this theory.

The 18,000 plus establishment of the 1924 Army would be down to 6,545 by 1931/32 though the Air Corps establishment would increase marginally, to 160 by 1 December 1928 and to 214 by $1931 / 32 .^{36}$ The initial increase was a number of appointments that were specifically required to facilitate the commissioning of the seven cadets of the 1926/28 'wings' class. (See chapter 6). The later increase, that introduced a Workshops Branch in $\mathrm{AC} \mathrm{HQ}$, may have been in response to the maintenance requirements of the eight Vickers Vespa army cooperation aircraft bought in 1930 and 1931. The purchase of these aircraft confirmed army cooperation to be the Air Corps' main combat support role and the period 1930 to 1935 was dominated by training for same.

In the years 1929/30 and 1930/1931 a substantial investment in such aircraft was authorised. The Council of Defence meeting of 4 November 1929 noted that OC Air Corps had made a final recommendation as to the types of aircraft to be purchased;

1. 4 Army Co-operation Vickers Vespa aircraft c/w (Geared Jaguar) engine @) $£ 4,500-£ 18,000-0-0$.

2. Equipment, wireless, camera, navigation lights, observers' instruments, armament and other service equipment @ $£ 442$ per machine - $\underline{£ 1768.0 .0 .}$

3. One workshop tool kit Jaguar - $\underline{£ 30-0-0 .}$

4. Three Avro Type 621 Training aircraft@@1700-£5.100-0-0.37

The meeting approved the expenditure of $£ 24,898$ and specified that the seven aircraft should be supplied before 31 March $1930 .^{38}$ Though only one aircraft, an Avro 621 , was delivered before 31 March a total of $£ 20,905$ was spent before that date, indicating that the greater bulk of the purchases had been made within the designated

\footnotetext{
${ }^{36}$ O'Halpin, Defending Ireland, p. 87; DFR 23/1929, amending Orders No. 3, 1 Dec. 1928; Peace establishments 1931 - 1932 (Stationery Office, 1931), pp 20-23.

${ }^{37}$ COD minutes, 4 Nov. 1929 (MA).

${ }^{38}$ Ibid.
} 
financial year. Capital expenditure, on aircraft and armament, to a total of $£ 23,957$ was incurred during 1930/31. The major part of this was probably the $£ 19,768$ for the purchase of four more Vickers Vespa aircraft. ${ }^{39}$ An important aspect of the increasing emphasis on army cooperation was the participation of two pilots, W.P. Delamere and L.T. Kennelly, as students on an Army Co-operation Course at Old Sarum, Witshire, from 5 May 1930 to 25 July $1930 .^{40}$ Participation in the Army's combined exercises in the autumn of 1933 was one of the more practical training aspects taken on at that time. A detachment of the $1^{\text {st }}$ Co-operation squadron was placed under command to the Eastern Command brigade that constituted the Yellow Forces and was based at the Phoenix Park from 9 to 25 September 1933. The main emphasis was on the production of oblique and vertical photographs to accompany reconnaissance reports. ${ }^{41}$

Without a specific establishment for a dedicated squadron establishment the Vickers Vespas were initially operated by 'B' Flight of No. 1 Training Squadron of Air Corps Schools, initially within the 160 all ranks limit of 1928 , and later within the 214 all ranks limit set by the peace establishments 1931/32. Eventually, in October 1934, an increased Air Corps establishment of 284 all-ranks provided for the ' 1 st Co-operation Squadron [Training] Cadre' of fifty-one all-ranks for the operation and maintenance of the Vespa aircraft. ${ }^{42}$

In other ways the GHQ policy for the Air Corps in the period 1929 to 1935.was more enlightened than might have been expected at a time of financial retrenchment. ${ }^{43} \mathrm{At}$ a time when pupil intake was very modest the older training aircraft, the Avro 504Ks and DH Moths were replaced with a total of seventeen Avro machines (three Avro 621s, four Avro 626s, six Avro 631 Cadets and four Avro 636s). More importantly a decision was taken to send students on an RAF flying instructors' course. With no evidence of prior consultation with the Air Corps on the matter GHQ initially indicated that it had been intended to send two officers, Capt. O.A.P. Heron and Lieut. A.G. Russell, to the Central Flying School, RAF Wittering, in February 1932. Within days it was indicated that the

\footnotetext{
${ }^{39}$ Kearns, 'Irish Air Corps', p. 449; 'Cost statement of Army Air Corps 1926/27 to 1940/41' Annex G, Report and finding of the committee, 10 Jan. 1942 (MA, ACS 22/23).

${ }^{40}$ Officers' history sheets (MA, SDR 664; SDR 4258)

41 'Administrative Order No. 1', 11 Sept. 1933, P.J. Hassett papers (in possession of Capt. Eoin Hassett)

${ }^{42}$ Log books, Vespa I to VII (AC Museum); Peace establishment, 22 Oct. 1934 (in my possession).

${ }^{43}$ Duggan, Irish Army, pp 160-5.
} 
second officer was to be replaced by Lieut. D.J. McKeown. ${ }^{44}$ Early in January 1932 the officer commanding, Major J.J. Liston, was made aware that a further change was being directed, apparently by the Chief of Staff.

It has been decided to send one officer of the Air Corps to attend the Central Flying School instructors' course, R.A.F., Wittering, which will commence on $2^{\text {nd }}$ February, 1932 and end on $16^{\text {th }}$ April, 1932. The Officer selected to attend the course is [Second] Lieutenant W. Keane. ${ }^{45}$

It is not clear by whom the original proposal was initiated. The absence, from the Air Corps file on the subject, of correspondence indicating how the course initially came about might suggest that the Air Ministry and or RAF had invited the Army to avail of a student placement on the particular course. In the matter of student selection it is not obvious what influences were brought to bear in order to effect changes and the final decision or what appreciation GHQ had of the abilities and potential of individual pilots. Possibly, after informal consultation with the newly established Office of the Director of Military Aviation in GHQ, it was considered that Capt. Oscar Heron, an ex-RAF pilot, was unacceptable to the Army leadership. Similarly Lieut. A. Russell and Lieut. D.J. McKeown (former pupils of the 1922/23 pilot intake), may have been considered to have been inadequately qualified while all three may have been considered too old. The eventual selection of Lieut. W.J. Keane, the senior graduate from the cadet class of $1926 / 28$ and the student who achieved the second highest marks on the officer and cadet course, could be considered to have been an inspired decision. If made with such considerations in mind it represented faith in the more highly motivated youth of the Corps that would have had neither RAF nor IRA baggage. (See Chapter 6) After the course $2 /$ Lieut. Keane reported that he had become a ' $B$ ' category flying instructor, the highest qualification available to him:

\footnotetext{
${ }^{44}$ OC AC to ACS, 25 Nov. 1931; OC AC to ACS, 28 Nov. 1931 (ACF/36/8, in my possession).

${ }^{45} \mathrm{ACS}$ to A/DMA, $11 \mathrm{Jan} .1932$ (ACF/36/8, in my possession).
} 
I got third place in the examination on ground subjects, qualified as an instrument or "blind" flying instructor and competed in the final of the aerobatic and inverted flying competition for the Clarkson trophy. ${ }^{46}$

In the seven months after his return 2/Lieut. Keane ran two instructors' courses and qualified a total of fourteen pilots as flying instructors. He subsequently requested authorisation to return to Wittering for re-categorisation. ${ }^{47}$ While Major Liston supported his case and requested the appropriate sanction re-categorisation did not take place immediately. He eventually attended C.F.S. Wittering again in June/July 1935 where he underwent a refresher course and was graded as an 'Al' category flying instructor. ${ }^{48}$

\section{Changes in command}

On 24 July 1925 Major T.J. Maloney was replaced by Colonel C.F. Russell as Officer Commanding Air Corps. The reasons and circumstances are not explained. On or about 25 July Maloney received a written directive from the COS:

Colonel Charles F. Russell is appointed officer commanding, Army Air Corps as from this date. You will on receipt of this communication hand over to him all the duties of corps commander.

Pending further instructions you will act as squadron commander. ${ }^{49}$

There was no indication of dissatisfaction with the Maloney's effectiveness in the appointment. Russell may well have been appointed as a result of his satisfactory record in various posts. The necessity to perform functions rising from his position vis-à-vis civil aviation may have been a minor factor - technically he was still Director of Civil Aviation. Early in 1926 Russell was the DOD representative on an 'Interdepartmental committee on civil aviation' where his function was to further the Minister's desire that

\footnotetext{
${ }^{46}$ W.J. Keane to OC AC, 9 Feb. 1933 (ACF/36/8, in my possession).

${ }^{47}$ Ibid.

${ }^{48}$ W.J. Keane to OC AC, 20 July 1935 (ACF/36/8, in my possession).

${ }^{49}$ COS to Maj. T. J. Maloney, 24 July 1925, MS/613 (in my possession).
} 
Defence should control all aviation within the Saorstat, civil and military and to have the government appoint a director of civil aviation, a civilian, answerable to the Department of Defence. ${ }^{50}$

While Russell was only to serve about two years as officer commanding at a time when the Air Corps had no identified function in a peacetime Army and when its future was not assured he had at least one notable achievement. In fact his abilities in the area of air staff duties and planning may have been factors in his being recalled to the Air Corps. Apparently soon after his return he was tasked with the drafting of a syllabus for the training of pupil officers and cadets. Though he was most likely under pressure to produce a syllabus in time for the start of the course in the summer of 1926 he apparently took his time, and possibly advice from RAF sources, before completing an instrument that would set a very satisfactory standard for $a b$ initio flying training for many years and establish a very satisfactory basis for future syllabi. ${ }^{51}$ (See Chapter 6)

In a manner similar to the termination of Maloney's service as officer commanding Russell's military service ended abruptly and without satisfactory explanation. He is recorded as having been appointed OC 3 Brigade, Cork, with effect from 1 February and as reporting there on 8 February 1927. He was appointed to the GHQ Inspection Staff with effect from 25 April 1927 and retired on 30 April 1927. It is possible that his removal from the appointment of $\mathrm{OC} A C$ and his subsequent retirement was on the basis that he no longer met the medical requirements for military flying. ${ }^{52}$

Commandant J. C. Fitzmaurice took over the duties of OC AC on 7 April 1927. For reasons that are not apparent he had been performing the duties in an acting capacity from 11 October 1926. He went on a general course for senior officers at the Army School of Instruction in October / December 1927 and achieved a mark of 81.7\%. There is little in the official record to suggest that Fitzmaurice undertook the administrative responsibilities of the appointment with great enthusiasm. In fact the opposite is the case. In February 1928 he received a missive from the chief staff officer to the General Staff

\footnotetext{
${ }^{50}$ COD minutes, 3 Feb. 1926 (MA).

${ }^{51}$ C.F. Russell to CSO GHQ, 7 Oct. 1926 (MA, 2/1113); DFR 7/1927, 18 Mar. 1927; Report and findings of the committee, 10 Jan. 1942, XXVII (MA, ACS 22/23); Draft syllabus, 4 Nov. 1935, ACS/103/11/2 (courtesy of School Commandant, 2006).

52 Personal file (MA, SDR 3693); Obituary, Irish Independent, 11 Mar. 1965; Personal comment, Ms Agnes Russell, 2 June 2004.
} 
reminding him of a number of files and other documents that had apparently not received his attention and on which replies were awaited in GHQ. ${ }^{53}$ Before and after the senior officers' course much of his energies appear to have been centred on his ambition to achieve the first East - West, non-stop crossing of the North Atlantic - an interest that no doubt distracted him from the more mundane duties of officer commanding. In September 1927 he was part of the crew of the Princess Zenia that made an unsuccessful attempt at the Atlantic crossing. ${ }^{54}$ In April 1928 he was the second pilot on the Junkers W33 (Bremen) aircraft that made the first successful crossing of the Atlantic from east to west. ${ }^{55}$ Subsequent to this latter event he spent much time on leave of absence but was back on duty in time to present commissions to the successful cadets of the 1926/28 'wings' class, on 5 November $1928 .^{56}$

With ambitions to capitalise on his new fame the now Colonel Fitzmaurice submitted his application to retire on 29 January 1929, had it accepted with effect from on 15 February and had vacated his quarters by 15 March. ${ }^{57}$ He did not leave the service on the best of terms with higher authority. At the time of resigning he cited the poor state of the Air Corps and the fact that little progress had been in the previous year. Early in 1929 he submitted a copy of his 1927 report, for 1928, on the basis that so little had changed it made no difference. It possibly never occurred to him that he had spent most of 1928 pursuing his own ambitions and business and had obviously done little to improve the state of his corps. ${ }^{58}$ About the same time it was reported that the Air Corps had come to such a point of stagnation that Fitzmaurice had 'informed the minister for defence that the Air Corps as then organised was a useless organisation, costing $£ 100,000$ to maintain. Its equipment was a collection of junk and its mechanical personnel was inadequate'. ${ }^{59}$ With or without the prompting of Fitzmaurice's derogatory comments

\footnotetext{
${ }^{53}$ CSO GHQ to OC AAC, 28 Feb, 1928 (in my possession).

${ }^{34}$ Fennelly, Fitz, pp 135-51.

${ }^{35}$ Ibid, pp 167-182.

${ }^{56}$ Col. W.J. Keane, 'The first class of cadets - 60 years ago' in An Cosantoir, 46, no. 3 (March, 1986), p. 10.

57 Officer's history sheet (MA, SDR 925).

${ }^{58}$ Fennelly, Fitz, p. 279, citing no source.

${ }^{59}$ Quigley, 'Air aspects of the emergency' in Irish Sword xix, Nos. 75 \& 76 (1993-40), p. 86, citing $\mathrm{ACF} / 564$ / DOD 2/49025 (MA). The investigation report of $1941 / 42$ put the cost of the Air Corps for $1928 / 29$ at $£ 40,469$.
} 
GHQ was apparently already displaying a more progressive stance in terms of equipping the Air Corps for army cooperation functions in support of ground troops.

\section{Director of military aviation}

On 15 February 1929, the effective date of Fitzmaurice's retirement, Commandant G.J. Carroll was appointed officer commanding and served in that appointment for a largely unrecorded thirty-three months at the end of which he appears to have been replaced on a veritable whim. He seems to have fallen into disrepute with GHQ mainly as a result of circumstances surrounding an accident at the Curragh on 9 April 1931. However the convening of a number of Courts of Inquiry in 1930, and his subsequent observations on the findings had already placed his judgement in such matters under examination. A memorandum on the subject, presented to a meeting of the Council of Defence on 23 March 1931, found that three courts of inquiry had not been convened in the proper manner with the appropriate personnel and that, as a result of the investigations being conducted by Air Corps officers only, the relevant factors were not thoroughly examined and reported upon. ${ }^{60}$ Matters were brought to a head as a result the proceedings and findings of a court of inquiry into a crash at the Curragh on 9 April 1931 and of the particular circumstances in which it took place. On 23 June 1931 the Council of Defence considered a memorandum that commented upon the proceeding and findings of the court of inquiry. Without examining the precise circumstances and causes or the factors contributing to the accident (Vespa No.4 was apparently destroyed) the memorandum highlighted the fact that OC Air Corps needed no authority other than his own to send an aircraft to the Curragh in order to give pilots flying practice and to give air experience flights to officers of the Curragh Camp. It was suggested that the Quartermaster General might have some unspecified function in the matter. ${ }^{61}$ Examination of Air Corps Standing Orders indicates that the important function of the granting of authorisation to undertake a flight in any aircraft was not specifically provided for prior to June 1931 . One of the more important aspects of such a function, deciding whether the weather conditions were

\footnotetext{
60 'Memorandum on courts of inquiry', COD minutes, 23 Mar. 1931 (MA).

${ }^{61}$ 'Memo on crash of Vickers Vespa No. 4 at Curragh Camp on 9/4/31', COD minutes, 23 June 1931 (MA).
} 
suitable or not, was still being exercised by the aerodrome duty officer up to $1937 .^{62}$ The inference of the comments on the inquiry into the accident on 9 April 1931 was that the officer commanding informally authorised flying to take place on the basis of the weather reports of the aerodromé duty officer. On 29 June 1931, probably as a result of adverse comments from GHQ on the manner in which the contentious flight of April 1931 had been authorised and administered, a new standing order, providing for the 'Flying Detail', was drafted and issued. The order specified the manner in which the corps commander, squadron commander or chief instructor could detail, in writing, flying for training, service or test purposes as well as the manner in which all flights would be recorded and administered. ${ }^{63}$

The matter of the incident of 9 April 1931 was further considered at the Council of Defence meeting of 16 November 1931 when it was decided that none of the officers immediately involved in the accident could be held responsible.

... but in this case (as in the case of the crash at Foxford 2/27066) it was clear that the administration of the Army Air Corps leaves a great deal to be desired. While the present officer commanding is possibly as suitable for his position as any other officer within the corps it will be necessary to seek outside an officer who will administer the corps. The chief of staff will nominate a suitable officer. ${ }^{64}$

Within a week, on 23 November 1931, Commandant James Joseph Liston, an infantry officer who had been a GHQ staff officer earlier in his career, was appointed officer commanding Air Corps. However it appears that this appointment was not solely related to the adjudged unsatisfactory administration of the Air Corps flying. The peace establishments of 1931/32 (authorised by the Minister, Desmond Fitzgerald in September 1931) had re-introduced the previously unofficial appellation 'director of military aviation' which attached to the appointment of officer commanding Air Corps. It also established the 'Office of director of military aviation' in GHQ with a single appointment

\footnotetext{
${ }^{62}$ Air Corps Routine Order 243/37, 22 Oct. 1937 amending Air Corps Standing Order 26 (in my possession).

${ }^{63}$ Air Corps Routine Order No. 148, Section 54, 'Flying Detail', 29 June 1931 (in my possession).

${ }^{64}$ COD minutes, 16 Nov. 1931 (MA).
} 
for a captain. The same instrument specified that 'officer commanding, Air Corps', and a number of other corps commanders, would 'act on the general staff as directors when required'. Carroll was appointed to the office of the DMA on 14 November nine days before Liston was made OC Air Corps. The establishment tables specified that the OC Air Corps also 'acts as director of military aviation'. ${ }^{65}$ However in the absence of a regulation or other explanatory instrument the authority and function of the DMA, and of the GHQ office, was not explained. While corps directors were, by custom of the service, suitably qualified officers with particular expertise in the techniques and disciplines of a particular army corps, this was not the case with Liston. There was apparently nothing in his training or experience that fitted him for either function. He was quite unsuited except to the extent that the authority of his rank and appointment enabled an infantry officer to exercise command over pilots and other officers of the Air Corps. ${ }^{66}$

The question arises as to why such an inexpert officer was appointed in this manner. The deliberations of the Council of Defence make it clear that it was considered that Carroll took the matter of courts of inquiry too lightly and that as a result courts were not being assiduous in apportioning blame for aircraft accidents or in assessing the costs to public funds. The Council of Defence appears to have viewed the authorisation of flying, and the convening and conduct of any resulting courts of inquiry, as administrative matters that could be better performed by a line officer. The drafting and issuing of an order providing for the 'flying detail' was probably required so that officers other than OC Air Corps could authorise specific flights. While this cleared the way for an inexpert officer to act as OC Air Corps it does not clarify how Liston could act as director of military aviation, in a capacity which presumably required appropriate aviation expertise. In the event Liston only held both titles for less than eight months, from 23 November 1931 to 30 June 1932. On I July 1932, in accordance with a minor amendment to the 1931/32 peace establishment, the staff appointment in the office of the DMA was raised to the status of commandant and Comdt. J.G. Carroll was made director

\footnotetext{
${ }^{65}$ Peace Establishments 1931 - 1932, pp 20-3; 74; Curriculum vitae O/1662; O/287 (courtesy of Commissioned officers record office, DFHQ, 1 Sept. 2006).

${ }^{66}$ GRO 26/1932, 29 Sept. 1932, amending peace establishments, 1931/32, with effect from 1 July 1932 (in my possession).
} 
of military aviation while the said appellation was removed from Major J.J. Liston. Carroll was to continue as the director until 1 April $1935 .{ }^{67}$

In the absence of an adequate body of relevant correspondence the involvement of the DMA in the resolution of a contentious flying matter, suggests, to a certain extent, how the director and his office was meant to function. During May and June 1933 night flying exercises were being conducted under the direction of Capt. P.J. Hassett, OC No. 1 Squadron. The aircraft were being flown in conditions that were clear of cloud but very dark. Four pilots reported difficulty in performing normal turning manoeuvres while some had entered inadvertent spins. Recovery from such spins, at night and with very poor ambient light, proved difficult and dangerous. The reported incidents highlighted the fact that pilots had not been instructed, and were insufficiently practiced, in instrument flying. In addition Bristol Fighter (and other) aircraft were not adequately equipped for instrument or night flying while cockpit and navigation lights were also generally inadequate. Landing incidents about the same time also indicated that the aerodrome was poorly equipped for night flying, mainly in terms of the lighting of obstructions. In effect four officers considered that the night flying exercises detailed by OC No. 1 Squadron were dangerous in the particularly dark conditions and with poorly equipped aircraft. OC No. 1 Squadron suggested that the aircraft were no less equipped that the RAF aircraft of the period since 1918. He indicated that turn indicators had only recently been installed in RAF aircraft - implying that Air Corps machines were not so equipped. He stated that he had 'never had any difficulty in flying the machine by horizon or by occasional ground lights' and that, in the past, 'night flying was carried out under far worse conditions' ${ }^{68}$ The tone of the complaints, and of the squadron commander's reply, suggest that night flying exercises were being carried out in meteorological conditions for which the pilots were not adequately prepared and for which the aircraft were inappropriately equipped.

Having been given both sides Major J.J. Liston referred the matter to the Director of Military Aviation. Commandant G.J. Carroll replied to the effect that he would discuss the matters raised with $\mathrm{OC} \mathrm{AC}$ on his next visit to Baldonnel and that in the meantime

\footnotetext{
${ }^{67}$ Curriculum vitae details, O/1662, O/287, courtesy of Commissioned officers records office, DFHQ, 1 Sept. 2006; GRO 26/1932, 29 Sept. 1932.

${ }^{68}$ Capt. P. Quinn to OC AC, 18 May 1933; Lieut. D.J. McKeown to OC No. 1 Sqn., 22 May 1933; $2 /$ Lieut. T.J. Hanley to OC No. 1 Squ., 22 May 1933; Lieut. M.J. Cumiskey to OC No. 1 Sqn., 22 May 1933; OC No. 1 Sqn. to OC AC, 23 May 1933 (MA, AC/2/6/3).
} 
night flying should be suspended. Apparently, before Carroll could discuss the matter with Liston, the school commandant, who was responsible for the direction of the annual training of pilots, made a number of suggestions that probably pre-empted such discussions. Capt. W.P. Delamere's main recommendation was to the effect that night flying should only take place when 'there is a good moon and reasonable visibility, i.e. sufficient to allow a clear horizon in all directions' and, secondly to the effect that if night flying was to take place in very dark conditions that appropriate blind flying instruments and instruction in instrument flying should be provided. ${ }^{69}$ In July and August of 1933 night flying continued 'during suitable periods of the moon'. ${ }^{70}$ While the DMA does did not appear to have given a formal direction on the particular matter of night flying it would appear that the director's main function was to compensate for the lack of aviation expertise of the infantry corps commanding officer. However there is little evidence of the involvement of the DMA in similar technical matters while the evidence cited at the Air Corps investigation of 1941/42 would suggest that squadron commanders were assumed to have the appropriate professional expertise to adjudicate on technical areas outside the competence of unqualified commanding officers. (See Chapter 11)

\section{The Capt. P.J. Hassett affair}

Lieut. P.J. Hassett was a former IRA and former infantry officer. When he qualified as a pilot in 1928 he achieved the highest marks of the officer group on the 1926/28 course. During the first air firing and bombing exercises, held at Kilworth in 1932, he achieved the best score of the sixteen officers taking part. ${ }^{71}$ He apparently carried out a keen study of aviation, civil and military, and held the second civil pilot's licence issued by the Saorstat Eireann. ${ }^{72}$ During the early 1930s, as lieutenant and captain, he was an energetic flight commander and squadron commander in No. 1 Training Squadron and later in the $1^{\text {st }}$ Army Co-operation Squadron in which appointments he had a leading role in training

\footnotetext{
${ }^{69}$ Capt. W.P. Delamere to OC AC, 29 May 1933 (MA, AC/2/6/3).

${ }^{70}$ OC AC to DMA, 7 July 1933 (MA, AC/2/6/3).

${ }^{71}$ Undated 'Tests as per DFR 7/1927' (MA, AC/1/7/3); 'Aerial firing and bombing, July 1932' (MA, 2/30989)

${ }^{72}$ HMSO receipt for books and manuals, 23 Sept. 1930; Saorstat Eireann, 'B' Licence No. 2, 1 Nov. 1930, P.J. Hassett papers (in possession of Capt. Eoin Hassett, Skerries).
} 
for the army cooperation role. ${ }^{73}$ In 1931 he contemplated retiring due to lack of promotion and intended going into commercial aviation possibly with Iona, the first civil air carrier in the state. ${ }^{74} \mathrm{He}$ demanded an interview with the minister for defence in regard to securing a retirement gratuity the granting of which was apparently at the minister's discretion. The minister refused point blank to allow him to retire suggesting that it cost the state $£ 5,000$ to train him as a pilot. The interview did, however, achieve a positive result for Hassett. As a former IRA officer with a proven good record he should, according to the minister, have already been promoted to the rank of captain and was so promoted within a month.

Arising from the vociferous nature of his dealings with GHQ and the minister, and the questions most likely raised by the minister regarding his promotion, Hassett's name was very likely noted by the headquarters staff. In October 1931 Major J.J. Liston, a former GHQ staff officer, was appointed OC AC. During his introductory address at Baldonnell he apparently singled out Hassett when he declared that he was going to put a stop to officers writing into GHQ. Hassett observed that Liston continually sought opportunities to take disciplinary action against him. ${ }^{75}$

Notable confrontation was avoided until 1935 and then arose out of Hassett's command of the Air Corps' participation in a display in the Phoenix Park in May of that year. With pilots rehearsed and detailed for the display Hassett contended that Liston interfered in the flying arrangements to such an extent that he persuaded a number of pilots not to make themselves available on the day of the actual display. While the display was completed with a changed line-up of pilots Hassett remained convinced that Liston had endeavoured, and succeeded, in having officers refuse to fly in accordance with the flying detail. Hassett reported the matter to GHQ and tried, and failed, to have it formally investigated on his terms. ${ }^{76}$ Later Major Mulcahy reopened the matter in the context of the Air Corps investigation of 1941/42:

\footnotetext{
${ }^{73}$ Flying log book, P.J Hassett, P.J. Hassett papers ( Capt. Eoin Hassett)

${ }^{74}$ Personal comment, Pierce Cahill.

${ }^{75}$ Lt. Col. J.P. Hassett, unpublished memoir, circa 1959, Hassett private papers (in possession of Capt. Eoin Hassett.

${ }^{76}$ Ibjd.
} 
Colonel Mulcahy, in his evidence (page 585) stated "the younger officers of the corps refused to fly at the Phoenix Park where a public display had been arranged and advertised, and for which they had been detailed and had carried out some weeks' practice". ${ }^{77}$

The committee, having access to the original GHQ confidential file on the matter, found that Liston had been party to a discussion amongst a number of younger officers on the night prior to the display. However it also found that the pilots (four officers and one cadet) had indicated a desire to withdraw from the display on the basis of lack of experience but had that made themselves available the following morning only to be replaced by older officers on Hassett's instructions. The committee found that the matter had been investigated at the time (1935) and that it had been recommended that owing to the peculiar circumstances surrounding the whole affair, no disciplinary action would be taken. $^{78}$

With no determination being made at the time relations between Hassett and Liston apparently remained very cool. However, they were both soon to leave the Air Corps. Liston was replaced by Major P.A. Mulcahy on 3 June 1935 while Hassett was transferred to the Cavalry Corps within months. On 3 June 1935, the day that Mulcahy was appointed, Capt. P. J. Hassett ceased to be OC $1^{\text {st }}$ Co-operation Squadron and was posted to the appointment of OC Technical Workshops. On 5 September 1935 he received orders to report to the director of cavalry four days later and was attached to that corps from 9 September $1935 .^{79}$ While the precise circumstances of Hassett's departure cannot be easily discerned, matters related to the proceeding of two courts of inquiry held in 1935 and his annual confident report for the period 1 January 1935 to 9 September 1935 were pertinent. On 6 January 1936 Hassett was paraded by Mulcahy so that he could be given the details of the confidential report concerning that part of 1935 he had served in the Air Corps. Hassett took notes:

Military conduct and general compliance with regulations; Fair.

\footnotetext{
${ }_{77}^{77}$ Report and findings of the committee, LIX,10 Jan. 1942 (MA, ACS 22/23).

${ }^{78}$ Ibid.

${ }^{79}$ P.J. Hassett, unpublished memoir, circa 1959, P.J. Hassett papers (Capt. Eoin Hassett).
} 
Suitability for present [Air Corps] appointment; unsuitable.

If not suitable recommendations for alternative employment; See results of courts of inquiry. This officer has been transferred to the Cavalry Corps.

Ability, executive and / or administrative; has shown good executive and administrative ability.

General rating; unsatisfactory.

Special note on officer of outstanding ability; [nil]

Recommendations and remarks; [nil]

Date; 6 Jan. 1936 [signed] P.A. Mulcahy, Major. Director of artillery \& A/OC Air Corps. $^{80}$

While the findings of a two courts of inquiry were cited as being the reasons for the unsatisfactory rating this did not afford any explanation to the subject officer. Despite being a witness at both courts of inquiry he was not party to either the proceedings or the findings of either. As an officer adversely commented upon he had not been afforded the right to cross examine witnesses giving evidence supporting alleged wrong-doing on his part. In a vain attempt to have the rating changed, or even have the basis of a bad report explained he wrote to an unspecified higher authority in such terms and demanded the withdrawal of the adverse report. ${ }^{81}$

It will be understood that the purpose of courts of inquiry, as originally conceived, was to investigate all manner of accidents, particularly traffic accident involving military vehicles, but did not specify aircraft accidents. Insofar as aircraft accidents were concerned, a court was usually required 'to enquire into the circumstances surrounding the accident to aircraft number $\mathrm{xx}$ on a stated date at a stated location. The court of three officers, that took evidence under oath, was also asked to report on the 'cause of the accident, the extent of the damage and cost of repair' and to state whether the accident was 'due to negligence on the part of any person or persons' Witnesses were questioned individually in private while those who might be the subjected to adverse comment would not be made aware of such evidence. The court of inquiry was, at best, a quasi-

\footnotetext{
${ }^{80}$ Handwritten copy, Annual confidential report, 6 Jan. 1936, P.J. Hassett papers (in possession of Capt. Eoin Hassett).

${ }^{81}$ Copy letter, Capt. P.J. Hassett, 13 Jan. 1936, P.J. Hassett papers (in possession of Capt. Eoin Hassett).
} 
judicial process the proceeding and finding of which, prior to the promulgation of DFR A5 on 10 April 1937, were withheld from those who might be the subject of adverse comment. In those circumstances the findings could, in theory, be cited to state whatever higher authority wished them to say. ${ }^{82}$

In the case of Capt. P.J. Hassett the main court of inquiry cited was that into a flying accident that occurred on 2 May 1935 and resulted in the death of a young officer. The findings apparently resulted in the squadron commander being held partially responsible for the accident. Hassett insisted that the accident had happened after the pilot had departed from the flying exercise for which he had been detailed, in effect disobeying lawful orders. The second court of inquiry is understood to have concerned damage to an aircraft engine. There are unexplained aspects to the circumstances surrounding Capt. Hassett's transfer out of the Air Corps while the factors contributing would appear to be broader than those pertaining to the aircraft accident and the court of inquiry. P.J. Hassett, as a pilot from a distinctly IRA and infantry background, was unique in that he had apparently embraced the aviation ethos to an extent not matched by his infantry colleagues or, indeed, by some of the cadets with whom he had trained. As a flight and squadron commander he had demonstrated considerable enthusiasm for the Air Corps' army cooperation role and for air firing. He advocated and encouraged instrument and night flying even though the role of his squadron did not require such disciplines and the aircraft were not fully equipped for same. ${ }^{83}$ To that extent he was far-sighted, enthusiastic and progressive to an extent that might not have been appreciated by his superiors, and possibly, some of his colleagues.

While the antipathy between Liston and Hassett was most likely a manifestation of the antipathy between GHQ and the pilot group as a whole P.J. Hassett had adopted the culture and ethos of aviation to such an extent that he no longer represented the infantry ethos that GHQ hoped to inculcate in the Air Corps. He may well have been seen as being disloyal to his infantry roots. It is likely that he was posted out of the Air Corps by higher authority as much for his newly acquired allegiance to aviation as for any alleged responsibility for the fatal accident of 2 May 1935. This course of action was

\footnotetext{
${ }^{82}$ Defence Order 5/1922; DFR 41/1928; DFR 55/1929; GRO 4/1933; GRO 2/1935: DFR A5, 10 Apr. 1937.

${ }^{83}$ Files 2/30989; AC/2/6/3 (MA).
} 
possible because proceedings of courts of inquiry remained confidential while an officer had no redress under the 1923 Defence Act except in the case where the alleged wrong was done by his commanding officer. ${ }^{84}$

In relation to the questionable reasons cited for his banishment the question arises as to why he was not formally charged. Had Hassett's role, and degree of responsibility, been such that it warranted his being permanently removed from his chosen corps it might have been considered appropriate to formulate a suitable formal charge. It may have been simply that, due to the fact that that the 1923 Defence Act did not legislate specifically for any aspect of military aviation, an appropriate charge could not be framed. ${ }^{85}$ While it considered likely that the unseen finding of a secretive court of inquiry process was used as a pretext in order to banish a troublesome pilot officer it is possible that the court did find Hassett to some degree to blame for the accident. Again, in the absence of sight of the proceedings the basis for such a finding remains unknown. Related matters must, as a result, remain somewhat speculative.

While a transfer to another corps, albeit with adverse reflections on reputation and character, might not be seen as a very severe punishment, this was not the case. When Capt. P.J. Hassett was transferred permanently to the Cavalry Corps he lost eight shilling (flying pay) per day for the remainder of his military career - in effect, a summary deduction of over $£ 3,200$. P.J. Hassett served twenty-three years in the Cavalry Corps and reached the rank of lieutenant colonel. Long after his death in 1959 he was remembered by his corpsmen as having making a valuable contribution to his corps and as a fine and loyal officer. ${ }^{86}$

The manner in which P.J. Hassett was treated is in sharp contrast to that of another flying officer who had a long and colourful career in the Air Corps and who eventually retired, as a lieutenant, on age grounds. In his case he was found, amongst other things, to be most irresponsible and undisciplined and generally unfit for his Air Corps appointment. It was recommended (in 1942) that he either be transferred to another corps or that his services be dispensed with entirely. ${ }^{87}$ In the event the officer, a 1931

\footnotetext{
${ }^{84}$ Section 122, Defence Forces (Temporary Provisions) Act, 1923 - 1935.

${ }^{85}$ Defence Forces (Temporary Provisions) Act, 1923 - 1935.

${ }^{86}$ Personnal comment, the late Col. Roger McCorley.

${ }^{87}$ Report and findings of the committee, 10 Jan. 1942, LXIV - LXV (MA, ACS 22/23).
} 
graduate of the Cadet School, Military College, served the remaining seventeen years of his career in the Air Corps. He was from time to time transferred out of the Air Corps and attached back, for example from 7 October 1935 to 18 February 1936. Though such a posting did not involve actually moving to another Army unit the resultant loss of flying pay, almost $£ 54$ in this instance, served as monetary punishment for whatever misdemeanour of which he was deemed to be guilty - without burdening officialdom with the legal niceties of due process. ${ }^{88}$

While the summary manner in which these two officers had been treated may have been interestingly similar it is the dissimilar outcome that is considerably more pertinent. In the first instance an obviously diligent officer flying officer appears to have been posted out of the Air Corps permanently in circumstances where justice was not seen to have been done. In the second case an individual whose competence as an officer and pilot was seen to be very questionable and, in fact, was considered worthy of dismissal, retained his commission in circumstances about which there was no dispute. It might be considered that P.J. Hassett was too good for the Air Corps and that the second officer was too bad for the Army.

\section{The early command of Major P.A. Mulcahy}

On 3 June 1935 Major P.A. Mulcahy, a GHQ staff officer, was appointed acting OC Air Corps in addition to his then current position as director of artillery. From the records available the rationale for this General Staff decision is not obvious. Being similarly situated to his immediate predecessor Mulcahy had no qualifications that might fit him for an air appointment and, in common with those who had appointed him would have had little concept of the nuances of military aviation. Later sources would suggest that the substantial reason for Mulcahy's appointment was related to discipline, i.e. the perception that Air Corps pilot officers were undisciplined. Military Archives' keen protection of the reputations of the forces and individual officers combined with the absence of case history relating to the disciplinary sections of defence legislation preclude objective study

\footnotetext{
${ }^{88}$ Curriculum vitae, O/4431 (courtesy of Commissioned officers records office, DFHQ, 1 Sept. 2006). The period in question was 134 days at eight shillings per day.
} 
of such matters. However it is very possible that understandable friction between the disparate pilot groupings may have been seen as signs of indiscipline. Similarly the fact that GHQ staff and Major Liston, and later Mulcahy, could not relate to flying officers in aviation terms suggests a cultural divide that was most likely interpreted by the GHQ as indiscipline.

A number of sources point to Mulcahy having been appointed primarily to impose discipline. The most obvious was the amendment to Air Corps Standing Orders issued on his first day in office.

The Commanding Officer expects from all officers under his command such undeviating support as will ensure the prompt execution of all orders he may deem necessary to issue for the maintenance of discipline in the corps. ${ }^{89}$

That Mulcahy considered it necessary to make an order with such an emphasis on his first day in the appointment strongly suggests that his orders, from GHQ, were to regain and retain a required level of discipline - a level that might have been perceived by GHQ not to have existed during Liston's command. A similar impression comes from an unusual source. A brief Air Ministry intelligence summary noted that Col. P.A. Mulcahy had been transferred to command of the Air Corps to tighten up discipline. ${ }^{90}$ The latter opinion may have originated with Mulcahy himself. From June 1940 Mulcahy had an unusually open relationship with the British air attaché who passed all such details to London. (See Chapter 8) Mulcahy's disciplinary qualities were endorsed much later by a comrade artillery officer who recalled that artillerymen were "ever proud to recall having served under "Muller" in his martinet days'. 91

Col. C.F. Russell, who edited and published the 'Aviation' magazine for three years (1935 to 1937), expressed considerable alarm at the appointment of Mulcahy and at the fact that the separate position of director of military aviation, as recently held by a flying officer, had been abolished.

\footnotetext{
${ }^{89}$ Air Corps Standing Orders, 1 Jan. 1929, amended Section II, 3 June 1935 (in my possession).

${ }^{90}$ Air Ministry, Air Intelligence notes, Nov. 1940 (NA, Air 10/3990).

${ }^{9}$ Appreciation by Col. C. M. Mattimoe in An Cosantoir, 47, no. 5 (May 1987), p.22.
} 
Army General Headquarters never have, and do not now understand the peculiarities of an air unit in regard either to its technical requirements or the methods of air command. ............Flying personnel cannot be commanded and will have no real respect for anyone over them who is not an active flying officer. No greater mistake could have been made, therefore, than the appointment of a non-flying officer to command the Air Corps'. ${ }^{92}$

Russell, believing that the minister was most likely unaware of such consideration, suggested that he should 'look into the Air Corps organisation and administration, independent of Army General Headquarters which has proved hopelessly ignorant of the problems involved'. ${ }^{93}$ If GHQ or the minister were aware of Russell's observations they probably ignored the advice offered. Notwithstanding Russell's words were to prove prophetic. (See Chapter 11)

While J.J. Liston appears to have been more concerned with administrative aspects and generally left flying matters to the squadron commanders Mulcahy was more proactive and concerned himself greatly with air related matters. Not long after being appointed Mulcahy wrote to the COS stating a brief case for the abolition of the cadet scheme of pilot intake that had been used intermittently since 1925 and proposed that pupil pilots for the corps should only be recruited from the ranks of newly qualified Cadet School officers or from the ranks of young officers already serving in other corps units. His only argument, actually a statement of fact, was that Air Corps cadets were handicapped by having insufficient basic military training. The communication outlining the proposal was annotated as being approved by the minister on 16 Oct. $1935 .{ }^{94}$ Without delay Mulcahy submitted a draft DFR that he intended would replace DFR $7 / 1927$, the pilot flying course syllabus. He also submitted for the approval of higher authority a newly drafted training syllabus for the young officers' $a b$ initio flying training course, substantially based on the earlier DFR that he was proposing to have cancelled. Mulcahy incorrectly stated that the change to an officer-only scheme of intake and flying

\footnotetext{
${ }^{92}$ Col. C.F. Russell, 'The Army Air Corps' in Aviation i, no. 6 (June 1935), p.209.

${ }^{93}$ Ibid.

${ }^{94}$ OC AC to COS, 23 Sept. 1935 (MA, AC/1/7/10).
} 
raining required the cancellation of DFR $7 / 1927$ and its replacement by one along the lines of the draft submitted.

This apparent misrepresentation of the situation should have been obvious to higher authority. Since 1926 several classes that included both officers and cadets, had received $a b$ initio training in the flying school in accordance with the same syllabus. As its title suggests the 'Syllabus of training - pupil officers and cadets in the Army Air Corps' had been specifically drafted to provide for training both categories of pupil. ${ }^{95}$ Thus a new DFR was not required if recruitment was confined to officers alone.

The department, if they were aware of Mulcahy's misleading assertion, did not dispute the point, most likely on the basis that the change in DFR would not affect other than the Air Corps and that the commanding officer was assumed to know what was best for the corps. On 21 May 1936 Frank Aiken, in his capacity as Minister for Defence, signed the new regulation. In accordance with paragraph three of the new DFR the 'Young officers' flying training course' was fundamentally a list of the ground school subjects that bore little relationship to the previous, detailed and comprehensive, ground syllabus. The term 'Airmanship: Flying training' constituted the complete definition of the associated practical flying. ${ }^{96}$ It was, at best, a prospectus rather than a syllabus. (See Appendix 6 and Appendix 7)

Having been acting officer commanding since 3 June 1935 Major Mulcahy commenced flying training three weeks after the signing of DFR 40/1936. Capt. T.J. Hanley was asked by the investigation committee some years later whether the commanding officer's right to be graded as a pilot was governed by DFR 7/1927 or by DFR 40/1936:

D.F.R. 40/1936, he first received instruction from me on 10 June 1936. His instruction continued until 21/1/'37 and he flew solo on several occasions during this period. After $21 / 1 /$ ' 37 he got no further instruction from me and discontinued

\footnotetext{
${ }^{95}$ OC AC to CSO, DOD, 4 Nov. 1935 (MA, AC/1/7/10); DFR 7/1927, 18 Mar. 1927.

${ }^{96}$ Paragraph 3, DFR 40/1936, 21 May 1936.
} 
solo flying. In March 1938, he received 2 hours 20 minutes instruction from Lt. McCullagh but was not allowed to go solo. ${ }^{97}$

Hanley also stated that Colonel Mulcahy did not undergo the flying and ground school tests prescribed in the young officers flying course syllabus for the training of new pilots as issued and signed by Major P. Mulcahy on 16 Oct. 1936. He also stated that he did not know who had certified that Mulcahy had qualified as a pilot, engaged in flying duties and was entitled to draw flying pay. ${ }^{98}$ In this respect it appears that Major Mulcahy most likely provided his own certification to the effect that he had undergone flying training in accordance with DFR 40/1936 while avoiding the fact that the DFR was, in effect, only a preamble to the syllabus proper. In August 1936 he received notification, possibly in response to the said certification and his application for flying pay, that financial sanction had been received from the Department of Finance. He was to be paid four shillings per day, the pupil pilot rate of flying pay, from 3 June 1936 to 6 July 1936 - he presumably went flew solo for the first time on 6 July - and at the qualified pilot rate of eight shillings a day from 7 July $1936 .{ }^{99}$ In effect, by granting Mulcahy flying pay DOD had confirmed him as being a pupil pilot for five weeks and as being a duly qualified pilot thereafter. Between 10 June 1936 and 31 March 1939 Major Mulcahy's flying amounted to a total of 135 hours and 30 minutes, 40 hours and 35 minutes of which was during the financial year 1938/39. ${ }^{100}$ Capt. Hanley's evidence would suggest that all Mulcahy's flying between March 1938 and 10 January 1941, was as a passenger. No other officer qualified for the receipt of flying pay solely in accordance with the terms of the particular DFR. The matters of Mulcahy's flying training, receipt of flying pay and his wearing of pilot's 'wings' was to have severe effects on pilot morale and on general esprit de corps during the Emergency.

\footnotetext{
97 T.J. Hanley to AC investigation, 17 Apr.1941 (MA, ACS 22/23).

98 Ibid.

${ }^{99}$ Office of COS to Major P.A. Mulcahy, 27 Aug. 1936 (MA, SDR 1892).

${ }^{100}$ Appendix No. XVIII (B), Report and findings of the committee, 10 Jan. 1942 (MA, ACS 22/23).
} 


\section{Conclusion}

While the reorganisation process of the post-Civil War period was somewhat complicated by the mutiny or army crisis there is every reason to believe that Finance and DOD saw no compelling reason for the retention of military aviation. The military, as demonstrated by General Mulcahy and by O'Duffy's scheme of reorganisation, were quite ambivalent about the matter and left the matter for the decision of the Executive Council who approved the scheme complete with appointments for 155 all-ranks. As evidence of its ambivalence GHQ pinched four appointments for use elsewhere in the Army establishment. Notwithstanding the roles projected for it the new Army Air Corps was but a simulacrum. Major T.J. Maloney's brief on the matter of reorganisation would strongly suggest that the 1924 establishment was only token and temporary. Temporary in this instance would be ten years as it was to be October 1934 before an Air Corps of a headquarters and two squadrons, as originally proposed by McSweeney, got the appropriate sanction.

While the period 1924 to about 1929 was spent in the aviation and organisational doldrums a more enlightened element in GHQ saw the necessity to develop an operational squadron to complement the flying training school. Though the formation of a fighter squadron was initially decided upon, and a third of the aircraft actually purchased in 1926, an army cooperation squadron was eventually informally developed from 1930 but not formally established until 1934.

During the years 1922 to 1931 a succession of five flying officers held the appointment of officer commanding but none for much more than two years. There is little or no evidence of the individual influence of these officers in matters that could be construed as constituting policy - an aspect apparently directed by DOD and the Council of Defence. The appointment of Major J.J. Liston as officer commanding OC in 1931, and, in particular the circumstances surrounding that of P.A. Mulcahy in 1935, strongly suggest that the General Staff were not convinced that an air officer could maintain the strict code of discipline expected of all officers. However it is not clear on what basis discipline was perceived to be the problem. Formal charging of officers was apparently avoided though the records of judicial proceeding remain confidential. While proceedings 
and finding of courts of inquiry are also retained it appears that these were used by GHQ as a disciplinary procedure during the 1930s. While the practice does not appear to have been very common the posting of an officer to an appointment outside the Air Corps resulted in pilots loosing flying pay at the rate of eight shillings per day for an arbitrary period of time. While the extent of formal disciplinary action is not known it is likely that air and army officers spoke different military languages and that efforts of Air Corps pilots to give expression to their particular aviation ethos and culture were interpreted as departures from military discipline. ${ }^{101}$

The move into army cooperation gave the Air Corps a new focus in the early years of the 1930s while the sending of students on the relevant RAF course was, no doubt, a very welcome and open-minded departure on the part of DOD. The dispatch of a young second lieutenant on a RAF flying instructors' course in 1932 was a particularly enlightened move though it is not known where the credit for initiating such action should lie. The adoption of an army cooperation philosophy brought to the fore a younger ex-IRA, ex-infantry officer who appears to have embraced the air ethos to a greater extent than the Army leadership might have expected or been able to comprehend. The departure of Capt. P.J. Hassett from the Air Corps in somewhat obscure circumstances does not reflect well on the system of military justice as practiced during the 1930s. His posting was probably influenced by the inability of higher authority to countenance a military culture other than infantry.

\footnotetext{
101 The Army's perception of the indiscipline of the Air Corps flying officer persisted through to my career in the Air Corps (1961-1999). From observation the perception was directly related to petty jealousy over the receipt, by flying officers, of flying pay.
} 


\section{CHAPTER 6}

\section{PUPIL PILOT INTAKE 1922 TO 1945.}

Notwithstanding the fact that the Air Service had only two pilots the early stages of the Civil War and that one of these was very much involved with the business of setting up the service and in the process of buying aircraft there was a great reluctance to recruit the additional pilots so obviously needed. This reluctance was related solely to the RAF background of the only Irish pilots that were then available and to the sensitivity about the recruitment of any ex-British servicemen, particularly those without pre-Truce IRA service. Though the number of pilots had been brought up to ten, on Collins' authority, by 4 December 1922 the Air Service was directed to commence pilot training. The naive concept of the time would have officers from the ranks of the old IRA trained as pilots with a view to replacing ex-RAF pilots who were, initially at least, on short term contracts. This basic choice, between air officers and infantry pilots, was to be the fundamental dichotomy that would underlie the pilot selection and training processes until 1945 - and beyond. After 1924 the choice was to be between young cadets, with particular motivation to become military pilots and mostly recruited direct from civilian life on the one hand and (generally) young officers, originally awarded Army cadetships, from army units or as newly graduating officers, on the other. In practice, with relatively few young officers opting for aviation careers, officers in the latter category were to be, in effect, volunteers for flying careers.

This chapter will examine the conflicting influences brought to bear on the matter of the selection and training of army officers, mainly of the infantry corps, on the one hand, and cadets specifically recruited for their motivation to be pilot officers, on the other. Individual intakes of pupil pilots will be assessed to identify the dominant influences of the time and assess the extent to which the recruitment and training of pilots of an infantry disposition was a military priority.

From the earliest weeks of the civil war there was evidence of differences in culture and ethos between the pre-Truce IRA, including the evolving command of the 
army, and the new and hastily established Military Air Service. This mutual antipathy, that would in time significantly influence GHQ's perception of military aviation, was initially more evident at a local level. The first manifestation of this appeared very early in Baldonnell with the ideological and physical separation of infantry and air personnel literally into separate camps - exemplified by the duplication of military functions and of the standard institutions of a military post. To what extent this cultural divide was based on the widespread antipathy, in the National Army, to all things British, in this specific case to ex-RAF officers, is not clear. The slow rate at which ex-RAF pilots were recruited to an air service that obviously needed them in the latter part of 1922, highlighted the great sensitivity, at all levels of the Army, about recruiting Irishmen with British military service but no pre-truce service at home. Such prejudices were probably frequently uttered but seldom recorded. A notable exception was in the context of a substantial subtext to the mutiny of 1924 as recorded in the inquiry of the time and in subsequent studies. ${ }^{1}$ J.C. Fitzmaurice, one of the ex-RAF group of officers engaged by General W.J. McSweeney on the authority of Michael Collins, provides a slight flavour of the atmosphere that must have existed in Baldonnell during the Civil War. .

.. and we Irishmen who had held His Majesty's commissions were treated with great distrust by the politicians and the majority of the old I.R.A. officers... ...... The then director of military intelligence debased his office by arranging the appointments of subordinate officers on non-technical ground duties at our headquarters to carry out a campaign of snoopery and witch-hunting of a most loathsome kind. ${ }^{2}$

Fitzmaurice was singularly outspoken in regard to the relationship between the ex-RAF officers and the old IRA and was particularly scathing in his assessment of the character of the infantry officers at Baldonnell, individually and collectively, in the early autumn of 1922. He suggested that 'an air of hedonism prevailed the atmosphere' amongst a group of officers who 'apparently had distinguisher careers as guerrilla fighters against the

\footnotetext{
'Maryann Gialanella Valulius, Almost a rebellion, the Irish Army Mutiny of 1924 (Cork, 1988), passim.

${ }^{2}$ Col. J.C. Fitzmaurice, unpublished memoir, p. 143 (Estate of the late P. Selwyn-Jones).
} 
Black and Tans' and who 'bore exalted ranks that they had apparently conferred upon themselves' and regarded their appointments in the National Army 'as a form of life pension'. ${ }^{3}$ In being so critical of IRA officers Fitzmaurice possibly reflected a superior attitude on the part of the ex-British aviation personnel of the Air Service, an attitude that, no doubt, did not help matters. No doubt this outspoken, superior and somewhat condescending attitude only served to intensify the opposition and ire of those of solid republican backgrounds.

Fitzmaurice, however, did not hold all old IRA officers in such low regard. He was particularly friendly with and admired Commandant Billy Aston, the local commander at Fermoy (1922/23) even though he recognised that they would most likely be on opposite sides in the festering unrest that would culminate in the mutiny of $1924 .^{4}$ Similarly Fitzmaurice held Colonel Michael Hogan in very high regard. ${ }^{5}$ To a large extent the mutual antipathy of the infantry and air groups could not be avoided. When Collins set out to introduce an aviation aspect to the army during the Treaty negotiations he had no option but to engage the services of two ex-RAF pilots. Subsequently, as the main action of the Civil War moved south-westwards, the decision to take on more pilots in order to assist McSweeney and Russell and to facilitate the sending of an attachment of aircraft and personnel to Fermoy, had to be taken by Collins. ${ }^{6}$ During the Civil War the sensitivity regarding the employment of ex-British personnel who lacked pre-Truce service is reflected in the manner in which the matter was reported to government by Collins' successor as commander-in-chief, the then Minister for Defence General R. Mulcahy.

The commander in chief reported that only a limited number of ex-officers of the British Army had been taken into the Army, that they were Irishmen and that they were employed mainly in instructing capacities and in some cases in an assisting capacity. $^{7}$

\footnotetext{
${ }^{3}$ Ibid, pp 121-3.

4 Ibid, p. 140.

${ }^{3}$ Ibid, p. 130-1.

${ }^{6}$ Conference minutes, 16 Aug. 1922 (UCDA, MP, P7/49/48).

${ }^{7}$ Provisional government decisions, PG 101, 26 August 1922 (NAI, DT, S.1302).
} 
It was this sensitivity to the recruitment of Ex-RAF personnel that delayed the logical early expansion of the air operation during the Civil War. The pilot appointments were not advertised in the national press but were made known by word of mouth to attract to the Air Service some of the Irish ex-RAF pilots. Eventually another eleven ex-RAF pilots were commissioned into the Air Service though a maximum of ten served in that service at any one time. ${ }^{8}$ The fact that all were Irish by birth appears to have made little if any difference to the attitude of the more republican echelons of the predominantly infantry Army despite the fact that a further 147 former members of the British forces were still serving elsewhere as officers in the Army at the time of the mutiny. No doubt a concentration of a dozen officers of an alien military culture and background, engaged in a military discipline with which a former guerrilla army could not identify, was easily identified as a suspect group.

\section{The first pupil pilot intake - officers and other ranks}

The extent of difficulty experienced by GHQ dealing with the new aviation culture can be judged by the manner in which they sought to minimise the influence of the ex-RAF pilot group and the manner in which they endeavoured to put an infantry imprimatur on the recruitment and training of pilots from a inordinately early stage of the development of the Air Service. An examination of the process of pilot recruitment of 1922-23 and subsequent courses and of the subsequent training and careers of the individual officers will indicate that GHQ used its authority to promote a policy that extolled the merits of infantry culture while endeavouring to subjugate what was seen as an alien culture that was assumed to be incompatible with military discipline. On 20 December 1922, with the Civil War far from over and many months prior to the formal confirmation of existing appointments in the Air Service, GHQ issued its first written edict on any aviation matter. This advertised the fact that there were a limited number of vacancies for pupils in the aviation department of the Army and invited applications from officers between the ages of 18 and 23 indicating that candidates would undergo an exacting medical examination.

\footnotetext{
${ }^{8}$ Michael O'Malley, 'The Military Air Service 1921-1924', Appendix 4 (BA thesis, NUI Maynooth, 2002).
} 
Applicants were reminded to clearly understand that no rank above lieutenant would be granted. Applications, with the recommendation of the command GOC, were required to reach the Department of the Adjutant General not later than the 31 December 1922.'

It should be noted that, as already stated, the Air Service of mid-December 1922 had no defined status in the military scheme of things. The ten pilots then in service were in effect employed on a contract basis having been 'admitted on approval and if not satisfactory' would have been 'dispensed with at once'. ${ }^{10}$ The informal organisation had the No. 1 Squadron divided into two Flights. The operational type aircraft, the Bristol Fighters and the Martinsyde F.4 Buzzards, were being operated by 'B' Flight whose main focus was the air operations in the south-west with four pilots and four aircraft at Fermoy and a single pilot and aircraft operating out of Tralee. That left only five pilots, including McSweeney, at Baldonnell where the 'A' Flight, using the Avro 504K training aircraft had apparently begun pilot training pupil pilots on an informal basis as early as the middle of October 1922. ${ }^{11}$

While no records survive to illustrate the nature of the order directing McSweeney and the Air Service to undertake pilot training, or the parameters within which such a flying course was to be constructed, there is little doubt that the ' $A$ ' Flight of the single squadron of the Air Service of late 1922 lacked the basic prerequisites for such a task. The hastily established air element, still at a rudimentary stage of its development clearly lacked any capacity or tradition in flying training. It had no structures or adequate staffs to undertake instructional duties. The most basic deficiency was that of a flying school with a syllabus appropriate to an $a b$ initio flying course. In this regard the most that could have been available to Comdt. J.J. Flynn, Officer Commanding 'A' Flight, No. 1 Squadron, was a schedule of exercises or flights, gleaned from his own experience, that he considered should be completed by each student.

From an examination of a manuscript record of pupils and the staggered dates on which they started training it can be concluded that the Adjutant General was not inundated with applications from officers anxious to become pilots. While no contemporary record or nominal roll of this intake has been found it appears that the

\footnotetext{
${ }^{9}$ General Routine Order No. 9, 20 December 1922.

${ }^{10}$ Conference minutes, 16 Aug. 1922 (UCDA, MP, P7/B/49/48).

" Aircraft Log Book, Avro II (AC Museum).
} 
students reported, and commenced training, on different dates, and that no theory or ground school, to support the flying programme, was taught. Of the fourteen pupils who apparently commenced training under the scheme at least five were non-commissioned personnel, who were designated as 'flight cadets' during training, while six others, holding commissioned rank, came from various Army units. The balance was made up of three Air Service lieutenants, Lieut. Tom Nolan, McSweeney's first observer and two former NCOs who were possibly granted temporary commissions by General McSweeney in order to qualify to undergo the course. The fourteen pupils commenced flying training at various dates between October 1922 and the end of July 1923. ${ }^{12}$ While an early army report states that six out of a total of sixteen pupils were flying solo on elementary type training aircraft by the end of 1923 the basis for the latter number is not apparent. $^{13}$

The training of Lieut. Timothy Nevin may have been typical of that of many of the group. He commenced training on 18 June 1923 and flew some twenty instructional flights with various instructors before completing his first solo flight on 12 August 1923 after eight hours and fifty-five minutes of flying time. ${ }^{14}$ Flight cadet Daniel J. McKeown commenced flying in mid-July 1923 but did not fly solo until 16 December 1923 after almost thirteen hours of dual instruction. ${ }^{15}$ If a formal schedule of flying exercises was followed no such details are evident in the pilot or aircraft $\log$ books examined. Each of the above pupils had graduated to the service aircraft, the Bristol Fighter, by about forty hours flying while dual instruction made up about thirty percent of that total.

It is not obvious at what stage a pilot was considered qualified. In T.J. Nevin's case it appears that he succeeded in getting his pilot's certificate and wings in December 1923 by which time he had between thirty and forty hours flying experience. ${ }^{16}$ However he died on 24 January 1924, as a result of injuries received in an accident in Bristol Fighter BF II the previous day, shortly after commencing training on the type. ${ }^{17}$ In D.J. McKeown's case no formal end to the course of instruction is indicated in his pilot's log

\footnotetext{
12 'Record of pilot intake to Air Corps'; Aircraft Log Books, Avro I; II; III; IV (AC Museum)

${ }^{13}$ Undated 'Memo on the development of the forces 1923-27' (MA, MM/1).

${ }^{14}$ Pilots Log Book, Lt. T.J. Nevin (original held by G.M. Nevin, Athenry.Co. Galway)

${ }^{15}$ Pilot's Log Book, Capt. D.J. McKeown (original held by Mr. P. Molloy, Celbridge).

${ }^{16}$ Nevin family papers (in possession of G.M. Nevin)

17 OC AAS report, 23 Mar. 1924 (MA, A/11270).
} 
book. It is more difficult to detail the rest of those who were deemed to have qualified as pilots from the course of 1922-24 but six would appear to be the maximum number while a further three qualified as observers or navigators. ${ }^{18}$ Of this number only four remained in service after the demobilisation, mutiny and reorganisation processes of 1924 . The aggregate of the subsequent service of the six successful pupils was only about thirty years, giving an average service of five years. While the successful pilots and observers of this first intake apparently did no ground school subjects this deficiency was eventually put right. Those who remained in service after the reorganisation of 1924 completed ground school examinations in $1925^{19}$ or took ground school subjects and examinations in conjunction with the cadet and officer intake of 1926 that qualified in $1928 .^{20}$ It is significant that no officer, who qualified as a pilot or observer from the class of 1922-24, achieved a rank above that of captain in the Air Service / Air Corps while three of the successful pupils were killed in flying accidents during training or subsequently. In terms of the small number who qualified, the apparently low standard achieved and the brevity of subsequent service this intake must be considered a failure. The results serve to suggest that the decision of the General Staff to have pilots trained in such adverse circumstances during a civil war was irresponsible in the extreme and probably only justified by the prejudice towards those who had served with British forces. During the reorganisation process, entrusted to Eoin O'Duffy as result of the mutiny, this first intake of pupil pilots was the subject of adverse comment.

I am informed that although every effort was made during the past 12 months to secure the right type of prospective pilot no satisfactory results were obtained, and a considerable amount of time and instruction were expended without any corresponding return. ${ }^{21}$

For O'Duffy to state that every effort was made to get the right type appears somewhat disingenuous. The original advertisement implied that many officer volunteers were to be

\footnotetext{
${ }^{18}$ Record of pilot intake to Air Corps (AC Museum); General Routine Orders, 1922/24; Staff Duty Memos, 1923/24.

${ }^{19}$ Routine Order by Col. C.F. Russell, paragraph 1263, 25 November 1925 (in my possession).

${ }^{20}$ Undated memorandum, ground school course results, circa June 1928 (MA, AC/1/7/3).

21 'O'Duffy's scheme', Explanatory notes, 1 July 1924, p.37 (NAI, S.3442B).
} 
interviewed, and therefore selected by the director of aviation. In the event it appears that about half the personnel who were accepted were from the non-commissioned ranks and that no selection process was applied to the fourteen applicants who eventually commenced flying training. In effect the first pupil pilots appear to have been volunteers who were not required to meet any selection criterion other than an aviation medical examination. The recruitment process and training regime that was followed indicates a total naivety on the part of GHQ in regard to the prerequisites of pilot training. It is considered that, had Air Service officers expressed opinions on the matter it is highly probable that they would have been ignored. It will be noted that C.F. Russell, who might have had a constructive influence on the concept of undertaking pilot training at such an inopportune time, had been posted to the Railway Protection and Maintenance Corps in mid September. The precipitous action of GHQ in ordering the training of new pilots so early in the formation of the air arm was clearly aimed at having the ex-RAF pilots train their own replacements. Had the first flying course borne the fruit expected by GHQ there is little doubt that most, if not all, ex-RAF pilots would have been demobilised as quickly as possible after the Civil War having been replaced by pilots of a good infantry background with the requisite pre-Truce service.

\section{The second pilot training course 1926/28 - cadets and officers}

With the formal establishment of the Army being put into effect in October 1924 the Army leadership had to come to terms with an Army Air Corps that owed its existence to Collins' Civil War intelligence requirements rather that to an ideologically based decision. In view of the failure to obtain satisfactory results, in terms of quality and numbers, from the first pupil intake a new approach was required. Arising out of the reorganisation process, entrusted to General Eoin O'Duffy in his capacity as GOC the forces, the need for an alternative recruitment process was recognised. Subsequently a cadetship scheme for the Air Corps, that would latter evolve to become the cadetship intake system for the Army generally, was recommended: 
While suitable candidates from the Army should get preference, it is deemed advisable to secure as far as possible candidates direct from school between 18 and 21 , and possessing the following qualities - physical fitness, courage, keenness, decision, self reliance and intelligence. ${ }^{22}$

In a somewhat contradictory manner the same explanatory note suggested that there was no alternative but to train a small number of infantry as pilots. ${ }^{23}$ Towards the end of 1924 the Department of Finance was made aware of a proposal for the employment of cadets for training as pilots in the Air Corps:

The necessity for the employment of additional personnel in the Army Air Corps has been established and the proposal that suitable candidates for the Air Service [sic] might be obtained by the engagement of a limited number of suitable unmarried young men for training has received the assent of the Minister for Defence. $^{24}$

It was proposed that a number of young men would undergo an exhaustive course of training and that commissions in the Air Corps would only be issued to such cadets as qualify in every respect as flying officers and show other required qualities during training. The proposed age limit was to be eighteen to twenty-two years while cadets in training would wear officers' uniforms without rank markings or any other badges. The proposal as forwarded to the Department of Finance for financial sanction indicated that while the Air Corps only had vacancies for four more officers at that time authority accordingly was being requested for an establishment of ten Cadets at a proposed rate of pay of six shillings per day. While the Minister for Finance gave approval in principle for the proposed cadet scheme in December 1924 he requested, in particular, details regarding the method of selection. In reply Defence explained several conditions that would attach to the proposed competition. The fact that the Defence Forces (Temporary

\footnotetext{
22 General O'Duffy's scheme, Explanatory notes, 1 July 1924, p.37 (NAI, DT, S.3442B).

23 Ibid, p.36.

${ }^{24}$ AFO to Sec DF, 20 Nov. 1924 (NAI, DF, S.004/383/24). The Army Air Service became the Army Air Corps on 1 Oct. 1924.
} 
Provisions) Act 1923 made no provision for the rank of cadet was circumvented by the decision to consider cadets as Class III privates with pay of two shillings and six pence per week plus the four shillings per day flying pay due to NCOs or soldiers of the Air Service undergoing instruction. It was also suggested that the men selected would be issued with officers' uniforms, without rank markings, from stores and would be entitled to the privileges of officers. The final condition, to ensure a proper educational standard, specified that these men chosen should undergo a special examination by the Civil Service Commissioners. ${ }^{25}$ On 18 May 1925 the Department of Finance approved the revised scheme 'regarding the employment of a certain number of cadets in the Army Air Service $\left[\right.$ sic] ${ }^{2}{ }^{26}$

The notice advertising 'Cadetships in the Army Air Corps' were carried in the country's main newspapers in the last week in September and first week in October 1925 with the closing date for the receipt of applications given as 24 October 1925. In addition to carrying the DOD advertisement some papers included a news item drawing attention to the new career opportunity for the young men of the country. The Limerick Leader, under the headline 'Saorstat Army Air Corps - cadetships' reprinted the department's substantial information sheet that accompanied the application form. This document presented a detailed description of the career 'in the new art of aviation' on offer and also give the major subject headings extracted from the syllabus of training that was being drafted by Col. C.F. Russell. Considerable detail of the course of military, ground and flying training that awaited the successful applicants was included with the ground school subjects being given particular mention. This, and other newspapers, portrayed a career that must have appeared, and no doubt was, very attractive to the youth of the country then ravaged by unemployment. ${ }^{27}$ By way of contrast another newspaper put a much different slant on the decision to recruit cadets for training as flying officers:

In pursuance of its policy of encouraging the development of civil aviation in the Irish Free State the Ministry for Defence gives notice of a number of vacancies in the Army Air Service [sic]. Although the cadets are to be trained as flying officers

\footnotetext{
${ }^{25}$ AFO to Sec DF, 1 May 1925 (NAI, DF, S.004/383/24).

${ }^{26}$ DF to AFO, 18 May 1925 (NAI, DF, S.004/383/24).

${ }^{27}$ Extract from Limerick Leader, 3 Oct. 1925 (NAI, DF, S.004/383/24).
} 
with the Army Air Corps it is understood that the civil aspect of their training will take precedence of the purely military side of aviation. ${ }^{28}$

This connotation, which could possibly reflect Russell's leaning towards civil aviation, does not appear to reflect the intentions of the General Staff and DOD. While the new state was still anxious to be able to encourage civil aviation the public records of this time do not suggest any civil aviation context to the instigation of the first cadet class in the forces.

Subsequent to the advertising of the cadetship vacancies some 773 application forms, regulations including conditions of service and syllabi of the competitive examination were distributed on request. Only 140 completed application forms were received by DOD by the closing date. ${ }^{29}$ As early as March 1925 the Chief of Staff had indicated that the 'officer commanding, Army Air Service [sic]' would be a member of a committee of selection but only in the capacity of a technical advisor. ${ }^{30}$

The selection board, consisting of four colonels, included Col. C.F. Russell, presumably acting in his capacity as a technical advisor, reported to the Chief of Staff on 26 January 1926. The Board was apparently less than impressed with the quality of many of the 140 applicants. In particular they found fault with the more menial backgrounds of some of the applicants. They also observed that 'candidates graded entirely unsuitable were those whose utter incapacity was quite apparent such as half simpletons, out-ofwork, and those whose character was obviously of the lowest'. Some forty-five applicants were declared ineligible or had withdrawn their applications before 23 December 1925 while forty-eight of the remaining ninety-five subsequently withdrew or failed to turn up for interview by the military selection board. With a total of twenty-nine candidates being rejected by the selection and medical boards only eighteen were summoned to undergo the Civil Service Commissioners' examination. Only nine of the sixteen who actually took this examination were deemed to have achieved a pass mark and suitable for the award of a cadetship. The selection board attributed the poor quality of the applicants to

\footnotetext{
${ }^{28}$ Extract, Irish Times, 30 Sept. 1925 (NAI, DF, S.004/383/24).

${ }^{29}$ Advertisement in An t-Oglach, iii, no. 20 (3 Oct. 1925), p. 17; Selection board report, 26 Jan. 1926 (MA. 2/1113)

${ }^{30} \mathrm{COS}$ to AFO, 6 Mar. 1925 (NAI, DF, S.004/383/24).
} 
the effects of unemployment and the relatively good pay for a cadet as well as the fact that there was no pension scheme to attract the type of man the Army needed. ${ }^{31}$

While there may well have been some very poor candidates in the Air Corps cadetships competition in 1925/26 the subsequent actions of GHQ suggest that the conduct of a cadetship competition was largely a matter of going through the motions and that, in fact they were not necessarily disappointed with the quality of candidates. O'Duffy's original recommendation had indicated that suitable candidates from the Army should get preference in a cadetship competition. The upper age limit had been extended by one year for any candidate who had six months service in Oglaig na hEireann, the Irish Volunteers, Fianna Eireann or in the National Forces and by two years in the case of any candidate who has given twelve months such service and was still serving in the Defence Forces on 1 January 1926. ${ }^{32}$ At least three serving personnel had reached the final stages of the competition while, apparently many officers who were well outside the age limit made known their desire to become pilots. ${ }^{33}$

While the cadet selection was completed before the end of January 1926 it was to be June before the flying course got under way. This delay was most likely caused by the Machiavellian actions of the Army leadership in regard to the eligibility of serving officers who did not meet the age requirements for the cadetship competition but whom GHQ was apparently anxious to facilitate. About a month after the selection of cadets had been made the Department of Defence made further representations to Finance:

In connection with the recruitment of suitable persons as pilots and observers in the Army Air Corps, I am informed by the Chief of Staff that the result of the recent examinations for cadets for this service has not quite provided the most suitable type of man. He mentioned that even in addition to the cadets to be selected for the Air Corps, applications have been received from young infantry officers who were desirous of training as pilots and observers. Generally speaking this type of officer would be under twenty-five years of age, and would only be accepted for training

\footnotetext{
${ }^{31}$ Selection board report to COS, 26 Jan. 1926 (MA, DOD 2/1113).

32 'Appointment of cadets in the Army Air Corps - provisional regulations', 25 Sept. 1925 (NAI, DF, S.004/383/24).

${ }^{33} \mathrm{DF}$ file memo, $19 \mathrm{Apr} .1926$ (NAI, DF, S.004/383/24).
} 
after very careful scrutiny into the bona fides of the application, and after a thorough medical examination. The advantages of having officers within the ranks of the Army trained in pilots' and observers' duties are obvious from a military point of view. ${ }^{34}$

In considering the latest proposal, particularly the passage underlined Finance consulted with the Civil Service Commission and observed that in two or three cases candidates gave suggesting that two or three of the candidates who took the Commission's examination were from the army. The most telling observation was to the effect that the reduction in the number of eligible cadetship candidates was as a result of thorough sifting of some ninety applicants by the Army - the inference being that the motives of the Army, in conducting the elimination process in the manner in which it did, were not entirely disinterested. ${ }^{35}$

In supporting the case for over-age officers neither the Chief of Staff nor the army finance officer suggested the reason why a significant number of infantry officers had expressed their interest in becoming pilots. It was probably related to the fact that the flying pay of a pupil pilot represented a fifty percent increase in pay while a successful pupil would realise a pay increase of almost ninety percent. The more attractive pay considerations (flying pay at four shillings and eight shillings per day) had not applied back in 1922 when pupil pilots had first been sought. ${ }^{36}$ It might be construed that the cadetship applicants had been subjected to a cull in order to denigrate the standard and to facilitate a case for having mature officers declared eligible to undergo a flying course. In response to the Finance query as to whether or not infantry officers would be exempted the educational test that applied to cadets, the Army Finance Officer replied:

It may be stated that it is proposed that the transfer of such infantry officers to the Air Corps is to be of a temporary nature, while permanent transfer, not subject to

\footnotetext{
${ }^{34}$ AFO to DF, 24 Feb. 1926 (NAI, DF, S.004/383/24).

${ }^{35}$ DF memo, 19 Apr. 1926 (NAI, DF, S.004383/24).

${ }^{36}$ Comdt. W.J. Brennan - Whitmore, (Ed.) Defence Forces Army List and Directory, 1926, (An tOglach, 1926), p. 136.
} 
educational test, will be conditional on the necessary technical qualifications being gained during the training course, as confirmed by a practical test. ${ }^{37}$

In effect this somewhat obscure reply stated that officers would not have to meet the educational standard applying to cadetship applicants. They would only be attached to the Air Corps during training and that only those who passed the prescribed flying and ground school tests would be posted into officer vacancies in the Corps. GHQ did not allude to the fact that all successful officers would have army seniority over all successful cadets and that the revised scheme would ensure that the future leadership of the Air Corps would be in the hands of infantry officers with acceptable IRA service and of nationalist backgrounds. More importantly, the officer group, in training, would not be susceptible to the influence of what was perceived to be an alien culture, that of the exRAF officers, as would be the case where young and impressionable cadets were concerned.

It was 12 November 1926 before the Department of Finance had given approval for the flying training of ten officers at any one time but however stated that the original DOD proposal of 24 February 1926 did not clarify whether it was intended to retain such trainees when qualified for the purpose of filling any vacancies on its establishment' and requested further information on the point. ${ }^{38}$ In replying Defence prevaricated somewhat:

I have to inform you..... that it is hoped some of the Officers now under training will prove sufficiently suitable to warrant their retention as [Air] Corps Officers. It is, however, premature to undertake a final selection, but it is expected that the preliminary tests will be completed in about two months' time, when you will be informed of the result. ${ }^{39}$

In the meantime the nine cadets who had reported to the Army School of Instruction on 12 April 1926, for the basic military aspect of their course, subsequently reporting to Baldonnell on 27 June for the flying course. At Baldonnell no less than

\footnotetext{
${ }^{37} \mathrm{DF}$ to AFO, 22 Apr. 1926; AFO to DF, 22 May 1926 (NAl, DF, S.004/383/24).

${ }^{38}$ DF to AFO, 12 Nov. 1926 (NAI, DF, S.004/383/24).

${ }^{39}$ AFO to Sec DF, 3 Dec. 1926 (NAI, DF, S.004/383/24.
} 
seventeen officers, apparently volunteers, who had not undergone any selection process, were already attached to the Air Corps for instructional purposes having reported there prior to 4 June. ${ }^{40}$ These officers apparently varied in age from about twenty-three to at least twenty-six. ${ }^{41}$ They held the ranks of lieutenant, captain and commandant. ${ }^{42}$ In effect, while the Air Corps originally had vacancies for four flying officers in late 1924 when the cadet scheme was first proposed, this, the second flying course, began in June 1926 with twenty-six students. This was at a time when the Air Corps officer establishment provided for a total of twenty-two appointments only six of which were vacant at the particular juncture. ${ }^{43}$ The seventeen officers were already attached to the Air Corps despite the fact that Finance was not to grant the appropriate sanction until December 1926. On 1 June 1926 Col. C.F. Russell approved the results of a preliminary or assessment test, in Algebra, Geometry and English, undertaken by sixteen of the seventeen officers. While a pass mark of $35 \%$ had been laid down twelve officers achieved marks between $40 \%$ and $85 \%$. The other four were granted a 'Pass' mark though numerical values were not recorded. The latter four officers plus another who had achieved $75 \%$ in the assessment test are recorded as having been returned to their original units within a few weeks of the start of the course. Twelve officers, including one who had not taken the assessment test, commenced the course proper. ${ }^{44}$

Mindful of the fact that the first flying course had been a failure both GHQ and the Air Corps were apparently anxious that the flying and ground school syllabus to be followed was appropriate to the course target of producing appropriately qualified military pilots. GHQ, whose staff boasted of no qualifications or expertise in any aspect of aviation, apparently delegated the task of drafting this syllabus to Col. C. F. Russell. Russell, who had been posted out of the Air Service in September 1922 and had more recently been director of the Army Corps of Engineers, was apparently the driving force behind the establishment of the Army Corps of Engineers approved under Orders No. 3.

\footnotetext{
${ }^{40} \mathrm{OC}$ AAC to CSO GHQ, 4 June 1926 (in my possession).

${ }^{41}$ According to his Defence Forces CV Lt. P. Quinn was born on 10 June 1899

42 Record of pilot intake into Air Corps (AC Museum); Local strength return, 11 June 1926 (MA, LS8/LS9).

${ }^{43}$ Orders No.3, Defence Forces (Organisation) Order, 1 Oct. 1924, pp. 34-5; Local strength returns, (MA, LS8/LS9).

${ }^{44}$ Undated question papers; 'Examination results', 1 June 1926, P.J. Hassett papers (in possession of Capt. Eoin Hassett); Record of pilot intake to Air Corps (AC Museum).
} 
He had been appointed OC Air Corps in July 1925. For reasons that are not at all clear, but which possibly related to Russell's superior ability and record as a pilot, commander and staff officer, Major T.J. Maloney had been abruptly removed from that position and replaced by Russell. ${ }^{45}$

While the drafting of the syllabus for the pilot training course had not been completed and thus had no formal status it is probable that the course commenced and proceeded on the basis of a current draft. Russell completed his work on the document in October 1926. He wrote to GHQ enclosing an amended syllabus of training, covering a period of two years for pupil officers and cadets. Indicating that there had been previous discussion on the matter he reiterated the fact that he considered that a special allotment of test mark should be made for the keeping of note books on lecture material. He indicated a certain degree of frustration arising out of his dealings with GHQ in relation to the drafting of the syllabus adding a manuscript note suggesting that his expertise as a pilot was being questioned by those with no knowledge of aviation. ${ }^{46}$

In any event the completed syllabus was eventually approved and published. On 18 March 1927, DFR 7 of 1927, providing for the 'Syllabus of training, pupil officers and cadets in the Army Air Corps', was duly signed by the Minister for Defence and came into effect. This regulation, a detailed and comprehensive syllabus, was to be the only such regulation specific to the Air Corps ever issued by the Department of Defence. It laid down, in considerable detail, a two-year course divided into elementary and advanced stages. The sixteen ground subjects were sub-divided into appropriate areas of instruction and study. In addition the marking scheme for ground school examinations was specified while the full range of tests on elementary types of aircraft and the other conditions relating to service aircraft that were to be fulfilled before a pupil officer or cadet was deemed qualified to wear the flying badge, were also laid down. ${ }^{47}$ (See Appendix 6)

In the meanwhile the course had been progressing. Eventually only seven of the remaining twelve pupils of the officer group achieved the qualifying standard in the written examinations. One of these apparently did not pass the requisite practical tests in

\footnotetext{
${ }^{45} \mathrm{COS}$ to Maj. Thomas J. Maloney, MS/613 dated 24 June 1925 (in my possession).

${ }^{46}$ C.F. Russell to CSO GHQ, 7 Oct. 1926 (MA, 2/1113).

${ }^{47}$ DFR 7/1927, 18 Mar. 1927.
} 
flying and was returned to his army unit. Only six, or 35\%, of the officers who had volunteered for pilot training duly qualified. Of the cadet group of nine seven qualified six as pilots - double the success rate achieved by the officers. The seventh cadet qualified as an observer in accordance with an amended syllabus having 'being found too small of stature to carry out effectively the duties of a pilot'- he could not reach the rudder pedals. One cadet had been discharged on medical grounds earlier in the course. The ninth cadet had been discharged having been found guilty of a civil charge in the Dublin District Court. He is recorded as being "dispensed with as a result of a court prosecution for "cheat and fraud in obtaining admission to the Army Air Corps." 48 Apocryphal comments suggest that another person had taken the Civil Service Commission examination on his behalf.

With the alleged poor quality of the cadet intake implied by the Selection Board Report and the much lauded qualities of the mature infantry officer and the assumed potential value of this particular group to the Air Corps as suggested by GHQ it is of considerable interest to examine the examination results and make comparisons between the two groups of successful students. In the ground school examinations, with a pass mark of $50 \%$, the officers averaged $52.4 \%$ while the cadets achieved an average of almost $64 \%$. The fact that the best officer achieved a mark that was only marginally better than the worst cadet (1005 against 1004, out of a possible 1640) indicates the difference between the two groups, at least in terms of ground school. In percentage terms twice as many cadets as officers achieved the pilots 'wings' standard. While the tests in flying were on a pass or fail basis the later course files examined indicate that those who did better in ground school subjects were generally the better pilots - suggesting that the cadets of 1926/28, individually and collectively, also graduated as the superior flying officers. $^{49}$

Notwithstanding their better performance the cadet were, by definition, junior to their officer colleagues and would remain so for the remainder of their careers. One of the

\footnotetext{
${ }^{48}$ Sec DOD to Sec DF, 27 Oct. 1928 (MA, 2/1113).

${ }^{49}$ Undated 'Tests as per DFR 7/1927', circa June 1928 (MA, AC/1/7/3); Files ACS/103; ACS/103/11/2; ACS/103/5/1; ACS/177/11; ACS/14/2; S.I. 109/1 (courtesy of School Commandant, 2005).
} 
successful officers of the 1926-28 flying course subsequently summarised the course as follows.

In accordance with a policy of changing the atmosphere at Baldonnel it was decided to transfer in young officers of IRA service. In 1926, under this scheme 17 officers, of which I was one, were transferred to the Air Corps. The ex-RAF personnel made it difficult for us but despite this, after the two years prescribed course $12 / 14$ qualified as pilots. ${ }^{50}$

While the recollection of the number of officers who qualified is wide of the mark the comment does tend to confirm that the basic reason for the instigation of the officer element to the course was to neutralise the influence of the ex-RAF element in the corps.

It should be understood that the successful officers, previously attached to the Air Corps were posted into appropriate appointments on reaching the pilot qualifying standard - in about June 1928. In September 1928 DOD made Finance aware of the outcome of the cadet course (that had also finished in June) and the fact that the seven cadets were due to become commissioned officers. Defence reminded Finance that this could only happen if vacancies existed and that only two such vacancies were then available. The secretary, on behalf of the minister, indicated that in a recently proposed revision of the Air Corps establishment there would be vacancies for an additional eight second lieutenants and recommended that 'financial sanction should be accorded for the appointment of these cadets to commissioned rank in anticipation of sanction of the revised scheme of organisation'. ${ }^{51}$ Again we find the Department of Defence being less than frank with the Department of Finance. The necessity to commission seven cadets as officers, something they were obliged to do, was used by DOD to support their case for an increase in the establishment. This increase was made necessary by the fact that six army officers, now qualified as pilots, had already been absorbed into the existing organisation, in effect, filling the appointments for which the cadets had been recruited and trained. An increase of a total of thirteen pilot officers was eventually negotiated,

\footnotetext{
${ }^{50}$ Unpublished memoir, Lt. Col. P.J. Hassett, circa 1959 (in possession of Capt. Eoin Hassett).

${ }^{5}$ Sec DOD to Sec DF, 27 Sept. 1928 (NAI, DF, S.004/383/24).
} 
approved by Finance and put into effect on 1 December 1928. Some of the additional appointments that were still vacant in 1931/32 were to be abolished in the establishment change of that year. ${ }^{52}$ In the meanwhile the cadets who had qualified for their pilots 'wings' were eventually commissioned with effect from 5 Nov. $1928 .{ }^{53}$ From an army point of view the campaign had been a success. GHQ had succeeded in pulling the wool over the eyes of Finance and had trained six infantry officers, of an acceptable IRA background, and posted them into the Air Corps with the appropriate seniority to imbue military aviation with an infantry ethos.

\section{Capt. M.J. O’Brien}

With the commissioning of the successful cadets of the 1926/28 intake pilot training ceased for a number of years though some officer appointments remained unfilled. Thereafter no particular policy was followed in the matter of filling those pilot vacancies that arose. From about 1933 proposals for the establishment of an Army Co-operation Squadron created a specific requirement for pilots though unstructured recruitment had been initiated earlier. Capt. M.J. O'Brien had transferred to the Air Corps and had functioned as an observer from about 12 March 1929. On 23 February 1931, presumably on the authority of Major J. J. Liston, OC Air Corps, he commenced training as a pupil pilot. On 28 April 1933 he was certified as having successfully passed the pilot's flying tests specified under DFR 7/1927 and that he was duly qualified in that respect. ${ }^{54}$ In May 1933 it was reported to the minister for Finance that, while Capt. O'Brien had completed the flying requirements, as the only pupil officer under instruction considerable difficulties had been encountered in making systematic progress with his ground instruction and that it was necessary to request sanction to extent the course beyond the two year programme specified by the regulation and to continue to pay him at the rate of flying pay appropriate to pupil pilots. Finance approved an extension to the ground

\footnotetext{
52 DFR 23 of 1929, effective 1 Dec. 1928; Peace establishment 1931/32, (Stationery Office, 1931).

${ }^{53}$ Col. W.J. Keane, 'The first class of cadets - 60 years ago' in An Cosantoir, Vol. 156, no. 3 (March, 1986), p. 10.

${ }^{54}$ Observer's log book, Capt. M.J. O’Brien (in my possession).
} 
school programme and the continuation of flying pay at the pupil pilot rate of four shillings per day, from 24 February1933 to 27 June $1933 .^{55}$

\section{The officer and cadet class of 1934/35}

The first formally organised ab initio flying course since that of 1926/28 commenced in January 1934, with eight young officers and a single cadet as the pupil pilots. This occurred in the context of proposals being made for establishment of an Army Cooperation Squadron at cadre strength within the current approved strength of the Army:

The existing establishment provides for the Corps Headquarters, the office of the Director of Military Aviation and the Air Corps Schools but no provision is made for a tactical unit capable of co-operation in the field with other arms of the forces. $^{56}$

DOD stated that an increase in the number of flying officers in the Air Corps could not be affected except by recruiting cadets for training as pilots. Sanction was requested for the recruitment, with the assistance of the Civil Service Commission, of ten Air Corps cadets. ${ }^{57}$ In view of the manner in which the Army leadership had manipulated the cadet and officer intake of 1926 it is of note that DOD again cited the cadetship method as the only viable one for pilot intake and training. In considering the matter Finance noted that ten (army) cadets were already provided for in the financial year and that, while the 'Provisional war establishment' included provision for '[Table] 38W The Army Co-operation Squadron (in course of compilation)', no authority existed in the current peace establishment for such a flying unit. The additional cost of $£ 964$ was also seen by Finance as a difficulty. ${ }^{58}$ A complementary opinion suggested that 'the appointment of Air Corps cadets would, I think, be more useful to the Army than the piling up of additional numbers of infantry cadets'. It was also suggested that

\footnotetext{
${ }^{55}$ Sec DOD to Sec DF, 8 May 1933; Sec DF to Sec DOD, 11 May 1933 (NAI. DF, S.004/0060/33).

${ }^{56} \mathrm{Sec}$ DOD to Sec DF, 13 Apr. 1933 (NAI, DF, S.004/0052/33).

57 Ibid.

${ }^{58}$ DF memo, W. Doolin to E. O'Neill, 24 Apr.1933 (NAI, DF, S.004/0052/33).
} 
the additional funding, required for flying personnel, would not be available in the current financial years and that in any event a sufficiently strong case for such a tactical unit had not been stated by DOD. Notwithstanding these adverse comments Finance apparently did approve an intake of ten cadets for the Air Corps in addition to at least twelve allowed for the infantry. ${ }^{59}$ In August 1933 a cadetship competition was held and 39 candidates sat the Civil Service Commission examination though only nine passed to the required standard. Of these seven failed the medical examination and one failed to impress the interview board. The single successful candidate, Cadet Malachi Higgins, was to complete his Cadet School training during 1934 and commence flying training in 1935, with the succeeding class.

At this juncture DOD appears to have adopted two schemes of pilot selection at the same time. As a result of only getting one cadet DOD authorised the Army to try to make up a class of six pupil pilots from whatever source. They started by offering Air Corps cadetships to infantry cadets already in training in the Military College. Six cadets were found suitable but five failed the air medical examination. Cadet Lorcan J. Byrne was awarded an Air Corps cadetship on 5 November 1933. However he did not subsequently train as a pilot and was commissioned with the $6^{\text {th }}$ army Cadet Class $(1932 / 34) .{ }^{60}$ Cadet D.K. Johnston, who had been an infantry cadet since 14 November 1932, had his application to transfer to the Air Corps approved in November 1933 and was the single cadet in the 1934/35 Air Corps class. ${ }^{61}$

Also selected for this course was Lieut. A.C. Woods, whose commissioning 'in pursuance of the provisions of Sections 10 and 19 of the Defence Forces (Temporary Provisions) Acts' 1923-1933 was first proposed by the Minister for Defence in March 1933. This appointment was pursued by Defence despite the objections of Finance whose concurrence, on financial grounds, was required before such an appointment could be made. Finance pointed out that while the government had authority to appoint officers it had become the standard practice to hold open competitions in accordance with Civil Service Commission regulations. They also raised objections to the effect that both

\footnotetext{
${ }^{59}$ DF Memorandum on 'Army Air Corps', 16 Jan. 1934, (NAI, DF, S.004/0165/33); 'Directory of Cadet School graduates' in An Cosantoir, XXXIX (Sept. 1979), pp 287-93.

${ }^{60}$ 'Directory of Cadet School graduates' in An Cosantoir, xxxix, no. 9 (Sept. 1979), p. 288.

${ }^{61} \mathrm{DOD}$ to Sec EC, 24 Aug. 1935 (MA, 2/29679).
} 
educational and medical standards were possibly being ignored. Finance stated that the minister's proposal seemed 'to be against general public policy' and was 'really a personal exercise of patronage by the Minister for Defence'- Frank Aiken. ${ }^{62}$ Further strongly worded objections by the Minister for Finance did not prevent the matter being placed on the agenda for the Executive Council meeting of 22 May 1933. At this meeting the commissioning was approved, and was published in Iris Oifigiuil, on 26 May. ${ }^{63}$ Second Lieutenant Andrew C. Woods was posted to the Air Corps on 2 October $1933 .{ }^{64}$

About the same time Defence informed Finance that the Minister for Defence had 'under consideration the question of a scheme for the training of officers as pilots for co-operation squadrons in the Air Force [sic] on similar lines to that recently adopted in the British Air Service [sic]' and 'did not see any other means by which it would be possible to create a reserve of co-operation pilots'.

Owing to the fact that the training of this type of pilot is particularly difficult and that pupils must possess an intimate knowledge of military matters, it is not considered feasible to create a reserve of co-operation pilots from volunteer or civilian sources. It is accordingly proposed to second to the Air Corps certain officers specially selected from other units, who would undergo training in flying duties for twelve months, after which period they would, if successful in their training, be graded as pilot officers and serve a further year with the Air Corps. ${ }^{65}$

The proposal envisaged that co-operation pilots would revert to their parent units after the second year and return to the Air Corps for refresher training for one month each year for six years thus creating an 'efficient reserve of co-operation pilots'. DOD requested financial sanction for flying pay for an initial four officers. The pupil rate of four shilling a day during training, and eight shilling per day for the years as qualified pilots, would be paid subject to the appropriate approval. This scheme was not interpreted by Finance as a substitute for a cadet intake scheme but rather for one that

\footnotetext{
${ }^{62}$ DF internal memorandum, 31 Mar. 1933; DF to MFD, 13 May 1933 (NAI, DF, S.004/0034/33).

${ }^{63}$ Agenda of meeting of Executive Council, 23 May 1933; Sec EC to Private Sec MFF, 25 May 1933;

Extract from Iris Oifigiuil, 26 May 1933 (NAI, DF, S. 004/0034/33).

${ }^{64}$ Sec DOD to Sec DF, 12 Dec. 1933 (NAI, DF, S.004/0052/33).

${ }^{65} \mathrm{Sec}$ DOD to Sec DF, 11 Dec.1 933 (NAI, DF, S.004/0052/33).
} 
proposed 'the training of members of the OTC and Volunteer Reserve as personnel for an Air Force Reserve' - a case that had apparently been mooted earlier. ${ }^{66}$ Arising from this initiative three second lieutenants, K.T. Curran, F.F. Reade and M.E. McCullagh, from various army units, were selected for flying training that commenced in January $1934 .^{67}$ Subsequently four more young officers, apparently in place of cadets not recruited, were attached to this class and training started on 18 January 1934. Of the total of nine pupils on the 1934/35 course seven, including Cadet D.K. Johnston qualified. ${ }^{68}$ In time, with officers not being returned to infantry units, the two schemes merged into each other though the full circumstances cannot be gleaned from the files. In March 1936 Defence stated that it was not proposed to persevere with the scheme for 'the formation of a reserve of Air Corps Co-operation pilots' and that they proposed to affect the permanent transfers of the three pilots who qualified under the reserve scheme. ${ }^{69}$

\section{The young officer and cadet class of $1935 / 36$}

With the approval of Finance and the availability of ten vacancies created by the formal establishment of the $1^{\text {st }}$ Co-Operation Squadron (Cadre) with effect from 22 October 1934 (in addition to those vacancies created by retirements since 1928), a further six pupils - four direct entry officers and two cadets - commenced training on 1 April 1935 and qualified in March $1936 .^{70}$

\section{Syllabus changes}

From June 1935 new influences would be brought to bear on the matter of the recruitment and training of military pilots. While the army hierarchy had paid lip service to the concept of cadet entry in the period from 1924 to 1934 thereafter no pretence

\footnotetext{
${ }^{66}$ Ibid.

${ }^{67}$ Sec DOD to Sec DF, 31 Jan. 1935 (NAI, DF, S.004/0165/33).

${ }^{68}$ Record of pilot intake into Air Corps (AC Museum).

${ }^{69}$ Sec DOD to Sec DF, 21 Mar. 1936 (NAI, DF, S.004/0165/33).

${ }^{70}$ Sec DOD to Sec DF, 25 June 1935 (NAI, DF, S.004/0165/33; Peace establishments, 1934 (MA); Record of pilot intake into Air Corps (AC Museum).
} 
would be made in efforts made to reduce the possible influence of professional aviators on those entering the profession. This was mainly due to the subsequent actions of Major P.A. Mulcahy who was appointed acting OC Air Corps and DMA on 3 June 1935. As the director of artillery he had no qualifications, experience or training or professional expertise of any description in aviation matters. He had come to the Air Corps following an unsettled period during which Major J.J. Liston had been in command. Liston's clash with one of his subordinates had resulted in both leaving the Air Corps. (See Chapter 5)

Two of the more significant matters in which Mulcahy took an interest in the early stages of his command were the matter of pilot recruitment and training and the closely related matter of the syllabus of flying and ground instruction. In September 1935, a few months after taking up his appointment he wrote to the Chief of Staff stating that 'it was not in the best interest of the Air Corps that commissioned officers or cadets should be appointed to it without having sufficient training in military duties' and that 'cadets should not come to the Air Corps at all'. He cited no study or statistical basis for such a view. In effect he was stated categorically that only officers commissioned in the Cadet School of the Military College could or should be trained as pilots and so recommended to the Chief of Staff. ${ }^{71}$ This approach can only be seen as a measure to ensure that pilots were primarily of an infantry persuasion and that motivation towards aviation was very much a secondary consideration. More importantly, by having officers complete their formative training in a strictly infantry atmosphere impressionable young men would be spared the influence of what was probably perceived as an alien culture the remnants of the ex-RAF group and those former cadets of the 1926/28 class - a very air-oriented rump of the officer body. Having received approval in principle Mulcahy informed the COS that the decision required that the flying training syllabus as laid down in DFR $7 / 1927$ be cancelled and that it be replaced by a DFR that he would draft. In making the latter suggestion Mulcahy was misleading - probably deliberately so. The syllabus drafted by C.F Russell and in use since 1926, by its very title applied equally to the training of commissioned officers and cadets. A decision therefore, to train only commissioned officers, did not necessitate a change in the syllabus incorporated in the regulation.

${ }^{71}$ OC AC to COS, 23 Sept. 1935 (MA, AC/1/7/10). 
After nine years it is reasonably certain that DFR $7 / 1927$ would require amending. This however needed to take the form of revision and expansion to reflect the developments in aviation technology and developments in the theory and practice of flying as well as advances in such areas as navigation and instrument flying - not a reduction to a list of general headings as represented by the new DFR. While progressive changes were not reflected in DFR 40/1936 they were to be incorporated in the actual syllabus that was to be used for subsequent 'wings' courses. ${ }^{72}$

During the latter months of 1935, while he was negotiating with GHQ on the matter of a new DRF Mulcahy appears to have detailed the School Commandant to draft a new syllabus. This task was completed by 4 November 1935 and its receipt in GHQ was noted on DOD file 2/32653. The minute sheet, still attached to the original draft syllabus, indicates that the document had been forwarded to GHQ to be approved by training staff and to be designated as a training instruction (T.I.). A staff officer, Comdt. Eamonn Rooney, held onto the document until April 1936 before returning it to Mulcahy. He had made pencilled annotations which indicated small changes in wording but none of any substance. He indicated that he 'had been pecking at it when its issue as a T.I. was contemplated' but that his superior had indicated that the 'document which implements that proposed Schools D.F.R. [40/1936]' was not suitable for issue as a Training Instruction. It was suggested that 'it could be issued by the corps simply as "Notes on the young officers' course" or some such title'. He further suggested that his pecking might be 'of some help to Capt. Delamere in his further attention to the matter' ${ }^{73}$ This ruling, in the words used, was actually quite ambiguous. On one level it intimated that the new, and much abbreviated DFR, ( DFR 40/1936 of 21 May 1936) that was actually issued about three weeks later, constituted the 'wings' course syllabus and that the school commandant's draft syllabus was simply explanatory notes to the regulation. On another level the Adjutant General's branch had stated that the newly drafted school syllabus would have the affect of implementing the DFR. This contradiction was not apparently recognised and thus did not become an issue.

\footnotetext{
72 OC AC to CSO DOD, ACF/36/24 dated 25 Sept. 1936; Corrected draft 'Syllabus of young officers' flying training', 25 Sept. 1936 (in my possession).

${ }_{73}$ Memo, Comdt. E. Rooney to OC AC, 28 Apr. 1936, (in my possession)
} 
Very shortly after receiving back the draft syllabus Mulcahy forwarded it to Capt. Delamere instructing him to examine it carefully. He agreed that the document could be issued as suggested by the Adjutant General's branch and suggested that when the final document had been approved by that branch it would have the status of a training instruction. Delamere made a number of minor changes. The syllabus was subsequently typed. On 25 September 1936 Major P.A. Mulcahy forwarded, "for approval, the syllabus for the young officers' flying training course', to GHQ. ${ }^{74}$ In the absence of a response it can only be presumed that some form of approval was granted.

From inspection of the final draft it can be stated that the syllabus, that was to be used first for the young officers' course of 1937/38, represented a significant improvement on that of 1927. In particular it was more comprehensive and detailed in defining the scope and content of both flying and ground school. It brought all ground school subjects and flying disciplines in line with advances in technology and flying techniques while specifying the Air Publications (as published by the Air Ministry) that should be the required texts appropriate to both flying and to individual ground school subjects. The qualifying standard laid down for pilots' flying technique placed greater emphasis on the ability of the pilot where previously some flying tests were dictated by the performance characteristics of the aircraft.

\section{The $3^{\text {rd }}$ Young Officers' Class, $1937 / 38$.}

When Mulcahy came to the Air Corps it was, like the Army generally, in the early stages of preparation for the anticipated emergency. Such preparation should have included an increase in pilot numbers. However, during Mulcahy's first eighteen months as officer commanding no pupil pilot intake occurred. Mulcahy appears to have been preoccupied with organising the changes in intake policy, changes in Defence Force Regulations and in the flying course syllabus. He also took the opportunity to undergo an abbreviated 'wings' course and, in five weeks, qualified for the receipt of flying pay at the rate appropriate to pilots completing the year long flying course. (See Chapter Five) It was January 1937 before the next group of pilots, the $3^{\text {rd }}$ Young Officers Class, commenced

\footnotetext{
${ }^{74}$ P.A. Mulcahy to CSO, DOD, ACF/36/24 dated 25 Sept. 1936 (in my possession).
} 
training. Early that month some fourteen second lieutenants, drawn from the graduates of the $5^{\text {th }}, 6^{\text {th }}, 7^{\text {th }}$, and $8^{\text {th }}$ (Military College) cadet classes, reported to Baldonnell for flying training. Prior to the commencement of the course four were rejected on the basis of a medical examination or interview. The rejected candidates were returned to their original units before the course proper started on 18 January $1937 .^{75}$

While the class was in training the rate of flying pay for qualified pilots, which the successful individuals had every reason to expect on qualification, was reduced from eight shillings per day to five shilling. DFR 7/1937, which authorised this reduction, was issued on 8 February 1937 and had retrospective effect to 31 October 1936. As a consequence the eight successful pupils of the $3^{\text {rd }}$ Young Officers' Flying Course, who had volunteered to train as pilots and had joined in the expectation of receiving eight shillings per day flying pay perceived themselves to have been wronged. The end of course report of the 1937 class recorded that the reduction in flying pay represented an inappropriate decision that had caused dissention and distraction amongst the student pilots during their course. ${ }^{76}$ There is no suggestion that Mulcahy had an active part in this reduction in pay. However there is no evidence that he concurred with the opinion of the School Commandant or that he took any action to have the decision reversed. This reduction in flying pay was to have certain repercussions in the context of the investigation into the Air Corps carried out in 1941. (See Chapter 11) The decision however, may have suited the Minister for Defence. It is a matter of record that the minister and Mulcahy agreed that Air Corps pilots were not at all inclined to retire to fly with the newly established Aer Lingus - the inference being that they were too well paid. Perhaps it was considered by higher authority that a reduction in flying pay might make pilots consider a career in civil aviation. ${ }^{77}$

\footnotetext{
${ }^{75}$ C Confidential memo, 7 Jan. 1937, ACS/103/11/2 (courtesy of School Commandant); Record of pilot intake to Air Corps (AC Museum); 'Directory of Cadet School graduates' in An Cosantoir xxxix, No. 9 (Sept. 1979), p. 288.

${ }_{76}$ School Commandant to OC AC, 7 Feb.1938 (MA, AC/2/6/15).

${ }^{77}$ Minutes of 'Conference with minister on Saturday 17 July 1937', Appendix No. I to Report and findings of the committee, 10 Jan. 1942 (MA, ACS 22/23).
} 


\section{The short service or reserve pilot scheme}

In regard to the staffing of Aer Lingus with native pilots it might be considered that the initiation of the short service scheme, in August 1939, represented a more substantial expression of the Minister's concern, and that of Mulcahy, for the future provision of pilots to civil aviation. In the four year period between 3 June 1935 and the outbreak of war on 3 September 1939 only eight pupil pilots, who had not already been in training on the day Mulcahy took over, qualified as military pilots. This number represents the successful students of the $3^{\text {rd }}$ Young Officers' Class, originally ten in number, who were attached for training in January 1937. They had apparently been recruited in anticipation of the $50 \%$ increase in the officer establishment figure from the thirty provided for in the 1934 establishment to the forty-five provided for in the establishment of 1 April 1937. The latter establishment introduced the ' $1^{\text {st }}$ Reconnaissance and Medium Bomber Squadron (Cadre)' that consisted of a headquarters and a single flight totalling thirty (all ranks) personnel. $^{78}$ The maximum number of officers permitted under the 1937 establishment was forty-five with no distinction being made in respect of appointments specifically intended to be filled by pilots, observers or line officers. Following the qualification of the $3^{\text {rd }}$ Young Officers' Class of 1937 there were a total of thirty-two pilots in service in $1938 .^{79}$

In the meanwhile, early in 1937, P.A. Mulcahy had attempted to initiate action to substantially increase pilot numbers in the context of making advanced preparation for the future expansion of the Air Corps. Noting that it had been difficult to get ten young officers for the 1937 class, he stressed the Air Corps' future dependence on Cadet School graduates - a dependence that was due to the policy he had initiated. He recommended that, in order to ensure a proper supply of pilots to the army, twenty-five cadets should be appointed specifically for posting to the Air Corps after they had successfully completed their officer cadet course. To add urgency to his request he indicated that it would be actually four years before such cadets will be of real value to the Army. In response to

\footnotetext{
78 'Record of pilot intake to Air Corps' (AC Museum); Peace establishments 1934, 22 Nov. 1934; Amendment 14 to Peace establishments 1934, 5 Apr.1937 (MA).

${ }^{79}$ 'Record of pilot intake to Air Corps' (AC Museum).
} 
this important proposal Mulcahy received only a verbal reply, via a telephone call, which he recorded rather cryptically:

Memo. C/S Staff Officer rang at $16.00 \mathrm{hrs} \mathrm{12/2/37.} 15$ cadets will be reserved for Air Corps on next lot of 30 to be appointed at once. If suitable material amongst those in training at College now, Air Corps will get. PAM 12/2/37. ${ }^{80}$

As this verbal reply was not subsequently supported by written confirmation Mulcahy might have surmised that the subject of Air Corps pilots was not high on the priorities of the Chief of Staff or his staff at that juncture. If he himself was concerned it did not show. It was to be a further eleven month before he is recorded as next communicating with GHQ on the matter - suggesting that this key personnel area was not of major importance to him. In January 1938 he reminded the COS that he had previously requested the recruitment of twenty-five cadets specifically for the Air Corps and had been promised fifteen but was not aware that any had been appointed. He indicated that it would be appropriate to start another 'wings' course in late 1938 but that this would require a change of policy:

I am satisfied that the younger we get prospective pilots for training the better will be the results. I am also of the opinion that if we are to ensure that a requisite number of pilots are to be available for service in the event of war, we must modify our present military training of cadets and concentrate on the flying training. ${ }^{81}$

Mulcahy proposed that Air Corps cadets be recruited for five years service - six months military training, twelve months elementary training and three and a half years advanced and tactical flying training - followed by a permanent commission or transfer to a reserve force. This suggestion, in the context of a previous memo to the Chief of Staff (File 2/33692) on 28 September 1937 that proposed a reserve of 200 pilots, was the basis of

\footnotetext{
${ }^{80}$ Handwritten memo, P.A. Mulcahy, 12 Feb. 1937, ACF/564/1 (courtesy of School Commandant.

${ }^{81}$ P.A. Mulcahy to COS, 11 Jan. 1938, ACF/564/1 (courtesy of School Commandant).
} 
the short service scheme that would eventually commence in August 1939. ${ }^{82}$ At this stage Mulcahy most likely recognised that GHQ had no intention of assigning Cadet School graduates to the Air Corps - for flying training or otherwise - as it was undoubtedly considered that the Army's need for such officers was paramount. Between 1937 and 1945 the Cadet School produced some 275 graduate officers, none of whom were posted to the Air Corps until the Emergency was over and demobilisation was in progress. ${ }^{83}$

Three months later, apparently not having received written replies to his communications of 10 February and 28 September 1937 and 11 January 1938, Mulcahy suggested to the COS that it would be appropriate to start a 'flying training course' in September 1938 and requested an early decision on the matter so that appropriate new regulations could be drafted. The Chief of Staff's response was to request a copy of the letter of 11 January 1938. At best he had forgotten about the matter and at worst he was ignoring it. Subsequently, apparently arising from verbal exchanges with the Assistant Chief of Staff, Mulcahy submitted a detailed draft regulation for 'short service commissions - Air Corps' ${ }^{84}$ While the final details of the scheme, and the conditions of service of the cadets, were still to be worked out Defence outlined the proposal to Finance in October 1938.

I am directed by the acting Minster for Defence to state that he has had under consideration the question of augmenting the officer personnel of the Air Corps for the twofold purpose of providing sufficient pilots for the extra aircraft now on order..... and creating an adequate reserve of this class of officer' ${ }^{85}$

The correspondence went on to state that a scheme had been prepared to provide for the appointment of officers to 'short service commissions in the Air Corps'. The service conditions provided for six months as cadets followed by thirty months as officers with a possible extension of a further two years and a further seven years on the Reserve. The payment of gratuities, apparently to provide for adaptation to civilian life - possibly not in

\footnotetext{
82 Ibid.

83 'Directory of Cadet School graduates' in An Cosantoir xxxix, No. 9 (Sept. 1979), pp 288-89; Record of pilot intake to Air Corps (AC Museum).

${ }^{84}$ OC AC to COS, 19 Apr.1938, ACF/564/1 (courtesy of School Commandant).

${ }^{85}$ Sec DOD to Sec DF, 19 Oct. 1938 (NAI, DF, S.004/0093/38).
} 
aviation - were also provided for in the scheme. Permanent commissions would be granted in a certain limited number of cases. While the scheme was proposed in the context of unspecified immediate needs the requirement to build up a substantial reserve of pilots received greater emphasis:

It is estimated that a reserve of 300 pilots will be required and it is hoped to eventually reach this figure under the proposed scheme. For the moment however, it would not be possible to cater for more than 20 cadets every eighteen months and it is desired to commence the scheme on this basis at an early date. ${ }^{86}$

In practice, while 300 pilots might eventually have been trained, Finance calculated that Defence's target of a reserve of 300 pilots could not be achieved. This was due to the fact that successive intakes of officers would go off the reserve after ten years at which stage numbers would level out at 100 . In fact with the traditional failure rate of about one third, for which Finance did not allow, an active reserve of 100 was unlikely ever to have been achieved. ${ }^{87}$ The Department of Finance, in studying the financial and other implications compared the proposed scheme very favourably with that operated by the RAF about that time but considered the intended gratuity structure to be too generous. However it was also observed that 'one result of the proposal would be the regular infiltration of the new blood of youth which is particularly desirable in an air force'. Finance perceived the civil aviation aspect of the scheme as being very important;'s interpre

It is a further advantage that after their three or five-year period of initial service there will be a steady turn out of competent flying men to take their places in any civil commercial flying enterprises that may be expected to develop in this country. ${ }^{88}$

Noting that during the recent international crisis, authority had been granted for the purchase of thirty-five new aircraft that had committed the State to an immediate and

\footnotetext{
${ }^{86}$ Ibid.

${ }^{87}$ DF memo dated 25 Oct. 1938 (NAI, DF, S.004/0093/38).

${ }^{88}$ W. Doolin to MFF, 10 Nov. 1938 (NAI, DF, S.004/0093/38).
} 
considerable expansion of the Air Corps' Finance considered that a short service scheme was preferable to permanent expansion. ${ }^{89}$ In conveying the minister's approval in principle to the proposed scheme DOD suggested that proposed gratuities be reduced to $£ 200$ when retiring after two years commissioned service and $£ 300$ after five. It was also stated that "the minister would also like to receive an assurance that the Army authorities have available a ground force of mechanics, fitters etc. adequate to maintain sufficient aeroplanes for the training scheme contemplated'. ${ }^{90}$ After a delay of five months the Minister for Defence mentioned to the Minister for Finance, at a meeting on 14 April 1938, that 'the matter of a scheme for the appointment of officers to short term Commissions in the Air Corps was still under consideration by the Department of Finance' intimating that a reply was outstanding. Sean MacEntee subsequently reminded Aiken that approval in principle had been granted back in November 1938 and that amendments to regulations, and clarification on certain other points, was awaited from DOD and that Finance had not yet heard from Defence. ${ }^{91}$ Apparently ignoring the contacts between the two ministers, but adopting a degree of urgency not previously obvious, DOD immediately wrote to Finance enquiring about their opening submission of 23 November 1938.

I am directed ....to refer to the proposed scheme ....for short service commissions in the Air Corps, and to state that as the need for additional officers for the Air Corps is now one of the utmost urgency the minister proposes that this department will arrange for the recruitment of the cadets..... ${ }^{92}$

To expedite the selection procedure Defence proposed to dispense with the customary Civil Service examination for cadet entry and to accept, for interview and consideration by a 'military selection board', candidates between the ages of seventeen and nineteen years with Leaving Certificate (Pass) or Matriculation and those, up to the age of twentythree years, with a university degree. The secretary, DOD also indicated that the

\footnotetext{
${ }^{89}$ Ibid.

${ }^{90} \mathrm{Sec}$ DF to Sec DOD, 23 Nov. 1938 (NAI, DF, S.004/0093/38).

${ }^{9} \mathrm{MFF}$ to MFD, 17 Apr. 1939 (NAI, DF, S.004/0093/38

${ }^{92}$ Sec DOD to Sec DF, 19 Apr. 1939 (NAI, DF, S.004/0093/38).
} 
necessary personnel and equipment, including machines, would be available to cope with the training of twenty cadets while the erection a new Cadets' Quarters building costing $£ 17,000$ was being arranged by the Commissioners of Public Works. ${ }^{93}$

Between May 1938 and the initiation of the scheme in August 1939, and with no obvious sense of urgency, much correspondence was directed by the Air Corps to GHQ/ DOD apparently responding to verbal queries on the matter of the conditions of service to apply to the short service commission scheme. The main points at issue were the length of commissioned service, the age limits and the level of gratuity to be paid on transfer to civilian life. While the Air Corps recommended four and a half years of commissioned service to ensure an adequate level of flying training and experience before transfer to the Reserve, DOD insisted on thirty months with a possible extension of two years. DOD insisted on an entry age limit of seventeen to nineteen. This factor, as the Air Corps predicted, was to eventually restrict the number of cadets in the first class recruited to less than the approved number of twenty. DOD fixed the gratuity at $£ 200$ after two and a half years and $£ 300$ after four and a half years commissioned service. In its approach to the short service scheme DOD apparently took notice of the conditions pertaining to a similar scheme offered by the RAF. Eventually the influence of Finance decided the more contentious points. ${ }^{94}$

On 8 November 1938 a draft peace organisation was submitted by Mulcahy who stated that the organisation or establishment was that required for an Air Corps consisting of a Depot, School and three operational squadrons. He also stated that, as it would not be possible to procure or accommodate the complete personnel at the present time he was, at the COS's request, suggesting the numbers that could be recruited in 1939. He suggested that the organisation being proposed for the Air Corps School was only sufficient to train one elementary flying course of twenty pupils and that the School establishment would have to be increased further to allow another class of twenty to start immediately after the previous one had completed the elementary stage. The squadrons he proposed were reduced to training cadre status as greater numbers could not be accommodated in

\footnotetext{
93 Ibid.

2h OC AC to CSO DOD, 10 May 1938; 16 May 1938; Draft regulation, 27 June 1938: OC AC to CSO, 30 Nov. 1938; Draft regulation, Feb. 1939; RAF advertisement, cutting from unidentified newspaper, ACF/564/1 (courtesy of School Commandant).
} 
Baldonnell or trained over the following twelve to eighteen months. The peace establishment of 14 April 1939 did not increase the instructional capacity of the Air Corps Schools. The 1940 war establishment, however, practically doubled the size of the Schools and allowed for a second intake of twenty pupils once the previous class had completed the elementary stage of training. ${ }^{95}$

With conditions of service for cadets still the subject of correspondence OC AC informed the COS that "we have taken delivery of our new training aircraft and are in a position to start the training of the first class'. ${ }^{96}$ During the early summer of 1939 the details of conditions of service and necessary amendments to regulations worked out between Defence and Finance. The cadetships were eventually advertised in the Irish Press and Irish Independent on 1 June 1939. Due to the age restriction and the fact that the closing date, 24 June 1939, was prior to the promulgation of the Leaving Certificate results for 1939 only forty-two applications were received (from Leaving Certificate graduates of 1938). Twenty-five of these were deemed ineligible on education or age grounds or both. Two candidates failed to turn up for medical and interview while three more of the last seventeen failed the medical examination leaving twelve at the interview stage. ${ }^{97}$

The interview board was made up of five Air Corps officers including Major G.J. Carroll. Major Carroll was at this time seconded to Aer Lingus Teoranta as general manager. ${ }^{98}$ His presence on the interview board emphasised the fact that the longer-term aim of the short service scheme was to provide pilots for civil aviation, in effect, Aer Lingus. ${ }^{99}$ One of the twelve interviewed was found unsuitable. The successful candidates were attested on 16 August 1939 and commenced flying training on 21 August 1939 just days before to outbreak of war. ${ }^{100}$ Early in 1940 the 1939 short service class completed the first term of military flying training and, having been deemed suitable for

\footnotetext{
${ }^{95}$ P.A. Mulcahy to COS, 8 Nov. 1938 ( ACF/564/1, courtesy of School Commandant); Table 33P, 1939 peace establishment; Table 36W, 1940 war establishment (MA).

\%6 OC AC to COS, 29 Mar. 1939 ( ACF/564/1, courtesy of School Commandant).

${ }^{97}$ OC AC to COS, 28 June 1939; COS Convening order, 15 July 1939, ACF/564/1 (courtesy of School Commandant..

${ }_{98}^{98}$ Bernard Share, The flight of the Iolar; the Aer Lingus experience 1936-1986 (Dublin, 1986), p. 34.

${ }^{99}$ It is understood that all twelve interview boards for the scheme, that ended with those interviewed in 1960, included a senior Aer Lingus pilot. Capt. A.A. Quigley (1940 short service intake) was the Aer Lingus representative at my interview in October 1960.

${ }^{100}$ School Commandant to OC AC, 23 Jan. 1940, ACF/564/1 (courtesy of School Commandant).
} 
commissioning, approval was granted by Finance on 22 February $1940 .^{101}$ The eleven cadets were commissioned at Baldonnell on 12 April and nine successfully completed flying training by 1 August $1940 .^{102}$

\section{The 1940 Short Service Class}

In the meanwhile, while seeking financial sanction for a further intake DOD advised that, with the new accommodations being built, it was opportune to commence arrangements for an intake of twenty, and that to ensure a 'bigger field of choice' the age bracket should be expanded to seventeen to twenty-one years and to twenty-three for university graduates'. ${ }^{103}$ In due course a second class, of twenty cadets, was recruited and commenced training on 7 May 1940. The recruitment, with this class, of an over-age candidate with seventy hours military flying training with the Italian Air Force, was also approved by Finance. ${ }^{104}$ In due course a total of twenty-six cadets from these two classes received shorts service commissions with twenty - three qualifying as military pilots.

\section{The Sergeant Pilot Class 1943/45}

In 1943, based mainly on a recommendation of the investigation committee and still under the aegis of the short service scheme, a class of thirty-one other ranks commenced training to become sergeant pilots. These were selected, by interview, from 'seventy-five candidates with the requisite qualifications'. ${ }^{105}$ The course file indicates that class A comprised fifteen personnel - twelve recruited for the first time and three with previous army service. Class B was made up of four Air Corps privates and twelve privates from Army units. The course ran from November 1943 to 22 December 1945 with twenty pupils qualifying. ${ }^{106}$ This number of NCO pilots was twice that provided for in the 1943 establishment and in the subsequent establishment of 1946 . With the war over and any

\footnotetext{
${ }^{101}$ Sec DOD to Sec DF, 19 Feb. 1940 (NAI, DF, S.004/0093/38).

102 OIC Records to Adj. E. Comd, 4 Apr. 1940, ACF/564/1 (courtesy of School Commandant).

${ }^{103}$ Sec DOD to Sec DF, 10 Nov. 1939 (NAI, DF, S.004/0093/38)

${ }^{104} \mathrm{DF}$ to Sec DOD, $30 \mathrm{Apr} .1940$ (NAI, DF, S.004/0093/38).

${ }^{105} \mathrm{Sec}$ DOD to Sec DF, 9 May 1952 (NAI, DF, S.004/0093/38).

${ }^{106}$ Chief Instructor to School Commandant, 9 June 1944, Sergeant pilots' course file (courtesy of School Commandant).
} 
perceived emergency well in the past GHQ reverted to the army officer intake system as first suggested by Mulcahy back in 1935 . The $4^{\text {th }}$ Young Officers class had been selected and had commenced training by July 1945 . While it marked a return to the officer-only intake policy it did not however mark the end of the short service scheme. This was subsequently resurrected, at Aer Lingus's request, with nine further classes, with ninetythree cadets, being recruited between 1953 and $1961 .{ }^{107}$

A comparison between the numbers of pupil pilots recruited and training in the period October 1922 to December 1937 and the numbers recruited and trained in the period 1939 to 1945 is most revealing. During the earlier period, by means of seven generally poorly organised intakes, sixty-four pupil pilots commenced flying training with about two thirds were successful. During the Emergency, by way of a carefully organised short service scheme, three intake classes totalling sixty four pupil pilots commenced training and again approximately two thirds were successful. No more than in the case of the training initiated during the Civil War it is debatable whether it was wise to undertake such a significant training commitment during the emergency. However, unlike the situation that pertained in 1922/23 the training of pilots, in terms of aircraft and instructor resources, appears to have had priority over operational considerations during the Emergency.

\section{Conclusions}

While the Army leadership may have had sensitivities about the recruitment of ex-RAF pilots, as authorised by Michael Collins, in the 1922/23 period they had little or no influence on the matter. Thereafter GHQ would endeavour to ensure that, initially at least officers of suitable IRA background would fly the State's military aircraft. In his regard however the first intake, of a non-descript collection of young officers and other rank volunteers, was almost a total failure in that it produced six poorly qualified pilots and did not achieve the aim of replacing the ex-RAF group of officers.

\footnotetext{
${ }^{107}$ Aer Lingus to Lt. Col. W.J. Keane, 7 June 1951 (in my possession); Record of pilot intake to Air Corps, (AC Museum). Cadet Michael O'Malley was the last to train and qualify under this scheme.
} 
While O'Duffy's scheme of reorganisation introduced the concept of cadet entry it also permitted the powers that be to train as pilots older officers with acceptable preTruce IRA service and infantry values. The latter intake could only have been intended to ensure that ex-IRA, and not ex-RAF, pilots would be a dominating influence over the future leadership of the Air Corps. The intake of seventeen officers in addition to the nine cadets, at a time when only four to six vacancies existed in the Corps, was a cynical manipulation of the situation on the part of GHQ to ensure the primacy of the infantry ethos.

During the 1930s, while no cohesive intake policy was ever expounded the preference of GHQ in the matter of pilot intake for the Air Corps was to have newly qualified (Cadet School) army officers trained as military pilots. The underlying philosophy was based on the assumption that such pilots would not be required to operate other than in a battlefield reconnaissance role of the type that had evolved during the 1914/18 war (and which would be out of fashion by the WWII) and that only officers trained in the Military College would be able to understand the nuances of infantry tactics and operate army cooperation aircraft in the required manner. However this intake method was abandoned for the period 1938 to 1945 . GHQ apparently had little time for consideration of the Air Corps' pilot requirements approaching the Emergency and apparently considered that Cadet School graduates were much too valuable a military commodity to waste on the flying of aircraft. With no more officers being made available for flying training after January 1937 P.A. Mulcahy eventually proposed the short service scheme in April 1938. All concerned, including Mulcahy, displayed a remarkable lack of urgency regarding the matter of expanding pilot numbers approaching the Emergency. The first short service class, that was planned to commence with twenty pupils, eventually provided only nine trained pilots. The delay, until August 1939, in initiating this scheme strongly suggests that the aim of the scheme was to have sufficient civil pilots available after the war rather than to supply military pilots for the Emergency. There is nothing in the relevant correspondence (of the Air Corps, GHQ, DOD or Finance) or in the proceedings of the investigation of 1941, to suggest that the provision of pilots for the Emergency was a military priority of primary importance. This, to a large extent is borne out by the fact that, unlike previous intakes, GHQ handed over the 
selection procedure to the Air Corps - apparently on the basis that short service officers would not be expected to have long term careers in the Army and that it was up to the Corps to select their own temporary officers. The resumption of the officer intake system immediately after the Emergency serves to confirm the civil aviation emphasis of the short service scheme operated from 1939 to 1945. 


\section{CHAPTER 7}

\section{AVIATION POLICY AND PLANNING 1935 - 1940}

Despite the absence of any substantial ideological argument for its retention the Army Air Service survived the demobilisation and reorganisation processes of 1923/24 and the machinations of the army mutiny of the spring of 1924. It is doubtful if the establishment of 1 October 1924, a headquarters of eighty-three all ranks and a single squadron of sixtyeight, could be deemed to constitute an Army Air Corps. The records of the time suggest that this was in fact a provisional establishment that would require further consideration and appropriate expansion before being considered viable. While McSweeney and Maloney had, in their turn, insisted that a viable air element should have consisted of a minimum of two squadrons it was to be 1934 before such a situation came about. In the meanwhile the minister's proposal, for the establishment of a fighter squadron of eighteen aircraft by 1928/29, had been initiated and abandoned. The Council of Defence had replaced this concept with one based on developing an army cooperation squadron and succeeded in purchasing, and taking delivery of, eight Vickers Vespa aircraft by May 1931. While the $1^{\text {st }}$ Army Co-operation Squadron (Cadre) was not formally established until 22 October 1934 an increased number of maintenance personnel in the headquarters element had facilitated the primary preoccupation of the early 1930 s i.e. training for an army aviation role in support of ground troops. While the appointment of Major P.A. Mulcahy was seemingly influenced by the perception of a necessity for greater discipline the aviation related decisions and actions of his seven and a half years term as OC Air Corps were to have major consequences. Not least important of these was the decision to initiate the purchase of Avro Anson aircraft, a process that was set in train within weeks of his appointment. The acquisition of medium range general reconnaissance aircraft indicated a considerable departure from the role of support for ground formations then being provided by the Vespas of the cooperation squadron.

This chapter endeavours to establish and examine the nature of the air policy - to the extent that such a policy could be deemed to have existed - and the aviation aspects of 
the defence strategy devised and proposed by the General Staff. It will be necessary to identify the role played by P.A. Mulcahy, who was apparently assumed a policy function by the default of his superiors. A significant aim will be to identify and evaluate Mulcahy's emergency preparations and planning in terms of organization, aircraft, personnel, training and aerodromes. These assessments will be made in the context of the Army's defensive policy and planning that were developed in parallel with, though quite separate from, the Government's defence strategy which appears to have been developed in close harmony with the United Kingdom (See Chapter 8). A major aspect of the organisation proposed by Mulcahy and eventually endorsed by GHQ / DOD by way of the war establishment of 1940, was a move away from traditional army aviation roles towards those commensurate with an aviation element of air force status.

\section{Fundamental Factors}

The period between the reorganisation of the Army in 1924 and the 'Emergency' was characterised by a number of unsuccessful efforts on the part of the Army's General Staff to have the government declare a policy in relation to external defence. ${ }^{1}$ While air defence was not a major consideration it did have at least one significant advocate. Colonel M.J. Costello later summarised his concerns of the early 1930s:

Some time in 1930 this matter of policy as to the future development was under discussion and I endeavoured at the time to obtain a decision as to the amount of money which would be available annually for the development of the Air Corps and to have the policy which would govern its development settled. The net result of these discussions was that it could not be said in advance what sum of money would be available from time to time for the Air Corps, nor could anything definite be obtained on the question of policy than a general decision that there would be an Air Corps. ${ }^{2}$

\footnotetext{
'P. Young, 'Defence and the new Irish state, 1919-39' in Irish Sword xix (1993-94), pp 1-10, passim.

${ }^{2}$ M.J. Costello to AC investigation, 18 Feb. 1941 (MA, ACS 22/23).
} 
This general position in effect reflects the original decision, taken during the reorganisation process of 1924, to retain a token Air Corps and would appear to confirm the proposition that, as the Army was not in receipt of a definitive defence policy, the Air Corps, as a very minor army corps, was unlikely to have its peace or wartime roles and functions defined. While the consideration of air defence matters was to remain a minority concern for the Army leadership Costello would continue to demonstrate his belief in the necessity to develop a properly equipped and trained Air Corps to be part of a substantial conventional defensive force. Costello's proposals for a greatly expanded Air Corps will be discussed in the context of the 'suicidal defence planning' of the period. ${ }^{3}$

A somewhat different assessment of the Army's defensive responsibilities was reflected in a comprehensive study of the question of defence policy in the context of future hostilities in Europe and warned of the ramifications of such an event for the internal and external defence considerations for the country. This assessment was contained in a document produced by Colonel Dan Bryan of the GHQ intelligence staff in 1936. ${ }^{4}$ It was directed primarily against the 'utter insanity' of a group of senior officers who were 'talking extensively about a military war against the British and the successful manner in which such a war could be waged'. 5 Bryan suggested that Saorstat Eireann, relying solely on its own resources, could not wage war with any reasonably strong state except for a very limited period. Munitions and all manner of military equipment and supplies would soon become exhausted. In contrasting the strategic position of Ireland during World War I and its future position it was suggested that the development of new weapons such as aircraft and submarines had made the protection of naval bases more difficult and, in effect, greatly enhanced the strategic value of Irish harbours on the North, West and South coasts. In the military aviation context Bryan indicated a certain level of ignorance in respect of the considerable number of inland aerodromes and airfields developed by the British War Office during World War I, indicating that he was unsure whether they were used for training or local defence. He did, however, correctly

\footnotetext{
${ }^{3}$ Theo Farrell, 'Professionalization and suicidal defence planning by the Irish Army, 1921-1941', in Journal of strategic studies,xxi, no. 3 (Sept. 1998), pp 67-85, passim.

4 'Fundamental Factors affecting Saorstat defence problem', May 1936 (MA, G.2/0057).

${ }^{5} \mathrm{E}$. O'Halpin, Defending Ireland, p.136, citing 'Fundamental factors'.
} 
deduce that several coastal air stations had been developed for the US Naval Air Service and were used in support of anti-submarine warfare. In context of possible future hostilities Bryan considered what air force measures would be required:

Under the circumstances generally assumed... it is quite certain that even more extensive air forces than during the 1914-1918 period would have to be located on or near the Irish coasts. Reconnaissance, patrol, anti submarine duties would have to be undertaken.... Because of the more serious threat it would also probably become necessary to employ aircraft on reconnaissance for possible raiding forces, and to provide fighter aircraft to deal with hostile air attacks on shipping off the Irish coast and other centres situated on the coast. ${ }^{6}$

The above measures were identified by Bryan in the context of Britain's defensive interests and needs and the likely aviation roles that would require to be performed in the maritime areas to the north, west and south of Ireland, presumably by British aircraft from British bases in the vicinity of treaty ports as provided for by the Anglo-Irish treaty of 1921. It was also suggested that the British would expect certain Saorstat Eireann military aviation to undertake some poorly defined defensive measures:

Great Britain would also expect that the Saorstat should undertake the aerial activities necessary for purely local Irish coastal control and defence. In areas used by the British fleets or on the main trade routes, her attitude to Irish activities would probably depend on the general relations and degree and nature of Saorstat cooperation and in particular on the capacity of Irish air forces to undertake such functions. ${ }^{7}$

\footnotetext{
6 'Fundamental Factors', May 1936 (MA, G.2/0057)

${ }^{7}$ Ibid.
} 


\section{Army planning for war}

The period from 1936 to the start of the war was characterized in GHQ by a considerable level of planning and preparation for the training and equipping of a large conventional field army. ${ }^{8}$ In September 1936, in the context of a greater realisation at Government level of the country's military inadequacies expansion programme was put forward in the context of the situation stated in 'fundamental factors' regarding the defence of the country. The plan was to complete existing units of the Defence Forces in the shortest possible period as a basis for the development of a long term defence policy. The programme mainly proposed a major expansion, and in the case of the Air Corps, a major increase in personnel numbers was envisaged. In addition to providing for the equipping of the six brigades of a notional war establishment the scheme called for major improvements in air defences that envisaged the establishment and development of no less than nine squadrons of fighters and light bombers at a capital cost, in this area alone, of $£ 2.1$ million. While considering that the existing Air Corps was minuscule and really only an adjunct to the field troops it was proposed that Air Corps numbers be increased by 200 officers and 1,200 men in an expanded air service or air force - in effect, more than quadrupling the current strength The scheme included provision for about approximately 100 aircraft organised in nine Squadrons and for the construction of three aerodromes, in addition to Baldonnell, while the capacity of Baldonnell, in terms of buildings and accommodation, would have to be doubled. Capital expenditure, on aircraft and miscellaneous stores amounting to $£ 883,000$ and on aerodromes and other buildings costing $£ 665,000$, came to a total of $£ 1,548,000$ while annual recurring expenditure was predicted to be $£ 431,100{ }^{9}$ Such expenditure should be viewed in the context of total defence spending, in the financial year $1936 / 37$, of $£ 1,373,257$ and a total of $£ 73,426$ actually spent on the running of the Air Corps for the same period. ${ }^{10}$

Whether the Army leadership appreciated it or not such a proposal was nigh on impossible even if the Government had immediately authorised the expenditure and the

\footnotetext{
${ }^{8}$ Theo Farrell, 'Professionalization and suicidal defence planning by the Irish Army, 1921-1945' in Journal of strategic studies, xxi, no. 3 (Sept. 1998), pp 67-85, passim.

9 'Completion of existing defence units', COS to MFD, 22 Sept. 1936 (UCDA, MacEntee papers, P67/191).

${ }^{10}$ Duggan, Irish Army, p.165; Annex G. Report and findings of the committee, 10 Jan. 1942 (MA, ACS 22/23).
} 
expansion in personnel. Such an expansion would have called for upwards of 150 new pilots - an impossible target in the context of the existing miniscule training capacity and the output of the training squadron since 1922. It is doubtful if the General Staff had considered at any length the practical aspects of, in effect, creating an Air Force starting from a minimal situation. Notwithstanding the urgency that the Army endeavoured to generate, and their warnings regarding complacency about the international situation, the submission to Government made in late 1936, in the context of 'fundamental factors', made no impression. Finance argued that there would be no war and that if there were, and if Ireland were invaded, defence against the superior force of a major power would be futile. The Government viewed national defence in term of Anglo-Irish relations and saw no need for a major expansion to form a conventional defence force. ${ }^{11}$

\section{The development of an Army / DOD air defence strategy}

As early as 1935 the first indication, suggesting that the Air Corps, whether under the direction of GHQ or simply with its acquiescence, was examining an air role other than one falling within the remit of army aviation, appears. On 1 July 1935 two flying officers, Commandant G.J. Carroll and Captain W.P. Delamere, accompanied by Mr. R.W. O'Sullivan, the Air Corps civilian assistant aeronautical engineer, attended the Society of British Aircraft Constructors exhibition and display at Hendon. The main purpose of the visit was to familiarise the Air Corps with the state of design and development of new aircraft of all types as well as engines, armament and various aircraft equipment. Among the matters subsequently reported upon were the rapid improvements in aircraft development included the movement towards cantilever monoplane aircraft, closed cockpits, retracting undercarriage, supercharging as well as increased engine power and significantly enhanced performance in terms of altitude and speed. The Air Corps personnel particularly noted that 'in the twin engine class the type which had most interest for us was the Avro 652A coastal reconnaissance and bombing aircraft'. ${ }^{2}$ The reasons for interest in this particular aircraft, a civil passenger aircraft still in the process

\footnotetext{
${ }^{11}$ O'Halpin, Defending Ireland, p. 139. See also Theo Farrell 'Professionalization and suicidal defence planning'.

S.B.A.C. Display report, 17 July / 8 Aug. 1935 (MA, AC/1/9/9).
} 
of development for military applications, are not obvious. The Army's emphasis, first espoused in O'Duffy's reorganisation scheme and subsequently reiterated in the context of the establishment of the $1^{\text {st }}$ Army Co-operation Squadron, was on the necessity to perfect the associated skills and techniques of traditional close reconnaissance and cooperation with ground troops. It may be the case that the General Staff recognised that future hostilities, whether the country was involved or not, would necessitate the prior development of some capacity for general reconnaissance and had requested assessment of appropriate aircraft.

Notwithstanding the existing emphasis on the army support aspect of the Air Corps the Army estimates for $1936 / 37$ included provision for $£ 15,000$ for the purchase of two twin-engine long distance reconnaissance and bombing aircraft. ${ }^{13}$ In his case supporting the proposed purchase OC Air Corps stated that such an aircraft had been subject to evaluation for a number of years and that the Avro 652A Anson met all the requirements of the Air Corps specification for such an aircraft with the exception of target towing for anti-aircraft artillery. Mulcahy recommended the purchase of two aircraft that were required for training in aerial navigation, long distance and coastal reconnaissance and for 'wireless, bombing and gunnery'. They were to cost $£ 7,800$ each with an additional $£ 500$ for unspecified additional equipment. Mulcahy suggested that the balance of $£ 1,600$, not provided for in his initial estimate, could be met by foregoing the purchase of two elementary trainers on the basis that he had no immediate plans to undertake the training of additional pilots. ${ }^{14}$

The aircraft were duly purchased and taken on charge on 20 March 1937. While they had been purchased for navigation training and long-range patrol, the aircraft were not fitted with any form of direction finding equipment - even when the appropriate modification was made available by the manufacturers. Similarly no ground direction finding facilities were available to the State's military aircraft. These deficiencies were to severely limit the effectiveness of reconnaissance operations during the Emergency. Two

\footnotetext{
${ }^{13}$ QMG to OC AC, 1 Apr. 1936, estimates 1936/37 (MA, AC/2/2/7).

14 OC AC to QMG, 1 Aug. 1936 (MA, AC/2/2/7). A class of pupil officers was recruited in December 1936 and commenced flying training in January 1937.
} 
more Ansons were taken on charge on 19 January 1938 followed by a further five on 2 February 1939. ${ }^{15}$

In the meantime the 1934 establishment had been amended by the addition of a second service squadron, the " $1^{\text {st }}$ Reconnaissance and Medium Bombing Squadron (Cadre)' with effect from 1 April 1937. This consisted of a headquarters and a single flight providing for only thirty personnel - six flying officers, eight NCOs and sixteen privates. The establishment did not provide for navigators (observers), wireless operators or gunners. Bearing in mind that Mulcahy had, in effect, justified the purchase of four (and eventually nine) Avro Anson aircraft on the basis of a requirement for training in aerial navigation and long distance and coastal reconnaissance as well bombing and gunnery, the combination of poorly equipped aircraft and an inappropriately structured training cadre having only six pilots and only thirty personnel in total, was ill equipped to train and prepare for the coastal patrol role it was soon to undertake. (See Chapter 10) The addition of this new training cadre brought the total Air Corps establishment up to a total of 399 all ranks - forty-five officers, ninety-one non-commissioned officers and 263 privates. ${ }^{16}$

\section{The minister's priorities}

On Saturday 17 July 1937 Major P.A. Mulcahy was summoned to the office of the Minister for Defence, Frank Aiken, where they discussed general aviation matters. Mulcahy gave the minister a verbal report on progress in the Air Corps under his command. However the meeting did little to clarify the position regarding military aviation strategy or policy and where the Air Corps might stand in the anticipated emergency. Mulcahy recorded the principal points discussed:

He agreed with me that a definite policy of [army] expansion, to take place over a period of years, must be laid down before satisfactory Air Corps expansion could make any headway. He stated that he hoped to get such a policy agreed to before

\footnotetext{
15 Kearns, 'Irish Air Corps', p. 449; p. 459; Report and findings of the committee, 10 Jan. 1942 (MA, ACS 22/23), passim.

${ }^{16}$ Amendment 14 to Peace establishment, 1934, 1 April 1937 (MA).
} 
long, but that as such a policy entailed very heavy financial commitments, it was a matter that could not be decided upon in a hurry. ${ }^{17}$

In his position as OC Air Corps Mulcahy might have been expected to emphasise the necessity of expanding the Air Corps but appears to have chosen to totally subordinate the Air Corps to an Army policy that had yet to be formulated. Perhaps sensing the minister's priorities, Mulcahy gave tacit agreement to the minister's belief that military aviation had distinctly lesser priority than land forces in the context of preparation for the expected emergency. Seemingly the minister's main air concern was in the area of civil aviation:

He realised the difficulty of procuring and training pilots for civil air companies and favours training some of our apprentice-mechanics as NCO pilots with a view to supplying the companies' demands. He realises that this will take quite a long time and as the present officer pilots are unwilling to resign their commissions and accept jobs with the civil companies, he is inclined to consider detailing serving pilots for short periods of duty with civil companies. ${ }^{18}$

In effect the discussion introduced the concept of the secondment of military pilots to Aer Lingus and the parallel proposal of developing a short service pilot training scheme, again for the benefit of Government sponsored civil aviation. While no firm decisions were taken the tone of the discussions makes it abundantly clear that, with European war looming, the minister for Defence and the OC Air Corps considered that the aircrew requirements of Aer Lingus (established just a year earlier) took precedence over the plans and preparation for the employment of military air resources in time of war. The leisurely fashion in which the short service scheme was eventually established underlines the civil aviation emphasis of that scheme. The discussion also clearly indicated that

\footnotetext{
17 'Conference with minister on Saturday 17 July 1937', Appendix No.1, Report and findings of the committee, 10 Jan. 1942 (MA, ACS 22/23).

${ }^{18}$ Ibid.
} 
financial costs would be a major consideration that would greatly influence decisions relating to air defence generally. ${ }^{19}$

Notwithstanding the lowly priority of military aviation the minister and Mulcahy gave some consideration to the matter of expanding the number of aerodromes. They agreed that 'about four more military aerodromes should be established' but that due to the heavy expenditure involved "it would have to be considered when the general Air policy was being considered'. Mulcahy explained his priorities:

In this connection I emphasised the necessity of being able to state that we would send a squadron to Aerodrome X. in say 1939 and a Squadron to Aerodrome Y. in say 1941, so that arrangements could be made to make these places suitable for occupation before these dates. ${ }^{20}$

This was to prove a prophetic statement. As will to be discussed later, when an air detachment was sent to Shannon in late August 1939, this requirement, to have aerodromes prepared well in advance, will be seen to have been completely overlooked. The last matter agreed between the minister and Mulcahy was fundamental:

He asked me had we considered the question of sea planes versus land planes for our purposes. I stated that we had not considered this matter in any detail, but that it was my opinion that we were committed to the continued use of land planes. $\mathrm{He}$ stated that that was his opinion too. ${ }^{21}$

Notwithstanding agreement on this basic principle Mulcahy was subsequently to be detailed by the Minister to buy amphibious aircraft and to operate them out of Shannon. It is not easy to reconcile the minutes of the conference of 17 July 1937 with the Army plans for an expanded and better-equipped Air Corps as proposed in September 1936. On the one hand Mulcahy had agreed with the Minister that Air Corps expansion could be postponed pending the expansion and equipping of the

\footnotetext{
${ }^{19}$ Ibid.

${ }^{20}$ Ibid.

${ }^{21}$ Ibid.
} 
ground forces and on the other he was cooperating with General Staff in their planning for expanded military aviation required for conventional defence against possible invasion. As suggested by other commentators it would appear that Army planning was based on the policy the Army wished the Government would endorse while the Government, in keeping with its rapprochement with Britain, saw no urgency in regard to preparations for, in this instance, conventional air defence.

\section{The General Staff's Air Corps proposals of 21 March 1938}

On or about 28 September 1937 P.A. Mulcahy had proposed 'a general scheme for the Air Corps' that apparently incorporated the principles of the Army plan of September 1936. On 22 March 1938, prior to which he had had meetings with Col. Liam Archer and Col. M.J. Costello regarding Air Corps expansion, Col. Mulcahy received a secret memorandum from Colonel Costello who was acting on behalf of the General Staff. ${ }^{22}$ The memorandum contained considerable detail on the previously agreed outline plan for the expansion of the Air Corps and requested his submission providing 'estimates of the capital and maintenance costs' for its implementation. The ACS outlined the rationale for the expansion:

We have neither the financial nor industrial resources to create a large Air Force and the demands on the available resources which will be made by Land Forces including Anti-Aircraft Units are such as to require the modification of your proposals for the expansion of the Air Corps as presented by you to Colonel Archer. .... At the same time it is possible that a situation may arise in which it would be necessary for us to expand rapidly and in which the necessary machines and other equipment would be available. It is, therefore, proposed to organise and maintain the framework for such expansion to a strength approximate to that outlines by you. ${ }^{23}$

\footnotetext{
27 P.A. Mulcahy to AC investigation, 22 Jan. 1941 (MA, ACS 22/23).

23 ACS to OC AC, 21 Mar. 1938, Appendix 11, Report and findings of the committee, 10 Jan. 1942 (MA, ACS 22/23).
} 
The General Staff's proposal provided for one first line squadron of pursuit machines for the defence by air of Dublin to fundamentally act as a deterrent to bombing attacks. It was suggested that this squadron should be at full strength and be fully equipped at all times and have available reserves of aircraft, equipment and personnel. It was proposed to locate a coastal patrol squadron at Shannon. This squadron's main role would be patrols of the coastline and include spotting for coastal defence artillery, to attack enemy vessels and to function in cooperation with marine coastal patrols. It was also intended to have flying boats based at Shannon Airport on a permanent basis and to have an unspecified number of bases around the coast as well on inland lakes and at harbours. A further element was proposed in the form of a half squadron of reconnaissance and medium bomber aircraft to be based in Dublin. While the numbers and types of aircraft for each squadron were not specified GHQ, paradoxically, proposed to duplicate the number of aircraft in order to maintain the squadrons at full strength at all times and to provide for training. ${ }^{24}$

In order to provide the necessary flying officers it was suggested that Mulcahy's scheme for the recruitment of short service officers would be put into effect in addition to the training of officers of the Volunteer Reserve. In the event of an emergency it was proposed that a considerable proportion of the fitters employed in the motor trade would be made available for technical duties. In regard to aerodromes the General Staff intended to maintain Baldonnell as a permanent station and Fermoy, Oranmore and Gormanston as temporary camps. The most puzzling aspect of the plan was the proposal to organise and train, including the 'first line units' a total of four pursuit, four coastal patrol, two reconnaissance and medium bomber squadrons and the necessary infrastructure organisation and ground organisation. As had been the case with the scheme recommended to Government in September 1936 this expansion plan did not specify the status of the additional units or how, when or in what circumstances they might be raised. $^{25}$

\footnotetext{
${ }^{24}$ Ibid.

25 Ibid.
} 
Mulcahy was apparently encouraged by what he later stated he had interpreted as constituting a 'statement of policy'. ${ }^{26}$ In response to GHQ's request he submitted figures of estimated expenditure under four main headings. Under the heading of transport he listed a total of fifty-five air support vehicles, in addition to eleven already in hand or ordered, at an estimated additional cost of just over $£ 39,000$. Under general stores, listing aircraft among a wide range of aviation equipment, he suggested provision be made for twenty-six pursuit aircraft at a total cost of $£ 182,000$. The context suggests that the Gloster Gladiator was the type proposed. The Air Corps had taken delivery of four on the March 1938 while a further four were included in the 1938/39 Army Estimates. ${ }^{27}$ The latter four aircraft were never delivered. .

Twenty coastal patrol aircraft, of an unspecified type, were to be provided for at a total cost of $£ 300,000$. He allowed $£ 100,000$ for an additional ten reconnaissance and medium bombers, apparently Ansons, costing up to $£ 10,000$ each. Four transport aircraft and four anti-aircraft artillery target towing aircraft were to cost an additional $£ 68,000$ and twenty training machines another $£ 40,000$. No less than 150 parachutes, costing $£ 10,000$, were also required. The total cost of a long shopping list of aircraft and associated ground equipment, excluding the $£ 50,000$ worth already in stock or on order, was estimated at $£ 822,300$. $^{28}$ A fuel reserve for six months, estimated on the basis of a very ambitious 200 hours per aircraft, was predicted to come to a total of 500,000 gallons while no estimate of cost was made. ${ }^{29}$ An estimate for the annual cost of fuel, oil and ammunition came to $£ 69,650$. $^{30}$

The March 1938 expansion plan and Mulcahy's estimate of the expenditure required to support it were rendered irrelevant by subsequent staff action at GHQ level. This was clarified by Col. Costello some three years later in the context of his explanation, to the committee of investigation, of the rationale for the scale and scope of his proposal. He first explained that he had carried out his planning on the assumption that ten million pounds was being made available, on the authority of the minister, for capital expenditure on the Army over a number of years and that ten percent of that

\footnotetext{
${ }^{26}$ P.A. Mulcahy to AC investigation, 22 Jan. 1941 (MA, ACS 22/23).

${ }^{27}$ Appendix No. III (B), Report and findings of the committee, 10 Jan. 1942 (MA, ACS 22/23).

${ }^{28}$ Appendix No. III (C), Report and findings of the committee, 10 Jan. 1942 (MA, ACS 22/23).

${ }^{29}$ Appendix No. III (J), Report and findings of the committee, 10 Jan.1942 (MA, ACS 22/23).

${ }^{30}$ Appendix No. III (K), Report and findings of the committee, 10 Jan. 1942 (MA, ACS 22/23).
} 
would be made available for the expansion of the Air Corps. He proposed to buy the aircraft to equip two and a half squadrons - a pursuit squadron to consist of thirteen aircraft, a reconnaissance squadron and a coastal patrol squadron that would have ten aircraft each while reserves of the same magnitude would be in place to ensure that all squadrons could be maintained at maximum aircraft strength at all times. He assumed all the aircraft required to equip one of each type of squadron would be purchased immediately to ensure against rising costs and to ensure homogeneity of equipment during a period when aircraft were undergoing rapid change. ${ }^{31}$

Costello proposed that the Air Corps, which would include only forty permanent pilot officers, would be expanded by the raising and training of three quarters of all personnel on a reserve basis. This was to include 104 short service flying officers who would be recruited directly into the Air Corps and trained as pilots before returning to civilian life after a maximum of three and a half years in service. One hundred officers of the Volunteer Reserve were also to be recruited directly into the Corps to undergo a oneyear flying course. The plan also suggested that technical personnel would come from the existing boy apprentice scheme supplemented by a number of graduates of the technical schools. While the absence of a civil aircraft industry was recognized Costello considered that retiring reserve pilots need not necessarily be absorbed into flying positions but that unnamed industrial concerns, besides civil aviation, could absorb a considerable proportion of aircrew. A central aspect of Costello's scheme for expansion of military aviation was the assumption that the Air Corps would be able to avail of the results of the development of infrastructure for civil aviation by the Department of Industry and Commerce. He assumed, wrongly, as was later to be demonstrated, that this development would provide the Air Corps with aerodrome facilities at Limerick and Cork, and possibly at Galway and provide a flying boat base at Rineanna / Shannon. ${ }^{32}$

He secondly explained how the plan had been submitted by the then COS to the minister, Frank Aiken, who had accepted it. Subsequently it was circulated to the officers, including the Adjutant General, the Quartermaster General and Col. Liam

\footnotetext{
${ }^{31}$ Costello to AC investigation, 18 Feb. 1941, (MA, ACS 22/23).

32 Ibid.
} 
Archer, Director of Intelligence, who attended General Staff meetings but none of them concurred. Costello explained what followed:

The next that I heard about it was that during Mr. Aiken's absence the late Colonel O'Higgins and Colonel Archer were instructed to prepare an alternative scheme. The then Chief of Staff, with some of his staff officers had a meeting with the Taoiseach, as a result of which the late Colonel O'Higgins was directed to prepare an entirely new scheme without reference to the one approved by Mr. Aiken. ${ }^{33}$

At the second of a series of meetings with the Taoiseach, Costello, who apparently had not been at the first, 'asked specifically if the scheme had been abandoned and was informed that it had been' abandoned. The Chief of Staff added that the scheme 'did not have the approval of any responsible officer'. ${ }^{34}$

\section{The flying boat option}

The GHQ proposal to operate flying boats in a coastal patrol role was of very recent origin. On 14 March 1938 Mulcahy had requested clarification from the COS on the matter stating that he had only recently been made aware of the plan and that it had been directed that the proposal should now be considered by the Air Corps. No doubt mindful of the fact that the minister had agreed, on 17 July 1937, that the operation of flying boats was not a consideration for the Air Corps, he sought clarification as to the advantages accruing from such a decision and the specific duties of such a unit. ${ }^{35}$ In the absence of an immediate response and mindful of the fact that the (civil) Airport Construction Committee, of which he was a member, was due to meet on 29 March 1938 he outlined some of the infrastructural implications of basing a squadron at Shannon. Mulcahy suggested that the airport committee dealing with the question should be made aware that, in making decisions on the locations of airport buildings, adequate provision should

\footnotetext{
33 Ibid.

${ }^{34}$ Ibid.

${ }^{35}$ OC AC to COS, 14 Mar. 1938, Appendix No. IV, Report and findings of the cominittee, 10 Jan. 1942 (MA, ACS 22/23).
} 
be made for military exigencies - '22 officers, 43 NCOs, 144 men, squadron offices, stores, workshops, hospital, photographic section, etc. ${ }^{36}$

While it is not obvious was action was taken by GHQ and or DOD in relation to accommodation and facilities at Shannon, or what Mulcahy was authorised to seek at the meeting of 29 March, there is no evidence that any building works, specifically for the Air Corps, were incorporated in the Department of Industry and Commerce's plans for the development of Shannon Airport. It must be presumed that there was no Department of Finance or government authority with regard to military facilities at Shannon. In the meanwhile Mulcahy's position on seaplanes appears contradictory. While the records of the period indicate that he was not in favour of seaplanes in July 1937 and had, in March 1938 , in effect been detailed to develop such a capability, he subsequently stated that 'in 1937 my idea was to have seaplane reconnaissance at the Shannon'. ${ }^{37}$ These statements cannot all be right and is not clear how or why the latter statement could have been made.

\section{The Committee of Imperial Defence advice}

The rationale, for the outline plan for an establishment consisting of two and a half first line units, including a flying boat unit, becomes clearer when one examines the advice offered by the British Committee for Imperial Defence in January / February 1938. Apparently in the context of a request, from Dublin, for guidance in regard to defence strategy and expenditure CID forwarded a paper suggesting that Eire only be required to spend $£ 1.4$ million in capital expenditure on defence plus a recurring total annual defence expenditure of about two million pounds to build up adequate air and land defences. The proposals, made on the assumption that the United Kingdom and Eire would be allied in resistance to a common enemy will be seen to assume a major significance when one compares them with the 1939 peace establishment and the war establishment of May 1940 and with the eventual numerical strength and disposition of the somewhat token level of air resources actually raised for the emergency. In regard to shore-based air forces the CID indicated as follows:

\footnotetext{
${ }^{36} \mathrm{OC}$ AC to ACS, 26 Mar. 1938, Appendix No. V, Report and findings of the committee, 10 Jan. 1942 (ACS, 22/23).

${ }^{37}$ Mulcahy to AC Investigation, 21 Jan. 1941 (MA, ACS 22/23).
} 
It is understood that the air force of Eire is in a fluid state but that the intention is to organize it into three squadrons on a volunteer basis ...... it is suggested that as the forms of attack are limited to seaborne raids, and possibly long range air attacks from shore bases on the continent, two of these squadrons should be equipped with a type of aircraft suitable for general reconnaissance and bombing and should be stationed in the south and west of Eire ..... the third should be equipped with fighter aircraft and should be stationed in the vicinity of Dublin. ${ }^{38}$

The CID recognised that the organisation of such squadrons and their equipping with modern aircraft would involve a considerable increase in the appropriation for the maintenance of air forces in Eire. While suggesting that economies were available to Eire if she exercised her rights as a member of the British Commonwealth of Nations and engaged the Air Ministry as a purchasing agency it was indicated that the capital costs of a general reconnaissance squadron, with nineteen Blenheim aircraft, and with the addition of ground equipment, general stores, spares and mechanical transport costing $£ 15,000$, would come to a total of about $£ 290,000$ with an annual expenditure of $£ 77,000$ for maintenance and personnel. While indicating that the newly developed Spitfires or Hurricanes were the appropriate fighter aircraft to acquire the CID calculated the cost of a fighter squadron on the basis of nineteen Gladiators, a much less potent and slower biplane. Nineteen Gladiators and appropriate stores were estimated to cost $£ 119,000$ with annual maintenance and personnel costs of $£ 63,000$. The total capital cost of equipping three squadrons came to $£ 714,000$ with annual maintenance cost, including that of personnel, of $£ 217,000$. In addition to land-based aircraft the CID recommended that $£ 500$ be spent on facilities for mooring twelve flying boats at Bantry and that the flying boats would be operated for trade protection purposes. No estimate was made of the capital and maintenance expenditure associated with flying boats. ${ }^{39}$

It is of interest that, of the $£ 1.4$ million of capital expenditure that the CID had recommended for equipping the whole Army, in excess of half was aimed at the

\footnotetext{
38 'Eire: estimate of defence requirements', CID, Feb. 1938 (UCDA, MacEntee Papers, P67/192). The appendixes to this document are dated 21 Jan. 1938

39 Ibid.
} 
development of air resources. In any event the CID recommendation, which was perceived by the Army leadership as a relatively modest level of spending on land and air defence, was used by the initial recipients of the said advice, the government, to undermine the more ambitious and expensive Army plans for a well equipped conventional force for the defence of the country. Despite the relatively modest level of spending suggested by the CID and, while the British advice regarding air defence will be seen to be reflected in later establishments, the commensurate level of expenditure was unlikely to be approved by Finance. In the context of an evolving government defence strategy it is suggested that defence preparations remained more symbolic than practical. $^{40}$

\section{The chief of staff's proposals - 21 May 1938 .}

The UK advice regarding flying boat facilities at Bantry appears to have caught the eye of the Minister for Defence, Frank Aiken. Mulcahy subsequently recalled that 'we had no seaplane base at which to base seaplanes and the minister insisted we should have seaplanes'. ${ }^{41}$ This new interest in flying boats was to be reflected in the next major Army / DOD submission forwarded to Government on 21 May 1938. The Army was continuing its planning for an expanded force, of almost 50,000 all ranks that included the Air Corps, on the basis of a conventionally equipped field army. The Air Corps aspect of this plan appears to have been an outline version of that forwarded to Mulcahy (for the calculation of the cost) on the same day. In addition to a main proposal for a field army of 25,605 that included the equipping of four reinforced infantry brigades, DOD recommended that the Air Corps be expanded to a total of 1,500 all ranks and no less than ten operational squadrons. The proposed expanded corps was depicted as follows:

\section{Air Corps.}

1 Fighter Squadron )

1 Flying Boat Squadron ) $1^{\text {st }}$ Line.

${ }^{40}$ O'Halpin, Defending Jreland, p. 141.

${ }^{41}$ P.A. Mulcahy to AC investigation, 22 Jan. 1941 (MA, ACS 22/23). 
$1 / 2$ Reconnaissance Squadron, organised without machines.

3 Fighter Squadrons.

3 Flying Boat Squadrons.

$11 / 2$ Reconnaissance Squadrons

Total: 1500 all ranks. ${ }^{42}$

The proposal, made in the context of organisation alone, made no provision for such important aspects as aircraft types and numbers or for the posting of air elements to aerodromes yet to be developed. While the plan depicted the breakdown of numbers in Army formation no such distribution of personnel between the various air squadrons was given - just a grand total of 1,500 all ranks. With only two squadrons depicted as ' 1 st Line' the precise status of the other formations remained obscure, particularly when it is considered that no Air Corps reserve existed and that civil aviation provided practically no scope for any form of reserve or auxiliary aviation. It would appear that only two front line, permanent squadrons were contemplated and that the balance would be dependent on authorised future expansion. However, the roles of the proposed ' 1 st line' squadrons, as implied by the nomenclature did not fit in with the existing two squadrons, one nominally an army cooperation squadron and the other a reconnaissance squadron being equipped with Anson aircraft.

While the Chief of Staff's May 1938 proposals for Army expansion included, without adequate argument, an ill-defined expansion of the Air Corps it also indicated how an additional $£ 150,000$, out a sum $£ 600,000$ sanctioned by the Government, would be spent on military aviation. In regard to the Air Corps allocation of $£ 150,000$ it was proposed spend $£ 30,000$ on four fighter aircraft, $£ 40,000$ on two reconnaissance and medium bombers, and $£ 60,000$ on six advanced training aircraft. The proposals to spend $£ 600$ on fifty sets of flying clothing and $£ 1,800$ on thirty parachutes suggest a more modest and possibly more realistic assessment, on the part of the General Staff, as to what level of personnel and expenditure would be seen as appropriate by the Department of Finance. A significant provision was that of $£ 1500$ for 'temporary hutments for 40 cadets', suggesting that proposals for a short service pilot scheme were still in preparation

\footnotetext{
${ }^{42}$ COS to MFD, 21 May 1938 (UCDA, MacEntee papers, P67/193(2)).
} 
despite the rejection of the Costello plan of March 1938. ${ }^{43}$ The itemised list of proposed expenditure on the Air Corps actually came to $£ 149,000$. At this juncture in 1938, while GHQ continued to plan for Army and Air Corps expansion there existed no concept of a national defence policy and therefore no Government approved policy, strategy or plan for military aviation. ${ }^{44}$

\section{Aircraft purchases}

The $£ 150,000$ earmarked for military aviation translated into proposed capital expenditure of $£ 75,000$ for each of the financial years $1938 / 39$ and $1939 / 40$. As the capital expenditure in $1937 / 38$ had totalled $£ 46,636$ the $£ 75,000$ represented a $63 \%$ increase in capital expenditure for each of the following years. In the event however the full amount was not spent over the two years. While $£ 80,250$ was spent in 1938/38, mainly on new aircraft, only $£ 61,980$ was spent in 1939/40 - again mainly on aircraft. The shortfall in spending over the two years was probably due to the failure to secure delivery of the second batch of Gladiators. Had these been purchased the Air Corps would have been overspent by approximately $£ 20,000 .^{45}$

With regard to the selection of aircraft for individual squadrons the die was fairly well cast. In 1936/37 two Avro Ansons had been purchased. Two more were bought in 1938/38. In the context of completing a reconnaissance and medium bomber squadron of sixteen aircraft a further twelve Ansons were ordered. Five of these were delivered in February 1939 while the remaining seven were embargoed by the UK authorities as they were about to be delivered in September 1939. ${ }^{46}$

In a similar fashion the main equipment of Fighter Squadron was decided by the purchase, in 1937/38, of four Gloster Gladiators. At the time eight aircraft had been ordered but only four were released by the Air Ministry. While the purchase of this aircraft, the last biplane fighter type to enter service with the RAF, probably made sense in 1938 the machine was already being rendered obsolescent by the development of the

\footnotetext{
${ }^{43}$ COS to MFD, 21 May 1938 (UCDA, MacEntee papers, P67/193(4)).

${ }^{41}$ Peter Young 'Defence and the Irish state 1919-39' in Irish Sword xix, Nos 75 \& 76 (1993-4), pp 1-10, passim.

${ }^{45}$ Estimates, 1938/39 (MA, AC/2/2/11; Estimates 1939/40 (MA, AC/2/218).

4t, Keains,' Irish Air Corps', p. 445.
} 
Hurricane and Spitfire fighters. Subsequently eight more aircraft were ordered for delivery in 1939 but were not received. ${ }^{47}$ While it is possible that this was due to a UK embargo it might alternatively have been as a result of the cessation of production in $1938{ }^{48}$ An additional six aircraft, Westland Lysanders, the standard British army cooperation aircraft, bought because advanced training aircraft could be not purchased, were put on the strength of Fighter Squadron. ${ }^{49}$ As a result Fighter Squadron (Cadre), designated to be equipped with twenty two fighter aircraft, was to enter the Emergency with three obsolete fighters as its main equipment (Gladiator No. 23 had been crashed and written off on 20 October1938). It also had six close reconnaissance aircraft and a miscellany of other aircraft that were even more inappropriate to the task. ${ }^{50}$ (See Chapter 10) With approval for the short service pilot scheme it was necessary to buy new elementary training aircraft - Miles Magisters. These cost about $£ 22,500$ which was paid out of the $1938 / 39$ provision. A further five Magisters, costing about $£ 11,250$ were bought in $1939 / 40 .{ }^{51}$

\section{Walrus coastal patrol aircraft}

To equip the proposed coastal patrol squadron cadre the minister's direction to purchase seaplanes was put into effect in early 1939. It is not clear that any great thought was put into the selection process and in all probability cost was the most important criterion. Three Supermarine Walrus aircraft, single-engined amphibian machines, were bought and delivered by 4 March $1939 .{ }^{52}$ This was just prior to formal approval of the establishment of the cadre of fifty-one personnel that included six officers, seventeen non-commissioned officers and twenty-eight privates that was authorised with effect from 14 April 1939. ${ }^{53}$

\footnotetext{
${ }^{47}$ Ibid, p.459.

${ }^{48}$ K.J. Meekoms, E.B. Morgan (eds), The British aircraft file; British military and commercial aircraft specifications 1920-1949 (Tonbridge, 1994), p. 255.

${ }^{49}$ Comdt. M. Sheerin to AC investigation, 23 Jan. 1941 (MA, ACS 22/23).

50 'Fighter Squadron; Internal organization', 16 Dec. 1940 (in my possession).

${ }^{31}$ Kearns, 'Irish Air Corps', p. 459; Estimates 1938/39 (MA, AC/2/211).

${ }^{52}$ Kearns, 'Irish Air Corps', p.449.

${ }^{53}$ Table 32P, 1939 Peace establishments (MA).
} 
The suitability of the Walrus as a coastal patrol aircraft can be gauged from the outcome of a number of flights carried out in May 1939. Apparently as part of the process of introducing the type to service, surface and air reconnaissance of Bere Haven [sic] and Lough Swilly was carried out with a view to alighting in the vicinity of the forts. Test flights for assessing the suitability of Castletownberehaven as a seaplane base were carried out on the 12,20 and 22 May when that location, as well as the cooperation of the artillery personnel and their launch, was apparently found to be satisfactory. The minister himself went on the flight on 22 May though the purpose of his visit to Bantry Bay, or its outcome, is not indicated. While operating into and out of Castletownberehaven appears to have been reasonably satisfactory in the weather of May 1939 the same cannot be said for Lough Swilly. The waters around the forts (Dunree and Lenan) were found to be very suitable for alighting and anchoring. A sheltered beach at Fort Dunree was too soft to allow the amphibian to come ashore while the western aspect at Fort Lenan meant that it was an exposed anchorage at practically all times. With the test flights concentrating on two major inlets in the month of May 1939 the report did not give an overall assessment of year-round flying boat operations in Atlantic waters. Nor was the Walrus tested on rivers and lakes. However it seems probable that the Walrus was not at all suited to operate in the waters of the south-west, west and north-west of Ireland even in the benign weather conditions of summer. It is even more probable that their use, even in the most shelters waters, was totally out of the question under winter conditions. It would appear from Mulcahy's evidence to the investigation committee that the three Walrus aircraft were bought to be used as training aircraft while he paid lip service to the Minister's wishes regarding their potential to operate off coastal waters. ${ }^{54}$

\section{Government strategy}

During the immediate pre-war years it is very strongly suggested that while the Army was planning for the expansion, training and equipping of a substantial field army to defend the country against invasion, from Britain in particular, the government, while

\footnotetext{
${ }^{54} \mathrm{OC}$ AC report to COS, 24 May 1939 (MA, AC/2/8/1); P.A. Mulcahy to AC investigation, 21 Jan. 1941 (MA, ACS 22/23).
} 
maintaining de Valera's neutral stance, was taking defence advice from Britain and planning a cooperation strategy that would concentrate on intelligence and counter intelligence. This situation was, of course, indicative of the belief that no government, in the first twenty years of the state, considered that it had the complete loyalty of the Army. ${ }^{55}$ The separate defence strategies appear not to have been reconciled even after a series of at least six meetings of the committee on emergency measures held between 7 September and 14 October 1938. These meetings, apparently all chaired by de Valera and attended by representatives of the Departments of Agriculture, Defence, External Affairs, Finance, Industry and Commerce and the Taoiseach, were arranged to discuss measures necessary to take in the eventuality of a European war in the context of the defensive priorities set out in de Valera's memorandum for the government dated 6 September 1938. ${ }^{56}$ The circulation of this memorandum would appear to be the first occasion on which the government had made known its broad defensive policy or strategy for the expected emergency. In the circumstances the Army might have recognised that their planning for a large conventional arm was at considerable variance with de Valera's priorities regarding neutrality and cooperation. (See Chapter 8)

\section{Organisation}

While the Army continued to advance their grand plan the rejection of the Costello Air Corps proposals of 21 March 1938 was confirmed by de Valera at the second of the above meetings while a Colonel O'Higgins was directed to prepare an entirely new scheme without any reference to that approved by Mr. Aiken. The Chief of Staff had ruled that Major Mulcahy was the responsible officer and that his advice would have to be followed. Costello later recalled that the new scheme was prepared by O'Higgins and in so far as it related to the Air Corps it consisted of proposals submitted to him by Mulcahy and that, in effect, the opinions of other GHQ staff officers were not invited. ${ }^{57}$ Mulcahy's advice, in the form of draft establishment tables based on the then current

\footnotetext{
${ }^{53}$ Eunan O'Halpin, 'Army politics and society in independent Ireland 1923-1946' in T.G. Fraser and Keith Jeffrey (eds.), Men, women and war: historical studies, xviii (Dublin, 1993), p. 159.

${ }^{56}$ File memos dated 20 Sept., 11 Oct. and 18 Oct. 1938 (NAI, DT, S.10,823). Minutes of these meetings do not appear to survive.

${ }^{57}$ Costello to AC Investigation, 18 Feb. 1941 (MA, ACS 22/23).
} 
peace establishment, was forwarded as the establishment required for a corps consisting of a depot, a flying school and three service squadrons. He justified the cadre status and strength of Coastal Patrol Squadron on the basis that only one flight could be established in the first year. Similarly the other squadrons had been reduced to cadre strength on the grounds that the required personnel could not be trained or accommodated in the following twelve to eighteen months. ${ }^{58}$ The latest proposal, which came into effect as the 1939 peace establishment on 14 April 1939, departed from Costello's concept of an Air Corps organised, recruited, and trained mainly on a reserve basis and with a total strength of 1,500 all ranks. Instead, the new establishment provided for increased permanent establishment consisting of sixty-three officers, 150 non-commissioned officers and 351 privates, a total of 564 all ranks or a $41 \%$ increase on the that of 1 April 1937. Only two and a quarter operational squadrons were provided for, all apparently to be based at Baldonnell Aerodrome, and all designated as training cadres. ${ }^{59}$ However, it is of note that, while Costello credited Mulcahy with providing the advice to Colonel O'Higgins and GHQ in the drawing up peace and war establishments, Mulcahy himself, in his evidence to the investigation committee of 1941, insisted that he considered that the Air Corps had been prepared for the Emergency on the basis of Costello's policy recommendations alone. (see Chapter 11)

As with all previous establishments no specific aircraft types or numbers were designated for individual squadrons. The selection of aircraft types, based on perceived training and operational requirements, was usually decided by a technical selection procedure at Air Corps Headquarters. His involvement in the assessment of the Avro Anson suggests that the selection of aircraft was a principle function of the chief technical officer, Commandant G.J. Carroll. The number of aircraft, in operational squadrons in particular, appears to have been a function of the amount of money Finance were prepared to spend in the particular financial year.

The formulation of the peace establishment of 1939 was apparently only an interim measure leading to a much larger war establishment. As late as 26 June 1939 GHQ was planning for such an establishment to include three operational squadrons,

\footnotetext{
${ }^{38}$ OC AC to CSO G.1 Branch, DOD, ACF/564 dated 8 Nov. 1938 (in my possession).

${ }^{59}$ Peace establishment, 1939, Air Corps tables $29 \mathrm{P}$ to $34 \mathrm{P}$ (MA).
} 
based on the existing training cadres, operating no less than fifty-four aircraft. The Fighter Squadron was to have twenty two aircraft and was to 'be employed in the defence of Dublin'. The Reconnaissance and Medium Bomber Squadron was intended to operate sixteen aircraft for 'coastal patrol duties and special duties as necessary' while the Coastal Patrol Squadron would operate another sixteen aircraft and, as the name suggests be 'required for the patrol of the coast'. ${ }^{60}$ It should be noted that, as discussed above only twenty-two aircraft in total had been specifically purchased for three first line units in preparation for the Emergency. A total of nine Avro Ansons had been purchased for the Reconnaissance \& Medium Bomber Squadron. Three Supermarine Walrus aircraft, less than a fifth of the notional establishment, were purchased for the Coastal Patrol Squadron. Four Gloster Gladiators, when delivered in March 1938, were assigned to the Army Cooperation Squadron which was re-designated as Fighter Squadron in April 1939. Six Westland Lysanders, erroneously purchased as advanced training aircraft in July 1939 were also assigned to Fighter Squadron. (See Chapter 11)

\section{Aerodromes}

In the pre-war planning for the possible expansion of the Air Corps the study and consideration of the occupation of aerodromes other than Baldonnell appears to have been uncoordinated and inconclusive. On 17 July 1937, in his discussion with the minister, Mulcahy had agreed that about four more aerodromes should be established for a future emergency situation. ${ }^{61}$ Mulcahy had requested that a programme for the occupation of four aerodromes should be agreed well in advance of their eventual occupation and use. Costello's expansion plan of 21 March 1938 proposed that one and a half squadrons would remain at Baldonnell while a coastal patrol squadron would be stationed at Shannon Airport. ${ }^{62}$ He erroneously assumed that the Department of Industry and Commerce would develop various civil aerodromes that would be available to the

\footnotetext{
60 'Memorandum on Army re-organisation', 26 June 1939, quoted in Report and findings of the committee, VIII (MA, ACS 22/23). This report is paginated in Roman capitals.

61 'Conference with minister on Saturday 17' July, 1937', Appendix No. I, Report and Findings, 10 Feb. 1942 (MA, ACS 22/23).

62 ACS to OC AC, 21 Apr. 1938, Appendix No. II, Report and findingsof the committee (MA, ACS 22/23).
} 
Air Corps in emergency times thus saving DOD the relevant expense and providing some operational flexibility. ${ }^{63}$

In April 1938 Mulcahy supplied the General Staff with an outline of the living accommodations required at Baldonnell, Shannon Airport, Midleton, and Oranmore, a former British airfield of the 1919 to 1922 era, while indicating that it would be required that Gormanston be maintained. He made no estimate of the necessary financial provision for aeronautical facilities at Shannon but suggested that provision should be made for 'living accommodation, including married quarters, for twenty-two officers and 186 Other Ranks' as well as workshops, hangars for twenty aircraft, slipways and administrative buildings. ${ }^{64}$ In December 1938 some $£ 300,000$ was apparently earmarked for the development of two aerodromes other than Baldonnell. ${ }^{65}$ In relation to such monies Defence made a case to Finance that reflected indecision and lack of coordination on the part of the General Staff and DOD. The department sought the provision of funds for the provision of additional accommodation for a reconnaissance and medium bombing squadron stating that while it was proposed to detach it from Baldonnell it had not been decided where the squadron would be located. DOD detailed the particular requirements at such a station:

The necessary accommodation will include the provision of four hangars with runways; a new building to house 175 officers and mMen; storage and office accommodation; wireless, photographic and medical huts; quartermasters and barrack services stores; petrol tanks; dining, cookhouse, recreational and gymnasium facilities; married quarters for 4 officers, 10 non-commissioned officers and $20 \mathrm{men}$; a transport shed for vehicles; and light, water and sewage facilities. ${ }^{66}$

The sanction of the Minister for Finance for the spending of an estimated $£ 135,000$ was sought 'for inclusion in the 1939/40 estimates for public works and buildings' with the actual works to be carried out under the direction of the Commissioners of Public Works

\footnotetext{
${ }^{63}$ M.J. Costello to AC Investigation, 18 Feb. 1941 (MA, ACS 22/23).

${ }^{64}$ OC AC to ACS, 21 April 1938, Appendix III (A), Report and findings (MA, ACS 22/23).

${ }^{65}$ DF memo dated 6 Feb. 1939 (NAI, DT, S.11,101).

${ }^{66}$ Sec DOD to Sec DF, 17 Dec. 1938 (NAI, DF, S.007/0009/39).
} 
at a location to be notified later. ${ }^{67}$ In April 1939 Defence renewed their request in respect of provision for additional accommodation for an Air Corps reconnaissance and bombing squadron stating that it was proposed to locate the proposed accommodation at Gormanston Camp. It was stated that it was the minister's desire that the provision of the necessary accommodation should be regarded as a matter of extreme urgency and that sketch plans and a revised estimate of the total cost of the project would be forwarded as soon as possible. ${ }^{68}$ The revision of the works and the estimates was made necessary by the fact that Gormanston, like Baldonnell a former RFC/RAF training depot station, was showing the effects of twenty years of neglect. ${ }^{69}$ Consideration, by the Department of Finance, of a revised estimate of $£ 165,000$ for the reinstatement of Gormanston was delayed due to difficulties with security of tenure. Due to the fact that much of the lands of the aerodrome were held on a yearly tenancy it was suggested that it would be necessary to obtain a more secure tenure before incurring any expenditure on the proposed new works and the Minister's sanction was sought for entering negotiations with the owner. ${ }^{70}$ In July 1940 it was recorded that Defence had directed OPW, in September 1939 , to defer plans for building works at Gormanston. ${ }^{71}$ This decision was probably related to an operational decision, apparently arrived at in the latter days of August 1939, to send an Air Corps reconnaissance detachment to Shannon post haste. ${ }^{72}$ There was to be no full-time use of Gormanston by the Air Corps during the emergency.

The net effect of all discussions and consideration of the development of aerodromes was that the combined efforts of General Staff and the Department of Defence resulted in the development of no new facilities for the specific use of military aviation in the coming emergency. This situation is in stark contrast to that pertaining to the development of the civil aerodromes. In October 1941 the OPW, quoting from a statement of expenditure and commitments to 30 Sept. 1941, reported that the state had invested some $£ 607,248$ in the development of Collinstown (Dublin Airport) and a

\footnotetext{
${ }^{67}$ Ibid.

${ }^{68}$ Sec DOD to Sec DF, 19 Apr.1939 (NAI, DF, S.007/0009/39).

${ }^{69}$ Hayes, RAF and US NAS, p. 85.

${ }^{70}$ Sec OPW to Sec DF, 4 July 1939, (NAI, DF, S.007/0009/39).

${ }^{71} \mathrm{Sec}$ OPW to Sec DF, 19 July 1940 (NAI, DF, S.007/0009/39).

${ }^{72}$ OC AC to COS, 29 Aug. 1939 (MA, AC/2/9/12).
} 
further $£ 495,585$ in the development of Shannon. ${ }^{73}$ This level of expenditure (in excess of $£ 1.102$ million), prior to the construction of concrete runways at either location, can be compared with the $£ 1,119,296$ that the Department of Defence calculated was the total cost of running the Air Corps from 1 April 1926 to 31 March 1941 - an average of $£ 74,619$ per annum. ${ }^{74}$ This emphasis on the development of civil aviation facilities, despite the on-going emergency, strongly suggests that the concept of air defence was somewhat irrelevant in the Government's overall strategy - something that was later be emphasised by the extreme parsimony of Finance when dealing with the provision of facilities for the Air Corps at Rineanna (Shannon) during the early years of the Emergency. (See Chapter 10) In the same context it can be concluded from the amount of money spent on new and permanent buildings at Baldonnell between 1935 and 1946 $(£ 153,262)$ that it was Government policy to minimise the expenditure on facilities at other locations that might be occupied only on a temporary basis - or not at all. ${ }^{75}$

\section{The start of the Emergency}

At the start of the emergency the Air Corps was notionally functioning under the 1939 peace establishment (564 all ranks). Recruitment of privates was apparently permitted within the strength provided for by the war Establishment that would not get Department of Finance sanction until May 1940. On 20 September 1939, about three weeks into the Emergency, Mulcahy replied to a verbal query from the CSO at DOD in a very matter of fact fashion. He stating that, "in accordance with your telephone instructions of today, I give herewith a general report on the Corps'. The report suggests that, in terms of personnel and training, and notwithstanding the considerable notice of the outbreak of hostilities, the Corps was unprepared for the most basic wartime role. The position in regard to pilots was particularly stark. Only thirty-three of the forty officers on strength were pilots and the twenty-seven of these assigned to flying units (Schools and three squadrons) comprised less than $23 \%$ of the number provided for in the war establishment.

\footnotetext{
${ }^{73}$ OPW memo, 31 Oct. 1941 (MA, 2/72465 part III).

74 'C Cost statement of Army Air Corps 1926/27 to 1940/41', Annex G to Report and findings of the committee, 10 Jan. 1942 (MA, ACS 22/23).

${ }^{75}$ Michael O'Malley, 'The Officers' Mess and other works of W.H. Howard Cooke at Baldonnell Aerodrome', Appendix A (undergraduate essay, NUI Maynooth, 2001).
} 
While eleven pupil pilots commenced flying training on 21 August 1939 no new pilots had been trained and qualified since January 1938. The training of eleven rear gunners and observers had only commenced in March 1939. Eleven wireless operator mechanics, for duty in Anson aircraft which had first been taken on charge in March 1937, were only in training since June 1939. Four of the best of the class, still only partially trained, were already flying on patrols out of Rineanna by the beginning of September 1939. The delay in initiating the training of gunners and wireless operators was caused by the fact that the 1937 peace establishment did not provide for such trades. Mulcahy reported that, in addition to fifty-seven mechanics being trained under the boy apprentice scheme, 'approximately 60 recruits are being trained in trades in the Depot' but that 'the material is not good and not more than $50 \%$ are expected to be satisfactory' ${ }^{76}$

Mulcahy cited establishment and strength figures in tabular form to illustrate the extent to which the Air Corps was under-strength vis-à-vis the War Establishment. He showed that the corps had only $47 \%$ of the total numbers to be permitted by the war Establishment that was to become effective in June 1940. The position in regard to officers, specifically pilots, was particularly stark. Total pilot numbers came to $28 \%$ of the June 1940 provision. The position relating to the pilots in the combined operational squadrons was even more alarming. While the war establishment was to allow for 101 pilots a total of only eighteen, or less than $18 \%$, were serving with the three squadrons on 30 September 1939. This however was offset somewhat by the fact that the aircraft strength was about $41 \%$ of that allowed. The overall (all-ranks) positions of the individual squadrons were little better than that of the officers. The Fighter Squadron had ninety-three personnel compared with an establishment figure of 233 - less than $40 \%$. The Reconnaissance and Medium Bomber Squadron, a detachment of which was already patrolling the west coast out of Rineanna / Shannon had 116 all ranks (or about 44\%) against a war establishment figure of 265. Coastal Patrol squadron, with a strength of twenty-two versus an establishment of 273 , could hardly have been termed even a token unit. In this latter regard it will be remembered that it had been the minister's original intention to have a seaplane squadron based in Shannon. What was in existence in September 1939 no doubt fell well short of that originally envisaged.

\footnotetext{
${ }^{76} \mathrm{OC}$ AC to COS, ACF/631 dated 20 Sept. 1939 (in my possession).
} 


\section{Conclusions}

In the context of preparation and planning for the raising of a conventional three-service force for the defence of the country the General Staff foresaw the necessity of preparing plans for the expansion of the Air Corps. The agent of this process was to have been Colonel M.J. Costello who rightly recognized that, if the Army was to have an air dimension commensurate with a realistic conventional defence of the country, that such an element should be appropriate to the air mission in terms of organisation, personnel, equipment and training. Costello's plan of March 1938 was bold in its scale and concept being predicated on capital expenditure in the order of one million pounds. He had a vision of an Air Corps having a nucleus of three permanent squadrons and a capacity to expand to ten operational squadrons and 1,500 personnel in time of war. However this expensive option was never going to get Department of Finance or government approval. In fact it did not even get the approval of his peers.

In achieving the approval of the Minister for Defence for his scheme, Costello appears to have incurred the wrath of the General Staff who, in effect, deemed him not to be a responsible person for the purposes of planning in the matter of the state's military aviation. Instead the General Staff placed their faith in Major P.A Mulcahy who had achieved dubious aviation qualifications subsequent to being ordained Director of Military Aviation in addition to his appointment as Officer Commanding in 1935. The first significant development under Mulcahy was the assessment and purchase of Avro Anson aircraft. It is not at all clear what considerations influenced the decision to evaluate medium range reconnaissance aircraft at this juncture. It is possible that at this early stage the General Staff foresaw, based on observation of the reconnaissance carried out during the Great War and the concept indicated in the 'fundamental factors' document, the necessity to develop a general reconnaissance capability for coastal areas. The purchase of Ansons indicates the beginnings of a significant ideological shift, in terms of Air Corps roles and functions, from those of an army air corps to those of air force status. However the aircraft, and thus the air power capacities of the three rudimentary squadrons eventually raised, were not destined to assume air force status. 
In terms of organisation the Air Corps entered the Emergency, under the 1939 peace establishment, with three under-strength squadrons of training cadre status - in effect the training element of the scheme proposed by Costello. However due to the apparent failure to set training goals and the actual failure to train adequate aircrew, including pilots, observers, gunners and wireless operators the Air Corps of the early Emergency lacked adequate numbers of skilled personnel in practically all key areas. These inadequacies were exacerbated by an unstructured aircraft selection and purchase programme that equipped the Corps with, at the very best, second rate aircraft for potentially front line operations - and in inadequate numbers. There is no evidence that the twenty-two aircraft acquired for service squadrons in the 1937/39 period were purchased because of their suitability for intended roles, but rather because they were the aircraft available at the time and because only token amounts of monies were made available by Finance by direction of government.

One of the more significant shortcomings entering the Emergency was in the number of pilots - only thirty three compared with a notional establishment of sixty in 1939 peace establishment) and no less than 140 under the 1940 war establishment. The small number of pilots did not concern Mulcahy or the General Staff prior to the Emergency. There is little doubt that the short service scheme was instigated, and continued during the Emergency, with the assumed future needs of civil aviation in mind.

The compromise represented by a token level of manpower and a token level of second or third rate aircraft left the Air Corps in a limbo. Notionally it had a defensive role in accordance with Army thinking while it had no stated or implied function under the State's strategy of cooperation with the British, while neither strategy was expressed in any form that might have clarified what constituted military air policy in time of war or emergency. The uncoordinated consideration and general indecision in the matter of the development of military aerodromes appears to have been indicative of the fundamental differences between the Government and the Army in terms of an overall defence policy. The state's emphasis on the development of Shannon and Dublin Airports while minimising expenditure on military aviation appears to confirm the government's continuing priority to be civil rather than military aviation - even in time of national emergency. 


\section{CHAPTER 8}

\section{GOVERNMENT DEFENCE STRATEGY AND \\ ANGLO IRISH COOPERATION, 1938 - 1943}

Though Colonel M.J. Costello had, as early as 1930, endeavoured to have the General Staff declare some form of air policy and indicate the nature of air resources likely to be raised for defensive purposes, the Army leadership could progress no further than accepting the broad principle that the Defence Forces should have an air corps - without any concept of what such an organisation might constitute. During the early 1930s the role implied by the organisation and aircraft was that of army aviation in support of ground forces. Costello brought the matter of air policy to the fore again in the context of the planning for the raising of a large conventional force in preparation for the defence of the country in the context of a European war. He envisaged that a force of ten squadrons could be deployed in the form of limited air power in support of a conventional defence of the state against external attack. This, the Costello plan of 21 March 1938, which was contingent on a significantly enlarged organisation, a broadened training programme and a major increase in spending on aircraft and other equipment, was not to materialise. The level of funding required, that realistically was never going to be approved by Finance, would have produced three operational squadrons with air force roles, if not status, and created a reserve structure to facilitate expansion to the required ten squadrons. When this plan was abandoned on Government instructions responsibility for planning for the Emergency devolved to Major P.A. Mulcahy. The organisation established, and resources acquired under Mulcahy's influence, though broadly based on the Costello proposals, fell well short of forming a viable air element. In effect, having earlier abandoned the role of army cooperation and later failing to equip and train adequately for future air force tasks, the Air Corps of late 1939 fell between two stools. At the same time the Minister for Defence appears to have reflected the government's indifference in the matter of military aviation by putting such preparations, except for the possible use of coastal patrols, in abeyance. In a similar manner to the reorganised corps of 1924 the Air Corps of 1939 was very much an inadequately manned, equipped and trained token force. 
Against the above background this chapter aims to identify the Government's strategy for the security of the state - a strategy that that was to dictate a minimalist approach to defensive preparation in terms of ground forces and that resulted in the establishment of a token military aviation element. This assessment will be done in the context of the assistance and advice gleaned from the British in 1938/39 that appears to have lead to the formulation of a largely passive defence strategy by de Valera's administration. The state's emergency strategy will be seen to place a premium on relatively passive defence measures such as intelligence and counter-intelligence, coast watching and air and naval intelligence and censorship measures which would appear to have been planned in a manner commensurate with the interests of the UK. Also to be examined is the manner in which the pre-war London / Dublin cooperation on defensive preparations translated into north / south military cooperation centred on the $18^{\text {th }}$ Military Mission during the Emergency. In a military aviation context the liaison activities of the UK air attaché and the extent of the cooperation given him by Col. P.A. Mulcahy will be examined in the context of the cooperative, though cautious, political and military atmosphere of the early years of the Emergency. While the Department of External Affairs closely monitored the inter-army contacts it will be suggested that the unofficial air attaché, appointed in early June 1940, appears to have been afforded great scope for an unknown level of intelligence activity in addition to his official liaison duties with the Air Corps

\section{Initial Anglo-Irish contacts}

From the time of the 1938 negotiation leading to the return of the Treaty ports the British maintained an ambition to have the use of these major naval anchorages in the event of war. ${ }^{\prime}$ As a result the period between the Anglo-Irish agreement of 1938 and the outbreak of war was marked by a considerable number of contacts, both in person and written, between the Irish and British administrations. Even though these contacts, on matters relating to defensive planning, were mainly at the level of senior civil servant as war approached military contacts also took place. At the time of the 1937 Imperial

\footnotetext{
' Robert Fisk, In time of war; Ireland, Ulster and the price of neutrality1939-45 (Dublin, 1984), p.40.
} 
Conference (14 May to 15 June 1937) UK ministers approved of talks being held with representatives of Eire, regarding food matters, on similar lines to those held with representatives of other dominions at the conference. ${ }^{2}$ Informal contacts appear to have started about November 1937 when some informal discussions took place between Sir Henry French and John Dulanty, the Irish high commissioner in London, and suggestions for talks between officials of the two Governments were incorporated in a note transmitted by Mr. Dulanty to the Eire government. The Dominions Office credited this, and a second note, with prompting de Valera to propose more formal discussions between the two governments. ${ }^{3}$ The DO quoted de Valera's communication of 24 November 1937:

This being the case, the government of Saorstat Eireann are [sic] satisfied that piecemeal discussion between civil servants on the economic and other aspects of the situation that would arise in the case of a major war can achieve no useful purpose until some prior understanding in principle has been reached between the two Governments. ${ }^{4}$

While the exact nature of the understanding reached is not indicated it appears that no substantive contacts took place until August 1938. As early as February 1938 however it had been indicated that discussions on matters of common defence interest would eventually involve contacts between military officers. On 9 February 1938 Joseph Walshe, secretary of the Department of External Affairs, reported that he had met with Sir H. Batterbee (UK Dominions Office) and three members of the Committee of Imperial Defence, Colonels Hollis and Lunn and Wing Commander Frazer, in London on 3 February. Referring to the three officers he stated that he found them cold and aloof and that they gave the impression that they were at the meeting because they had been ordered to do so and that they could not come to terms with the fact that they were no longer responsible for the defence of Ireland. 'I am earnestly hoping that when our

\footnotetext{
2 'Eire co-operation in defence matters', H.F. Batterbee to Sir Horace Wilson, 29 Aug. 1938 (NA, $\mathrm{CAB} / 104 / 23)$.

3 Secret DO memorandum, 'Eire and defence preparations', 3 Sept.1938 (NA, CAB/104/23).

${ }^{4}$ Ibid, quoting paragraph 5 of de Valera dispatch of 24 Nov. 1937.
} 
military colleagues meet these officers they will not have the same cause to freeze up as I had. $^{5}$

\section{Food supplies in time of war}

The high commissioner was, as a matter of course, in frequent contact with the Dominions office in particular. However the first meeting of departmental officials, on the broad subject of preparation for war, resulted from a secret memorandum concerning the supply of food and feeding stuffs to the United Kingdom in time of war. The memorandum from the UK Food (Defence Plans) Department had originally been received by External Affairs in November 1937 and was referred to Defence on 19 August 1938, following a query from Sir Henry French in July 1938, in effect reminding the Irish Government that no response had been made to his original note and asking whether suggestions made by him for a discussion were now acceptable. ${ }^{6}$ DEA, after this delay referred the matter to Defence:

The minister for External Affairs [Mr. de Valera] considers that a stage has been reached in our relations with Great Britain at which such informal conversations might take place he would accordingly be grateful if the minister for Defence would be good enough to appoint a representative or representatives of his department who would be ready to attend a discussion on this matter at a very early date with a view to holding the meeting suggested in the British memorandum. ${ }^{\text {? }}$

In referring the matter to Defence External Affairs pointed out that that it was the intention of the United Kingdom Government to establish complete control of imports and exports of the principal foodstuffs immediately on the outbreak of war and that that level of control in the UK would imply similar control in Eire owing to the country's position as an exporter of foodstuffs to Great Britain and as an importer of foodstuffs from that country. The tables that accompanied the British memorandum emphasised the

\footnotetext{
5 'Dear President', J.P. Walsh to E. de Valera, 9 Feb. 1938 (UCDA, de Valera papers, P150/2183)

${ }^{6}$ Sec DEA to Sec DOD, 19 Aug. 1938, quoting UK correspondence from Nov. 1937 (MA, S.49).

7 'Food supplies during time of war', Sec DEA to Sec DOD, 19 Aug. 1938 (MA, S. 49).
} 
latter point well. The first table, showed the total imports of certain principal foodstuffs and chief countries from which they had been imported. It quoted the average figures for the years 1933 and 1934 from Free State statistics. The figures indicated that the amounts of staple foods such as wheat, flour, maize, sugar, tea, coffee and other commodities and emphasised fact that the greater bulk came from or through Great Britain and Northern Ireland. The second table showed the average production and exports of the principal foodstuffs of the Irish Free State during the years 1933-35 and main countries to which it was sent. The second table was even more emphatic. It demonstrated the almost total dependence of the country on Britain and NI in terms of the exportation of foodstuffs of all types. The figures showed that between ninety and one hundred percent of Irish exports of such principal commodities as live animals (cattle, sheep and pigs), various meats, milk and other dairy products and other commodities were exported to Britain and Northern Ireland. ${ }^{8}$ External Affairs endorsed the British suggestion that an informal exchange of views should take place between officers of the Food (Defence Plans) Department and representatives of Ireland relating to the common interests of the two countries in Eire's imports and exports of food and foodstuffs. ${ }^{9}$ In the event, when the meeting took place ten days later Defence was not represented while the file on the matter closes with the nomination of the QMG and the contracts officer to represent DOD - suggesting that the Government treated the matter as a political rather than a defence issue.

At a meeting with Sir H.F. Batterbee on Saturday 27 August 1938 Dulanty indicated that de Valera was very concerned about the international situation and intended sending over three senior officers, Mr. Walshe, Mr. Leydon, and Mr. Twomey, to discuss co-operation in matter of control of foods in the context of a possible emergency. Dulanty stated that 'it was most important, of course that the visit should be kept most secret'. Dulanty also enquired about the possibility of his attending meetings of the Committee of Imperial Defence as an observer. He indicated that he had had some discussion on the matter with de Valera but had been given no formal instructions in the matter. Batterbee suggested that the request would most likely get favourable

\footnotetext{
8 Ibid.

${ }^{9}$ Ibid.
} 
consideration from the U.K. Government but that such a request should be initiated by de Valera. Batterbee understood that Mr. De Valera might personally be inclined to favour the proposal but that opposition was likely to come from Frank Aiken, minister of Defence. ${ }^{10}$ Batterbee felt sure that Lord Stanley would be in favour of all measures that would entice the Irish administration to take part in discussions on Commonwealth defence matters but that the matter was one for the Prime Minister. While there was much subsequent correspondence on this latter aspect and the British had no major objection it is not clear that Dulanty ever attended this important defence forum.

In the context of discussions on food plans Mr. MacLean, representing H.L. French, was exhorted to 'give the Eire representatives all the information possible and to do everything in his power to encourage further talks. ${ }^{11}$ On the following Monday, 29 August, two officials, Leydon, of the Department of Industry and Commerce and Twomey, of the Department of Agriculture, accompanied by Dulanty, attended a meeting in London with representatives of Food (Defence Plans) Department, the Board of Trade, Dominions Office and the CID. The Irish representatives asked a number of questions as to the plans of the Food Department and they were supplied with answers. Subsequently, at a meeting with the Food Department, Board of Trade, Petroleum Department and Ministry of Agriculture, the Irish representatives were given further information on United Kingdom plans for control of food and raw materials in time of war and also the proposed a scheme for the control of merchant shipping. ${ }^{12}$

In the absence of minutes indicating the specific questions that had been put by the Irish, or what precise information was given, it is not possible to assess the precise intent of the U.K government in the matter of food supplies. The meetings of late August 1938 and the correspondence dealing with Irish imports and production and exports of the mid-1930s, may have been intended to remind de Valera how greatly dependent the country was on food trade with the UK and how vulnerable the country was in so far as the UK could influence the importation and exportation by the IFS of food and food stuffs. Similarly the level of control of shipping that could be exercised by the UK in the event of war was possibly explained.

\footnotetext{
${ }^{10}$ Secret memorandum, H.F. Batterbee, 29 Aug. 1938 (NA, CAB 104/23).

"Sir Harry Batterbee to Sir Horace Wilson, 29 Aug. 1938 (NA, CAB 104/23).

12 Secret memorandum, 'Eire and defence preparations', 3 Sept. 1938 (NA, CAB 104/23).
} 


\section{Censorship}

About the same time the Irish Government had been involved in discussions on other aspects peripheral to defence policy. Acting on instructions of the government, conveyed by M. Moynihan, secretary to the Executive Council, T.J. Coyne, acting principal officer, Department of Justice, proceeded to London on 28 September 1938 to engage in discussions on censorship on behalf of the Department of Defence. A certain degree of urgency is indicated by the fact that the visit was arranged without the usual prior sanction of the Minister for Finance. ${ }^{13}$ In London T.J. Coyne had separate discussions with Major Stephenson representing the Controller of Posts and Telegraphs Censorship and with representatives of the Admiralty, Air Ministry, and Board of Trade. He introduced himself and outlined Eire's position on censorship:

At our first meeting I explained that the purpose of my visit was to ascertain, without prejudice to the decision that might eventually be arrived at (a) what measures the British authorities would like us to take in regard to censorship in Eire in the event of it becoming necessary to institute a general censorship in Great Britain as a result of an outbreak of war in which the United Kingdom was involved and (b) what the censorship policy of the United Kingdom was likely to be in time of war with regard to direct and transit 'closed' mails to and from this country. ${ }^{14}$

In regard to the first matter Coyne was informed that, in an emergency situation, Britain expected Eire to take censorship measures as close as possible to those that pertained in Great Britain. He was also informed that the British did not propose to exercise any censorship over mail going to, or coming from, third countries. Fundamentally the situation was that the War Office took the view that that censorship in Great Britain would be ineffective unless there were similar and compatible censorship arrangements in Eire. ${ }^{15}$

\footnotetext{
${ }^{13}$ Sec DOD to Sec DF, 15 Nov. 1938 (MA, S.67).

${ }^{14}$ T.J. Coyne to Sec DOD, 4 Oct. 1938 (MA, S.67).

${ }^{15} \mathrm{Ibid}$.
} 


\section{Petrol rationing}

Following the Munich crisis of September 1938 the U.K. Petroleum Department had correspondence and discussions with the Irish Department of Industry and Commerce as a result of which the Irish Government agreed that, in the event of war they would introduce a scheme for the rationing of motor spirit broadly the same as that pertaining in Great Britain. In September 1939 de Valera's Government also agreed to the transfer of seven tankers, which had been registered in Dublin, to the British flag. Subsequently, after only four weeks of petrol rationing, the Department of Supplies proposed that the level of rationing, that included a reduction of two thirds for private cars, was far too drastic. In a six-page submission the Irish department cited, amongst other affects, the fact that motor car assembly had practically closed down with the loss of 700 jobs and that the loss of revenue would amount to $£ 580,000$ per annum. This was the equivalent to seven pence in the pound on income tax. Also the garage industry had lost 1,600 jobs. It sought to have importation of motor spirit restored from about $66 \%$ of pre-war requirements to $90 \%$ of same.

The Petroleum Department noted that Eire was dependent on the UK for oil supplies and, thought it was not obliged to do so, that Eire had sought the approval of H.M. government for the introduction of rationing on a reduced scale. It was considered that, as a deteriorating tanker situation had caused the depletion of UK stocks that these had to be made good rather than being further depleted. It was also felt necessary to maintain the principle whereby all countries of the Empire should share the sacrifice equally. Citing also the foreign exchange implication of oil purchase the Petroleum Department advised against a reduction in rationing in Eire. The Treasury agreed with the latter reason for rejection. While a final decision is not reflected in the correspondence a draft response advised discussion on the matter with a compromise level of rationing in mind while recognising the Eire Government's difficulties and emphasising those of Britain. ${ }^{16}$ Subsequent comment indicating that "the petrol ration for those involved in essential services was miserly' and that 'for the ordinary citizen it was

\footnotetext{
${ }^{10}$ Department of Supplies, Dublin to Petroleum Department, 17 Nov. 1939; Petroleum Department to DO, 22 Dec. 1939; Treasury to DO, 5 Jan. 1940; DO draft memo, 16 Jan. 1940 (NA, DO 35/1067/4).
} 
non-existent' would suggest that Britain did not compromise. ${ }^{17}$ It might be considered that de Valera's government had been a bit hasty and naïve in agreeing to the same scale of rationing as the UK without knowing exactly what was entailed. Similarly the handing over of control of tankers at such a critical juncture appears naïve. However given the economic control available to Britain de Valera probably had no alternative.

\section{Preparations for war and intelligence contacts}

A significant aspect of the contacts between the British and Irish, coordinated by the high commissioner, was a request from the Department of Foreign Affairs for various British papers, documents, memoranda and progress reports regarding preparations for war. This request was prompted by the receipt, by the Irish Government, of two documents relating to British emergency legislation and by informal contacts between Dulanty and the South African representatives in London through which Dulanty became aware that the other Dominions were in receipt of information and guidance that was not available to the Irish Free State. On 30 August 1938 Joseph Walshe was in London and forwarded a letter for Sir Harry Batterbee in which he asked that the Irish government be supplied with copies of the Government War Book, the third report of the War Emergency Legislation Committee and eight other secret or highly confidential documents or reports relating to contingency planning for war. He also requested copies of all defence documents that had already been supplied to Canada and South Africa. He also requested documents dealing with air raid precautions, censorship and espionage. ${ }^{18}$ Later the same day Walshe approached Major General Ismay of the CID, who had been forewarned about the request for documents, on the said matter. Batterbee and Ismay subsequently exchanged notes on what was obviously a very sensitive issue. Ismay had pretended to Walshe that he was not aware that Walshe had already made a request to Batterbee 'for a cartload of promiscuous documents'. He explained his approach to the problem:

\footnotetext{
${ }^{17}$ Bernard Share, The emergency; neutral Ireland, 1939-45 (Dublin, 1987), p. 55.

18 J.P. Walshe to H.F. Batterbee, 30 Aug. 1939 (NA, CAB 104/23).
} 
.... But I think I persuaded him that the Eire authorities ought to give a good deal of consideration to the precise problems which they wished to study before embarking on a wholesale collection of documents, many of which it would merely be a waste of their time to read. ${ }^{19}$

Ismay had explained to Walshe that the UK's defensive preparations were of a much larger range and scope than those of Eire and had been built up over a considerable period years. He suggested that the Eire authorities should concentrate on essentials such as coastal defence, counter espionage, protection of vulnerable points, censorship, food supply and distribution, fuel supply and distribution, and war emergency legislation. In accepting this explanation Walshe asked for further advice as to how best to choose the documents pertinent to his government's requirements. Ismay suggested that firstly the UK might give the Eire defence authorities a general idea of the field covered by UK defensive preparation and secondly that the Eire authorities might decide which particular aspects of the wider defence problem they required to study. The third and final step suggested was a consultation process on an Irish provisional list of documents followed by the supply of selected relevant material. This approach met with Walshe's approval and, 'as a very special favour' he was given 'a copy of the preface and table of contents of the Government War Book'. He did not get the latest document, which included reference to a very secret emergency scheme which had just been formulated, but the previous and less sensitive edition. Inskip and Batterbee understood from Walshe that it was because they had previously sent certain CID documents that de Velera had sent officials to London to discuss the food plans and other aspects of co-operation. As a result they considered that Britain had a better chance of securing de Valera's full cooperation by displaying the maximum confidence in him by giving him an insight into the preparations necessary for war. ${ }^{20}$

Counter-espionage was a particular defensive aspect that Colonel Ismay recommended to Mr. Walshe, who in turn indicated to Batterbee that it was a matter that he would like to tackle immediately. On 31 August 1938 a meeting on this matter was

\footnotetext{
${ }^{19}$ Maj. Gen. Ismay to H.F. Batterbee, 30 Aug. 1938 (NA, CAB/104/23).

${ }^{20}$ Ibid.
} 
held at the High Commissioner's office where Dulanty and Walshe had discussions with Capt. Guy Liddell, head of counter-espionage in MI5 throughout the war. While details of this meeting are not available Capt. Liddell is recorded as preparing a memorandum that reflected that the discussions had been very satisfactory and indicated a desire on the part of the Irish authorities to co-operate fully with the intelligence agencies in Britain. ${ }^{21}$

In early September 1938 de Valera himself was in London and had separate discussions with Sir Thomas Inskip, the British Attorney General, and the Duke of Devonshire of the Dominions Office. If he was concerned about the progress of various secret or confidential meetings that his officials were having with representatives of several different government departments he did not reveal it and appears not to have referred to the broad defensive and military considerations that were being explored on his behalf about that time. In fact he appears to have ignored military and defensive matters while confining his attentions to the broad political aspects relating to the relationship between Eire and the UK Government vis-à-vis partition and the six counties of Northern Ireland. British accounts of discussions with de Valera on 8 September 1938 indicate that de Valera had been offered a copy of the war book, a secret manual of instructions for the military authorities in the preparation for the outbreak of hostilities. De Valera is reported as being reluctant to accept the offer because its scope was unnecessarily wide for Eire and because he was not very anxious to have a document which it was important to keep secret. He also indicated that he was very much in the dark about how the limited resources at his disposal could be best used. Inskip expressed the opinion that if the UK became involved in war de Valera was sure that the first instinct of the government of Eire would be to keep out of it. ${ }^{22}$

This account of de Valera's reported attitude to the matter of the war book is not consistent with the position indicated by Walshe's written request, for copies of a considerable number of sensitive documents including the war book, made just nine day earlier. Assuming, as we must, that Walshe, on 30 August 1938, was acting on the instructions of de Valera the position indicated in Inskip's report of his conversation with de Valera suggests that Irish prime minister may have wished to distance himself totally

\footnotetext{
${ }^{21}$ DO memorandum, 'Eire and defence preparations', 3 Sept. 1938 (NA, CAB 104/24); Eunan O'Halpin, (ed.) MI5 and Ireland, 1939-1945; the official history (Dublin, 2003), p. 22.

Fisk, In time of war, p. 69, citing minutes of Inskip / de Valera meeting, 8 Sept. 1938 (NA, FO 800/310).
} 
from purely military and defensive considerations, concentrating on political matters safe in the knowledge that his Government departments, particularly External Affairs, had such aspects under control. An alternative interpretation, to the effect that his departmental secretary was acting on his own initiative, would suggest engagement with the British, on sensitive military matters, that had no political authorisation. Whatever the true position it is curious that two British files referring to such a sensitive matter should reflect such conflicting positions vis-à-vis war planning documents, a matter central to the discussions between the two countries and central to the Eire's preparation for the expected emergency.

Following the meeting of 8 September with de Valera the CID was still anxious to progress the matter of the defended ports and suggested that de Valera be asked to 'authorise immediately the dispatch of the necessary defence experts to discuss this question with the appropriate experts here'.

It is understood that in accordance with arrangements previously discussed, it is contemplated that it would be possible to arrange that civilian experts should come from Dublin to London to consult with the appropriate authorities here as to defence measures.... ${ }^{23}$

The British also indicated that they would welcome the attendance of Defences Forces experts in London but recognized that the express authority, from de Valera, who was then in Geneva, would be required. ${ }^{24}$ However with de Valera unavailable contacts between Eire and the United Kingdom did continue. On Thursday 15 September 1938 the high commissioner and General Ismay of the CID discussed various defensive matters. Dulanty reported that the table of contents of the war book had been given to the authorities in Dublin and that they had made known the selection of the UK's most recent papers that they wished to study. Ismay indicated that copies of documents, dealing with the Oil Board, the Principle supply officers committee and censorship and so forth, that dealt with the problems that would be of interest to Eire, had been put aside. It was

\footnotetext{
${ }^{23}$ Memorandum, circa 8 Sept. 1938 (NA, CAB 104/23).

24 Ibid.
} 
suggested that the Eire authorities were welcome to these reports but that they would 'merely find them confusing, since they would be in the position of a layman (I expressed this as tactfully as I could), who was presented with the last chapter of a technical treatise without any explanation of the basis'. He explained further:

I suggested that it would be most useful for the Eire authorities to know the general principles on which our scheme had been prepared: in other words what they should have was not the most recent progress reports but ... some of them at least 10 years old. $^{25}$

Ismay showed Dulanty some more recent reports so that the latter could be convinced, and appreciate, that such documents were not relevant to the rudimentary state of Irish preparations for war. Dulanty agreed that the older documents and papers would be more appropriate and was given copies. While Ismay and his colleagues were trying to ensure the cooperation of the de Valera administration the tone and content of the record of the British position vis-à-vis Irish knowledge of UK defensive matters makes it obvious that they did not trust the Irish with details of the most up to date information.

Dulanty said that he would show the papers to the Staff in Dublin, and that he would then like to bring one or two military officers to London to discuss them in the context of their relevance to the Irish situation. It was suggested by Ismay that departmental officials had a large part to play in early preparations for war. In response to Ismay's query, as to what Irish government departments might be represented at meetings to start with one at the Committee of Imperial Defence, Dulanty indicated that representatives the Department of Justice and the secretary to the cabinet might be sent over.

In the course of our conversation, Mr. Dulanty told me in confidence that we would find Irish military officers and civilian officials very anxious for full co-operation with us, but that the minister for Defence was just the other way, and would

\footnotetext{
${ }^{25}$ Secret memorandum, 15 Sept. 1938 (NA, CAB/104/23).
} 
probably be critical of Mr. de Valera for having been too forthcoming in these matters. ${ }^{26}$

On his return from Geneva de Valera apparently gave authority for further contacts on defence matters. On 11 and 12th October 1938 John Dulanty and Joseph Walshe held a general discussion on the defence of Eire with representatives of the CID and of the Dominion Office in London who made a summary report:

Mr. De Valera.... is very interested in defence matters. The discussions were very rambling since the delegates had no specific questions they wanted to put, but they seemed to find the talks useful in bringing to their notice all the new problems and points of view which had obviously never occurred to them before. Mr. Walshe had not studied defence at all, it seems to see, but he is clearly most anxious to get their whole defence arrangements put on a proper footing. He repeatedly emphasised that the whole basis of their preparations would be that they would co-operate with us.

I gathered that their military authorities had never thought out the defence problem at all. They have carried on with a small land force, organised for a purpose which they are not quite clear about themselves, ever since the I.R.A. rebellion was repressed after the truce in 1922. Now some of their people are approaching the problem of providing defences for the country rather like a boy buying firecrackers. They think it would be nice to have a packet of this and a packet of that, but for what purpose they are not quite clear. ${ }^{27}$

From an Irish point of view the main aim of the discussions was to assure the British that de Valera was proposing co-operation and that, in the event of hostilities, Eire would be most likely to fight in support of the United Kingdom rather than against. The discussions provided the Irish delegates with much advice on the preparations necessary for war. It

\footnotetext{
26 Ibid.

${ }^{27}$ Unsigned 'Note of discussion on defence with Mr. Dulanty and Mr. Walshe on $11^{\text {th }}$ and $12^{\text {th }}$ October $1938^{\prime}, 13$ Oct. 1938 (NA, CAB 104/23).
} 
was suggested that the Irish formulate their defensive ideas in a memorandum taking Chapters I and II of the Instructions for the preparation of defence schemes as a guide.

The question of advice and help to them was discussed between us a great deal. They asked me to give my frank opinion as to the best way in which they could use our offered help. I told them that the best way would probably be to as New Zealand, for example, had done, and for them to take a loan of one or two officers from us to help them through their early stages. .....Mr. Walshe thought it would not be at all impossible to "smuggle in" one of our experts for a while to help them, but he did not go into the matter in detail at all. ${ }^{28}$

The CID suggested that alternatively Irish defence experts should come over to London for discussions but should have their defence problems formulated and on paper before hand. Arising out of the meetings the UK representatives formed opinions about the Irish military:

This [latter] topic led to the question of their senior serving officers. Practically none of these men are of any education at all. I gathered that the brightest of them was a man called [M.J.] Costello, who has some military training in America. He is about 35 , but might not, for political reasons, rise to the highest positions of responsibility in the army. Mr. Walshe told me that some of their younger officers, aged about 28-30 were of good education....It is quite clear that the outlook of the defence services in Eire at present is really that of the guerrilla leaders who are still their backbone. ${ }^{29}$

It is considered that there was more to the meetings of the $11 / 12$ October 1938 than is reflected in the four-page report subsequently placed on a secret cabinet file. The tone and content suggest that the thoughts of someone other than Walshe and Dulanty are reflected in the summary. Walshe struck the British as being uninformed in military matters while Dulanty, based in London, might be considered well removed from military

\footnotetext{
${ }^{28}$ Ibid.

${ }^{29}$ Ibid.
} 
matters also. It is considered that the recorded insights into Irish military matters, particularly to the fundamental military ideology of guerrilla leaders, may have come from an Irish military source. It is suggested that this possible military source, who might have represented the guerrilla ideology of yore, was Colonel Liam Archer. Contemporary records indicate that Archer went to London on 10 October 1938, and place him there, not just for the two days in question, but also for 13 October, and indicate that he returned to Dublin on the 14 October 1938. DOD had requested Finance as follows:

I am directed by the minister for Defence to state that, on the instructions of the Taoiseach, Colonel Liam Archer proceeded to London at very short notice on two occasions recently on business of a confidential nature. The periods of the visits were from the $10^{\text {th }}$ to the $14^{\text {th }}$ October 1938 and from the $4^{\text {th }}$ to $6^{\text {th }}$ ultimo. ${ }^{30}$

It is significant that Archer was in London, on the days of the defence discussions, on de Valera's authority and acting on his specific instructions. Published accounts of the events of the period suggest that Archer's discussions and contacts with UK officials were solely in relation to intelligence and counter intelligence matters. ${ }^{31}$ However attendance at such meetings would not necessarily preclude his attendance at informal meeting, also attended by Walshe and Dulanty, on the periphery of defence related discussions. In the context of discussions on Irish defence matters, where the main Irish delegates were not fully au fait with military matters, it would appear desirable that a senior military officer be available. While Archer's main preoccupation may have been related to intelligence matters he may well have had a broader brief from de Valera and, though not attending formal meeting, may have acted as a military advisor at informal discussions. A subsequent summary report by Archer, dealing with the general subject of cooperation with the UK during the Emergency, while it does not relate to this particular period, suggests that Archer was the main go-between in the context of north - south

\footnotetext{
${ }^{30} \mathrm{Sec}$ DOD to Sec DF, 10 Dec. 1938 (NAI, DF, S.105/0048/38).

${ }^{31}$ E. O'Halpin (ed.) MI5 and Ireland. 1939-1945; the official history,(Dublin, 2003) passim ; Nigel West (ed.), The Guy Liddell diaries, Vol. I : 1939-1942 (Abingdon, 2005), passim.
} 
military cooperation from 1940 to $1945 .{ }^{32}$ While it is possible that Archer only met UK intelligence personnel in October 1938 it is considered most unlikely that he would be in London on the particular days and not represent de Valera's views in the context of the military aspects of preparation for war and Anglo-Irish military co-operation.

Possibly the last contacts between the Irish and British in the latter part of 1938 was the second visit to London, from 4 to 6 of November1938, made by Col. Liam Archer. He was again acting on de Valera's instructions. ${ }^{33}$ While the specific purpose of this visit is unknown, Archer may have been sent to discuss some more specific aspects of defence applying to Eire, as suggested by the British at the meetings of 11/12 October. It is, however, equally possible that he was engaged on intelligence business. Archer's last known pre-war visit to London took place as late as 25 August 1939. He was engaged on similar confidential business as that authorised by de Valera in October and November $1938 .^{34}$ While the nature of his latest duty in London is not known, it may be no coincidence that within days of the visit, on 30 August 1939, a detachment of Air Corps personnel and aircraft was dispatched to Rineanna (Shannon) without notice, planning or preparation. The specific, though unrecorded, mission of this detachment was the patrolling of the south and west coasts in an intelligence role. ${ }^{35}$ It is not clear whether this precipitous action was taken as a result of a British request, initially to Archer, or represented a gesture on the part of de Valera to replace the maritime intelligence value of the treaty ports.

\section{Military contacts}

Mention of one of the earliest and most unusual Anglo Irish military contacts, some time in 1937, comes from the biography of an Irish officer who had served with the RAF:

\footnotetext{
32. 'Summary of contacts with foreign armies, British - Irish military relations and contacts', Col. L. Archer, circa March 1944 (MA, SCS/14). (Hereafter 'Archer summary')

${ }^{33}$ Sec DOD to Sec DF, 10 Dec. 1938 (NAI, DF, S.105/0048/38).

${ }^{34}$ Sec DOD to Sec DF, 30 Sept. 1939 (NAI, DF, S. 105/0048/38).

${ }^{35}$ Capt. W.J. Keane to OC S. Comd., 12 April 1940, Appendix No. XXII, Report and findings of the committee, 10 Jan. 1942 (MA, ACS 22/23).
} 
I don't know whether it would be a good thing to mention a visit of an Irish Republican Air Force squash team to play the Aldergrove team. It was certainly a great success from a liaison point of view. It paved the way for a welcome for Aldergrove officers going down to Dublin for international rugby matches. ${ }^{36}$

While this visit is not mentioned elsewhere there is no reason to doubt that it took place. Such contact, at a sporting level in the mid-1930s, does seem unusual. In all probability Major P.A. Mulcahy was on the Air Corps team. Squash, which he took up on being posted to Baldonnell, was apparently about the only thing he had in common with the flying officers of the Air Corps. ${ }^{37}$

Archer's meetings with British officials were not the only official and confidential contacts between the two countries at a military level in the pre-war months. On 26 April 1939 Major Sullivan (Army) and Commandant W.P. Delamere (Air Corps) accompanied by the two senior engineers of the Post Office, Monaghan and O'Neill, visited London. They were received by Squadron Leader McEvoy of the Air Ministry and attended a meeting held at G.P.O. Headquarters, in the context of the proposed inclusion of Eire in the U.K. Air Raid Warning System.

Major Sullivan explained that along the eastern coast of Eire, to a depth not yet decided fighter sectors and observer groups would be set up on the English model and air raid warning districts also would be established. The personnel for the observer groups would be drawn from the civil guard [sic] which would also be responsible for those duties in connection with air raid warnings which in the United Kingdom are performed by the chief constables. The Irish fighter command would be near Dublin and would be equivalent in status to a fighter group in this country. ${ }^{38}$

\footnotetext{
${ }^{36}$ Doug Stokes, Wings aflame; the biography of Group Captain Victor Beamish DSO and bar, DFC, AFC (London, 1985), p. 56.

${ }^{37}$ Personal comment, the late Lt. Col. P. O'Sullivan; Appreciation by Col. C.M. Mattimoe in An Cosantoir Ixvii, no. 5 (May 1987), p. 22.

38 'Extract from G.P.O. file', 30 May 1939 (NA, Air 2/5129).
} 
The question of obtaining efficiency in observer communications was discussed at length on the basis that UK practices would suit Eire just as well. However the small number of telephone lines and the prevalence of many two-line and three-line telephone exchanges throughout Ireland were identified as being detrimental to efficiency. In order to append the proposed Irish system, which should consist of about four or five warning districts, to the English system and still leave the Irish system in Irish control, it was proposed that only Dublin should receive warning messages issued from Fighter Command RAF. The Irish representatives promised to contact the UK representatives when the number and layout of warning districts in Eire was known. ${ }^{39}$ In the event an Irish air raid warning system of the kind envisaged was not put in place and therefore not connected to its British equivalent.

In July 1938, following a visit to London in connection with the purchase of aircraft, Major P.A. Mulcahy had recommended to GHQ that authority should be sought for flying officers to visit RAF and civil flying schools. While outline financial sanction had been received on 10 September 1938 he considered that it necessary to confirm the sanction and complete the visit well in advance of the start of the training of the short service commission pilots'. ${ }^{40}$ The visit eventually took place between 4 and 14 February 1939. The two officers, Capt. W.P. Delamere (who was promoted commandant on 6 April 1939) and Lieut. K.T. Curran, concentrated on elementary, intermediate and advanced training schools and subsequently briefly visited two operational squadrons. During their two day visit to the de Haviland Elementary Flying Training School they were briefed by the chief flying instructor on the latest instructional methods and flying techniques employed in $a b$ initio training. They observed flying training in progress and noted the use of the Link trainer, at a very early stage of the fifty hour course, as an introduction to instrument flying. Before proceeding to the intermediate school they were supplied with copies of several official publications and instructional notes.

That evening, on arrival at Stow-on-the-Wold they were met by a squadron leader and the CO's car. They were driven to Little Risslington where a special meal was provided in the Officers' Mess at 22.00 hours. Once more the CFI was their host on their

\footnotetext{
${ }^{39}$ Ibid.

${ }^{40} \mathrm{OC}$ AC to COS, 18 Nov. 1938 (MA, AC/2/6/16).
} 
two day visit to No. 6 Flying Training School. This intermediate squadron had forty-eight pupils, divided into three squads, for a fifty hour flying course. The major emphasis was on instrument flying and the use of a Link trainer while cross countries flights of up to 200 miles were also important. The two officers had a discussion with Group Captain ab Ellis on matters concerning RAF training and on the proposed Air Corps short service course. The group captain considered the Link trainer to be the best piece of instructional equipment ever invented. ${ }^{41} \mathrm{He}$ arranged for the supply of all publications, notes and orders that could be spared. At the same station Squadron Leader Day conducted a visit to the Advanced Training Squadron where pupils arrived with 100 hours flying and completed a further fifty. The emphasis was on camera-gun flying practice, photography, navigation and night flying - all in preparation for the gunnery and live bombing of the last fortnight of the course. They concluded their visit with a review of ground instruction facilities and the ground aids to air gunnery training. The visiting officers were duly impressed with their reception:

A point of interest at this station was the fact that our whole trip appeared to have been carefully organized. No time was lost going from one place to another, and each officer picked us up in turn and appeared quite prepared to give us any information we asked for. ${ }^{42}$

While the above comment was relevant to their reception at training establishments similar comment could not have been made about their visits to two operational squadrons. Having arrived there the previous night Delamere and Curran visited RAF Tangmere at 09.00 hours on 13 February 1939. The station commander, Group Captain F. Sowery, and OC No. 43 Fighter Squadron were not available. The report indicates that they got a perfunctory overview of 43 Squadron, conducted by Flying Officer Hull, during the morning. The squadron, that had eighteen Hurricane I aircraft, concentrated on

\footnotetext{
${ }^{41}$ The Link was the first instrument and radio aid synthetic trainer. Originally invented in the US in 1929 the first Link trainers arrived in the UK in 1936. One was installed in Baldonnell in 1940 and another in Rineanna the following year. See Rosina Brown, 'Finding the missing Link' in Aeroplane, 1 Sept. 2004, pp 85-8.

42 'Report of visit to RAF training establishments', Capt. W.P. Delamere and Lieut. K.T. Curran to OC AC, 17 Feb. 1939 (MA, AC 2/6/16).
} 
initial and advanced training of fighter pilots, instrument flying and air firing while a Link trainer was also in use. The squadron pilots were forbidden to perform aerobatics presumably to prolong the fatigue life of the aircraft. It was noted that the aircraft were equipped with radio telephony and oxygen.

In the afternoon they visited No. 217 Squadron and again, in the absence of the squadron commander, were conducted around by a junior officer, Flying Officer Bool. No. 217 General Reconnaissance Squadron had twenty-four Avro Anson I aircraft but was due to be equipped with Lockheed Hudsons. The most interesting comment was to the effect $75 \%$ of the squadrons training was in navigation. To this end they had a fully qualified navigation officer on the strength of the unit. They also commented on the youth of the flight commanders who, with about two years squadron service appeared to responsible for the whole training of the younger pilots.

It is notable, from the tone and content of the report, that Delamere and Curran got first class attention from the senior personnel of the training establishments. As well as getting detailed briefings and considerable insight into the business of flying training, they were supplied with all manner of relevant publications, manuals and instructional material. By way of contrast their visits to two operational squadrons at Tangmere, admittedly of secondary importance to the staff of a flying school, were conducted in a single day and while they gleaned some very important information they were only afforded an overview of the workings of operational squadrons by more junior personnel. While the unavailability of more senior personnel may have been a coincidence it may have been a manifestation of the reserve and confidentiality observed by the Air Ministry and the RAF where current operational matters were concerned. Subsequently, despite the representations of the High Commissioner it was not possible to obtain copies of manuals, such as Tactics of shore based aircraft and Air fighting tactics, dealing with operational matters. $^{43}$

\footnotetext{
${ }^{43}$ Ibid. James J. Halley records that Ansons remained in service with No. 217 Squadron until December 1940 when they were replaced by Beaufort I aircraft.
} 


\section{Government defence strategy}

As early as 6 September 1938 de Valera had initiated action that suggests that he was formulating what could be interpreted as a broad defensive strategy. He proposed to "the government for consideration the question of measures which it is necessary to take in preparation for the eventuality of a European war'. He suggested that 'among the matters that would require immediate attention in the event of war' were the following.

1. Supplies of food and other essential commodities and the regulation of external trade.

2. Censorship, counter-espionage, control of communications and publicity.

3. Coast watching.

4. Financial and monetary policy

5. Control of transport.

6. Military measures.

7. Air Raid precautions.

8. Protection of vulnerable points, such as Government Buildings, the Shannon Hydro-Electric Works, etc.

9. Alternative accommodation for Government and staffs.

10. The safeguarding of important documents.

11. The safeguarding of works of art, etc.

12. Legislation. ${ }^{44}$

In the context of ongoing discussions between the two countries one is struck by the similarity between the listed defensive measures or planning areas and the titles of UK planning documents (as requested by Walshe) and the particular war plans subjects on which Walshe had been advised Eire should concentrate. ${ }^{45}$ This similarity assumes greater significance when one examines the history of the Emergency and reviews the actual 'Emergency' measures taken by de Valera and Aiken. In the context of that history

\footnotetext{
44 'Memorandum for the Government', 6 Sept. 1938 (NAI, DT, S.10823).

${ }^{45}$ J.P. Walshe to H.F. Batterbee, 30 Aug. 1938; Ismay to Batterbee, 30 Aug. 1938 (NA, CAB 104/23).
} 
it is suggested that the above memorandum, in effect, constituted Government strategy for the period and that the contacts, advice and the various official publications received from the UK greatly influenced and informed that strategy.

de Valera placed greatest emphasis in the first three preparatory measures. He suggested that it was very urgent that emergency legislation and regulation should be drafted so as to enable the government to deal with a war situation. In the context of subsequent emphasis on various intelligence aspects, including a substantial level of military cooperation with the UK during the emergency, and of the government's relatively lowly opinion of military measures it could be concluded that that this particular memorandum, in effect, constituted the government's defence strategy. De Valera proposed that it was necessary to consider whether the general supervision of the preparatory measures should be entrusted to a committee of government or to a committee of heads of departments who would act as a general co-ordinating and supervising body responsible to the government or a government committee. In recommending that one committee should consist of the secretaries of the Departments of Agriculture, Defence, External Affairs, Finance, Industry and Commerce and An Taoiseach, he suggested that the first task would be to arrange the preparation of an emergency book of instructions as to the steps to be taken by the various departments in an emergency. While a committee of heads of departments would carry out planning, coordinating and supervisory functions the executive functions would fall to the existing departments of State. ${ }^{46}$

It is of considerable interest to note the three strategic areas on which de Valera placed greatest importance. On the other hand the placing of the matter of military measures at number six would suggest that given the spirit of cooperation between the two countries, purely military defensive matters were not of paramount importance. The most intriguing subject on the list - at number three - was the matter of coast watching. Not only was it considered to be of major importance but apparently was not considered a defensive or military measure. In terms of the complete defence of an island state it might have been considered that coast watching was an essential aspect of early warning of

\footnotetext{
${ }^{46}$ Ibid.
} 
invasion and essentially defensive in character. In this particular case, as will be seen later, the term had a different connotation. (See Chapter 10)

\section{Wartime military cooperation}

While the very public antagonism between de Valera and Churchill might suggest that the state was totally at odds with the UK throughout the Emergency it is now generally recognised that there was a considerable degree of cooperation, particularly between the respective headquarters staffs at Dublin and Belfast. During the pre-war phase of cooperation the important contacts were at senior civil servant level while the wartime contacts and coordination were to be predominantly military to military. The bones of this cooperation are laid bare by Col. Liam Archer in his 'summary of contacts with foreign armies'. However, being equally economical with word and fact, this report had to be revised and expanded upon in 1947 so that the post-war Army leadership could understand what actually had gone on. Archer observed that liaison had existed between the British War Office and GHQ on security and counter-espionage matters from September 1938 and that a British naval attaché had been appointed as early as October 1939. The Childers report cites the first military to military contacts in the context of the perceived threat of invasion following the then recent German invasion of Holland and Belgium:

On 23 May 1940, Colonel Archer and Mr. Joseph Walsh .was [sic] sent to London to make contact with the British War Office in order to discuss with the British authorities steps to co-ordinate our respective defence measures against a German invasion of Ireland'. ${ }^{47}$

The report went on to outline the visit of Archer and Walshe to London, their arrival into a conference at the Dominions Office being attended by senior officers of the British Army, Navy and Air Force and the resultant visit to Government Buildings in Dublin of

\footnotetext{
${ }^{17}$ Archer summary, circa March 1944, (MA, SCS/14); 'Notes on the origin and development of contacts with British Army 1940-1945', Lt. Col. R.A. Childers, 17 Oct. 1947 (MA, SCS/1). (Hereafter 'Childers report').
} 
Col. Clarke and two other British officers on 24 May $1940 .{ }^{48}$ While the above is the official Irish account contemporary records suggest that Archer may have been in the UK for some time prior to the DO meeting of 23 May 1940. On 20 May 1940 Cecil Liddell, head of the Irish section of MI5 reported to the CID on events:

I have written to Archer as you suggested. In the meantime you may perhaps care to know what moves have been made recently. After the meeting the other day which Sir Vernon Kell attended, I saw Walsh[e] at Dulanty's office. He was quite unacquainted with the [illicit] wireless [interception] situation and asked me to discuss it with Archer when I saw him at Droitwich where he was undergoing a cure. $^{49}$

At about five o'clock on 15 May 1940 Cecil and Guy Liddell arrived at Droitwich and met Archer at his clinic. While they had intended discussing wireless related matters the invasion of Holland had brought to their attention the possibility of something similar happening in Eire. Arising from their concerns and encouraged by Archer's positive reaction to the suggestion of some form of staff talks in case existing Irish forces proved to be inadequate in an invasion situation, the Liddell brothers brought the idea of military staff talks to the Dominions Office. There they were informed that the two governments had been thinking along similar lines. ${ }^{50}$ Arising from the military discussions, in London on 23 May and in Dublin on 24 and 25 May 1940 liaison contact between the military, north and south was initiated on a quite informal basis. The Army's meetings with their northern counterparts were closely monitored by civil servants while some more sensitive matters were referred for ministerial approval. ${ }^{51}$

A major aspect of the cooperation was the completion of a series of questionnaires provided by the British. The first concerned the technical aspects of the

\footnotetext{
48 Ibid. See also R. Fisk, In time of war, pp 233-36.

${ }^{49}$ Cecil Liddell to CID, 20 May 1940 (NA, CAB 104/184); O'Halpin, MI5 and Ireland, p.53. A file in Military Archives that is catalogued as 'not open to the public', DOD '2/92140, Medical treatment, engagement of Dr. T.J. O'Reilly in the case of Col. Liam Archer and others', suggests that Archer may not have been the only officer undergoing some form of cure, apparently at public expense, during the Emergency.

${ }^{50}$ Cecil Liddell to CID, 20 May 1940 (NA, CAB 104/184); West, The Guy Liddell diaries, p. 79.

${ }^{31}$ Archer summary, Mar 1944 (MA, SCS/14); Childers report, 17 Oct. 1947 (MA, SCS/1).
} 
wireless broadcasts carrying details of foreign aircraft movements as reported by Air Defence Command. A report accompanying a copy of the first completed questionnaire suggests that the meeting of 25 May 1940 concentrated on providing Squadron Leader Potter of Aldergrove with aeronautical information on Baldonnell, Collinstown and Foynes and other locations suitable for the operation of aircraft. It also provided armament and wireless details relating to Walrus, Anson, Lysander and Gladiator aircraft. The details provided on Foynes actually pertained to the Air Corps station at Rineanna. The Irish representatives, Gen. McKenna and Col Archer, were unable to provide much detail without consulting others by telephone - a process that prolonged the Saturday afternoon meeting. British were informed that Baldonnell was fully equipped but, with due cause, were sceptical. At that time the British had every right to be sceptical about Baldonnell as an airfield for possible use by modern fighter aircraft. Air defence consisted of the machine gun posts only just being installed. There was no anti-aircraft artillery while half the aerodrome was permanently staked to discourage aircraft landing. Communication with aircraft was by wireless telegraphy only. ${ }^{52}$ Aspects not noted include the absence of hard surface runways while the small area of the aerodrome would have precluded the dispersal of aircraft. It had no meteorological station or even a remote-reading anemometer. The most glaring inadequacy was the absence of a direction finding service for military aircraft.

Subsequent questionnaires concerned the organisation, disposition and equipment of the Defence Forces as well as details of communications, infrastructure and resources and other strategic considerations. The return of a completed questionnaire was occasionally delayed until political approval was given on matters the Army considered to be politically sensitive. Childers observed on the care taken when supplying military information to the UK:

The answers were to be supplied on un-crested paper and were to be related to the questions only by paragraph number. Every care was to be taken that in the event of their capture by the Germans, their actual origin could not be proved. ${ }^{53}$

\footnotetext{
52 'Report re movements on 25. 5. 40', 27 June 1940; 'Report No. 1', 11 June 1940 (NA, Air 2/5129).

53 'First questionnaire on plans for aid', Childers report, 17 Oct. 1947 (MA, SCS/1).
} 
The chronology apparent in the layout of the Childers report suggests that the first real staff conferences involving the two armies took place in June and July 1940. The first was at Headquarters British Troops Northern Ireland on 3-5 June and the second in the Irish Army's Plans and Operations Branch on $1-3$ July. The conferences agreed a plan for the evacuation of Dublin, a plan for military routes to be used by the British Army in a move southwards and many important aspects relating to a combined defence against a German invasion of Eire.

The most valuable outcome was undoubtedly the fact that for the first time the two staffs had sat down together to consider a joint problem. They had opportunities also, of informal talks together during reconnaissance and over meals. ${ }^{54}$

Notwithstanding the exchange of military papers relationships between the military forces north and south were somewhat fraught during the spring and early summer of 1941. This reflected the lack of trust at Government level and was exacerbated by the presence of at least one representative of External Affairs at military staff meetings in Dublin. Fundamentally the level of military cooperation was restricted by a reserved and cautious approach insisted upon by the Irish Government. In addition the Irish Army felt that the British refusal to supply armaments was based more the necessity to keep the Army weak due to distrust of de Valera rather than on an inability to supply. ${ }^{55}$ Two aspects of the north / south cooperation took more tangible forms. At Carton House, Maynooth a dump of 250,000 gallons of motor spirit was stockpiled for use by UK troops coming south to defend against a German invasion. Another anti-invasion action was the preparation, for demolition, of the bridges across the Shannon. This action was to protect the British right flank as they moved south. ${ }^{56}$

The appointment of General Franklyn as GOC BTNI in June 1941 proved to be a turning point in the relations between the two armies and indeed, the two countries. He visited Dublin on 16 to 18 June 1941 and although the Chief of Staff was not permitted

\footnotetext{
${ }^{54}$ Ibid.

${ }^{i j}$ Ibid.

${ }^{36}$ Archer summary, circa March 1944 (MA, SCS/14).
} 
by the Taoiseach to accompany him on a tour of the country the Army felt that they had convinced him that the Irish Army would fight any invading force with determination and loyalty. This, and a further visit by Franklyn on 10 December 1941, helped to improve relations with the $18^{\text {th }}$ Military Mission while Franklyn is credited with influencing the better supply of arms from the UK. ${ }^{57}$

\section{Mulcahy and the air attaché}

The Archer summary and the Childers report outline a succession of contacts, between British and Irish headquarters staffs, that were carefully monitored by officials of External Affairs. In contrast however the activities of the air attaché were apparently not subject to the same scrutiny. The appointment of a military (army) attaché had been discussed by Col. Clarke with Joseph Walshe in Dublin on 24/25 May 1940 and the latter had indicated if was put forward by the U.K. Government it would be acceptable provided that the appointment was suitably disguised and that the officer wore civilian clothes. Subsequently the Air Ministry suggested that, if effective assistance was to be rendered by the RAF in an emergency, it was most desirable that an air attaché should also be appointed.

In the context of attachés and military liaison the matter of wireless communications was of primary concern. The UK authorities were prepared to supply a wireless set for direct communication between Dublin, Northern Ireland H.Q and the Service Departments in the UK. However, as the three stations had to be operated by the same service a decision had to be made as to whether the equipment and the British operating staff would be located at the UK representative's office or be attached to Eire's Defence HQ. ${ }^{58}$ Subsequently a point-to-point wireless net, linking Army Headquarters, Belfast, the Air Ministry and station A.A. Dublin to the HQ of 75 Operations Wing (NI) was set up. This net was part of the organisation of an Irish fighter group being proposed in the context of the air defence of Eire. ${ }^{59}$ However there is some doubt about the actual

\footnotetext{
57 'First questionnaire on plans for aid', Childers report, 17 Oct. 1947 (MA, SCS/1).

${ }^{58}$ Cypher telegram to Maffey, 28 May 1940 (NA, Air 2/5129).

${ }^{59}$ Undated wireless net, 'W/T Organisation - communications Abbot', circa June 1940 (NA, Air 2/4601);

'Proposed layout for Irish fighter group', AM to AOC, Fighter Command, 11 July 1940 (NA, Air 2/5185).
} 
use and the efficacy of the Dublin station. On 27 June 1940 a meeting was held at Kinnaird House on the matter of communications with Ireland in case of an emergency situation. The meeting was informed that the air attaché possessed a transmitting set which had not yet been used as it was desired to keep its existence secret and that it would be used should the normal land line (telephone and telegraph) direct to the Dominions Office break down'. An outline plan was agreed:

It was finally agreed that an alternative set for Sir J. Maffey should be established in a friendly house in or near Dublin which Sir J. Maffey must arrange and that Col. Vivian [of MI6] should, as soon as possible, produce one set with two trained operators. The necessary arrangements with the Irish government should be made on the level of staff talks, and / or with Col. Archer. ${ }^{60}$

It appears that the air attaché's wireless was in place and in use as early as 11 July 1940. On that date 'Station A.A.' was sent a cypher message from the Air Ministry, directing certain action to be taken by Lywood, and to which Lywood replied by telegram presumably in order not to make a wireless transmission that might be detected by the Irsh Army. ${ }^{61}$ This apparent early use of Lywood's wireless does not fit in with the view that the equipment was not manned until August unless, as a trained pilot, Lywood himself received and recorded the coded message. Two Special Intelligence Service personnel, who were understood to be wireless operators, were attached to the air attaché's staff as domestic servants in August 1940. However is suggested that it subsequently came as a surprise to the British representative's office to learn that the men considered themselves accountable to SIS and that the radio did not work. ${ }^{62}$ Given the concern regarding good communications between Dublin, Belfast and London it might be assumed that this matter was soon put right.

\footnotetext{
60 'Memorandum of meeting', 27 June 1940 (NA, CAB 104/184).

${ }^{61}$ Coded wireless message, A M to Station A.A. 11 July 1940; Cypher telegram, Lywood to AM, 13 July 1940 (NA, Air 2/5129).

${ }^{62}$ E. O'Halpin, 'Aspects of intelligence' in Irish Sword, xix Nos. 75 \&76 (1993/4), p. 64; O'Halpin (ed.) MI5 and Ireland, 1939 - 1945; the official history (Dublin, 2003), note 3, p. 21, citing DO 130/4 and DO 130/14 (NA).
} 
Meanwhile by 29 May 1940 the appointment of both military and air attachés had been agreed with Dublin with Walshe insisting that neither attaché would wear military uniform or use military rank. ${ }^{63}$ The UK having reluctantly agreed to the conditions, the air attaché, Wing Commander Lywood, left for Dublin via Holyhead on Monday 3 June 1940. Given the urgency of the situation 'Mr' R.G.W. Lywood got down to business immediately. Arising out of his first meetings with Foreign Affairs, GHQ and the Air Corps he submitted a detailed first report to his UK superiors:

June $4^{\text {th }}$, 1940, I was introduced to Mr. Walshe, Minister of External Affairs [sic], who subsequently arranged an introduction to Col. Archer, director of military intelligence. The discussion was of a very general nature, but I gathered that they wished my liaison with the Air Corps to be carried out as inconspicuously as possible.

June $6^{\text {th }}$. [I was] introduced to Col. P.A. Mulcahy, chief of Air Corps [sic], by Walshe. It was suggested at this interview that I should be introduced to other members of the Air Corps as a civilian from the Air Ministry who was attached to the British Representative's Office to assist them in obtaining aircraft spares'. ${ }^{64}$

It was explained that his identity should not be disclosed lest junior personnel with contrary political opinions might misconstrue his presence in Dublin and deduce that the UK was exerting undue pressure and interfering in Irish affairs. In this respect he was, no doubt, referring to some of the ex-IRA pilot group who would still retain anti-British views. After a very open and frank introductory meeting Col. Mulcahy drove Lywood out to Baldonnell. Following a brief tour of the installation had a lengthy discussion on Air Corps matters. Mulcahy apparently regaled Lywood him with accounts of his past activities in the service of Eire - presumably his part in the Civil War on the pro-Treaty side. Mulcahy commenting on the country's determination to resist invasion by any outside force stating that 'the country would rise up and tear limb from limb any invaders'. Mulcahy gave Lywood a briefing memorandum on Air Corps organisation.

\footnotetext{
${ }^{63}$ Cypher telegram, Maffey to DO, 29 May 1940 (NA, Air 2/5129).

${ }^{64}$ 'Report No. 1', R. Lywood, 11 June 1940 (NA, Air 2/5130) The associated appendixes are dated 20 May 1940 suggesting that they had been prepared well in advance or for the information of others.
} 
Lywood considered that the whole Air Corps could be considered to be a training cadre because training was continuous in all units. Lywood later got six attachments. These dealt in detail with subjects of 'fuel', 'radio' and 'aerodromes' as they pertained to both military and civil air installations of the country and 'ammunition' 'personnel' and 'aircraft' as particular to the Air Corps. ${ }^{65}$

On the following day Lywood resumed his familiarisation visit to the Air Corps and observed basic flying and navigation training in progress. He remarked on the similarity with that conducted in the RAF but considered flying discipline to be more relaxed. In the afternoon he was brought on a reconnaissance flight of 'existing aerodromes and possible landing grounds' at the Curragh, Foynes, Rineanna, Ardnacrusha, Kildonan and the Phoenix Park with Mulcahy standing behind him in the Anson pointing out everything of interest. Lywood subsequently commented on the extent of the obstructions to aircraft landings that existed at the main military and civil aerodromes. He also reported on the ground defences of Baldonnell and Rineanna and made no comment, adverse or otherwise. He did however suggest that the air ammunition and bomb holdings were inadequate except for the briefest of aerial engagements. In general it could be stated that Lywood received a most complete briefing on, and a comprehensive oversight of the state of military aviation in June 1940. In this regard it is of interest that he was introduced by the secretary of the Department of External Affairs and not, as might be expected, by an officer of the intelligence staff. It could be surmised that GHQ had little regard for the liaison and intelligence aspects of military aviation and placed no strictures on Mulcahy or the attaché. Alternatively the Department of External Affairs may have wanted Lywood to be able to function without stricture. In any event it appears that neither department considered it necessary to monitor Lywood closely. ${ }^{66}$ Similarly it is significant that neither Archer nor Lt. Col. Childers, in their summary reports on the Emergency, gave any account of the activities of the air attache while the liaison on army matters was recorded in detail. ${ }^{67}$

\footnotetext{
${ }^{65}$ Ibid.

${ }^{66}$ Ibid.

${ }^{67}$ The Childers report of 17 Oct. 1947 refers to no less than fourteen 'tabs' or original explanatory documents that were not released to me in Military Archives.
} 
Lywood met Mulcahy again at Baldonnell on 14 June 1940. The tone of his report seemed to suggest that Mulcahy understood that, in the event of invasion by Germany, the RAF would constitute the substantially greater part of air support to ground forces. Mulcahy indicated that he was 'anxious to have some idea as to the nature and extent of assistance from [the] United Kingdom that can be expected'. Lywood indicated that, with the assistance then being given in France, he could not predict:

Regarding an aerodrome to be placed at the disposal of [the] R.A.F. in [the] event of assistance being asked, for operating from and to be used as a possible storage for fuel, bombs and ammunition for R.A.F. aircraft, Col. Mulcahy understands this to be Baldonnell, though I gather this was by no means definite. ${ }^{68}$

Lywood's comments on this question appeared to favour a location other than Baldonnell but he indicated that the selection might depend on the type of RAF aircraft and the balance, between Irish and British, of the eventual command structure. Mulcahy also raised questions on matters he might well have dealt with before the outbreak of hostilities - such as the camouflage of Air Corps aircraft and of military aerodromes and the very limited supplies of 100 octane fuel available in the country. In regard to army cooperation Lywood formed the opinion that, while some training had been carried out on Army manoeuvres, 'very little work of this kind' had actually been done. Lywood was interested in the conduct of reconnaissance of both land and sea areas - presumably in view of British suspicions about alleged IRA and German activities. He reported, without comment, on what appears to have been a mediocre capacity for general reconnaissance:

Land [reconnaissance is] combined with training navigation flights over most of Eire. Any special information in the light of intelligence reports to hand [sic] are communicated to crews and are the subject of special attention on such flights. When necessary a special reconnaissance [flight] is ordered. ${ }^{69}$ 68 'Report No. 2', R.W.G. Lywood, 18 June 1940 (NA, Air 2/5130).
${ }^{69}$ Ibid 
Lywood was also brought up to date with regard to the coastal reconnaissance being carried out by the R. \& M.B. Squadron detachment at Rineanna.

Sea reconnaissance has now been abandoned. 3 of 9 Anson aircraft were lost carrying out this duty. ...........Col. Mulcahy considers that the system of "coast watches" organised around the coast.......is carrying out effective work and that in view of the small number of aircraft he has now available he does not feel justified in using them for this particular duty. ${ }^{70}$

Mulcahy and Lywood discussed and agreed a system of visual and wireless telegraphy signals to be used by RAF aircraft crossing the Eire coast or land frontier in the event of the Irish government requesting air assistance. These were copied for the approval of the Air Ministry and RAF. The tone and content of Mulcahy's contribution to the discussion suggest that he understood that assistance from the RAF was practically guaranteed while he believed that he would get up to three hours notice of an attack. Arising out of his latest visit to Baldonnell Lywood was asked by Mulcahy to hasten the delivery of aircraft spares and equipment to the Air Corps In view of his supposed role he felt obliged to request that the Air Ministry take effective action to expedite matters. ${ }^{71}$

In response to Lywood's first report the air intelligence division of the Air Ministry suggested that the Irish authorities be advised that the two most likely points for a German invasion were the Curragh and the Foynes / Rineanna area. The Curragh was considered vulnerable, even if the Army reserve there had not been committed elsewhere, because it had not been obstructed against aircraft landing and German airborne troops had superior firepower to Irish infantry. Similarly the Foynes / Rineanna area was seen as being vulnerable because it was not adequately defended. It was considered that the capture of two stocks of aviation fuel, at Foynes and Rineanna / Shannon would be a key German objective.

Regarding the second report and the extent of assistance that might be expected the Air Ministry suggested that few German aircraft would be intercepted en route,

\footnotetext{
${ }^{70}$ Ibid.

${ }^{71}$ R.W.G. Lywood to AM, 17 June 1940 (NA, Air 2/5130).
} 
particularly if attacking by night. The extent of direct support would be limited by the fact that the enemy would be well ensconced before assistance was called for by the Irish authorities. They did not envisage occupying any existing aerodromes but suggested it would be necessary to identify aerodromes sites for RAF fighter squadrons on the South East and East Coasts and that Lywood might be able to collect information on suitable areas. The Air Ministry also suggested that Col. Mulcahy was being extremely optimistic in believing he would get three or four hours notice of invasion. The British expressed disappointment with the decision to terminate programmed coastal patrols out of Rineanna.

It is felt that the abandonment of sea reconnaissance is a great error. The coast ... contains many bays where a vessel might discharge personnel and small arms and even vehicles....suggest .... that they should recommence coastal reconnaissance ....... of bays and inlets for suspicious craft. ${ }^{72}$

In October 1940 Lywood arranged for Air Commodore T.N. Carr, AOC RAF NI, to visit Dublin specifically to meet Mulcahy and to establish a personal liaison with him. Carr subsequently reported to his superiors in London:

The visit was a definite success and I was most cordially welcomed by Colonel Mulcahy. He showed me over the aerodrome at Baldonnel and also the headquarters of the Observer Corps.........I discussed at length with Colonel Mulcahy the state of his aircraft and the readiness of the Eire air force for active service. He agreed that as a factor in the defence of Eire it could .... be ignored. The pilots are very keen but only half trained owing to lack of aircraft. ${ }^{73}$

Arising out of the visit the RAF considered that it might be possible to come to a mutually satisfactory arrangement with the Irish Government. It was hoped to get the Air Corps to build aerodromes where the RAF wanted them at the price of some

\footnotetext{
72 Director of plans, AM, to R.W.G. Lywood, 6 July 1940 (NA, Air 2/5130).

${ }^{73}$ T.N. Carr to AM, 14 Oct. 1940 (NA, Air 2/5130).
} 
obsolete aircraft - on the basis that Mulcahy would accept almost anything on which the pilots could get some flying. ${ }^{74}$ The Air Corps and the Corps of Engineers selected and developed an airfield at Rathduff, Golden, Co. Tipperary ostensibly for Air Corps use. However the contemporary record makes it clear that it was intended as an RAF forward airfield for use in the event of German invasion. Though Lywood had a similar brief it is not clear that he was involved with the selection of either, Gaybrook County Westmeath, that was not developed, or Rathduff that was. The development of Rathduff included arrangements for the acquisition, at short notice, of Summerfield tracks. This metal paving, designed to stabilise soft ground, was to be provided by RAF NI as and when required to cater for the higher tyre pressure of the more modern fighters or Wellington bombers. ${ }^{75}$ (See Chapter 10)

While Rathduff appears to have been ready for RAF emergency use before the end of 1941 the British authorities were very tardy in supplying training or recently obsolete aircraft. It was to be February 1943 before six ex-RAF Miles Master II training aircraft, of 1938 design, were released. Similarly it was the latter part of 1943 before the British supplied six Hawker Hurricane Mk. I fighter aircraft. These were followed by four more in February / March 1944. The Hurricanes had been withdrawn from service having been superseded in RAF fighter squadrons by the Mk. II. ${ }^{76}$

Despite the whole-hearted cooperation of Mulcahy Lywood appears to have functioned in a more covert manner in gathering information from civilians. ${ }^{77}$ While Lywood's main duty was to establish liaison and promote goodwill with the Eire Air Corps he also had tasks on which he was directed that it was not appropriate to refer reports 'to the authorities in Eire'. As early as July 1940 Lywood had been directed 'to make extensive reconnaissance to identify sites suitable as landing grounds of possible use to an enemy or the RAF. He was advised that if he was too busy to do so the necessary reconnaissance could be conducted by two or three officers travelling in civilian attire. He advised against this suggestion. ${ }^{78}$ In view of the whole-hearted

\footnotetext{
${ }^{74}$ Secret memo to CAS, 16 Oct. 1940 (NA, Air 2/5130).

${ }^{75} \mathrm{OC}$ AC to COS, 13 Oct. 1941; OC AC to COS, 17 Oct. 1941 (MA, AC/2/9/14).

${ }^{76}$ Kearns, 'Air Corps' p. 459; Halley, Squadrons of the RAF, passim

${ }^{77}$ O'Halpin, 'Aspects of intelligence, Irish Sword xix, p. 64.

${ }^{78}$ Cypher message, AM to Station A.A., 11 June 1940; Lywood to AM, 13 June 1940; AM minute, 12 June 1940 (NA, Air 2/5129).
} 
cooperation of Mulcahy and the Air Corps in many matters, including the development of forward airfields, it is not clear why Lywood had to carry out reconnaissance in respect of possible landing grounds. O'Halpin's observations regarding the covert activities of Lywood and others would seem to confirm his role in Ireland to be primarily that of an intelligence officer. ${ }^{79}$ Coinciding with the receding threat of invasion Lywood left Ireland early in 1942 and was replaced by Wing Commander Begg who, with Pryce's replacement Brigadier Wodehouse, was appointed an attaché on an official basis. ${ }^{80}$

\section{Conclusion}

A main aim of this chapter has been to demonstrate the level of cooperation between the two administrations on defensive preparations. With the Irish Government as the main beneficiary the number, variety and nature of the contacts, both personal and written, between the Irish and British administrations during the period 1937 to 1939 suggest that de Valera needed cooperation with the UK almost as much as the latter required a cooperative and non-belligerent neighbour. It is not clear why de Valera accepted war preparation advice from the UK rather than task his own administration - including the Army. He possibly realised that the state had no tradition in such matters while the Army harboured an excessively belligerent attitude that tended, initially at least, to preclude military cooperation with the United Kingdom. In any case de Valera's administration did not entirely trust the Army and its leadership.

With the wartime use of the treaty ports in the back of their minds the British did all in their power to encourage the maximum level of discussion and cooperation on defence and related matters. As a result, by supplying a considerable array of older, but still useful planning documentation, the UK appears to have greatly informed the Irish government and significantly influenced the shape of defence strategy and plans for war as well as ensuring that the largely passive defence measures subsequently put into affect were compatible with those taken in the UK. Despite the initial aggressive

\footnotetext{
${ }^{79}$ O'Halpin, 'Aspects of intelligence', p. 64.

${ }^{80}$ Childers report, 17 Oct. 1947 (MA, SCS/1).
} 
stance of the Army, in the absence of funding conducive to mounting a robust defence against invasion, the Army was to have little option but to conduct its activities in a manner commensurate the cooperative stance and passive defence strategy laid down by Government.

A similarly important aim has been to indicate the scale of cooperation between military officers both before and during the Emergency, particularly during the first two years. While Col. Archer's pre-war contacts with UK his counterparts were to presage a more substantial level of cooperation on intelligence matters during the Emergency the nature of the instructions received from de Valera, on general military cooperation, is a matter for conjecture. The not insignificant level of pre-war military contacts prepared the way for level of wartime north / south military cooperation that could not have been predicted.

It is significant that the matter of liaison between the respective defence forces on air matters was left to the discretion of Col. P.A. Mulcahy. Wing Commander R.W.G. Lywood, as an unofficial air attaché, appears to have made the maximum use his assumed role as an Air Ministry representative. In the context of the time, with aircraft spares and military supplies being withheld from a cooperative Air Corps, it might be considered that expediting supplies for the Air Corps would have been his primary liaison function rather than the charade it actually was. The detail of Lywood's reports suggests the fullest cooperation from Mulcahy who in turn appears to have withheld few secrets in order to acquire, in particular, training aircraft. In his liaison role, between those preparing the RAF defence of Eire, and the Army and Air Corps, Lywood appears not to have been monitored to any great extent by either External Affairs or the intelligence branch of the Army. Such leeway apparently gave good scope for whatever other intelligence duties he was expected to perform. 


\section{CHAPTER 9}

\section{SUPPORT SERVICES}

General O'Duffy's reorganisation scheme of 1924 suggested aerial fighting, bombing and reconnaissance as the essential elements of military aviation's main role of cooperating with the army. However the Air Corps of the mid-1920s, to the extent that it was capable of performing any army aviation role, was probably only capable of a modest level of reconnaissance, the more fundamental role that had evolved during the war of 1914-18. Reconnaissance had been the Civil War role and was the primary function of the first operational squadron that was eventually formally established in 1934.

In 1924 O'Duffy's scheme did not adequately highlight the deficiencies in wireless communications, meteorology and transport that had become apparent during the Civil War. However he did indicate the necessity to establish wireless and meteorological services but only in the context of civil aviation and the state's obligations under the International Commission for Air Navigation. Aviation communication was mentioned as a function of the Signal Corps but its development was not seen as an immediate army priority but rather a problem to be addressed later. As a result no communications personnel were included in the formally established Air Corps of 1924 while aircraft are not known to have been fitted with wireless telegraphy sets until about 1932.

Similarly the requirement to have meteorological information available for the safety and accuracy of aviation was recognised but again only in the context of civil aviation. Though the 1924 establishment provided for an Air Corps meteorological officer no officer was so qualified and no meteorological reporting and forecasting services, civil or military, were developed by the state while the country's observation stations were to remain the responsibility of the Air Ministry until 1936.

This chapter will examine the development of the three main support services to aviation - meteorology, communications or signals and air traffic control (ATC) during in the period 1922 to 1945 in the context of their applicability to military aviation. It will 
be contended that, while the Air Corps had an understandable professional interest in such matters and had varying degrees of involvement in their establishment, these principle support services to aviation were established primarily for the benefit of civil rather than for military aviation. It will be suggested that the development of a national meteorological service, despite the state's international obligations, took an inordinately long time particularly as the Air Service / Air Corps had a requirement for such a service right from the beginning in July 1922 and that there was a modest level of civil aviation in Ireland prior to the advent of Aer Lingus in 1936. An aspect of this delay will be the somewhat reluctant participation of the military, including the Air Corps in the process of starting a meteorological service

It will also be asserted that, while the Air Corps had an expanding requirement for various communications services during the $1930 \mathrm{~s}$, the services provided by the independent Signals Corps, particularly in the critical early year or so of the Emergency, fell well short of the scope and standard required. The signals aspect will be examined in the context of the technical advances and of the application of wireless telegraphy, radio telephony and direction finding services to the developing air navigation techniques that were required for coastal reconnaissance in particular. It will be demonstrated that the civil aviation communications and direction finding services provided in Baldonnell / Collinstown and at Foynes / Shannon were far superior to those available to the Air Corps at the start of the Emergency and that the latter improved little thereafter. In the matter of direction finding in particular even the RAF was provided with superior services on Irish soil.

The development of support services should be appreciated in the context of their application to aviation, both civil and military. Such services, particularly meteorology and wireless communications, would have evolved in step with the evolution of military aviation. As such, these services came to be supplied by aerodrome authorities for the benefit of all aircraft using a particular aerodrome. The independence granted to individual military aviation units (squadrons) by the widespread availability of aviation communications and meteorological reporting and forecasting stations became an essential aspect of the mobility and flexibility of developing air power. Though not strictly speaking a support service this study includes consideration of relevant aspects of 
air navigation due to its close association with, and dependence on air communications and direction finding.

\section{Meteorology}

For reasons that are not clear it was to be 1964 before a properly organised, staffed and equipped meteorological station was established at Baldonnell to provide hourly meteorological observations on a twenty-four hour basis. And it was even later before a forecaster was part of the staff there. Weather observations, during daylight hours only, had been supplied since 1941 by service personnel. ${ }^{1}$ From 1964 the twenty-four hour service has been provided by the civilian staff of the Meteorological Office, under the aegis of the Department of Transport and Power and its successors. This development was mainly influenced by the purchase of search and rescue helicopters in late 1963, the start of SAR operations and the formal establishment of the Search and Rescue Flight (Air Corps) the following year. ${ }^{2}$ This situation had taken an inordinate time to evolve.

A fully equipped observation station, not a forecasting station as suggested in the O'Duffy scheme of reorganisation, had existed at Baldonnell up to May 1922 as a standard facility on an RAF aerodrome. Four times a day it had provided the standard meteorological observations as the long-established observation stations, at Valentia, Birr, Malin Head and Roche's Point, that were to remain under British management until $1936{ }^{3}$ The Air Service of 1922 had no capacity to make meteorological observations and had no access to a forecasting service. Though the observations taken in the Phoenix Park under the supervision of the survey blacksmith would have been of limited use to the new air organisation it was recommended that the staff of the Meteorological Office should be put at the disposal of the Air Service and that a trained observer should be

\footnotetext{
'Frank Clabby, 'The Met. Office at Baldonnel', unpublished paper, 14 Nov. 1986 (in my possession). ${ }^{7}$ Andy Roche, 'The Air Corps and the Meteorological Service' in Lisa Shields (ed.), The Irish Meteorological Service; the first fifty years 1936-1986 (Stationery Office, 1987), pp 82-4; Lt. Col. M. O'Malley, 'In the beginning' in Capt. David Swan (ed.), Irish Air Corps; celebrating 30 years of helicopter operations 1963 - 1993 (Defence Forces, 1993), pp 3-4.

${ }^{3}$ Appendix 2, Report on meteorological services, 6 July 1925 (MA, MS/418); Shiels, The Irish meteorological Service, p. 1.
} 
appointed and put in charge with immediate affect. ${ }^{4}$ In August 1922 it was reported that the Department of Agriculture, that had apparently take over responsibility for meteorology, had arranged for the observations of the Ordnance Survey station to be passed to Baldonnell by telephone by 10.30 hours each day. It was recognised that the records of one station were not of great value. It was also reported that the Meteorological Office in London had been requested to send copies of its observations, special reports and maps to Baldonnell each day. ${ }^{5}$

As a result of this request the Air Service was soon in receipt of the 07.00 hour and 13.00 hour telegraphic forecasts addressed daily to the officer commanding, Baldonnell Aerodrome. However, in May 1923, the Air Ministry informed the AFO that the ministry was then incurring charges for the telegraphic and telephonic services relating to the transmission of meteorological information to Baldonnell and that the annual transmission cost to the new state would amount to about $£ 205$. $^{6}$ Subsequently the army finance officer was informed that transmission of the forecasts had been discontinued with effect from Tuesday, 19 June 1923.

An amount of $£ 44$. 7. 4. has been expended on this service in respect of the period 1 April 1923 to 18 June inclusive, and I am to enquire whether you are prepared to accept this amount as a charge against the vote of your department. ${ }^{?}$

The AFO, under the mistaken impression that the meteorological stations were funded by the Irish state, suggested that the cost of transmitting meteorological information could be more than offset against the financial value of the meteorological reports from stations in the west of Ireland and requested that the Air Ministry agree to waive the charge. ${ }^{8}$ The Air Ministry responded stating that the meteorological information was free but that the transmission costs were payable and pointed out 'that the cost of the services rendered by the meteorological observers at the various Irish stations was borne, not by Saorstat

\footnotetext{
${ }^{+}$Capt. J.A. McNamara to C-in-C, 25 July 1922 (UCDA, MP, P7/B/49/29-30).

${ }^{5}$ Minister for Agriculture to C-in-C, 10 Aug. 1922 (UCDA, MP, P7/B/10/16).

${ }^{6} \mathrm{AM}$ to MFD, 4 May 1923, (NAI, FIN/2976).

${ }^{7}$ AM to Sec DOD, 30 June 1923) NAI, FIN/2976).

${ }^{8}$ AFO to Sec AM, 18 July 1923 (NAI, FIN/2976).
} 
Eireann but by Air Ministry votes. ${ }^{9}$ However, with no obvious reference to the Army or the Air Service, the AFO only sought financial sanction for the initial account having apparently decided to terminate receipt of the meteorological forecast service on the basis of cost. The account was subsequently settled by Defence with the approval of the Department of Finance. ${ }^{10}$

In 1924/25 an interdepartmental committee considered the arrangements for the collection and distribution of meteorological observations made in the Saorstat and the possible establishment of a meteorological service. Acting Major T.J. Maloney, then OC $\mathrm{AC}$, was nominated as the main DOD representative with Liam Archer (OC Signals) as a joint representative. Having sought direction from the Chief of Staff Maloney was informed that the Army had, in effect, no interest in meteorology. ${ }^{11}$ Notwithstanding, in his contribution to the committee Maloney emphasised the strategic importance of meteorology to ground forces that had been demonstrated during the recent war. He noted that the modern tendency was for states to place meteorological services under the defence or war departments and to assign its management to a military aviation service. He emphasised the increasing importance of weather forecasts in the context of aircraft flights of the order of 200 miles or more. Though not placing great stress on the necessity for synoptic meteorology and forecasting in the Air Corps context he did suggest that the headquarters of such a service should be at Baldonnell. ${ }^{12}$ The committee's report recommended that a meteorological service should be established in the country.

That so far as synoptic meteorology is concerned the existing [British] machinery of forecasting should not be duplicated, but efforts... should be directed towards establishing a system of local forecasts based upon a study of the general forecast in relation to local and geographic and meteorological conditions. ${ }^{13}$

\footnotetext{
${ }^{9}$ AM to Sec DOD, 9 Aug. 1923 (NAI, FIN 2976).

${ }^{10}$ AFO to Sec DF, 28 Aug. 1923; Sec DF to AFO, 31 Sept.1923 (NAI, FIN/2976).

1 T.J. Maloney to MS, 2 June 1924; MS to T.J. Maloney, 6 June 1924 (MA, MS/418).

12 Undated 'Memo on the constitution and organization of a meteorological department' by Major T.J. Maloney, circa May 1925 (MA, MS/418).

${ }^{13}$ Memorandum, Rev. W. O'Riordan, circa 3 Oct. 1935, quoting 'Report of inter-departmental committee on meteorology', 7 May 1925 (MA, 2/27175).
} 
Notwithstanding the fact that Baldonnell was the sole aerodrome in the state for both military and civil aviation no specific recommendation was made to locate there the meteorological facilities required by international agreement. With no organisational changes forthcoming the Air Corps' involvement with meteorology was to remain largely theoretical for some time. Though the 1924 establishment provided for a meteorological officer no officer was so qualified. An Edward Cannon made an unsolicited application to the Air Corps for such a post in August 1925. By return of post he received a copy of R.G.K. Lampfert's Meteorology which he was requested to review. ${ }^{14}$ On the basis of the handwritten review supplied to A/Major T.J. Maloney, by now reduced to squadron commander, No. 1 Squadron, it was considered that Mr. Cannon's knowledge of synoptic meteorology was insufficient to justify his employment. 'He might find employment in the state meteorological service, the formation of which is being awaited. 15

At about this time the Air Corps' approach to an appreciation of the actual weather conditions was rather basic. On a daily basis the Duty Officer was required 'to test the air, and render a short report to the squadron adjutant as to weather conditions, and suitability or otherwise for flying. ${ }^{16}$ The report of Lieut. T.J. Prendeville on 30 June 1925 was probably typical. He reported that the air at 500 feet was gusty and bumpy and at 1,500 feet it was just bumpy while, at ground level, the wind was 'SW 15-20 mph'. ${ }^{17}$

In June 1928 the International Commission for Air Navigation requested the General Staff to supply details of the meteorological facilities and services available at Free State aerodromes. The specific questions, as to what observations were made at Baldonnell and the other sources of weather data available, were referred initially to Air Corps Headquarters and by the acting Officer Commanding, Comdt. G.J. Carroll to Rev. W.M. O'Riordan, M.Sc. C.F. Father Bill, was the only person on the station who had a good working knowledge of meteorology and was recognised as the Air Corps' authority on the subject until $1936 .{ }^{18}$ He reported that observations of barometric pressure, wet $\&$

\footnotetext{
${ }^{14}$ E. Cannon to OC AC, 18 Aug. 1925, ACF/338, in my possession.

15 Ibid, 'Minute sheet No. 1' 11 Sept. 1925.

${ }^{16}$ Standing order, 'Duties of duty Officer', Sept. 1924 (MS/685, MA).

17 'Duty Officer's report', 30 June 1925 (MA, MS/685).

${ }^{18}$ A/OC AC to CSO DOD, 21 July 1928; OC AC to Rev. W. O'Riordan, 9 Mar.1936 (ACF/338, in my possession).
} 
dry bulb (relative humidity) thermometers, and maximum and minimum thermometers were taken daily at Baldonnell by the Air Officer on a daily basis. He suggested that, as the instruments were unreliable, not of the proper type and not properly mounted, the observations were of little or no value. He also reported that the daily weather reports of the Meteorological Office, London were being supplied to Baldonnell but being sent by post they arrived one to three days late. As a result these reports were of use for instructional purposes only. His conclusion was blunt and factual:

I would respectfully point out that the international commission's enquiry is regarding facilities available in the aerodromes of the Irish Free State and it will be seen that there are no such facilities whatsoever of a reliable nature. ${ }^{19}$

In the $1928 / 29$ estimates $£ 200$ had been sanctioned for the equipment of a first class station but apparently had not been expended. In $1929 £ 48$ was sanctioned for the purchase of meteorological instruments for the training of officers of the Air Corps. ${ }^{20}$ One of the principal instruments purchased was a mercury barometer that was delivered to Baldonnell on 15 July 1930. The instrument subsequently began giving inaccurate readings due to air leaking into the vacuum and returned to the manufacturers in London in June 1931. The manufacturers could find no fault with it so it was returned to service only to be found, in October 1931, to under-read by five millibars. After inconclusive inspection of the instrument by the Jesuits at Rathfarnham Castle, and its return to Baldonnell, the tube was found to be cracked, apparently due to accidental damage in transit. After repair in Dublin the instrument was deemed to be functioning normally during the summer of 1933 but in need of calibration and certification that could only be carried out in London. In late October 1933 the barometer was brought to the National Physics Laboratory in London by Commandant J.G. Carroll. However, when about to be collected in November, it was reported by the high commissioner to have been found to

\footnotetext{
${ }^{19}$ Rev. W.M. O'Riordan to A/OC AC, 30 June 1928: A/OC AC to CSO DOD, 2 July 1928 (ACF/338, in my possession).

${ }^{20}$ Sec DOD to Sec DF, 25 Nov. 1929; Sec DF to Sec DOD, 27 Nov. 1929 (NAI, DF, S.008/0076/29).
} 
have the original vacuum problem. ${ }^{21}$ Due to unexplained delays the necessary repairs were not completed until June 1936 with the account for $£ 3$. 18s. 6d. being settled in August of that year. ${ }^{22}$ It would appear that much bureaucratic lethargy, and most likely the indifference of $\mathrm{OC} \mathrm{AC}$ or his subordinates, had contributed to this inordinate delay.

By 1930 the Air Corps was receiving the 07.00 hours Air Ministry forecast by telephone at about 10.00 hours - with no mention of the cost. ${ }^{23}$ By February 1931 this arrangement had apparently been terminated as it was reported that since the previous February the wireless station at Baldonnell did not have the appropriate equipment to take the 09.10 hours Air Ministry weather report transmitted from Rugby. ${ }^{24}$ At the end of that year it was reported that the daily weather report from the Air Ministry had been received throughout the year - in written form. As these reports were being forwarded through the Secretary of the Department of Defence they were being received several days late, a situation that had more recently been remedied. ${ }^{25}$ In 1932 arrangements were made to receive occasional weather reports on request, from the British station at Valentia, County Kerry. While the reports were free, to obviate transmission expense to the Air Ministry, the Air Corps messages requesting special reports were sent on a reply paid basis. ${ }^{26}$ While difficulties with the receipt of weather reports and forecasts were frequent in the early 1930s there was no evidence of any adverse effect on the conduct of flying.

The 1931/32 peace establishment made provision for a meteorological instructor and for a single observer of private rank. Lieut. J.P. Twohig was made responsible for the recording of meteorological observations at Baldonnell. With his untimely death in September 1933 Rev. W. O'Riordan took over the task of making and recording the daily weather observations and, when pilot training courses were in progress, also acted as the instructor in meteorology theory. He did not consider himself competent to give practical instruction in it the subject. He also advised that, while he was very willing to assist in

\footnotetext{
21 'Memorandum, Kew barometer', 12 Dec. 1933 (NAI, DF, S.008/0076/29).

2 Sec DOD to Sec DF, 18 Aug. 1936; Sec DF to Sec DOD, 21 Aug. 1936 (NAI, DF, S.008/0076/29).

${ }^{23}$ Lieut. J.P. Twohig to OC AAC, 20 Mar. 1930 (ACF/338, in my possession).

24 OC AC to Army Signal Corps, DOD, 31 July 1931 (ACF/338, in my possession).

${ }^{25} \mathrm{DMA}$ to DOD $25 \mathrm{Jan} .1932$ (ACF/338, in my possession).

${ }^{26}$ DS to DMA, 16 Nov. 1932; DMA to Valentia Observatory, 24 Feb. 1932; M.T. Spence to DMA, 26 Feb. 1932; DMA to ACS, 7 Mar. 1932 (ACF/338, in my possession).
} 
various ways concerning meteorology, he suggested that a duly qualified meteorologist should be on the staff of the aerodrome to provide weather forecasts. ${ }^{27}$

In July 1935, when about to go on leave, Fr. O'Riordan wrote to the adjutant, for the information of the commanding officer, to the effect that his understudy, Pte. James Flavin, the 'Meteorologist (private)' of the 1934 peace establishment, would also not be available to make the once-daily observations due to other duties. He suggested that this brought into focus the question of having a permanent meteorologist appointed and intimated that he would like to discuss the matter with the commanding officer. On the same day, apparently responding to this information, the newly appointed OC, Major Mulcahy, directed a pupil pilot to take over the observation duties and to consult the Chaplin with regard to making himself familiar with the work. Two days later Fr. O'Riordan wrote to the adjutant, Capt. D.J. Murphy, in effect reminding the commanding officer that he had suggested that he was anxious to discuss the whole matter of meteorological observation. He emphasised the shortcomings of the situation pointing out in particular that a full range of observations, that would be of assistance to pilots, needed to recorded much more frequently. Though he disagreed with the concept of the observations being taken over by a pupil pilot he referred the young officer to the Observer's Handbook for full and complete instructions. The adjutant studied the five relevant files reflecting the history of meteorology since 1922 and discussed the matter with the chaplin. He recommended to Major Mulcahy that a committee of investigation be appointed to report on the matter. ${ }^{28}$

Later in 1935 Fr. O'Riordan penned a substantial paper on the subject of 'Meteorological facilities for pilots in the Free State' stating that there were, in effect, no such facilities. He pointed out that Northern Ireland had at least one properly equipped weather station, at Aldergrove, and that if the Free State wanted to establish itself as the terminus for transatlantic flights, it was imperative that the state provide similar facilities. 'It should not be forgotten that Saorstat Eireann has definite international obligations in

\footnotetext{
27 O'Riordan to Adjt. AC, 23 July 1935; O'Riordan to OC AC, 1 Mar. 1934; O'Riordan to OC AC, 16 Mar. 1934 (ACF/338, in my possession).

${ }^{28}$ Rev. W. O'Riordan to Capt. D.J. Murphy, 23 July 1935; OC AC to OC AC Depot, 23 July 1935; Rev. W. O’Riordan to Capt. D.J. Murphy, 25 July 1935; Capt. D.J. Murphy to OC AC 27 July 1935 (ACF/338, in my possession).
} 
this matter' in accordance with the International convention for air navigation. These obligations were particularly in respect of climatology, or historic weather records, current weather reports for synoptic purposes and short or long term forecasts for specified areas.

Quite apart from these international obligations, there is a definite obligation on the government of the Saorstat to provide meteorological facilities for its own military and civilian pilots. The need for these facilities has not been appreciated as it might up to the present. ${ }^{29}$

He reviewed the proceedings of the inter-departmental commission which had been set up by the Minister for Education eleven years previously. He restated the terms of reference, and the four principal conclusions of the earlier study and indicated that no steps had been taken to give effect to its recommendations. Fr. O'Riordan, indicating that expert advice was available from academics in Dublin and from the senior officials in Cahirciveen (Valentia Observatory), suggested the establishment of a meteorological service consisting of four or five main stations and a large number of observer stations. While he considered that the question of meteorological services was not applicable only to the Department of Defence he suggested that any scheme should include locating a trained meteorologist at Baldonnell as well as extra meteorological equipment and appropriate radio facilities on a twenty-four hour basis.

The meteorologist would be trained in forecasting and would preferably be a civilian. He would need a staff of two or three at least. One of his duties would be the issuing of forecasts to military pilots as required. ${ }^{30}$

He recommended that all the existing equipment at Baldonnell could be used but that a number of additional instruments would have to be obtained - at an added cost of about

\footnotetext{
${ }^{26)}$ Undated memorandum, 'Meteorological facilities for pilots in the Free State', Rev. W. M. O'Riordan, circa 3 Oct. 1935 (MA, 2/27175).

${ }^{30}$ Ibid.
} 
$£ 500$. This sum was to have included $£ 200$ for an anemometer (to measure and record wind velocity). In conclusion he stated that a broad view should be taken of the matter as not alone were lives at stake - those of citizens of the Saorstat and visitors - but also the honour of the country. ${ }^{31}$

Mulcahy forwarded the submission to the Chief of Staff complete with a brief covering letter. He stated that he had earlier had discussions on the subject with Fr. O'Riordan and with Tom Morley of Valencia Observatory:

As a result of these talks I asked Fr. O'Riordan to prepare a memorandum under certain headings so as to assist me in drawing up a report on the matter. As his memorandum is so admirable I send it complete. ${ }^{32}$

He suggested that the subject should be taken up without delay by the Department of Industry and Commerce and that the said department should be reminded of its responsibilities in the matter of meteorological services. ${ }^{33}$

In view of the indirect exchanges between Mulcahy and the chaplin and the fact that the file (ACF/338) reflects no personal contact one has to be somewhat sceptical about the manner in which Mulcahy, in effect, claims some credit for the proposals formulated by the chaplin. In his submission O'Riordan had cited the loss of an aircraft on a flight from the US to Ireland in unknown weather conditions as his reason for highlighting the absence of meteorological services in the Free State. He had made no reference to specific discussions with Mulcahy and Morley. While Mulcahy gave the proposal his general endorsement he made no reference, as he might have done as DMA, to the specific needs of military aviation. Mulcahy, if he had adequately appreciated the needs of military aviation, might have availed of the opportunity to emphasise that Baldonnell, as the state's only military aerodrome and the civil airport for Dublin and the state at that time, had an immediate and urgent need for such a service and for an appropriate meteorological station on the

\footnotetext{
${ }^{31}$ Ibid.

${ }^{32}$ Maj. P.A. Mulcahy to COS, 4 Oct. 1935 (MA, 2/27175).

${ }^{33}$ Ibid.
} 
aerodrome. His subsequent correspondence with Fr. O'Riordan would suggest that Mulcahy did not appreciate the relevance of meteorology to military aviation and, at best, only saw the matter in the context of civil aviation.

On 15 October 1935 Major . J.P. Cotter, director of signals, having been given a copy of Fr. O'Riordan's report and Mulcahy's covering letter by the Chief of Staff, visited Baldonnell to discuss meteorology. ${ }^{34}$ Following discussions between Cotter, OC $\mathrm{AC}$ and Fr. O'Riordan the COS established an Army committee on meteorology under the chairmanship of Cotter with Comdt. J.G. Carroll, a flying officer, Mr. R.W. O'Sullivan (Aeronautical Engineer) and Rev. Fr. O'Riordan, all of the Air Corps, as members. Their brief was to cooperate with the inter-departmental committee in establishing a meteorological scheme for the Saorstat and to investigate 'all aspects of meteorology as they affect military activities in this country'. ${ }^{35}$ On 4 November 1935 , for reasons that are not clear, only Cotter and Fr. O'Riordan attended a preliminary meeting held at Baldonnell in preparation for a conference to be held in the Department of Industry and Commerce the following day. Some months later, subsequent to a number of meetings of the inter-departmental committee Fr. O'Riordan felt obliged to write to the commanding officer:

Since I was present at the conferences on the question of meteorological services in November last, I have been under the impression that it was intended to provide a fully equipped and staffed meteorological station at Baldonnell before the crosschannel air services started. Now, however, I hear rumours to the effect that part of the duties of Lieut[enant]s Cumiskey and Stapleton will be the issuing of weather reports to the pilots of these Services. ${ }^{36}$

He went on to point out that not only were the two named officers not adequately qualified for the intended duties but that no one on the station was. Lest he be held responsible in view of the fact that he had been lecturing on meteorology to Air Corps

\footnotetext{
${ }^{34}$ File memo, P.A. Mulcahy, 16 Oct.1935 (ACF 338, in my possession).

${ }^{33}$ 'Departmental Committee on Meteorology', COS to Comdt. G. Carrolt, 31 Oct. 1935 (ACF/338, in my possession).

${ }^{36}$ O'Riordan to OC AC, 8 Mar. 1936 (ACF/338, in my possession).
} 
pilots and pupils for some time he disclaimed any responsibility for the fitness of the two officers mentioned for the duty of issuing weather reports in the absence of a meteorological station. He reminded OC AC that the instruction he had given over the years was purely of a theoretical nature aimed at giving pilots an elementary knowledge of the principles of meteorology. ${ }^{37}$ The inferences in Fr. O'Riordan's latest note went far beyond the matter of the competence of two pilots, then being groomed for positions as control officers. It appears that following an unknown, but apparently small, number of meetings of the inter-departmental committee held in November 1935 Fr. O'Riordan was no longer party to the discussions. It also appears that the military contributors to the main committee had no concept of the application of meteorology to army or air activities and therefore made no special representations on the matter of establishing a meteorological station at Baldonnell.

As it transpired, no station, for civil or military use, was to be established at Baldonnell during the four years that the civil air services operated to and from that location. In fact it was to be over thirty year before Baldonnell would have a meteorological station with a forecaster on the staff. It could be inferred that the military influence at the inter-departmental committee, most likely conveyed by Major Cotter, was very negative in character and that the case for a station at Baldonnell, as proposed by O'Riordan but not supported by Mulcahy, was not projected. Mulcahy's response to Fr. O'Riordan's latest, and apparently last communication on the matter, was terse and dismissive and contrary to the tone of his fulsome endorsement of the latter's submission of October 1935.

....The fact that any responsibility might rest with you is not at all apparent.

A job has to be done and I am using the materials available. I am quite aware that the officer personnel here are not expert in meteorological matters but have got to control this end of the [civil air] service and not only the two officers whom you mention but, all officers will have to take on the job of control officer. ${ }^{38}$

\footnotetext{
${ }^{37}$ Ibid.

${ }^{38}$ OC AC to Rev. W. O'Riordan, 9 Mar. 1936 (ACF/338, in my possession).
} 
He informed the chaplin that his efforts in the matter of meteorology were much appreciated and that he was confident of having his assistance again if and when required. ${ }^{39}$ This response, insofar as it actually dealt with the matter of the duties of control officers, ignored the fundamental fact that Baldonnell was not to have a meteorological station despite it status in civil and military aviation, and also implied that the chaplin's assistance was unlikely to be required by Mulcahy. While Fr. O'Riordan acted as meteorological instructor to the 1937 'wings' course there is no record of him offering, or being asked for, further assistance or advice on matters of policy during the remainder of Mulcahy's command.

The Meteorological Service was established in December 1936 and took over the management of the existing stations from the British on 1 April $1937 .^{40}$ With no station being established at Baldonnell and, with the station planned for Dublin Airport yet to be put in place (in 1939) area forecasts for Baldonnell, taking into account local conditions, would not have been available. Civil and military pilots would have had to rely on interpretation of the general forecast available from Foynes from 1937. ${ }^{41}$ The apparently negative attitude of Mulcahy, possibly reflecting a similar attitude in GHQ, can be understood in the context of an Army leadership that displayed no understanding of the strategic importance of meteorology to ground operations. They probably saw military aviation as an army ground forces matter that did not require knowledge of meteorology. However it is not easy to understand why Mulcahy was so reluctant to accept advice on a highly complex matter from one who knew. The somewhat indirect exchanges with Fr. O'Riordan strongly suggest that Mulcahy did not seek or welcome advice in matters that were clearly outside his comprehension.

A golden opportunity, to have appropriate meteorological facilities established, having been passed up in 1936 little progress appears to have been made subsequently before, during or after the Emergency. From as early as June 1937 financial sanction for the supply and installation of a remote-reading anemometer at Baldonnell, as originally

\footnotetext{
${ }^{39}$ Ibid.

${ }^{40}$ Dermot O'Connor, 'A brief history of the Meteorological Service' in Lisa Shields (ed.) The Irish meteorological Service; the first fifty years, 1936 -1986 (Dublin, 1987), p. 1.

${ }^{41}$ Lisa Shields (ed.), The Irish meteorological service; the first fifty years (Dublin, 1987), passim.
} 
recommended by Fr. O'Riordan, was in place. ${ }^{42}$ However, as late as 24 May 1942, with an obvious lack of urgency on the part of the Air Corps leadership and with evidence of bureaucratic lethargy in various Army offices, the equipment had still not been installed by the Corps of Engineers or even supplied by the Meteorological Service. ${ }^{43}$

From October 1943 the taking of observations at Baldonnel was put on a more formal basis by arrangement with the Meteorological Service. While the three military meteorologists provided by the 1943 Establishment also performed aerodrome control duties their primary responsibility was the taking of meteorological observations. These were apparently taken twice a day and made available to the meteorological service on the latter's Forms 7440 and $7441 .^{44}$ Early in 1944 R.W. O'Sullivan, the Air Corps' (civilian) aeronautical engineer, forwarded a brief case, supporting a proposal for the installation of a proper meteorological station at Baldonnell, for the consideration of OC AC, Maj. W.P. Delamere.

The present arrangement consists of telephone communication with the Dublin Airport at Collinstown by means of which information based on an analysis of the general weather situation and on observations at Collinstown is used to prepare a daily weather chart at Baldonnel. .... It takes no account of local conditions at Baldonnel..... 45

He pointed out that the local conditions at Baldonnell were very different to those at Collinstown due to the effect of the proximity of the Dublin / Wicklow hills on the amount and height of cloud and the wind speed and direction in particular. He suggested that the Director of Meteorological Services would generally be in favour of the idea on the basis that an increase in personnel was pending. However Major Delamere did not

\footnotetext{
t2 $\mathrm{COE}$ to OC AC, 21 Jan. 1942 (MA, AC/2/4/6).

${ }^{+3}$ File memo, 24 May 1943 (MA, AC/2/4/6).

${ }^{+1}$ Air Corps establishment, 29 Mar. 1943 (MA); ‘Baldonnel - Wind analysis', 1 July 1944 - 30 Sept. 1948 (in my possession); File memo, 1 Oct. 1943 (ACF/338, in my possession); Marty Keane, "The weather observation network' in Lisa Shields (ed.), The Irish meteorological service; the first fifty years (Dublin, 1987), p. 26.

45 'Meteorology in the Air Corps', R.W. O'Sullivan to OC AC, 12 Feb.1944 (MA, ACF/338, in my possession).
} 
agree. He annotated the submission to the effect that he had discussed the matter with the director and that it was not opportune to put forward a case. ${ }^{46}$ He was probably correct as later that year it was reported that additional personnel were not being recruited and that some meteorological personnel were being moved from Dublin Airport to Shannon resulting in a reduction in the standard of service available to the Air Corps. ${ }^{47}$ From 1 February 1945 there was no duty forecaster at Dublin Airport. In the meantime arrangements were in place for the Air Corps to receive special forecasts from Foynes. ${ }^{48}$

There is an intriguing post script to the pre-war failure to establish a meteorological office at Baldonnell. From the tone and content of later correspondence it is not clear why such an office was not actually established in 1939. In 1957 the then Officer Commanding, Col. P. Quinn, in the context of dwindling numbers of military meteorologists, made a detailed and well argued case for an appropriately staffed meteorological office at Baldonnell. In order to substantiate the case being made Col. Quinn referred to DOD files and correspondence going back to 1945, 1942, 1939 and $1937 .^{49}$ The submission was initially referred to the director of plans and operations in GHQ.

This matter, as far as can be seen, was first raised in 1939 (C.R. File S/91) and again in June 1945 when the Dept. Of Defence on the recommendation of the then Chief of Staff wrote and asked the Dept. of Industry and Commerce to allot one meteorological officer to the Air Corps to act as instructor and forecaster. ${ }^{50}$

In its reply dated 27 July 1945 Industry and Commerce indicated that the Minister for Finance, as long previously as 1939, had granted sanction for the recruitment of one meteorological officer and four assistant officers for Baldonnell. It was stated, paradoxically, that the appointments could not be filled at the time because of staff

\footnotetext{
${ }^{46}$ Ibid.

${ }^{47}$ A.H. Nagle to OC AC, 28 Oct. 1944 (ACF/338, in my possession).

${ }^{48}$ A.H. Nagle to OC AC, 15 Jan. 1945 (ACF/338, in my possession).

19 'Meteorological personnel in the Air Corps', OC AC to ACS, 24 July 1957, DOD 2/93247. DOD file $2 / 93247$ had been opened in 1945 . It was still in use when examined by me in the early $1990 \mathrm{~s}$.

${ }^{50}$ T.J. Gray to Sec DOD, 29 Aug. 1957, quoting Sec I \& C to Sec DOD, 27 July 1945, DOD 2/93247.
} 
shortages but that one officer and two assistants could then (1945) be appointed. While the military agreed with the 1945 proposal Industry and Commerce did not make the appointments and GHQ apparently did nothing about it. ${ }^{51}$

Nothing in the military correspondence of 1957 suggests that either the Army or the Air Corps were aware of the financial sanction dating from 1939 while the Department of Industry and Commerce appears to have been remiss in not pursuing the recruitment of the personnel authorised in 1939, and again in 1945. Similarly Defence could be faulted for not pursuing the matter when made aware in 1945. It is however, curious that the Air Corps general file on meteorology, (ACF/338), contains no correspondence for the period from 9 March 1936, when Fr. O'Riordan was 'dismissed' by Mulcahy, until after the appointment of the latter's successor in December 1942.

\section{The beginnings of air traffic control}

From as early as September 1924 the functions of an aerodrome control officer were the subject of a daily roster. Initially those duties went well beyond the basic one that specified that the "duty officer' "will ensure that both the landing "T" and wind vane are correct and that the aerodrome is clear of all obstructions during flying'

At about 9 am he will test the air, and render a short report to the squadron adjutant as to weather conditions, and suitability or otherwise for flying. ....He will be responsible for ...warning of pilots, observers and pupils for flying duties, and detailing of machines in connection with flying for the day. ${ }^{52}$

Air Corps standing orders of 1927 defined the duties of the air officer in slightly different terms. In addition to testing the air he had to record his observations regarding the weather in the commanding officer's daily weather log book at 09.00, 14.00 and 17.00

\footnotetext{
${ }^{31}$ Ibid.

52 'Duties of duty officer', Sept. 1924 (MA, MS/685).
} 
hour. 53 The following year these duties were considerably widened to include those relating to the arrival and departure of civil aircraft transiting the Irish Sea. Apart from the sending, by telephone, of arrival and departure messages the air officer had particular alerting responsibilities in the event of an aircraft being over due. In effect the Air Officer, on a daily basis, monitored the conduct of civil aviation and performed the related various administrative functions on behalf of the Department of Industry and Commerce. ${ }^{54}$ It should however be appreciated that civil arrivals and departures were rare happenings in the late 1920 s and early 1930s. In fact they were so rare that the events were often mentioned in the newspapers of the time. ${ }^{55}$

At some time between October 1931 and June 1935 the aerodrome control officer had been relieved of the responsibility of making the decision relating to the suitability of the weather for flying and for any arrangements relating to the organising of flying - this task having apparently been transferred to the orderly officer in $1935 .{ }^{56}$ However his responsibilities relating to the safe operation of the aerodrome were further clarified to the effect that sheep and cattle should be removed from the landing and take off area of the aerodrome when flying was imminent or in progress. In 1937 the duties relating to the control of civil air traffic remained substantially the same as those of 1928 while the alerting procedures relating to overdue aircraft were brought up to date. For reasons that are not clear, as late as 1937, no wireless telegraphy set existed at Baldonnell for civil aviation communications with the corresponding station in the UK, Seaforth radio station. $^{57}$

\footnotetext{
33 'Duties of air officer', Appendix J, Standing Orders for Baldonnell Aerodrome, l Feb. 1927. P.J. Hassett private papers (in possession of Capt. Eoin Hassset).

34 'Amendments to Standing Orders for Baldonnell Aerodrome', 1 Jan. 1928, P.J. Hassett papers (in possession of Capt Eoin Hassett).

5aldonnel; Dublin's civil airport 1919 - 1939 (Irish Air Letter, 1989), passim.

${ }^{56}$ Section 32, Air Corps Standing Orders, 1935 (in my possession) .

${ }^{57}$ Corps Routine Order 243, amending Section 26, Air Corps Standing Orders 1935, 22 Oct. 1937 (in my possession).
} 


\section{More formal air traffic control}

In the meantime the Departments of Defence and Industry and Commerce had had the matter of the training of personnel in civil air transport control duties under consideration in the context of preparations being made for a state-sponsored civil air service based at Baldonnell. The department decided that while the existing military personnel could also do civil control duties it was preferable that they should undergo specialist training. ${ }^{58}$ In pursuance of this matter DOD requested that the high commissioner in London be asked to make enquiries as to the conditions under which three officers might, as soon as possible, attend a course of instruction at Croydon, then London's civil airport. ${ }^{59}$ The high commissioner replied to the effect that the Air Ministry did not provide such courses at Croydon or elsewhere but that they would facilitate extended visits for familiarisation purposes. The Dominions Office had indicated that the Air Ministry was prepared to take two officers, one at a time for a fortnight each, starting on 1 January 1936. Return visits would be possible and no fees were payable. ${ }^{60}$

Subsequently the two flying officers made a report on the "course of instructionCroydon Airport' that commenced at 11.00 hours on 13 January 1936. They confirmed that there had been in fact no formal system of instruction but were satisfied that they had come away from Croydon with a complete knowledge of the system of control in use there. Devoting most of their attention to the operation of the control tower they had observed the work of the control office, meteorological office and the communications department. The 'W/T and R/T station', with 'four powerful transmission and receiving sets' was the major component of the communications department. Wireless telegraphy, using the 'Q Code' of the era, appears to have been the predominant means of communication with aircraft while the methodology and extent of the use of radio telephony is not clear. They noted the inter-relationship between the various departments

\footnotetext{
${ }^{58}$ Sec DOD to Sec DEA, 9 Nov. 1935 (MA, AC/1/1/27).

59 Ibid.

${ }^{60} \mathrm{HC}$ to Sec DEA, 5 Dec. 1935 (MA, AC/1/1/27).
} 
and the records kept and obtained a supply of the special forms used in communications. They also visited the Air Ministry and obtained a number of useful publications. ${ }^{61}$

Subsequently the duties of aerodrome control officer were performed by individual officers on a daily basis as detailed. Until the transfer of the Aer Lingus operation to the new Dublin Airport in January 1940 the task was predominantly one of facilitating the safe conduct of civil aircraft into and out of Baldonnell. ${ }^{62}$ The Air Corps' 1939 peace establishment put this assistance in air traffic control on a more formal basis by providing two lieutenants for civil aviation duties.

In the meanwhile, with Aerodrome Control at Baldonnell being carried out by any and all flying officers, the emphasis in control matters changed. The development of the flying boat base at Foynes gave rise to the necessity for air traffic control personnel at that location which, in effect, took precedence over the requirements of Baldonnell (and later Dublin Airport) prior to and during the Emergency. From 1936, until he retired in 1948, Capt. E. F. Stapleton from the Air Corps, was attached to the Department of Industry and Commerce as a 'control officer'. He commenced duty at Foynes in August 1937 and was transferred to Shannon Airport on 3 January $1946 .{ }^{63}$ During the Emergency period Stapleton was a permanent fixture on the control officer roster that required six officers to man the two control positions at Shannon Airport - Foynes. ${ }^{64}$ By January 1944 no less than nine flying officers had spent extended periods of duty at Foynes performing functions that apparently took precedence over the flying duties for which they had been trained and appointed. It was to be 1964 before a military air traffic control section, with officers solely trained for the specific function, was established in the Air Corps. ${ }^{65}$

By way of summary it can be stated that the original responsibilities the duty officer of 1924 evolved little until October 1931 when the control and signals aspects of civil aviation began to take precedence over military considerations. With the imminent start of scheduled civil air services from Baldonnell the requirement to

\footnotetext{
${ }^{61}$ Lieut. E.F. Stapleton and Lieut. M.J. Cumiskey to A/OC AC, 30 Jan. 1936, AC/ 1/1/27, MA.

${ }^{62}$ Corps Standing Orders, 1935, amended 22 Oct. 1937 (in my possession).

${ }^{63}$ 'Record of Control Officers - Foynes', 5 Jan. 1944; chief control officer to OC AC, 4 Jan. 1946 (in my possession).

64 'Control officers - roster', August 1943 (in my possession).

${ }^{65}$ Peter Tormey and Kevin Byrne, Irish Air Corps; a view from the tower (Defence Forces, 1988), p. 25.
} 
adopt more formal civil procedures precipitated the familiarisation visit to Croydon in 1936. The new knowledge acquired was soon essential to the trans-Atlantic aircraft using Foynes. During the Emergency ATC support of civil operations at Baldonnell, Dublin and Foynes became a fixed task for the Air Corps while pilots' flying duties apparently became a secondary consideration.

\section{Communications or signals}

During the Civil War the absence of appropriate air-to-ground and ground-to-air communications was evident and had a detrimental effect on the conduct of reconnaissance operations and on delivery flights from the UK. While the Air Service had an aviation wireless officer his duties were probably confined to providing standard army communications. Even though the particular need for air communications had been commented upon, the opportunity presented by the Army reorganisation scheme of 1924 to establish a Signal Corps element appropriate to the needs of military aviation, was passed up. While the 1927 syllabus of training for pupil pilots required instruction in wireless (theory) and in buzzing (wireless telegraphy - W/T) no provision was made for aviation signals personnel until the peace establishment of 1931-1932. ${ }^{66}$ The Department of Defence signals unit then included provision for two W/T instructors, one lieutenant and one corporal, who were attached to Air Corps Schools for the instruction of pupil pilots in receiving and transmitting in Morse code. ${ }^{67}$

Throughout the army cooperation training regime of the early 1930s the emphasis put on communication by W/T was most notable. A mobile W/T station had been used at Kilworth in 1932 (and presumably also at the air firing practices of 1933 and 1934) for communication between pilots and the ground observers who provided information as to the accuracy or otherwise for the guidance of individual pilots. This service was observed to be an essential aspect of such exercises. ${ }^{68} \mathrm{~W} / \mathrm{T}$ communication, backed up by visual signals and message dropping, was also an essential aspect of successful artillery

\footnotetext{
${ }^{66}$ DFR 7/1927, 18 Mar. 1927.

${ }^{67}$ Peace establishments 1931-1932, (Stationery Office, 1931) p. 22.

68 OC AC to Director of Taining, 27 Aug. 1932 (MA, 2/30989).
} 
cooperation at this time and of early exercises conducted with the Cavalry Corps. ${ }^{69}$ The emphasis on the use of Wireless Telegraphy in the context of army cooperation training contrasts with the situation at Baldonnell where training aircraft were not equipped with wireless equipment and where no ground station existed for the routine military aviation traffic. In effect policy in air communications matters, distinctly biased towards the needs of the army, was still being laid down by GHQ through the aegis of the Director of Signals or his equivalent - just as had been the case in 1922.

By the time that civil operations were being planned for Baldonnell in 1936 (while Dublin Airport was being planned and built) the situation was slightly better though the aerodrome was still poorly equipped even for military aviation. The only aviation communications facility available was a military W/T station with a range of fifty miles while the aerodrome was not equipped for night flying. However the Department of Defence and GHQ facilitated all developments required to equip the aerodrome for civil aircraft operations. In fact Colonel O'Higgins of GHQ is quoted as having informed the Department of Industry and Commerce, and the Post Office authorities, that 'while the civil airport was at Baldonnell the needs of military flying and wireless would be subordinated to those of the civil air service' ${ }^{70}$ In due course the state's first civil radio station for aviation communication was installed and inaugurated at Baldonnell to coincide with the commencement of civil air services by Aer Lingus in May 1936. The start of the service was announced by statutory instrument:

As from Wednesday, 20 May 1936 a new radio station, providing a radiocommunication and direction-finding service available to all aircraft, will be brought into operation at Baldonnel aerodrome, Co. Dublin. ${ }^{71}$

While the notice suggests that the radio station was for the use of all aircraft, civil and military, the station provided both W/T (Morse code) and radio telephony ( $\mathrm{R} / \mathrm{T}$ - two-way voice communication) facilities, including a direction finding service, for civil aircraft

\footnotetext{
69 'Tactical exercise, Air Corps, 25 July 1932 (MA, 230989); 'Air patrols, September 1933', 21 Aug. 1933, P.J. Hassett papers (in possession of Capt. Eoin Hassett).

${ }^{70} \mathrm{O}$ h Allmhurain, Aviation communications service 1936-1986, pp 10-12.

${ }^{71}$ Department of Industry and Commerce, Civil Aviation Notice No. 3 of 1936, 15 May 1936.
} 
only. Military aircraft continued to proceed in accordance with the traditional visual ground signs displayed on the aerodrome. In the context of military communications in the period 1938 to 1941 the standard of airborne W/T and R/T equipment, and of the corresponding ground equipment, as well as the non-availability of a dedicated military direction finding service, were all to impact adversely on the efficacy of aircraft operations and indeed on the morale of individual pilots. (See Chapters $10 \& 11$ )

The investigation of $1941 / 42$ provides a review of the Air Corps signals matters from 1936 to the end of 1941 . The most telling remark was not any aspect of the evidence given but rather the opening question put to Capt. P.J. Murphy (AC Signal Company, 1936/39; AC HQ signals staff officer, 1939/43 andAC Signal Company, 1943/45), on 30 January 1941, some sixteen months into the Emergency. 'We understand the position is that we are gradually building up a signal service within the Air Corps? ${ }^{, 72}$ Murphy answered in the affirmative. In the context of the time the admission that the communications facilities for the Air Corps were still being gradually built up can only be seen as an admission of failure - failure to provide adequate facilities on the first day of the Emergency some sixteen months previously. Murphy added that when he had arrived into the Signal Company at Baldonnell in 1936 there were practically no aircraft equipped with radio. Equipment was gradually acquired and the Air Corps radio service was built up. Except for the five most recently acquired Ansons it had been quite difficult to equip the aircraft with radio as most of the radio equipment was only acquired from the UK in dribs and drabs. By the end of 1940 some sixteen aircraft (six Ansons, three Walrus, I Hawker Hind and six Lysanders) had been fitted with wireless telegraphy equipment which operated on medium and short wave frequencies and required a wireless operator as part of the crew. The Lysander, fundamentally a battlefield reconnaissance aircraft, had the same type of medium to long range wireless as that fitted to the Ansons. Similarly the Hind, like the Gladiators and Lysanders designated by Mulcahy as fighter aircraft, was fitted with a W/T wireless. In the context of aerial combat and the fighter operations of the time the use of W/T sets was as impractical as it was antiquated. It is apparent that the Hind and Lysanders of 1940 should have had the

\footnotetext{
${ }^{72}$ Committee of investigation to Capt. P.J. Murphy, 30 Jan. 1941 (MA, ACS 22/23).
} 
same R/T set as was fitted to the Gladiators of the same squadron even though neither was a fighter in the accepted sense.

The three Gladiator (fighter) sets operated on short wave only. At some unknown date, apparently not later than October 1938, these aircraft were fitted with T.R. 9B radio telephony sets providing two-way voice communication. For fighter aircraft such equipment would have been essential to the performance of its intended combat role. The ground station for this radio consisted of the transmitter and receiver salvaged from Gladiator 23 that had crashed on 20 October 1938. The T.R 9B radio, used in conjunction with this underpowered ground station gave an operating range of ten miles or less. The same aircraft radio in RAF use afforded a range of thirty-five miles. ${ }^{73}$

Notwithstanding the fact that the first aircraft that required a radio operator, the first two Avro Ansons, had been in service since 20 March 1937 the training of operators did not commence until after 14 April 1939. This situation arose because the recruitment and paying of wireless operator mechanics (WOMs) had not been provided for in the 1937 peace establishment. ${ }^{74}$ Mulcahy had anticipated that, as had traditionally been the case, the Signal Corps would post qualified operators into the newly created vacancies. Probably due to general demand for such skilled personnel, and despite making representations to GHQ, and to the Signal Corps, trained operators were not forthcoming. As a result the training of men as wireless operators for Air Corps aircraft did not commence until June 1939.

The training of operators was not the responsibility of the Air Support Company (Cadre) Signal Corps but that of Capt. P.J. Murphy, the signals staff officer in AC HQ. When it did get under way training was provided for only eleven men even though the 1939 peace establishment allowed for a total of nineteen wireless operators in the service squadrons. Such was the urgency to complete, what should have been a twelve month course in the fastest possible time that $\mathrm{OC}$ AC instructed Murphy that the instruction was to be curtailed to the actual operating of the W/T sets. The delay and defects in wireless operator training were highlighted by Murphy in the context of the posting of

\footnotetext{
${ }^{73}$ Capt. P.J. Murphy to AC Investigation, 30 Jan. 1941 (MA, ACS 22/23); Annex No. III to Operations Order 1/1940, 28 May 1940 (MA, EDP 1/1); 'Fighter Squadron - Internal organisation', 16 Dec. 1940 (in my possession).

${ }^{74}$ Amendment 14 to Peace establishment, 1934, 1 Apr. 1937 (MA).
} 
Reconnaissance and Medium Bomber Squadron to Rineanna, apparently with the minimum of notice, on 30 August 1939:

Shortly afterwards, on the outbreak of war, owing to the lack of qualified operators in the Air Corps, in order to enable patrols to be carried out from Rineanna I had to go as one of the two qualified operators and between use we took four of the best pupils for a period of six months. ........and I carried them on all flights for the purpose of training them. When they were sufficiently trained to carry out communication on patrol, I was recalled to Baldonnel to take up my normal duty as Air Corps Signal Officer. ${ }^{75}$

In effect these four pupil operators, who had the theory and technical aspect of their course suspended, were flying on operational missions within three month of commencing training. Subsequently they achieved the required standard of operator skills by way of on-the-job training during operational missions patrolling the south and west coasts in wartime and North Atlantic winter conditions. By January 1941 the Air Corps Signal Officer was able to report that some eighteen men had been trained as wireless operators for service as aircrew though only one could be graded as a $1^{\text {st }}$ Class Operator. This low standard was attributed directly to the fact that his instructions were to train a certain amount of raw personnel to operate sets in the shortest possible time and to eliminate the technical training. By this time the war establishment of 1940 allowed for a total of forty-five wireless operators. As a training objective this number would appear to have been unattainable given the fact that Air Corps did not have an establishment provision of training personnel and the meagre progress made since June 1939. ${ }^{76}$

In January 1941 it was reported that the position regarding the range of airborne and ground $\mathrm{R} / \mathrm{T}$ reception improved greatly with the acquisition of a more powerful ground transmitter. This development was related to the fact that back in September 1940 , due to the fact that it had not been possible to get delivery of a satisfactory ground installation from commercial sources, the director of signals had accepted the offer of a

\footnotetext{
${ }^{73}$ Capt. P.J. Murphy to AC investigation, 30 Jan. 1941(MA, ACS 22/23).

${ }^{76}$ Ibid; War establishment, 1940 (MA).
} 
Thomas Murphy, an amateur radio enthusiast (or radio ham), to demonstrate radio equipment which he had built. It was demonstrated for test purposes with the possibility of the equipment being purchased or rented. The equipment was a transmitter of Murphy's own design and manufacture built mainly of commercially available components but including a small number of parts sourced through the Signal Corps. On 18 and 19 September 1940 extensive tests were carried out on the transmitter installed at Baldonnell using Gladiator and Hind aircraft fitted with the T.R 9B R/T set. A number of flights, by day and by night, as far north as Dundalk and as far south as Carnsore Point and at altitudes between 1,000 and 12,000 feet, were carried out with very satisfactory results. The test results provided 'reliable communication both ways from the plane to the ground and from the ground to the plane up to about 40 miles dependent on the altitude of the aircraft. The satisfactory results achieved with Murphy's amateur transmitter were only possible because a very good receiver was loaned by Lieut. A.C. (Andy) Woods, an Air Corps flying officer and radio enthusiast, to his friend Thomas Murphy. ${ }^{77}$ One of the pilots involved in the tests, Capt. T.J. Hanley, suggested that ground-to-air communication was possible out to sixty or seventy miles and recommended that this could be achieved using a transmitter with an output of 2,000 watts or more and a good type of receiver. ${ }^{78}$ When it is considered that the radio sets used for the tests were those produced by (apparently well qualified) amateurs, the question arises as to the commitment of the Signal Corps to air communications. It could be surmised that the Signal Corps, under the influence of GHQ, saw as its primary function the provision of $\mathrm{W} / \mathrm{T}$ communication services as appropriate to the army cooperation function and concentrated on this to the detriment of those communications commensurate with air force roles, particularly that of the Fighter Squadron. Similarly the technical competence of the Signal Corps could be questioned. It might be considered that the Signal Corps should have had, and used, the requisite technical expertise to manufacture and install a ground transmitter and receiver sets to a specification appropriate to the $\mathrm{R} / \mathrm{T}$ requirements of the Air Corps. In theory they should have been better placed that Thomas Murphy to do so.

\footnotetext{
${ }^{77}$ Capt. P. J. Murphy to AC investigation, 30 Jan. 1941 (MA, ACS 22/23).

${ }^{78}$ Capt. T. J. Hanley to AC investigation, 23 Jan. 1941 (MA, ACS 22/23).
} 
Deficiencies in the preparedness of the Air Corps Company, Signal Corps, whose main responsibility was the maintenance and operation of ground stations, for both air and army purposes, was also highlighted when, on the outbreak of war, a 24 hour watch on ground stations was introduced. This was only possible at Baldonnell and Rineanna by using the wireless operators, who had been being trained as aircrew by and for the Air Corps, as operators of the ground station wireless sets. This continued until April or May $1940 .^{79}$ In effect the Signal Corps, having failed to provide or train wireless operators for the Air Corps similarly failed to provide adequate wireless operators for its own ground stations and, initially at least, had to rely on partially trained Air Corps operators to carry out the most fundamental Signal Corps responsibilities required at military aerodromes.

\section{Navigation.}

The purchase of Avro Anson reconnaissance aircraft in 1937, 1938 and 1939, a total of nine aircraft, strongly suggests the development of at least a medium range coastal reconnaissance capability. To what extent P.A. Mulcahy appreciated the necessity of advance the requisite level of air navigation is not clear. Whereas army cooperation called for the fundamental disciplines of map reading and dead reckoning (DR) navigation, longer range reconnaissance with the Anson put a greater emphasis on the third basic element of navigation, the fixing of position by means of the plotting of position lines on appropriate navigation charts. In 1937/38 a young pilot, Lieut. Jim Devoy, was nominated to undergo two courses of training in navigation with the RAF. As with previous courses with the RAF, the army cooperation course of 1930 and the flying instructor's course of 1932, the records do not show how this came about. It is contended that the Air Ministry or RAF had offered a place on each course gratis. Devoy summarised his participation on the courses.

I completed two navigation courses in England in 1937 and 1938 at the RAF

School of Navigation, Manston. The first was known as the short navigation course

${ }^{79}$ Capt. P.J. Murphy to AC investigation, 30 Jan. 1941 (MA, ACS 22/23). 
and the second as the specialist navigation course. I qualified in both courses. The short course is approximately equivalent to the civilian $2^{\text {nd }}$ class navigator's certificate and the standard of the specialist's course is approximately equivalent to the standard civilian $1^{\text {st }}$ class navigator's certificate. ${ }^{80}$

Having completed one course of three months duration and a second of six and a half months duration, Lieut. Devoy was employed as the navigation instructor in Air Corps Schools. On his return from the more advanced course, in July 1938, he had recommended the running of a course of navigation for as many officers as possible. He continued to press his superiors on the matter and was eventually asked to make a written submission for the attention his CO. In April 1939 Devoy made his commanding officer aware of the unsatisfactory level of navigation equipment available to pilots while stating that that navigation, as part of all pilots' training, was in effect grossly neglected. In particular he was very dissatisfied with the general standard of practical navigation. He went on to respectfully suggest that he be instructed to arrange a short course in theoretical and practical navigation for the R \& MB Squadron and another for the Army Co-operation Squadron. Emphasising the importance of meteorological information to the safe navigation of aircraft he recommended the appointment of a meteorological officer, the receipt of the short wave coded reports and forecasts from Rugby and the purchase of a list of recommended navigation equipment. ${ }^{81}$ Shortly afterwards he was instructed to run a very short navigation course. When he requested a greater length of time to cover a greater amount of an intended syllabus he was told that additional time could not be spared. As a result he drew up an abbreviated syllabus based on the time available. Even then the practical navigation aspect was not completed. ${ }^{82}$

By the beginning of July 1939 the school commandant was able to report on the results of the short navigation course conducted in the period 5 June 1939 to 3 July 1939. The course had been conducted for nine pilots of the thirty-three pilots then in service. Noting that attendance on the whole was good he reported that general military duties,

\footnotetext{
${ }^{80}$ Capt. J. Devoy to AC investigation, 20 Mar. 1941 (MA, ACS 22/23).

${ }^{81}$ 'Navigation', Lt. J. Devoy to OC AC, 21 Apr. 1939, Appendix XVII (A), Report and finding of the committee (MA, ACS 22/23).

${ }^{82}$ Capt. J. Devoy to AC investigation, 20 Mar.1941 (MA, ACS 22/23).
} 
such as Orderly Officer, had caused some interruption. Despite Devoy's earlier recommendation regarding adequate supplies of navigation equipment it was very limited, especially mathematical tables and instruments. For reasons outside the control of the school the flying programme had been considerably reduced, mainly due to an unspecified number of special flying missions and tyre trouble. While the programme called for nine flights each for pupils to practice practical navigation only four each were actually completed. While good progress was reported in terms of more advanced instruction in interception problems and elementary instruction in continuous navigation out of sight of land it was observed that the officers could not be considered to be qualified navigators. $^{83}$ In brief a somewhat abbreviated and basic course was further abbreviated and had been run for just over one quarter of the qualified pilots in the Corps. To judge from the brevity of the course, lack of equipment and insufficient practical navigation, a small proportion of the flying officers of the Corps had achieved a very modest level of proficiency where a significantly higher standard for all should have achieved.

The question arises as to why it took until June 1939 to initiate navigation training. Had the two RAF courses become available because of an initiative on the part of Mulcahy, or on the part of pilots who might conceivably have influenced him, it is probable that the newly qualified officer would, on his return, have been immediately tasked to instruction in navigation for the maximum possible number of pilots. In the circumstances however it is probable that the places on the course were made available by the UK authorities gratis and that a pilot was nominated and sent with no particular thought as to how he might subsequently be employed. Bearing in mind that Devoy had to prompt Mulcahy into authorising a navigation course, it seems probable that the commanding officer had little or no appreciation of current navigation practice or of its application to the operation of reconnaissance aircraft such as the Avro Anson. With an instructor duly qualified in navigation to the specialist level applying in the RAF it is not obvious why Mulcahy did not immediately proceed to have all pilots trained to at least the basic standard, and those of the R \& MB Sqn. to a somewhat higher standard

${ }^{83}$ W.P. Delamere to OC AC, 7 July 1939, Appendix XVII (B), Report and findings of the committee, 10 Jan. 1942 (MA, ACS 22/23). 
commensurate with the range and intended role of the Anson aircraft. Devoy himself would have settled for the position where all pilots would be trained to the lower standard, that equivalent to the civil $2^{\text {nd }}$ class navigation certificate. ${ }^{84}$

When asked by the investigation committee if the fullest use had been made of a qualified navigation instructor Mulcahy proceeded to mislead the committee:

He has been engaged as an instructor in the school both flying and navigational and I considered that it was more important that he should be available to the Schools than that he be employed elsewhere. ${ }^{85}$

Stating, in effect, that it was not possible for Devoy to carry out advanced courses in navigation for service pilots apparently satisfied the committee. The members were not aware of the actual situation. Between January 1938 and August 1939 no pupil pilots were in training in the flying school. Devoy was not involved in flying instruction or navigation training with pupil pilots as implied by Mulcahy and would have had ample time to train and qualify many pilots to an acceptable standard. It is somewhat ironic that the 'wings' course syllabus, drafted by W.P. Delamere, and authorised and signed by Mulcahy in September 1936, specified the Air Ministry Manual of Air Navigation of 1935 as the reference text for instruction in air navigation. This manual should have been a more than adequate guide as to how to proceed in navigation training for the expected emergency. ${ }^{86}$ It is doubtful that Mulcahy, who had received no ground school training of any description, was familiar with this essential text. In his ignorance of air navigation, and of its application to long range reconnaissance, he apparently saw no need for navigation techniques more advanced than the map reading applicable to army cooperation.

\footnotetext{
${ }^{84}$ Capt. J. Devoy to AC investigation, 20 Mar. 1941 (MA, ACS 22/23).

${ }^{85}$ P.A. Mulcahy to AC investigation, 24 Oct. 1941 (MA, ACS 22/23).

${ }^{86}$ Corrected draft syllabus, Young officers flying training course, 25 Sept. 1936 (in my possession); Air Publication 1234, Manual of air navigation, Vol. I, (HMSO, 1935), passim.
} 


\section{Direction finding services}

As already stated an aviation communications service, with a direction finding service as an aid to the safe navigation of civil aircraft, had been operated at Baldonnell since May 1936. From July 1937 similar services were made available at Ballygireen, Co. Clare, complete with two direction finding stations, for transatlantic traffic approaching the Shannon / Foynes area while the Foynes seaplane base itself also had a DF station to facilitate aircraft landing in the river estuary. At Ballygireen the Marconi DFG10 medium wave direction finder was suitable for use by military aircraft such as the Ansons equipped with $\mathrm{W} / \mathrm{T}$ wireless sets while the DFG12 short wave station was compatible with the R/T equipment of fighter aircraft. ${ }^{87}$ The Baldonnell medium wave DF station could only be used by those aircraft, mainly reconnaissance types, fitted with W/T sets. While this DF facility was intended specifically for the use of civil aircraft Air Corps pilots could avail of the service at such times when it was not engaged with civil traffic. The Air Corps use of the civil DF stations at Baldonnell and Ballygireen was mainly in the context of Anson and Walrus aircraft transiting between Baldonnell and Rineanna / Shannon.

With the operation of the Baldonnel civil DF station only available between 09.15 and 17.00 hours, and the available service severely curtailed within those hours the availability, or more correctly the non-availability, of dedicated direction finding services for military navigation purposes was to become a somewhat confused and contentious issue during the first fifteen months of the Emergency. In April 1939 Lieut. Jim Devoy had recommended that at least two direction finding W/T stations be installed in selected locations as essential aids to the safe navigation of military aircraft. ${ }^{88}$ The matter had been the subject of (unseen) correspondence from the Director of Signals to OC AC on 24 February 1939 and vice versa on 5 April 1939. Later that year a board of officers was assembled by order of the COS to investigate the proposal put forward by the director of signals to purchase four (G.12, short wave) Direction Finding sets - a proposal

\footnotetext{
${ }^{87}$ Carmella Corbett, 'History of the service 1936-1986' in Sean O' hAllmhurain (ed.), Aviation Communications Service 1936 - 1986 (Department of Communications. 1986), pp 6-17.

${ }^{88}$ 'Navigation', Lieut. J. Devoy to OC AC, 21 April 1939, Appendix XVII(A), Report and finding of the committee (MA, ACS 22/23).
} 
apparently agreed between himself and OC Air Corps. The board, comprised of staff officers of GHQ, questioned Major Gantly as to the necessity for four stations and as to whether the type proposed was the most efficient that could be procured. He was also asked whether he had satisfied himself and the OC AC that such installations would meet the direction finding requirements by day and by night. Gantly explained that four stations, to be erected at Baldonnell, at the Curragh for the training of Signals Corps personnel, and at Athlone and Cork was the minimum to cover the needs of the Air Corps and the training of personnel. The board was very sceptical about the Signals proposal and commented on the fact that relevant correspondence between Signals and the Air Corps was not available to it. The board commented on a main proposal:

The chairman drew Major Gantly's attention to the proposed locations of the stations on the map and the limited effective range of direction finding in Ansons, Lysanders, and Walrus (70 miles) and Gloster (35 miles) and pointed out that the erection of stations at Baldonnel, Curragh, Athlone and Cork would appear to leave many parts of the country uncovered. ${ }^{89}$

In particular the board considered that Athlone was an unsuitable location due to the nature of the topography, the proximity of the Radio Eireann's transmitter and the distance from the west coast. It was considered that if four stations were essential and could be justified, locations at Baldonnell, Galway, Sligo and Cork should be examined instead of those originally suggested. On 16 December 1939 the board discussed the matter with Mulcahy who specified the Air Corps' requirements:

(1) 3 S.W. D/F sets were considered sufficient for Air Corps requirements.

(2) He was aware of the limitations of S.W. D/F especially at night, nevertheless he was satisfied that the installations were an urgent necessity.

(3) Medium wave D/F sets were not suitable for erection in the vicinity of military aerodromes; masts cause considerable obstruction and would not cater

\footnotetext{
${ }^{89}$ Report to COS, 22 Dec. 1939 (MA, AC/2/8/4).
} 
for all types of aircraft. The whole tendency in Wireless was development of S.W.

(4) He had no objection to courses of instruction for Signal Corps personnel being carried out at Baldonnel so as to obviate the need for a training station at the Curragh.

(5) He did not favour a homing device in military aircraft. There was no room in fighters for receivers, and loop aerials in fighters or bombing aircraft could not be permitted. The system would demand erection of masts on aerodromes to which there would be the same objection as in the case of medium wave $\mathrm{D} / \mathrm{F}$ installations. ${ }^{90}$

It is not at all easy to understand the position taken by Mulcahy as it suggests the absence of any genuine commitment to improving communications and direction finding facilities for military aircraft. His objection to having medium wave DF at military aerodromes, in effect to both Baldonnell and Rineanna, appears to be almost contrived. With the existing DF facilities available at the two aerodromes dedicated almost exclusively to the use of civil aircraft medium wave DF might have been seen as a distinct requirement at both for W/T equipped aircraft while short wave DF was also required at Baldonnell for the use of fighter aircraft equipped with RT equipment. The positioning of large aerial arrays at a small aerodrome such as Baldonnell, if the will was there, should not have been an insurmountable problem. With the civil DF stations at Ballygireen and Foynes inappropriately located a DF station was required at Rinanna for navigation and for badweather approaches to landing. However it appears that neither Mulcahy nor his signals officer recognised these points.

Similar comments could be made about Mulcahy's dismissal of the obstructive nature of ground installations connected with the transmitters to serve airborne directionfinding loop aerials. While the number of ground transmitters compatible with such homing devices as loop aerials, normally fitted to aircraft like the Anson, was limited Mulcahy's objection to the concept of loop aerials in Ansons could only be considered

\footnotetext{
${ }^{90}$ Ibid.
} 
spurious and ill-informed. In his evidence to the investigation Capt. T.J. Hanley highlighted the position regarding loop aerial for Anson aircraft:

The modification to have the loop aerial installed on Ansons was issued by A.V. Roe on 23/11/38, Anson modification No. 214. On 7/1/39, the modification was passed to OC Workshops, to requisition the material. This was not done as OC Workshops got instructions [from higher authority] not to requisition them. ${ }^{91}$

Higher authority in this instance could have been Comdt. P. Quinn, OC Air Corps Depot but was more likely Col. P.A. Mulcahy.

On 16 December also the Air Corps Signals Officer was interviewed by the board and reported on the unsatisfactory nature of the results of test conducted to test the

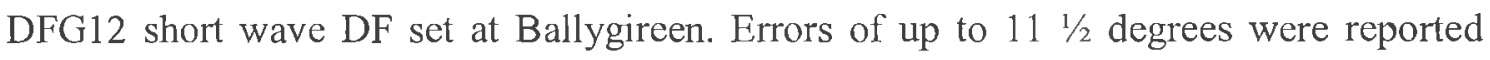
from daytime tests while 'at night on one occasion he was unable to get any bearing'. When questioned as to the reported 'perfection of a mobile S.W. D/F set in France' Murphy indicated that he had read about it in the technical literature but could offer no opinion on it. ${ }^{92}$

When the board recalled the director of signals it pointed out that tests did not justify the purchase of the DFG12 short wave set and that OC AC now only required three DF stations. It was suggested that his original submission supporting a case for four DF stations was still unsatisfactory. More importantly it was indicated to Major Gantly that a serious view was being taken of the fact that a DFG12 set had been delivered to the North Wall - apparently its purchase had not been properly sanctioned. In his defence of the test results Gantly stated that the tests carried out were only for calibration purposes and that errors detected would be taken into account when communicating with aircraft. In this latter regard it is suggested that the director of signals was on unsafe ground. The DF tests described by Lt. P.J. Murphy appeared to concentrate on the track between Rineanna and Baldonnell. It is not possible to calibrate the accuracy of a direction finding station on the basis of a single direction or bearing. A properly conducted

${ }^{91}$ Capt. T.J. Hanley to AC investigation, 23 Jan. 1941 (MA, ACS 22/23).

${ }^{22}$ Report to COS, 22 Dec. 1939 (MA, AC/2/8/4). 
calibration test would entail a flight or series of flights and the recording of many bearing around a full compass rose around, in this case, Ballygireen. Such compass bearings would necessarily have to be taken when the aircraft was over known geographic points so that the DF bearing can be compared with the known bearing of the particular point. It is most doubtful that such calibration could produce a trustworthy compensation table capable of correcting errors of up to eleven and a half degrees.

Gantly accepted that a DF station at the Curragh could be dispensed with but that it should be installed elsewhere so that the country could be covered as far as possible especially having regard to illicit transmitters. Despite his previous position favouring four stations suitably situated the chairman of the board 'suggested that having regard to all factors in the case two installations would be sufficient', one at Baldonnell and one in the Cork area. Gantly reluctantly accepted this suggestion on the understanding that he would not be held responsible if two proved to be inadequate. After further discussion on the merits of short wave DF sets for the detection of illicit radio transmitters the board formed the opinion that two short wave DF sets together with the services of the [civil] station at Ballygireen would be ample and recommended accordingly. ${ }^{93}$

Given the final decision it appears that the various parties may have been at cross purposes. The decision suggests that the board was primarily interested in DF as an aid to locating illicit transmitters while Mulcahy was, somewhat half-heartedly, pursuing DF stations for air navigation purposes. It is perplexing to note that no recommendation was made in respect of the short wave DF set that had presumably been purchased by DS on his own initiative. More perplexing is the thought that 'two short wave direction finding sets' had been apparently been purchased in January 1940, but were still 'lying in the stores of the Signal Corps' two years later. ${ }^{94}$

During 1940 the position regarding DF services, at Baldonnel in particular, did not improve much and the matter of the poor service available to military aircraft drew the attention of the Capt. T.J. Hanley (R \&MB Sqn. at Baldonnel, later OC CP Sqn.) in early January. He reminded OC AC that the Aer Lingus service was shortly due to move to the recently developed Collinstown (Dublin) Airport, that as sufficient DF facilities

\footnotetext{
93 Ibid.

'4'Report and Findings of the Committee', 10 Jan. 1942, LIV (MA, ACS 22/23).
} 
and staff are already available at Collinstown he suggested that the DF station and staff at Baldonnell were surplus to civil needs. He stated a substantial case to prevent the civil DF station being closed down, which had been the previous plan, and to have it and its Posts and Telegraphs staff taken over as a dedicated military facility. He argued that every effort should be made to preserve the safety of aircraft in service stating

... any personnel or equipment which exist in this country and which we think is necessary to preserve those aeroplanes should, not only be put at our disposal, but should if necessary be seized by military authority. The DF Station and staff at Baldonnel come into this category. ${ }^{95}$

Hanley was dismissive of the concept of the possible installation of a short wave DF system.

I desire to state that during the last previous three years I have had made a considerable study of D.F. systems for navigation and approach purposes. I have read any British or American book which I could buy or borrow on the subject of D.F. and one and all agree that short wave D.F. inside distances of 300 miles is most unreliable. ${ }^{96}$

And, quoting from his own experience of the tests conducted in June 1939, gave witness to that assertion. ${ }^{97}$ It is not clear how Mulcahy reacted to these recommendations but pencil annotations on the letter suggest that he agreed with the general thrust but would stop short of recommending the military seizure of civil aviation facilities. On 17 January 1940 the acting CO suggested that until such time as a military short wave station was installed at Baldonnell the existing civil DF, which would continue to function as a standby for emergency civil use after the transfer of air services to Collinstown, might, with

\footnotetext{
${ }^{95}$ 'Civil medium wave DF station at Baldonnel', Capt. T.J. Hanley to OC AC, 6 Jan. 1940 (MA, AC/2/8/4).

${ }^{96}$ Ibid.

${ }^{97}$ Ibid.
} 
the cooperation of the Department of Posts and Telegraphs be used to train Signal Company or Air Corps wireless operators in DF procedures. ${ }^{98}$

In due course Posts and Telegraphs responded to the proposal as forwarded by DOD. They indicated that the Baldonnel DF was still required, during the normal hours of the service of the Collinstown station, for emergency purposes only. The PO also stated that it was anticipated that the Baldonnell DF receiver would be required at Shannon Airport in a few months. Permission was granted to allow Air and Signal Corps personnel become familiar with procedures and to use the station for give DF bearings to military aircraft subject to conditions. The main condition specified that while civil aircraft were in flight on the cross-channel service in either direction that the training of army personnel should be suspended. The receiver at Baldonnel could only be tuned to the military frequency when there was no civil aircraft on the cross-channel service. The final condition stated that training and DF facilities could only be provided while the Post Office operator was in attendance so that, if DF services were required after normal hours of operation, prior arrangements should be made. ${ }^{99}$ Having been asked to specify the times at which a DF service and training facilities would be required Mulcahy confirmed that the service would be required during normal Air Corps duty hours and stated that he appreciated that Civil Aviation must receive priority from the D.F. station. ${ }^{100}$ While this arrangement might have appeared satisfactory in terms of the potential availability of DF bearings on the Air Corps medium wave frequency, it must be seen in the context of two civil cross-channel flights in each direction each day - a situation that would have obviated such services for large parts of the standard day. In regard to operator training the Signal Corps apparently failed to supply additional personnel to train in DF procedure and it fell to the Air Corps to supply a small number of wireless operators who had to be withdrawn from flying duties. ${ }^{101}$

While the withdrawal from service, and the removal, of the Baldonnel DF station had been anticipated it continued to remain in service. It was intimated once more in October 1940 that as the services at Dublin Airport were then well established the

\footnotetext{
${ }^{98} \mathrm{~A} / \mathrm{OC} \mathrm{AC}$ to DS, 17 Jan. 1940 (MA, AC/2/8/4).

${ }^{29}$ Dept. P \& T to DOD, 4 Mar. 1940 (MA, AC/2/8/4).

100 OC AC to DS, 26 Mar. 1940 (MA, AC/2/8/4).

${ }^{101}$ Capt. P.J. Murphy to OC AC, 19 Apr. 1940 (MA, AC/2/8/4).
} 
question of the closing down of the DF station at Baldonnel for civil purposes was being considered and the views of the Air Corps on the matter were requested. ${ }^{102}$ Mulcahy, replying through the office of DS, stated that, as it was the only DF facility at Baldonnell it was required, in bad weather, for aircraft of the R. \& M.B. Squadron and for the training of young pilots in the use of DF during instrument flying practice. He insisted that the DF continue to be made available for military aircraft when necessary and indicated that in the event of the PO staff being withdrawn Army personnel would have to take over the operation of the Station'. ${ }^{103}$ With the director of signals apparently not responding to the latest regarding the possible closure of the DF station OC AC was sent a reminder on the matter by Industry and Commerce and was asked for his views on the continued use of the station for civil stand-by purposes. ${ }^{104}$ Having consulted two of his staff officers (Comdt. D.V. Horgan, Operations Officer; R.W. O'Sullivan, civilian aeronautical engineer) and OC AC Signals Company (Capt. M. Egan) Mulcahy recommended 'that the DF station should be retained for civilian purposes as an alternative to Collinstown' on the basis that 'the latter could be rendered useless by enemy action'. ${ }^{105}$ The net result of this apparently perverse recommendation was that the Baldonnell DF station continued in its traditional civil aviation role until 5 September $1941{ }^{106}$ It might have been considered that the DF station could have been transferred to military control much earlier on the basis that it could revert to civil use in the unlikely event of the Collinstown station being destroyed. It is significant that despite the agitation on the part of the pilots who required a proper DF service OC AC and his headquarters staff could not be convinced that such a service, under military control, was essential.

Notwithstanding the reluctance of AC HQ to take over the station it appears to have become more accessible for military use. Arising out of increased use those primarily concerned with the quality of the service and most familiar with its limitations, Lt. A.C. Woods and Capt. T.J. Hanley, endeavoured to have action taken to improve on the cumbersome and slow method of transmitting bearing to military aircraft. As there

\footnotetext{
${ }^{102}$ Dept. of I \& C to OC AC, 8 Oct. 1940, (MA, AC/2/4/29).

${ }^{103}$ OC AC to DS, 12 Oct. 1940 (MA, AC/2/4/29).

${ }^{104}$ Dept. I \& C to OC AC, 6 Nov. 1940 (MA, AC/2/4/29).

${ }^{105}$ OC AC to Dept. I \& C, 13 Nov. 1940 (MA, AC/2/4/29).

${ }^{100}$ 'P.O. DF station. Baldonnel', OC AC Coy, Signal Corps to OC AC, 12 Sept. 1941 (MA, AC/2/4/29).
} 
being no military transmitter co-located with the DF station the operator had no direct method of transmitting bearing information to the requesting pilot. The bearings were first sent by land line telephone to the Air Corps wireless station for transmission to the requesting aircraft, thus imposing an unacceptable delay. Lieut. A.C. Woods proposed two alternative wireless solutions that would speed up the process greatly - particularly for the benefit of aircraft as they get closer to the station. Capt. Hanley endorsed the observations and recommendations of his operations officer and suggested that if the system could not give four bearings per minute it should be changed without delay. ${ }^{107}$

The very next day the tenuous position regarding the use of the station for military purposes was demonstrated by an incident, and its aftermath, involving the unauthorised us of the civil facility by the military. On the morning of 21 November 1940 Anson 42 was flow by Capt. T. J. Hanley to Rineanna. Acting on instructions, he was conveying a medical officer on a brief visit to the R. \& M. B. Squadron detachment there. Having checked the weather forecast prior to his departure at 11.00 hours he indicated to the Air Corps Signal Officer that he would require DF assistance on his return, the time of which depended on the length of medical officers stay in Rineanna. At about 16.00 hours the aircraft left Rineanna in good flying conditions but encountered bad weather just west of Baldonnell. With cloud at 500 feet, fog at ground level, visibility of about 400 yards and the conditions getting rapidly worse it was essential that DF assistance be requested. ${ }^{108}$ In the meanwhile Lieut. A.C. Woods, Operations Officer, CP Squadron had established that the aircraft had left Rineanna and that it would not reach Baldonnel until about 17.30 hours and observing that the weather at Baldonnell was deteriorating to the extent that the aircraft would require DF services. He also established that the Post Office staff had closed down the station at 16.15 hours, the usual time. As Capt. M. Egan (OC Air Corps Signal Company) had indicated that he did not know what might be done Woods ascertained that 2/Lieut. Sinnott (Signal Officer, Fighter Squadron) knew how to operate the equipment and suggested that Sinnott be allowed to operate the station with the safety of the aircraft crew as the primary consideration. With the agreement of Capt. Egan

\footnotetext{
${ }^{107}$ Lieut. A.C. Woods to OC CP Squadron, 20 Nov. 1940; OC CP Sqn. to AC Signals Officer, 20 Nov. 1940 (MA, AC/2/4/29).

108 'Entry of Post Office D.F. station', Capt. T.J. Hanley to OC AC, 9 Jan. 1941 (MA, AC/2/4/29).
} 
Lieut. Woods and Lieut. Sinnott gained access to the DF station with the caretaker's cooperation. The DR station was opened at 16.45 hours and, in the period from 16.56 to 17.35 hours, Lieut. Sinnott passed bearings to the incoming aircraft. At 17.35 hours the aircraft made a safe night landing in poor weather conditions and the station was closed three minutes later. ${ }^{109}$

Two days later Capt. P.J. Murphy submitted a report to OC AC giving a brief outline of the circumstances relating to the use of the DF station. He did so, not by way of complaint but rather to highlight the urgent necessity for having satisfactory DF facilities available to aircraft whenever necessary. ${ }^{110}$ Without waiting for written reports or explanations on the matter Major Mulcahy wrote to the commanding officers of the two relevant units.

I am informed that, on the evening of $21^{\text {st }}$ instant. 2/Lieut. Sinnott of your unit entered the Post Office D.F. Station and operated the station in the absence of the Post Office DF operator.

You will inform this officer that his action was irregular. ${ }^{1 / 1}$

He also reminded OC Fighter Squadron that the DF station closed down at 16.15 hours and that it was only with the permission of the Post Office that DF facilities could be made available thereafter. On the same day Mulcahy communicated in similar terms to OC CP Squadron reprimanding Lieut. A.C. Woods except that his actions were considered to be most irregular. ${ }^{12}$ Apparently no effort was made to establish why the AC Signals Officer, a member of Mulcahy's staff, had failed to ensure that the DF station remained open after 16.15 hours.

Woods was to express his dissatisfaction with the implications of his commanding officer's reprimand when explaining the matter to his squadron commander, Capt. T.J. Hanley, who had been the pilot of the aircraft. He detailed all the circumstances and,

\footnotetext{
${ }^{109}$ DF station log, 21 Nov. 1940; Lieut. A.C. Woods to OC CP Sqn., 29 Nov. 1940 (MA, AC/2/4/29).

${ }^{110}$ AC Signal Officer to OC AC, 23 Nov. 1940 (MA, AC/2/4/29).

II OC AC to OC Fighter Sqn., 28 Nov, 1940 (MA, AC/2/4/29).

112 OC AC to OC CP Sqn., 28 Nov. 1940 (MA, AC/2/4/29).
} 
while accepting that his action was considered irregular, justified his action on the basis of the safety of the aircraft and crew:

I take full responsibility for my actions in this case, I accept responsibility for both Capt. Egan and 2/Lt. Sinnott, as these officers, knowing me to be a flying officer of experience agreed with me. I must confess that if a similar situation were to arise again, I would still feel it my duty to do the same thing. ${ }^{113}$

Due to his being indisposed it was to be early January 1941 before Capt. T.J. Hanley could address the issue. He first confirmed that he had, as directed, made Lieut. Woods aware of the CO's displeasure regarding the irregular use of the DF station. As pilot of the aircraft he made a comprehensive report on all pertinent aspects of the flight and the incident. He confirmed that the Corps Signals Officer had stated that he would arrange D.F facilities, would fly on the aircraft to Rineanna in order to carry out an inspection there and would act as Radio Operator on the flight. Having encountered the adverse weather conditions in the Baldonnell area Hanley stated that he was most thankful for the D.F. assistance and that he had not been aware that the regular operator was not on duty. He also stated that he would expect no less from Lieut. Woods or any other officer left in charge. He reminded $\mathrm{OC}$ AC that when he (Mulcahy) had been flown from Rineanna to Baldonnell on 9 December 1940 the DF station was also manned by Air Corps personnel in circumstances similar to those of 21 November. He was openly critical of his CO;

This bears out my statement that any officer with a sense of responsibility will have no compunction to ensure the safety of an aeroplane and its crew. To me the deplorable part of the situation is, that officers who do their obvious duty in such circumstances are admonished by their superiors, and all because no proper DF facilities exist at Baldonnel for Air Corps aeroplanes. The question of providing proper facilities for the Air Corps has now been going on for years without result, and these irregularities would not occur if (a) The DF station were handed over to

\footnotetext{
${ }^{113}$ Lieut. A.C. Woods to OC CP Sqn., 29 Nov. 1940 (MA, AC/2/4/29).
} 
the Air Corps or (b) Post Office operators were stationed at Baldonnel where one of them would be at all times available. ${ }^{114}$

While not couched in personal terms this robust endorsement of the actions taken by Woods was, in effect, a considerable criticism of Major Mulcahy and his lack of empathy with pilots and the aviation culture. In November 1940 Capt. Hanley had already taken matters a stage further when he wrote to the Minister complaining about the failure of the Air Corps to purchase vacuum pumps, essential equipment on Anson aircraft. ${ }^{115}$ The highlighting of such matters was a manifestation of the frustration of the pilot body in general having regard to the standard of aircraft and other equipment as well as training and support services.

Folklore accounts of the $1939 / 41$ period suggest that the pilot body was at loggerheads with its commanding officer and that pilots were threatening to remove their pilot's wings because the CO wore wings to which he was not, as they saw it, entitled. The above critical correspondence would have been received by Colonel Mulcahy on 10 January 1941, on the same day that the Chief of Staff had convened an 'investigation into the effectiveness, organisation, equipment, training and administration of the Air Corps'. The convening of this investigation was made necessary by "the evidence of demoralisation, in some cases inefficiency and stagnation, and the inadequacy and unsuitability of equipment'. The committee concluded as follows:

The confidence of a large number at least of the junior officers of the Air Corps in Colonel Mulcahy has, through one cause or another, been hopelessly undermined. ${ }^{116}$ (See Chapter 11)

As stated above the investigation committee, on 30 January 1941, was able to comment favourably on the fact that the signal service within the Air Corps was gradually being built up, implying a considerable improvement of an earlier position. Notwithstanding,

\footnotetext{
${ }^{114}$ Capt. T. J. Hanley to OC AC, 9 Jan. 1941 (MA, AC/2/4/29).

115 Capt. T.J. Hanley to AC investigation, 23 Jan. 1941 (MA, ACS 22/23).

${ }^{116}$ Report and Findings of the committee, 10 Jan. 1942, LXIX - LXX (MA, ACS 22/23).
} 
the situation illustrated by the evidence on signals matters suggests that the unsatisfactory states of communications and direction finding services were large contributors to the demoralisation of the pilots and central to the distrust that existed between them and their commanding officer in the latter part of 1940.

However to fully appreciate the poor situation regarding these services it is necessary to compare the communications services available to civil aviation - the cross-channel and trans-Atlantic services - and those available to military aviation on 3 September 1939. Baldonnell civil airport had both W/T and R/T transmitter and receiver sets of the appropriate frequency and power to serve the Irish sector of the cross channel air route. In addition it had a medium wave DF station to assist navigation and approach to the civil airport. ${ }^{117}$ These facilities were to be duplicated at the new Collinstown airport by January 1940. The Foynes / Shannon area was very well provided with the communication appropriate to the flying range of the trans-Atlantic flying boats using them. Ballygireen had three transmitters and receivers covering a broad spectrum of frequencies appropriate to long range communication. It also had one short wave and one medium wave DF station. At Urlanmore there was a short wave transmitter / receiver for point-to-point communication with Botwood, Newfoundland, Canada - over two thousand miles away. This wireless was remotely controlled from Ballygireen. Foynes itself had a single transmitter / receiver and a medium wave DF for air traffic approaching and departing the seaplane base. ${ }^{118}$

At the same time the military aerodrome at Baldonnell had a medium wave W/T transmitter and a receiver giving a range of fifty or sixty miles. In addition the aerodrome had a transmitter / receiver set, salvaged from an aircraft, operating on short wave and limited to a range of five or ten miles - and no DF station. Rineanna had a mobile radio car that had insufficient range to maintain contact with aircraft any further than sixty miles away - and no DF facility. ${ }^{119}$

The quality of communications generally, and direction finding facilities in particular, which were available to the Air Corps is in sharp contrast to those available,

\footnotetext{
117 Dept. I \& C, Civil Aviation Notice, No. 3 of 1936, 15 May 1936

118 'Radio stations for Shannon Airport', 14 July 1939 (MA, EDP/30).

119 P.J. Murphy to AC investigation, 30 Jan. 1941 (MA, ACS 22/23).
} 
on Irish soil, to the RAF during the emergency though it is not clear when these facilities became available. Towards the end of the war the UK Government noted a number of facilities it feared could be withdrawn by de Valera in uncertain circumstances:

There are two Post Office wireless stations (operated by Southern Irish personnel) on Southern Ireland territory, one at Valentia and the other at Malin Head; these are used as direction finding beacons by our aircraft .....the withdrawal of the facilities would be a serious loss. ${ }^{120}$

Similarly when listing the "facilities obtained from the government of Eire during the war' the Dominions Office acknowledged 'the use by United Kingdom ships and aircraft of two wireless direction finding stations at Malin Head'. ${ }^{21}$ Although the end of the war prevented its construction, de Valera had given the UK authorities permission to build and operate a radar station, for use in its campaign against German submarines in the North Atlantic, in the same compound on Malin Head. Had it been built the UK authorities had agreed with Col. Liam Archer (by then Assistant Chief of Staff) that it would have been passed off as a 'radio lighthouse' or a 'glorified marker beacon' for the guidance of aircraft. ${ }^{122}$

\section{Conclusions}

The question arises as to what influence the development of the support services of meteorology, air traffic control and signals had on the Air Corps by late 1940. During the 1920s while the Air Corps was somewhat anxious to obtain appropriate weather forecasts at no stage did pilots get exercised by the matter while no great urgency was given to the matter of having a meteorological station at Baldonnell. While the national Meteorological Service was eventually established this was purely to coincide with the commencement of a civil air service to the United Kingdom. Though the air

\footnotetext{
${ }^{120}$ Appendix to report by Sir Findlater Stewart, 18 Mar. 1944 (NA, PREM /3/133/3).

I21، 'Top secret', Memo W.X. 101/92, No. 50, 21 Feb. 1945 (NA, DO 114/117).

122 Sir John Maffey to Sir Eric Machtig, 6 Mar. 1945 (NA, DO 35/2117).
} 
service operated from Baldonnell from May 1936 to January 1940 the fact that a station was not established at Baldonnell appears almost contrived. Fr. W. M. O'Riordan M.Sc. and R. W. O'Sullivan, aeronautical engineer, had clear views as to the relevance of meteorology to military aviation. However Major Mulcahy attached no importance to the subject and most likely acted in a manner detrimental to the setting up of a meteorological station at Baldonnell. The position of the pilot body is perplexing. Given Mulcahy's attitude to Fr. O'Riordan, who was the expert on the manner, it is quite possible that pilots were dissuaded from voicing opinions and that early in Mulcahy's command they may have been in awe of a known disciplinarian.

As with meteorology the air traffic control function was developed specifically for civil aviation and initiated in 1936. Air Corps officers performed this function at Baldonnell on behalf of the Department of Industry and Commerce until early January 1940 and thereafter at Dublin Airport. The same duties were performed at Foynes from August 1937 to January 1946. There is no evidence that the emphasis on civil ATC had any detriment influence on the conduct of military aviation except to the extent that many flying officers were rostered for civil ATC duties for longer or shorter periods during the Emergency - suggesting that the provision of services to civil aviation had great priority than had air defence.

As the civil air service was being initiated in 1936 an appropriate wireless and direction finding service was established at Baldonnell for the sole use of civil aircraft. While the Signal Corps had traditionally provided W/T services for the army cooperation role function the new squadrons of the late 1930s would have required communications technically appropriate to air force roles. The evidence suggests that the Signal Corps, the independent arbiter of what was appropriate in terms of Air Corps communications requirements, totally failed to identify such requirements, did not keep abreast with modern developments and, as a result failed to develop systems appropriate to the implied roles of military aviation. In view of the ease with which two amateurs, Thomas Murphy and Lieut. Andy Woods, provided and demonstrated how R?T could be provided, it is not easy to understand why the Signal Corps could not have manufactured a ground station appropriate to the needs of fighter aircraft. 
Similarly the failure of the Signal Corps to research and develop direction finding services is perplexing.

Mulcahy's failure to ensure the equipping of aircraft and aerodromes with appropriate navigation facilities can only be understood in the context of his lack of expertise and knowledge that put him, literally, on a different frequency to the flying officers. The contrast, between the substantial communications resources put in place for commercial civil aviation (at Baldonnell, Dublin, Foynes, Ballygireen, and Urlanmore) and the rudimentary facilities that existed at Baldonnell on 3 September 1939, could not have been starker. The ultimate irony regarding communications, though the Air Corps pilots would not have been aware at the time, was the fact that the RAF had the use of far superior direction finding facilities on Irish soil during the Emergency. 


\section{CHAPTER 10}

\section{THE AIR CORPS' EMERGENCY}

Notwithstanding the approach of the outbreak of hostilities in the late summer of 1939 neither the Army nor the government had definitive plans made, or even in preparation, for the defence of the country. The Army's initial concept, of a conventional three service (army, air \& naval) force mounting a conventional defence of the country, did not materialise due to the lack of Government approval and the necessary sanction of Finance. An integral part of such a defence, the Costello Air Corps proposals of 21 March 1938, had been stillborn. The 1939 peace establishment, essentially the three cadre-strength training squadrons of Costello's plan, in terms of aircraft types and numbers, equipment and personnel, fell very short of the prerequisites for the effective functioning of three operational squadrons purporting to perform at an air force level of air power and airmanship.

In the meanwhile the government's covert strategy of cooperation with the UK while remaining neutral, reflected Finance's belief that the country could not and should not mount a military defence of its territory. As presaged in discussions between the minister and Major Mulcahy in 1937 military aviation was yet to be assigned a role in the security of the country. As a result a token level of funding, that dictated that the three operational squadrons of 1939 which notionally might have comprised a total of fiftyfour aircraft of three modern types, actually consisted of thirty obsolete machines of seven different types with minimal defensive or offensive capability. In keeping with the state's parsimonious approach to air defence generally no aerodrome other than Baldonnell was prepared for use during the Emergency. Given the basic nature of it support services, particularly meteorology, communications and direction finding services, Baldonnell's state of preparedness as a military aerodrome was itself highly questionable.

The following chapter initially examines the general deployment of officers, predominantly pilots, which appeared to reflect the priority given by the state to civil 
aviation before and during the Emergency. Of major importance was the decision to deploy an Air Corps reconnaissance detachment to Rineanna (the future Shannon Airport) before the outbreak of war. The establishment of a base there and its operation during the early months of the Emergency will be examined in detail. It will be contended that the reconnaissance effort at Rineanna had run its course by June 1940. The air aspects of the more acute emergency situation that arose in May 1940 will be assessed in the context of Army plans for defence against IRA-assisted German invasion. In particular the role of the Fighter Squadron will be examined in the context of the plan for the air defence of the Dublin region and of Mulcahy's apparent reversion to army cooperation as the preferred general role for the Air Corps. In the context of the plan for the defence of Dublin it will be contended that the Air Corps' pretence at air defence had totally evaporated by the end of 1940 . However, sundry other activities, those connected with civil aviation and those connected with Irish - British cooperation in air matters, was to prolong the usefulness of the Corps long after the degradation of its operational capabilities had been exposed.

\section{The pilot officer situation}

The Air Corps entered the Emergency on the basis of the 1939 peace establishment that provided for sixty-three officers, 153 NCOs and 351 privates, a total of 567 all ranks. While the strength on 20 September 1939 (512) represented over $90 \%$ of that permitted many had only recently been recruited and were untrained while there were significant deficiencies in the key disciplines of a technical corps. The main personnel shortages were in pilots, wireless operators, fitters, riggers and armament artificers - in effect in those occupations essential to the operation of military aircraft. The pilot numbers, at thirty-three, was a little over $50 \%$ of the notional establishment figure and less than a quarter of the number that was to be permitted by the 1940 war establishment. This number included the commanding officer, Major P.A. Mulcahy whose qualification as a pilot back in 1936 was highly suspect and who was not authorised by the school 
commandant to fly on his own after March 1938. 'Notwithstanding the paucity of pilots only one class of pilots had trained and qualified under Mulcahy's command. In 1938/39, with GHQ unwilling to post newly commissioned officers for flying training and with Mulcahy only displaying moderate concern about initiating the short service scheme there was no perception of an overall pilot shortage or within individual squadrons. Indeed it is of particular note that Comdt. G.J. Carroll and Capt. T.J. Hanley spent much of 1939 in the employ of Aer Lingus. Both had returned to the service by 1 September 1939. While Hanley served from June 1939 to March 1945 Carroll (chief technical officer and second-in-command) returned to Aer Lingus on 23 October 1939 and, except for brief periods in 1940 and 1941 spent the greater part of the Emergency away from the Air Corps on half pay. ${ }^{2}$

During the first sixteen months of the Emergency pilots were employed on the basis of about one third between AC HQ and Schools, one third between R \& MB and CP Squadrons and one third with Fighter Squadron. The training cadre status of the three squadrons indicates that the squadrons were not considered capable of performing to an operational standard. ${ }^{3}$ While pilot numbers increased with the qualification of twentythree young officers in 1940/41 the squadrons were never to achieve anything like full strength in flying officers under the 1940 war establishment. However this deficiency never became a critical factor. As will be explained the manifest deficiencies in aircraft performance and numbers, and in squadron operational capabilities, far exceeded any disadvantage represented by low pilot numbers. After 1940 the matter of pilot numbers was no longer even of academic interest except to the extent that flying instructors had to be withdrawn from the service squadrons from time to time to ensure the progress of the short service scheme in Schools. ${ }^{4}$ Paradoxically it was the training of pilots for civil

\footnotetext{
I OC AC to COS, ACF/631 dated 20 Sept. 1939 (in my possession); 'Record of pilot intake into Ail Corps' (AC Museum); T.J. Hanley to AC investigation, 17 April 1941 (MA, ACS 22/23).

Officer's history Sheet O/287, courtesy of Commissioned officers record office, DFHQ ; T.J. Hanley to AC investigation, 12 Nov. 1941 (MA, ACS 22/23); OC AC to OC E. Coind., ACF/495/1 dated 2 Jan. 1946 (in my possession).

3،Appointments Officers', 5 May 1939; OC AC to COS, 20 Sept, 1940; 'Fighter Squadron internal organisation', 16 Dec. 1940; 'Organisation chart', R \& MB Sqn., 14 Jan. 1941; 'Coastal Patrol Squadron' Dec. 1940; 'Corps HQ, Workshops and Depot', 18 Dec. 1940; 'Air Corps Schools', Dec. 1940 (in my possession).

${ }^{4} \mathrm{OC}$ AC to COS, ACF/631 dated 20 Sept. 1939 (in my possession).
} 
aviation that appears to have had greater priority than any other Air Corps activity during the emergency. (See Chapter Five)

The deployment of individual officers during the Emergency indicates that the Air Corps' mandate to support civil aviation had priority over military missions. This is evident in the record that shows that, during the period July 1937 to December 1944, seventeen officers were seconded to civil aviation air traffic control (at Foynes, Collinstown, Rineanna / Shannon, and Baldonnell up to January 1940) for periods ranging from one month to five years. These duties removed pilots and observers from operational duties for extended periods. Similarly flying instructors were taken from instructional duties. Capt. P. McCormack, an aeronautical engineer and pilot, carried out ATC duties for nineteen months in 1943/44 to the neglect of his responsibilities as the officer in charge of Workshops in Maintenance Unit. As early as December 1943 six officers were seconded to Industry and Commerce for an ATC course. Of these three were appointed to civil ATC and had retired by November 1944. As late as January 1945 four pilots were still detached from their units on loan to civil ATC while the last one remained so detached until January $1946 .{ }^{5}$

\section{Reconnaissance and Medium Bomber Squadron}

On Tuesday 29 August 1939 OC AC received a verbal instruction from the Chief of Staff, possibly by telephone, as a result of which he immediately replied:

In accordance with your instructions of today the Shannon airport will be occupied by the Reconnaissance Squadron (Cadre) tomorrow... The following matters are required to be arranged immediately....authority to use the labour camp at the airport...[the] Department of Industry and Commerce to be notified.. ....Southern Command to be instructed to facilitate... in regard to armed guard, supply of

\footnotetext{
${ }^{5}$ 'Outline of services rendered by Air Corps, military and civil personnel to Civil Aviation Dept.', 1 July 1937 to 31 Dec. 1944 (MA, EDP23/3); Record of control officers at Foynes, 1937 to 2 Jan. 1946, ACF/503/2; Undated list, 'Officers appointments', 1943 establishment (in my possession).
} 
bedding [and] rations. medical officer and medical orderly to be attached... arrangements to be made for mass ....on Sundays. ${ }^{6}$

Mulcahy also requested that a previous arrangement, for the refuelling of military aircraft by Irish Shell, be approved by the QMG and renewed. He also requested that a telephone line be installed at the squadron commander's headquarters. He requested the return of a workshop lorry that had originally been purchased for the Air Corps but which had been transferred to the Supply and Transport Corps some years previously. While this was considered essential to the servicing of aircraft, literally in the field, there is no record of its return. That the Air Corps got the minimum notice is confirmed by Colonel Mulcahy in his evidence to the investigation committee in late 1941. In response to assertions made by a number of officers that they had no training or experience in maritime reconnaissance Mulcahy explained:

It must be borne in mind that sea reconnaissance was sprung upon us and that we moved to Rineanna to carry out coast reconnaissance at 48 hours notice. ${ }^{?}$

While Mulcahy's response to the verbal order suggests that he got only twenty-four hours notice, in the military tradition, he may well have received a warning order the previous day. The timing of the detachment, in the absence of any previous military preparations, strongly suggests that the decision to occupy Shannon had only just been taken - not by the Chief of Staff but by the government. While the Government may have discussed the matter with the Chief of Staff it seems highly unlikely that Mulcahy was consulted on the matter or that the ability of the Air Corps to undertake a viable maritime reconnaissance role, in the North Atlantic in winter weather conditions, was given much consideration.

While much correspondence survives to illustrate administrative aspects of the detachment there is a great paucity of material relating to operational matters. The most obvious deficiency is that of a written order authorising and establishing the detachment and stating its mission. In an organisation that was hide-bound by written orders and

\footnotetext{
${ }^{6}$ OC AC to COS, 29 Aug. 1939 (MA, AC 2/9/12).

${ }^{7}$ Mulcahy to AC Investigation, 23 Oct. 1941 (MA, ACS 22/23).
} 
regulations the absence of a written order in this instance must be taken as deliberate. While the original decision may or may not be related to Archer's visit to London on 25 August 1939 it is certain that the posting of an Air Corps detachment to Shannon / Rineanna on 30 August 1939 had little to do with national defence and much to do with British-Irish cooperation. Subsequent records relating to Air Defence Command support the contention that the role of this detachment, whose 'instructions were to carry out coastal patrols of our territorial waters from Lough Swilly along the west and south coasts to Wexford Harbour', was as part of the intelligence gathering machine that included over eighty look-out posts of the Coast Watching Service, some 759 Garda stations and a small number of military posts, that observed and recorded aircraft and shipping movements during the Emergency. ${ }^{8}$ This contention is well supported in the context of subsequent British consideration of Irish demands for aircraft spares on the basis of the reconnaissance patrols which the Air Corps was carrying out and the reports on German submarine activities the country was then furnishing to the UK."

The question however arises as to what influences were brought to bear to bring about such a precipitous decision. Mulcahy was apparently informed on 28 August 1939 almost a week prior to the signing of the Emergency Powers Order, 1939 and the declaration of war by the UK. The detachment had taken place almost immediately. On or about 30 September the minister for Defence stated that it had been found necessary to send Archer to London, on 25 August 1939, on business of a similar confidential nature to that first authorised by de Valera in October 1938. ${ }^{10}$ Accepting that Archer's original visit to London, from 10 to 14 October 1938, was related to intelligence and counter intelligence matters it seems not unreasonable that business of a similar confidential nature, in August 1939, would relate to intelligence matters. "I In this instance, with de Valera withholding use of the treaty ports, it is possible that the resulting lack of air and naval intelligence became an urgent matter for the UK in the context of its own defence. I suggest that, while it might not have been the main reason for Archer's latest visit to

\footnotetext{
8 'Report', W.J. Keane to OC S. Comd, 12 Apr. 1940, Appendix No. XXII, Report and findings of the committee, 10 Jan. 1942 (MA, ACS 22/23), (hereafter Keane report, 12 Apr. 1940); Air Defence, Operations Order No. 1/1940,25 May 1940 (MA, EDP 1/1). Undated 'Key to air and marine intelligence special map', G.2 Branch, GHQ (in my possession).

${ }_{9}^{9}$ File notes, J.E. Stephenson, 3 May 1940 (NA, DO 35/1078/3).

${ }^{10} \mathrm{Sec}$ DOD to Sec DF, 30 Sept. 1939 (NAI, DF S.105/0048/38).

I'E. O'Halpin (ed.), MIS and Ireland, 1939-1945; the official history (Dublin, 2003), p. 22.
} 
London, these matters were possibly raised by the British and that the Irish government was subsequently requested to post a reconnaissance element to Rineanna. Alternatively the matter may have been raised and arranged at a diplomatic level. Whatever the exact circumstances within five days of Archer's last pre-war visit to London the decision had been taken and the detachment was in position.

\section{The detachment}

An Air Corps detachment of 3 Ansons and 2 Walrus aircraft arrived at Rineanna on the

Table 10.1 Establishment and Strength - R \& MB Squadron detachment, Rineanna.

\begin{tabular}{|c|c|c|c|c|c|}
\hline R \& MB Squadron. & Officers & NCOs & Privates & Total & Aircraft \\
\hline 1937 Establishment (Cadre) ${ }^{12}$ & 6 & 8 & 16 & 30 & $\begin{array}{l}\text { Not } \\
\text { specified }\end{array}$ \\
\hline Proposed - 26 March $1938^{13}$ & 22 & 43 & 144 & 209 & Do. \\
\hline Proposed - 21 April $1938^{14}$ & 22 & {$[62]$} & {$[124]$} & 208 & Do. \\
\hline $\begin{array}{l}1939 \text { Peace Establishment. } \\
\text { (Cadre) }\end{array}$ & 17 & 32 & 61 & 110 & Do. \\
\hline 1940 War Establishment. Less & 37 & 72 & 156 & 265 & \\
\hline '[72 O/Ranks] not to raised" 15 & 37 & 48 & 108 & 193 & 16 \\
\hline Average strength $1939 / 40$ & 11 & 10 & 65 & 86 & {$[9]^{1 /}$} \\
\hline Attached personnel & 1 & 6 & 6 & 13 & \\
\hline Total ${ }^{16}$ & 12 & 16 & 71 & 99 & \\
\hline
\end{tabular}

\footnotetext{
12 Amendment 14 to 1934 establishment, 1 Apr. 1937 (MA).

13 OC AC to ACS, 26 Mar. 1938, Appendix No. V, Report and findings (MA, ACS 22/23).

${ }^{14}$ Maj. P.A. Mulcahy to AC investigation, 21 Apr. 1938, Appendix No. 111(A) (MA, ACS 22/23). The figures in brackets are estimated.

${ }^{15} 1940$ War establishment (MA).

${ }^{16}$ Keane report, 12 Apr. 1940 (MA, ACS 22/23).

${ }^{17}$ The nine Avro Ansons were distributed between R \& MB Sqn, CP Sqn. and AC Schools.
} 


\begin{tabular}{|l|l|l|l|l|l|}
\hline Strength, R \& MB Sqn. & 10 & 19 & 74 & 103 & 6 \\
14.1.1941 & & & & & \\
Attached, Sigs, Cav, Arty $^{18}$ & 5 & 8 & 40 & 53 & \\
Baldonnell -Maintenance. $^{19}$ & 1 & 6 & 14 & 21 & \\
Total & 16 & 27 & 114 & 157 & \\
& & & & & \\
\hline
\end{tabular}

evening of Wednesday 30 August 1939. The Air Corps personnel consisted of eleven officers (ten pilots and a signals officer cum W/T instructor) and seventy-seven other ranks. The attachment of a medical officer and three other ranks brought the total on the first day of occupation to ninety-two all ranks. This total should be noted in the context of the R \& MB Sqn. that had a notional establishment of 110 all ranks - seventeen officers, thirty-two non-commissioned officers and sixty-one privates. As such the squadron was not equipped to function without such garrison services as catering, guards, accommodation, recreational facilities and sundry stores. Within days of arriving a pilot officer was detailed to report to Foynes for ATC duties while an officer, six NCOs and thirty men of $1^{\text {st }}$ Battalion reported for Garrison duties but were apparently not placed under Air Corps' command. ${ }^{20}$ During the first seven months, when the operation was at its most intense, the average strength of the detachment, including attached personnel, was less than one hundred. Even after the transition to the 1940 War Establishment the strength of the air element was just above $50 \%$ of the permitted 193 while the number of pilots was marginally above $25 \%$. Rather than being kept at a maximum possible strength, within the limits of current Establishments, it might be considered that the Rineanna detachment was actually kept to the minimum.

\section{The aerodrome}

It will be appreciated that Shannon Airport was still at a very early stage of its development as a civil airport for trans-Atlantic air services. In August 1939 it could best

\footnotetext{
${ }^{18}$ Strength return, 'The Air Corps Rineanna', 14 Jan. 1941 (in my possession).

${ }^{19}$ Keane report, 12 Apr. 1940 (MA, ACS 22/23).

${ }^{20}$ Administrative diary, 30 Aug; 1 Sept. 1939 (in my possession).
} 
be described as a mile square of recently reclaimed marsh. Its only buildings were about thirteen timber Nissan hut style buildings - the Labour Camp - that had housed the labour force who had carried out the drainage work during the period from 8 October $1936 .^{21}$ Basic aeronautical facilities, such as telephones, aeronautical communications, direction finding station, meteorological station and night flying equipment, that should exist on any military aerodrome well before the arrival of an operational squadron, were not available. The major deficiency was that of an aircraft hangar. In its absence aircraft had to be picketed in the open for the first nine months while a marquee and tents, without duck-boards, were used initially to store spares and other materiel. ${ }^{22}$ To protect aircraft from the elements some were returned to Baldonnell while makeshift covers were made for others using material salvaged from a barrage balloon that had been shot down by the squadron. ${ }^{23}$

It was to be 22 September 1939 before DOD contacted Finance with regard to the provision of covered accommodation for aircraft that, of their very nature, were never intended to be parked in the open at night or in inclement weather. Defence emphasised the necessity to arrange the erection of a hangar as quickly as possible indicating that aircraft and instruments were subject to rapid deterioration. Consideration had been given to the question of dismantling the ex-RAF hangars at Fermoy and re-erecting them at Rineanna. The idea had been dropped on the basis of the dilapidated state of the hangars and the fact that they were required for the accommodation of Southern Command troops. While consideration was also given to the erection of temporary canvas hangars the department opted for a new and permanent hangar as the solution to the problem. Having been in contact with Messrs Thomas Thompson of Carlow, and ascertaining that that company had sufficient stocks of steel to build a suitable hangar, Defence had the director of engineers draw up a specification in consultation with the firm. The sanction of the Minister for Finance was sought, 'as an emergency measure for placing an order' for 'the complete structure (including electric light)' that could 'be erected at a cost not exceeding $£ 10,000$ '. ${ }^{24}$

\footnotetext{
21 Shannon Airport, 50 years of engineering, 1937-1987 (Aer Rianta, Shannon, 1987), passim.

${ }^{22}$ Rinanna administrative diary, 1 Sept. 1939 (in my possession).

${ }^{23}$ Keane report, 12 April 1940 (MA, ACS 22/23).

${ }^{24}$ Sec DOD to Sec DF, 22 Sept. 1939; DF file memo, 29 Sept. 1939 (NAI, DF, S. 007/0024/39).
} 
About a week later Finance had considered the proposal and directed the Office of Public Works to take charge of the project. Under the instructions of Defence OPW was to place the contract with Thompsons, without the customary tendering process, and to supervise the completion of the contract. ${ }^{25}$ Having studied the drawings and specification proposed by Thompsons the OPW identified several deficiencies in the design. They considered that the structure would need to be strengthened for erection in such an exposed location and that the provision for natural lighting was inadequate. It was also thought that the roof and walls, of galvanised corrugated iron, would allow extremes of heat and cold and cause excessive condensation. They concluded that the structure was of a type which could only be justified by the emergency situation. The OPW also noted the absence of adequate provision for site works and that the Air Corps would require some sort of apron in front of the hangar that would add a further $£ 1,000$ to the cost. The OPW's preferred option was for a permanent hangar of better construction and costing as much as $£ 22,000$ but which would not be ready until July or August 1940. As the Air Corps had indicated that such a delay was unacceptable the OPW indicated that they had arranged with Thompson \& Sons Ltd. to proceed at once with the erection of the hangar. The OPW sought sanction for a total of $£ 12,100$ to cover the cost of the hangar and the apron. $^{26}$ An official of the Department of Finance considered the proposal to be unattractive but, recognising that action had to be expedited to provide shelter for the aircraft, provided the required sanction. ${ }^{27}$ After further exchanges of views on the matter of the cost of the apron Finance sanctioned the expenditure of $£ 500$ for the apron, $£ 200$ for site works and a total of $£ 11,100$ for the provision of a hangar. ${ }^{28}$ The contract for the erection of a military hangar, costing $£ 10,988$, at Shannon Airport, Co. Clare, was placed with Thompsons of Carlow without a competition by specific direction of Finance. ${ }^{29}$

The development of military accommodations must be seen in the context of the simultaneous development of the civil airport, a project that apparently had had greater priority. The 'Airport Committee', no more than any other agency, did not know what the medium to long term policy of the DOD might be and was concerned about the provision

\footnotetext{
${ }^{25}$ Sec DF to Sec OPW, 30 Sept. 1939 (NAI, DF, S.007/0024/39).

${ }^{26}$ Sec OPW to Sec DF, 25 Oct. 1939 (NAI, DF, S.007/0024/39).

${ }^{27}$ DF file memo, 3 Nov. 1939 (NAI, DF, S.007/0024/39).

${ }^{28}$ Sec DF to Sec OPW, 31Oct. 1939; Sec DF to Sec OPW, 4 Nov. 1939 (NAI, DF, S.007/0024/39).

${ }^{29}$ 'Extract from list of contracts', OPW to DF, 16 Jan. 1941 (NAI, DF, S.007/0024/39).
} 
of some form of accommodation for its own administrative purposes. The committee was endeavouring to take a decision regarding the spending of $£ 1,800$ on temporary huts in 1940 and $£ 18,000$ to $£ 20,000$ on more temporary accommodation in 1941 and subsequent years or the construction of a first phase of a permanent building to cost about $£ 45,000$. They considered that there would be no temporary accommodation problem during the Emergency if the Air Corps could be got out of the labour hutments which they had taken took in August. ${ }^{30}$

Meanwhile OPW had included $£ 2,000$ in its estimate for $1940 / 41$ on the basis that the hangar works would not be completed before 31 March 1940 and that retention on the main contract $(£ 550)$, the cost of the apron $(£ 1,000)$ and contingencies (£450) would come to that amount. ${ }^{31}$ In February DOD sought $£ 250$ in addition to the $£ 500$ already sanctioned for the apron area. They also indicated to Finance that it would be necessary to provide a water supply and sewage system as well as drinking water and water for the washing of aircraft. ${ }^{32}$ Financial approval for an additional $£ 250$ was received in March. ${ }^{33}$ The matter of a water supply was further addressed by OPW in the context of a new water main which is being laid between the well in the military camp and the new civil buildings then being built. It was suggested that a water connection be made to the hangar. However, rather than have mains sewage, it was recommended that an elsan toilet closet similar to those available in the military huts, be installed in the hangar. The water and sewage proposals, costing $£ 100$ each, were put forward as something inexpensive. ${ }^{34}$ The OPW received sanction for the required $£ 200$ by return of post. ${ }^{35}$ Subsequently OPW sought and received financial sanction for further $£ 88$ spent on the apron, $£ 75$ for a sealing coat on the apron surface and $£ 48$ for the installation of two winches to facilitate opening and closing of the heavy hangar doors. ${ }^{36}$ The water connection and sanitary works, originally estimated at $£ 200$, eventually cost $£ 282$. 8s. Od and was duly sanctioned. ${ }^{37}$

\footnotetext{
${ }^{30}$ Airport construction committee to Sec I \& C, 26 Oct. 1939 (NAI, DF, S.007/0024/39).

${ }^{31}$ OPW, 'Annual estimate 1940-1941' (NAI, DF, S.007/0024/39).

${ }^{32}$ Sec DOD to Sec DF, 26 Feb. 1940 (NAI, DF, S.007/0024/39).

${ }^{33}$ DF to OPW, 11 Mar. 1940 (NAI, DF, S.007/0024/39).

${ }^{34}$ Sec OPW to Sec DOD, 11 Apr. 1940 (NAI, DF, S.007/0024/39).

${ }^{35} \mathrm{Sec}$ DF to Sec OPW, 11 Apr. 1940 (NAI, DF, S.007/0024/39).

${ }^{36}$ Sec OPW to Sec DF, 4 Mar. 1941; Sec DF to Sec OPW, 25 Mar. 1941 (NAI, DF, S.007/0024/39).

${ }^{37}$ Sec DF to Sec OPW, 4 July 1941 (NAI, DF, S.007/0024/39).
} 
While additional huts were built by March 1940 living conditions were poor for officers and other ranks alike. Further modest expenditure was incurred during 1941 and 1942 as more hutments were built to provide for additional army troops as the aerodrome assumed the status of an outpost of the Southern Command. ${ }^{38}$ The measured, and belated, expenditure on facilities for the Air Corps at Rineanna during the Emergency might be contrasted with the substantial investment, at least $£ 1.1$ million, made in developing Dublin and Shannon at about the same time. ${ }^{39}$

\section{The aircraft}

The detachment arrived in Shannon / Rineanna with three Avro Anson I aircraft out of a full complement of nine, and the two Walrus amphibian aircraft (out of three delivered in March 1939). The number of aircraft at Rineanna at any one time was not significant as the aircraft had to be returned to Baldonnell for servicing after only twenty hours flying or for anything other than minor repairs. Air Corps folklore recalls that many aircraft were rotated on Saturdays and Mondays so that some married personnel could return to their families in the Dublin area at week-ends. The number of aircraft was kept to an absolute minimum due to the lack of shelter and the damage done to aircraft and instruments by the high relative humidity. In effect the R \& MB Squadron at Rineanna and the $\mathrm{CP}$ Squadron at Baldonnell were run as flights of a single squadron operating from the same pool of aircraft. ${ }^{40}$

The Avro Anson Mk. I, or Avro 652A, was a military development of a six seat commercial aircraft and had gone into service with the RAF in March 1936 having been produced to a specification for a general coastal reconnaissance aircraft. It was a twinengined monoplane with a fabric covered metal fuselage and wooden wings and had a maximum range of 790 miles and a cruising speed of $158 \mathrm{mph} .{ }^{41}$ In RAF service before the war the Anson was primarily used in a variety of training roles, such as twin-engined conversion, reconnaissance, bombing and navigation. Well into 1940 a small number of

\footnotetext{
38 'Accommodation Rineanna' (MA, File AC/2/9/12).

${ }^{39}$ OPW memo, 31 Oct. 1941 (MA, 2/72456 part III).

${ }^{40}$ Keane report, 12 Apr. 1940 (MA, ACS 22/23).

${ }^{41}$ K.J. Meekoms, E.B. Morgan (eds), The British aircraft specifications file; British military and commercial aircraft specifications 1920 - 1949 (Tonbridge, 1994), p. 213.
} 
squadrons were operating the type in an inshore coastal reconnaissance role at various locations around the UK but only until such time as the production of aircraft such as the Lockheed Hudson, Blenheim and Whitney facilitated their withdrawal from front line service. As early as the summer of 1939 Hudsons, that had much superior speed, range and endurance, had begun to replace some of the Ansons of ten Coastal Command squadrons. Thereafter Ansons reverted to training or were used for inshore search and rescue duties. ${ }^{42}$

\section{The operation}

Considering the secrecy surrounding the original decision and operational matters generally it not surprising that little is known about the actual mission and the manner in which it was undertaken. Coastal patrols had begun on 31 August 1939 after Captain T.J. Hanley had explained the purpose and details of patrol to all officers. The first patrol was forced to return owing to bad weather conditions. On the same day the squadron commander, Captain W.J. Keane visited Foynes meteorological station to make arrangements for 06.00 hours and 14.00 hours weather forecasts to be relayed via the telephone in the Civic Guard barracks on the airfield. Subsequently arrangements were made to three hour forecasts by telephone five times each day. Similarly arrangements were made with Ballygireen radio station, which was located six miles north of Rineanna, with particular reference to the availability of its civil Direction Finding service for use if and when the said station was not busy with trans-Atlantic traffic using Foynes. ${ }^{43}$ The basic nature of the facilities at Rineanna was emphasised by an incident in early September.

Lt. Ryan, when returning from patrol found it necessary to land in [the] dark, as [the] landing light in [the] machine (A45) had been removed. An emergency flare-

\footnotetext{
42 J.J. Halley, Squadrons of the Royal Air Force (Tonbridge, 1985), passim; Ray Sturtivant, The history of Britain 's military training aircraft (Yeovil, 1987), pp 77-87; Michael Armitage, The Royal Air Force; an illustrated history (London, 1993), p. 75.

${ }^{43}$ Administrative diary, 31 Aug; 4 Sept. 1939 (in my possession).
} 
path was made of lighting hay, and with [the] assistance of [the] headlamps of a car, he landed successfully. ${ }^{44}$

Subsequently the squadron commander reported that he had procured some Toledo flare for runway lighting and had erected some temporary obstruction lights in the vicinity of the aerodrome. In the absence of a proper ground station for communication with patrolling aircraft, and for the transmission of patrol reports to GHQ, these services were provided from a mobile radio car. Within days of arriving at Rineanna the signals officer, Lieut. P.J. Murphy received instructions form the director of signals in GHQ. The main directive was based on the fact that the Department of Posts and Telegraphs had agreed that the civil aeronautical communications station at Ballygireen would take over as the ground station for communications with the squadron aircraft. Ballygireen was to be used, not just for aeronautical communications, but also for the normal military wireless traffic with GHQ including patrol reports. On completion of the necessary arrangements with Mr. Enwright of Ballygireen, and the installation of a direct telephone line to GHQ via Ballgirreen, the wireless van was to be returned to Baldonnell. ${ }^{45}$

Many disadvantages, both technical and operational, were identified by Capt. W. $\mathrm{J}$. Keane and his signals officer. These points were taken up by Mulcahy after he had visited Rineanna on 9 September. He informed the ACS that the arrangement, made by the director of signals, that Ballygireen radio station take over the military ground station duties was unworkable. He had observed that while he was in Rineanna one Air Corps patrolling aircraft working with the military wireless car while Ballygireen was working, on a different frequency, a flying boat which was on its way to Foynes. He concluded that Ballygireen could not be of service to military aircraft in such circumstances. He also pointed out that confidential matters in the reconnaissance reports had to be sent by secure radio reports to Command HQ and to intelligence branch (G2) of GHQ at the end of each patrol and that such matters could not be handled by the civilian staff. He stated that the wireless car must remain at Rineanna for aircraft duties and that Ballygireen

\footnotetext{
${ }^{44}$ Administrative diary, 4 Sept. 1939 (in my possession).

${ }^{45}$ Telephone message, DS to Capt. P.J. Murphy, 7 Sept. 1939 (MA, AC/2/8/4.)
} 
could handle all normal ground messages and provide DF in cases of necessity. ${ }^{46}$ The wireless car remained at Rineanna as the only means of communication with aircraft on patrol and as a secure means of communication with Southern Command and GHQ intelligence staff. ${ }^{47}$

In the absence of reports on operational matters at Rineanna it is not clear to what extent the medium wave DF at Ballygireen was used either for navigation purposes or as an aid to aircraft returning to the airfield in bad weather. It is however known that pilots were given instruction and practice in both instrument and night flying and used the DF station in making practice approaches to Rineanna. The squadron commander reported that there was no DF station at Rineanna and that the use of E.I.P. (Ballygireen) demanded the utmost precision as pilots familiarised themselves in approaching with the aid of QDMs and QDRs' (magnetic bearings towards the station and magnetic bearings from the station). ${ }^{48}$ This precision was required due to the fact that the DF station was so far removed from the airfield at Rineanna. Aircraft initially had to home to overhead Ballygireen and then fly towards Rineanna on a QDR or reciprocal bearing. The further the aircraft progressed towards the airfield and away from the DF station the greater the effect of the slightest deviation from the desired track. A track error of more than one degree might mean the airfield would not be sighted in poor weather conditions.

Such use might have been made of Ballygireen DF on 10 October 1939 but apparently was not. On that day Anson 44 was being brought back to Rineanna after servicing. Having left Baldonnell at 18.30 hours the aircraft encountered low cloud and very poor visibility en route. When the conditions got too bad to continue visually the pilot decided to carry out a forced landing in blinding rain. In doing so the aircraft bounced and struck a hedge causing some $£ 1,245$ worth of damage to the aircraft, engines, and equipment. It is apparent from the abbreviated report on file that the subsequent court of inquiry did not examine the full circumstances of the accident at Ardcroney, Nenagh. ${ }^{49}$ Had the court done so it might have inquired why the aircraft, returning to Rineanna at dusk and in bad weather, was not flown at a safe altitude

\footnotetext{
46 Ibid; Capt. W.J. Keane to OC AC, 8 Sept. 1939; OC AC to ACS, 11 Sept. 1939 (MA, AC/2/8/4).

${ }^{47}$ DS, 'Technical Instruction No. 24', 18 June 1941 (in my possession).

${ }^{48}$ Keane report, 12 Apr. 1940 (MA, ACS 22/23).

${ }^{49} \mathrm{Sec}$ DOD to Sec DF, 25 May 1940 (NAI, DF, S.008/0029/39).
} 
towards the DF station at Ballygireen prior to making an instrument approach into Rineanna.

By 19 December 1939 a total of three Ansons had been removed from service as a result of accidents. The first, Anson 45, had been badly damaged as early as 8 September as a result of engine failure and a forced landing at Ballyferriter, county Kerry. The main contributory cause was a faulty fuel cock that caused fuel starvation. On 19 December 1939 Anson 43 was damaged beyond repair due to engine failure that resulted in a forced landing into Galway Bay. Ansons 44 and 45 were to remain out of service for some time due to the difficulty in procuring spares. ${ }^{50}$ As early as November 1939 Mulcahy had reported that 'the coastal patrol is being maintained with difficulty' and that some aeroplanes 'are being kept serviceable by taking parts and instruments from other aeroplanes'. 51

The question arises as to the number of patrols undertaken. Initially the squadron carried out two per day. This frequency was quickly reduced. On 5 September the squadron commander recorded that until further notice there would be only one patrol per day with two pilots and crews on standby. While no figures are available for the total number of patrols carried out Mulcahy gave a somewhat vague indication to the investigation:

....during last winter the reconnaissance squadron flew approximately 80,000 miles and covered generally the coastline from Wexford to Donegal, with particular attention to the west coast from Belmullet to the Mouth of the Shannon and the south coast from Mizen Head to Waterford. ${ }^{52}$

When asked what the distance represented in patrols Mulcahy suggested an average of one to two patrols per day suggesting that the complete area would be covered once a week and special areas once daily. ${ }^{53}$ This description does not appear to indicate more than a patrol per day at best. By April 1940, with three Ansons out of service pro tem the

\footnotetext{
${ }^{50}$ Keane report, 12 Apr. 1940 (MA, ACS 22/23); Sec DOD to Sec DF, 27 May 1940; Sec DOD to Sec DF, 16 Sept. 1941 (NAI, DF, S.008/0029/39).

${ }^{51}$ OC AC to COS, 23 Nov. 1939 (MA, AC/2/2/35).

${ }^{52}$ P.A. Mulcahy to AC investigation, 21 Jan. 1941 (MA, ACS 22/23)

${ }^{53}$ Ibid.
} 
maintenance of the remaining six was proving difficult due to lack of spares. ${ }^{54}$ The major difficulty was that, while twelve months supply of spares had been ordered when ordering aircraft, spares for Ansons were only arriving spasmodically. In the meanwhile radio sets and armament was being received for other aircraft that had not been delivered. On 29 April 1940 only three of the six remaining Ansons were serviceable as the other three awaited engine spares and it was predicted that if spares did not arrive quickly the coastal patrol operation would cease. ${ }^{55}$

The matter of aircraft serviceability and its effect on coastal patrols was brought to a head, not by Mulcahy but by the intervention of Col. M.J. Costello, by then OC Southern Command and Capt. W.J. Keane's immediate superior. Costello acknowledged the Chief of Staff's role in directing and monitoring the conduct of patrol out of Rineanna. He indicated that it was with hesitation that he wrote on a matter that was strictly speaking outside his remit. The basic point that he made was to the effect that he considered that the Ansons were almost at the end of their useful life:

.....the present position is so unsatisfactory that, unless there is a reasonable prospect of maintaining a reconnaissance squadron at a reasonable [aircraft] strength the entire position of the Air Corps will have to be reviewed. ...In order to survive [sic] the limited number of flying hours left patrols are not now undertaken save in the most favourable weather conditions......... I am sure that you fully realise the serious strain on the morale of all ranks at Rineanna which the gradual petering out of their equipment imposes. ${ }^{56}$

Costello also described the living conditions at Rineanna in stark terms:

At the same time the accommodation in the camp is unsatisfactory from the point of view of its security, as well as from the point of view of the health and morale of

\footnotetext{
${ }^{54}$ Keane report, 12 Apr. 1940 (MA, ACS 22/23).

55 Sec DEA to DO, 6 May 1940 (NA, DO 35/1078/3).

${ }^{56}$ OC S. Comd. to COS, 3 May 1940 (MA, PC586).
} 
the troops. ...I think that we could not expect the squadron to survive another winter with the present accommodation...... 57

The alarming aspect of the situation described by Costello was not that it had developed to such a poor state - in the circumstances it was probably inevitable - but that Mulcahy was not aware of, or had not seen fit to highlight in similar terms, gross inadequacies in the contexts of aircraft, the operation and general living conditions. On receipt of this letter from Costello the COS discussed the matters with Mulcahy and decided, amongst other things, to suspend coastal patrols, withdraw the Ansons to Baldonnell where they would be used for instruction in twin-engined aeroplane flying, navigation by radio and bomb aiming. The Walrus aircraft were to remain in Rineanna to carry out training for operation off water, instrument flying and navigation blind approach practice using DF. Calls for special missions were to be referred to $\mathrm{OC} A C$ who would decide whether to use aircraft from Baldonnell or from Rineanna. ${ }^{58}$

Mulcahy later recalled that 'general coastal patrols were discontinued in May 1940 ' because the 'few suitable aircraft available were becoming due for complete overhaul' and that it had been necessary to conserve flying time 'so that they would be available for other missions should the situation get worse'. He made the situation out to be less futile than it actually was:

Also the necessity arose at this time for holding aircraft for special missions as ordered by the Chief of Staff and the Officers Commanding Southern and Western Commands. Such missions included the interception of belligerent aircraft and special patrols of portions of the coast line'. ${ }^{59}$

This interpretation of the situation that pertained from about 10 May 1940 suggests that Mulcahy did not fully appreciate that the squadron cadre in Rineanna, and the remainder of the two reconnaissance elements located at Baldonnell had little or no capacity for normal or special missions at the particular juncture. The committee did not seek

\footnotetext{
57 Jbid.

${ }^{58}$ COS to OC S. Comd, 10 May 1940 (MA, PC586).

${ }^{59}$ P.A. Mulcahy to AC investigation, 19 Nov. 1941 (MA, ACS 22/23).
} 
clarification as to what Mulcahy had meant by the suitable aircraft. With three aircraft out of action there were still six Avro Ansons in service - in theory sufficient to carry out the mission. The use of the term probably arises from an aspect explained by Capt. T.J. Hanley:

All Ansons have blind-flying equipment. The first four Ansons bought have only elementary blind-flying equipment which is insufficient for safe flying in bad weather. The last five Ansons have the complete blind-flying [instrument] panel but lack the vacuum pumps to operate the instruments. ${ }^{60}$

The points Hanley was making were to the effect that with three of the five newer aircraft unserviceable since 1939 only two others of the more suitable aircraft were available. But even these lacked the vacuum pumps that were a more reliable source of suction (for gyroscopic instruments) than the standard externally mounted venture tube that was susceptible to icing. In May 1940 these two Ansons, Nos. 41 and 42, on the basis of total flying hours, were close to major inspections the completion of which would be prolonged by the absence of spares.

About this time Capt. D.V. Horgan and R.W. O'Sullivan (Air Corps) and J.B. Carr of DOD spent twelve days in the UK. There, with the assistance of the high commissioner, they made representations to the War Office and Dominions Office about the supply of army equipment and to the Air Ministry about, in particular, the supply of fifteen advanced trainers. The delivery of six (ex-RAF) Hawker Hinds and five new Miles Magisters resulted. A major concern however was the supply of spares for various aircraft, including the Ansons already in service. In the matter of spares the AM required lists and quantities required over a specified period and undertook to try to arrange a contract as required by DOD. A visit, by special written permit, to A.V. Roe was no more promising. Subject to 'instructions to proceed' being issued by the Air Ministry Mr. Burley promised that his company would do everything possible to assist. ${ }^{61}$ It is not discernable that any improvement in aircraft serviceability resulted. At this time, as

\footnotetext{
${ }^{60}$ Capt. T.J. Hanley to AC investigation, 23 Jan. 1941 (MA, ACS 2223).

${ }^{61}$ 'Memorandum of visit to England', 21 May - 2 June 1940 (MA, AC/2/2/41).
} 
previously, the UK authorities were well disposed to assist in training matters but less so in regard to aircraft, equipment and spares that might be put to operational purposes. In the context of the intelligence value of coastal patrols this UK position appears somewhat contradictory

No records to indicate the extent of such reconnaissance missions or their effectiveness have been seen. The General Report on the Defence Forces 1940/41 made no reference to the Rineanna operation and, of course, did not note the termination of scheduled patrols. Similarly neither Archer's summary report of March / April 1944, on relations and contacts with the British military, nor Childers' (1947) comprehensive review of the Emergency period, make any reference to this important, but short-lived, aspect of Irish - British wartime cooperation.

\section{The Fighter Squadron and Air Defence Command}

If the reconnaissance squadron in Rineanna was engaged on a fool's errand - and an examination of the voluminous investigation proceedings of 1941 and the report of 10 January 1942 will support no other conclusion - the $1^{\text {st }}$ Fighter Squadron (Cadre) at Baldonnell will be seen to have been no better equipped for a viable wartime mission. The squadron was established under the peace establishment of April 1939 by the renaming of the $1^{\text {st }}$ Co-operation Squadron that had existed, informally and formally, since 1930. While the Rineanna detachment had verbal orders Fighter Squadron, at least up to May 1940, appears to have had no orders, written or verbal, from OC AC or higher authority. At the outbreak of war Mulcahy reported that during the immediate pre-war period the Fighter Squadron had 'concentrated on training to fit in to the air defence scheme for Dublin'. ${ }^{62}$ In terms of manpower the Fighter Squadron of September 1939 was nine over strength due to a considerable surfeit of privates. At the same time pilot strength was about $40 \%$ of the number permitted by the 1939 peace establishment. The maximum number of pilots attained during 1940, under the war establishment, was twelve or about $40 \%$ of the approved war establishment figure of twenty-seven.

\footnotetext{
${ }^{62} \mathrm{OC}$ AC to CSO DOD, ACF/631 dated 20 Sept. 1939, ACF/631 (in my possession).
} 
Table 10.2 Establishment and strength - No.1 Fighter Squadron

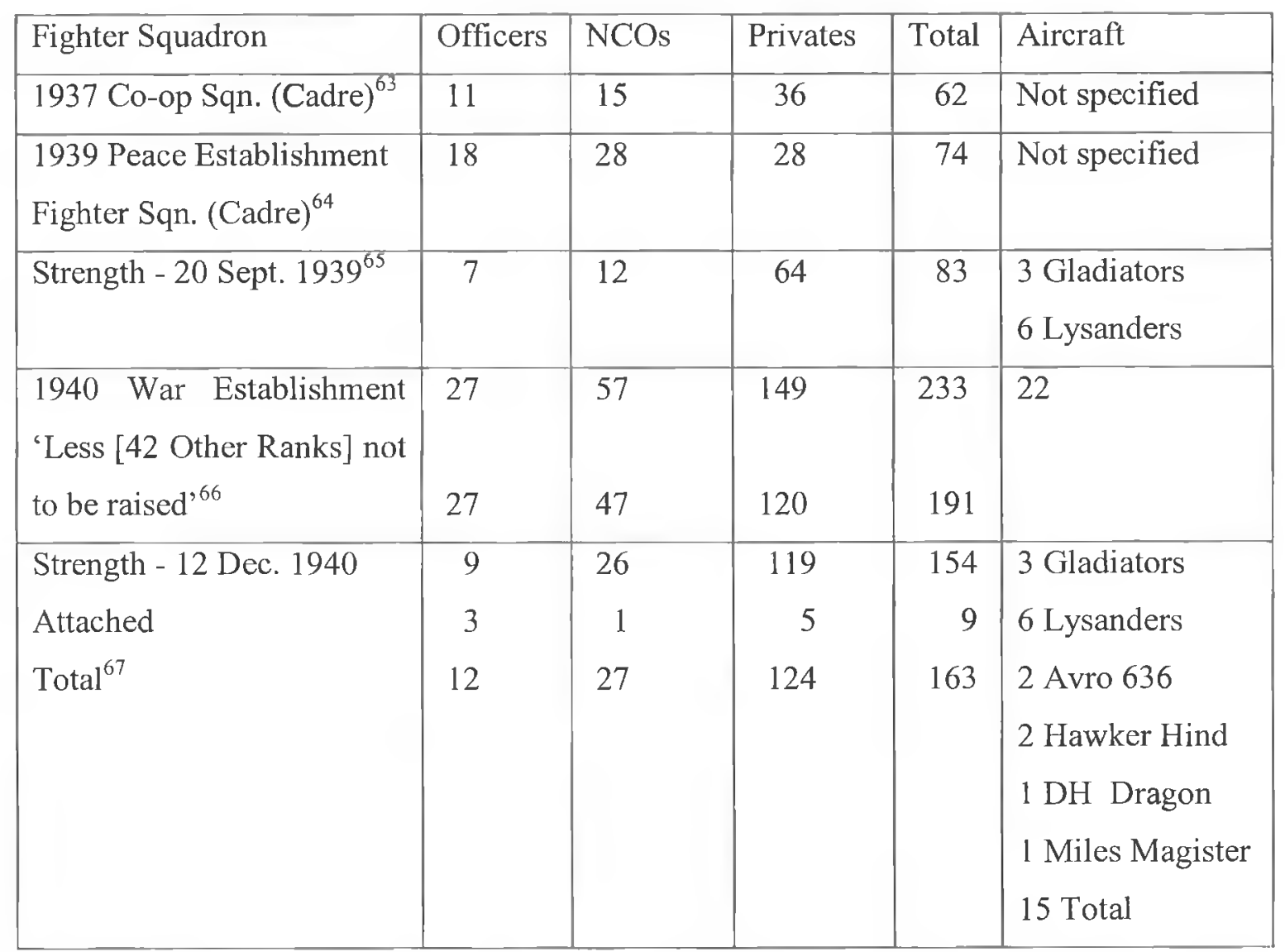

The 1940 war establishment was the first (and last) to provide for a specific number of aircraft for each squadron, in this case twenty-two. By convention the aircraft of a fighter squadron would be of a single current fighter type. Notwithstanding, the No. 1 Fighter Squadron's main equipment, on the 3 September 1939, consisted of three Gloster Gladiator I aircraft. It also had six Westland Lysander II and sundry older aircraft. The Gladiator was the last of a very long line of biplane fighters to serve with the RAF and was in production from 1935 to $1938 .^{68}$ Even as it was in production and entering squadron service it was being rendered obsolescent by the design and

\footnotetext{
${ }^{63} 1937$ Peace establishment (MA).

${ }^{64} 1939$ Peace establishment (MA).

${ }^{65} \mathrm{OC}$ AC to CSO DOD, ACF/631 dated 20 Sept. 1939 (in my possession).

${ }^{66}$ War establishment, 13 June 1940 (MA).

67 'Internal organisational chart', Fighter Squadron, 12 Dec. 1940 (in my possession).

${ }^{68}$ K.J. Meekoms and E.B. Morgan (eds), The British aircraft specifications file (Tonbridge, 1994) p. 211, 255; Michael Armitage, The Royal Air Force; an illustrated history (London, 1993), pp 78-9.
} 
manufacture of high performance monoplanes such as the Hawker Hurricane and the Vickers Supermarine Spitfire. By the outbreak of war the Gladiator had been withdrawn from over $70 \%$ of the RAF's UK-based front line squadrons. The remainder were replaced by April 1940 as scores of frontline squadrons were being re-equipped with various marques of Hurricane and Spitfire from 1938 onwards. ${ }^{69}$

The Lysander II aircraft had been delivered in July 1939. The type had been originally developed in response to an Air Ministry requirement for an aircraft capable of an artillery spotting and reconnaissance role to replace the Audax and Hector types which had been in service since $1934 .^{70}$ In its reconnaissance role it was well suited to the static style of warfare of an earlier era but not to the highly mobile armoured warfare of 193945. In the RAF context it was largely withdrawn from the army cooperation role by $1941 .^{71}$ While the Westland Lysander was a purpose built army cooperation aircraft it was adapted, in RAF service, for roles such as the special operations into France dropping supplies and agents, that made the best use of its short take-off and landing characteristics. ${ }^{72}$ In the Air Corps context it had originally been purchased as an advanced trainer - apparently erroneously so. When questioned on this point by the investigation committee Mulcahy was somewhat coy:

To the best of my recollection the Lysander was selected as the most suitable type available at the time as an advanced trainer. The order was placed, but as far as I know the firm was unable to supply dual controls. The machines had been built for us and we took delivery. The Lysander is a suitable machine for advanced operational training. ${ }^{73}$

The committee was not satisfied with this evasive answer and asked Mulcahy if it was normal to have Lysander aircraft fitted with dual controls. His response was brief:

\footnotetext{
${ }^{69}$ J. J. Halley, Squadrons of the RAF, passim.

${ }^{70}$ Meekoms \& Morgan, Specifications file, p. 201

${ }^{71}$ Armitage, RAF illustrated history, p. 83.

${ }^{72}$ Halley, Squadrons of the RAF, p. 185.

${ }^{73}$ P.A. Mulcahy to AC Investigation, 23 Oct. 1941 (MA, ACS 22/23).
} 
It is normal to have Lysander aircraft fitted with dual controls when such aircraft are being used for flying instruction in the same way as advanced trainers are fitted with dual controls. ${ }^{74}$

The committee did not detect that the second answer was even more misleading than the first and, being satisfied, moved on to a different matter. However Mulcahy had succeeded in concealing the true situation from the investigation committee, who, to judge by many of the questions put, and the answers accepted, were very naive in technical matters. He implied that the Air Corps, when ordering the aircraft, had specified the inclusion of dual controls in a small batch specifically built for the Corps. Had this been the case the non-availability of dual controls would have been made known at the time of ordering. The Air Ministry production specifications indicate that the production of Lysander II commenced on or about 14 June 1939..$^{75}$ The Air Corps took delivery of the six aircraft, apparently off the standard production run of the type, on 15 July 1939.

With regard to the aircraft being bought as an advanced trainer the truth probably lies in the 1939/40 Defence estimates. These proposed the capital expenditure of $£ 47,400$ for ' 6 single engined training aircraft (Lysander) @ £7,900' each. ${ }^{76}$ It is not easy to understand how the Lysander II could be purchased as an advanced trainer. It was, purely and simply, an army cooperation aircraft. Though it was reasonably well armed nothing in its design, performance and handling characteristics fitted it for advanced training purposes. While the Directorate of Technical Development of the Air Ministry specified that provision be made for the installation of a dual control conversion kit there is no record of a Lysander being so modified. ${ }^{77} \mathrm{Had}$ such a machine been developed it could only have been used for the conversion of pilots to the type and, most decidedly, not as an advanced trainer.

In effect, in their anxiety to expeditiously spend the monies allotted in the financial year 1939/40 the Air Corps apparently purchased aircraft without adequate reference to detailed technical specifications and without indicating any requirements. In

\footnotetext{
${ }^{74}$ Ibid.

${ }^{75}$ Meekons and Morgan, Specifications file, p. 269

${ }^{76}$ Sub-head 'O', Defence estimates $1939 / 40$ (NAI, DF, F.102/0065/38).

${ }^{77}$ Meekoms and Morgan, Specifications file, p. 235
} 
this case Mulcahy ended up with six aircraft unsuited to any training role. The anxiety to purchase training aircraft was due to the intended intake of short service cadets which eventually took place in August 1939. Notwithstanding any misunderstanding about dual controls it is not easy to understand how Mulcahy could have considered a classic army cooperation aircraft as being suitable for advanced training. Advice on the selection of aircraft would normally have been available from Comdt. G.J. Carroll. However the chief technical officer (and second-in-command of the Air Corps) was on half pay while functioning as general manager with Aer Lingus from 31 January to 1 September 1939. Mulcahy's evidence to the investigation committee strongly suggests that he took his own advice on aircraft selection at this time. ${ }^{78}$ In Air Corps service, while operated by Fighter Squadron, the Lysander was designated as an army cooperation machine. Despite it being unsuitable Mulcahy was satisfied that it could be used as a fighter. ${ }^{79}$ Fundamentally the parasol type wing arrangement, and stability at slow speed that made it a very suitable aircraft for observation of the battlefield, in addition to its poor performance, rendered the type practically useless in terms of air combat. It could, if unopposed, act as a ground attack aircraft.

\section{The first operations orders - May 1940}

Unlike the Reconnaissance and Medium Bomber Squadron (Cadre) that was, in effect, on active service since 30 August 1939 the manifest inadequacies of the Fighter Squadron were not exposed until the summer of 1940 when the fear of a German invasion was at its height. It was at this time that the first GHQ operations orders were drafted, for all Army elements, to direct action to counter the perceived threats of the IRA agitation and German invasion. Emergency defence plan No. 1/1940 was drafted on the basis that available information showed that the IRA was 'planning something in the nature of a major operation' and that the operation might 'involve the support of a foreign power,

\footnotetext{
${ }^{78}$ Extract of officer's history sheet, O/287, courtesy of Commissioned officers record office, DF HQ, 2006; P.A. Mulcahy to AC investigation, 21 Jan. 1941 (MA, ACS 22/23).

${ }^{79}$ Annex III to Operation Order No. 1/1940, 28 May 1940 (MA, EDP 1/1); Mulcahy to AC investigation, 21 Jan. 1941 (MA, ACS 22/23).
} 
directly or indirectly' ${ }^{80}$ Additional comment would suggest that there was little by way of a firm basis for the perceived threat other than 'a study of the developments to date in the present international conflict'. The resulting Operations Order No.1/1940 of 24 May 1940 apportioned the defence of the state mainly on a geographic basis dictated by the command areas of the Eastern, Western and Southern Commands with mobile columns forming the first line of defence. ${ }^{81}$

The operations order assigned no mission to the Air Corps. It appears however that at about the same time Mulcahy had been instructed to draft an Air Corps annex. Annex No. III was submitted four days later for the approval and signature of the chief staff officer, operations, Maj. Gen. Hugo McNeill. Other annexes that would concern the Air Corps were those on the 'Defence of Aerodromes' (Annex V) and 'Air Defence' (Annex VI). Assessment of the various orders is made difficult by the lack of coordination apparent in the drafting of the main order and the several annexes. This resulted in fundamental responsibilities, particularly in relation to the air defence of the Dublin area, not being fixed definitively. It might be considered that the role of Fighter Squadron would have been clarified by orders relating to the air defence of the eastern region of the country and that Air Defence Command would be the appropriate agency to direct and co-ordinate the efforts of all air defence elements, including fighter aircraft. It might also be expected that the Air Corps responsibilities would be clearly set out in Annex III. Such assumptions would not be entirely valid. During the summer of 1940 the air defence of the region was mainly the responsibility of the $1^{\text {st }}$ Anti-Aircraft Brigade, McKee Barracks whose orders purported to include some responsibility for the coordination of Air Corps aspects of air defence:

The air defence scheme for the protection of Dublin provide for combined active defence by aircraft and anti-aircraft units and its co-ordination and development in conjunction with passive defence measures. ${ }^{82}$

\footnotetext{
80 'Outline of Emergency defence plan No. 1, May1940 (MA, EDP 1/1).

${ }^{81}$ Colm Mangan, 'Plans and operations' in Irish Sword xix, nos. 75 \& 76(1993-4), p. 48-9, citing EDP No. 1, May 1940 (MA).

${ }^{82}$ Operations Order No. 2/1940, $1^{\text {st }}$ AA Brigade, 25 May 1940 (MA, EDP/1).
} 
However neither ADC nor the AA Brigade made provision for the coordination of antiaircraft defences while the Air Corps aspect of air defence, in the event, was to be of little consequence. The air defence annex of Operations Order No. 1 mainly related to the responsibilities of Air Defence Command in coordinating and plotting the results of the intelligence gathering functions of various agencies.

A special scheme has been agreed upon between General Headquarters and Garda Siochana headquarters for the collection and rapid transmission of information concerning the activities of foreign aircraft seen over our territory or territorial waters. The scheme provides that look-out osts of the Marine Coast Watching Service and Garda stations will co-operate in the collection of such information. ${ }^{83}$

The orders required observers to supply detailed reports on all aircraft, not identified as Irish, in such spatial and temporal detail that the movements of individual aircraft, seen or heard, over land or sea, could be plotted at Air Defence Command, Dublin Castle, and any potential threat assessed. The ADC was required to keep OC Air Corps informed of all reported movements of belligerent or unknown aircraft so that the 'Air Corps Interception Service' could be called into action. To illustrate the naivety of GHQ's concept of what might constitute a defence against aircraft of an invading force it is necessary to quote a modicum of the relevant order:

(d) On receipt of all such information aircraft will be dispatched to intercept offending aircraft flying over Irish territory or territorial waters provided there is a reasonable chance of aircraft affecting this purpose.

The pilot of [the] Irish aircraft will signal to [the] foreign pilot that he is over neutral territory and endeavour to ascertain his mission.

If in communication by radio with his headquarters he will remain in [a] position of observation, report and await orders.

If not in radio communication he will collect all information and proceed to [the] nearest aerodrome, where he will make an immediate report.

83 'Air Defence, Annex No. VI, Operations Order No. 1', 25 May 1940 (MA, EDP 1/1). 
He will not initiate offensive action but if attacked will take all necessary defensive action. $^{84}$

This order must be seen in the context of the time when a German invasion was expected at any moment. Air Defence Command's primary function was the collection and recording of air and marine intelligence with particular reference to the movements of aircraft and ships. It did not constitute an early warning system in an accepted sense and, in particular, bore no relationship to the system exemplified by the use of static and mobile radars of the UK 'Chain Home' and 'Chain Home Low' stations. The latter system was particularly effective during thee Battle of Britain in the autumn of $1940 .^{85}$ By virtue of the visual and aural nature of the Irish observer system the identification of hostile aircraft, and the prediction of the tracks and possible targets, would be so delayed as to obviate interception by three obsolete aircraft on stand-by on the ground. Totally inadequate aircraft and pilot resources ruled out the possibility of standing patrols. In any event Baldonnell was too close to the target area of Dublin - even if appropriate and sufficient aircraft were available. In the hypothetical context of a defence of Dublin several squadrons of aircraft would have been required to have been based in south-east Leinster.

The implication of the above order was that Fighter Squadron aircraft were expected to respond to each and every incursion of Irish airspace by foreign or unidentified aircraft. However, in practice, the order only applied to the 'artillery zone of the A.A. defence of Dublin' - delineated by lines joining Howth Harbour, Killiney Hill, Tallaght Aerodrome and Blanchardstown to Howth Head. With an average of over 400 belligerent aircraft being identified each month during May to July 1940, mainly in the eastern region, such a task would not have been practical except with appropriate resources and systems. ${ }^{86}$ In the event single aircraft, that constituted the greater bulk of sightings, were ignored. The order was subsequently formally amended to reflect the fact

\footnotetext{
84 Ibid.

${ }^{85}$ Armitage, RAF illustrated history, pp $95-112$

${ }^{86} \mathrm{OC}$ AC to COS, 16 July 1940, EDP/21; Appendix No. I, (MA, General report on the defence forces, 1940-41).
} 
that the simultaneous incursion of two or more aircraft together was to be considered a hostile act. ${ }^{87}$

The order was totally impractical from the points of view of the number and type of aircraft available and their inadequate communications. In the unlikely event of one of three Gloster gladiators intercepting a belligerent aircraft the Irish pilot would probably not have been able to maintain two-way communication with base due to the underpowered ground station at Baldonnell. It is not clear to what extent interceptions were attempted. In September 1940 an Air Corps note dealing with the activity of foreign aircraft did not elucidate but indicated that adequate numbers of suitable aircraft and pilots were not available to give an adequate interception service for the Dublin area. It also indicated that if Air Corps efforts at interception were to be successful it would be essential to get earlier and more accurate reports from observer stations. The context would suggest that attempts at interceptions were very rare. ${ }^{88}$

Notwithstanding the obvious impotence of the Fighter Squadron and the utter futility of interception as the squadron mission the 'Air Defence Annex of Operations Order No. 4/1941', a slightly revised version of the previous, was issued a year after the first. It designated to the Air Corps the task of continuing to operate the 'Air Corps Interception Service' as previously described. To a large extent it appears to have been a classic example of a staff officer taking out the previous order and changing the dates. The Air Corps paragraph was repeated practically verbatim in spite of the obvious major deficiencies. $^{89}$ One is reminded of the candid admission made by Mulcahy to Air Commodore T.N. Carr only a few months after this order was renewed. Mulcahy made it clear that, having regard to the state of the aircraft and the state of readiness of the Air Corps, the corps could be ignored as a factor in the defence of the country. ${ }^{90}$

\footnotetext{
87 'Air Defence - Addendum No. 1 to Operations Order No. 1', 8 Aug. 1940 (MA, EDP 1/1).

${ }^{88}$ A/OC AC to COS, 11 Sept. 1940 (MA, EPD/21).

89 'Air Defence, Annex No. 2 to Operations Order 4/1941', 8 July 1941 (MA, EDP/21).

${ }^{90}$ Air Commodore T.N. Carr to AM, 14 Oct. 1940 (NA, Air 2/5130).
} 


\section{The Air Corps' orders in 1940}

From May 1940 Air Defence Command functioned primarily as an intelligence organisation. It was also the nearest the country got to having an early warning system. The $1^{\text {st }}$ Anti-Aircraft Brigade was responsible for the air defence of the Dublin region though the air defence response was not subject to central coordination measures. The Air Corps annex, though drafted by Mulcahy at Baldonnell, was signed by Gen. McNeill and had the same standing as other GHQ orders. It did not read like an operations order per $s e$. It was poorly constructed and laid out and confusing as to its intent. In particular it made no reference to the current situation or to the specific Air Corps interception role indicated in the air defence order. Divided into three sections the annex initially imparted information to ground commanders regarding the broad roles and characteristics of both service and training aircraft that the order intimated would be operating in an army support role if and when the invasion came. The second section indicated the current mission of the Air Corps to consist of occasional coastal patrols out of Rineanna, aircraft on call at Baldonnell and Rineanna for special duties, and training. ${ }^{91}$

The future missions included the peacetime missions then being done. The retention of fighter aircraft for the future defence of Dublin was also mentioned, but in a manner that did not reflect the scope or urgency of the mission detailed in the air defence order. In effect the concept of an Air Corps Interception Service was largely ignored. However the third section made it abundantly clear that, in the event of invasion, a significant proportion of Air Corps resources would be dispatched to selected landing grounds in various commands where reconnaissance would be the principal air mission in cooperation with ground troops engaged in active operations. ${ }^{92}$

From an examination of Annex III and bearing in mind the other orders it could be construed that the author was not an fait with all the relevant documents. In the hectic and somewhat confused circumstances of the last ten days of May 1940 this may well have been the case. Mulcahy appears to have been kept in the dark about many operational matters. He did not receive copies of operations orders as a standard practice

\footnotetext{
9! Annex No. III, 28 May 1940, Operations Order No. 1/1940, 24 May 1940 (MA, EDP 1/1).

92 Ibid.
} 
but, if GHQ considered it necessary for him to read a particular order, he 'had to go in [to GHQ] and read and initial it'. In this regard he is certified as having seen, on 23 December 1940, Operations Order No. 3 dated 17 December 1940. In relation to his familiarity with Army orders he was asked, in October 1941, 'are you informed of the plans for defence and employment of the forces, of the divisions and the commands?' He answered in the negative.' ${ }^{93}$

In drafting and authenticating Annex No. III, Mulcahy was, in effect, acting as a GHQ staff officer. Continuing in this role he circulated an instruction on 'Landing Fields' on 30 May 1940. He informed the Commands that he had been directed by the Chief of Staff to point out that it was essential to have landing grounds near column headquarters. He suggested that column commanders should identify suitable fields convenient to their headquarters and that the locations should be made known to the Air Corps so as to save aircraft flying time when they were being sent to cooperate with ground troops. He indicated the minimum dimensions of the fields required by Anson, Lysander, Magister and Avro 631 Cadet. Included with the instruction was a list of fifty-four fields mainly located in Leinster and Munster. He indicated that the fields had been inspected at various dates between 1932 and 1937 and had originally been licensed for aerial circus work. He suggested that the list of fields 'might be of assistance when aircraft were operating with your columns'. ${ }^{94}$ Two days earlier GHQ had distributed copies of a 'list of known places' which had been prepared by the Air Corps and was recommended to the commands as being up to date. GHQ considered that any of the 139 fields, identified on One Inch OS sheets, would be 'suitable in an emergency'. 95

With the three Gladiators tasked to the defence of Dublin it might be assumed that that Mulcahy had issued orders, written or verbal, to the squadron or to individual pilots. However, no such orders are reflected in the EDP material or mentioned in the proceedings of the Air Corps investigation in Military Archives. Considering the extent and detail of the instruction regarding the designation of army cooperation landing fields the absence of orders for the conduct of interception is difficult to understand. The only

\footnotetext{
${ }^{93}$ 'List of officers' 23 Dec. 1940 (MA, EDP/1/2): P.A. Mulcahy to AC Investigation, 22 Oct. 1941 (MA, $\operatorname{ACS} 22 / 23$ ).

94 'Landing fields', OC AC to Commands, 30 May 1940 (MA, EDP/4).

${ }^{95}$ CSO G.1, GHQ to commands, 28 May 1940 (MA, EDP/4).
} 
instruction relating to the movement of fighter aircraft was issued in the context of arrangements for the dispersal of aircraft 'in the event of the situation becoming more serious'. In the event of an attack, to prevent the destruction of the aircraft in the hangars, serviceable aircraft of Fighter Squadron were to be picketed around the perimeter of Baldonnell 'ready to take the air for defence or reconnaissance purposes'. 96

At best pilots may have had verbal orders from Mulcahy to get airborne when ordered to do so. Mulcahy's attitude is illustrated by his evidence to the committee of investigation early in 1941 :

Q. Why have you such a mixed collection of aircraft in the Fighter Squadron?

A. Because it was the most suitable equipment I had with which to train and keep on training the Fighter Squadron.

Q. The bulk of the equipment is training equipment?

A. Yes, it is something to progress with until something better comes along.

Q. Why should you have a Fighter squadron?

A. Because if you do not have fighter aircraft you could never have air superiority over an area. Fighter aircraft is [sic] the best form of anti-aircraft defence. Except you have fighter aircraft you cannot even have local air superiority.

Q. What use would our 3 Gladiators be against a determined attack on, say, Dublin? A. Supposing bombers came over and that our three Gladiator pilots were shot down over Dublin, it would be a certain consolation to the people and would improve their morale by letting them know that we had at least done what we could. $^{97}$

The above suggests that Mulcahy considered that Fighter Squadron was fundamentally still the peace-time training cadre of the 1939 peace establishment. However while he did

\footnotetext{
96 'Supplementary to Annex III' to Operations Order 1/1940, circa 15 June 1940 (MA, EDP/4 (1940)).

${ }^{97}$ P.A. Mulcahy to AC Investigation, 21 Jan. 1941.
} 
not specify so in writing, he appears to have had little difficulty in committing an inadequate number of obsolete aircraft to a war time defensive task that was patently impossible. His attitude is further explained by the tone and content of his 'order of the day', issued on 4 July 1940, when all aircrew were required to stand-by on the air station:

If we fail to get into the air, if we loose our aircraft on the ground, we have failed utterly in our duty to our people. It is therefore necessary that the crews of the service squadron and detachment at Baldonnel be readily available to their aircraft at all times. ......Let us, therefore, bear inconvenience cheerfully now so that we will be standing by to perform [-] whatever the task and whatever the hour. ${ }^{98}$

While Mulcahy appears to have willingly to accept an impossible task in behalf of Fighter Squadron, given the military situation in the summer of 1940 he had little choice in the matter. With fears of a German invasion running very high there was tacit agreement that British forces would come to the country's assistance. However it was de Valera's policy that before British assistance could be requested the Irish Army, of which the Air Corps was an integral part, had to take the brunt of an initial assault. ${ }^{99}$ In such circumstances the squadron's efforts would have been of little effect. (See Appendix 8)

The true attitude of GHQ to the effectiveness of the Air Corps in 1940 is reflected in a GHQ 'map manoeuvre' exercise, undertaken in preparation for the updating of defence plans, at which Colonel P.A. Mulcahy was assistant director in charge of air operations. The exercise 'German estimate' of 'the enemy forces and disposition' concluded that 'as regards opposition to our attack, the Irish air force may be regarded as non-existent'. ${ }^{100}$ At the same time and while holding the above opinion GHQ, through the aegis of the air defence order, purported to defend the Dublin area by means of a largely mythical 'Air Corps Interception Service'. Notwithstanding the provisions of the ADC order relating to the interception of aircraft, there is no evidence to indicate that Air Corps aircraft were ever scrambled to intercept unidentified foreign aircraft while encounters with even single aircraft were apparently invariably fortuitous, ineffective and

\footnotetext{
98 Ibid.

${ }^{99}$ Fisk, In time of war, pp 234-240.

100 'General Staff estimate of the situation No. 2', 30 Oct. 1940 (MA, EDP/19).
} 
embarrassing. ${ }^{101}$ The folklore suggests that the only aircraft intercepted were the relatively slow civil aircraft that occasionally strayed of the designated track into or out of Collinstown (Dublin Airport).

\section{The release and recovery of Allied aircraft}

The short-lived coastal patrol operation at Rineanna was the most substantial direct assistance rendered by the Air Corps, on order, to the UK. However, in the wartime records, this intelligence gathering activity was not acknowledged by the UK and studiously ignored by (or possibly deleted from) the Irish records. However there were other air-related activities that contributed to the UK air war effort. In February 1945 the Dominions Office listed the 'facilities obtained from the government of Eire during the war'. The list of briefly stated activities appears to have been intended to merely acknowledge, rather than to emphasise, the considerable extent of the military assistance and cooperation received. The use of the Donegal corridor by aircraft patrolling the Atlantic is the best known and most cited instance of the facilities granted by de Valera's government. This facility allowed flying boats based at St. Angelo on Lough Erne to fly due west across the south of Donegal and enter the North Atlantic expeditiously and commence anti-submarine patrols. This privilege was relatively innocuous compared with some of the others. The list did include acknowledgement of the fact that 'full assistance was given in recovering damaged aircraft'. ${ }^{102}$ The matter referred to was the operation, mounted mainly by the Air Corps under the direction of the intelligence branch of GHQ, to salvage and return repairable Allied aircraft to the UK. Not specifically mentioned by the Dominions Office was the not inconsiderable number of allied aircraft that force-landed in Eire, usually through lack of fuel, and which were refuelled or otherwise helped to make a speedy return to their own jurisdiction.

It is not obvious how this process was initiated. Examination of files suggests that this it was probably something that developed out of British necessity and an undeclared

\footnotetext{
${ }^{101}$ Aidan Quigley, 'Air aspects of the emergency' in Irish Sword xix, Nos. 75 \& 76 (1993-4), p. 90. 102 'Facilities obtained from the government of Eire during the war', 21 Feb. 1945 (NA, DO 114/117). A slightly differently worded version of this list is reproduced, in Ronan Fanning, Independent Ireland (Dublin, 1983), pp 124-5, citing CAB 66/62, 21 Feb. 1945 (PRO, London).
} 
willingness on the part of the Eire government to render assistance in covert ways. The precedent for allowing British aircraft landing in the state to depart was set on the very first day of the war. On 3 September 1939 Royal Navy flying boats alighted at both Skerries and Dun Laoghaire seeking shelter from particularly bad weather while traversing the Irish Sea from south to north. After appropriate questioning of the aircrew and consultation between the $\operatorname{COS}$ and the minister these aircraft were permitted to resume their journeys. Eleven days later a third aircraft alighted at Ventry Harbour due to a broken fuel pipe. This aircraft was allowed to depart after effecting repairs with assistance from 'Sean Clancy's garage, Bridge St. Dingle' where 'the seaplane mechanic soldered the pipe himself'. ${ }^{103}$

Thereafter the first land plane recorded as having been allowed to depart was one that made a forced landing at the Curragh at about 05.00 hours on 16 May 1940. The manner in which this forced landing was dealt was possibly typical of many that followed. A young officer was woken early that morning in Baldonnell and went to the airfield at the Curragh Camp having been authorised by higher authority to refuel the RAF Hampden bomber. Accompanied by the camp commandant the young officer supervised the refuelling of the aircraft with 200 gallons of the appropriate aviation spirit and received a receipt. The aircraft had been refuelled and departed for Aldergrove by 09.30 hours the same morning. ${ }^{104}$ While it is not explicit in the surviving records it would appear that by this time outline arrangements were in place, or at least being formulated, that would facilitate aircraft to be refuelled and depart so rapidly. The general position was later explained by DOD.

During the period 1940 - 1945 aircraft of the British and American forces were forced down in this country as a result of fuel shortage, weather conditions, damage by belligerent aircraft, etc. Informal arrangements were made with the air attachés of these countries under which assistance was afforded by the Defence Forces in

\footnotetext{
${ }^{103}$ Capt. T.F. Doherty, 'Report of seaplanes landing at Skerries', 3 Sept. 1939; Capt. Ivory, G.2 journal, 3 Sept. 1939 (MA, G2/X/1224); HQ S Comd. to G.2 GHQ, 21 Sept. 1939 (MA, SI/319).

${ }^{104}$ Lieut. P. Swan to OC AC, 16 May 1940 (MA, ACF/S/36).
} 
the rescue of crews and the salvage, repair refuelling, etc. of any planes forced down to enable as many as possible to take off again. ${ }^{105}$

With Wing Commander Lywood in the process of being appointed and taking up duty in early June 1940, it would appear that the an informal agreement was not yet in place to cover the above aircraft. However, for an aircraft to be turned around so rapidly, the decision makers must already have been well disposed. Subsequently at least twenty-nine British and eighteen US aircraft were facilitated in a similar manner. ${ }^{106}$ Col. W.J. Keane suggests that the Air Corps rendered assistance in about thirty-one of those cases and that a total of 7,900 gallons of fuel was supplied. ${ }^{107}$

The next two British aircraft that force-landed in Eire were recovered to Baldonnell and, after repair, were pressed into service. The first of these was Hawker Hurricane P.5178 of 79 Squadron, RAF Pembry (Wales), which landed at Ballyvaldon near Enniscorthy, County Wexford on 29 September 1940. Having landed with its undercarriage retracted the aircraft had sustained only minor damage to the underside. A local gentleman rendered assistance to Pilot Officer Paul Mayhew and was inclined to spirit him away and assist his return to the UK. However a Local Security Force officer, Major Bryan, himself a former RAF pilot, intervened and made sure that the pilot was detained by Gardai and subsequently interned in the Curragh. The aircraft was dismantled and brought to Baldonnell, repaired and entered service as Hurricane 93. A Miles Master which force-landed at Dungooley, County Louth on 21 December 1940 was also recovered to Baldonnell and subsequently entered service with the number $96{ }^{108}$

Early in 1941 one of the largest and longest salvage operations taken on followed the landing of RAF Lockheed Hudson number P. 5123 at Skreen, County Sligo on 24 January. A salvage crew of an officer and nineteen other ranks was dispatched the following day. On 30 January Col. Mulcahy reported to the Chief of Staff that the aircraft appeared to be in reasonable condition and that the question of making it serviceable so as to fly it to Baldonnell was being examined. As a modern reconnaissance machine, a

\footnotetext{
105 'Memorandum for the Government', DOD 3/2314, May 1949 (in my possession).

${ }^{106}$ File, 'Reports of force landed or crashed aircraft (foreign)' ( MA, no reference).

107 'Crashes and forced landings, 1939-45' (MA, PC143).

${ }^{108}$ Comdt. D. Mackey to CSO G2, 2 Oct. 1940 (MA, G.2/X/0513); Kearns, 'Irish Air Corps', p.459.
} 
generation ahead of the Anson and valued at about $£ 30,000$, there would have been a great desire to acquire such an aircraft. The salvage operation was hindered by the remote location, inclement weather and very soft ground conditions. A further complication was the fact that the Air Corps did not have tools appropriate to American built aircraft or experience of aircraft of semi-monocoque construction.

After being raised onto its undercarriage the aircraft was moved to a better location and subjected to a damage inspection. The officer in charge of the salvage made a request for a considerable amount of materials, tools, tarpaulins, duckboards, Wellington boots and other equipment. These were withheld pending the minister's decision regarding salvage. The major damage discovered by civilian inspector Ted Hoctor was serious cracks in the bottom members of the forward mounting on both engines. This matter having been reported, the COS authorised the sending of an officer to Northern Ireland to obtain materials required for the initial repairs - intimating that the minister had approved the completion of at least the recovery aspect of the salvage. ${ }^{109}$

The UK air attaché and RAF NI were very cooperative in facilitating the return of the Hudson to serviceability. Materials, spares and tools sourced in NI were delivered, by 'Mr. Roberts' to the crash site via the Customs Post at Belcoo. All concerned with the delivery were instructed to keep the matter very quiet. The officer in charge in Sligo, Lieut. Jim Teague, who had been instructed to tell his men to be discreet in regard to the origin of delivery, met the lorry at the border. The main items delivered to the crash site were two propellers, two engine bearers and an engine tool kit. ${ }^{110}$ Subsequently, engine mounting bolts, not available in NI were procured in the UK through the good offices of Wing Commander Lywood. ${ }^{111}$

In due course the aircraft was repaired to a condition that allowed it to be flown to Baldonnell. For this purpose the services of an officer of the Air Corps Reserve, Captain Ivor Hammond of Aer Lingus, were arranged by DOD. The aircraft was eventually flown to Baldonnell on 27 March 1941, nine weeks after it had landed. While no financial calculation appears to have been made there is little doubt that considerable resources

\footnotetext{
${ }^{109}$ Licut. J. Teague to OC AC Depot, 2 Feb. 1941; File note, Comdt. P. Quinn, 4 Feb. 1941; Ted Hoctor to R.W. O'Sullivan, 3 Feb. 1941; File note, Col. P.A. Mulcahy, 6 Feb. 1941(ACF/S/67, in my possession). ${ }^{110}$ Undated file note; Receipt signed J. Teague, 11 Feb. 1941; P.A. Mulcahy to COS 12 Feb. 1941 (ACF/S/67, in my possession).

111 File memo; 5 Mar. 1941; 6 Mar. 1941; 7 Mar. 1941; 8 Mar. 1941 (ACF/S/67, in my possession).
} 
were committed to the venture. Not least of these were a total of 1,609 man days of labour and the completion of some 5,690 miles by sundry Air Corps vehicles. A considerable inventory of spares and materials were used in the repair while much equipment, tools and clothing was rendered unserviceable. ${ }^{112}$ After further inspection and repair the Hudson entered service with the Air Corps number 91. In June and August 1941 two Hawker Hurricane II aircraft forced landed, were recovered to Baldonnel and entered subsequently Air Corps service. Similarly a Fairey Battle light bomber had been acquired on 24 April 1941. ${ }^{113}$

A system of skeleton crews, with five or six named individuals being nominated for the recovery of three different categories of allied aircraft, was put in place in April 1941.

A. The repairing and servicing of aircraft that can be flown to an aerodrome in Eire.

B. The dismantling, packing and transporting to Baldonnel of aircraft that appear to be in a fairly good state of repair and are likely to be rebuilt.

C. The breaking up and transporting to a Military Post aircraft that are badly damaged. ${ }^{114}$

The context suggests that an ad hoc system had been in place and that salvage crews were put together on a case by case basis. The recovery vehicles, possibly purchased in the 1940/41 financial year, comprised a single five-ton crane and two two-ton tractor and trailer combinations. ${ }^{115}$ The categories of aircraft and the actions to be taken suggest that the delivery of aircraft to the border had not yet started. The records indicate that the first aircraft to be handed back to the UK was a Spitfire that force-landed at Clogher Strand, County Donegal on 16 December $1941 .^{116}$ It is not obvious how this came about. Perhaps the air attaché had noted how the Air Corps had salvaged a total of six aircraft, between

\footnotetext{
12 OC AC to COS, 2 Apr. 1941 (ACF/S/67, in my possession).

113 A.P. Kearns, 'Irish Air Corps', p. 446.

114 Comdt. P. Quinn to OC AC, 18 Apr. 1941 (MA, AC/2/1 1/20).

115 Ibid; Estimates 1940/41 (MA, AC/2/2/34).

${ }^{116}$ Undated list, 'Aircraft salvaged and returned', W.J. Keane (MA, PC143)
} 
May 1940 and August 1941, and converted them to their own use. With aircraft always at a premium it would have made good sense to have lightly damaged aircraft returned to Allied service. It must be assumed that the suggestion got government approval before any action could be taken by the Air Corps. Defence's justification for this service was directed by government:

.....the international situation existing during the emergency was such that the state considered it politic at the time that belligerent aircraft landing on out territory should be removed therefrom with all convenient speed. ${ }^{117}$

This assertion, that suggests that all foreign aircraft landing or crashing in Eire during the Emergency were repatriated, is not quite true. In practice the only aircraft allowed to depart, after minor repair and refuelling, were aircraft of the Allied countries. Similarly only Allied aircraft that were repairable were salvaged and delivered to the border. Where the recovery of an aircraft was very difficult secret or sensitive items, plus armament, were removed and the wreckage left in place. Crashed German aircraft, if not already destroyed, were blown up in situ after the removal of secret and sensitive equipment of intelligence value to the UK.

With circumstances conducive to the quick dispatch of serviceable aircraft existing almost from the beginning and the first repairable aircraft being handed back in December 1941 the aircraft recovery operation was apparently put on sounder footing in the first half of 1942. Defence subsequently explained the circumstances:

During the emergency certain equipment was supplied to the Air Corps by both the British and American authorities under special arrangements made separately from the ordinary purchase channels. The supplies included equipment for the salvage of crashed aircraft together with equipment for general Air Corps use, e.g. spare parts and radio equipment. The total value of the equipment so supplied was $£ 14,600$ of which supplies to the value of $£ 10,600$ were expressed to be a free gift. ...... The

\footnotetext{
117 'Memorandum for the Government', DOD 3/2314, May 1949 (in my possession).
} 
balance of $£ 4,000$ represents transport equipment of which $£ 2,400$ worth was received from the British and $£ 1,600$ worth from the American authorities. ${ }^{18}$

It seems that hand tools, sundry items of equipment and clothing, including Wellington boots, were included in the salvage equipment supplied. ${ }^{119}$ It is not clear when this informal arrangement was strengthened or exactly when the donated equipment entered service. However it appears that the main items, two sixty foot tractor and low loader combinations, were in service by May 1942. On 14 April 1942 a Hudson reconnaissance bomber had force-landed at Ely Bay, Blacksod, County Mayo. The following month it was transported by the Air Corps from there to Garrison, County Fermanagh. With an empty weight of 11,630 pounds or more this aircraft could not have been moved on the small capacity Air Corps low loader - strongly suggesting that "the heavy transport and equipment supplied from Northern Ireland' had been used. ${ }^{120}$

While Fisk was not referring to the return of aircraft he might well have been when he hinted at the value of repatriated aircrew to the Allies:

Of much greater material value was the collusion between the Irish and British Governments over the Allied air crews whose planes crashed in Eire and who should, under the rules of neutrality, have been interned for the duration. ${ }^{121}$

While twenty-seven allied aircraft were handed back at the border (in addition to some forty-seven aircraft permitted to take off again), the repatriation of experienced aircrew was probably of equal or even greater military value. The management of the repatriation function, to the extent that it can be assessed, would tend to confirm collusion at a political level. During the period a total of 537 Allied aircrew survived crashes and forced landings in Eire. Of 273 RAF personnel in those categories only forty-five were interned. Eleven RAF aircrew escaped while most of the others were released long before the end of hostilities mainly on the basis of representations made at a diplomatic level by

\footnotetext{
118 Ibid.

119 OC AC to A/COS, 26 June 1944 (MA, AC/2/10/9).

${ }^{120}$ OC AC to COS, 2 Nov. 1942; G2, W. Comd. to OC AC, 13 May 1943 (ACF/144/1, in my possession); C.F. Shores, 'Lockheed Hudson Mks I to VI', in Aircraft Profile 253 (April, 1973), p. 174.

${ }^{121}$ Fisk, In time of war, p. 176
} 
the British representative, Maffey. By contrast all German aircrew (and sailors) were interned for the duration and remained so on 30 June $1945 .^{122}$

The relatively small number of RAF internees is accounted for by the fact that all aircrew were encouraged to state that they were on training rather than operational missions or that they were involved in search and rescue. While De Valera accepted such concocted stories it appears Col. Archer had authority to make decisions on individual cases. ${ }^{123}$ In early 1942, while Air Corps officers were handling the matter of a Hurricane that had landed at Collinstown, directions were handed down by GHQ.

Col. Archer, Assistant Chief of Staff, phoned Comdt. Delamere to say he had decided to release the Hurricane and the pilot and that it was to proceed first thing on Thursday $29^{\text {th }}$. We were to ensure that the aircraft was checked and serviced ....filled with petrol... the pilot given instructions to proceed straight to Aldergrove Aerodrome...... ${ }^{124}$

The aircraft departed for Aldergrove at 10.28 hours on 29 January 1942. One pilot who could not make a claim to being on a training flight made a force-landing near Athboy (Meath) on 21 August 1941. His Hawker Hurricane II had long range fuel tanks (and twenty gallons of fuel) and no less than ten Browning machine guns with about 900 rounds of ammunition remaining. ${ }^{125}$ On the following day the Irish Press carried a brief report under the headline 'British plane down in Co. Meath'.

The Government Information Bureau issued the following statement yesterday; 'A British plane made a forced landing in Co. Meath this afternoon. The pilot, who was uninjured, has been interned. ${ }^{126}$

\footnotetext{
${ }^{122}$ Intelligence file, 'Summary of chronological list of forced landings or crashes of belligerent aircraft from the outbreak of war to 30 June 1945', (MA, no reference).

${ }^{123}$ Fisk, In time of war, pp $327-330$.

${ }^{124}$ W.P. Delamere to CSO G.2, 29 Jan. 1942 (MA, G2/X/0961).

125 Capt. M. Cumiskey to CSO G.2, 5 Sept. 1941(MA, G2/X/0827); Fisk, In time of war, pp 327-330

${ }^{126}$ Press cutting, Irish Press, 22 Aug. 1941 (MA, G2/X/0827).
} 
The Daily Mirror of 22 August 1941 carried basically the same report under the headline 'Eire interns RAF pilot'. Woolgar and Roberts' Press Cutting Agency supplied their client, 'Eire', with the relevant cutting. While de Valera's Government was no doubt interested to know how Irish affairs were being reported in the UK they were probably more concerned to give the impression, to Irish people, home and abroad, that all such aircraft incidents resulted in the internment of the crew. This of course was not always the case. ${ }^{127}$

While the memorandum for the government states that the arrangements for the return of aircraft were informally agreed it transpires that the DOD aspect of the matter, the salvage of aircraft as carried out by the Air Corps, was put on a regulatory basis in 1943. This came about as part of the reorganisation that took effect on 29 March 1943. In the Technical Workshops of the Maintenance Unit a 'Salvage' section comprising a captain, six NCOs and sixteen privates was provided for. Listed under the heading of 'vehicles', in the Transport Section of the Air Corps Depot, were no less than five 'tractors, aircraft'. ${ }^{128}$ A total of about 162 crashes and forced landings are recorded as having been dealt with by the armed forces during the period $1939-45{ }^{124}$

\section{Aerodromes for RAF use}

While the major practical aspects of Eire - UK cooperation during the Emergency were directed by Government policy and affected by GHQ the Air Corps was involved in air related aspects other than air intelligence. One such significant aspect was the matter of aerodromes for the use of the RAF that might operate in Eire in support of a defence against a possible German invasion. In the context of such a defence it is considered that Gormanston was ideally placed for the initial stages at least. However the position regarding the likely use of this aerodrome during the summer of 1940 is not obvious.

It is significant that Lywood's first report indicated that the service tanks at Gormanston held 12,000 gallons of aviation fuel, or $70.5 \%$ of its storage capacity of

\footnotetext{
${ }_{127}^{27}$ Press cutting, Daily Mirror, 22 Aug. 1941 (MA, G2/X/0827).

128 Tables $30 \mathrm{~W}$ and $30 \mathrm{a} \mathrm{W}, 1943 \mathrm{AC}$ establishment

${ }^{129}$ Intelligence file, 'Summary of chronological list of forced landings or crashes of belligerent aircraft from the outbreak of war to 30 June 1945' ( no reference, MA).
} 
17,000 gallons, on or about 20 May 1940. Nine days later the holding was recorded by the Air Corps as 11,355 gallons or $66.8 \%$ of capacity. On the same day, 29 May, Baldonnell, where fuel was in daily use and with a similar capacity, held only $59 \%{ }^{130}$ The question arises as to why Gormanston should hold more aviation fuel than Baldonnell at a time when German invasion, via the south coast, was feared. Under GHQ Operations Order No.1 of 29 May 1940 Gormanston was not designated for Air Corps use in any circumstance. In fact the 'defence of aerodromes' annex, that directed defence measures for Baldonnell, Collinstown and Tallaght as well as three small private airfields in the Eastern Command area, did not provide for the air defence of Gormanston though it was probably the most vulnerable and accessible of all. ${ }^{131}$ This omission is intriguing when it is considered that Gormanston, though somewhat run-down, had been built to the same training depot station specifications as Baldonnell and was potentially a viable air base - for friend or foe alike. It is unlikely that the fuel at Gormanston represented an Air Corps reserve. At that time the return of fuel stocks indicated 102 tons of fuel in bulk storage, as well as spare storage for a further fifty-eight tons, at Dublin docks. The centrally stored fuel at Dublin was much closer to Baldonnell which itself had spare capacity. ${ }^{132}$ In effect there was no apparent operational or strategic reason for such a relatively large stock of fuel at a non-operational aerodrome such as Gormanston. A possible explanation for the absence of air defence and the presence of a significant amount of aviation fuel is that Gormanston may have been designated, during the initial period of concern regarding invasion and for a relatively short period, as a first base for RAF aircraft answering the call to repel a German invasion in the early summer of 1940. Its location, just fifty miles south of the border and on the east coast, would have made it the natural first base for the RAF in Eire. In December 1940 Gormanston was initially included on a list of 'Emergency Landing Grounds'. Subsequently the name was deliberately obscured on EDP copy of the order - suggesting that the aerodrome was intended for some special purpose. ${ }^{133}$

\footnotetext{
${ }^{130}$ Fuel Stocks, 29 May 1940, (MA, AC/2/8/3)

131 Annex No. V to Operations Order No. 1, 29 May 1940, (MA, EDP 1/1)

132 'Report No. 1', Lywood to AM, 11 June 1940 (NA, Air 2/5130).

133 Operations Order No. 3/1940, 17 Dec. 1940 (MA, EDP 1/2, Plan 2).
} 
Subsequent to the initial alarm period of May to July 1940 the RAF commenced a planning process aimed at the air defence of Eire in the context of a British response to a German invasion - if and when asked. An early warning order directed that, in the event of German invasion of Eire or Northern Ireland immediate action was to be taken against the invading forces by the air forces stationed in Northern Ireland. ${ }^{134}$ Fighter squadrons were to be the backbone of this defence.

.....when the situation in Eire permits, the need to establish fighter sector stations in the Dublin and Wexford areas with the object of affording protection to Eire and to British shipping in St. Georges Channel and the Irish Sea...... ${ }^{135}$

This initial proposal provided for the operation of two fighter squadrons from Baldonnell 'with an advanced landing ground at Wexford' and a further squadron located 'in southern or central Eire'. ${ }^{136}$ Staff studies also considered the occupation of Collinstown, Curragh, and Rineanna and the posting to Ireland of five fighter squadrons and a servicing unit in addition to the RAF Headquarters and seven squadrons already in Northern Ireland. ${ }^{137}$ While a later study projected as many as seven sector stations and two forward aerodromes in Eire, plus a major expansion of R.D.F. (radar) stations to include the south and east coasts, RAF planning concentrated on the concept of Baldonnell and Collinstown as fighter stations with an advanced or forward airfield in Wexford. This latter plan, which outlined the communications for the R.A.F. in the event of operations outside Northern Ireland put two Battle squadrons at Collinstown, three Hurricane fighter squadrons at Baldonnell and capacity for two fighter squadrons at Wexford. The same plan provided for No. 11 Repair and Salvage Unit to be located at 'Gormanstown' and No. 23 Workshop Service Unit at Baldonnell. ${ }^{138}$

\footnotetext{
${ }^{134}$ Deputy Chief of Air Staff to OC RAF Aldergrove, 21 June 1940 (NA. CAB 104/184).

135 Fighter Command RAF to Deputy CAS, 19 July 1940 (NA, Air 2/5185).

136 Ibid.

137 'Plan for the preparation of air forces for operations in the event of a German attack on Eire or Northern Ireland', 4 Aug. 1940 (NA, Air 2/5130).

${ }^{138}$ War Cabinet, 'Review of the Air Defence of Ireland', Oct. / Dec.1940 (NA, Air 2/5172); HQ RAF NI to HQ Fighter Command, 28 Sept. 1940 (NA, Air 16/530).
} 
As early as July 1940 the availability of existing aerodromes and the selection of forward landing grounds had concerned both the RAF and the Air Ministry. ${ }^{139}$ Lywood was given direction on the matter:

For Lywood. It is desired make extensive reconnaissance Eire to ascertain landing grounds of possible use by enemy or ourselves. In view [of] your pre-occupations such reconnaissance might be conducted by two or three officers as tourists on instructions from Operations Department Air Ministry under your direction. ${ }^{140}$

Notwithstanding the excellent relationship that developed between Lywood and Mulcahy - a relationship that might have negated the necessity for such subterfuge - the Air Ministry was still disposed to such covert action in February 1941. ${ }^{141}$ In the meanwhile the cooperation with Lywood appears not to have included information on sites suitable for advanced landing grounds though many such sites had been identified in the context of Air Corps' army cooperation responsibilities. As Lywood himself had produced a survey of an unspecified number of sites, and because of difficulties and objections, the idea of spying trips was dropped. ${ }^{142}$ On 14 February Lywood was instructed by the Air Ministry to make representations to prevent some fourteen sites, presumably originally identified by him, from being ploughed under the compulsory tillage scheme. He was also to ask Mulcahy for any detailed information available on the sites. ${ }^{143}$

It appears that at about this time Mulcahy was being particularly helpful to Lywood - apparently arising out of Mulcahy's need of training aircraft.

It is necessary to make it clear that the question of the supply of these 10 Hector aircraft to Eire did not arise as the result of an official request from the Eire government. It has arisen in the course of a useful liaison which has grown up in the last few months between our air attaché in Dublin and Colonel Mulcahy ...... ${ }^{144}$

\footnotetext{
${ }^{139}$ HQ RAF NI to AM, 30 July 1940 (NA, Air 2/5130).

${ }^{140}$ Cypher message, AM to Station A.A., 11 July 194, (NA, Air 2/5129).

${ }^{141}$ Minute 36, 8 Feb. 1940; Minute 37, 12 Feb. 1940, AM, S.5503 (NA, Air 2/5172)

${ }^{142}$ Minute 39, 15 Feb. 1941, AM, S.5503 (NA, Air 2/5172).

${ }^{143}$ AM to R.W.G. Lywood, 14 Mar. 1941 (NA, Air 2/5172).

${ }^{144}$ File Memo, 'Supply of aircraft to Eire', 26 Jan. 1941 (NA, Air 8/361).
} 
With Lywood supporting the supply of training aircraft, which have little potential offensive value Mulcahy had undertaken to ask his superiors for sanction for the construction of aerodromes in the Wexford and Cork sectors where the RAF need them most. $^{145}$ In March 1941 Mulcahy gave instructions for the conduct of a survey of aerodromes for RAF rather than Air Corps use. He issued guidelines with regard to the characteristics required. Pilots were reminded that the surveys were to be kept secret and that in obtaining information about particular sites the real aim was not to be revealed. ${ }^{140}$ Subsequently Mulcahy received reports and plans relating to nine sites from the Command Engineer, Eastern Command. The sites included Gaybrook, county Westmeath, Rathduff, county Tipperary and Rosegarland, county Wexford, the last being one of the RAF's preferred sites. Mulcahy forwarded copies of the reports and plans to the COS. ${ }^{147}$ In August 1941 the COS made an announcement in relation to the 'Preparation of emergency aerodromes':

It has been decided that two emergency aerodromes are to be prepared - one near Cashel and one near Mullingar and that no other aerodromes will be prepared elsewhere. The selected sites are Rathduff, Co. Tipperary and Gaybrook, Mullingar'. ${ }^{148}$

It was not explained why Rosegarland was not considered further but it seems probable that the projected development cost of $£ 13,480$ was the deciding factor. ${ }^{149}$ It was specified that two runways at right angles with 'minimum dimensions of $1,000 \times 50$ yards', a capacity for further extension and 'capable of taking a total load 7,000 lbs' were required at each site to be developed. This represented a more demanding specification than the previous. This decision was endorsed by the minister a few days later. ${ }^{150}$ When acknowledging the decision Mulcahy indicated that he would have the sites resurveyed

\footnotetext{
145 'Memorandum by Vice CAS', 24 Jan. 1941 (NA, Air 8/361).

146 OC AC to Squadron commanders, 26 Mar. 1941 (MA, AC/2/9/14).

147 OC AC to Command Engineer, E. Comd, 12 July 1941 (MA, AC/2/9/14).

${ }^{148} \mathrm{COS}$ to OC AC, 21 Aug. 1941 (MA, AC/2/9/14).

149 OC AC to COS, 16 July 1941 (MA, AC/2/9/14).

${ }^{150} \mathrm{COS}$ to OC AC, 21 Aug. 1941; File memo dated 25 Aug. 194 (MA, AC/2/9/14).
} 
by his civilian aeronautical engineer and an officer appointed by the director of military engineering. Also he warned that the change in the specification requiring greater runway length might cause difficulties in one case. ${ }^{151}$

Within the week he submitted a further report indicating that runways of the required length and at right angles could not be fitted in at Rathduff due to ploughed fields. The position in relation to Gaybrook was even less satisfactory to the extent that the preparation of the site to the required specification would be a lengthy and expensive operation. It was recommended, in order to reduce expenditure, that less stringent provisions as regards the runway length might be acceptable. 'Before arriving at a decision, I consider that certain interested parties should be consulted and permitted to inspect both sites'. ${ }^{152}$ In August 1941 DOD had received outline financial approval 'for the arrangements made in connection with the emergency accommodation of troops.' In September the department stated that 'landing ground[s] for Air Corps purposes' and 'for use in certain eventualities' are required near Mullingar and near Golden (Rathduff).

Subsequently, following further inspection by engineers, the development of Gaybrook was abandoned - apparently on the grounds of the potential expense resulting from the amount of levelling and grading required to meet the revised specifications. ${ }^{153}$ In requesting confirmation of verbal sanction previously given DOD requested approval for agreements to be entered into with the three landowners at Rathduff, Golden, Co. Tipperary. It was proposed to pay annual reservation fees of $£ 52$ to Mrs. D.H. Edwards, $£ 12$ to Thomas Burke and $£ 6$ to Denis Kennedy and to undertake to compensate for damage done by removing fences. A rental payment was intended in the event that the lands were actually used subsequently as an aerodrome. ${ }^{154}$ By October 1941 it was reported that the aerodrome at Rathduff was being developed to the modified requirements of 21 August 1941 except that the runways were at 93 degrees to each other in order to fit them in with surface details. Outstanding works, including the levelling of banks, ditches and hollows, would take six weeks to complete with one hundred men employed. The difficulty presented by the presence of a 200 yard strip of stubble that

\footnotetext{
${ }^{151}$ OC AC to COS, 23 Aug. 1941 (MA, AC/2/9/14)

152 $\mathrm{OC}$ AC to COS, 29 Aug. 1941 (MA, AC/2/9/14)

${ }^{153} \mathrm{OC}$ AC to COS, 3 Dec. 1941 (MA, AC/2/9/14).

${ }^{154} \mathrm{Sec}$ DOD to Sec DF, 4 Sept. 1941 (MA, AC/2/9/14).
} 
would not bear the required load was easily resolved. Arrangements were made with headquarters, RAF NI to make available the necessary quantity of Summerfield track for emergency runways if and when required. Mulcahy had gone to Fowlmere Aerodrome in August 1941 and inspected the reinforced wire mesh track (RSP- reinforced steel planking) used to stabilise soft ground. ${ }^{155}$ Rathduff was most likely ready for use by the end of 1941 but was not destined to be used by the RAF. The only Air Corps recorded use occurred during the Army exercises of September 1942. ${ }^{156}$ In May 1941 the Air Corps took delivery of ten ex-RAF Hawker Hectors and in January 1942 a further three. The machines were apparently supplied at a notional cost of $£ 200$ each, plus $£ 15$ each for equipment. $^{157}$

\section{Conclusions}

From 1936 the Government's concept of the Air Corps had been as a source of technical personnel and expertise for the advancement of civil aviation. The priority given to the employment of pilots in civil ATC from 1936 to 1946 can be seen as a major aspect of that policy. A second aspect was the conduct of three wings courses during the Emergency. With sixty-four students recruited and forty-three qualified the output of the previous seventeen years was duplicated in six while the post-war pilot requirements of civil aviation would be more than adequately provided for. It is significant that the Air Corps second-in-command spent the bulk of the Emergency period in a managerial position with Aer Lingus. It is similarly significant that an elusive and apparently minuscule Air Corps reserve that included Capt. Ivor Hammond, was not called to the flag.

Given the lack of preparation and planning, that was, in effect, part of the Government's policy for the Emergency, it is easy to understand the quite unsatisfactory nature of the Air Corps' contribution during the first twelve to sixteen months of the period. Whatever the circumstances, with the decision to post an air detachment to the

\footnotetext{
${ }^{155}$ Major J. Gleeson to OC AC, 9 Oct. 1941; OC AC to COS, 13 Oct. 1941; OC AC to COS, 17 Oct. 1941 (MA, AC/2/9/14).

${ }^{156}$ Undated 'Report on Army exercises 1942', circa Sept. 1942 (MA).

${ }^{157}$ A.P. Kearns, 'Irish Air Corps' p. 459; Sec DOD to Sec DF, 6 Jan. 1943 (NAI, DF, S. 008/0029/39).
} 
south west, the campaign started badly and from there matters got worse. It could rightly be stated that the R \& MB Sqn. element exchanged the aviation backwater of Baldonnell for the aviation wilderness of Rineanna. Nothing in the aeronautical circumstances at Rineanna was conducive to the conduct of a successful military mission. The inadequacies included an ill-equipped and inadequately supported obsolete aircraft that was unsuited to the environment and to the mission. It could be stated that the loss of three aircraft early in the mission and the obvious lack of adequate spares were the main factors contributing to the degradation of the patrolling mission. However, the primitive nature of the location and facilities, including meteorology, communications, direction finding and other basic requisites, compounded by the absence of preparations of any description, contributed in no small way to an outcome that was probably inevitable in the circumstances.

At Baldonnell the position of the other operational squadron, from May 1940, was, if anything, even more unsatisfactory. The composition of the 1940 Fighter Squadron was an aeronautical nonsense. With fifteen aircraft of six inappropriate and obsolete types it was, as the investigation report subsequently stated, fighter in name only. While it is not possible to adequately assess the likely affect, in practical operation, of GHQ's disjoined and uncoordinated operations orders, the concept of Fighter Squadron being the backbone of an Air Corps Interception Service indicates a naivety on the part of the military leadership which defies belief. The terms in which Mulcahy indicated his acceptance of the suggestion that a training cadre might make a worthwhile contribution to the defence of Dublin strongly suggests that his greater naivety influenced those who should have known better.

With its core roles ceasing to be of value it subsequently fell to the Air Corps to be the main conduit for the return of force-landed and repairable crashed aircraft. While the full circumstances of the evolution of this function are obscure it apparently soon became the Corps' main significant contribution to the ongoing cooperation with the RAF. Mulcahy's cooperative relationship with the UK air attaché, though it was at least partially driven by his need for spares and more particularly for training aircraft, tended to transcend the difficult political relationship between the two countries. That only one advanced airfield was developed for the RAF was probably not due to any lack of 
diligence on Mulcahy's part while the number of aircraft acquired, albeit more obsolete than the previous, suggests reward for a degree of cooperation that the RAF and the Air Ministry could not have anticipated. 


\section{CHAPTER 11}

\section{THE AIR CORPS INVESTIGATION OF 1941 \\ AND \\ THE 1943 REORGANISATION}

In August 1939 the Air Corps, without the benefit of planning or preparation commenced the emergency period by dispatching, to Rineanna a detachment of less than 100 all ranks with Anson and Walrus aircraft. Their reconnaissance mission was to patrol the west coast and to report, in particular, German submarine activity. This operation, probably directed by government, and possibly at the request of the UK, was undertaken despite inappropriately equipped obsolete aircraft, inadequate training and abysmally poor aerodrome infrastructure, maintenance, spares and support services. Within eight months adverse circumstances, particularly very poor aircraft serviceability caused by chronic lack of spares, dictated that the coastal patrol operation be reduced to occasional patrols.

From May 1940, in similar circumstances of obsolete aircraft and inadequate service support the Fighter Squadron at Baldonnell was given an improbable role in a scheme for the air defence of the Dublin area. This scheme was ill-conceived and inadequately directed, controlled and coordinated. Despite the futility of its assigned role Fighter Squadron remained on endless stand-by for an invasion about which, had it happened, the squadron would have been capable of doing precious little. The minuscule Coastal Patrol Squadron, also based at Baldonnell, had no operational function but acted as a training element for the reconnaissance detachment in Rineanna. It was to be through the professional interest and the unprecedented intervention of two officers of this squadron that the inadequacies of the commanding officer and of aerodrome service support systems, particularly communications and direction finding, were to be highlighted.

This chapter will examine the immediate circumstances, identifying the particular aspects that caused officers to complain to higher authority about those decisions and actions of Colonel Mulcahy, which eventually lead to the investigation. The 
deliberations, the report and findings and main recommendations of the committee of investigation will be assessed with particular reference to any possible bias or prejudice in respect of any individual or group. It is also intended to establish the extent to which the report and proceedings reflect an accurate exposition of the effectiveness of the Air Corps and of the circumstances that brought its pilots to a demoralised and depressed state. The committee's assessment of individual pilots will be explored. Central to this study will be an assessment of the roles and functions of Col P.A. Mulcahy from June 1935 to January 1942 and of the degree to which he may have contributed to the problem. The main findings and recommendations, in particular those relating to Mulcahy will require close examination in the context of his decisions and actions over the years. The post-investigation period will be examined to assess the Army's change of emphasis in air matters and, in effect, the return of the Air Corps to the army cooperation fold for the latter years of the Emergency.

\section{The committee}

The 'Committee of investigation into the effectiveness, organisation, equipment, training and administration of the Air Corps' was established by a convening order, dated 10 January 1941, issued by the Chief of Staff. It consisted of Major General H. McNeill, Assistant Chief of Staff, and three majors (equivalent to lieutenant colonels). While the report states that the committee first convened on 28 January the first witness was heard on Tuesday 21 January 1941 . The committee took evidence, under oath, four days each week until 18 April 1941 and from 23 September 1941 to 21 November 1941. They began formulating their report and findings on 8 December 1941 and delivered the report on 10 January 1942, exactly one year after the order had been issued. Though not cited as such it was, in effect, a court of inquiry as provided for by Defence Forces Regulation A.5 dated 10 April 1937, a process normally used to investigate vehicle accidents and losses and deficiencies of military stores. The regulation provided for the examination of witnesses and for rebuttal evidence in the event of a witness making remarks affecting the military reputation of an officer or giving evidence contradicting that of another witness. In practice the investigation examined each witness in private with all evidence being 
duly recorded. Subsequently an officer who had been the subject of adverse comment was given the opportunity to give rebuttal evidence. In its preamble on procedure the committee indicated that while the conduct of the investigation was formal and on oath the evidence was not necessarily spontaneous:

While the evidence is recorded in the form of question and answer, it was found desirable, because of the very wide scope of the matters under investigation, to permit witnesses to discuss with the committee and explain the points they desired to make. These discussions were then reduced to relevant and essential facts in the form of questions and answers and are so recorded. ${ }^{1}$

It is considered that this convenience the committee afforded themselves may have provided scope for a degree of selectivity in regard to what was considered relevant and essential. It is noted that, on occasion, the committee steered witnesses away from matters they might have preferred to pursue but that the committee might not. In the event the committee examined some forty-one witnesses - all Air or Signal Corps personnel with the single exception of Colonel (later General) M. J. Costello, a senior officer on McNeill's operations staff in GHQ. A total of 588 pages, or approximately 265,000 words, of witness evidence was recorded while the report and findings, annexes and appendixes added a further 274 pages of typed foolscap. The appendixes comprised various correspondence and reports, mainly predating the investigation, that were accepted in evidence. Due to his key roles as OC Air Corps and director of military aviation and to the amount of criticism expressed before and during the investigation Colonel Mulcahy provided a proportionately large amount of this evidence - about $20 \%$. This was mainly due to his being recalled a number of times to give rebuttal evidence in respect of adverse comments on aspects of his command, decisions and actions. The committee also consulted some forty-four DOD and Air Corps files, the flying log books of forty-seven officers and sundry records and orders. ${ }^{2}$

\footnotetext{
${ }^{\prime}$ Report and findings of the committee, 10 January 1942, I-II (MA, ACS 22/23). The report is paginated in roman capitals.

2 'List of files and other records examined', Appendix No. XLII to Report and findings of the committee, 10 Jan. 1942 (MA, ACS 22/23).
} 


\section{The cause of the unrest}

The terms of reference, the evidence of witnesses and the report and findings of the committee do not indicate the exact circumstances that led to the investigation. It would appear that the condition of the Air Corps during what Mulcahy called the invasion nervous' months of the summer of $1940^{3}$ and the manner in which Mulcahy exercised his command and the functions of DMA before and during the early stages of Emergency were central factors. From Mulcahy's final submission to the investigation committee on 21 November 1941 it transpires that, during the latter part of 1940 in particular, his command was under severe strain due to alleged irregular communications from junior officers to persons outside the Army - including the minister. Mulcahy cited a visit to Baldonnell by the minister and the COS on 23 October 1940 in connection with certain allegations made in writing to the minister - apparently in the recent past. While it is not clear by whom allegations had initially been made it appears that T.J. Hanley may have been one. We are not given any indication as to the exact nature of these allegations but the evidence of witnesses suggests several matters aired during the investigation hearings. These included standards of navigation and instrument flying, the standard of aircraft equipment such as instrument panels, direction finding equipment, communications generally and the failure to acquire vacuum pumps and loop aerials for Ansons. ${ }^{4}$

Subsequent to the visitation of 23 October, with the minister's permission, two officers submitted written complaints. His evidence to the investigation confirms that Hanley was one of those invited to write to the Minister - which he did on 4 November $1940 .^{5}$ One of the matters he complained of was the fact that vacuum pumps (for the better operation of gyroscopic instruments in Ansons), had been requisitioned by the Air Corps in June 1939, not ordered by Contracts Section DOD until June 1940 - and apparently still not delivered in January $1941{ }^{6}$ While he possibly also mentioned the failure of the Air Corps to seek the purchase of loop aerials for Ansons, (a modification that was available since November 1938), this is not explicit in his evidence to the

\footnotetext{
${ }^{3}$ P.A. Mulcahy to AC investigation, 21 Nov. 1941 (MA, ACS 22/23).

${ }^{4}$ T.J. Hanley to AC investigation, 23 Jan.; 17 Apr.; 12 Nov. 1941 (MA, ACS 22/23).

${ }^{5}$ P.A. Mulcahy to AC investigation, 19 Nov. 1941 (MA, ACS 22/23).

${ }^{6}$ T.J. Hanley to AC investigation, 23 Jan. 1941 (MA, ACS 22/23).
} 
committee but is intimated in Mulcahy's November 1940 defence of the allegations made against him.

On 15 November 1940 Mulcahy wrote to the COS in response to the matters contained in the two official letters to the minister. One of the main planks of his defence against the allegations was to denigrate Hanley for his lack of experience of staff duties stating that he was in no position to criticise constructively the administration of the Air Corps. Mulcahy went on, in an oblique fashion, to blame the procurement system for the failure to acquire equipment which Hanly saw as being of little importance to Mulcahy and his headquarters staff but a matter of life or death to those who flew every day. He summed up Hanley as follows:

Like many others he feels that every demand he makes for new or more equipment should be supplied without delay. He forgets that these officers who built up the [Air] Corps flew for years without the aid of modern equipment which he now has and without the new instruments and equipment which he states are essential. $^{7}$

While Mulcahy blamed the system of financial control for the failure to acquire new instruments and equipment required by pilots he avoided direct reference to the failure to purchase the loop aerial and vacuum pump modifications for the Ansons. In the case of the loop aerial modification Hanly's evidence to the committee strongly suggests that Mulcahy had knowingly withheld authority to buy the required materials. ${ }^{8}$

In denigrating Hanley's lack of administrative experience and knowledge of procurement and, in effect, stating that pilots never had it so good, Mulcahy attempted to deflect attention away from Hanley's fundamental point that Mulcahy's Air Corps was not keeping Anson aircraft up to date in terms of equipment conducive to good navigation and that the failure to incorporate such modifications as vacuum pumps and loop aerials had rendered the reconnaissance operation more untenable than it might have been. It was in the context of this antipathy between Mulcahy and Hanley that the

\footnotetext{
${ }^{7}$ P.A. Mulcahy to AC investigation, 19 Nov. 1941 (MA, ACS 22/23.

${ }^{8}$ T.J. Hanley to AC investigation, 23 Jan. 1941 (MA, ACS 22/23).
} 
incident, concerning the alleged irregular use of the civil DF station at Baldonnell on 21 November 1940, had occurred.

On 24 October 1940 Mulcahy had felt obliged to issue orders prohibiting officers of one squadron from visiting other squadron areas to converse with fellow pilots except on official matters and then only with the permission of their unit commander. On 1 November 1940, having been asked to do so by the COS, Mulcahy explained the reason for the order. The necessity arose because of Mulcahy's belief, apparently based on his observation of the casual movement of officers between offices, that the practice of 'officers consorting with each other' represented a waste of time and that it should be stopped. He considered that officers had deliberately misconstrued his order and reported it in an irregular manner. ${ }^{9}$ The tone of Mulcahy's order about officers consorting with others, and the complains made by some officers to higher authority, strongly suggests that the dictatorial nature of his command, his lack of appreciation of the technical nuances of the aviation of the day, together with the inevitable demoralisation caused by the impotence of the two main operational squadrons, was causing great unrest amongst the flying officers. Mulcahy subsequently cited the letters of complaint, and other incidents, in concluding that "while these incidents were occurring, it was impossible to keep secret the fact that some disruptive element was at work and the effect on Corps morale and discipline will be appreciated'. ${ }^{10}$ In this regard it might be considered that Mulcahy mistook the symptoms for the cause.

There is one matter that particularly demonstrates the adverse effect Mulcahy had on the morale of pilot officers. A 1943 study of accident figures versus flying hours illustrated that in the first full year of Mulcahy's command of the Air Corps, 1936, one flying accident was occurring every 950 hours of flying. By 1938 the figures reflected an accident every 525 hours. By 1942, the last full year of Mulcahy's command, an accident was occurring, on average, every 210 flying hours. The statistics for 1941 and 1942 reflected the loss of a total of eighteen aircraft (nine each year). By way of contrast no aircraft was lost in 1943, the first year of W.P. Delamere's command."

\footnotetext{
${ }^{9}$ P.A. Mulcahy to AC investigation, 21 Nov. 1941 (MA, ACS 22/23).

${ }^{10}$ Ibid.

11 'Memorandum on flying accidents for the information of senior officers of the Air Corps', W. P. Delamere, 29 Nov. 1943 (in my possession). The statistical study supporting the memorandum was
} 
A picture emerges of a demoralised and frustrated pilot officer body that was no longer prepared to grin and bear it. In Hanley, who qualified in 1928, the younger pilots had a spokesman who had the professional expertise and moral authority of a longqualified pilot (and who probably saw his future career as being outside military aviation) who could highlight the inadequacies of the director of military aviation. Notwithstanding, in the dictatorial atmosphere of the Army of the Emergency, where higher authority was right by virtue of superior rank, Hanley's could have been a high risk strategy. It seems possible that Hanley and others had safeguarded their positions by keeping the Dail opposition informed thus obviating precipitous disciplinary action on the part of GHQ or the General Staff.

\section{The investigation}

It appears that, irrespective of the nature of Mulcahy's defence against the written complaints higher authority (COS, DOD or the minister) deemed that a thorough investigation was warranted. In the circumstances outlined the investigation might have been centred on Mulcahy's command and direction of the Air Corps that had resulted in demoralisation, inefficiency and stagnation. ${ }^{12}$ However the terms of reference, and the manner in which the committee proceeded, ensured that the spotlight was kept firmly on the perceived inadequacies of the Air Corps and the shortcomings of the pilots individually and collectively - tending to presuppose that Mulcahy had little responsibility in the matter. In investigating 'the effectiveness, organisation, equipment, training and administration of the Air Corps' the committee addressed a number of standard questions, based on the nine main question in the terms of reference, to the more senior witnesses in particular. More specific questions were put to individuals as appropriate to their appointments, functions and evidence. The committee reported their proceedings, findings and recommendations under nine broad headings and several subheadings.

conducted by Lieut. Jim Teague (Air Corps aeronautical engineer, 1940 to 1981). In later years Lt. Col. Jim Teague was scathing in his comments on P.A. Mulcahy's command of the Air Corps and of the adverse effect he had on morale and flight safety.

12 Report and findings of the committee, 10 Jan. 1942, LXIX (MA, ACS 22/23). 


\section{Effectiveness of the present Air Corps}

The effectiveness or otherwise of the Air Corps was assessed by the committee in the context of the first question:

.....whether the Air Corps, as now organised and equipped, is capable of cooperating with other units of the Forces or of functioning usefully in any other capacity? To enable it to deal adequately with this question the Committee had to decide what type of co-operation our ground forces should expect from the Air Corps. ${ }^{13}$

The committee, apparently without taking evidence on the matter or citing existing planning or policy documentation, but presumably drawing on the operations backgrounds of McNeill and Major (later Colonel) J.J. Flynn, stated that the co-operation required by the Defence Forces of the Air Corps might be divided into war and peace missions'. ${ }^{14}$ (Appendix No.10) The war missions, in their broadest contexts, could be reconciled with the missions implied in the nomenclature of the three operational squadrons and might have been feasible in the context of Costello's ten squadron Air Corps if properly equipped, manned and trained. In essence the war missions would have required an independent air force having an operational capacity many times that which existed during the Emergency. The peace missions, had the principles been applied in training prior to the Emergency, would have required several squadrons of army aviation, dispersed amongst the manoeuvring ground formations and devoted to the practice and simulation of wartime battle conditions. In the context of totally limited resources and the equally limited capabilities of the squadrons established the missions as stated have to be seen as being almost totally theoretical in nature.

Bearing in mind the fact that higher authority had not previously defined war and peace missions the introduction of such principles in the context of a major review of the

\footnotetext{
${ }^{13}$ Ibid, VI.

${ }^{14}$ Ibid.
} 
effectiveness of military aviation might have unduly complicated the study. In the event the investigation was to concentrate on its perception of the effectiveness of the existing Air Corps and on the corps' potential, as army aviation, in support of ground forces. It did not try to compare what it actually found with the stated ideal. The introduction of the concept of war and peace missions, in the final report in January 1942, appears to emphasise the fact that the Army had neglected to address such important matters at a more appropriate earlier juncture.

The effectiveness of Air Corps aircraft was assessed with reference to the extent to which 'a heterogeneous collection of aircraft, service and training, having as many different characteristics as there are types' could perform their war missions or, in a future reorganisation, be adapted to reconnaissance missions. There were no conflicts of evidence in regard to the manifest inadequacies of individual aircraft types. The Gloster Gladiator, of which only three were in service in 'A' Flight of Fighter Squadron, was described as a single seat fighter of limited range with a poor radio and no armoured protection for the pilot. 'In speed, armament and performance they would be completely outclassed by modern fighter aircraft.' It was seen as having limited potential as a reconnaissance aircraft in that, as a single seat machine it did not have a rear gun and could not carry an observer. ${ }^{15}$

The committee reported that the other serviceable aircraft of Fighter Squadron consisted of five Lysanders organised in two flights. The sixth machine had been adapted for the target-towing requirements of anti-aircraft artillery. ${ }^{16}$ These were recognised to be very suitable army cooperation aircraft which, when used as fighters could use their low speed and manoeuvrability to avoid being shot down but, in reality, which would stand little chance in normal combat. ${ }^{17}$ In terms of effectiveness the committee suggested that, with both fighter and army cooperation aircraft, the Fighter Squadron could fulfil neither role satisfactorily. While the bulk of its aircraft were army cooperation machines that were unsuitable as fighters the pilots were also inadequately trained in army cooperation duties. The report did not reflect the fact that during the pertinent period, the latter half of 1940, the Fighter Squadron had a total of fifteen aircraft (as against a

\footnotetext{
${ }^{15}$ Ibid, IV.

${ }^{16}$ A.P. Kearns, 'Irish Air Corps', p.459

${ }^{17}$ Report and findings of the committee, 10 Jan. 1942, VI (MA, ACS 22/23).
} 
notional twenty-two) of no less than six different types - three Gladiators, six Lysanders, two Avros 636s, two Hawker Hinds, a DH Dragon and a Miles Magister - organised into four flights. The squadron had only eleven pilots out of a notional war establishment of twenty-seven. 'B' Flight, Fighter Squadron had five aircraft of no less than four different types. All-in-all the composition of the squadron, in the context of the norms of the organisation and equipment of air squadrons of the period, was a total nonsense. ${ }^{18}$ The committee concluded that 'the fighter squadron is fighter in name only'. The committee's final assessment was brutally frank:

The Committee considers that the employment of this insignificant unit would not be justified for fighter purposes. Such employment would be an unwarranted waste of life without any gain to the Army or the state. ${ }^{19}$

The committee described the Ansons of the R \& MB Squadron as 'twin-engined, slow, heavy and of limited manoeuvrability which renders them very easy prey to any type of enemy aircraft'. In this case the committee seems to have seen qualified merit in the manner in which the Anson was, and could in the future, be used:

The Anson machines can be employed on coastal patrol in normal weather during the present period of the emergency. They have in fact been employed on such duties during the autumn and winter of 1939, operating from a base at Rineanna Aerodrome.......In the most favourable circumstances, they could be used to report whether hostile sea-borne forces were at sea, were approaching our coast and the location of such forces being put ashore. ${ }^{20}$

In considering a possible army cooperation role for this squadron the committee suggested that the Anson might be used 'over quiet sectors where hostile aircraft is [sic]

\footnotetext{
${ }^{18}$ Examination of The squadrons of the Royal Air Force indicates that the vast majority of squadrons had no more than a single aircraft type except when being re-equipped. Eighteen or twenty-four aircraft would be a normal complement.

${ }^{19}$ Report and findings of the committee, 10 Jan. 1942, VIII (MA, ACS 22/23).

${ }^{20}$ Ibid, V-VI.
} 
not operating' or in lulls 'between periods of hostile air activity'. ${ }^{21}$ As an operational unit the Reconnaissance and Medium Bomber Squadron was assessed to have the deficiencies inherent in its aircraft. The Coastal Patrol Squadron was deemed to be similarly afflicted. It was cited as having two 'obsolete type Walrus aircraft', one Avro Anson and two Avro Cadet training aircraft. Due to the lack of spare floats the Walrus aircraft were not allowed to operate from water.

The committee summarised the operational capacity, and thus 'the effectiveness of the present Air Corps', in necessarily blunt terms:

It will be seen from the foregoing that not alone is the Air Corps equipment obsolete, with the exception of the Lysanders, but is also totally inadequate. A socalled Fighter Squadron is maintained, possessing 8 service machines of which only 3 are fighters of an obsolete type. The Reconnaissance and Medium Bombing and the Coastal Patrol Squadrons have only enough aircraft to equip one flight each. In view of these facts the most that can be hoped for from the Air Corps under favourable conditions is intermittent [reconnaissance] information in limited areas subsequent to invasion. ......Protection of the civil population and the Defence Forces is definitely not possible. ${ }^{22}$

The committee found that the extent and nature of the cooperation that the Air Corps, as then organized and equipped, could offer to the ground forces to be 'so negligible that it can be discounted'. They considered two possible recommendations with regard to the future of the Corps. While they considered the disbandment of the Air Corps with its personnel being formed into an infantry unit or transferred to other ground units they recommended that the best use of personnel and equipment could be affected by a reorganisation of the Corps. The main role of a reformed Air Corps would be 'assisting in the training of our ground forces in anti-aircraft measures and helping to overcome the psychological effects of aircraft bombing and machine-gunning attacks' ${ }^{23}$

\footnotetext{
${ }^{21}$ Ibid, V.

$2 ?$ Ibid, IX.

${ }^{23}$ Ibid, IX-X.
} 


\section{Organisation and equipment of the Air Corps and previous policies and organisation schemes}

The second question addressed was that of the suitability of the current organisation and equipment of the Air Corps for defence purposes and the changes to both that might be required under the prevailing conditions of financial stringency and uncertain supply. The committee prefaced its deliberations by stating that the 'organization, equipment and training of the Air Corps, as in the case of any branch of the service, must be based on a definite policy' in turn based on the general policy of the Defence Forces. Before taking evidence they proceeded to 'examine all relevant and available documents' in order to review the historical position in respect of previous policies and organisation schemes. In reviewing the material relating to policy available on file it found that a conference of 17 January 1929 had been made aware, by the then OC AC, of the inadequacies of the aircraft then in service and of the poor level of technical expertise available to maintain them. Quoting from the same file, DOD 2/49025, the committee noted that the minister, on 23 January 1929, had stated that 'he considered it more essential to have mechanical personnel trained and the pilots trained' before spending large amounts of money on aircraft and that 'in whatever crisis that would arise in which the Air Corps would be required in war, the machines could and would be found'. The committee noted that no decision was taken as to whether pilots were to be trained for reconnaissance or fighter missions or for both. 'In other words the defence role of the Air Corps was not adequately defined. ${ }^{24}$

The committee, quoting from DOD file 2/33693 noted that Major Mulcahy had, on 16 September 1937, requested clarification from the Chief of Staff regarding 'general aviation policy' and, pursuant to such a policy, the numbers of aircraft required for the following ten years. It was subsequently recorded in a minute of 18 October 1937, following discussions between the minister and the COS that 'the government cannot at the moment lay down the policy on which a decision could be reached'. On 28 September 1937 Mulcahy had recommended, 'as the minimum number of Squadrons required', the

${ }^{24}$ Ibid, $X$. 
establishment of '5 Fighter Squadrons' and '5 Reconnaissance Squadrons' to be dispersed to aerodromes in the vicinities of Dublin, Cork, Limerick, Sligo and Athlone. He further recommended that one squadron of each type should be maintained at full strength and the remainder at cadre strength strong enough to maintain all essential services and to carry out the required aircrew training. ${ }^{25}$

The committee considered that the Costello plan of 21 March 1938 that provided for the immediate raising of three squadron cadres and ultimately for a total of ten squadrons appeared to have been the first time that the Air Corps was given a definite objective towards which to aim. 'From the nature and nomenclature of the Squadrons, their general role in the defence scheme can be judged. ${ }^{26}$

They also noted that subsequently the government had come to no definite decision on the ultimate development of the Air Corps. ${ }^{27}$ On this point the evidence of Costello and Mulcahy clashed. While Costello insisted that his plan of 21 March 1938 had been abandoned Mulcahy stated that he had not been so informed. The committee apparently saw no point in resolving the matter. This may well have been because the problem was getting close to home. With the abandonment of the Costello plan the matter of air policy appears to have been devolved, unknowingly, to Mulcahy while McNeill, Costello and Flynn, all of whom had occupied positions in the operations function of GHQ, could be faulted for not taking action to make the position adequately clear.

The committee noted that later, under the general scheme of organisation for the Army, war establishment tables were drawn up for one each of three types of squadron and financial sanction sought. Having received the approval of the Taoiseach on 10 December 1938 and of the Government on 31 January 1939 these 1938 tables became the War Establishment that eventually came into effect on 13 June $1940 .^{28}$ The committee however noted that the approved establishment included no provision for the expansion, to ten squadrons, as favoured by both Costello and Mulcahy. The committee intimated that, as the Air Corps' general role in the scheme of defence could be deduced from the nomenclature of these squadrons, this in effect, constituted an adequate statement of the

\footnotetext{
${ }^{25}$ Ibid, XI, quoting OC AC to COS, ACF/564 dated 28 Sept. 1937. While this submission was quoted by Mulcahy a number of times he was unable to produce a copy for the committee.

${ }^{26}$ Report and findings of the committee, 10 Jan. 1942, XI-XII, quoting DOD file S/157 (MA, ACS 22/23).

${ }^{27}$ Report and findings of the committee, 10 Jan. 1942, XI-XII (MA, ACS 22/23).

${ }^{28}$ Ibid.
} 
Air Corps mission in wartime. They also considered that 'like the earlier proposals of March 1938, this organisation of December 1938, gives the [Air] Corps a definite, though more limited objective' but stated that the decision came too late (January 1939) in terms of acquiring the numbers of the aircraft that would be required under a war establishment.

In assessing the 'form of organisation suitable for defence needs' the committee considered that such a study should be carried out on the basis of 'what an Air Corps is required for', 'how it will be employed' and 'its size which must be governed by financial considerations'. It used the statement of missions as it had discussed earlier to suggest that 'close reconnaissance aircraft of the [army] cooperation type' were required to 'obtain information of enemy movement and disposition after he had gained a footing in our territory'. Two such squadrons would be required, one per army division 'decentralised to provide flights to work in close cooperation with Brigades' and for 'occasional special missions'. It was calculated that the capital expenditure for "new aircraft requirements and ancillary equipment for two squadrons' would amount to $£ 290,000$ with about $£ 91,000$ annual expenditure on personnel maintenance and spares’.

In relation to coastal patrol aircraft the committee considered that its primary function was to "provide information of and on the approach of hostile forces to our shores'. The committee summarised its discussion of alternatives in obscure language:

In the case of invasion from the continent, it is possible that the other belligerent would be in a position to acquaint us of the movement by sea of hostile forces. In the case of invasion by the other belligerent, the main blow would almost definitely come overland and the need for long distance sea reconnaissance would not arise in an acute form'. 29

The committee considered that long range maritime reconnaissance could only be executed efficiently by modern multi-engined aircraft as were in common use in Britain and cost over $£ 30,000$ each. They considered that 'close-in reconnaissance of territorial waters' 'sufficient to deal with an invader other than a continental one' could be done by

${ }^{29}$ Ibid, XIV. 
close reconnaissance aircraft - such as the Lysander. On the basis that long range reconnaissance could be regarded as a passing phase the existing Ansons could perform long range reconnaissance prior to the outbreak of hostilities. In effect having earlier highlighted the inadequacies of the Anson the committee, influenced by the cost of reequipping with, for example Lockheed Hudsons, recommended that no financial provision be made for different, modern, maritime patrol aircraft. ${ }^{30}$

While acknowledging that 'the maximum size of the force maintained must be determined by our financial resources considered in relation to our commitments for other elements of the Defence Forces' the committee proceeded to embark on a study of a fighter force of outlandish proportions. The study of the employment of fighter aircraft considered that, while it would be impossible 'to estimate accurately the strength of an adequate fighter force' in order to be reasonably safe 'a force of 30-40 squadrons would probably be required. It calculated that the capital cost of a force of forty squadrons would be $£ 6,400,000$ based on a 'fighter aircraft of the Hurricane type' while the recurring annual expense per squadron would amount to $£ 48,000$.

To this must be added the cost of the necessary ancillary services required to enable a fighter force to function efficiently, including observer system, radio detection system, direction finding system, central control, provision of aerodromes and accommodation. ${ }^{31}$

The latter facilities were, in essence, the essential facilities that were absent from the existing authorised war establishment, the absence of which, along with inappropriate and inadequate numbers of aircraft, rendered the squadrons ineffective. In attempting to cut their cloth to suit the state's measure the committee, recognising 'the necessity of affording some degree of protection for Dublin, Cork and Limerick' considered 'that a force of five fighter squadrons is the absolute minimum required' for which capital expenditure of $£ 800,000$ and recurring costs of $£ 240,000$ per annum, exclusive of ancillary services, would be required. While acknowledging that it was for the

\footnotetext{
${ }^{30}$ Ibid.

${ }^{31}$ Ibid, XV.
} 
government to decide whether the degree of protection which would be afforded by such a force would justify the level of expenditure the committee recommended. The committee found that the minimum number of operational squadrons required would be five fighter and two reconnaissance squadrons. ${ }^{32}$

\section{'Factors affecting organisation and equipment'}

The committee considered the time, personnel, and financial aspects of the implementation of the significantly expanded organisation proposed and made equally significant recommendations. The two reconnaissance squadrons at a capital cost of $£ 432,000$ were to be equipped with a total of forty-two Lysanders at a capital cost of $£ 432,000$ and be located at Rineanna and Collinstown. These squadrons would be manned by existing pilots. The flying school would need to be organised and re-equipped to train an additional seventy-three officer and NCO pilots for the fighter squadrons. It was recommended that seventy modern fighter aircraft (with another 35 in reserve) were required for the five fighter squadrons which would be dispersed to separate locations Collinstown, Cork, Rineanna, Curragh and Gormanston. They proposed capital expenditure of over $£ 1,185,000$ spread over four years at an annual cost of $£ 296,000$. In relation to fighter aircraft the committee suggested that 'nothing but the most modern aircraft should be considered and that the "complete equipment for one fighter squadron should be purchases every year ad infinitum'. ${ }^{33}$

The 'recurrent annual expenditure', for two reconnaissance and five fighters squadrons, as well as an 'administrative and training organisation' that would entail the recruitment of no less than 742 more personnel, was put at $£ 440,000$. ${ }^{34}$ While recommending the decentralisation of service squadrons - thus 'throwing them on their own resources' and making 'them more self reliant' - no provision was apparently made for the new aerodrome facilities that would be required. ${ }^{35}$ The decentralisation of five squadrons should have been seen to be totally impractical except in the context of a

\footnotetext{
32 Ibid, X-XVII.

${ }^{33}$ Ibid, XX.

${ }^{34}$ Ibid, XVIII; XXIII.

${ }^{35}$ Ibid, XVIII.
} 
substantial investment in infrastructure and camp staffs. As had been demonstrated in the case of the Rineanna detachment squadrons had no resources on which to rely if removed from an established aerodrome.

In the context of the investigative review being undertaken, and of the annual expenditure on the Air Corps ( $£ 176,644$ for 1940/41), the capital and recurring costs of the proposed reorganisation could only be described as alarming. ${ }^{36}$ Having regard to the Emergency circumstances of the time, with the threat of invasion not past and with a somewhat dysfunctional army air element in existence it is not clear why the committee contemplated such an ambitious expansion. The financial circumstances alone might have indicated to them that such a scheme was not feasible and would not even get past GHQ never mind DOD or Finance.

Notwithstanding the fact that the committee had calculated that a force of $30-$ 40 squadrons was, in ideal circumstances, what was required the recommendation of a significant expansion to seven squadrons might have been considered excessive in the light of their review of policy considerations. It should have been obvious, based on the known opinions of the minister and An Taoisach previously that the government saw no necessity for other than a token level of military aviation. The heterogeneous collection of aircraft purchased in the years prior to the outbreak of war was all the government was prepared to fund and was, in effect, appropriate to its neutrality stance and commensurate with the level of cooperation with the British in defence matters. Perhaps the committee felt it their duty to identify the extent of fighter defences required irrespective of the State's ability to fund such forces.

The most radical recommendation in respect of reorganisation was that '[Air] Corps Headquarters be abolished and replaced by a directorate of military aviation located at the Department of Defence'. The reason for this was explained:

It will bring the head of the Air Corps into closer touch with the General Staff; it will relieve him of many of the duties of administration and interior economy which seem to occupy so much time at the moment; it will give him greater freedom to concentrate on the inspection and training of the Corps; by removing

\footnotetext{
${ }^{36}$ Ibid, Annex G.
} 
him from so much close contact with junior officers in our principle air station and placing him on the same basis as any other Director, his prestige would be enhanced. ${ }^{37}$

One would have to see the above argument as being totally spurious, reflecting, as it does, the belief that a director, having the technical and professional deficiencies manifest in the current officer commanding and who lacked the fundamental qualifications to satisfactorily perform the functions of $\mathrm{OC}$ AC or director of military aviation could function better if his appointment functions were moved to the Department of Defence. The recommendation appears to have had the aim of facilitating the rehabilitation of Mulcahy by removing him from the presence of turbulent pilots.

\section{'Adaptation of existing organisation'}

Realising that their grand plan for an Air Corps, expanded to seven squadrons and some 1,440 personnel, would require Government approval and, if authorised, would take a considerable time to implement, the committee recommended that the existing organisation and equipment should be adapted to form the basis for the establishment of two reconnaissance squadrons. It was suggested that existing aircraft could be reorganised to form two 'provisional Squadrons' - No.1 Squadron, Rineanna (with Lysander, Anson and Walrus aircraft) and No. 2 Squadron, Collinstown (with Lysanders, Ansons and Gladiators). It was argued that while the grouping of the Lysanders and Gladiators at Collinstown and the Ansons and Walrus at Rineanna would have been more logical from organisational and maintenance points of view both squadrons should have some of the most useful aircraft, the Lysander. It was considered that the Rineanna squadron could not perform cooperation training with the $1^{\text {st }}$ Division without Lysanders. In effect, while the primary role of the two composite squadrons was to be army cooperation they could also do 'coastal missions'. It was suggested that if each squadron had a 'properly equipped' Anson training in navigation would be facilitated. This proposal was to be modified if and when thirteen Hurricanes, 'on order for a considerable

\footnotetext{
${ }^{37}$ Ibid, XXIV.
} 
time', were delivered, and if the Government was prepared to proceed with the programme for five fighter squadrons. ${ }^{38}$

\section{Question three - training of the Air Corps}

In the overall context of the committee's investigation into the state of the Air Corps in 1941 the module that addressed the questions relating to the 'training of the Air Corps' and possible changes in personnel, administration and training, was possibly the most crucial and most telling in terms of higher authority's attitude to the Air Corps in general and the body of flying officers in particular. This section sought to define the efficiency of individual officers as service pilots and sough to decide whether or not 'flying practice' was 'properly organised and carried out by flying personnel?' ${ }^{39}$ This emphasis suggests that the committee tended to place responsibility for the adjudged poor state of flying training and efficiency on squadron commanders who had to function in the absence of adequate guidance from the OC / DMA.

The committee experienced considerable difficulty in arriving at definite conclusions with regard to the abilities of individual pilots due to the conflicting nature of the evidence given and the fact that no standards were laid down in the Air Corps for service pilots'. This difficult arose because of the contradictory evidence of, on the one hand the commanding officer and squadron commanders who contended that the pilots were capable of carrying out any service mission using the aircraft available, and, of the more junior flight commanders and younger pilots on the other, who claimed that they had insufficient training in one aspect or another - a situation that undermined their confidence to execute service missions under difficult conditions. ${ }^{40}$

On the evidence of the pilots... of the school ....and service squadrons, the interrogation of individual officers, the absence of prescribed standards of training for service pilots and the nature and methods of training in the service squadrons provides ... the committee [with] cumulative proof that the pilots of the service

\footnotetext{
${ }^{38}$ Ibid, XXIII-XXIV.

${ }^{39}$ Ibid, XXV.

${ }^{40}$ Ibid, XXVI.
} 
squadrons have not attained as high a standard of training ... as should be possible with existing aircraft...... 41

The committee observed that no standards of proficiency, in flying or ground subjects were laid down by Air Corps Headquarters or the Department of Defence (i.e. the General Staff and the civil Secretariat) for either the flying school or the three service squadrons. They did not comment upon the fact that the General Staff and the staff of GHQ, similarly had not laid down such standards. It might have been considered appropriate that the 'first assistant to the chief staff officer', as designated in 1924, who was the 'technical officer responsible for inspecting the Air Corps', or his current equivalent, would have had some responsibility to ensure the setting of flying standards. ${ }^{42}$ The fact remained that no aviation expertise existed outside the Air Corps. It was, after all, at the insistence of GHQ that the syllabus of flying training for officers and cadets, that became DFR 7/1927, had been drafted by C.F Russell for the 1926/28 'wings' course. More recently the school commandant had up-dated that syllabus as his immediate superior, the DMA was ill-equipped for such a task.

It was noted that the last satisfactory training directive had been issued in $1936-$ presumably drafted by a flying officer on behalf of his newly appointed and uninitiated superior. It was also noted that those directives issued by Mulcahy in later years could not be regarded as having been an adequate guide as to exact nature and standard of flying expected of pilots in the operational squadrons. This failure to have a satisfactory training directive having the aim to pursue and improve the direction of training was not understood by the committee. Colonel Mulcahy's evidence to the committee on the matter was quoted without comment.

'There are no definite standards laid down, but unit commanders are sufficiently conversant with their duties and with what would be required of their officers to bring their units to a satisfactory standard'. ${ }^{43}$

\footnotetext{
4 Ibid.

4? 'Explanatory notes', O'Duffy Scheme, I July 1924 (NAI, DT, S.3442B).

${ }^{43}$ Report and findings of the committee, 10 Jan. 1942, XXX (MA, ACS 22/23).
} 
Being apparently satisfied with the hands-off policy adopted by Mulcahy with regard to standards and training the committee had proceeded to cross examine the three squadron commanders with particular reference to their respective unspecified responsibilities in the matter of flying training and proficiency. Notwithstanding the lack of direction from $\mathrm{ACHQ}, \mathrm{DOD}$ and GHQ there was no cause for the committee to question the effectiveness of $a b$ initio pilot training in Air Corps Schools:

It should be noted that not a single witness had any adverse criticism to offer of the school training, which training, in the opinion of the committee is generally satisfactory, except that advanced training is not catered for. In the school, the standards of training to be reached by the pupils in each subject are clear-cut and definite. $^{44}$

The committee did not comment on why this should be so. If it had done so it might have confirmed that the Schools' training syllabus was fundamentally based on the syllabus of training drafted in 1926/27 by Colonel Russell, probably brought up to date as a result of the RAF instructors courses attended by Lt. W.J. Keane in the early 1930s and further refined on the basis of the visit to RAF training establishments by Delamere and Curran in early 1939. The accumulated experience of the flying instructors, who were adjudged by the committee to be efficient and painstaking, would have contributed to this satisfactory situation.

The syllabus of flying training might be considered to be the single most important document relating to the aviation history of the period in question. It was the only substantive regulatory instrument relating to the flying of military aircraft, laid down the standards required of pupil pilots of the Air Corps and, in effect, underpinned standards generally. Notwithstanding, not only did the committee not connect the syllabus with the satisfactory state of Schools training, but they failed to include DFR 7/1927 of 18 March 1927 among the list of files and other records examined. ${ }^{45}$ Whether

\footnotetext{
${ }^{44}$ Ibid, XXVII.

${ }^{45}$ Appendix No. XLII to Report and findings of the committee, 10 Jan. 1942 (MA, ACS 22/23).
} 
this indicates that the committee failed to consult the regulation or merely chose to ignore its importance is not clear.

The committee did, however, interrogate the squadron commanders of the three service squadrons, at some considerable length, to examine the contention of many of the flight commanders and junior pilots that they had inadequate training in various aspects of their profession. From their examination of those concerned the committee found 'that the service training in the Fighter Squadron was of a haphazard type lacking in organisation, control and direction' with, for example a course for three young pilots started in February 1940 likely to take two years instead of six months while essential ground school subjects had not started by 20 November 1941. It also found that there was no organised training for older pilots. While OC Fighter Squadron contended that training in aerial combat and formation tactics, complained of by many squadron pilots, was carried out to the best of his ability the committee found 'that the individual training in aerial combat had not been as efficient as it should be' and that there was 'a definite lack of training in formation combat tactics'. The committee recognised, however that squadron formation could not be taught when there was only approximately a flight of fighter aircraft available. ${ }^{46}$ The criticism of this squadron commander can be understood on the basis that he was about forty years old in 1941. Air Corps folklore remembers this ex-IRA officer for his proficiency with handguns rather than his enthusiasm for flying.

In regard to training in R \& MB Squadron the committee found that during 1940 and up to the spring of 1941 it was carried out in an uncoordinated manner that prevented progress being measured but that the lack of organisation had since been remedied to the extent that pilots got more regular and useful flying. It could be argued that the adverse comment on training in the Rineanna detachment was ill-considered given the inadequate level of manpower, poorly equipped obsolescent aircraft, primitive airfield and inadequate support services - not to mention the total lack of preparation prior to the occupation of the 'aerodrome'. It was found that training in the Coastal Patrol Squadron (Baldonnell) that had, in effect, become the training element for the Reconnaissance Squadron detachment in Rineanna, was found to be conducted in a satisfactory manner.

\footnotetext{
${ }^{46}$ Report and findings of the committee, 10 Jan. 1942, XXVII - XXIX (MA, ACS 22/23).
} 
This included 'elementary aerial observation and elementary navigation instruction for other-rank aircrew members aimed at making them more efficient' ${ }^{47}$

The overall comment on training was to the effect that the 'majority of the officers of the Air Corps are not as efficient and capable of carrying out the duties of their appointments' as the available aircraft would permit. The finding detailed the many shortcomings perceived:

The most important subjects in which the officers are backward are - navigation, signals, night flying and service flying in general, including operating from improvised flying fields. ...... Flying training is not properly organised in service squadrons in as much as it is not designed to ensure the systematic progress of pilots towards acquiring and maintaining a definite standard of service proficiency. With the exception of the pupil pilots in the school and the young officers in the Coastal Patrol squadron, such flying training as is engaged in could be described as flying without an objective. ${ }^{48}$

The comments make no allowance for the fact that navigation training carried out in June / July 1939 was totally inadequate for the squadron detachment that was dispatched to Rineanna on a general reconnaissance role. Similarly the ground and airborne signals (or communications) equipment, as well as aircraft flying instrumentation were inappropriate to the task. Except for a mild rebuke in the matter of his failure to adequately direct training standards Colonel Mulcahy did not come in for adverse comment. On the basis of the accepted military principle that the commanding officer is responsible for all his formation does or fails to do Mulcahy might have been found to have overall responsibility for the unsatisfactory state of flying training. However the committee placed most of the blame on two squadron commanders whom Mulcahy had considered were 'sufficiently conversant with their duties and with what would be required of officers' in respect to standards of proficiency.

\footnotetext{
${ }^{47}$ Ibid, XXVII - XXIX.

${ }^{48}$ Ibid, XXXIV.
} 
However it did find that Colonel Mulcahy, in view of his 'limited technical training, could not be expected to be able to supervise and inspect' all aspects of Air Corps training 'without having to rely, to an undesirable extent, on his subordinates. ${ }^{49}$ There is adequate proof that Mulcahy did not welcome advice on such matters as navigation, meteorology, navigation and the communications although he functioned as director of military aviation in relation to all such matters. However the committee appears to have accepted that his limited technical training allowed him to devolve responsibility for training standards to the squadron commanders, in effect absolving him from the responsibility for those functions he purported to exercise since 3 June 1935.

The committee's main recommendation was to the effect that definite standards of flying proficiency should be laid down and that 'all standards should have the force of regulations'. The standards 'to be reached and maintained by service pilots' were to be appropriate to 'the peculiar conditions under which the Air Corps must operate'. The committee put major emphasis on the development of cooperation with ground forces including having 'a sound knowledge of the tactics, technique and organisation of such forces including practical experience in operating with these forces' - in effect recommending a return to the army cooperation role largely abandoned in the mid to late 1930 s. $^{50}$

Under a sub-heading of training the 'efficiency of Air Corps officers' was assessed on the basis of verbal evidence given. The committee put the pilots, with the exception of Colonel Mulcahy, into four categories reflecting their assessment of individual standards. The first group included a number of experienced pilots' who were considered to have failed to keep up to service standards due to lack of flying practice and instruction. It was considered that the majority of the pilots had completed a relatively good initial flying course but had not received progressive training since qualifying. The third group was made up of 'a small group of very keen and efficient officers' while the last were 'a few officers whose ability as Air Corps officers is in question'. 51

\footnotetext{
${ }^{49}$ Ibid, XXXIII.

${ }^{50}$ Ibid, XXXV.

sl Ibid, XXVI.
} 


\section{Flying qualifications of the Commanding Officer}

While not portrayed as such by the committee the questions as to whether the commanding officer should or should not be a flying officer, the flying qualifications of Colonel Mulcahy and the receipt by him of the flying pay appropriate to a duly qualified pilot, collectively represented possibly the most contentious issue to be examined by the committee. Paradoxically, of the seven substantive questions that it addressed the committee appears to have devoted least attention to what the pilots considered the most important consideration. The verbal accounts of the early Emergency, still frequently recalled during the author's service in the 1960 s, indicate that those pilots who qualified by successful completion of the standard flying course greatly resented the fact that Colonel Mulcahy was in receipt of flying pay at the rate appropriate to a fully qualified pilot and, more importantly, wore the flying badge or pilot's 'wings'. In fact many officers of that era believed that this matter was the main reason for the investigation. Mulcahy had completed an abbreviated course of flying instruction, reputed to have been only fifteen hours of flying, before putting up his wings. Subsequently, having had his certification of entitlement accepted and, being paid as a qualified pilot, he only flew as a passenger. It will be seen that the committee, in carrying out a somewhat superficial examination of the question as to whether the commanding officer should be a fully qualified pilot or not, chose to ignore the historical situation. To a large extent the committee actually avoided these matters claiming that "the term "flying officer" is somewhat lacking in precision in as much as it has no particular meaning in the Defence Forces':

It does not lend itself to an exact definition which will convey precisely a standard of proficiency or degree of knowledge. The committee decided that the term must have been intended to mean an officer who is fully qualified to take off and land service aircraft and to perform service missions under all conditions'. ${ }^{52}$

\footnotetext{
${ }^{52}$ Ibid, XLIII.
} 
In arriving at this loose definition of the term 'flying officer' the committee quoted no written authority. They again chose to ignore the original flying course syllabus, DFR $7 / 1927$ that prescribed in considerable detail the subject matter and standard that had to be met before the award of 'wings'. Similarly the committee chose to ignore DFR 40/1936 and, in particular the 'Young officers' syllabus of flying training' that devolved from the later DFR. Reference to the latter, more current, document would have provided a more than adequate definition of the standards of proficiency and degree of knowledge required by a qualifying pilot. Such a definition would, however, have identified Mulcahy as having qualified for flying pay without meeting the qualification standards laid down in the syllabus that devolved from the DFR. (See Chapter 5)

It is certain that the committee was well aware that Mulcahy was drawing flying pay at the higher rate of eight shilling per day as against the five shillings paid to those who qualified after him in accordance with the full syllabus. ${ }^{53}$ However the committee was prepared to accept, as DOD had previously, that Mulcahy had undergone flying training in accordance with the current regulation, DFR 40/1936, not realising, or not wanting to realise, that the DFR alone did not provide for the award of 'wings' and, by inference, did not provide for qualification for receipt of flying pay. (See Appendixes 6 and 7) The committee instead addressed the problems of the Commanding Officer.

It was brought home to the Committee at a comparatively early stage of the proceedings that the task of the present commanding officer of the Air Corps is a particularly difficult one for the following reasons:-

(a) Numerous problems of a highly technical nature are constantly coming up for solution.

(b) The long absence of a clearly defined policy for the Corps together with the lack of adequate up-to-date equipment and the difficulties of its procurement. ${ }^{54}$

The committee also cited as a difficulty the fact that the younger officers, who were highly critical of the commanding officer and his staff for the small amount of flying the

\footnotetext{
${ }^{53}$ T.J. Hanley to AC investigation, 17 Apr. 1941 (MA, ACS 22/23).

${ }^{54}$ Report and Findings of the committee, 10 Jan. 1942, XLIII (MA, ACS 22/23).
} 
said officers engaged in, also blamed them for the "present lack of equipment and weakness of the Corps in general' but did not understand that 'financial considerations and the attitude of foreign powers in respect of supplies are insuperable factors' and that administering the Air Corps curtailed the amount of flying Major Mulcahy and his headquarters staff headquarters staff could engage in. ${ }^{55}$

The report recorded that, in effect, the commanding officer should be a fully qualified pilot. Among the reasons cited were that he might 'have the necessary prestige in the corps' and 'set an example to the older as well as to the younger officers'. It was considered that such qualifications would ensure the $\mathrm{CO}$ had 'the necessary knowledge to fully appreciate the practical problems involved in flying, navigation and aerial operations' and to 'successfully guide training in Squadrons and Schools'. He would also be able to 'give satisfactory decisions on the many technical matters' that arise and appreciate modern developments. It was further observed:

The committee does not considerate it absolutely essential - though undoubtedly it is desirable - that the commanding officer should fully undergo the course, as a pupil pilot, prescribed for personnel qualifying as pilots in the school. He should however undergo such instruction as is necessary for him to get the qualifications required to fit him for his appointment.

In the event of the committee's recommendation regarding the appointment of director of military aviation and consequent abolition of the appointment of commanding officer, being accepted, the director should possess the qualifications outlined above as being essential to the commanding Officer. ${ }^{56}$

A majority of the committee subsequently recommended that Mulcahy be appointed DMA (in GHQ) but that he 'should be required, at an early date, to undergo the additional training to obtain the qualifications which the committee' considered absolutely essential for the officer holding the appointment of DMA. ${ }^{57}$

\footnotetext{
${ }^{55}$ Ibid, XLIV.

56 Ibid.

${ }^{57}$ Ibid, LXI.
} 
I suggest that the committee's position on the reappointment of Mulcahy as DMA is quite contradictory. At one level the committee had no apparent difficulty with Mulcahy's flying qualification and receipt of flying pay, in affect considering him to have been a duly qualified pilot. At another level the committee accepted that Mulcahy lacked the flying qualifications required, did not have the respect of his subordinates and generally lacked sufficient knowledge of flying to make aviation decisions or to direct and inspect flying training. His most glaring deficiency, as implied by the committee, was that he was unable to cope with the numerous problems of a highly technical nature that kept coming up. However these accumulated shortcomings were cited as mitigating circumstances that justified that he should undergo necessary additional training to qualify him to undertake the duties that the committee, in effect, considered he had been performing satisfactorily since 3 June 1935. The contradictions in the committee's position suggest that they wrestled unsuccessfully with their collective consciences in order to endorse the decision of DOD / GHQ to make the original appointment back in 1935 and the decision to grant him flying pay in questionable circumstances in 1936 . The committee, comprised mainly of GHQ staff officers, were not likely to be very critical of Mulcahy who had been on the same staff prior to 1935

\section{Flying Pay}

In considering the question 'is the present system of pay and additional pay satisfactory, and, if not, what changes are considered necessary and is additional pay for flying personnel at all desirable?' the committee mainly considered the case of the eight pilots who commenced flying training just prior to the publication of DFR 7/1937 dated 8 February 1938) that reducing the flying pay for newly qualifying pilots. In brief they recommended that the officers affected should get the higher rate of pay.

Another cause of concern to the younger pilots, who did the major part of service flying, was that the more senior officers, by virtue of their appointments, did little or no training or service flying but received the flying pay at the higher rate. Similarly some pilots and observers, who were in effect ATC officers with the Department of Industry and Commerce, did little or no military flying and yet continued to receive eight shillings 
per day. In this matter the committee recommended 'that flying pay should not be paid unless flying is being properly engaged in' and 'be payable only on certification'. As in other aspects of their investigations the committee did not allow the matter of Mulcahy's receipt of flying pay at the higher rate complicate matters. ${ }^{58}$

\section{Turn over of pilots}

In considering question six the committee discussed, in affect, how a reserve of pilots might be built up in such a manner as to have sufficient pilots available for an emergency. While it was not so stated the position that had existed immediately prior to the Emergency was one of stagnation with active flying appointments filled by relatively old pilots while the number of younger pilots was totally inadequate for the 1939 peace establishment and for the war establishment that was eventually activated in June 1940. The committee examined the problem in a vacuum - not related to the record of pilot recruitment and training, the total number of pilots then in service or to the actual deficiency in pilot strength evident during the early Emergency. In particular the committee ignored the fact that only eight pilots were recruited and trained under Mulcahy's stewardship in the years immediately prior to the war. It was considered that newly qualified pilots, after a number of years of service flying with a squadron, would revert to another corps and complete a short period of refresher flying training with the Air Corps on an annual basis. This idea was discarded on the basis that an officer could not be advanced professionally in two army corps at once. Also, once properly trained a pilot would have to function as such in any emergency thus depriving the other corps of an officer at a time of need. On a practical point, it was recognised, that a trained and motivated pilot would not easily settle down in any other corps.

The committee next considered the existing short service scheme as a basis for a turn over. It was felt that the fact that promising young officers could be retained in the Air Corps was a considerable advantage and that a reserve could be built up without affecting any other units. However the scheme was seen to have a major disadvantage

\footnotetext{
${ }^{58}$ Ibid, LXV-XLIX. P.A. Mulcahy was subsequently appointed COS of the Defence Forces for the period Jan. 1955 to Dec. 1959.
} 
that if, on passing on to the reserve, officers could not get employment in the state there would be a temptation to seek employment abroad and thus devaluing the reserve. In terms of the strength and composition of the reserve it was considered that the number would depend on the number of squadrons to be organised' and on the basis of having three pilots per aircraft - one pilot in permanent service and two on the reserve. In effect the committee endorsed the scheme in current use.

\section{Non-commissioned flying officers'}

The committee considered the question of training non-commissioned personnel as pilots in the context of the formation of an active reserve of pilots. Without taking evidence on the matter and without much reflection the committee made what they saw as pertinent recommendations on the subject of NCO pilots on the basis that it was the practice in other countries. They were very specific as to the main conditions to be met:

The Committee is satisfied that there is a case for non-commissioned officer pilots in one circumstance only, and that is if it is proposed to build up five fighter squadrons. In that it is recommended that non-commissioned officer pilots be recruited in the proportion of two to each flight of three aircraft. ${ }^{59}$

In this manner it was foreseen that NCO pilots could replace short service officers on the basis that twenty-four NCO pilots would require to be trained for each fighters squadron of whom sixteen would be maintained on the reserve. It was considered that NCO pilots were not required for reconnaissance squadrons because such pilots required a particularly high standard of training and a good knowledge of the tactics and techniques of ground forces and had to exercise command over non-commissioned aircrew members. ${ }^{60}$

\footnotetext{
${ }^{59}$ Report and findings of the committee, 10 Jan. 1942, LII (MA, ACS 22/23).

${ }^{60}$ Ibid.
} 


\section{General aspects of Air Corps organization, administration, discipline, equipment and personnel}

Under this heading the committee noted that various matters outside the terms of reference had been introduced in evidence and commented, generally very briefly, on some. Several complaints regarding aspects of the responsibilities of the Air Corps Company, Signal Corps had been raised in evidence. In commenting on these matters the committee demonstrated that it had understood little of the evidence relating, in particular, to aircraft wireless telegraphy and radio telephony sets and their uses. Similarly their grasp of the communications requirements of operational squadrons in general was not the best. In particular they did not understand of the necessity for radio telephony sets for fighter aircraft

In future.....if possible fighter sets should be capable of operating on the medium wave-band as in the case of the T.R. 1082/83 [wireless telegraphy set], thus obviating in normal operation the need for a multiplicity of ground stations. ${ }^{61}$

It had been adequately demonstrated in evidence, and by the demonstration of Thomas Murphy's transmitter in conjunction with Lieut. A.C. Woods' receiver, that fighter aircraft required a short wave radio telephony set, operated by the pilot, for effective twoway voice communication demanded by the role. However the committee recommended, quite ill-advisedly, that fighter aircraft should operate with wireless telegraphy sets compatible with those of reconnaissance aircraft so as to reduce the number of ground stations.

The committee's pronouncement on loop aerials was similarly lacking in perception. Acknowledging that loop aerials were only required on longer range aircraft they stated that 'except for the existing Ansons the problem does not call for any serious consideration'. No mention was made of the fact that loop aerials could and should have been fitted to Ansons from November 1938 and that such action would have been a boon to safe navigation and to the effectiveness of the reconnaissance mission. To have drawn

\footnotetext{
${ }^{61}$ Ibid, LIII.
} 
attention to this point might have implied criticism of Mulcahy and his command but this was something the committee tended to avoid.

While the committee acknowledged that 'the system by which ground direction finding facilities were [not] made available until recently' (late 1941) had been the subject of adverse comment they found no fault with the manner in which the matter of direction finding stations in general had been handled. They made no comment on the fact that it had taken so long for the Air Corps to be granted control and unrestricted use of the DF station at Baldonnell or to the fact that Air Corps HQ staff had contributed to the delay by putting civil aviation requirements ahead of the needs of military pilots who needed more and better aids to navigation. The greatest irony was in the fact that as the report was being drafted 'two short-wave direction finding sets' were 'lying in the stores of the Signal Corps' while no military DF stations had been installed. ${ }^{62}$ No mention was made of the fact that Air Corps-trained wireless operators, intended for flying duties, had to be used to carry out ground communications functions appropriate to the Signal Corps.

In effect the committee commented favourably on, in particular, the communications available at Baldonnell after the acquisition of Thomas Murphy's short wave transmitter. While this was a considerable improvement that on the abysmal situation pertaining on 3 September 1939 it only affected three aircraft and improved the general situation very little. Maybe for obvious reasons neither the committee nor the Signal Corps witnesses alluded to the excellent communications and direction finding services provided for a modest level of civil aviation. Similarly the committee demonstrated no appreciation of what the Air Corps expected of the Signal Officer in the matter of aviation communications. From January 1929 the duties of the Signal Officer had been laid down:

He will be responsible for all types of signal communication in the [Air] Corps .........He will be responsible for keeping in touch with all new designs and improvements in the different types of wireless apparatus used in aircraft from time to time. ${ }^{63}$

\footnotetext{
${ }^{62}$ Ibid, LIV.

${ }^{63}$ 'Signal Officer', Section 23, 1 Jan. 1929, Air Corps Standing Orders, 1929/35 (in my possession).
} 
In the above regard the evidence, mainly of Signal Corps personnel themselves, adequately demonstrated that the Signal Corps had not kept abreast of developments and had served the Air Corps very poorly at a critical time. As in the case of Mulcahy the committee appears to have been reluctant to criticise the Signal Corps. (See Chapter 9)

\section{Personnel Matters}

In its subsequent appraisal of individual officers the committee was generally complimentary. It commented favourably on the service of many of the more senior officers - P.A. Mulcahy, W.P. Delamere, P. Quinn, D.V. Horgan, T.J. Hanley, W.J. Keane, F. O'Cathain and K.T. Curran. However, in the context of promoting the retention of P.A. Mulcahy as DMA, the majority of committee expressed a major reservation about likely successors:

Whilst there is within the Corps a number of promising officers, none of them, in the opinion of three members of the committee concerned is fitted at this stage to effectively direct the Corps in its present condition. ${ }^{64}$

A further five officers were considered to have performed to a lesser level of satisfaction and, in effect, having stagnated in their current appointment, were recommended for transfer within the Air Corps in the interest of efficiency. A further four officers were recommend for transfer out of the Air Corps. Two of these were so recommended on the basis that they were ATC Officers seconded to the Department of Industry and Commerce. A single officer was identified as being unsuited in several respects for the duties of an Air Corps flying officer. His transfer to another corps, or dismissal from the service, was recommended. The last officer, Lieut. A.C. Woods, who had been active in his opposition to Mulcahy as DMA, was effectively identified as a disruptive influence and recommended for transfer out of the Corps. It was considered, without detailing the circumstances, that his action of procuring possession of official documents in an

\footnotetext{
${ }^{64}$ Report and findings of the committee, 10 Jan. 1942, LXI (MA, ACS 22/23).
} 
irregular manner, irrespective of his motivation, was reprehensible. In addition to those senior personnel favourably mentioned the committee also identified six very keen and efficient junior officers and recommended that they be considered for promotion when opportunities arose. ${ }^{65}$

The appraisal of Col. P.A. Mulcahy by the majority of the committee set out to ensure his reappointment as DMA. However the assessment (Appendix No.9) does not amount to a fulsome endorsement of his performance and record as officer commanding. To a certain extent it highlighted the shortcomings and failings that had been identified earlier and, only in a minor way, was he the subject of adverse comment:

Whilst Colonel Mulcahy bears responsibility for the low standard of training in the Air Corps, the mitigating circumstances mentioned ........ must be taken into consideration. ${ }^{66}$

The mitigating circumstances referred to, including the problems of the commanding officer already referred to, in effect, made Mulcahy unsuitable for the functions of his appointment. The impact of this recommendation was further reduced by the proviso that Mulcahy undergo training to fit him for the job he purported to have been doing since June 1935. While the majority recommendation of the committee was fundamentally in favour of maintaining the status quo in terms of the command and direction of the Air Corps the minority opinion of the chairman was to totally undermine their position:

I am satisfied that no one other than a fully qualified flying Officer possessing considerable practical experience should be placed in charge of the Air Corps. The fact that in the past several such non-qualified officers have been from time to time placed in charge of the Corps is, in my opinion, one of the causes of the condition of affairs this committee was set up to investigate. ${ }^{67}$

\footnotetext{
${ }^{65}$ Ibid, LXIII - LXVI

${ }^{66}$ Ibid, LXI.

${ }^{67}$ Ibid, LXX.
} 
McNeill went on to state that Mulcahy was not qualified for the appointment and did not enjoy the confidence of the officers under his command. 'With the best will in the world I do not see how this state of affairs can be completely set right.' He recommended that Mulcahy be relieved of his appointment (not command) and that 'Major G. J. Carroll be recalled to active duty as director of military aviation' ${ }^{68}$ In affect he was stating that Mulcahy was part of the problem and could not be part of the solution. This was a very radical position for McNeill to take. As a very senior GHQ staff officer from 1922, and latterly as Assistant Chief of Staff, he had been central to the decision making process that had appointed Mulcahy in 1935 and that had, in effect, given him free rein that had resulted in the demoralisation of the Air Corps. More recently, as ACS, operations, he had issued the various operations orders that had specifically tasked Fighter Squadron to the defence of Dublin. He probably realised more than anyone the extent to which GHQ was culpable for the mismanagement of the aviation functions of the Army.

\section{Implementation of the report - the 1943 reorganisation}

With the report being submitted to the COS on or about 10 January 1942 no action was obvious until the following December. GHQ summarised the condition of the Air Corps as the report was awaited.

It should be noted ... that the unavoidably protracted sittings of the board were bound to have an adverse affect as pending the issue of that report all promotions were held up and a general spirit of uncertainty prevailed in the Corps. ${ }^{69}$

However there is every reason to believe that the committee's two stated options, to reorganise the Air Corps or alternatively 'to disband the Corps and form the personnel into a ground combat unit or transfer them to other units of the forces' - were both being examined. Ironically the Air Corps of the period was better equipped to function as an infantry formation than in an air defence role. This situation derives from the fact that

\footnotetext{
68 Ibid.

69 'General reports on the Defence forces, I Apr. 1941 to 31 Mar. 1942' (MA).
} 
while the 1940 war establishment did not specify the number or types of weapons to be carried by any aircraft, reconnaissance or fighter, the number of revolvers, rifles and machine guns appropriate to each unit or squadron was so specified. While only 236 rifles, 157 revolvers and thirty-two light machine guns were to be specified in the 1940 war establishment already, in March 1939, the Air Corps units had a total of 485 rifles, forty-seven revolvers and thirteen machine guns. As late as April 1944 the units held a total of 565 rifles. $^{70}$

In May 1941 the flying squadrons held a total of fifty aerial machine guns. However, as early as December 1941 it was directed that some thirty-four machine guns, some recovered from allied aircraft, be sent to the Ordnance Depot to be converted to ground use. ${ }^{71}$ The situation being such, with the Air Corps better equipped in infantry weapons juxtaposed with impotent and ineffective operational squadrons it is not surprising that the disbandment of air units was contemplated. Air Corps folklore reflect the abiding fear of the young pilots that the aircraft might be placed on the aerodrome as deterrent to uninvited landings while all personnel would be armed and tasked in an infantry defensive role. Confirmation of the possibility of disbandment comes from an unusual quarter:

The Air Ministry should, however, be allowed to provide sufficient equipment to Eire at their own discretion in exchange for certain useful concessions which they are able to obtain through the Eire Army Air Corps, whose disbandment would not be in our interest. ${ }^{72}$

It is probable that this reading of the situation reached the UK Chiefs of Staff through intelligence gleaned from Mulcahy by Lywood.

The major decision resulting from the investigation was to reorganise the Air Corps. Prior to the reorganisation a new commanding officer was appointed. Despite the opinion of the investigation committee, that none of the current air officers were ready for

\footnotetext{
70 'Rifles inspected by Coindt. M. Kelly’, 24 Apr. 1941 (MA, AC/2/9/19).

${ }^{71}$ War establishment, 1940 (MA); 'Ordnance, Air Corps', 4 Mar. 1939; 'Location of aerial and land machine guns', 20 May 1941 (MA, AC/2/9/19).

${ }^{72}$ Chiefs of Staff Committee minutes 27 July 1942, War Cabinet report, 6 August 1942 (NA, Air 20/2442).
} 
the top leadership role, W. P. Delamere was promoted to acting major and appointed Acting OC Air Corps on 11 December 1942. With the new establishment of 29 March 1943 he was made substantive in the position. The appointment is considered significant in that Delamere was the last ex-RAF pilot in permanent service. The previous periods of command of ex-RAF officers had been marked by their brevity and the abruptness of departure. In appointing Delamere DOD had ignored the credentials of the remaining four ex-IRA officers who had been advantageously placed in 1928. The senior of this group, Comdt. P. Quinn, might have considered as suitable as Delamere though he lacked the latter's broad experience. In due course Quinn got his turn when Delamere was headhunted by the Department of Industry and Commerce and took the position of manager of Dublin Airport with effect from 2 October $1946 .^{73}$

Notwithstanding the committee's recommendation that two reconnaissance and five fighter squadrons be established in the medium term the new establishment represented a considerable reduction in personnel and squadrons. It appears to have been precisely tailored to absorb all those officers serving at the time. It provided for Air Corps Headquarters, Depot, Maintenance Unit, Schools, Central Control (Air \& Marine Intelligence) and a Fighter Squadron which was detached to Rineanna. The notional establishment comprised forty eight officers, 176 NCOs and 438 privates - a total of 662 all ranks. The Reconnaissance and Medium Bomber and Coastal Patrol Squadrons were disbanded and the aircraft redistributed. Some forty-eight aircraft of eight different types went on charge to the Schools. ${ }^{74}$

Despite the fact that five fighter squadrons were not going to be established the short service NCO pilot course commenced in December 1943. Starting with thirty-two pupils, (about a quarter of the total number since 1922), this course was to be the main preoccupation for the Air Corps for the remainder of the Emergency. ${ }^{75}$

\footnotetext{
${ }^{3}$ Curriculum vitae, O/644; O/2826, courtesy of Officers' Records Section, DFHQ; Record of pilot intake to Air Corps (AC Museum).

${ }^{7+}$ Tables 29W to $33 \mathrm{~W}$, Air Corps establishment, 1 Apr. 1943 (MA); 'Operational Instruction No. 1/1943Re-organization - Air Corps', OC AC, 3 Apr. 1943 (in my possession).

${ }^{75}$ Sergeant pilot course file (courtesy of School Commandant).
} 


\section{The 1942 Army exercises.}

The future direction of the Corps had already been set by the nature of its participation in the Army exercises of September 1942. Aircraft operating from Rineanna and Rathduff supported, respectively, the $1^{\text {st }}$ and $2^{\text {nd }}$ Divisions. With no fighter support on either side the style of air reconnaissance conducted was that appropriate to the early stages of the Great War. The main air task was the observation and reporting of the movements of the opposing forces. Operation below 1,500 feet was prohibited except for message dropping and for the final brief river defence exercise.

A major aim of the ground troops was to avoid observation by proper use of camouflage. All manner of aircraft, whether suited to the task or not, were committed to the exercises. Included were several low-winged monoplanes types. The Avro Ansons, which had been noted by the investigation committee as being totally unsuited, were used. Also included was the Miles Magister, which, without a wireless was even less suited and had to resort to the dropping of handwritten messages. While this anachronistic use of aircraft appears to have done little for the advancement of the Air Corps at least one general was very satisfied. ${ }^{76}$

I am more than pleased with the work of the [blue] air component..... They supplied a stream of information which was in the main much more accurate than that supplied by the ground forces. Their reports gave an excellent picture of most of the various crossings and attempted crossings of the Blackwater. They gave phase by phase reports of the movement of $4^{\text {th }}$ Brigade at the last stage of the first exercise and the movement of the $2^{\text {nd }}$ Brigade at the last stage of the second exercise. ${ }^{77}$

This glowing testament to unopposed air observation might appear to endorse the outmoded use of aircraft and the artificial air situation of the exercise. However General M.J. Costello was in fact acknowledging the direction of his air component by Coindt. W.J Keane and the exceptional skill and judgement in the evaluation of all

\footnotetext{
${ }^{76}$ Lieut. L. O'R[iain], 'A pilot looks down; an Air Corps officers impressions of the 1942 exercises' in $A n$ Cosantoir III, No. 3 (Mar. 1943), pp 163-68, passim.

${ }^{77}$ GOC $1^{\text {st }}$. Div. to COS 19 Sept. 1942, Army exercises 1942 file (MA, no reference).
} 
reconnaissance reports. It is highly unlikely that aircraft were used in the 1942 exercises to lend realism to an exercise in modern warfare. It is much more probable that the exercises were intended to bring the Air Corps back to its army cooperation roots and to remind the pilots that they were still part of the Army. Another exercise that might have had a similar aim took place in May 1944. Colonel Liam Archer led a team of no less than thirty-five officers in an inspection, by GHQ, of the basic infantry skills of the Air Corps. The other ranks personnel were divided into five companies of approximately eighty each and were tested in accuracy of aim and rapid fire. Other aspects of infantry training examined included syllabi, programmes and training diaries, coaching, range duties and zeroing of weapons. ${ }^{78}$

\section{Fighter Squadron and Hawker Hurricanes}

In what was probably a welcome break from the constant stand-by at Baldonnell thee three Gladiators were based at Ballinter House near Navan, County Meath during the summer of 1941. They were in support of the $2^{\text {nd }}$ Brigade's operation monitoring the suspicious movement of British troops along the border. A pilot observed that 'the unit flew an incredible number of patrol hours in daylight' during a two-month period. ${ }^{79}$ However, as late December 1941 it was the practice to maintain a flight of aircraft on "Stand-to" at Baldonnell for the purpose of intercepting belligerent aircraft infringing the country's neutrality. In January 1942 a single aircraft was still being detailed for the duty on a daily basis. In view of the futility of the operation the committee recommended that the practice be discontinued. ${ }^{80}$

From October 1940, and possibly earlier, the Air Corps had been trying to obtain more advanced fighter aircraft. Mulcahy used the occasion of Air Commodore Carr's visit to Baldonnell to indicate his 'urgent requirement' for 'one squadron of fighters, preferably Hurricanes, and ten advanced trainers' ${ }^{81}$ The RAF indicated that it was well disposed:

\footnotetext{
78 'Training Inspection', 1 May 1944 (MA, AC/2/9/19).

${ }^{79}$ Aidan Quigley, 'Air aspects of the emergency' in Irish Sword, xix, Nos. 75 \& 76 (1993-4) p. 88.

${ }^{80}$ Report and findings of the committee, 10 Jan. 1942, LVIII (MA, ACS 22/23).

${ }^{81}$ AOC RAF NI to AM, 14 Oct. 1940 (NA, Air 2/5130).
} 
.....In these circumstances it would surely be a mistake not to follow up the discussions which took place between Colonel Mulcahy and Air Commodore Carr? Probably we could get the Eire air force to build aerodromes where we want them at the price of some obsolete aircraft [for training], perhaps with the addition of a promise that we will give them Hurricane Is some time next month when we shall be replacing them with Hurricane IIs. The political effect of such an agreement would be wholesome. ${ }^{82}$

As a result of Mulcahy's RAF contacts ten ex-RAF Hawker Hectors were delivered in May 1941 and a further three in January 1942. However Hurricanes were not immediately forthcoming. The Air Corps had already acquired one force-landed Hurricane I on 29 September 1940 and two Hurricane Mk IIs in similar circumstances in June and August $1941 .^{83}$

With the selective implementation of the recommendations of the report and finding of the committee Fighter Squadron was relocated to Rineanna in April 1943. It comprised a HQ and three flights. Initially it had twelve aircraft - three each of Hawker Hurricane, Miles Master, Gladiator and Lysander. ${ }^{84}$ The squadron, though designated a fighter squadron initially at least, took the form of one of the two provisional reconnaissance squadrons as recommended by the committee. ${ }^{85}$ Eighteen pilots were provided for - eight officers and ten sergeant pilots. The latter had yet to be trained. On 15 April 1943 the personnel left Baldonnell at 07.00 hours, marched to Lucan South station and took a train to Limerick. From there they marched to Rineanna. ${ }^{86}$

At Rineanna the squadron was attached to the $8^{\text {th }}$ Brigade, Southern Command notionally as part of the defence of Rineanna / Shannon Airport. ${ }^{87}$ Gradually the squadron

\footnotetext{
82 RAF memo to CAS, 16 Oct. 1940 (NA, Air 2/5130).

${ }^{83}$ Kearns, 'Irish Air Corps', p. 459.

${ }^{84}$ 'Operational Instruction No. 1/1943, Re-organization - Air Corps', OC AC, 3 Apr. 1943 (in my possession)

${ }^{85}$ Report and findings of the committee, 10 Jan. 1942, XXIII (MA, ACS 22/23).

${ }^{86}$ Table 31W, 1943 establishment (MA); No. 1 Squadron Movement Order 1/1943, 11 Aprił 1943; 'Air Corps-appointments officers', 18 Mar. 1943; 'Reorganisation Air Corps', 3 Apr. 1943 (in my possession, Operational Instruction No. 1/1943; 'Aircraft', 3 Jan. 1945 (MA, EDP/24).

${ }^{87}$ Aidan A. Quigley, Green is my sly (Dublin, 1983), p.152.
} 
began to assume the form of a fighter squadron. In July four Hurricane Is were received in exchange for the two Mk. IIs which were returned to the RAF. The Gladiators were returned to Baldonnell, with two being scrapped in late 1943 and the third the following year. By November 1943 the three Lysanders, Nos. 61, 63 and 66 had been returned to Baldonnell. With the receipt of three Hurricane Is in November 1943 and a further four by March 1944, followed by the return of the three Masters to Baldonnell, Fighter Squadron became a single aircraft-type squadron for the first time. ${ }^{88}$

Notwithstanding its notional role in defence of Shannon the maintenance and operation of aircraft was not a priority with $8^{\text {th }}$ Brigade. As early as July 1943 it was reported that the number of aircraft unserviceable on a monthly basis was increasing rapidly - $25 \%$ in May, $42 \%$ in June and $58 \%$ in July - with a prediction that it would be up to $80 \%$ in August. This was put down to the fact that only twenty-two of the seventyseven technical personnel were available to work on aircraft on any given day. This in turn was put down to the number of personnel, by direction of OC $8^{\text {th }}$ Brigade, who were on involved in fatigues, guard duties, infantry training, kit inspections and cutting turf in the bog. ${ }^{89}$ A pilot recalled his feelings at the time:

I was only down there 4 days and I was sent off to the bog and I was the adjutant. I was out in the bog cutting turf!......and a lot of the aeroplanes were up on stilts in the hangars because the fitters.....were on guard duty, out cutting turf and on fatigues.....it was appalling...... appalling. ${ }^{90}$

The situation did not improve with the delivery of the ex-RAF Hurricanes in November 1943. Soon after arriving in Rineanna it was found that aircraft had components that were excessively worn. One machine was in such poor condition its continued service was in doubt. A major factor contributing to poor aircraft serviceability at Rineanna at this time was the fact that the Hurricanes, like practically all aircraft acquired during the

\footnotetext{
${ }^{88}$ Kearns, 'Irish Air Corps', p. 459; Lt. Col. J. Teague, 'Irish Air Corps aircraft registrations, 1921-1974', in my possession; A.P. Kearns, 'The Air Corps 1939-1945' in An Cosantoir 49, No. 9 (Sept. 1989) p.19 ${ }^{89}$ M.J. Noone, Air Corps operations 1939-1945 (MA thesis, NUI Maynooth, 2000), p. 31-42, citing W.J. Keane to OC AC, 24 July 1943 ( MA, ACF/750/17).

${ }_{90}$ M.J. Noone, Air Corps operations 1939-1945 (MA thesis, NUI Maynooth, 2000), p. 42, citing an interview with Capt. A.A. Quigley, 6 Dec. 1999.
} 
Emergency came direct from active service with RAF squadrons and were probably not in prime condition. In fact they were probably selected at squadron level because of their poor condition. Unlike aircraft supplied by manufactures they were delivered without technical familiarisation, airframe and engine manuals and appropriate hangar equipment essential to normal maintenance. The biggest difficulty was that spares were not available for aircraft like the Hurricane that was still in active RAF service while spares peculiar to older obsolete aircraft were probably not being manufactured. ${ }^{91}$ Tony Kearns summarised the situation:

During 1943/44 very little flying was done due to a chronic lack of spares, especially tyres. Day after day a Hurricane would be taken out of the hangar; its engine run up for five minutes and then silenced as it was pushed back into its stable. $^{92}$

As an indicator of serviceability the returns of flying hours show that the Hurricanes flew an average of thirty-three hours each in 1943 and less than fifty in 1944. None of the Hurricanes acquired in 1943/44 did more than 170 hours flying in four years of Air Corps service. With about ten pilots in the squadron they would have averaged less than fifty flying hours each in $1944 .{ }^{93}$ The Chief of Staff's report for the year ending 31 March 1945 gives the misleading impression that Fighter Squadron had been carrying out a worthwhile defensive role at Rineanna for the previous two years.

The general improvement in training discipline and morale [in the Air Corps]... .....has been well maintained. Towards the end of the period it was decided to move the Fighter Squadron to Gormanstown. This decision was made possible by the lessening danger of any sudden invasion. ${ }^{94}$

\footnotetext{
${ }^{91}$ R.W. O'Sullivan to OC AC, 12 Apr. 1944 (MA, AC/2/9/19).

${ }^{92}$ A.P. Kearns, 'The Air Corps 1939-1945' in An Cosantoir 49, no. 9 (Sept. 1989), p. 19.

${ }^{93}$ Lt. Col. J. Teague, 'Aircraft flying time 1943/8' (in my possession).

94 'General reports on the Defence Forces, 1 Apr. 1944 to 31 Mar. 1945' (MA).
} 
The main reason actually was that the authorities at Shannon (and the Department of Industry and Commerce), who had wanted rid of the Air Corps from very early in the Emergency, saw the squadron as a hindrance to civil aviation. Relief, for Shamon and the squadron, eventually came when the unit, with its ninety-five personnel and nine Hurricanes moved to Gormanston on 1 May $1945 .{ }^{95}$

\section{Conclusions}

The general belief, handed down by successive generations of flying officers, is that the matter of Mulcahy being in receipt of flying pay and wearing pilot's wings, was the main cause of the investigation. However the evidence, both written and verbal, as presented to the committee confirms that various complaints regarding the technical and professional failings of Mulcahy were primarily the factors that brought it about. While the precise nature of the written complaints made to the minister is not known they must have been very serious and well stated.

To a certain extent, when investigating the various matters, the committee was somewhat selective. While they had little difficulty in deciding that the Air Corps, as then organised, was ineffective and inefficient they accepted Mulcahy's plea that the UK in affect dictated the type of aircraft and the supply, or not, of spares. However they did not comment on Mulcahy's judgement in the matter of committing obsolete and poorly equipped aircraft to roles in the defence of the country.

In the matter of training standards the committee found Mulcahy at some fault but allowed his lack of expertise in such matters to be mitigating circumstances excusing his failure to adequately direct flying training and training standards. While the role of GHQ, whose function it was to direct all training standards for the whole Army, was ignored, the committee found it appropriate that the squadron commanders should share the major part of the blame.

The manner in which the committee found fault with the squadron commanders' training of their units and with the effectiveness of the pilot body generally contrasts with

\footnotetext{
${ }^{95}$ Lt. Col. M. O’Malley, Gormanston Camp 1917 - 1986 (Defence Forces, 1986), pp 17-19; 'Fighter Squadron movement order No. 1/45', 17 Apr. 1945 (in my possession).
} 
the minor rebuke of Mulcahy in respect of his direction of training - particularly when the proceedings and report more than adequately demonstrated the latter's incompetence in all technical and professional areas related to military aviation.

The committee, in trying to come to terms with the impotent state of the squadrons, researched much of the background to those policy decisions that resulted in an unprepared Air Corps being tasked to what soon became impossible tasks. The committee did not even consider, let alone adjudicate on, the decision to send a detachment to Rineanna on a wartime mission. They found the air defensive mission of Fighter Squadron to be so futile as to be an unacceptable risk to the lives of pilots. Yet they made no comment on the series of orders, including those of Mulcahy, which put lives unnecessarily at risk.

The main complaints from flying officers were in respect of the failure to keep aircraft modified with the latest equipment while also failing to ensure the availability of serviceable communications and direction finding and best practice in aircraft navigation. Notwithstanding the inadequacies elucidated before and during the investigation the committee, mainly from a position of not understanding such technicalities, failed to address these matters properly and were unable, or unwilling, to identify the failings of both Mulcahy and the Signal Corps in their respective areas.

In view of the fact that the Air Corps, as then organised and equipped, had been found wanting the medium term solution recommending two reconnaissance and five fighter squadrons is difficult to understand. The committee recognising that whatever establishment was put in place its size, role and equipment would be dictated by financial constraints without reference to perceived defensive needs. It is not to be wondered at therefore that DOD subsequently reduced the squadrons from three to one. It is surprising that GHQ purported to have Fighter Squadron, based at Rineanna, functioning in a worthwhile defensive role against invasion as late as 1944/45.

While the fact should have been obvious to DOD and Government long since, the inability of the Air Corps to perform any worthwhile defensive role was proved without doubt with the promulgation of the report of January 1942. Subsequently, apart from aircraft recovery and other cooperative contacts with the RAF, as well as support of civil aviation, the Air Corps had no other function - in the defence of the country or otherwise. 
As Fighter Squadron had only a notional role in the defence of Rineanna / Shannon the training of the large class of sergeant pilots in 1943/45 was to become the main function, and achievement, of the latter years of the Emergency. 


\section{CHAPTER 12}

\section{CONCLUSIONS}

It could be said that the conditions conducive to the establishment of the Military Air Service in 1922 came about as a result of fortuitous circumstances and ad hoc decision making that had as an original and main aim the setting up of a civil air service. These conditions evolved during the peace and treaty negotiations of the latter part of 1921 and in the six month period leading up to the start of the Civil War. In the aforementioned negotiations with the British the matter of defence, air defence in particular, was mainly discussed in terms of Britain's current and future requirements for naval and air bases in Ireland. On the other hand civil aviation was of particular concern to Michael Collins and, as a result, provision was made in the Treaty for a future convention on air navigation. Subsequent developments in both civil and military aviation devolve from an apparently very harmonious working relationship between Michael Collins and Charles F. Russell, a Dublin born ex-RAF flying officer.

For reasons that may never be fully understood the second Dail, with the influence and authority of Michael Collins who was aided and abetted by C.F. Russell, purchased two aircraft in October 1921. The circumstances indicate that the aircraft, one civil and one military were purchased during the Treaty negotiations with contrasting contingencies in mind. In the event of the peace negotiations breaking down in an acrimonious fashion the civil passenger aircraft was to have been used to transport Collins and his fellow delegates back to Dublin. If hostilities were subsequently rejoined the military aircraft appears to have been intended for bombing purposes against British forces in Ireland. With a peaceful outcome the civil passenger aircraft was to be used to start a civil air service to Britain. With the signing, and subsequent ratification, of the Anglo-Irish Treaty of 6 December 1921 the aircraft were not used for the original intended functions and both remained in storage at Croyden for some months.

In the first six months of 1922, again apparently with Collins' interest and authority, and following extensive study of the matter by C.F. Russell, a Civil Aviation 
Department was set up with the aim of regulating civil aviation, operating a civil aerodrome and commencing a civil air service subsidised by the state. While Collins demonstrated a certain level of interest in a civil air service the one-sided nature of the correspondence on the matter denies us a clear assessment of the extent of that interest and of the authority and scope he granted Russell in pursuit of an air service. Similarly we cannot estimate the extent to which Collins would have backed Russell in more favourable circumstances. However it is considered that the convening of an Air Council, the founding of a Civil Aviation Department and the taking over of a civil aerodrome could not have been achieved by Russell without Collin's considerable active support. It is probable that Collins viewed the initiation of a State sponsored air service, as was the international practice at the time, as a necessary expression of national identity and independence. Had the Civil War not intervened it is probable that a civil air service would have been established sooner rather than later.

By 28 June 1922 the Civil Aviation Department, under the aegis of the evolving Free State or National Army and the direction of C.F. Russell, had a small staff and an aerodrome at Baldonnell. By 22 July 1922 however this embryonic air service had been absorbed into its smaller military counterpart. In the meanwhile with the inevitable approach of hostilities, the small military air element, under another ex-RAF pilot, that heretofore had little or no official backing began to assume greater significance. As civil war approached it is probable that Collins took the initiative that resulted in W.J. McSweeney being authorised, on about 20 June 1922, to purchase a single reconnaissance aircraft in Britain. On 4 July, with no aircraft in operation and the Civil War in progress, Michael Collins appealed to Churchill for military aircraft to be used for reconnaissance purposes. Two Bristol Fighters handed over by the RAF at Collinstown were pressed into service carrying out reconnaissance missions against the Irregulars. From about 7 July 1922 until Collins' death on 22 August a minuscule force of three aircraft and two pilots carried out a modest campaign of reconnaissance flights mainly in south Leinster and north east Munster. The Military Air Service, which had absorbed its civil counterpart on or about 22 July, was an integral part of the National or Free State Army. However its operations, dictated by the progress of the ground war, appear to have been largely independent of Army GHQ. The reconnaissance effort was directed by 
Collins, managed and administered by McSweeney while the actual flying missions were carried out almost exclusively by C.F. Russell. While the intelligence value of this operation cannot be judged it was apparently sufficient to persuade Collins to authorise the purchase of more aircraft and the hiring of more ex-RAF pilots at a time when such officers were not welcome in the Army. Collins also authorised the expansion of the reconnaissance operation into Cork and Kerry as the ground campaign concentrated in that area.

After the death of Collins the Military Air Service was gradually expanded to eleven pilots and twenty-two aircraft and a total of some 243 all ranks. The reconnaissance operation, as originally recommended by Collins, was eventually moved to the south west and was conducted from bases at Fermoy, from October, and Tralee from mid November 1922 - but only after an apparently unjustified delay of about six weeks. With aircraft operating under local commanders, in the absence of reconnaissance reports, and from the evidence of inaccurately kept aircraft log books, it is not possible to quantify the work done much less to judge the intelligence or other military value of the armed reconnaissance and escort patrols.

With the end of the Civil War the financial retrenchment of the Department of Finance set in with immediate effect. Notwithstanding the modest amount (about $£ 29,000$ ) spent on the purchase and operation of military aircraft the future of a military air service was put in severe doubt by the Department of Finance's perception that the existing service had incurred a disproportionate amount of the Army's expenditure during the war. In spite of the opposition of Finance, the indifference of General Richard Mulcahy and of GHQ, General Eoin O'Duffy, in his reorganisation scheme of 1924, recommended to the Government that an Army Air Corps of 155 all ranks should be maintained. This recommendation was made subsequent to the demobilisation process of 1923/24, when seven Air Service officers were let go and after the trauma of the mutiny period when a further thirteen officers were discharged. The particular circumstances, in which Major General W.J. McSweeney and Commandant J.J. Flynn were discharged as alleged mutineers, were never adequately clarified. Examination of the personal files and other records strongly suggest that summary justice was based on rumour and perception of guilt. 
It is apparent from O'Duffy's scheme of reorganisation that the air element was not retained on ideological grounds. While army aviation was declared to be essential to a modern force, basically, had the air element not already existed, no such corps would have been included in O'Duffy's reduced and reorganised Army. The Air Corps of 1 October 1924 consisted of a headquarters and a single training squadron totalling 151 all ranks. Apparently established on a temporary basis this token force had insufficient personnel to include the functions of a camp garrison or those of the administration of a civil / military aerodrome in addition to its core functions of maintaining and operating aircraft. The commanding officer in 1924/25 had grave doubts about the Corps' capacity to even fulfil the latter functions. Aviation folklore suggests that the Army Air Corps of 1924 to 1930 was little more than a state-funded aero club.

The Air Service of $1922 / 24$ had been shaped by civil war circumstances and by pragmatic decisions made on a day to day basis without the benefit of policy or plan. The Air Corps of 1924 to 1945, as an integral part of a predominantly infantry Army, was to be little different - except to the extent that matters proceeded at a more leisurely pace. As with the Army of which it was an integral, if ill-defined, part the Army Air Corps was bereft of policy that might have dictated its organisation, established strength, roles and equipment. From 1922 to 1931 a series of ex-RAF flying officers were in command of the Air Corps for brief periods - averaging less than two years each. The minutes of the Council for Defence suggest that these officers were rarely, if ever, asked for their professional opinions on air matters. Policy, to the extent to which it could be deemed to exist, was dictated by minister and his Council of Defence. In 1925 six new Bristol Fighters were purchased, on the authority of the Minister, as part of a programme that was intended to result in the establishment of a fighter squadron. This programme was soon abandoned in favour of reconnaissance. From about 1930 M.J. Costello was determined that there should be an Air Corps policy on which to base aircraft roles and the numbers and types of aircraft to be purchased. Unable to get such guidance he concluded that the policy was that there should be an Air Corps - nothing more and nothing less.

In the absence of any defined policy it is not easy to understand why the Air Corps of June 1935, under the command of an Artillery Corps commanding officer, 
should initiate the evaluation process on a medium range reconnaissance aircraft. From 1930 , with the purchase of the Vickers Vespa aircraft, the implied operational role was that of army cooperation. The subsequent training in close reconnaissance and the eventual formal establishment of the $1^{\text {st }}$ Army Co-operation Squadron on 22 October 1934 confirmed the Air Corps' primary function as army aviation. Notwithstanding, within nine months of the formal establishment of that squadron, Air Corps officers had begun the task of assessing the suitability of an aircraft intended for a substantially different role - the Avro Anson and medium range reconnaissance.

By 1 April 1937 two Avro Ansons were in service. These were to be followed by two more in 1938 and another five in 1939. The most significant development, on 1 April 1937, was the establishment of the $1^{\text {st }}$ Reconnaissance and Medium Bomber Squadron (Cadre). Though comprised of only six pilot officers and twenty-four other ranks it should have marked the first steps towards the developing of medium range reconnaissance and the airmanship and navigation standards commensurate with such an operation. This trend towards air force roles continued in 1938 with the delivery of four Gloster Gladiators. Four others, ordered at the same time were withheld by the British as were a further eight ordered for delivery in 1939. However, the entry into service of a relatively potent fighter aircraft suggested the adoption of another air force role - that of the fighter squadron. In due course the Army Co-operation Squadron was re-designated as $1^{\text {st }}$ Fighter Squadron (Cadre) - suggesting the abandonment of the close reconnaissance army aviation role.

As the Gladiator was entering Air Corps service Colonel M.J. Costello was revealing his Air Corps expansion plan of 21 March 1938. The plan proposed a large expansion in personnel numbers, initially three training cadres and eventually ten operational squadrons with expenditure in the order of $£ 1$ million. Like the corresponding plan for a large conventional Army, it was never going to be realised. However the plan did shed light on the reasons for purchase of medium range reconnaissance and fighter aircraft. Three squadrons were initially proposed under Costello's plan - , Reconnaissance and Medium Bomber, Fighter, and Coastal Patrol - all at training cadre strength. These cadres were subsequently confirmed in the 1939 peace establishment and the 1940 war establishment. As three inappropriate Walrus aircraft were subsequently 
purchased for the Coastal Patrol Squadron it was to remain totally ineffective, except for training purposed, until being disbanded in 1943.

It would be convenient, but ill-advised, to blame P.A. Mulcahy for all the subsequent ills and short-comings of the Air Corps. To a large extent he was also a victim of circumstances. The Air Corps of 1939-1945 was the product of a tradition absence of policy combined with the Army's suicidal planning for a conventional air force that was to have been an integral part of a grand defence plan. Costello's proposals for an air force of ten squadrons was over-ambitious in all aspects and, as part of the Army's proposed large three-service conventional force, was never going to be approved by Government or funded by Finance. While GHQ envisaged a military defence of the country the government was working on a strategy that emphasised, almost exclusively, passive defence measures. This was done with the guidance and assistance of the UK administration and in a manner that was dependent on close wartime cooperation between the two countries. With the Costello plan abandoned the Air Corps of 1939/40 was comprised of three under-strength training cadres that, in effect, under the direction of Col. P.A Mulcahy, were masquerading as operational squadrons. This should not have been a problem even though the squadrons were equipped with thirty obsolete aircraft rather than fifty-four modern machines. This was so because the Government's strategy did not envisage a defensive role for the Air Corps while the token expenditure on aircraft, a modest expansion in personnel numbers and a minimal and much delayed training effort meant that the Corps was quite unprepared for even the most modest air task.

However the posting of the under-strength and poorly equipped reconnaissance detachment to Rineanna on 30 August 1939, in order to patrol the west coast, changed all that. The basic prerequisites, such as modern properly equipped aircraft and appropriate navigation equipment and training, were not in place. Similarly the aircraft were operating from a primitive airfield that had no redeeming features. It was a matter of when, not if, the mission would terminate. The fact that scheduled patrol missions were reduced from two per day to one per day within days of the start of the operation would seem to indicate the mission was in trouble from the very beginning. With the mission being eventually downgraded in May 1940 due to the loss of three aircraft and a chronic 
lack of aircraft spares it was a mercy that the squadron did not have to attempt a full patrol regime for another winter. It is not easy to understand how the Chief of Staff could stand over the initial ill-judged decision except to the extent that it was almost certainly directed by government, without estimate or evaluation of any description, but for good political reasons.

While the Army's leadership would have no option but to send the R \& MB Squadron to Rineanna in August 1939 the same cannot be said for the tasking of Fighter Squadron to the defence of Dublin in May 1940. When contemplating the improbable, nay impossible, task given to a flight of three aircraft - the Air Corps Interception Service - there is some consolation in the thought that at least the investigation committee eventually saw the mission for what it was - a potential waste of life for no possible return. It is difficult to understand the naivety of Colonel P.A. Mulcahy and his infantry superiors in presuming that the squadron could perform any worthwhile defensive role in an invasion context. No doubt the Chief of Staff and the Army were under severe pressure to be seen to be able to mount a sacrificial defence that had to be committed before the Government could request outside military assistance. However, given the abysmally poor resources available to the 'front line squadrons' it is easily understood how and why the pilot body in Baldonnell got totally frustrated and demoralised and took the unprecedented step of complaining to the minister.

While the period 1921 to 1945 was characterised by a total lack of policy in such key areas as organisation, establishments, manpower and role other matters were very much subject to day-to-day influences. This was particularly so in the area of recruitment and training of pupil pilots. From very early even Collins reflected the reluctance amongst the National Army to want to recruit ex-British officers. Early on in the Civil War, with very few reconnaissance missions actually being carried out and with aircraft being collected painfully slowly, it must have been obvious to Collins that he needed extra pilots. With McSweeney very much involved in aircraft purchase and the duties of his command the reconnaissance mission, up to 22 August 1922, was Russell's one man show.

The eventual recruitment of another eleven ex-RAF pilots, between July and December 1922, and the concentration of ex-British officers that it represented, probably 
made the problem of such officers without pre-Truce service more visible. However the ad hoc recruitment and informal training of a motley group of officers and other ranks, initiated late in 1922, was not the solution. The net output of this unstructured course for fourteen pupils was six pilots of mixed ability who qualified as pilots without the requisite ground training and theory. While not advertised as such this course had apparently been authorised by the Adjutant General to facilitate the qualification of pilot officers with suitable nationalist backgrounds and in sufficient numbers to allow the services of the ex-RAF officers to be dispensed with. O'Duffy, in his 1924 scheme of reorganisation, acknowledged that this venture had been a dismal failure.

O' Duffy recommended that pupil pilots for the Corps should be recruited from the school-leaving youth of the country who had the right motivation - the forerunner of the cadet scheme still in use today. After some questionable administrative practices in GHQ, that reduced 140 candidates down to nine the said nine cadets were attested in the Curragh and commenced training on 12 April 1926. In the meanwhile the Army leadership set about satisfying the ambitions of seventeen mature army officers who were too old to be cadetship candidates. There is little doubt that, in most cases, these officers were attracted to the Air Corps by the considerable increase in pay that eight shillings a day flying pay represented. Through administrative slight of hand in its dealing with the Finance GHQ arranged for seventeen army officers, in addition to the nine cadets already undergoing military training in the Curragh, to commence flying training. This was done at a time when there were only six vacancies out of a total officer establishment of twenty-two. The aim of this subterfuge was twofold. Imposing older ex-IRA officers on the Air Corps would help to negate the influence of the ex-RAF staff on young and impressionable cadets and, of course, the ex-IRA group would themselves be immune from contamination. In addition by the training of officers who would always retain seniority over their cadet classmates GHQ would ensure that the future leadership would first devolve to an officer of a suitable nationalist background and infantry ethos. It is possible that higher authority presumed that the juxtaposition of such opposing ethos and cultures might encourage ex-RAF individuals to move on.

The course, starting with twenty-six pupils ran from June 1926 to June 1928 with officers and cadets completing the syllabus drafted by C.F. Russell (DFR 7/1927 dated 18 
March 1927). Subsequently six of each group qualified and while the officers assumed the vacant appointment the cadets had to wait five extra months so that vacancies could be created to allow them to be commissioned. The delay was caused by the fact that approval for the creation of additional appointments had to be sought from the Department of Finance. The net result of four pilot intakes was that by 1928 the small pilot body consisted of four disparate groupings - ex-RAF pilots, ex-IRA officers and other ranks of the 1922/23 intake, newly commissioned cadets and newly qualified exIRA officers. The records do not show how the individual groups got on but it would seem inevitable that various tensions existed.

While a number of small intakes of officers and cadet took place between 1933 and 1935 a major change to the intake system were initiated by Major P.A. Mulcahy and approved by DOD and the Minister in 1936. By means of erroneous advice Mulcahy convinced higher authority to issue a new DFR the only direct effect of which was to allow him qualify as a military pilot after approximately fifteen hour flying and to draw the highest rate of flying pay while, paradoxically, being prohibited by his subordinates from flying aircraft on his own. Not surprisingly this action led to unrest, not least among those who subsequently saw that higher rate of flying pay reduced to their disadvantage while their irregularly qualified commanding officer continued to draw the higher rate for many years.

Mulcahy also brought about the situation where the Air Corps cadetship was done away with as a means of entry. This was justified on the basis that only duly qualified army officers had the knowledge and appreciation of infantry tactics to facilitate being trained as effective army cooperation pilots. This aspect backfired in two ways. Firstly, after only one such intake GHQ refused to post Cadet School graduate officers into the Air Corps between 1938 and 1945 - apparently on the basis that their infantry skills would be wasted on the Air Corps and on the flying of aircraft. In addition the reorganisation of 1939, in which Mulcahy had a hand, disbanded the Army Cooperation Squadron.

During the Emergency pilot intake was done on the basis of a short service scheme copied from the RAF. Between 1939 and 1945 three classes of pupils, totalling sixty - four, more than the total of all previous pupil intakes put together, were trained. 
The scheme had been projected to produce a reserve of 300 pilots, for the future benefit of civil aviation rather that for the current needs of the military. The records strongly suggest that the training of short service pilots absorbed significantly more Air Corps resources than the operational squadrons. This is on the basis of the flying instructors' time, aircraft flying hours and of new and used training aircraft acquired during the emergency. The small number of pilots in service in 1939 and the casual and belated start of the short service scheme testify to the fact that pilot numbers was never a factor and that neither Mulcahy nor his superiors ever intended to fill such vacancies even when some squadron numbers were below $25 \%$.

The impotent and ineffective state of the Air Corps that was eventually identified and acknowledged by the committee of investigation in 1942 was the product of many interrelated factors. These included inadequately equipped and obsolete aircraft, poor planning and preparation and lack of coordination between Army and government on defence strategy - aspects that resulted in two squadrons being sent on fools' errands. The manner in which effective support services for civil aviation evolved in time for the start of Aer Lingus 1936 was in sharp to the haphazard fashion in which the corresponding services became available to military aviation.

For unknown reasons the Air Service / Air Corps was very reluctant to take a meaningful initiative in the matter of meteorology. While the Air Service had weather reports and forecasts for a brief period during the Civil War the Air Corps was subsequently only in receipt of such information on an intermittent and delayed basis that made meteorology a theoretical rather than practical discipline. While meteorological theory was an essential aspect of ground school in pilot training it was to remain theoretical in the absence of a meteorological station and reporting and forecasting facilities. The Air Corps was fortunate to have a chaplin of an appropriate scientific background who was willing to impart meteorological theory to pilot 'wings' courses and who endeavoured to generate pilots' interest in synoptic meteorology. While it appears that Father Bill O'Riordan, by means of an informed and well-argued paper on the subject, was influential in having the state undertake its international obligations by setting up the Meteorological Service in 1936, he was less influential in Baldonnell. 
Despite the fact that Baldonnell was the country's only military aerodrome, and the airport of entry for civil aircraft, no meteorological station was located there in the period under review. The indifference of P.A. Mulcahy to the needs of pilots and his inability to take advice on matters outside his area of expertise resulted in a poor and arms length relationship with Father Bill. Mulcahy did not take advantage of the opportunity presented by the advent of commercial operations to insist on having a meteorological station established at Baldonnell. In fact it appears that he conspired with his GHQ superiors to frustrate such a development. The lack of motivation on the part of Air Corps pilots in regard to meteorology in general is notable. They do not appear to have expressed opinions on the desirability of a meteorological station at Baldonnell. Perhaps they had considered that Father Bill had a better chance of success than they had. Alternatively they may have been brow-beaten by a disciplinarian commanding officer who took little, if any, advice and possibly saw the offering of such advice as an indication of indiscipline.

Like the meteorological Service the civil Aviation Communications Service was established in 1936. The service installed communications and direction finding services in keeping with the best practice of the time and commensurate with the needs of civil aviation. Military aviation communications were non-existent during the civil war as the requirements of the GOC at the time were studiously ignored by Liam Archer in his capacity as OC Signals. In doing so Archer apparently got away with disobeying the lawful order of his superior General Mulcahy. Like meteorology, in the absence of personnel in the establishment and wireless sets in the aircraft, aviation communications was to be largely theoretical for some years. With the advent of training in army cooperation wireless sets were fitted to aircraft, apparently selectively, for annual air firing and for exercises with ground units from about 1932. No wireless sets, other than wireless telegraphy, were required up to 1938 and the delivery of the Gloster Gladiators. The Gladiators had a radio telephony set as standard equipment. No ground station existed for these aircraft until a Gladiator crashed and its salvaged transmitter and receiver were mounted as a ground station. The Air Corps started the Emergency with a $\mathrm{W} / \mathrm{T}$ ground station at Baldonnell and a mobile radio car at Rineanna each with a range of sixty miles while the $\mathrm{R} / \mathrm{T}$ station at Baldonnell had a range of ten miles or less. At the 
same time civil aircraft using Baldonnell civil airport were serviced by WT, R/T and DF stations appropriate to the requirements of the cross-channel air service. The Foynes / Shannon area was even more commodiously facilitated having ground-to-air and air-toground ranges of 1000 miles and more. It is not at all clear why the Signal Corps did not develop the W/T, R/T and DF systems appropriate to the Air Corps' aircraft, airborne equipment and notional roles. It is probable that Mulcahy, even though he had a signals staff officer to advise him, did not himself appreciate the scale and scope of the communications requirements of reconnaissance and fighter operations. The Baldonnell company or squadron of the independent Signal Corps did not answer to Mulcahy or his squadron commanders but to the director of signals. As Liam Archer had done in 1922 the Director independently decided the wireless and radio equipment appropriate to the various corps and units. Mulcahy's lack of technical appreciation, and an appreciation of what pilots required, even if he had been favourably disposed to that group, would have prevented him from demanding proper equipment and services. While the range of $R / T$ transmissions improved after the demonstration and purchase of Mr. Murphy's radio in 1941 it was a matter of too little too late. The communications and direction finding facilities available to the pilots of Air Corps aircraft on 3 September 1939 were abysmal and improve little thereafter.

The civil Air Traffic Control service, regulated by the Department of Industry and Commerce, and developed and delivered by the Air Corps, evolved from 1936. With two officers allotted to civil aviation duties at Baldonnel initially, this task expanded considerably from 1939. While the Air Corps' needs in terms of ATC were fulfilled by a small establishment of meteorologists from 1939 the various civil requirements at Foynes, Shannon and Dublin employed six officers at any one time. These duties were performed mainly by pilots but also by a few observers and engineers. The fact that flying officers were withdrawn from flying duties for extended periods during a national emergency indicates that the Air Corps' flying, and therefore its role in the defence of the country, was purely notional.

During the Emergency the two operational squadrons were, in effect, manned by the pilots left over after all other commitment had been met. Fighter squadron had a maximum of twelve pilots in 1940 while R \& MB Squadron had no more. The Air Corps 
second-in-command spent almost all the Emergency period in the employ of Aer Lingus. The Schools had to be kept staffed with flying instructors at a much higher level that previously due to the substantially larger number of pupils being trained while the civil ATC rosters appeared to have priority over most, if not all, other duties. In 1943 and after, by which time an additional twenty-three pilots had been qualified, Fighter Squadron never had more than a dozen pilots though it was, at least notionally, the only remaining operational squadron. Suffice it to say that the numbers of pilots never appeared to be a priority while pilot training and civil ATC received priority.

It is evident that Government expenditure on military aviation, prior to and during the Emergency, was of token proportions only. For example the expenditure on the Air Corps' somewhat primitive facilities at Rineanna, including $£ 11,000$ plus spent on the hangar, was kept to miserly amounts. However, while the expenditure put into the development of Foynes and Shannon from 1936 and Collinstown (Dublin) Airport from 1937, up to and including concrete runways at both of the latter locations, is unknown the indications are that it ran into several millions of pounds.

During the period the government followed a course of cooperative neutrality with the United Kingdom while the Department of Finance was vigorously exercising financial retrenchment in regard to the defence vote. At the same time two underresourced token squadrons were committed, albeit briefly, to operational roles that should have been seen by the Army's leadership to be potentially suicidal. It can only be concluded that those who had seen merit in the Army plan for a large, conventional threeservice defence of the country were too naïve to recognise the folly of the decision to allot such tasks to Reconnaissance and Medium Bomber Squadron and Fighter Squadron in 1939 and 1940. In the circumstances it is understandable that demoralisation set in so early in the Emergency. Notwithstanding, the aircraft recovery operation and other aspects of cooperation with the Air Ministry / RAF ensured a supply of training aircraft in numbers adequate to ensure the training of pilots for the post-war benefit of civil aviation. 


\section{BIBLIOGRAPHY}

\section{A: PRIMARY SOURCES}

\section{Public records}

\section{The National Archives, Kew.}

Air; Air Ministry: Air 2/4601; 5129; 5139; 5131; 5159; 5160; 5172; 5185; 5192; 5198; 5241. Air 5/185; 790; 792; 793; 800; 803; 804; 806; 808; 814; 818. Air 8/48; 49; 361. Air 9/48. Air 10/3990, Air 16/530. Air 20/1021; 2073; 2442;12,043. Air 76/78; 115; 130; $162 ; 165 ; 207 ; 208 ; 223 ; 314 ; 329 ; 331 ; 405 ; 440$.

BJ; Meteorology; BJ 5/35;

BJ

CAB; Cabinet Office; CAB 16/42; CAB 21/329; 821; CAB Microfilm 23/30; CAB Microfilm 66/10; 27; CAB 104/23; 24; 183; 184; CAB 115/55; CAB120/507; CAB 120/506; CAB 121/335; 337; CAB 123/185; 196;

CO; Colonial Office; CO 904/156B;

DO; Dominions Office; DO 35/ 526/6; 527/2; 548/41,1109/2; 1067/4; 1078/3; 2112; 2113; 2114; DO 114/117;

FO; Foreign Office; FO 371/32591

PREM; Prime Minister's Office; PREM 1/245; PREM 3/129/2; 129/6; 133/3; PREM $131 / 1 ; 131 / 2 ; 131 / 6$.

WO; War Office; WO 32/15333; WO 208/3347

\section{Air Corps Museum, Baldonnell}

Aircraft log books - Bristol Fighters, Avro 504K, Martinsyde Scouts, Martinsyde Type A, Mk. II, Vickers Vespa.

Manuscript 'Record of pilot intake to Air Corps'.

\section{Military Archives, Cathal Brugha Barracks, Dublin.}

Air Corps

Army census, 12/13 November 1922 
Army crisis, 1924

Army Estimates 1922-45.

Army mission to USA $1926 / 27$

Council of Defence minutes

Department of Defence -2 Bar.

Early Department of Defence $-\mathrm{A} /$ series.

Emergency Defence Plans

Establishment Tables, Air Corps, 1924-46

General reports on the defence forces

Liaison Papers

Local Strength Returns

Memorandum on the Defence Forces, August 1944

Ministers Secretary files

Officers' Personal files

Personal Collection 586 - Col. M.J. Costello

Personal Collection 143 - Col. W.J. Keane

Proceedings of committee of investigation into effectiveness, organisation, equipment, training and administration of the Air Corps.

\section{National Archives, Dublin}

Dail Eireann Accounts

Department of Finance Supply

Department of the Taoiseach

Early Department of Finance

Office of Public Works

\section{Collections of private papers}

\section{National Library of Ireland}

Art O'Brien Papers 


\section{University College Dublin Archives}

Eamonn de Valera papers.

Sean McEntee Papers

Richard Mulcahy papers

\section{Papers in my possession}

Aerodromes book RFC / RAF Ireland.

Air Corps files; ACF/36/8, ACF/144/1, ACF/338, ACF/465, ACF/503/2, ACF/S/67.

Air Corps Standing Orders 1927, 1929, 1935.

Army Book 129, Complete list of landing grounds - Ireland, Capt. C.M. Pixton, RAF.

Establishment Tables, Air Corps, 1924-46

Flying Time \& Aircraft Accidents 1923 - 1963 (Lt. Col. J. Teague)

Key to air and marine special map.

Maps / drawings; Baldonnell Aerodrome 1927, Fermoy Aerodrome1922, Tralee Landing Ground 1922, Rathduff 1942.

Memorandum for the government, DOD 3/2314, May 1949.

Miscellaneous documents - Air Corps files; ACF/36/34, ACF/150, ACF/336/5, $\mathrm{ACF} / 338 / 5, \mathrm{ACF} / 564 / 5, \mathrm{ACF} / 631$,

Nominal rolls - Air Corps officers; 12 July 1928, 3 June 1935, 1 April 1937, 5 May 1939, 16 August 1941, 18 April 1943, 2 December 1943, 14 December 1944, 4 January 1945.

Orders; Operational Instruction No. 1/1943, No. 1 Fighter Squadron - Movement Order 1/1943, No. 1 Fighter Squadron - Movement Order, 17 April 1945,

Unit organisational charts and nominal rolls, Dec. 1940 / Jan.1941; Air Corps HQ \& Depot, Air Corps School, Fighter Squadron, Reconnaissance \& Medium Bomber Squadron, Coastal Patrol Squadron.

\section{Other papers in private keeping}

Col. W.P. Delamere

Lt. Col. P.J. Hassett

Capt. D.J. McKeown

Lieut. T.J. Nevin
Peter Delamere, Kiliney, Co. Dublin.

Capt. Eoin Hassett, Skerries, Co. Dublin.

Padraic Molloy, Celbridge, Co. Kildare.

G.M. Nevin, Loughrea, Co. Galway. 
Air Corps Flying School files; ACF/36/23, ACF/564/1, ACS/14/2, ACS/103, $\mathrm{ACS} / 103 / 5 / 1, \mathrm{ACS} / 103 / 11 / 2, \mathrm{ACF} / 109 / 1, \mathrm{ACS} / 177 / 11$. In the keeping of School Commandant, Air Corps.

\section{Printed primary sources}

Fanning, Ronan (ed.), Documents on Irish foreign policy: Vol. I 1919-22(Dublin, 1998). (ed.) Documents on Irish foreign policy vol. II 1922-26(Dublin, 2000). (ed.) Documents on Irish foreign policy vol. III 1926-32(Dublin, 2000).

\section{Newspapers and contemporary periodicals}

Aeroplane

An Cosantoir

An t-Oglagh

Aviation $1935-1937$

Evening Mail

Flight

Freeman's Journal

Irish Times

\section{Defence Forces publications}

Defence Forces Handbook (1982)

Irish Defence Forces Handbook 1968

Irish Defence Forces Handbook 1974

The Army To-day (1945)

The Irish Air Corps 1922-1997

The Irish Defence Forces - a handbook (1988)

\section{Works of reference}

Lalor, Brian, (ed.) The encyclopaedia of Ireland (Dublin, 2003) 


\section{Official publications - Irish}

A handbook on the identification of aircraft, Department of Defence, March 1941.

Constitution of Ireland, 1 July 1937.

Dail Eireann parliamentary debates

Defence Forces (Temporary Provisions) Act, 1923-45.

Defence Forces Act, 1937

Ministers and Secretaries Act, 1924

Peace Establishments 1931 - 1932

\section{Official publications - UK}

Air publication 129, Royal Air Force flying training manual, Part I, Flying Instruction, (Air Ministry, 1923).

Air publication 129, RAF flying training manual, Part I, Flying Instruction (Air Ministry, 1931).

Air publication 1234, Manual of air navigation, Vol. I (Air Ministry, 1936).

Air Publication 1525A, Pilot's notes for Anson I (Air Ministry, 1943).

\section{Military regulations and orders}

Air Corps Standing Orders 1927; 1929; 1935.

Defence Forces Regulations

Defence Orders, October 1922 to November 1924

General Routine Orders 1922/23

Orders No. 3, Defence Forces (Organisation) Order, 1924.

Staff Duty Memos 1923/24

\section{B. SECONDARY SOURCES}

\section{General histories}

Azar, Gat, A history of military thought; from the enlightenment to the cold war (Oxford, 2001)

Bielenberg, Andy, The Shannon scheme and the electrification of the Irish Free State, 
(Dublin, 2002).

Boyle, Andrew, The riddle of Erskine Childers (London, 1977).

Doherty, Gabriel, 'The Ministers and Secretaries Act 1924 and the Council of Defence: a neglected controversy' in Administration, 43, no. 4 (Winter 1995-96), pp 76-88.

Doherty, Gabriel and Keogh, Dermot, (eds), Michael Collins and the making of the Irish state (Dublin, 1998).

Byrne, Liam, History of aviation in Ireland (Dublin, 1980).

Douhet, Giulio, The command of the air (London, 1943).

O'Carroll, Donal, 'The emergency army' in Irish Sword, xix, nos. 75 \& 76 (1993/4), pp19-46.

Duggan, J.P., A history of the Irish Army (Dublin, 1991).

Dwyer, T. Ryle, Guests of the state (Dingle, 1994).

Fanning, Ronan, Independent Ireland (Dublin, 1983). The Irish Department of Finance 1922-58 (Dublin, 1978). 'Neutral Ireland?' in An Cosantoir 49, No. 9 (Sept. 1989).

Farrar-Hockley, Sir Anthony, The army in the Air: the history of the Army Air Corps. (Stroud, 1994).

Farrell, Theo, 'The Model Army: military imitation and the enfeeblement of the Army in post-revolutionary Ireland' in Irish studies in international affairs, 8 (1997), pp 111-27.

'Professionalization and suicidal defence planning by the Irish army, 1921 - 1941' in Journal of strategic studies, 21, no. 3 (Sept.1998), pp 67-85.

Fisk, Robert, In time of war: Ireland, Ulster and the price of neutrality 1939-45 (London, 1983).

Girvan, Brian, The emergency; neutral Ireland 1939-1945 (London, 2006).

Hayes, Karl, A history of the Royal Air Force and U.S. Naval Air Service in Ireland 1913 - 23 (Irish Air Letter, 1988).

Heron, Capt. O.A., 'Ireland and aviation' in An t-Oglach, II, No. 3 (Oct.1929), pp 612.

Higham, Robin, Air power; a concise history (London, 1972). 
Hill, J.R. (ed.), A new history of Ireland VII, Ireland 1921-84 (Oxford, 2003).

Hotson, Fred W., The Bremen (Toronto, 1988).

Hopkinson, Michael, Green against green; the Irish Civil War (Dublin, 1988). (ed.), The last days of Dublin Castle: the Mark Sturgis diaries (Dublin, 1999).

Joubert de la Ferte, Sir P. The third service; the story behind the Royal Air Force (London, 1955).

Kearns, A.P., 'The Irish Air Corps; a history', in Scale aircraft modelling, iii, no. 10 (July 1981), pp 440-61.

'The Irish Air Corps 1939-1945' in An Cosantoir, xlix, no. 9 (Sept. 1989), pp 13-19.

Lee. J.J., Ireland 1912-1985; Politics and society (Cambridge, 1989).

McCarron, Donal, Wings over Ireland; the story of the Irish Air Corps (Leicester, 1996).

McCarthy, Patrick J., 'The R.A.F. and Ireland, 1920-22', in Irish Sword, xvii (1989), pp 174-88.

McCartney, Donal, 'From Parnell to Pearse (1891 - 1921)' in Moody, T.W., Martin, F.X.

(eds), The course of Irish history (Cork, 1984), pp 294-312.

McGinty, Tom, The Irish navy; a story of courage and tenacity (Tralee, 1995).

Mangan, Colm, 'Plans and operations' in Irish Sword, xix, nos. 75 \& 76, (1993-4), pp $47-56$.

Mason, Air Vice-Marshal Tony, Air Power; a centennial appraisal (London, 1994).

O'Carroll, Joseph T. Ireland in the war years 1939-1945 (Newton Abbot, 1975).

O'Farrell; Padraic, Who's who in the Irish war of independence and civil war (Dublin, 1997).

O'Halpin, Eunan, 'Aspects of intelligence' in Irish Sword, xix, nos. 75 \& 76 (1993/94), pp 57-65.

Defending Ireland: the Irish state and its enemies since 1922 (Oxford, 1999).

(ed). MI5 and Ireland, 1939-1945 (Dublin, 2003).

O’Malley, Lt. Col. Michael C., 'Baldonnell Aerodrome 1917 - 1957' in Dublin Historical Record lvi, no. 2 (Autumn 2002), pp 170-81. 
O’Malley, Michael, 'The Military Air Service 1921-24' (unpublished BA thesis, N.U.I. Maynooth, 2002). 'The Officers' Mess and other works of W.H. Howard Cooke at

Baldonnell Aerodrome' (unpublished undergraduate essay, N.U.I. Maynooth, 2001).

Oram, Hugh, Dublin Airport: the history (Aer Rianta, 1990).

O'R[iain], Lieut. Liam, 'A pilot looks down; an Air Corps officer's impressions of the 1942 exercises' in An Cosantoir iii, no. 3 (Mar. 1943), pp 163-68.

O'Rourke, Madeleine, Air spectaculars; air displays in Ireland (Dublin, 1989).

O'Sullivan, R.W., An Irishman's aviation sketchbook (Dublin, 1988).

Pakenham, Frank, Peace by ordeal; the negotiation of the Anglo-Irish treaty, 1921 (London, 1972).

Parsons, Denis, 'Mobilisation and expansion 1939-40' in Irish Sword, xix, nos. 75 \& 76 (1993-4), pp 11-18.

Quigley, Aidan, Green is my sky (Dublin, 1983).

'Air aspects of the emergency' in Irish Sword, xix, nos. 75 \& 76, (19934), pp 86-90.

Reynolds, David, In command of history; Churchill fighting and writing the second world war (London, 2004).

Ring, Jim, Erskine Childers (London, 1996).

Ryan, Meda, The day Michael Collins was shot (Swords, 1989).

Salmon, Trevor C., Unneutral Ireland; an ambivalent and unique security policy (Oxford, 1989).

Share, Bernard, The flight of the Iolar; the Aer Lingus experience 1936-1986 (Dublin, 1986).

Swan, Capt. Patrick, 'The Air Corps' in An Cosantoir, vii, No. 4 (Apr. 1947), pp 199-202.

Valiulis, Maryann Gialanella, Almost a rebellion; the Irish Army mutiny of 1924 (Cork, 1988).

Portrait of a revolutionary; General Richard Mulcahy and the founding of the Irish Free State (Dublin, 1992).

Young, Peter, 'The way we were' in An Cosantoir 49, no. 9 (Sept.1989), pp 33-38. 
'Defence and the new Irish state 1919-23', in Irish Sword xix, Nos. 75 \& 76, (1993-4), pp 1-10.

West, Nigel, MI5 British security service operations 1909-1945 (London, 1981).

West, Nigel, (ed.) The Guy Liddell diaries, vol. I: 1939 - 1942 (Abingdon, 2005).

\section{Biographies}

Fennelly, Teddy, Fitz and the famous flight (Portlaoise, 1997).

Hart, Peter, Mick: the real Michael Collins (London, 2005).

Lewis, Cecil, Sagittarius rising (London, 2003).

McGarry, Feargal, Eoin O'Duffy; a self-made hero (Oxford, 2005).

Pinkman, John A., In the legion of the vanguard, ed. Maguire, Francis E. (Cork,1998).

Ring, Jim, Erskine Childers (London, 1996).

Stokes, Doug, Wings aflame; the biography of Group Captain Victor Beamish DSO and bar, DFC, $A F C$ (London, 1985).

\section{Special subjects}

hAllmhurain, Sean, (ed.), Aviation communications service, 1936 - 1986 (Dublin, 1986).

Bowyer, Chaz, Bristol F2B Fighter; king of two seaters (Shepperton, 1985).

Byrne, Kevin and Tormey, Peter, Irish Air Corps; a view from the tower (Defence Forces Printing Press, 1991).

Cambridge University, Aircraft Navigation (Cambridge University Press, 1943).

Collins, C.B., 'Inter-aerodrome navigation' in Flight, 7 Dec. 1933.

Dunne, Tom et al, Shannon airport; 50 years of engineering 1937-1987 (Aer Rianta, 1997).

Erecting and aligning Avro biplanes. $3^{\text {rd }}$ ed., (A.V. Roe \& Co. Ltd, 1918).

Goulter, Christina, 'The war in the air: the bomber crew' in Liddle, Peter, Bourne, John, Whitehead, Ian, (eds), The great world war 1914-45 Volume I; lightning strikes twice (London, 2000).

Hughes, A.J., History of air navigation (Woking, 1946).

Irish Air Letter, Baldonnel; Dublin's civil airport 1919 to 1939 (Dublin, 1989).

Aviation on the Shannon (Dublin, 1985). 
The flying fields of Cork (Dublin, 1988).

Jackson, A. J., Avro aircraft since 1909 (London, 1990).

Johnson, Group Captain John E., Full circle; the tactics of air fighting 1914-1964 (New York, 1964).

Jordan, David, 'War in the air: the fighter pilot' in Liddle, Peter, Bourne, John,

Whitehead, Ian, (eds), The great world war 1914-45 Volume I; lightning strikes twice (London, 2000).

MacMillan, Captain Norman M.C., A.F.C., Air Strategy (London, [1941?])

Meekcoms, K.J. and Morgan, E.B., (eds.) The British aircraft specifications file; British military and commercial aircraft specifications 1920 - 1949 (Tonbridge, 1994).

Sanger, Ray, The Martinsyde file (Tunbridge Wells, 1999).

Shields, Lisa (ed.), The Irish Meteorological Service; the first fifty years (Dublin, 1987).

Sinclair, Duncan, 'Airport communications' in Flight, 7 Dec. 1933. 


\section{APPENDIX 1}

Summary of expenses in connection with the purchase, maintenance and equipment of two aeroplanes.'

Received from Art O'Brien - 19 Oct. 1921

$£ 1,500.0 .0$

Received from Art O'Brien - 12 Dec. 1921

$£ 1,300$. 0.0 .

Received from Art O'Brien - 30 Dec. 1921

$£ 250,0.0$.

Received from other sources

Total received

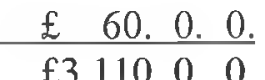

Purchased from Messrs. Martinsyde, Ltd. One five-seater aeroplane

$£ 2,300$

One set of floats for same

$£ 300$

One Avro machine

$£ 130$

Alterations to five-seater machine to increase accommodation

$£ 100$

To dual control by Company pilot ${ }^{2}$

$£ \quad 17.10 .0$.

Lieut. McSweeney, I.R.A., Expenses before the purchase of the machines

Maps, helmet and Compass Box

Petrol, oil and mechanic's fees

Travelling expenses Brooklands

Travelling expenses Woking

Irish travelling expenses

Hotel expenses - London \& Dublin

Miscellaneous expenses

Expenses in connection with two machine guns - London

Expenses (to Capt. Clarke)

Insurance \& garage for aeroplanes

Report on Haulbowline as an Air Station [supplied by Director of

Handley Page London - Paris service $]^{3}$

Total expenses

25. 0.0

$£ \quad 10.0 .0$.

$£$ 25. 0.0 .

$£$ 40.0.0. 0 .

$£$ 34. 0.0 .

$£$ 130. 0. 0 .

$£$ 65. 0.0 .

$£ \quad 10.0 .0$.

$£$ 5. 0.0 .

$£$ 10.0.0. 0 .

$£ \quad 20.0 .0$.

Total amount expended as per above

$£ 3,247$. 10.0 .

Total amount received as per above $£ 3,110$. 0.0 .

Balance due to C.F. Russell

$£ 137.10 .0$.

Statement of immediate financial requirements [7 April 1922] ${ }^{4}$

Packing \& shipping of Martinsyde aeroplane, London to Dublin $\quad £ \quad 150.0 .0$.

Packing \& shipping of Avro aeroplane, London to Dublin $\quad £$ 100. 0. 0 .

Balance due to Martinsyde, Avro aeroplane

$£$ 130.0.0

\footnotetext{
I Statement of expenses, C.F. Russell to Michael Collins, 27 Feb. 1922 (NAI, DT S.4002); London office accounts, I Oct. 1921 to 31 Dec. 1921 (NLA, Mss8431-2, Art O’Brien papers).

${ }^{3}$ Dual flying instruction on the Martinsyde aircraft

3 'Irish Air Force' undated Aviation Department memo, March / April 1922 (MA, PC 143).

${ }^{4}$ Minister for Defence to Minister for Finance, 7 April 1922 (NAI, DT S.4002).
} 
Balance due to Martinsyde, garage \& insurance

Salaries of staff for one month

Special - expenses for two of our mechanics to go to London to watch

Disassembling of these machines.

Miscellaneous

[Total costs associated with the purchase of two aircraft
$£ \quad 10.0 .0$.

$£ \quad 40.0$. 0 .

$£ \quad 40.0 .0$.

$£ \quad 50.0 .0$.

$£$ 520.0.0. 0 .

$£ 3,767.0 .0$. 


\section{APPENDIX 2 \\ POST OFFICE TELEGRAPHS. ${ }^{5}$ \\ TELEGRAMS RECEIVED IN THE IRISH OFFICE.}

Date -4 July 1922

Handed in at DUBLIN CASTLE at_ Received here at $11.39 \mathrm{am}$.

From

Cope

To Curtis for Mr. Churchill

Collins wants two aeroplanes one with undercarriage for bombing and one without. Reasons for request are

(1) McSweeney has not brought over his plane yet due to inclement weather.

(2) Telegraph and telephone communication is interrupted and particulars of the surrounding country are not available

(3) Reports come in of concentrations of irregulars in Dublin County and neighbouring Counties. Troops and transport are sent out on these reports and search country for hours for these concentrations but fail to find them and men and time are wasted.

(4) Collins is satisfied he could clean up the Country districts if he could get early information of concentrations and keep up communications. As an example of (2) above there were reports yesterday that irregulars were doing well in Drogheda. At P.G.'s request I got through to Gormanstown by wireless for information but wires were down between Gormanstown and Drogheda and no information could be obtained.

It would be most undesirable for P.G. to use our pilots owing to the dead set which is being made by republicans on P.G. receiving assistance from us. Each issue of the Republic of Ireland mentions either Mr. Churchill, General Macready or myself as giving assistance in the fight and the mainspring of the republican propaganda is that British forces are prompting and assisting in the killing of Irishmen.

I suggest one aeroplane being handed over at once. Can this be done please. The handing over should be at Baldonnell. The P.G. have one or two efficient airmen - of this I am certain.

\footnotetext{
${ }^{5} \mathrm{NA}$, Air $8 / 49$.
} 


\section{Appendix 3}

Statement of expenditure by Major General McSweeney from the sum of $£ 3,800$ advanced by the Ministry of Defence. ${ }^{6}$

\begin{tabular}{|c|c|c|}
\hline 1922 & & $£ \mathrm{~s} \quad \mathrm{~d}$ \\
\hline \multirow[t]{2}{*}{20 June } & Received from Chief of Staff & $1,300.0 .0$ \\
\hline & Received from Chief of Staff & $2,500.0 .0$. \\
\hline $\begin{array}{l}21 \text { June }-4 \\
\text { July } 1922\end{array}$ & $\begin{array}{l}\text { McSweeney - misc. expenses Dublin /London / } \\
\text { Dublin /London /Dublin }\end{array}$ & 43. 1.2 \\
\hline 24 June & Aircraft Disposal Co. & 400. 0.0. \\
\hline 26 June & C. Baker & 3. 7.0 \\
\hline 26 June & Gamages & 2. 2. 0. \\
\hline 1 July & Aircraft Disposal Co. & 400. 0.0. \\
\hline 1 July & G. Adams & 4.17. 0 \\
\hline 2 July & C. Baker & 9. 0.0 . \\
\hline 13 July & Yeates & 1.10. 0. \\
\hline 15 July & T.S. Harris & 86.12. 6. \\
\hline 15 July & Aircraft Disposal Co. & $1,100.0 .0$. \\
\hline 17 July & Royal Air Force & 4.18 .4 \\
\hline 30 July & Col. Russell & 9.17 .4$. \\
\hline $\begin{array}{l}30 \text { July }-14 \\
\text { Aug. }\end{array}$ & $\begin{array}{l}\text { McSweeney - misc. expenses Dublin /London / } \\
\text { Dublin }\end{array}$ & 37. 1. 2 . \\
\hline 31 July & Dixon Hempenstall & 2. 2. 0. \\
\hline 1 Aug. & Burberrys & 3. 10.0. \\
\hline \multirow[t]{6}{*}{4 Aug. } & Gieves. & 2.10 .0 \\
\hline & Wages & 21. 2. 3. \\
\hline & C. Baker. & 9. 0.0. \\
\hline & G. Adams & 6.5 .6$. \\
\hline & Col. Russell - Expenses & 10. 18.0. \\
\hline & Advance - Mr. Piercey, ADC. & 15. 0.0. \\
\hline 11 Aug. & Wages & 18. 7.10. \\
\hline 18 Aug. & Wages & 19. 2. 5. \\
\hline $25 \mathrm{Aug}$ & Wages & 25.14 .1$. \\
\hline \multirow[t]{2}{*}{30 Aug. } & Cox Shipping Co. & 32. 6.6 . \\
\hline & Lieuts. Crossley and Maloney & 35. 0.0 . \\
\hline 1 Sept. & Wages. & 17. 16.3. \\
\hline 9 Sept. & Wages & 29. 13.0 . \\
\hline \multirow[t]{3}{*}{16 Sept. } & Wages & 3. 15.0 . \\
\hline & Wages & 31.5 .6$. \\
\hline & Mr Piercey [Mono engine] & 100. 0.0. \\
\hline
\end{tabular}

\footnotetext{
6 'Statement of expenditure', 28 July 1923; 'Expenses of Major General McSweeney during year 1922$1923^{\prime}, 30$ Oct. 1922 (MA, AC/2/2/1).
} 


\begin{tabular}{|l|l|r|}
\hline 22-27 Sept. & $\begin{array}{l}\text { McSweeney misc. expenses Dublin /London/ } \\
\text { Dublin }\end{array}$ & 15.14 .8$. \\
\hline 3 Oct. & L.B. Fitch & 1.10 .0$. \\
\hline 10 Oct. & Dairy Engineering Co. & 6.6. \\
\hline 14 Oct. & Fox, carter. (Wages) & 12. 0.0 .0 \\
\hline 28 Oct. & Fox, Carter (Wages) & 67.10 .0$. \\
\hline 27 Jan. 1923 & Jacob's [second hand flying suits] & 829.10 .7$. \\
\hline 1 Nov. & Allowed as expenses - McSweeney & 360.18 .4$. \\
\hline 13 Sept. & Refunded to DOD. (National Land Bank) & $3,800.0 .0$ \\
\hline 13 Sept. & Refund to DOD (Munster \& Leinster Bank) & \\
\hline 1 Nov. 1923 & Account balanced &
\end{tabular}




\section{APPENDIX 4}

Department of Civil Aviation - 20 July $1922^{7}$

\begin{tabular}{|c|c|c|c|}
\hline Name & Duties & Salary & Commenced \\
\hline Chas. F. Russell & $\begin{array}{l}\text { Director, Civil Aviation, } \\
\text { Sec. Aviation Council }\end{array}$ & $£ 300$ p.a. & 1 April 1922 \\
\hline Miss McLoughlin & $\begin{array}{l}\text { Typist, Civil Aviation } \\
\text { Department }\end{array}$ & $£ 2-10$ s. p.w. & 1 April 1922 \\
\hline A.J. Russell & Junior Clerk & $£ 1-10$ s. p.w. & 23 April 1922 \\
\hline W.J. Guilfoyle & $\begin{array}{l}\text { Engineer, Baldonnell \& } \\
\text { Tallaght. }\end{array}$ & $£ 6-10$ s. p.w. & 30 April 1922 \\
\hline Frederick Laffan & Switch Board Attendant & $£ 3-10$ s. p.w. & 30 April 1922 \\
\hline A. Conmee & Switch Board Attendant & $£ 3-10$ s. p.w. & 30 April 1922 \\
\hline J. Byrne & $\begin{array}{l}\text { Engine Driver, Clondalkin } \\
\text { Pumping Station }\end{array}$ & $£ 2-10$ s. p.w. & 30 April 1922 \\
\hline L. Nelson & General Labourer & $£ 2-16$ s. p.w & 6 May 1922 \\
\hline Vol. G. Dunne & $\begin{array}{l}\text { Labourer, Sewage \& Fire } \\
\text { Hydrants }\end{array}$ & $£ 2-10$ s. p.w. & 10 June 1922 \\
\hline Vol. M. Horan & Fitter \& Turner & $£ 3-13$ s p.w. & 10 June 1922 \\
\hline P. Condon & $\begin{array}{l}\text { Store Keeper / Caretaker of } \\
\text { Aerodrome fittings }\end{array}$ & $\begin{array}{l}£ 2-18 \mathrm{~s} .-4 \mathrm{~d} \\
\text { p.w. }\end{array}$ & 10 June 1922 \\
\hline Chas. O'Toole & Aero Ground Engineer & $£ 5-0$ s. p.w. & 14 June 1922 \\
\hline H. Mathews & Labourer, cleaning duties. & $£ 2-3$ s. p.w. & 16 June 1922 \\
\hline M. Perkins & Fitter & $£ 3-13$ s. p.w. & 17 July 1922 \\
\hline M. O'Gorman & Electrician & $£ 3-10$ s p.w. & 17 July 1922 \\
\hline E. Broy & Accountant \& Clerk & $£ 5$ - 0s. p.w. & 19 July 1922 \\
\hline
\end{tabular}

\footnotetext{
${ }^{7}$ P7/49/38 (UCDA, MP).
} 


\section{APPENDIX 5}

Department of Military Aviation - 22 July $1922^{8}$

\begin{tabular}{|l|l|l|l|l|}
\hline Rank & Name & Duties & $\begin{array}{l}\text { Date of } \\
\text { Appointment }\end{array}$ & Pay per Week \\
\hline Lieut. & G. Dowdall & Adjutant & 25 May 1922 & $£ 4-0-0$ \\
\hline 2/Lt & $\begin{array}{l}\text { T. Nolan (in } \\
\text { Hospital) }\end{array}$ & Observer & 7 July 1922 & $£ 2-0-0$ \\
\hline 2/Lt & J. McCormac & $\begin{array}{l}\text { Pilot } \\
\text { (Dismissed) }\end{array}$ & 11 July 1922 & $£ 2-0-3$ \\
\hline S/Capt. & W. Stapleton & $\begin{array}{l}\text { Observer } \\
\text { (Acting) }\end{array}$ & 11 July 1922 & $£$ \\
\hline Capt. & Mills & M.O. & 11 July 1922 & $\begin{array}{l}\text { Not paid through } \\
\text { Aviation }\end{array}$ \\
\hline
\end{tabular}

\begin{tabular}{|c|c|c|c|c|}
\hline Sergt. & J. McCarthy & Rigger & 1 Feb. 1922 & $£ 2-10-0$ \\
\hline Cpl. & J. Curran & Rigger & 30 March 1922 & $£ 1-6-3$ \\
\hline Cpl. & A. Hughes & Fitter & 30 March 1922 & $\mathfrak{f 2}-14-3$ \\
\hline Cpl. & H. White & $\begin{array}{l}\text { QM \& } \\
\text { Discipline }\end{array}$ & & $£ 2-14-3$ \\
\hline Vol. & F. Kerrigan & Fitter & 7 June 1922 & $£ 1-4-6$ \\
\hline Vol. & M. Lawler & Rigger & 20 June 1922 & $£ 1-4-6$ \\
\hline Vol. & T. McGee & Fitter MT & 20 July 1922 & $£ 1-4-6$ \\
\hline Vol. & Behan & Fitter MT & $\begin{array}{l}\text { Attached from } \\
\text { Garrison }\end{array}$ & \\
\hline Vol. & J. Stephenson & Fitter MT & 20 July 1922 & $£ 1-4-6$ \\
\hline Vol. & Gerard & Rigger & & $£ 1-4-6$ \\
\hline Vol. & T. Clarke & Rigger & 20 July 1922 & $£ 2-12-6$ \\
\hline Vol. & J. Reid & Fitter & 20 July 1922 & $£$ \\
\hline Vol. & Hussy & Fitter MT & 19 July 1922 & $£$ \\
\hline Sergt. & Sean Waldron & Medical & )Not & Paid \\
\hline Vol. & W. Winters & Medical & ) & \\
\hline Vol. & M. Adamson & Medical & ) & \\
\hline Vol. & J. O'Leary & Medical & By & Aviation \\
\hline Miss & M. Kiernan & Typist & 24 March 1922 & $£ 2-10-0$ \\
\hline $\mathrm{Mr}$. & W. Keogh & i/c MT Repair & & $£ 4-10-0$ \\
\hline
\end{tabular}

\footnotetext{
${ }^{8} \mathrm{P} 7 / 49 / 37$ (UCDA, MP).
} 


\begin{tabular}{|l|l|l|l|l|}
\hline Mr. & H. Cleary & Cook & 12 July 1922 & $£ 4-10-0$ \\
\hline Mr. & F. Sullivan & Cook & 12 July 1922 & $£ 3-10-0$ \\
\hline Mr. & $\begin{array}{l}\text { M. Hennebry } \\
\text { (Survey) }\end{array}$ & Carpenter & 10 July 1922 & $£ 3-0-0$ \\
\hline Mr. & J. Hennebry & Carpenter & 10 July 1922 & $£ 3-0-0$ \\
\hline Mr. & A. Fay & Carpenter & 10 July 1922 & $£ 3-0-0$ \\
\hline Mr. & Doyle & C / Labourer & 21 July 1922 & $£ 2-10-0$ \\
\hline Vol. & P. Kelly & $\begin{array}{l}\text { Telephone } \\
\text { operator }\end{array}$ & 22 July 1922 & $£ 1-4-6$ \\
\hline Vol. & D. Kelly & $\begin{array}{l}\text { Telephone } \\
\text { operator }\end{array}$ & 22 July 1922 & $£ 1-4-6$ \\
\hline Vol. & M. Campbell & Rigger & 22 July 1922 & $£ 3-0-0$ \\
\hline Vol. & J. Daly & Rigger & 22 July 1922 & $£ 2-12-6$ \\
\hline Vol. & E. Sutcliffe & Rigger & 22 July 1922 & $£ 1-4-6$ \\
\hline
\end{tabular}




\title{
APPENDIX 6
}

\section{DEFENCE FORCE REGULATIONS}

\author{
$\underline{\text { Roinn Cosanta }}$
}

$18^{\text {th }}$ March, 1927

\section{SYLLABUS OF TRAINING.}

\author{
$\underline{\text { D.F.R. } 7}$ \\ 1927 \\ PUPIL OFFICERS AND CADETS IN THE ARMY AIR CORPS
}

1. The Duration of the training period for pupil Officers and Cadet in the Army Air Corps shall be two years. The syllabus of training for each year shall be as prescribed herein provided that during the first year flying instruction will also be given in addition to the ground instruction as prescribed in the syllabus for that year.

2. The Officer Commanding the Army Air Corps may use his discretion in covering the syllabus of training for the first year and shall not be definitely limited to the syllabus as laid down for each particular quarter of that year, provided the entire syllabus is covered within a period of twelve months.

\section{Syllabus of training $-1^{\text {st }}$ year}

\section{$1^{\text {st }}$ Quarter.}

This quarter will be devoted to a special Course of Infantry Training at the School of Instruction, Curragh Camp.

\section{$2^{\text {nd }}$ Quarter.}

This quarter will be devoted to lectures at Baldonnel, of an elementary nature on the following subjects and also elementary Flying Training (Dual control).

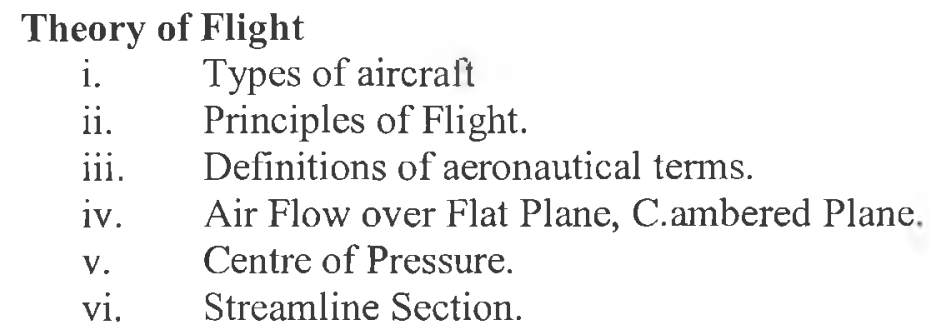


vii. Lift and Drag, Formuline and Curves.

viii. Function of control Surfaces.

ix. The Air Screw.

$\mathrm{x}$. The Aeroplane in Flight.

xi. Gliding and Gliding Angle.

Rigging.

i. Materials used in aircraft construction.

ii. Names of different parts and their uses.

iii. Construction of main planes and control surfaces.

iv. Measurement of angles.

v. Assembling and dismantling.

vi. Types of aeroplanes.

vii. Rigging characteristics.

Aero Engines.

i. Principles of internal combustion engine.

ii. Cycle of operations.

iii. Names of various parts and their functions.

iv. Cooling, lubricating and ignition system.

v. The carburetter. [sic]

vi. The magneto.

vii. Types of engines.

viii. Detailed information on the Mono Engine.

Wireless.

i. Elementary principles of magnetism.

ii. Theory of wireless.

iii. Transmission and reception of wireless wave.

iv. Timing.

v. Buzzing (Sending and receiving [morse code at] 6 words per minute).

Map reading.

i. Introduction and general definitions.

ii. Scales, representative fractions and conversions.

iii. Use of protractor and other instruments.

iv. Conventional signs, contouring and contours.

v. Relief, methods of showing and reading.

vi. Section drawing and mutual visibility.

vii. Map reading and orienting.

viii. Resection and traversing.

ix. Map enlarging.

Machine guns - Lewis and Vickers guns.

i. General description of the gun and parts.

ii. Stripping and assembling. 
iii. Sequence and operations.

iv. Loading, firing and unloading.

v. Care and maintenance.

vi. Points before and after flight.

\section{Machine drill.}

Pupil Officers and Cadets will be qualified to take charge of a crew moving and starting up machines and will be required to be proficient in the drill for swinging propellers.

Lectures will also be given in morale and discipline and instruction in physical training.

$3^{\text {rd }}$ Quarter.

During this period further lectures of a more advanced nature will be given in the subjects laid down above, and, in addition:

\section{Photography.}

i. Theory of light.

ii. Lenses.

iii. Theory of photography.

iv. Plates and filters.

v. Types of aerial cameras.

vi. Method of operation.

vii. Suspension and installation of cameras in the aircraft.

\section{Instruments.}
i. $\quad$ Air speed indicator.
ii. Revolution counter.
iii. Oil and pressure gauges.
iv. Altimeter.
v. Thermometer.
vi. Inclinometer.
vii. Reid control indicator.

\section{Meteorology.}

i. Constituents of atmosphere.

ii. Meteorological elements.

iii. Circulation of atmosphere.

iv. Methods of observation.

v. Winds, cloud formations.

vi. Visibility.

vii. Thunderstorms, cyclones and anticyclones.

viii. Weather forecasting.

\section{Navigation.}
i. Introduction and definitions.
ii. Measurement of distance on earth's surface.
iii. Projections. 
iv. Maps and charts.

v. Magnetism, properties of magnets, terrestrial magnetism, dip variation and correcting for variation.

vi. The Aero compass, compass adjustment, preparation of deviation card, compass errors.

vii. Measurement of bearing, fixing position.

viii. Bigswort chart board and protractor, effect of wind on aircraft, drift.

ix. Course setting, composition and resolution of forces, application of parallelogram and triangle of forces' to course setting.

$\mathrm{x}$. Radius of action.

xi. Interception of aircraft.

xii. Course and distance calculator.

xiii. Instruments used in aerial navigation.

\section{International Air Regulations.}

i. Regulation drawn up by the International Convention.

ii. Amendments and additions.

\section{Reconnaissance.}

i. Definition of reconnaissance.

ii. Uses of aircraft in this connection.

iii. What to observe and how to report it.

iv. Co-operation with Infantry.

v. Artillery co-operation.

\section{Bombs.}

i. Types of bombs and bomb racks.

ii. Safety devices.

iii. Care and maintenance.

iv. Bomb sights.

v. Bomb dropping.

\section{C.C. Interrupter gear.}

i. General description of gear.

ii. Operation of gear.

iii. Timing and fitting.

iv. Care and maintenance.

v. Points before and after flight.

\section{$4^{\text {th }}$ Quarter.}

This quarter will be devoted to revision of the lectures given above, and to examination in the various subjects.

The course will be divided into two periods:- Elementary and Advanced. Examinations will be held at the end of each period and marks will be allotted to the various subjects as set out below. 
In order to pass in the undermentioned subjects a minimum of 50 per cent must be obtained and Officers obtaining 80 per cent will be granted a pass with honours.

Elementary

$\begin{array}{lll} & \text { Total } & \\ \text { Subject } & \text { Mark } & \text { Pass } \\ & \text { Obtainable } & \end{array}$

\begin{tabular}{lrl}
\hline Rigging & 150 & 75 \\
Engines & 150 & 75 \\
Wireless theory & 150 & 75 \\
Buzzing & 50 & 25
\end{tabular}

Theory of flight and

Elementary mechanics 150

Machine drill

Map reading

General knowledge

(Aviation)

\section{5}

75

75

25

75
50
75
50
500 $\underline{\text { Advanced }}$

$\begin{array}{lll} & \text { Total } & \\ \text { Subject } & \begin{array}{l}\text { Marks } \\ \text { obtainable }\end{array} & \text { Pass }\end{array}$

$\begin{array}{lrr}\text { Photography } & 150 & 75 \\ \text { Instruments } & 40 & 20 \\ \text { Meteorology } & 100 & 50 \\ \text { Navigation } & 150 & 75 \\ \text { Reports } & 50 & 25 \\ \text { Armament, Bombs } & \\ \text { C.C. gear etc. } 100 & 50 \\ \text { International Air } & \\ \text { Regulations } \quad 50 & 25 \\ & & \\ & 640 & 320\end{array}$

4. Syllabus of training $-2^{\text {nd }}$ year.

Pupil Officers will be expected to have completed Dual Instruction and Solo Flying on the elementary types of machines at the end of the first year. The whole of the second year will be devoted to Dual Instruction and Solo Flying on the Service types of machines, and in addition practical application of the subject upon which lectures were given during the first year. Periods of bad weather, unsuitable for flying, will be devoted to revision of the lectures given during the first year and practice in Buzzing and machine guns and instruction in Army and Corps Administration.

Before passing on to service types of aircraft, Pupil Officers and Cadets must:-

i. Have completed a total of 40 hours solo and Dual on elementary type machine, of which 20 hours must be Solo flying.

ii. Be able to flymachine reliably and accurately, and land consistently well, tail down, at low speed.

iii. Have passed the following tests on the elementary type machine. Tests (a), (b), (c), and (j) will be carried out solo unaccompanied by an Instructor or passenger. Tests (d) to (i) will be accompanied by an Instructor, but the candidate will be required the manoeuvres himself, an will be considered to ha e failed in the tests if assistance is given by the Instructor:- 
(a) Climb to 6,000 feet and remain there for at least 15 minutes, afterwards making a good landing without the use of the engine, and coming to rest within 100 yards of the mark selected by the examiner.

(b) Make three landings without the assistance of the engine, the points where the aeroplane first touches the ground and where it finally came to rest within in a fixed circle of 150 yards diameter. In a ground wind of 15 m.p.h. or over this diameter will be reduced to 125 yards. (The prescribed limits will be indicated to the pupil before he leaves the ground).

(c) Carry out a cross-country flight of at least 60 miles without losing his way. On return the candidate will be required to describe accurately the ground details of three previously selected pin points on his route. These pin point will not be prominent land marks, nor will the route chosen be defined by railway, river or canal.

(d) Execute three sustained turns in each direction, with and without engine. Air speed of aeroplane not to vary by more than 10 miles an hour throughout the whole turn. Bank to be not less than 45 degrees.

(e) Execute small figures of eight without losing height or side-slipping.

(f) Stall his machine with and without engine.

(g) Sideslip his aeroplane in either direction without stalling or exceeding an airspeed of 75 m.p.h.

(h) Fly in clouds and rough weather, and manipulate a forced landing successfully.

(i) Execute spin, half-roll, stall turn, and loop.

(j) Take off and land his machine cross-wind.

In addition to the above tests on elementary types of aircraft, the following conditions must be fulfilled before a Pupil Officer or Cadet is granted authority to wear the flying badge:-

i. Have completed a total of 60 flying, of which at least 20 hours must be solo flying on a Service type aircraft.

ii. Be able to fly his service machine reliably and accurately and land consistently well, tail down at low speeds.

iii. Have carried a passenger in a service machine (two seater Service types only).

iv. Have a good working knowledge of the engine and in the use of Vacuum Controls.

v. Have passed to the following tests on his service machine: Tests (a), (b), and (c) and will be carried out solo unaccompanied by Instructor or passenger. Tests ( $\mathrm{d} 0$ to $(\mathrm{k})$ will be carried out accompanied by the Instructor, but the candidate will be required to execute the manoeuvres himself, and will be considered to have failed in the tests if assistance is given by the Instructor;-

(a) Climb to 15,000 feet and remain at that height for at least 15 minutes, afterwards making a good landing without the use of his engine, and coming to rest within 175 yard of mark previously selected by his examiner:

(b) Make three landings without the assistance of the engine the point where his aeroplane first touches the ground and where it finally comes to rest being included within a fixed circle, the diameter of which will be 150 yards for all types. In a wind 
of 15 m.p.h. or over, this diameter will be reduced to [1]25 yards. The prescribed limits will be marked and indicated to the candidate by the instructor

(c) Carry out four cross-country flights of at least 60 miles each over unfamiliar country, without losing his way. On return the candidate will be required to describe accurately the ground details of three previously selected pin points on his route. These pin points will not be prominent land marks nor will the route chosen be defined by a railway, river or canal.

(d) Execute three sustained turns in each direction with and without engine. Air speed not to vary by more than 10 m.p.h. throughout the whole turn. Bank not to be less than 45 degrees.

(e) Execute small figures of eight without losing height or sideslipping.

(f) Stall with and without engine.

(g)Sideslip in either direction without stalling or exceeding an air speed of 80 m.p.h.

(h) Satisfy the examiner that the candidate is a safe pilot in cloud and rough weather.

(j) Execute unassisted four forced landings in different field selected by the examiner.

(k) Compass Test - Candidates will not be provided with a map but will be given a compass bearing upon which they will be required to fly for 15 minutes. The Instructor will check the compass reading every 30 seconds. The maximum error will not exceed 30 degrees and the average error 15 degrees. On completion of fifteen minutes flying the instructor will give the candidate a map of the country, upon which he wil mark the position of the machine.

(1) Keep his position in a formation, and be capable of picking up and taking up position in a formation.

(m) Carry out six Reconnaissance flights and submit satisfactory reports.

(n) Take six Aerial Photography of prominent ground objects, the centres of which are approximately in centre of Plates. Take a satisfactory series of overlaps of a given area of ground.

5. Nomination of Cadets to the Executive Council for the grant of Commissions as $2^{\text {nd }}$ Lieutenants in the Army Air Corps will be conditional on their passing the above tests (Ground and Flying), their suitability for appointment to commissioned rank, and on vacancies existing in the Corps.

Made and prescribed in exercise of the powers in this behalf vested in me by Defence Forces (Temporary Provisions) Acts, 1923 to 1926.

[ Signed] 
APPENDIX 7

\section{DEFENCE FORCE REGULATIONS}

Roinn Cosanta, 21 may 1936

D.F.R. 40

1936

\section{AIR CORPS SCHOOL}

1. The function of the Air Corps School shall be-

i. To provide a uniform medium of instruction in the tactics and technique of the Air Corps for such officers, non-commissioned officers and men as are detailed.

ii. (a) To conduct the Young Officers' Flying Training Course.

[etc]

3. Young Officers Flying Training Course. The syllabus of the Young Officers' Flying Training Course shall be as follows:-

Group I. History of Aviation; Characteristics of Aircraft; Organisation and Administration of the Air Corps; Flight Administration; Elementary Theory of Flight.

Group II. Rigging; Instruments; Power Plants.

Group III. Air Navigation; Photography; Radio and other means of communication.

Group IV. Aerial Armament; Theoretical Instruction in Aerial Bombing; Practical Ground Gunnery.

Group V. Airmanship; Flying Training.

Group VI. Meteorology; Air Navigation Regulations

4. [etc] 


\section{APPENDIX 8}

To All officers at Baldonnel, through Unit Commanders. ${ }^{9}$

Although there is abundant evidence that an invasion of our country is contemplated, it is not possible for us to be told when or where the enemy will strike.

It is our duty to be at our posts, ready to take our part at the moment of attack.

We may get a few hours warning. We may get no warning. Nevertheless, it is our duty to be ready at the precise moment.

If we fail to get into the air, if we loose our aircraft on the ground, we have failed utterly in our duty to our people. It is, therefore, necessary that the crews of the Service Squadron and detachment at Baldonnel be readily available to their aircraft at all times.

Until further notice, the crews of service aircraft will occupy quarters in Camp. Married personnel whose families live out of Camp will be granted permission to visit their families during the afternoon or evening, dependent on military exigencies and such personnel must return to camp before 23.59 hours or earlier, if required.

All officers sleeping in Camp must be in their quarters before 25.59 hours and strict quiet will be maintained in quarters after that hour.

If any married officer should consider this order harsh because other Army units are not on active service let us remember that an officer of the ground forces may be able to make up for a few lost hours but an Air Corps officer who fails to get into the air to carry out his allotted task, has betrayed his trust.

Let us, therefore, bear inconveniences cheerfully now so that we will be standing by to perform whatever the task and whatever the hour.

Signed P.A. Mulcahy, Colonel, Officer Commanding, The Air Corps, 4 July 1940.

\footnotetext{
${ }^{9}$ P.A. Mulcahy to AC investigation, 21 Nov. 1941(MA, ACS 22/23).
} 


\author{
APPENDIX 9 \\ REPORT OF COMMITTEE OF INVESTIGATION INTO \\ [EFFECTIVNESS.] ORGANISATION. TRAINING. ADMINISTRATION \\ AND EOUIPMENT OF THE AIR CORPS. ${ }^{10}$ \\ $\underline{\text { SECTION } 1}$ \\ INTRODUCTION.
}

\title{
1. TERMS OF REFERENCE:
}

The Committee was established by Convening Order dated $10^{\text {th }}$ January, 1941, issued by the Chief of Staff. This Order read as follows:-

I. A Committee of officers composed as hereunder is herby constituted to investigate and report on the following matters:-

Chairman: Major General H. MacNeill, Assistant Chief of Staff

(Major T. Fox, Officer Commanding, $3^{\text {rd }}$ Brigade.

Members: (Major C. Whelan, Office of Chief of Staff.

(Major J. Flynn, General Staff.

II. The Committee will assemble at a time and place to be fixed by the Assistant Chief of Staff.

III. The Committee will enquire into the matters raised on the following questions and will provide an adequate answer to each. It will provide such additional information and such recommendations as, in its discretion, it may consider necessary.

1. Is the Air Corps, as now organized and equipped, capable of co-operating with other units of the Forces or of functioning usefully in any other capacity in the defence of the State?

2. (a) Having regard to our financial resources and the difficulty in obtaining equipment, is the present form of organization of the Air Corps the most suitable for defence needs?

(b) If the present organization is not considered suitable, what changes are recommended?

(c) Is the present type of equipment suited to our defence needs, and, if not, what type of equipment would be more suitable?

3. (a) Are the officers of the Air Corps as efficient and capable of carrying

\footnotetext{
${ }^{10}$ Report and findings of the Committee and Annexes thereto, 10 Jan. 1942, I-II (MA, ACS 22/23).
} 
out the duties of their appointments as available equipment permits?

(b) Is flying practice properly organized and carried out by flying personnel?

(c) If not what changes in personnel or in the system of administration and training are considered necessary?

4. Is it considered essential that:-

(a) The Commanding Officer should be a flying officer.

(b) He should have completed a full flying course as laid down for flying personnel of the Air Corps?

5. Is the present system of pay and additional pay satisfactory and, if not, what changes are considered to be necessary, and is additional pay for flying personnel at all desirable?

6. Could a scheme be evolved which would enable a turnover of pilots to be effected, i.e., could pilots after undergoing, say 3 years training be appointed to other units of the forces and returned to the Air Corps for a refresher course of, say a month each year?

7. Is the present system of limiting pilot personnel to commissioned ranks desirable, having regard to the practice in other countries of having N.C.O. pilots?

IV. The Committee will determine the method of procedure and the form of its report and shall have powers to take evidence on oath and call for documents relevant to the above matters.

V. The Committee will assemble as soon as circumstances permit and, on the conclusion of its investigations, will report without delay. 


\section{APPENDIX 10 \\ Missions of the Air Corps [10 January 1942 $]^{11}$}

The co-operation required by the Defence Forces may be divided into War and Peace Missions as follows:-

\section{War Missions}

(1) Provision of information regarding strength, disposition and movement of hostile forces at sea en route to invade our territory.

(2) Provision of similar information of hostile forces which have invaded our territory and may be in contact with or moving against our ground forces.

(3) Provision of communications on a small scale such as message dropping and transport of commanders and staff officers.

(4) Interception of bomber and dive bomber formations.

(5) Limited attack on hostile ground troops.

\section{Peace Missions}

(1) To accustom the ground forces to the tactics of bombing, dive bombing and machinegunning aircraft, by means of exercises demonstrating these tactics.

(2) To test and examine the concealment and camouflage of ground forces and thus perfect their technique in this important aspect of modern warfare.

(3) To test alarm and evacuation plans of ground forces.

(4) To test air discipline of ground troops in camps and on the move.

(5) To train ground troops and Air Corps, separately and in combination, in their War Mission.

\footnotetext{
"Report and findings of the Committee and Annexes thereto, 10 Jan, 1942, IV (MA, ACS 22/23).
} 


\section{APPENDIX 11}

\section{Colonel P.A. Mulcahy ${ }^{12}$}

Three members of the Committee favour the appointment of Colonel Mulcahy as Director of Military Aviation. The fourth member dissents and is submitting a separate recommendation. In recommending Colonel Mulcahy, these three members do so on the grounds that;

(i) Colonel Mulcahy took over the command of the Air Corps in 1935 when it was in a very bad condition. He was seriously handicapped by not having a policy for the Corps and by inadequate equipment.

(ii) He has a good conception of the requirement and role of the Air Corps and endeavoured to obtain a decision on policy. The supply of equipment has been to a large extent outside his control.

(iii) In a small Unit such as the Air Corps with officers having grievances about their flying pay, the inadequacies of equipment and lack of policy, discontent was bound to arise, thus making Colonel Mulcahy's task very difficult. In such circumstances, criticism is always rife.

a. That Colonel Mulcahy succeeded in maintaining a high standard of discipline in such circumstances rebounds to his credit.

b. Whilst Colonel Mulcahy bears responsibility for the low standard of training in the Air Corps, the mitigating circumstances in Section V, paragraph 24 , must be taken into consideration.

The above mentioned considerations render it necessary that any Officer nominated to replace Colonel Mulcahy requires to be a good administrator, have technical ability and possess strong character and personality. Whilst there is within the Corps a number of promising officers, none of them, in the opinion of the three members of the Committee concerned is fitted at this stage to effectively direct the Corps in its present condition.

In order to satisfactorily fill his appointment, however, the three members in favour of his appointment consider that Colonel Mulcahy should be required, at an early date, to undergo the necessary additional training to obtain the qualifications which the Committee have recommended in Section V of the Report as being essential for the Officer holding the appointment of Director of Military Aviation.

\footnotetext{
${ }^{12}$ Report and findings of the Committee and Annexes thereto, 10 Jan. 1942, LXI (MA, ACS 22/23)
} 


\title{
APPENDIX 12
}

\author{
Minoritv report re appointment of Director of Militarv Aviation. ${ }^{13}$
}

I regret that I cannot agree with my colleagues regarding the advisability of retaining Colonel P.A. Mulcahy in the Air Corps, even on the conditions set out in paragraph 39(b). ${ }^{14}$ This opinion is based on two factors, neither of which should be taken as reflecting in any way on Colonel Mulcahy personally. These factors may be summarised as follows:

I am satisfied that no one other than a fully qualified Flying Officer possessing considerable practical experience should be placed in charge of the Air Corps. The fact that in the past several such non-qualified officers have been from time to time placed in charge of the Corps is, in my opinion, one of the causes of the condition of affairs this committee was set up to investigate. As already stated in this Report, such officers must of necessity rely on their subordinates to an undesirable extent in matters connected with the organisation, training and administration of the Air Corps.

Colonel Mulcahy does not possess these qualifications and I firmly believe that no amount of training at this stage could bring him up to the required standard. Furthermore, if the continuance of Colonel Mulcahy in the Air Corps is made conditional upon his attempting to qualify as a Flying Officer as set out in Section V of this Report, I believe that this would have a very adverse effect on his prestige and upon the discipline of the Corps in general.

The confidence of a large number at least of the junior officers in Colonel Mulcahy has, through one cause or another, been hopelessly been undermined. Furthermore the confidence of Colonel Mulcahy in the loyalty of a large number of his officers has been similarly been undermined as a result of the existing situation. With the best will in the world, I cannot see how this state of affairs can be completely set right while Colonel Mulcahy and the Officers concerned are required to serve together in the same Corps.

I, therefore, recommend that Colonel Mulcahy be relieved of his present appointment and posted to some other appointment commensurate with his rank, qualifications and experience and that Major G.J. Carroll be recalled to active duty as Director of Military Aviation. This officer is a very experienced pilot, as far as I know he has not been connected with any of the existing factions in the Air Corps, and should, therefore, enjoy the full confidence of the Officers of the Corps.

[Aodh MacNeill] Major General. (Aodh MacNeill)

President, Committee of Investigation.

\footnotetext{
${ }^{13}$ Report and findings of the Committee and Annexes thereto, 10 Jan. 1942, LXX (MA, ACS 22/23).

${ }^{14}$ Should read $41(\mathrm{~b})$
} 